
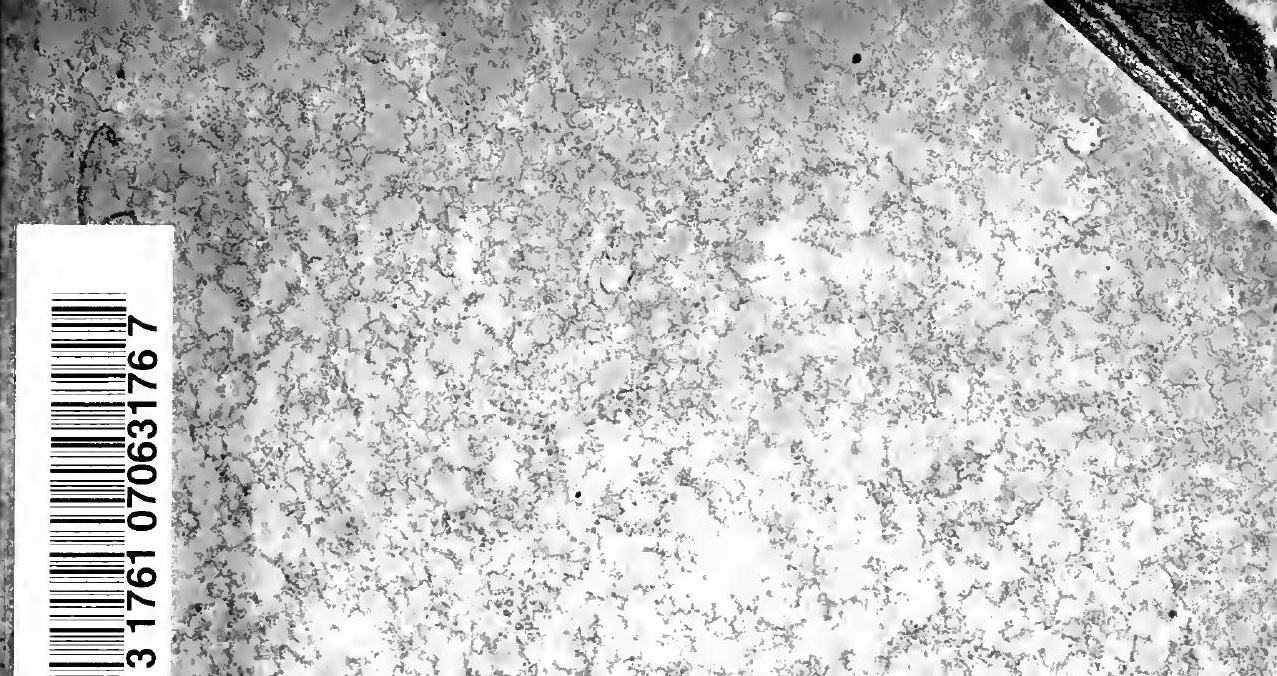

i.

(9)

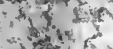

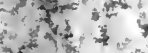

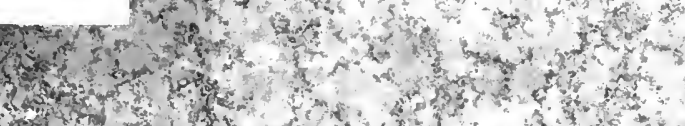

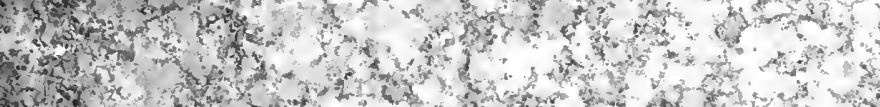

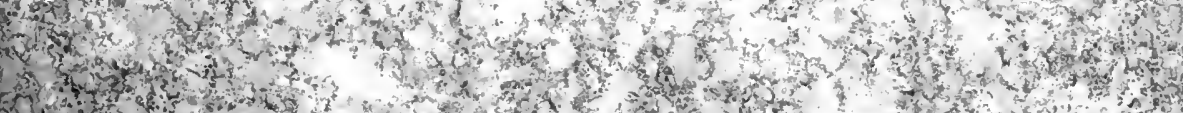

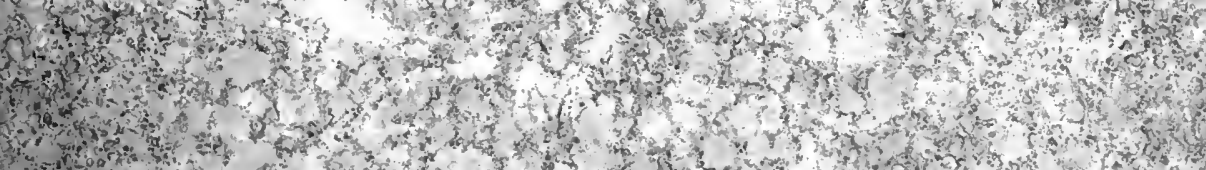

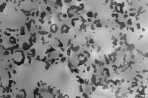

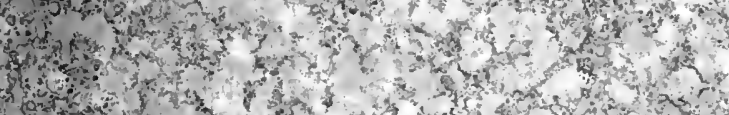

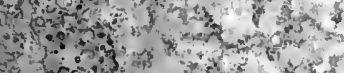

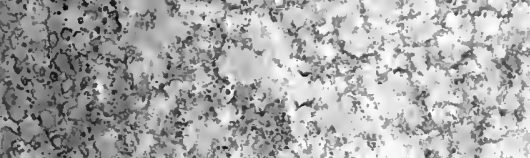

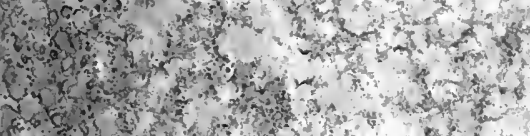

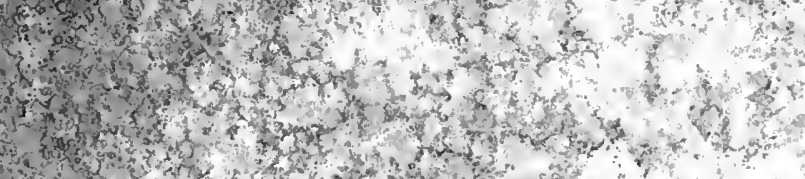

ment

Tot dy

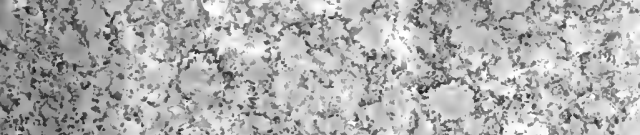

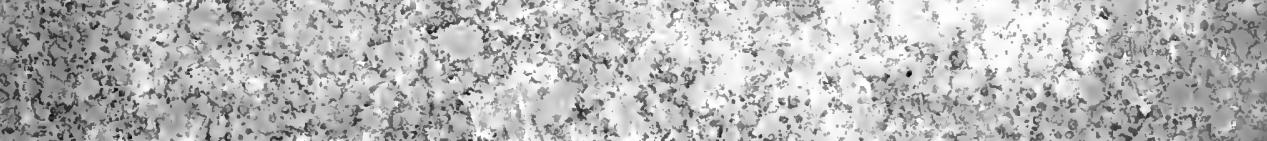

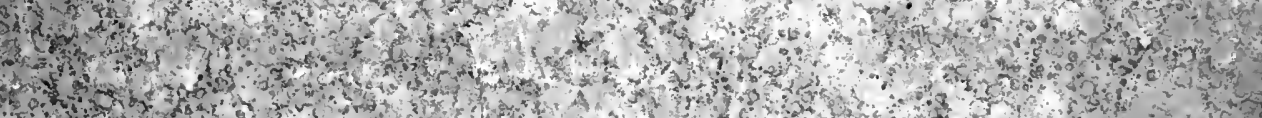

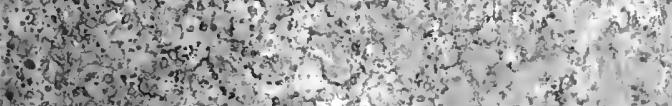

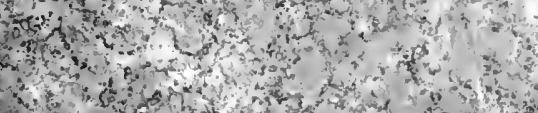

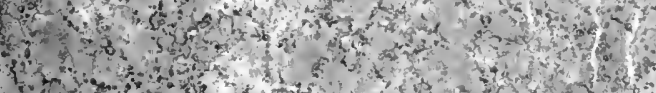

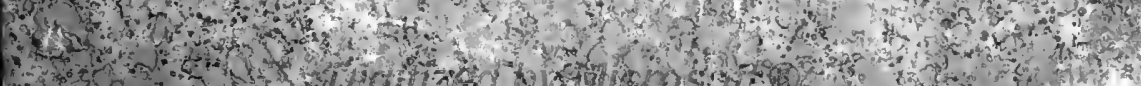


- tote

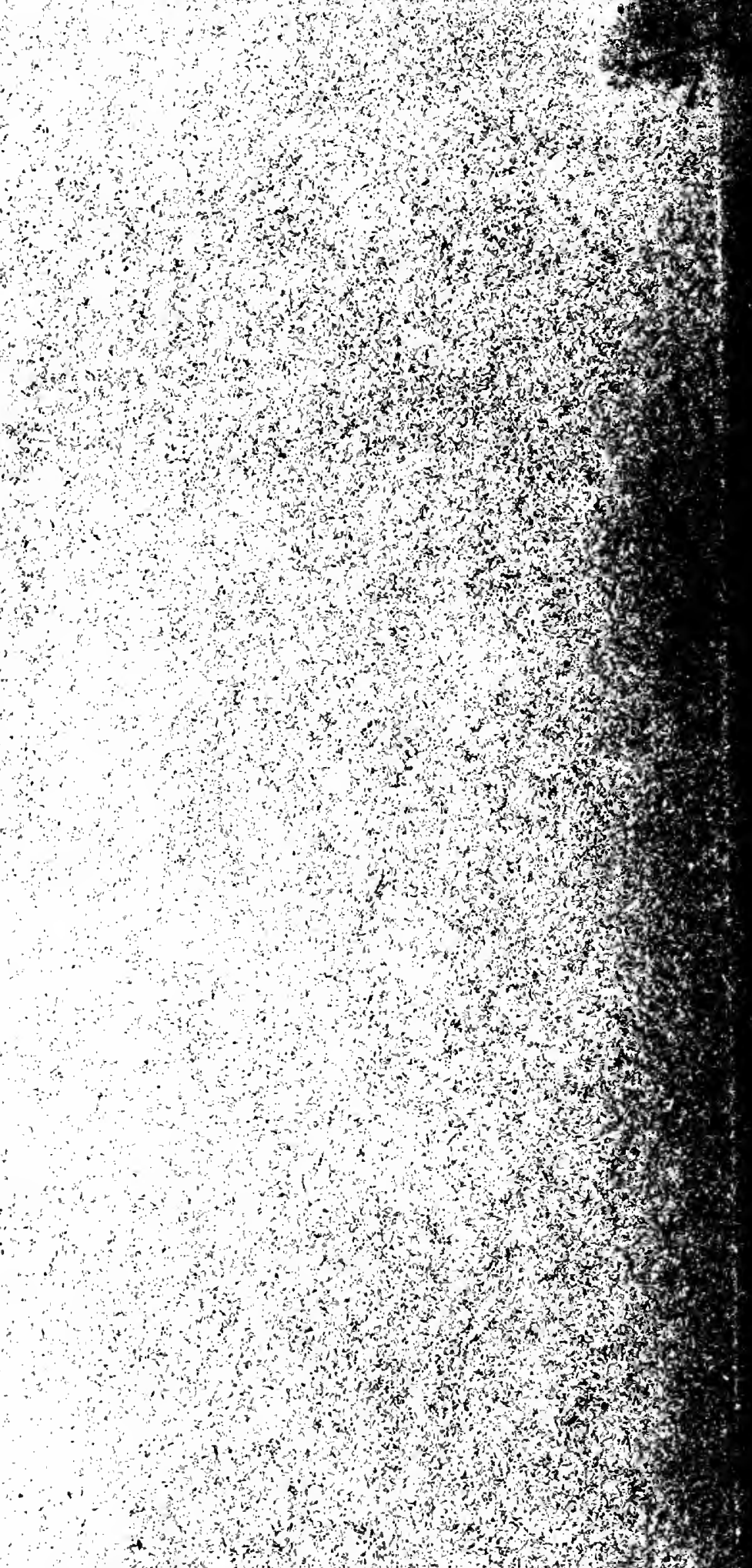





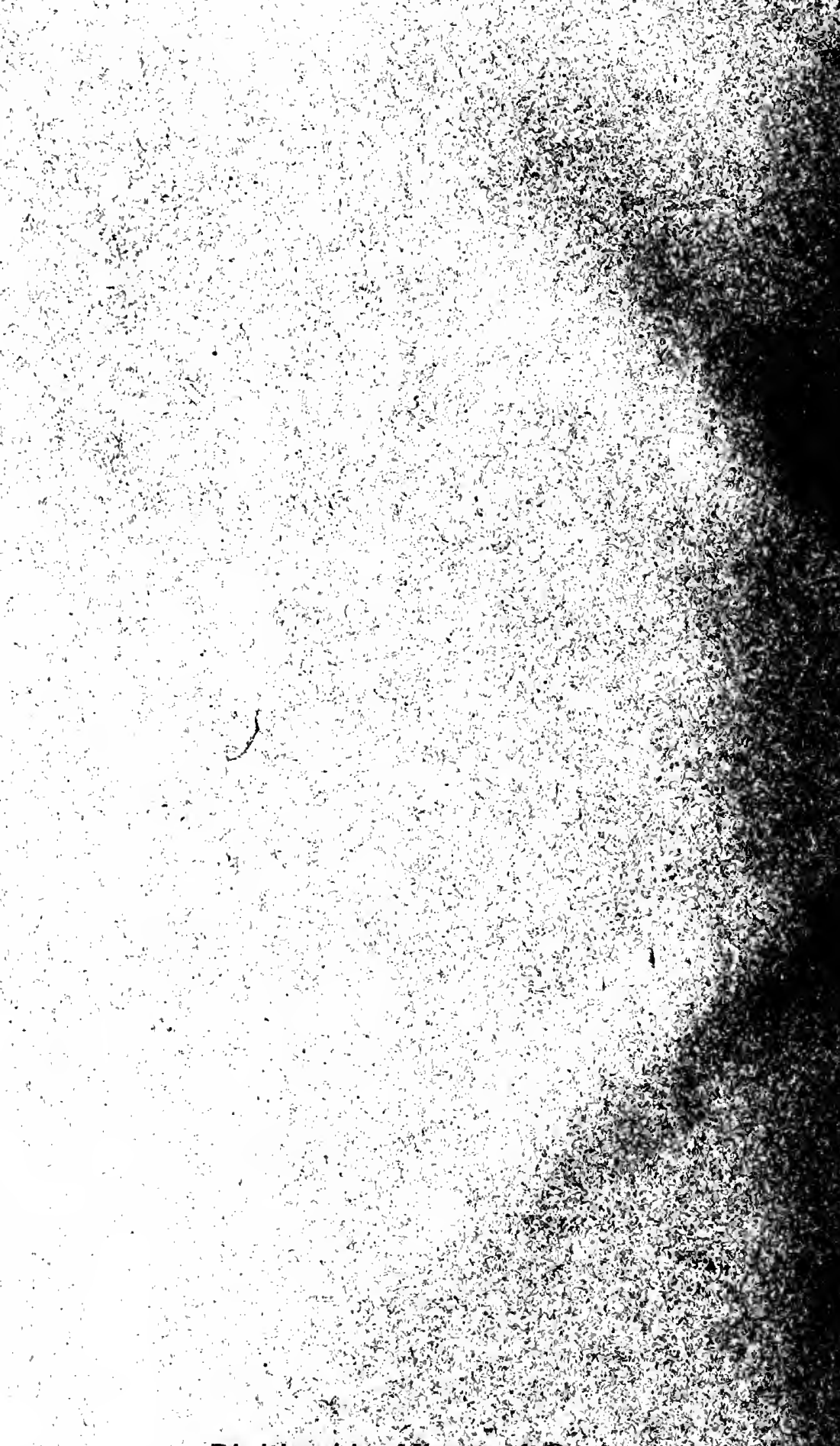

Digitized by Microsoft ( ) 


$$
\text { III Daniciés, Duro }
$$

\section{ИСТОРИЈА ОБЛИКА}

\section{СРІІСКОГА иии ХРВАТСКОГА ЈЕЗИКА}

Istorija oblika srpstoga

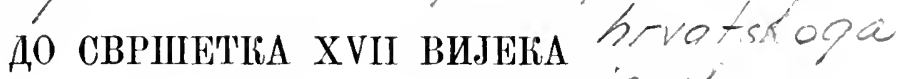
jezike...

HAIIICAO

'b. A A H И Ч $\mathbf{Y}$ '

У БИОГРАДУ

IЗЗААНE II UTAMIIA APऑ̈ABHE IITAMIIPИJE 
Laser.Gr
D/832isto

$\frac{6+2 n g h}{24.158}$ 
Облике из којшх су се развили облпци старога с.ловен скога језика показали су прије овога мога посла други људп, који су се особито око тога трудили: што је добра у мом послу с те стране, за то њима прпгада хвала. Али сам гдје гдје одступао од пута којим су они из старијих облика изводили словенске : то сам чинио само ондје гдје сам мисдио да је иријеко потребно самијех облика ради, остављајући све друго науци о гдасовима да расправи. Толико сам и међу границама самијех словенских језпка одстушао од гдјекоје дојакошње мисли. У томе мислим да је гдавно: је лі требадо одступати? Ако јест, онда мислим да ће мањи бити укор што одступајући нијесам ни сам свагда нашао штто треба.

Догнав у овом послу до конца XVII вијека заврпујем га за то што је до тада у сриском пли хрватском језнку веһ бидо свршено ако и није свуда преобдадало све чим се садашњи облици вегови раздикују од старијнх. А пзвори из којих цршох ово су:

АНДР. ДЕВ. - Витада Андријашевића Devocioni (,devotioni"). Млеци 1664.

АНДР. НАЧ. - Истога Pravi način za prositi milosti u gospodina boga. Млецा 1664.

АНДР. ПУ'Т. - Истога Put od raja. Млеци 1686.

БАНА. - Ивана Бандудавића Novo istomačen'je jištola i evangel'jih priko svega godišta. Млеци 1626.

BPH. - Nauke života redovniškoga, ke piše blaženi sveti Brnard sestri svojoj. Рукопис XVI вијека у бпбднотецп југослов. академије у Загребу бр. 642.

БУА. - Шияуна Будинића Ispravnik za ereji ispovidnici i za pokornih. Рим 1582.

БУН. - Ива Вучића Бунића Mandaljena pokornica. Јакин 1630. ВРАН. ЖИВ. - Фауста Вранчнћа Život nikoliko izabranih divic. Pyм 1606. 
BPAH. РJEY. - Hcrora Dictionarium quinque nobilissimarum Europae linguarum, latinae, italicae, germanicae, dalmati(c)ae et ungaricae. Млеци 1595.

I. - Гдасник сршског ученог друнтва.

ГЛАB. - Тр. Главинића Svitlost duše verne. Млеци 1685.

ГРАД. ДЈЕВ. - Бас. Градић̆a Libarce od djevstva i djevičkoga bitja. Млеци 1567.

ІРАД. ДУХ. - Кстога Libarce vele duhovno i bogoljubno od molitve i kontemplan'ja. Млеци 1567.

ГУНд. ПІ. - Ива Франа Гундулића Pjesni pokorne kralja Davida. Млеци 1630.

гУНД. СУЗ. - Истога Suze sina razmetnoga. Млеци 16(23). ГУЧ. - Аркангела Гучетића Rozario. Рим 1597.

Д. РАњ. - Динка Рањине Pjesni razlike. Фиренца 1563. ДИВ. - Матије Дивковића Пхвк клрстихскн. Млеци 1611.* ДОМ. - ऊКивот св. Саве. Наииса о доментијан. Издало друп тво српске словесности трудом Ђура данпчића. Бноrpad 1860.

TAM. - P. Ђаманићa Nauk za pisati dobro latinskiema slovima rieči jezika slovinskoga kojiem se Dubrovčani i sva Dalmatia kako vlaštitiem svojiem jezikom služi. Млеци 1639. 3АK. - Законик цара Стефана Душана ! II. J. IIIафарика Památky dřevn. písenın. jihoslov. IIpar 1851.

3БОР. - Pукопис у ком су различне ствари писан Һирнлицом годпне 1520 у библиотеци југосл. академпје у Загребу бр. 542.

3ЛАТ. - Доминка Златарићa Elektra tragedia, Ljubmir pripovies pastirska i ljubav i smrt Pirama i Tizbe. Млеци 1597. 30Р. - IІетра Зоранића Planine. Млеци 1569.

JEPK. - Матија Јерковићa Bogoljubna razmišljan'ja od slavnoga svetoga rozarija. Млеци 1634.

* Три књите код којнх овдје стављам звјездицу инјесам прочнтао цијеле, него веһ иа поласку нз Зачреба у Биоград, да бих п пз њих птто имао, ирочитах из сваке по неколико првијех листа, и то из Дивковиһеве првијех 16 пеоблежсинјех бројем и за њим 39 бројем обиљеженијех листа; из Ilocнловияеве 45 листа бројем облљеженјех; из Радниееве 100 страна. 
KAIII. - Барт. Kanußka Život gospodina našega Isukrsta (II život sv. bogorodice). Рим 1638.

KAII. ГРАM. -- Иcтога Institutionum linguae illyricae libri duo. Рим 1604.

КРН. - Брне Крнарутића Izvisna ljubav i napokon nemila i nesrićna smrt Pirema i Tižbe. Млеци 1627.

ЂЕT. - Ђетописи српски у II. Ј. НІафарнка Památky dr̈evn. písenm. jihoslov. ПIpar 1851.

M. - Monumenta serbica. Edidit Fr. Miklosich. Беч 1858.

MAT. - Cтјенана Матијевића Нсиовєламин. Рим 1630.

МИк. - Јакова Микаље Blago jezika slovinskoga. Дорет 1649.

МИК. ГРАМ. - Истог Gramatika talijanska. ภopeт 1649.

MPH. - Ивана Томка Mpнавићa Osmansćica. Pнм 1631.

Н. РАњ. -- Рукопис писан руком Ннколе Рањине године 1503 латиницом, у ком је из старога и новога завјета што се чита у цркіни преко године. и који је у библиотеци југосл. академије у Загребу бр. 653.

OPБ. - Мавра Орбина Zrcalo duhovno. Млеци (1621).

II. - Спомениц српски преписао кнез Медо Пуцић. Биоград 1858.

ІІь. - Споменци српски преиисао кнез Медо Пуцић. Биоград 1862.

ПІОС. - Павда Посиловића Пасмћєппе двховно. Млеци 1682.*

РАдН. - Мих. Радпића Pogrgjenje izpraznosti od svijeta. Рин. 1683.*

РАдОЈ. - Јур. Радојевића l'изделина Skazan'je kako gospodin bog vazda je providio svojim virnim slugam i sada ga molimo da pomože u ove sadane potribe krstianske. Okolišen'je i uzetji grada Budina. Падва 1686.

САB. - Живот св. Спмеуна. Написао св. Сава. У II. J. IIIaФapнка Památky dřevn. písemn. jihoslov. Праr. 1851.

CAB. СТАР. - Посданица св. Саве у четвртој књизи Старина, које издаје југосл. академија у Загребу.

СТ. ПИС. - Stari pisci hrvatski. Na sviet izdaje jugosl. akademija znanosti i umjetnosti. Knjiga I-V. У Загребу 1869 A0 1873.

CTAP. - Starine. Na sviet izdaje jugosl. akademija znanosti j unjetnosti. Knjiga I-IV. У Загребу 1869-1872. 
VI

СТЕФ. - ऊћивот св. Симеуна. Написао краљ Стефап. У П.

J. IIIaqapикa Památky dřevn. písemn. jihoslov. Праг 1851. ХЕКТ. - Петра Хекторовићa Riban'je i ribarsko prigovaran'je i razlike stvari ine. Млеци 1568.

ЧУБР. - Андрије Чубрановића Jegjupka. Млеци 1599.

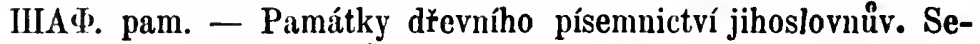
bral a vydal P. J. Šafař́k. Vydání druhé. V Praze 1873.

У Бпограду мјесеца јануара 1874.

Ђ. ААНИЧИЋ. 


\section{ПРЕГЛЕД.}

Приступ . . . . . . . . . . . . . . . . . 1

ОБлИЦП НОМИНАНИ.

Основе . . . . . . . . . . . . . . . . . 3

Номинатив јед. . . . . . . . . . . . . . . . 5

Генитив јед. . . . . . . . . . . . . . . . . 14

Датив јед. . . . . . . . . . . . . . . . 20

Акусатив јед. . . . . . . . . . . . . . . . 27

Вокатив јед. . . . . . . . . . . . . . . 30

Инструментал јед. . . . . . . . . . . . . . . 34

Локатив јед. . . . . . . . . . . . . . . . . 46

Номинатив мн. . . . . . . . . . . . . . . . 56

Генитив мн. . . . . . . . . . . . . . . . . 67

Датив мн. . . . . . . . . . . . . . . . . . 92

Акусатвв мн. . . . . . . . . . . . . . . . . 102

Вокатив жн. . . . . . . . . . . . . . . . . 112

Инструментал мн. . . . . . . . . . . . . . . 112

Локатив мн. . . . . . . . . . . . . . . . . 130

ОБАНЦИ ПРОНОМИНАЛНИ И САОЖЕНИ.

Основе . . . . . . . . . . . . . . . . . . 145

Номинатив јед. . . . . . . . . . . . . . . . 146

Генитив јед. . . . . . . . . . . . . . . . . 156

Датив јед. . . . . . . . . . . . . . . . . 162

Аћусатив јед. . . . . . . . . . . . . . . . 167

Вокатив јед. . . . . . . . . . . . . . . . . 170

Инструментал јед. . . . . . . . . . . . . . . 171

Локатпв јед. . . . . . . . . . . . . . . . . 178

Номшнатив мн. . . . . . . . . . . . . . . , 187

Генитив мн. . . . . . . . . . . . . . . . . 189

Аатив мн. . . . . . . . . . . . . . . . . . 195

Авусатив мн. . . . . . . . . . . . . . . 200 


\section{VIII}

Вокатив мн. . . . . . . . . . . . . . . . . 203

Инструментал ми. . . . . . . . . . . . . . . 204

Локатив мІ. . . . . . . . . . . . . . . . . 211

ДОДАЦИ.

Замјенице без рода . . . . . . . . . . . . . 215

Двојина . . . . . . . . . . . . . : . . 221

Триг четшин . . . . . . . . . . . . . . . . 236

Пет-десет . . . . . . . . . . . . . . . . 241

ОВАНЦИ РААРОАСКН.

Инфинитив . . . . . . . . . . . . . . . . 245

Садапюе вријеме . . . . . . . . . . . . . . 256

ІІрво лице јед. . . . . . . . . . . . . . . 257

Аруго лице јед. . . . . . . . . . . . . . . 267

Tpehе лице јед. . . . . . . . . . . . . . . 272

ІІрво лпе мн. . . . . . . . . . . . . . . 285

Аруго лщце мн. . . . . . . . . . . . . . . 288

Tpeће лище ми. . . . . . . . . . . . . . . 289

Авојниа . . . . . . . . . . . . . . . . . 297

Имнерекат . . . . . . . . . . . . . . . . 299

Аорист . . . . . . . . . . . . . . . . . . 317

Императив . . . . . . . . . . . . . . . . . 335

Іартиции садапиьега вр. актнвни . . . . . . . . . 346

ІІартицин саданнееа вр. паспвпи . . . . . . . . . 370

ІІартиции проплога вр. актнвин I. . . . . . . . . 370

Партицшп шроплога вр. активип II. . . . . . . . . 386

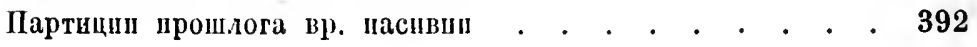




\section{ПРИСТУП.}

Об.дици постају од основа и паставака. Сваки облик има свој шаставак, већ ако га је изгубно или се замијенио другим обликом; а основа је свијем облицима исте ријечи иста, већ aro roja ријеч у ком об.ину узима другу оспову. ІІо томе разлике између једпога облика п другога исте ријечи долазе од њиховијех паставака, а разлике између једнога облика ријечи и истога облика друге рнјечи додазе од њиховијех оспова, и то од прајњега гласа у основе и његова слагања с наставком.

Није за сваки облик доста зпати како му сада гласи шли како би му сада гласпо крајњп гдас од основе и наставак: од талих гласова накіи су сада многи облик не би могао ни на који начин постати онаки какав је сада; јер облици не постају сада, него су ностали кад су сродни језици би.ди у заједници, с тога су ностали од г.асова какп су опда бнли и пю закопима каки су онда у њима бнлі, па

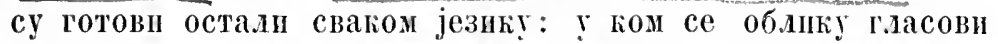
од којих је постао нијесу били смијенали пи промијенили у оној заједници, у њему се могао сваки глас од кога је постая само промијепити према законима свакога језика, који га има, па се за таки облик може рећи да ! свағом језику постаје п од опаких гласова какви су у том језику; али у ком су се облику гласови од којих је у оној ваједпицп постао смпјешали п промијепили јон $y^{\dagger}$ опој заједници, $r$ њему су се само они гласови поји су тнјем мијешањем п мијењањем поеталп могли промијенити према законима свакога језика, који га пма, а гласови које је па тај начип об.ик у ком језпку добно, често су са свијем други него пито би у истом језику бпли кад би се $г$ облику рдасови од којнх је (у заједници) постао само ірема законима истога језика ова丿Lи 
промијенили или се промпјењени и смиенали. За то тражеһи како поетају обдици не можемо гледати само како крајњы гласови у оспова и како наставци гласе или могу гласити у словенским језицима, него пам треба зиати гласове од којих еути сдовенеки гдасови постали, гласове, на које су се сврнивале осиове и који су били у наставцима онда кад еу облнци постајали, а то су гдасови који су заједнички језицима племена индоевропскога, међу које припадају и словенски, па су се у јединјем више а ! другима мање сачували. То треба особпто у паших пмена (nomina) и замјеница (pronomina), јер се \ њих еве речено највине јавља. - 'Тога ради показиваћу овдје завршетке у основа и наставке тијем заједничим гласовима. језнцима свагда к основама онаким како у њима гдасе, приступају наставци, доста ће бити да се само наставци покажу заједнитим гдасовима.

1 Да се не би ти тласови мијешали са словенскима, иего да би лакпе бнло иматі на уму да у словенским језнцима могу и другачије гласити докле се не покаже како доиста гласе, стављаћс се латинским крунијјм словима. 


\section{ОВЛИЦИ НОМИНАЛНИ.}

\section{$0 \mathrm{CHOBE}$.}

Основе именима словенских језика по гласовима на које су се свршивале кад су облици постајали јесу:

I. Оспове на ш; таке су у ријечнма мушким као во (основа воли), дом, мед, син.

II. Основе на а, и то

1. на чисто а; таке су

a) у ријечима мушким као бог (основа бога),

б) у ријечима средњега рода као село (основа села),

в) у ријечима женским као жена (основа жена);

2. на ја, од чега се глас $j$ по својим законима слаже с гласовима који се десе пред њим ${ }^{2}$; таке су основе:

a) у ријечнма эуньим као крај (основа краја), кон (основа коња),

б) у ријечима средњега рода као поље (основа поља),

в) у рнјечима женскпм као дуиа (основа дуна).

III. Основе на i; таке су

a)

б) у ријечима женслим као власт (основа власті).

IV. Основе на сугласно. - Сугдасна су осповама на крају у словенским језицима једнаға са зајединчии, и то

1. $\boldsymbol{~}$, пред којнм је у словенским језицима самогдаспо $\underline{e}$, тако

a) y ријечима мушким као кали (основа камен);

б) у ријечнма средњег рода као име (оспова пмен);

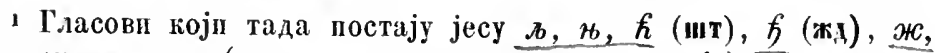
$u, u, u, 3$ (не свагда, него кад тако постаје); иза гласа $p$ држи се 5 у старије вријеме у неким приликама (ихри), а у некима се губи у гласу који њега ради буде за жим (пхри), послије испада и у првијем приликама (рхра). 
2. $T$, пред гојим је за словенске језике самогласно ж, које ! сриском језику гласи $e$; таке су основе у ријечнма средњега рода као јагње (основа јагњет);

3. с. пред којим је у словенским језицима самогласно $е$ така је основа ! рнјенима средњега рода као жебо, (основа небес);

能 4. $p$, пред којнм је у словенским језиция самогласно $e$; таке су основе у ријечима женским: мати (основа матер), кћи (оспова кћер);

伤 5. в, пред којим је у словенским језицима самогдасно т или о ; таке су основе у ријечнма женским као ьуби (основа жюьок или мювтк). Будчћн да ово сугдаспо заједно са самогласним које је пред њим постаје од другога и, за то се оваке основе свршују уцраво па друго ш: жюви; али како од тога самогдаснога постаје сугласно в, а у осталом се ријечи с таком основом не разликују од других с основом на сугласно, за то и жнх узимам међу ове.

у адјегтпва се словенских основе свршују само па а, и то нли на чисто а, као у нов (основа нона), нли на ја, као у туђ (основа туһа).

Мrore ст основе прешле пз своје врсте у другу одбацивпи своје особнне п примиви особие друге врсте, и то пли за све облике или само за неке: тако су се још у староме словенском језику ријечи с основом на и помијешале с ријетима у којих је основа на а, те осим правнјех својих обдика пмају п онаке какве могу пмати само ријечи с основом на а; тако су ! српском језику све ријечи мунке с основом на $\mathbf{i}$

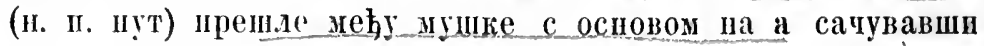
само неке облике које могу имати од основа иа $\mathbf{i}$; тако су п неке женске ријетп с основом иа $\mathbf{i}$ пренле међу женске с основом на а (п. пр. ријеч која је прије гласн.ла пјесан, сада је пјесма); тако н. пр. ријеч јелен, којој се основа управо сврнчје па сугласпо, те у старом словенском има нене облике од таке оспове, она је јоп у старом словенском језику у самом номиатищу јед. шренла међу ријечи мушке с осповов $\mathbf{i}$. а с тијем је ријечна опет у српском језигу пренла међ мушке ријечи с основом на а. 


\section{Н ОМИНА ТИВ ЈЕДНИНЕ.}

Наставак му је s, који стојећи на крају отиада у словенски језицима по правиду по ком сугласно пе може стајати на крају ријечи. Ријечи средњега рода пемају у овом падежу наставка, и оне између њих ! којих је основа на а замјењују овај падеж акусативом.

I. Основе на и. Крајње је и у основн кратко, те у словенским језицима слабећи ностаје п, поје у староме словенском остаје а у друтима отнада: сынт, син.

II. Основе иа а:

A. У мушки ријечи:

1. Крајње је а у основи кратко, те у словенским језпцима слабећи постаје 0 , које опет слабећи постаје т, па

a) у основама на чисто а остаје з постало од њега $y$ старом словенском језику а у другима отиада: родт, род; с промјеном крајњега $\lambda$ у 0 : лио М. 409. Н. Рањ. 58. туо Н. Рањ 182б.

б) у основама па ја п ностало од а мпјења се предњега гласа ради $\mathbf{l}$ : ако је предын глас само $j$, отнада иза њена 6. и у старом словенском језику, те га нема пи $y$ српском: коп, бој; - ако ли је предњи глас други, којп постаје од $j$ и гдаса који се пред њим десп ${ }^{1}$, онда ' у старом словепском остаје а у сриском опет отиада: конь, кож; - ако је пред $j$ глас $p$, ! старом се словенском глас $j$ губи $y$, или ако је било смијенано са $p$, остаје смијешани глас пезабнљежен као и други $(. b, \preccurlyeq)$, или се гдје гдје билежи знаком ", а $у$ сриском језику отнада и $j:$ прри, иар.

Међу ријечима с основом па ја биле су ждрхкни и истин, гдје је крајње $u$, које је гласило $j$, предњега и ради и отпадало: ждрєкн М. 180. шєти М. 273. II. 112. а мјесто ни долазило је разједначивањем и єи, али само у старије врнјеме: ж.цркке Стет. 23. Таке су се ријечи са завршетком иј послије промијениле одбацивни га или узевпи други: тако од почетка XVI вијека долази ждрпјеб Н. Рањ. 177. Банд. 198. петјак Мик. 316. али прва ријеч додази уз гдагол метати у ағусативу јед., којн је једнак с помниативом, XVI и XVII

1 Види напријед иа стр. 3. 
вијека још једнако са $и$ : ждрнјеби Збор. 29. 115. ждрнби Банд. 87. 93. Мат. 48. Мик. 760.

Нека народна имена која се сада говоре без крајњега ин шалазе се с тијем завршетком још XVI вијека: хрватин Ст. пис. 3, 55. жидовин Н. Рањ. 109. тако и XVII вијека: жудијші Банд. 104.

Од два сугдасна па крају, која и сада могу стајати на крају, могдо се задње и одбацити, као што и сада гдје гдје бива и то од X плаш Збор. 26. лис Ст. пис. 2, 88. 3, 187. Г'рад. дјев. 118. тако без задњега т има и крс Н. Рањ. 52б. - Кад су оба задња гласови ск и зг, долазе кад кад и без $а$, које се међу њих уметало као IIто се и сад умеће, допирући тако у сам XVII вијек: воск Н. Рањ. 112б. виск Ст. пис. 1, 243. тиск Вран. рјеч. 81. триск Ст. пис. 1, 243. Стар. 1, 235. Вран. рјеч. 40. жкив. 68. Мрн. 64. мозг Вран. рјеч. 60. Док су тако гласови ск и зг додазили без уметнога $a$, могао се задњи гдас и одбацити: вос Ст. пис 4, 349. 359. тијес Ст. пис. $2,315$. тријес Ст. пис. 4, 173. 266. 5, 188. Бун. 14. моз Ст. пис. 5, 55. Тако се без уметнутога а падази и басилк Ст. пис. 1, 78. кладенц Ст. пис. 5,45. мұдарц Каш. грам. 31.

у адјектива је као у супстантива: с основом на чисто a: нов, с основом на ја: тyf.

2. Крајње кратко а у основи ослаб́нши у о остаје не с.лабећи дале ! ријечима ніоје се говоре од мида (ипокористика) и које тога ради постају од других, особито у таким именима властитијем:

a) с основом на чисто а : P.хсько (т. ј. Рлстискикь) Дом. 4. Сакко М. 13. Берихо М. 12. Г'остияо М. 12. Вимо М. 240. Жорко M. 299. Aparo M. 62. Cтаmo М. 62. Mхро М. 246. Mихо М. 62.

б) с основом на ја: $a a$ ) остаје такођер о још непромијењено предњега 1'даса ради у $e$ : Блш (Бајо) М. 63 . Коо (Којӧ) M. 62. (тмю (Стајо) М. 62. - бб) мијења се $o$ на $е$ у ријечима од предњнх (као пто је Драго) па ново начињеншм: Pадос М. 2. Аригок М. 201. Марос М. 412. Mrioc М. 96. Внди јони код вокатива јед.

Уз оваке се рнјечи сачувао овако крајњи глас од основе и у гдјекојнм странијем именима вдаститијем и другим : тако 
још у старом словенском језику: Клктхо Микл. lех. Мартко Микл. Іех. и кад је основа иа ја, те се о мијења на $e$ : Ка-

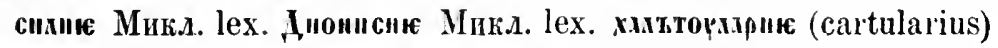
Микл. Іех. Тако је у сриском језику од најстаријих времена: а) с основом на а до краја XV вијегіа: Бхрьтомо М. 474. Кхиuenhto М. 40. Manonxo М. 62. Мхряко М. 180. Марьтоло М. 43. Мнхинхо М. 259. Михонхо М. 39. Пикихо М. 40. Фикнио М. 40. єрхрьхо М. 115. 116. пा послије: Александро Збор. 12б. Радн. 87. Алуберто Збор. 171б. Брнардо Збор. 14. Даннло Ст. пис. 1, 89. Јеропияо Збор. 12. Испдоро Збор. 7. Аарго Банд. XVII. Михаило КанI. 48. Андр. пут 122. Радн. ІІб́. ІІодидоро Ст. нис. 4, 401. Поликарно Банд. Х. Смарагдо Банд. XVII. - б) с основом па ја, гдје се о мијења на $e$ : до краја XV вијека: ПІњкохе М. 27. 115. 117. особнто ! основама које пред ја ихају $и$ : Мерькоүрнє Стеф. 25. Мсөоднє Стеф. 16. Пхнсїє М. 127. Өеблосїе М. 128. Днмитрїс Дом. 77. Дмитрне М. 43 өктвкри М. 537. и послије једнако: Мојсије Радн. 2. Cонюкми Стар. 3, 239. оваке стране рнјечи, у којих је у словенским језицима основа на ја, јошl у старом словенском језику одбацују у неким падежима $j$, те им се ни $о$ не мпјења на $e$, тако би у нас могло бити и у овом падежу у овијех ријечи, али мислим да һе прије бити талијански облик: Мхтпо М. 6. Млеск М. 187. фарисео Н. Рањ. 35. Хелисео Н. Рањ. 64б. Птоломео Збор. 9в. тако и Меркурио Ст. пис. 4, 146. Отавио Д. Рањ. 83б. Тудно Збор. 7. Матијо Ст. пис. 5, 320. а према нима и Мојсио ІІос. 6б. тако је страни облик и Аристотнле Збор. 12. Банд. IV. Пократе Збор. 126. Улисе.Ст. пис. 4,409. - Али је у свијех такнх странијех ријечи могао реченш крајњи глас у основи и ослабпти у т, као и $у$ других ријечи, а по том је т код пас отпало: тако у старом словенском језику пма п Мхртк Микл. lex., а у нас а) од основа на a : до краја X I вијека : Бхрьтоүо (т. ј. Бхрь-

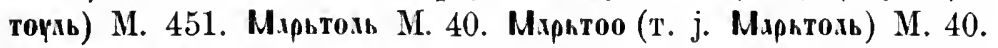
Михаия М. 287. Пхкии М. 40. Пихишь М. 7. Рлфиниь М. 221. Рапию (т. ј. Рмихих) М. 229. и послије: Аристотио Збор. 16. Гуч. 6. Брнарад Збор. 153б. Габрио Н. Рањ. 15б. Гуч. 295. Данил Ст. пис. 1, 90. данио Н. Рањ. 68. Ст. пис. 4, 372. Мавар Ст. пис. 5, 342. Михозио Збор. 124б. Банд. XVIII. 
Савао Банд. 191. Тодомеј 3бор. 6. Ходоферан Радн. 58. б) од основа на ја: до краја XV вијека: Нимикни М. 66 . и без крајњега $u$, које гласи $j$ : Вияси М. 40. І'ерккхси М. 40. Imuнтрн М. 39. охтокри М. 519. тако се палазп јoш и XVII вијека, прем да веһ ријетко: Баропиј Кан. 36. Еипфаниј Кан. 19. Матиј Јерк. 1. Тибурциј Вран жиз. 19.'

Б. У ријечи средњега рода овај се падеж замјењује анусативом јед.; алй им и у том падежу отпада његов наставак, а крајње кратко а у оспови слаби само уо које се у осповама на ја мијења на $e$ предњега гыаса ради: с основом на чисто а: стақо М. 4. т.1о Вран. жкив. 54. - с основом на ја: покхьнис М. 5. норе М. $42 .{ }^{2}$

Завршетак ню, од кога н од давна отшада, на се $j$ с гласом који се чред њим десп слаже по својим законима, надази се и сажет у $u$, прем да врдо ријетко: тако XIV вијека: хтпин М. 42. на крају ХV вијека: уди Ст. пис. 1, 38. 77. 99. 224. XVI вијека: уan Брн. 25. и у слшку: безакони Gт. пис. 5, 72. XVII внјека: уди Врап. жиз. 50. 82. окушени Пос. 3.

Неке су ријечи средњега рода шредазнде међу мушке с основом на а: тако се палази: весал Ст. пис. 5, 335. језер Андр. пут 280. рун Вран. рјеч. 110. Гупд. суз. III., LII. pух Bран. рјеч. 112. жив. 39. особнто у пјесмама: твој крнд Ст. нис. 2, 229. 260. 435. 3, 6. 45. 4, 86. 102. 149. 293. 351. 5, 67. 80. 144. тако ријеч средвега рода која је обична само у множнии налази се п међу мушина у једнини: уст Ст. пнс. 2. 225. мој уст Ст. пис. 2, 276.

Тако су онет неке ријечп мушке прелазиле међу рпјечи средњега рода: гвоздо Мрі. 142. здамено Ст. пис. $3,215$. југо Вран. рјеч. 12. пинезо Буд. 105. 109. плино Мрн. 83. 146. тудо Мрн. 119. И пзмеђу ријечи женских с основом на

- 0 евему овоме под 2. види још у мојој расправи која hе изаһн у 25. нли 26. књизи Рада југосл. академије.

2 Ірем да у други надежнма прелазе кад кад основе на ја меלу основе на чисто а, те се не мијења $о$ на $e$, опет мислим да hе у овом падежу битн какве год погрјешке : еунцо Д. Рањ. 24. нилосрдио Андр. 93. јер вите таких ирпмјера пе нађох.

3 Да би ово дошло уираво од знхмх као у Чеха јmeno од имж, не може се у ерпском језику миелити. 
і овамо је прелазила: мпдо Bран. рјеч. 71. жив. 29. такоЂер између истијех ријечи ријеч поја је обичиа само у множнни прелазила је међу ове ријечи и у једнини: јасло Вран. рјеч. 81. 122.

Ријеч средњега рода која је у обичају само у зиожини, налази се и у једнини XVI вијека: њидро Вран. рјеч. 98.

Ријеч која се сада говори и у средњем и у женском роду у множини, налази се тако двојако XVI вијека: кљпüha Вран. рјеч. 38. жив. 62. кьишће 3ор. 7.

Ријеч средњега рода тло мјесто облйкаิ једиине узима и облике миожине, код нојих hе се и споменути.

- У адјектива је као у супстантива: с основом на чисто a: ново, - с основом иа ја: туђе.

В. У женских ријечи: крајње је а у основи било дуго, за то у словенским језицима не слаби као у мушких ријетй, него само бива кратко $a$ : с основом на чисто $\mathbf{a}$ : жена́; с основом иа ја: дуииа.

Које се ријечи сврпују у овом падежу на ши и на жим оне су у старије врнјеме мјесто крајњега а имале и: сорди Дом. 55. тако у староме словенском језику и мнмостын. Како је таким ријечима донио и мјесто а, није доста протумачено; најприличније ми се чини да оне у овом падежу прелазе меלу ријечи с основом на $\mathbf{i}$ задржавајући своје $j$, па пм се меלу њима ь, које би добиле у овом падежу, једначи с тијем $j$ те постаје ", пред којим $j$ умекпава предње сугласно $н$ у ријечи михостжни, а у ријечи сордин губи се међу два ни, од којих је крајње могло гласитп в $u$ и $j$.

Између ријечи женских с основом на ја ријеч која је

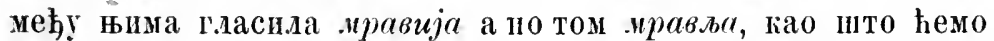
је видјети ! негим падежима, прелазила је и међу ријечи женске и мушке с осповом на $\mathbf{i}$, меңу којшма hе се споменути, а најпослије је прешла међу пушке с осповом на $\mathbf{a}$ : мали мрав lian. трам. 44. Андр. пут 313.

Ријеч вила долазила је у пјесмама п без грајњега $a$ остајући ! женском роду: онај вил Ст. пис. 2, 436. горска внл Ст. пис. 4, 127. твоја ви. СТ. пис. 5, 193. па је тако остајала и у другим падежима јед. не мијењајџи се: добре вил Ст. пис. 2,436 . ове вил Ст. пис. 2,440 . једне вил Ст. 
пис. 5, 331. њекој внл Ст. пис. 2, 436. овој внл Ст. пнс. 4, 148. вил овој Ст. ппс. 5, 192. горску внл Ст. пис. 2, 435. једну вил Ст. пис. 4, 117. вил туј Ст. пис. 5, 223. прид том вил Ст. пис. 2, 437. с драгом внл Злат. 96. тако и у множини: допле вил Ст. пис. 2,207. ове внл Ст. пис. 5, 203. драге внл Ст. пис. 5,195 . - Тако и стријела, али је она у номинат. јед. долазида и у мушком и у женском роду: стрил Ст. пис. 2,315 . стрил ки ме израни Ст. пис. 3 , 41. стрил справан Ст. пис. 4, 26. љувен стрил Ст. пис. 4, 179. стрпјел Ст. пис. 5, 46. златоперна стрил 3ор. 31б. стрид злаһена Крн. 5б. у осталијем је падежима долазила такођер без промјене али само у женском роду: ьуте стрид Ст. пис. 2,437 . својом стрнд Ст. пис. 2, 435. худом стрил Ст. пис. 2, 437. - Јамачно hе бити само тако окрњено и тисућ Ст. пис. 2, 53. и у слику : држав Ст. пис. 1, 41.

Ријечн као селе види код вокатива јед., који замјењују номинативом, али се у номинативу не налазе у изворима које употребих.

У адјектива је као у супстантива: с основом на чисто a: нова, - сосповом на ја: туђа.

III. Основе на i. Крајње је і у основи кратко, те слабеһн у словенским језицима постаје $\underline{\xi}_{2}$ а од њега ь, које староме словенском остаје а ! српском отпада:

a) у мушких рпјечи: натт, аут;

б) у женских: стмртть, сицт, тако : звијер Cт. пис. 4, 173. 5. 205. звир Хект. 22. мисао Д. Рањ. 162б. печао Н. Рањ. 204. Збор. 33. Ст. пис. 3, 20. Банд. 51. Радн. 68. пјеcall Збор. 123. Ст. пис. 5, 351. Град. дјев. 174. Гуч. 134. писан Вран. рјеч. 16. Банд. 9. шисам Хект. 15б. 3ор. 15. Банд. 89. погнию М. 252. Збор. 30б. Гуч. 199. Банд. 182. Андр. дев. 127. погнби. Јерк. 8:. свирао Ст. пис. 4, 121. тако и притач Хект. 4б. Вран. рјеч. 2. Бапд. 37. - Мең! овијем се женским ријечима палази ирешавши овамо и мрав Ст. пис. 4,86. и стран Хект. 4. - Мең! овијем је ријечима била до XVI вијека и обрв Ст. пнс. 1, 51. али се XVI вијека већ налази међу рнјечима женским с основом на а: обрва Вран. рјеч. 103.

Г'sас т иза $c$ на крају могаo се и одбацити (види напријед мушке ријечи с основом на а): кос Ст. иис. $4,307$. 
5, 128. крепос Ст. пис. 4, 297. 5, 47. Андр. дев. 159. Апјенос Андр. ден. 103. мас Ст. нис. 5, 119. свпјес Ст. пис. 4, 173. свитлос Ст. нис. 4 , 94. тако се могло т одбацити и иза самогласнога 1 : смр Ст. пис. $3,195.4,71$.

IV. Основе на сугдасно:

1. на $\varkappa$ :

a) у мушких ријечи самогласно, које је пред крајњим н у основи било кратко а а послије у словенским језицима постало $e$, с истијем крајњим $н$ шмајући за њим још наставак s, који је послије отпао, ирелази у дуго и, од којега за словенске језике бива т, а тај глас у српском језику гласи и: кими Сав. 11. М. 61. кими Стеф. 8. М. 26. 127. Н. Рањ. 56. Ст. пис. 2 , 89. 3 , 223. 4, 65. 204. 5, 35. Д. Рањ. IVб. Хект. 24б. Чубр. 9. Орб. 167. Іунд. суз. I, XV. Бун. 3. Каш. 44. Мнк. 185. пмии љет. 56. Ст. пис. 1, 49. Н. Рањ. 18. Чубр. 11б. Вран. жив. 37. прами Ст. пис. 4, 162. -- Али су таке ријечи још ! старом словенском језику прелазиле у том падежу мең! мүшке ријечи с основом на $\mathbf{i}$; по том је у нас од првијех времена и камиь М. 5. 127. камен Ст. иис. 2, 105. 4, 13.5,338. Злат. 100б. Крн. 9б. Мик. 184. пмммеи Љет. 57. пламен Ст. пис. 2, 154. 4, 7. 57. 5, 43. Злат. 1006. Вран. рјеч. 37. Орб. 166. Крн. 9б. а и не налази се другачије него тако у том падежу: коржм, „Сав. 4. корин Н. Рањ. 14. - Те су рнјечи прешавщи међу ријечи мушке с основом на $i$, опет с пима прешле $y$ српском језику меңу мушке с основом на а, како се може видјети у осталијем падежима, а прелазећи онамо ријечи иламен и ирамен могу и окрњити своју оенову одбацивши крајње сугласно и иред њим самогдасно: тако се налази од XVI вијека и плам Cт. ппс. 2, 422. 3, 467. 4, 4. 99. 5, 75. 338. Мик. 418. Андр. пут 161. прам Бун. 13.

б) у средњих речи: у њих, гако наставка није ни било, крајње сугласно у основи са предњим самогласнијем, које је такођер било п, дакле заједничко ап, прелази у словенске језике као ен, и у нима се слива у $\mathbf{A}_{2}$ које у српском језику гласи $e$ : вртме М. 555. ирнеме М. 311. нмс М. 1. раме Мак. 535. снеме М. 106. 
Рнјеч раме има од најстарнјих времена оспову и без крајњега ен као ријечп средњега рода с основом на а: р.мо Сан. 7. не само ! том надежу пего п у осталнјем: иа раму Ст. нис. 3, 283. рами свонан Ст. нис. 1, 53.

Рнјеч племе налази се и у мушком роду с цијелом основом међу ријечима с основом на а: племен Ст. пнс. 1, 220. 30p. 19. Мрн. 186.

2. на $т$ : све су ријечи с таком основом средњега рода, те пемају наставна у овом падежу, за то им крајње $т$ у оспови оставни на крају отнада; самогласпо юоје тада остаје на крају у старом је словенском језику ж, које у сриском гласи $e:$, „июете M. 329 .

С таком су основом била ! обпчај! пмена властита за људе: тако до краја XV вијека: Миде М. 240. Клмьде М. 7. Боке Г. 15, 290. Богде I. 15, 289. Бонуе I'. 15, 290 . Довре I. 15, 297. Ваде М. 190. Гакиже (Гавже, Гаоже) М. 295. 299. 320. Гр.де Г. 15, 297. Даке М. 61. Aияе Г. 15, 289. Аенуе Г. 15, 289. Аобре М. 60. 304. Жике М. 157. Жорс М. 295. Ккине М. 215. Мавре Пбб. 19. Ххинрс М. 295. Јорус М. 102. Хюке М. 564. Mate ПІб. 18. Muxe I'. 15, 290. Mnре Г. 15, 290. Mune М. 180.

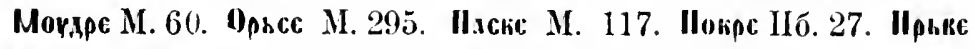
M. 59. Iprafc I'. 15, 289. Pxic I'. 15, 289. P.ure ['. 15, 227.

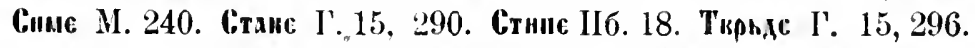
Тоне ІІб. 5. Трифе Нбб. 32. Тоңдс М. 62. Торие М. 564. Хрхие I. 15, 294. М. 564. Мке М. 180. тако јоп XVI вијека: Воре Ст. пис. 2, 392. 395. Петре Ст. иис. 5, 318. 350. Хект. 2. 35. тране Хект. 42ó. - Ова су пена још XIV иијека почела прелазити с цијелом својом основом међ! жепске рпјечи с основом на а: Ккьчет П. 20. Пкет М. 259. Ђорета Ст. IIис. 2,391 .

Ријеч кошиле налази се XVI вијека п међу ријечнма средњега рода с основом на а одбацивпи од своје основе крајње т с предњим самогласпим коннло Вран. рјеч. 67.

3. нал $c$ : ријечи с таком основом буд!һи средњега рода л за то пе пмајуһ п ! овом шадежу наставка, губе и од основе крајње $c$, а самогдаспо пред њим, које у словенским језицима ! цијелој оспови гдасп $e$ али које је постало од крат- 
пога а, оставпи на трају бива у словенским језицима о. као у ријечи средњега рода с основом на а: неб́о.

4. на $p$ : рпјечи су с таком основом женскога рода; по птто им је отпао наставак $s$, отшада за њнм и грајње сугласно $p$ од основе нанавни се па крају, а тада самогдасно за којим је било $p$ и које у словенски језццима гласи $e$ од старијега а, бива $u:{ }^{\prime}$ мати М. 39. Н. Рањ. 20. Ст. пис. 5, 95. Канг. 82. пұи М. 84. дхұн М. 415. тћи Н. Рањ. 68. кьки М. 7. кьцн М. 322. кьћн М. 373. ккн М. 386. кћн М. 425. Ст. пис. 4, 462. А. Рањ. 11. Здат. 6б. Гуч. 120. Бапд. 16. хки М. 78. хћи Ст. пис. 1, 32. 212. Н. Рањ. 26. 169. Стар. 1, 218. Д. Рањ. 122б. Зор. 8. Вран. рјеч. 36. жнв. 39. Попљедња се рнјет налази XVII внјека и с цпјелом осповом међу ријечияа с основом на і у овом падежу са свнјем пзједначена с њима, али веома ријетко: кhер Радн. 21. а налази се у исто вријеме и међу ријечпма женски с основом на а, али исто тако ријетко: хћера Крн. 90 .

5. на в: све су рнјечи с таком осповом женскога рода,

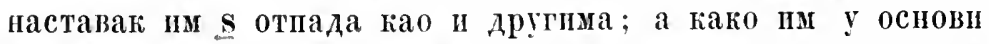
крајње в са самогласним које пред њим имају постаје од дутога и, исто дуго 1 ! овом падежу на крају предази !

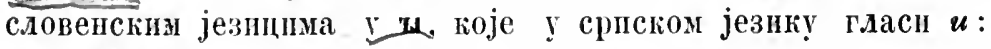
кюкы М. 5. көки Сав. стар. 4. 231. тако и XVI внјека, али рпјетко као пито је ријетко и данас: „ьубн Ст. пис. $4,469$. Чубр. 8б. тако је у старије вријеме би.о и иркм М. 112. Оваке су ријечи мог.де у том падежу шнрити основу добивајући на крају $u^{2}$ : по том је п у нас бнло јон XIV внјека и прккйи М. 60. 61. 145. џрьккм М. 122. А.и с̣ таке ријечи прелазиле међу опе с осповом на і и с њима се у том падежу са свнјем пзједначиле: тако је до краја XV вијека бпло у нас:

1 Како ту постаје $u$, није још доста протумачено; рекао бих до од заједничкога а, које се продуьује, бива дуго $\mathbf{i}$, које је у словенскпм језициа кратко $u$.

2 од куда пм то $u$, пије доста иротумачено; каво су те ријечи ирелазпле и меһу ријечи женске с основом на а, могло би то њиово « бити $у$ свези с онијем које у том падежу пмају пеке ријечи с основом на $\mathbf{a}$, п које такоһер јоп није доста протумачено. 
люььк М. 204. 302. пюкевһ М. 31. пюкавь М. 231. 275. П. 54.

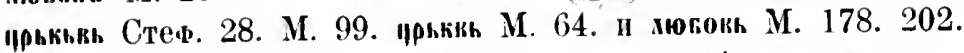
II. 8. 20. прьнокь Стеф. 15. М. 145. 533. послије се само прва ријен тако сачувала свега времена и то само на први на'пнн, т. ј. са $а$ пре в: дубав Ст. нис. 1, 122. Н. Рањ. 36б. Ст. пис. 2, 48. 3. 465. 4, 298. 5, 149. Хект. 44. Гунд. суз. I, LXXIII. Аруга је рнјеч још од XIII вијека прслазила и међу ријечи женске с основом на а, па је опдје остала и послије: ирькка М. 39. 99. и прва се па.лази мең? истијем ријечима XV вијека одбацивни $\theta$ иза $\sigma$ : жюкх II. 49. тако и послије, али $у$ данапњем зпачењу: .ьюба Хект. 6. Ччбр. 7.

\section{ГЕНИТИВ ЈЕДНИНЕ.}

Наставак је as, од којега додази и само -s, а његово -s стојећи на hрају без самогласнога за собом отнада у словенским језицима.

I. Основе на и. Крајње се и! основи шири ! aㅡ, од чега у с.иовенским језицима бива $y$ (оү), а од наставка додази само -s, liоје у словенсним језицима отпада: домон $\mathrm{M}$. 91. 140. тако joп $\mathrm{XV}$ впјека М. 438. али па свијем тијем мјестияа стоји тако шз црквенијех књита, а у сриском су језику joш од првијех времена, из којнх имамо иисапnјех споменика, све ријеяп с осповом на и пренле међу ријети с основом па а, те ! овом падеж! пмају као оне: cып М. 1. 5.

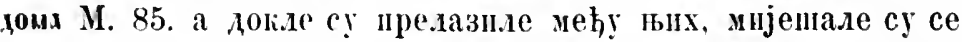
једне с друтима. те је и иа ријечи с осповом иа а прелазно облик какав је прнипчио само ријечнма с основом на и: тако још на крају XIV впјека има roқюү Пбо. 41.

II. Ocнoвe на a :

А. У ријечи мушкога и средњега рода: крајњ́е кратко a у оспови слијева се са а од наставка 5 дуто a, које у словеиским језицима бива пратко $a:{ }^{\prime}$

1 Tако Mик.1оши vergl. gram. III. 4. a III.ıjxep compend. стр. 537. 543. ве.и да је у тијем ријечима наставак -sја, пак је -sj- псна.10, тако вели особито за то ито у .итавеком језку нема у тијем ријечима $\mathrm{s}$, које се држы у другим ријечима. Aрукчије Ф. Mrısep у Revue de linguistique IV. 261. 
a) с осповом на чисто а: $a \alpha$ ) мушке ријечп: дорха М. 1. «тк М. 2. - бб) средње: рождстка М. 2. отьчиствя М. 5. ceni M. 74.

б) с основом ја: $a a)$ мүшке ријечи: (ющх М. 1. криститем М. 2. пми Стеф. 27. пятир Стеф. 23. пети (мјесто нетпја) М. 66. петја Зор. 30. - бб) средње: мокешп: М. 5. поми М. 86. морю М. 66. 82. - Иза p налази се $j$ још XIV вијека:

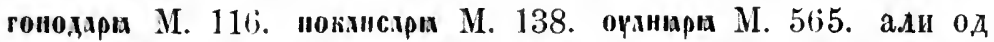
најстарнјих времена има и без њега: у муших ријечи: пхрх М. 5. 74. 90. Стеф. 10. Сав. 5. господарх М. 52. 386. 406. пастыра Сав. 6. П. 32. М. 233. покиискри М. 61. 63. 411. монхстиирх М. 79. г средњих : морл М. 10.

Између народннјех пмена, која се сада говоре без ин на крају, налази се ! старпје врнјеме са ин у овом падежу: гр кунма Стеф. 25.

Између женских ријечи с основом на ја прешавши овамо међу мушке с основом на а налазп се у овом падежу XVI вијека: мрава Ст. пис. 5, 8. тако и између женских с основом на i пренесене овамо међу средње с основом на а: мједа Збор 114. Гтч. 214. од једпога јасла Јерк. 28.

У пјесмама у слику и јамачно само тога ради налази се и као у ријечи с основом на $\mathbf{i}:$ свити Ст. пис. 5, 4. 11. 13. свијети Ст. пис. 5. 42.91.

Ријеч средњега рода т.ло осим редовпога тла Ст. пис. 1, 100. Вран. жив. 92. ияа у овом падежу и према женскпм ријечима с основом на а: тле Ст. пис. $4,127.131$. Злат. 446. 64б. 88. Види и генитив множине.

у-адјектива је за мушки и средњи род као у сушстантива: с основом на чисто а : хрнстокх М. 2. стрхиних М. 9. єегокх М. 19. пегока М. 116. 267. Град. дјев. 169. Зор. 54. Гуч. 39. господарева М. 199. госнодарова Н. Рањ. 152б. пххка М. 274. гола Н. Рањ. 46. мртва Ст. пис. 4, 451. велшка Град. дјев. 52. Злат. 74. Гуч. 106. мххх М. 19. мала (malla) Н. Рањ. $196 б$. Гуч. 3. Банд. III. пхрскх М. 161. мушка (рода и женскога) Н. Рањ. 115б. крстјанска Радој. 18. - с основом на ја: кожа М. 307. 321. Ст. пис. 1. 116. 212. Брн. 26б. Бапд. 10. векна М. 19. господих М. 11. 299. господим М. 460. 566. мн-

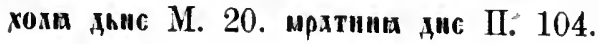


Б. У женских рнјечи: крајње је а у осповп кратко, измеһу њега и паставка -s, који послије отпада, долазп у словенским језцина r.дас $\mu$ :

a) ако је осиова на чисто а, прелази а с доданим $\mathcal{H}$ У дуго и, од којега за словенске језике бива п (као у првом

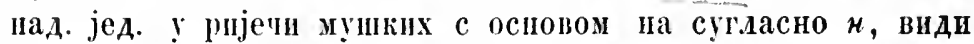
ианријед стр. 11). тако пу нашим старпјем вњнама јамачно по старом словенском језику: киднкм М. 5. гмли М. 11. көри М. 299. п у адјектива првдьтечеви М. 11. а у сриском су језику од пајстаријш времена ријечи ! којих је овака основа шзједначене ! овом падежу с рпјечима $y$ којих је осиова на ja, кано he се одмах ноказатн;

б) ако је оспова иа ја, грајње кратко а гласећи у словенским језицима о мијеша се онет предњега гдаса ради

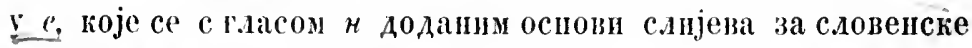
језике ! ג, које ! сриском језнку гласи $e$ : земк М. 4. zє-

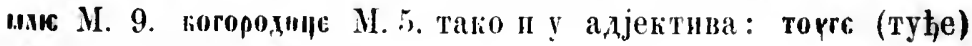
М. 60.' мєдктге М. 94.

Од рпјечи с основом иа ја пренио је у сриском језику $e$ у овом падежу и к ријеинма с осиовом па писто а замијепивни њихово т. и то о, иајстаријих времена : сих М. 2. пмк М. 2.2 и ! адјектина: пркк М. 92. ведике (ствари ии велика труда пе иптем) Г'рад. дјев 52. маде (nalle) 3.1ат. 456." - Као ито су у папем језпй рпјечи с основом на чисто а препле ! оном облику међ! ријеии с основом па ја, тако су у pyском језику a и у староме с.1овенском поньедњега иремена рпјечн с осповом на ја прен.е ! опом обаик међ! рпјечи с основом на чнсто а добнвни само " мјесто шихова и иред-

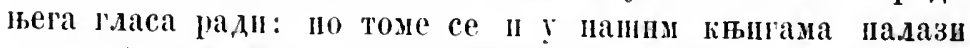
у старнје врнјеме ! овом падежу и земи М. 51.

' Наштамнано је ирь стоңге, а.ин мис.им да је с. од приједлога "zh п оламо иде.

2 Hıје генит. него је дат.: достојни сте євали Хект. 31.

" Од ирвијех је виемена овај об.ик у иридјева сажнмањем пзједначеи са сложени обликом, те се довољио пе разликују:

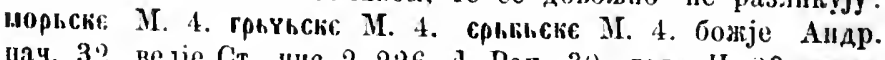
пач. 32. ве.је Ст. пис. 2, 226. Д. Рањ. 30. бомк II. 23. трете Буд. 56. Вран. јенв. 86. 
Налази се у овом падежу и Пикоми Стеф. 9. чему ће номинатив бити لнкохии" као соүдип мјесто соүдна. - A номинат. ће бити употребљен мјесто гепптива: Кмхси М. 32-33. 44. Амнтрье М. 44. - Међу ријечима жепскпм налази се у овом падежу кољепце Ст. пис. 4, 121. донце Ст. пис. 5, 102. погибије Каш. 118. и између ријечи женских с основом на $\mathbf{i}$ налази се и међу овима: сјена Андр. дев. 87. Радн. 18.

III. Основе на i. Кратко і у основи на крају пири се y ai, a то се сажима у дуго $i$, које је у словенским језицима кратко, а наставак $\mathbf{s}$ отпада; тако је сада у сриском језику у женских ријечи, а негда је било и у мушких:

а) у мущких: господи Стеф. 18. М. 562. гостн Пбо. 126. грытаин Стеф. 7. зетн М. 5. Стеф. 21. Сав. 4. поүтн М. 122. 135. 153. 264. тати М. 147. 162. Прем да овагп облик допире у XV вијек, опет су ове и оваке ријечи. од првијех времена из којих имамо писанијех споменика преш.ле међу мушке с основом на а: госнода М. 5. 10. 78. 89. Стет. 4. Сав. стар. $4,231$. госта М. 432. Н. Рањ. 34. Ст. пис. 5, 16. Збор. 39б. зетх М. 36. поүтх М. 87. 92. 127. 131. 198. Н. Рањ. 35. Ст. пис. 5, 84. Хегт. 35б. Каші. 93.' тит Зак. 41. 48. тако цреа Орб. 180. Бун. 38. Андр. пут 340. - И рпјеч дам пде међу ове ријечш, впди иод IV.

б) у женскпх : зымедн М. 2. овахстн М. 10. педн М. 20. части М. 315. чтн IIб. 26. дјеті Ст. ппп. 4, 396. Злат. 13. ратн М. 255. Ст. пис. 5, 165. погибнли Кан. 107. погибли Пос. 3б. сини Хект. 16б. - Међу овијем женским ријечима налазп се и обучаји Гунд. пс. 32. глибн Ст. пис. 5,60. добн Ст. иис. 5, 25. стиди Вран. жив. 37.

IV. Основе на сугдасно. Од наставка as, по пाто $\mathrm{s}$ на крају отшадне, а гласп у с.ловенспп језпциа $e_{\text {. }}$ тако прпстуна к основі:

a) у муниих ријечи јоп XIV и XV вијека: камене M. 131. ПІб. 74. у исто вријеме између ријечи којнма се оспова такође сврпује па сугдаспо, али юоје су још у старом словенском у самом поминатпву јед. прешле међу рпјечи с основом на і, пма кореие М. 71. 121. кортие М. 72. 317. Али јопा од XIV

' Гријеигом са ₹ мјесто а: поүтћ Стар. 4, 66. у истом споменику има и поүта Стар. 4, 65. 
вијека прелазе и тс и диуге таке ријечи у сриском језику међу мупке ријечи с осповом па а, и послије већ и нема друкијје: кменх ІІІаф. pam. 1873. 95. Н. Рањ. 56. Ст. иис. 2, 349. 5, 156. Зор. 69. Злат. 73. Гунд. суз. III. XXXIII. корешх М. 248. 249. портих М. 370. корния М. 427. корнен М. 467. Н. Рањ. 16. корепа Хект. 40. корппа Банд. 4. пламена С'т. пис. 2, 414. 5, 338. јељена Орб. 50 . Оспове иламен ирамен прелазе и тако међ! оне па а да и крајње ен одбацују XVII внјека: нлама Гунд. суз. III, XXXI. прама Гунд. суз. III, XXXI.

И рије" дан овијем падежем пде меלу ове рпјечи, те свега времена уласи : нис М. 20. 22. 47. жис М. 238. 404.450. од садањега дие Н. Рањ. 19б. ода дие Н. Рањ. 34. од дне до дие Н. Рањ. 39. пестога дне Н. Рањ. 88б. четпртога дне Ст. пис. 1, 5. прико дие Ст. пис. 3, 470. 4, 280. Град. дјев. 48. Мик. 711. прије дие Ст. пис. 5, 205. добра днс Збор. 37. ода дне Гуч. 143. од онога дне Вран. жив. 29. четвртога дие Врап. жив. 44. од дне Буд. 136. Мат. 54. ода дне до дне Банд. 31. десетога дне Бапд. 122. прија дне Мик. 56. од дие до дие ІІос. 6б. - Још у старом с.иовенском ова је ријеч као п друге с основом на сугдаспо прелазила и међу оне с основом на $\mathbf{i}$, те је и у на́с

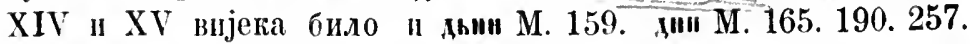
273. 302. - Али имамо јоп друкчнје: из датива и локатива јед., који су ! мунших рнјечи с осповом на і једнако гласили с генитивом јед., али су могли пред крајњнм $u$ имати ев, који су дапле и у ријечи дан могли имати ев (види код тијех падежа дан), из тијех је падежа, који су без ев били једнаки с генитивом, ирепцо ев и у генцт., да би и у томе бно једнак с њима, те од XV вијека има и одь дмимиега лиеки М. г30. поо по дпеви ІІ. Рањ. 67. дневи Ст. пис. $3,457$. од дневн судњема Град. дух. 29. дневн осмога Гуч. 86. дневи дананњега Гуч. 143. свакога дневи Орб. 10. дневи овога Кан. 67. оноға дневи Кан. 95. од диеви до дневи Андр. пут 299. - Како је ! мушких ријечи пестало генитива јед. са $u$ па крају, него оста само у женских, ваља да се за то джеви узима.ио као да је ш жепскога рода: „можемо к тому узроком овеј дневи размпслит колика се находи здоба на свијету, јере се овој сцијени да је даи оии, у који Јуда смје свога и нанега господина иродатн" Град. дух. 8. Предазеһн 
қао и друге рпјечп с основом иа сугласпо п на $\mathbf{i}$ међу оне основом на а, ова пренесе онамо пा ово своје $е в$, али тек од краја XV вијека: днева Ст. пис. 1.116. Хект. 25б. Буд. 156. Вран. жив. 25. Канг. грам. 32. Банд. 19. Мрн. 36. Г'лав. 44. а без $е в$ налази се међу ријечима с основом на а од друге половине XV впјека али много рјеђе: „их М. 525. дана Каш. грам. 32. Бун. 20. Мнк. 55. Пос. 25.

б) у средњих до краја XV впјека : кржиєие М. 35.339. II.14. 172. имене Стеф. 8. наенене М. 74. 360. 534. ІІб. 88. стиене М. 67. „ธтете II. 32. окчете Сав. 7. Жнкете М. 262. II. 147. Пб. 61. Жорете М. 337. ПI. 112. Пб. 36. 91. Монете ПІб. 23. Мркүете М. 212. Сниете ПІб. 81. НАкете М. 177. 287. II. 48. ПІб. 64. пекесе М. 220. 438. слокесе Стеф. 3. М. 161. телесе Стеф. 18. - Јоїі су у старом словенском језик! предазиле ове ријечи као и мушке међу ријечи с основом на $\mathbf{i}$; тақо је ІІ у нас било: нмєш! Стеф. 9. Сав. 2. стисни Сав. 11. скоксси М. 168. 193. остатак би од тога могао бити XVI вијека: с небеси Ст. пис. $2,111$. и одбацивни $e c$ : иеби Ст. пис. 2,441 . ади обоје може бити и ген. мн., за то ћу ондје навести вине.

Али су и ове ријечп средњега рода још од XIV вијега почеле прелазити међу ријечи с основом на а : тако XIV вијека: пхемешх М. 101. 183. иртиенх М. 215. Басета М. 158. Мншета ПГб. 34. 36. Трншетх М. 158. п послпје : врниенх М. 274. Ст. пис. 1. 99. Хект. 11б. Буд. 77. вркиєшх М. 286. ПІ. 95. Пб. 127. врјемена Н. Рањ. 25б. Ст. ппс. 2, 438. 3, 36. 371. 4, 12. Злат. 36е. Гуч. 109. времена Ст. пис. 5, 6. Д. Рањ. 39. Град. дјев. 40. брјемена (tempus) Н. Рањ. 19б. Град. дух. 3. бремена (tempus) Ст. пис. 4, 351. А. Рањ. ІХ. Бун. 40. Андр. дев. 57. бримена (onus) Ст. пис. 1, 58. брјемена (onus) Ст. пис. 2, 328. бремена (onus) Град. дјев. 44. имена Ст. пис. 1, 148. 5, 6. Хект. 34б. Крн. 6. пкеменх М.285. 303. ПІ. 147. Ібб. 86. рамена Ст. пис. 4, 91. Мик. 535. сјемена Н. Рањ. 20. симена Хект. 40. Аи,ретх II. 77. 105. 134. Марниячетх II. 49. Жниетх II. 105. 109. Кхинетх II. 105. Саметх М. 290. Пбб. 61. Сткеети II. 85. Стпетх II. 106. дјетета Ст. пнс. 4, 456. тако XVII впјека и дрвета Пос. 12б. - Којима се основа сврпује на $e c$, прелазећи меһу ријечи у којих је основа на а, одбацују крајње ес (внди датив): неба Н. Рањ. 63 . Ст. пис. 4, 212. Радн. 54. тијела Н. Рањ. 29б. 3бор. 3. Ст. пис. 3, 91. 
Град. дјев. 27. Злат. 73. тила Ст. инс. 4, 334. Буд. 86. слова Ст. пाгс. 4, 142. Хект. 9. кола (currus: враћапе се сједеће сврху кола свога. Ајел. ап. 8. 28.) II. Рањ. 1276. тако и ока Град. дјев. 48 , које је тағођер негда имало у основи на крају $e c$.

в) у женских: м.тере М. 9. Стар. 4, 75. КаІІ. 88. кћере М. 211. 495. ккре М. 358. II. 171. хһере Ст. нис. 1, 73. кһере Ст. пис. 4, 421. 439. 466. Злат. 1. Каші. 85. грам. 39. ирякке М. 64.94. лоүкке М. 3. жюбкке Стеф. 28. М. 518. пюкке М. 53. 437. ІІ. 8.82. Ст. пис. 1, 129. 193. 2, 103. Iрин. 16. Стар. 3. 323. пекюкке Стар. 3. 289. ${ }^{1}$ нрьке М. 263. Стар. 4, 134. тапіо н одбацивши в иза б: жубе Н. Рањ. 145б. Још у старом словенском све се налазе и међу опима у којих је основа па $\mathbf{i}$; $\mathbf{y}$ нас се налазе тако све осим прве и између жих најкаспије $к ћ u$ : кћери Град. дјев. 150. Радиг. 72. 100. ирьккн М. 13. 116. 134. кюкокн Пбо. 81. љубавй Н. Рањ. 191б. Ст. пис. 1, 105. 2, 136. 436. 4, 284. 301. 5, 89. 190. 3бор. 112б. А. Рањ. 66б. Хект. 7. Брн. 5б. Злат. 40б. Гуч. 7. Чубр. 5. Банд. 23. Андр. нач. 36. Пос. 29. Глав. 5. крьвн М. 255. 381. II. 82. Н. Рањ. 23б. Ст. пис. 1, 28. 3, 251. 5, 189. тако и избацивни 6 пза 6 : љуби Злат. 55б. Чубр. 10.

\section{А АТ ИВ ЈЕДНИНЕ.}

Наставак је ai.

I. Оспове на ч. Крајње се и шири у аи, које пред самогласнијем наставком гласп аv, а у словенски језицима ов; наставаг се аi сажнма у дуго i, које ! словенским језицима шостаје кратко: по томе је у старом словенском језику ст нок-и, а негда је тако бнло и у српском: смноки Стеф. 15. инровїн М. 71.

Али мјесто овога падежа додази и локатив, коме отпада наставак, те ов оставни иа грају без самогласнога за собом повраћа се y y (оү): тако је п у старом словенском језику, а у срнском је од најстарнјих времена тако II тако је остало: смноү М. 5. 75. домоү М. 9. Стеф. 23. помоү Сав. 12.

1 Према том је што се и данас гдје гдје говори, како ми писа пријатељ мој Ст. Новаковић: љубаве ти! тако ти љубаве! 


\section{II. Основе на а:}

А. У мушких п средњнх ријечн изгубио се овај падеж од најстаријих времена тако да га немају ни у старом словенском језнку од својнх основа, него су од рнјечи с основом на и прниле онакп какав само у њих може постатн, п то

1. прави датив пренесен од рпјеч с основом на и имале су и у српском језику али само у прва времена ријечи мушке с основом а) на чнсто а: ьогови Сав. 13. М. 538. лоүхокн Сав. 3. - б) на ја с промјеном гласа 0 на $e$ предњега гласа ради: минстмреки М. 6. моүжеки Стар. 4,65. У старом је словепском језику тако (прем да врдо ријетко) и у рнјечи средњега рода с основом на чисто а: змктвн, и на ја: хниекн, морюеки (Миклошић, vergl. gram. III. 34).

2. мјесто датива докатив пренесен од рнјечи с основом на и, којим се и у њих замјењује датив (внди под I), пмале су од првијех времена и послпје једнако имај! у српском језику ријечи мушке и средње:

a) с основом на чисто а: мушке ријечи: когоү Сав. 13. Стеф. 9. М. 22. паставиїкоү М. 3. грддоү М. 21. вечеру Ст. пис. 4, 104.

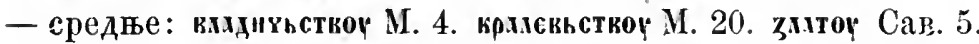

б) с основом на ја: мушке ријечн: орстрон М. 5. адрвкню М. 9. петию ПI. 159. нркхю М. 13. мхиастырю М. 10. 79. ' моүакоу М. 14. отіро М. 3. көсzв М. 7. - средње: кмдмиюю М. 2. инпосрьдно М. 5. сскнштоү М. (3.. - Иза $p$ отпада $j$ од најстаријнх времена, прем да у наведеним прнмјерима стоји: у мушких: мхихстнроү М. 6. парв М. 43. 90. господару М. 460. у средњих: мору М. 23.

y- адјектива је с основом на а и на ја за мушке и средње као и у супстантива: пєдостонноү М. 5. пеговя М. 106. Буд. 86. господарекя М. 460. дачну Ст. пис. 1, 306. мртву Ст. пис. 4, 440. тужну Ст. пис. 4, 418. бистру Д. Рањ. ІХб. кљасту Град. дјев. 79. дужну Вран. рјеч. 26. - ммогоү М. 5. сммошеств М. 101. господню М. 166. божју Ст. пис. 1, 263. Брн. 24. малу Радој. 29. велу Радој. 26.

Мјесто овакога датцва, кад се њим замијенио докатив (види даље год њега), додазио је у пјесмама али врло ри-

' Не по изговору него само по старом начину писања стојı ю мјесто оу: кехерю М. 79. ка́о и у другим прнликама. 
јетко и нрави докатив ! ријечи с основом на ја: $\mathbf{y}$ мупике ријечи изваи слика: к танци Ст. ипс. 2, 78. у средын ! слику: дици С'т. пис. 1, 288. изваи слика: срци Ст. пис. $2,104.257$.

Б. У ријечн женскога рода. Крајње је а у основи дуго, те за словенске језике постаје кратко; $с$ њим се наставак ai, nо пто се оба и сажму у једно, прелијева у словенским језицима $y$, иред којнм се $2, \kappa, x$ мијења $y$ з, $u, c$, а које се у оспова на ја мијења у и предњена гласа ради:

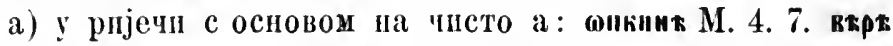
М. 20. женг М. 22. 54. сик M. 44. тако се пине још XV вијека:

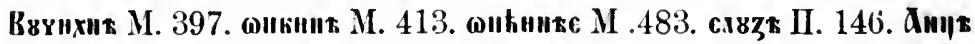
II. 111. - Aли XIV п $\mathrm{XV}$ вијека мјесто в додази но садашњем источном roвору $e$, и то не само у споменицима писаним $y$ крајевима садашњега источнога говора него и јужнога и западиога (негдје може бити за то ито се с у јужном говору чнтало као $е$, негдје за то пाто су сиоменике у крајевима јужнога и западнога говора писали ьуди који су говорили псточнијем говором или се у инсању држали источнога говора, а сврх свег'а тог'а може бити и за то што садашња три говора ошда још нијесу бпла утврђена): Мигсишс М. 518. Боснс М. 230. 239. 280. коккодс М. 238. 258. 395. конде М. 284. voivode

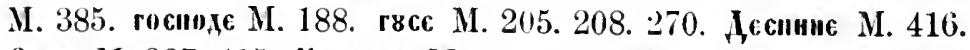
Esenc М. 387. 415. Kaталенe. М. 415. Мвџе М. 416. Мhкохе М. 421. wnkine M. 346. chopase M. 481. татіс M. 205. 208. 270. Toдope М. 415. Хсорс М. 280. - У псто вријеме додази ио садашњем западном говору и лјесто в у споменицима писанијем у крајевима садапњені не само западнога неко и јужнога говора: Анин М. 274. Боснн М. 105. 226. 247. 485. Ваддн ПI.

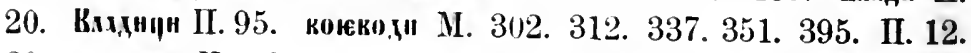

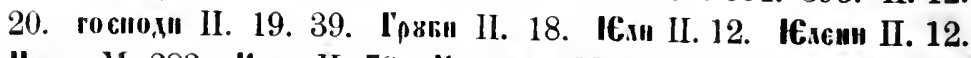
Нюд" М. 283. Кати II. 78. Кхтарини М. 519. Катекнин М. 416.

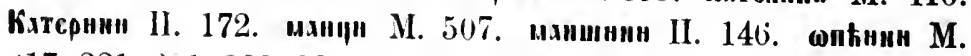
ㄴ17. 221. 301. 328. 383. 402. 420. 430. II. 105. 133. ІІб. 90. прл-

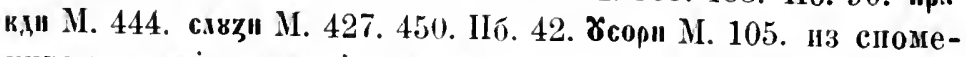
пика ппсанијех у крајевна источнога говора пмао бих само два така примјера са $и$ : кмщији М. 191. и онкни ІІб. 79. али је ! првом птамнарска погрјешка, јер у А. Аврамовића 
опис. древ. 55, одакле је споменик прештамиан, стоји мм.инґ, а други је прнијер у прнјенису писану у дубровнику. -Од почетка XVI вијека долази само са $и$ мјесто в у књигама и западнога п јужнога говора: вернзи C'т. пис. $3,136$. води Н. Рањ 139б. војсци Стар. 3, 258. Ст. пис. 4, 440. госпи Cтар. 3, 275. дјевојци Н. Рањ. 178б. Д. Рањ. 66б. женн Н. Рањ. 61б. Град. дјев. 31. зраци Град. дух. 68. књизи 3бор. 32 љепоти Град. дјев. 89. Ауци Д. Рањ. 10. мајци Збор. 121. Зор. 29б. Гуч. 22. Крн. 5б. Марн З.лат. 97б. муси Ст. нис. $4,87$. одлуци Мрн. 122. натријарци Гуч. 117. руцн Збор. 33б. слузи Н. Рањ. 118. Ст. пис. 2, 157. 5, 34. Збор. 97. А. Рањ. 17. Гуч. 187. Банд. 22. тетщи Јерк. 18. тузи Ст. иис. 4, 277. Крн. 210. Мрн. 19. Мпк. 485. худоби Град. дјев. 14.

Налазе се гутурали п непромијењени: првн је прихјер $\mathrm{XV}$ вијека, али п једнни тога времена: „скоик М. 416. а и послије је врло рнјетко: мајки Ст. пис. 1, 186. патријарки Стар. 1, 230. вонски Стар. 3, 238. 259. 276. 277. Мрн. 45. 51. арки Град. дјев. 4ti. случи 3ор. 62. Кірг. 13б. сврхи Буд. 36. Орб. 277. Мат. 10. прилики Вран. жнв. 26. туги Крн. $13 б$. Радн. 72. крстјанки Андр. пІут 361.'

б) у ријечи с основом на ја, гдје се. како је речено,

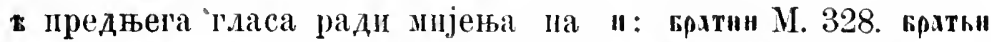
М. 185. прлтн М. 177. 302. 545. Пб. 30. Јамимиін М. 485. госпожаи М. 5. госногн М. 22. II. 24. госион М. 274. Кнтау" II. 24. Бхош"

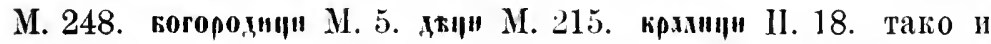
послије: братји Ст. ппс. 3, 474. Злат. 36k. zмићи (змпји) Збор. 114. госпођп З.лат. 97б. госпоји Ст. шпс. 3, 407. к!ћи Н. Рањ. 39. несрећи Ст. пис. 3, ㄴ․ дуни Н. Рањ. 44б. грјешници Ст. пис. 3, 389. дјевици Н. Рањ. 15. - On XIV вијека почиње додазити у овијех ријечи * мјесто $u$ нитега другога ради него пито су ријечи с оваком основом прелазиле међу оне с основом на чисто а: у прнијернма XIV вијека квћнирт, вм-

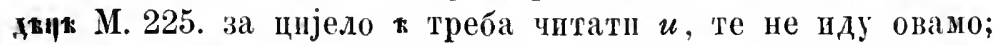
тако би се могло мислити да је и ! примјеру XV вијека

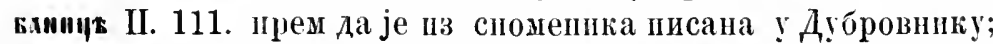
алп шма и чисто $e$, које се појављује $\mathrm{XV}$ вијека, па га пстога

' Kaшı грам. 39 вели: slugi vel sluzi. 
вијека и пестаје из овога облика :' врлтнєе ІІб. 117. врхтє М. 287. 298. 424. вратье М. 453. крхтс М. 516. 536. Екгенне II. 37. Пиинаие М. 503. 507. 508. госноге М. 387. 415. 418. Пбб. 122. госноне М. 457. 458. rocное М. 501. Рваке М. 416. „вше ПІб. 123. М. 417. богородніс М. 416. ІІб. 122. впвчние М. 415.

у адјектива до краја XV вијека држи се код основа на чнсто а онако као у супстантива а $u$ код основа на ја: с основом на чисто а : хмимьси М. 19. 225 . хмьмсін М. 225. 226. ПІб. 39. хвньсіן М. 231. 248. 385. 438. 450. 485. Кекнџћ М. 95.

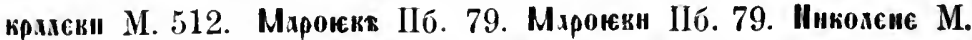
416. пегокь М. 225. Il. 19. пегоке М. 473. пстокн Шб. 34. 35. М. 464. пюгоки Пб. 96 . пегоке М. 286. 298. 424. 481. роспн М. 519. - сосноном иа ја : Стєпмн М. 93. ${ }^{2}-$ Од краја XV и свега XVI вијека долази још доста често али највппе у слику и само са $u$ код осиова на а и на ја: тужни Ст. инс. 1, 177. Пидатови 184. љувени Ст. пис. 2, 173. љути 409. пусти 412. Јакобови Н. Рањ. 39. његови 118. Јудини 163б. заручени 178 . Јобовп Ст. пис. 3, 149. бољежљиви 341. тужпи 342. поражени 339. вишњи Ст. пис. 4, 224. гиздави 440. лијени 446. малахни 420. 430. млади 425. небози 148. 149. 182. 188. несрићни 439. плачни 405. прихуди 74. 171. студени 51. 114: 147. тужни 401. 407. 411.414.419. 462. Исукрстови Збор. 122. уморни Д. Рањ. 105. Аовринчеви Хект. 44б. раскопии Зор. 10б. текући 10б. славни 10б. бистри 30. хладии 31. вегови 41. ташћи Буд. 93. очеви 126. његови Врн. 4б. 5б. Исукрстови 46. убијени 35б. осујени 23б. припрости 61. разумни 61. Пелонови Злат. 35б. немили 37. тужни Чубр. 4б. - XVII вијека већ је врло риједак овај облик: јупнтеровп Вран. жив. 26. расцвнљепп Крн. 3. мили 5б. у то ra је вријеме са свијем замијенио сложени, а да је још XVI вијека био изнемогао, види се и од туда што су га писали и гдје не треба: тој муци наклени Ст. пис. 2, 127. к тој воді студени Ст. пис. 2,51. 114. тужни овој Ст. иис. 4, 419. 457.

- Нестаје ra, јер и извора иисанијех источнијем говором нестаје међу изворима које употребих. А прелажење основа на ја меһу основе на чисто а у овом падежу налази се и у садашњвм црквеним књигама: тронц (у ијесми херувимској).

2 gnigni M. 385 за цијело је погрјешка мјесто gnigin (вију), те не иде овамо. 
И у адјектпва долази овај облшк п без промјене гутурала још прије него у сунстантива алп врло ријетко: XIII вијека : грхдскк М. 28 (три пута). XV вијека: хвиски М. 448 . н послије : драги Ст. пис 1, 45. велики 3ор. 33. к тихи води 66.

III. Oснове па i. Kрајње кратко i у основи шири се у ai, па се сажима у дуго $\mathbf{i}$, које је у словенским језнцима кратко; иза таке основе наставак ai сажет у $\mathbf{i}$ отнада:

a) у мушких рнјечи: поүтн Зак. 32. Али су мушке ријечн с таком основом још у старом словенском језику прелазиле у овом падежу међу ријечи мушке с основом на я, те су као оне пред иаставком $u$ имале $\underline{-6}$, којему су $o$ мијењале на $e$ као и ријечи с основом ја, тувајући само тијем особину своје основе: тако је бпло не само у старом словенском језику него и $\mathrm{y}$ српском до половине $\mathrm{XV}$ вијека: господеки Стеф. 2. М. 75. 88. 91. 100. поүтеки П. 169. тьстевм Дом. 203. тако још XVI вијека у ријечи дан: дневи Н. Рањ. 72. Ст. пис. 2 , 233. а то се узимало као да је и женскога рода (видн напрпјед код генптива): свакој дневи Град. дух. 8. - Алп прешавши ријечи с таком осиовом међу оне с основом на а изједначиле су се с њима и у том пाто су узеле и друго обличје које опе имају у том падежу, т. $\mathrm{j}$. које се сврпује на $y$ : и то је бивало још у старом словенском језику па је и у нашем од првијех времена, и тако је остало: госиодо Стеж. 6. 9. M. 77. зетоү Дом. 204. гостоү М. 470. Н. Рањ. 64. Збор. $39 б$. кметв М. 183. Ријеч дак прелазећи онамо задржава од XVI вијека и ев које је добнла у облику дневи, и још узима завршетак $y$ мјесто $u$ : дневу Зор. 27б. Мрн. 111. Кан. грам. 32. а-узима $y$ и без ев, и то као да му се основа свриује на ја, али само у књигама које су писане црквенијем језиком: дню Стар. 4, 77. а као ријечи с осповом на чисто а не само у књигама тако писанијем: жьоү Стар. 4, 76. него ш у књигама које су писане народнијем језиком, али тек од краја XVI вијека, а п тада врло рнјетко: дну Брн. 41 дану Каш. грам. 32.

б) у женских ријечп: уасти II. 40. меноти М. 47. рати М. 100. нарави Ст. пис. 2, 435. писни Банд. 124.

Ријеч Сом налази сс једном у овом падежу ивједначена са женским ријечима̊ у којих је основа на а: Соке М. 280. Внди још код докатива. 
IV. Основе па сугдасно. Наставак се сакима у дуто i, које је у словенски језиция кратко, и тако иристуна к основи:

a) у мунких : кимени ! старом словенском;

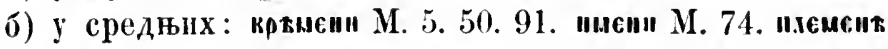
М. 49. свисин СТ. 3. - спокеси М. 122. 166. тамесп Д. 114. ую.f. сіI Дом. 32.

Рнјечи мункола и средњега с оваком основом прелазе као и мупке с основом на $\mathbf{i}$ меbу ријечи с основом на $\mathbf{a}$, па су се п оне ! овом падежу свринияле и на еви, и то од првијех времена: средње: ирғисиски С'т. 12. синсиєки М. 107.

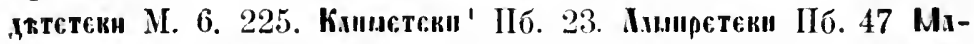
тєтеки ІІб. 18. ориорустскн М. 6. Хрьсстеки М. 53. Али то не сеже иреко XIV вијека, него од тога вијека пмај! ! овом падежу само завршетак y према рнјечима мунин с осповом на а: за мушке је потврда тек из XVI внјека: гамену Н. Рањ. 65, али за средње XIV вијека: синсив М. 106. Бісетв М. 156. Бистетю Пб. 23. Нокретв IIб. 27. Cinetв IIб. 22. Стинетв IIб. 18. Трниєтв М. 156. тако XV вијека: икенсия М. 284. 287. 290. An црств II. 49. Ннкомств II. 49. и послије: имену II. Рањ. 14. сјемену Н. Рањ 156. врјсмену Орб. 50. дјетоту Ст. нис. 4, 454. чељадету Андр.311. - Излеңу имена властптијех с основом иа ет налази се тако јоп XVI вијека: Франету Xект. 426. а по том таке ријечи мијењају оспову: тако је без крајњега ет основа на а : Іетри Ст. пис. 5. 307. 312. 318. 320. 348. - Између средњих ријечи којна се основа свршује на

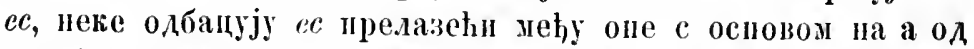
нрвијех времена: скокоу М. 9. ткиоч Сав. 5. М. 15. 44. твмо М. 10. телу Ст. пис. 1. 32. 61. тпл! Хект. 20. тијелу Орб. 158. небу Ст. пис. Б, 140. Вран. жни. 45. колу (спти: прнложи се колу овомуј. дјел. апl. 8, 29.) Н. Рањ. 127б. - Тако се без $e c$ находи жебо н онда кад као и друге рпјечи предази међу оне с основом па $\mathbf{i}:$ п пебн Ст. пис. 5 , 134. против пеби Гунд. cy3. III, LXXII.

в) у женски: матери Н. Рањ. 26. ('т. пис. 5, 121. Каш. 82. пнисри М. 416. кикери М. 54. ніћер" М. 225. Н. Рањ. 89. хккер II. 78. хћери Н. Рањ. 100б. „кери II. 172. хюккки М. 20.

' Гријешком је наштампано К.имиситекн. 
пюкки II. 18. 31. бубави Ст. ІІис. 2, 407. 4, 351. џрыккн М. 12. кркм М. 15. крвн Н. Рањ. 83б. - Налази се од XIV вијека и према ријечима с основом на а: мюькт II. 20. 36. 53. ир ьккт II. 38. прькке М. 416.

\section{АКУ САТИВ ЈЕДНИНЕ.}

Наставак је am, од којега иза самогдасних отпада а.

I. Основе на и. Од наставка додазп само $\mathbf{m}$ и $о н о$ отпада у словенским језицима, а крајње и у основц слаби у словенски језицима те постаје т, које у српском језику отпада, као у номинативу јед., код кога и примјере впди.

у ријечи које значе пито живо палазп се акусатив и незамијенен генитивом пе само у старија времена: да оүзима

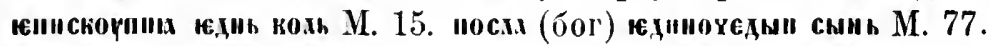
него јон XVI вијека: сншь шєдпгх Збор. 37б. Внди и код рнјечи мушких с основом на а.

II. Основе на а:

А. У мушких ријечи: од паставка долази само $\mathbf{m}$, те у словенским језицима отпада, а крајье кратко а у основи гдасећи у словенским језицпма o слабщ $\mathbf{~ т , ~ к о ј е ~ у ~ о с н о в а м а ~}$ на ја бива ц, а нза самога $;$ отнада а у српском језнку отіада свагда и т и ь, као ! номинативу јед., код кога и примјере види. - Тако је и у адјектива.

У ријечи које значе пाто жнво налаза се акусатив и и незамијењен генитивом, прем да ријетко, не само у старије врнјехе : моүам Стеф. 7. сдни нсрен оставихь сь совою Сав. 12. zа ком М. 52. него и на крају $\mathrm{XV}$ вијека: уз коњ Ст. пис. 1, 13. бијућ скот Ст. пис. 1, 148.

Неке ријечи у овом падежу с прпједлогом употребљене адвербијално долазе с доданим $a$ на крају, гоје се и иначе на крају додаје (као сада, јера): у реда (continuo) Ст. пис. 1, 175. на двора (foras) Ст. пис. 2, 497.

Б. У ријечи средњега рода: отнада у словенским језицима $\mathbf{m}$ од наставка такођер, а крајње кратко а у основп гласи у словенским језицима 0 , које у основама на ја предњега гласа ради бива $e$, ша се тако замјењује и номинатив јед., код кога и примјере внди. - Тако је п у адјектнва. 
B. У женских: наставак се $\mathbf{m}$ с крајњим а од основе слијева у ж, које у сриском јевику гласи $y:$ с основом па писто a: ктру М. 2. кннгя М. 2. - с основом на ја: земкю М. 4. причу II. Рањ. 26б. - Тако је и ! адјектива.

НІто има: из сриду срца Ст. пис. 1, 159. ту је акусатив употребљен као приједлог, те је остао и пред другнм приједлогом, као искрај (т. ј. из крај).

III. Основе на i. Наставак отпада и у мушких и у женских ријечп, а крајње $\mathbf{i}$ у оспови кратко будући слаби у словенским језицима те постаје ь, које у српском језику отпада; тако тај падеж бива једшак с номинативом јед., код кога и иримјере види.'

Ријеч даж, која се у другим падежнма колеба између рнјечи с основом на $\mathbf{i}$ и онијех с осповом иа сугласно, у овом падежу не додази у српском језпку друтачије него дннь М. 2. дан.

Између ријечи женских с оваком основом додази у овом падежу п с основом на а: пјесну Ст. пис. $5,347$.

IV. Основе на сутласно. Од наставка am отнада $\mathbf{m} \mathbf{y}$ словенским језицима, а његово а гласи у словенским језицима $e$, и тако прнстуна к основи:

a) у мунких : пияєе у старом словенском језпку; алп мушке рпјечи прелазе још у старом словенском међу ријечи с основом на $\mathbf{i}$, а ондје се ! срнском језику - буд!ћи да у њему пема разлике пзмеђу т и ь - изједначују с муниим ријечима у којих је основа на а: кммєи М. 73 . Ст. пис. 4, 72. Хект. 21. Вран. жнв. 29. пхмень Дом. 28. Ст. пис. 2, 91. 94. 5, 338. прамен Ст. пис. 4, 185. 5, 27. гремен Ст. пис. 4, 120.Уз ријечи, којнма овај падеж једнако гдаси с номпнативом јед., изједнатнле се и ове ријечи у та два надежа тако да им и прави номинатив од основа на сугдасно долазн мјесто акусатива, и то од XIV вијека кроза све вријеме: кимни M. 94. кхми М. 95. 127. Н. Рањ. 35б. 65. Ст. пиlс. 2, 89. 296. 434. 4, 27. 74. 91. 158. 5, 138. 145. 335. А. Рањ. IVб. Хект. 24б. Орб. 265. Гунд. суз. I. XLII. нламп Ст. нис. 1, 30. прами Ст. пис.

' IIIто нма нонм сь собою zети скоюro С'теф. 21 . то није акусатив него мјесто нега генитив, као ито и у других мупких ријечи, које зпаче што живо, долази гевптив мјесто акусатива. 
4, 162. а прешавши међу ријечи с основом на а налази се међу њима и с окрњеном основом, т. ј. без крајњега ен, од XVI вијека: пиам Ст. пис. :?, 366. 430. 445. 3, 469. 4, 64. 5, 339. 347. Чубр. 13б. Гунд. суз. I, XXXIV. Бунг. 5.

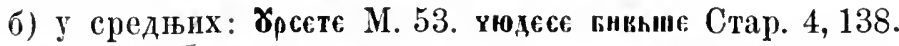
кад хотк чзитн их пекеск М. 465. - али средње ријечи долазе од првијех времена и без наставка, те им је овај падеж једнак с првијем : кржис М. 9. пеко М. 4. оүхо М. 9. За чељад додази као и у других ријечп ијесто овога падежа генитив. прелазећи као п $y$,дугим падежима међу ријечи с основом на а XIV и XV вијека: Бистетх Пбб. 9. Жорета Пбб. 37. Кхниета М. 104. Мкета П. 117. а према томе XVI вијека и дјетета (пађопе Марпју и Јосефа II дјетета постављена у јасли) Н. Рањ. 21б. Ст. пнс. 4, 444, 457. - Имена вдастита прелазе с пијелом основом п међу женске ријечи с основом на а XIV иі XV вијека: Жоретв М. 230. II. 16. Аи,ретв II. 49. Мкетв Пб. 127.

в) у женских : иттере Стар. 4, 137. - али п оне као и мушке прелазе још г старом словенском међу ријечи с основом на $\mathbf{i}$; тако је и у пас од првијех времена: матсрь Стеф. 10. М. 9. 274. Каш. 96. пьисрь Сав. 2. хһер Ст. пис. 1,84. Н. Рањ. 208. Вран. жнв. 50. Мрн. 70. кћер Н. Рањ. 165. Збор. 5б. КаІг. 95. Радн. 100. хюкоки М. 89. 158. 193. жюкьки М. 240. пюгакь М. 104. 234. 258. 306. I. 32. 56. 127. Ст. пис. 4, 297. 5, 127. Хект. 35. ${ }^{1}$ прнкокь М. 130. 531. прькики М. 10. 110. 216. Како су обје попљедње п $у$ помин. јед. прешле међу ријечи с основом на $\mathbf{i}$, те им помин. п акус. једнако гласе, с тога се првој од њих двије и прави њезпн номин. помијешао $c$ акусат. те долазп мјесто њега, али тек XVI внјека: љуби Ст. пис. 5, 173. Чубр. 4. - а обје ! овом пгдежу као и у другима предазе и међу ријечи женске с основом на а: тако од XIV внјека: жюкькя М. 217. прьккоч М. 87. 417. цркву Н. Рањ. 37б. А. Рањ. Уб. Гуч. 47.

' IIIто има zи исгокя кубх 3бор. 124. ту hе бити гријешком изостављено 6 . 


\section{В 0 КА Т ИВ ЈЕДНИН Е.}

Није правп облик, за то пема ни паставка, него је само усклик, те се основи иа крају гдас скраһује нли продужује.

I. Оспове на и. Крајњи се гдас у основи пири $\mathbf{y}$ au као и $\mathbf{y}$,дугим падежима, те у словенским језицима бива y. (or): смиоя Caз. стар. 4, 230. сыню (гријеником ю мјесто оү) М. 9. Тако се та ријеч сачувала до краја XVII вијека: сину Ст. нinc. 1. 225. 330. Н. Рањ. 20б. 30. 37. 46. 117. 165. Зóop. 32. 74. Ст. нис. 2, 343. 3. 228. 319. 334. 4, 116. 440. 5, 46. 292. Брн. 14. 21. 3.дат. 1. Гуч. 191. Врап. жив. 10. 18. Банд. 9. 27. 38. 45. Јерк. 87. 101. Кап. 121. Андр. дев. 134. пут 43. али ако се и јест тако држыла, опет се палази и као рпјечи с основом на а, и то дај буди од почетка XVII вијека, кад је пренисана књита ! којој долази: сыне Сав. 9.

II Ochoве na a :

A. У myllim pнјечн:

1. Основе на чисто а: крајње кратко а ослабивши у

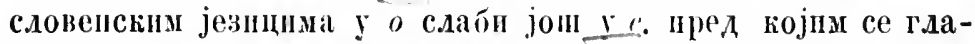
сови z, $\kappa, x$ мијењају у ж, ч. и: грақс Стеф. 26. Хект. 37б. орле Cт. пис. 4, 314. согоде Ст. пис. 4. 315. пожс М. 25. човјече $A$. Рањ. IX. синче Ст. nne. 4, 314. 318. Аnтионе Стар. 3, 301.

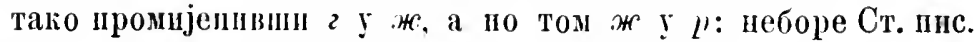
1, 9. 2, 55. 4. 317. Хеlт. 40б. 3лат. 476.

2. Основе па ја: пренле су још х старом сдовенском меңу оне па и: Крькии М. 1. Андријапу Хект. 13. мужу Хект. 346. крпжу Ст. пис. 5, 151. Андр. пут 170. краль Град. дух. 88. рхо Стеф. 26. Јурју Збор. 49. славју (номпшат. јед. славиј) Ст. нис. 3, 73. прюю М. 130. п без j пза $p$ : пррор Сав. 7. М. 126. 158. 314. 322. дикару Банд. 291. пастијеру (т. пнс. 5, 209. пастиру Бун. 29. цесару Град. дух. 89. по пито је отпало $j$ иза p, пзједначнле су се оспове у којих је таки завриетак с онима на тисто а, те се од краја XV внјека налази п онако нао у њих: цесаре Ст. пाне. 1, 219. Врап. жпв. 8. 14. царе Збор. 34. - Које у основи пред а нмајч зшди и, опе одбацујући ,j. којнм су постали ти гласовн и тако мјесто ыьих добнвни оне од којнх су постали, а то су z и $к$, пелазе међу ријечи с основом иа 
чисто а: киеке М. 1. витеже Хект. 2. пткуе М. 73. оче Н. Рањ. 26. инак се налази н славицу Ст. нис. 3, 73.

Које уз ријечи с основом на ја, које уз рнјечи с осповом на и, долазе XVI и XVII нијека доста често са "y и оне y којнх је основа на чисто a: бану Ст. пис. $4,416$. бисерј Ст. пис. 2, 351. блуду Ст. пис 4, 432. граду Хект. 376. д!ху Ст. пис. 5, 89. животу Д. Рањ. 61. Јерк. 64. Андр. дев. 28. зиду Злат. 866. кину Кан. 87. крстјаннпу Пос. 1. лијеру Андр. дев. 25. мрамору Ст. пис. 4, 118. појасу 3лат. 73б. разговору Бун. 46. Апдр. дев. 129. сануру Град. дух. 88. уресу Ст. пис. 4, 102.

3. Којима у пом. јед. крајњи глас у ослови слаб́и само у 0 , у कнх остаје тако и у овом облику : с основом на чисто a: синко Cт. пис. 4, 296. 312. 5, 120. 180. Вран. жив. 18. Анв. 24. Крн. 5б. ћаћљо Ст. пис. 4, 303. Андр. дев. 8. нач. 40 . Һајко Ст. пис. 4. 303. књего Ст. нис. 5. 332 . Аго (Агустин) С'т. нис. 5, 325. Димо Ст. пис. 5, 336. 337. Франо Ст. пис. 5, 292. с основом на ја : брајо Ст. ппс. 4, 324. 328. Хект. 6б. и кад се у основама на ја мијења у номинатнву јед. о па $е$, остаје у овом облику како је у номинативу јед.: Гююригнє Стеф. 4. Пнкомє М. 73. 109. Балд. 130.

4. У адјектива је бпло као у сунстантива: кесьмьтьне Сав. 7. прниоцокие С.Теф. 27. скете М. 115. беzияекие М. 546. али од XIV вијека налази се и номцатив јед. мјесто вокатнва: (уодоткорче) хрнстики М. 109. тако кад кад и XVI внјека у пјесмана особито у слику : приблакеп Ст. пнс. 3, 319. прндраг Ст. пнс. 3, 389. 4. 208. (боже) милостив Ст. ппс. 4, 381 (о суче) праведан С'. иис. 4, 379. али је и тада већ бно обичнији мјесто овога об.лика сложени номишат.: драги Ст. пис. 4, 381. мили Ст. нис. 4, 416. родни Злат. 3. внишн 3.лат. 18.

Б. У рнјечи средњега рода: једнако је као у номинативу : чєцо Стеф. 4. дјетеце Ст. иис. 4, 451.

Тако је и у адјектива.

В. $\mathbf{y}$ женских крајње негда дуго а у основи бива кратко, те у словенским језпцина гласп о, које се у основама на ја мијења на- $e$ предњега г.ласа ради:

а) с основом на чисто а: војеводо Хект. 13б. Андр. нач. 56. госпо Ст. пис. 1.251. 5, 116. Елизабето Гуч. 134. жено 
3лат. 60. Катарино Банд. 130. небого Злат. 74. сндо Град. дјев. 103. Сузано Ст. пис. 4, 358. Томо Збор. 29. - тако и мозо Стеф. 29. јер тој рпјечи з пе постаје од $j$ и гласа који би пред њим бно, те јој оспова иије на ја.

б) с основом на ја: крхтне М. 184. крхтне М. 247. Марије Ст. пис. 1, 227. Буд. 8. Јерк. 15. - робпње Вран. жив. 88. - госnоге II. 2. 12. 17. 103. Ст. пис. 2, 5. 4, 449. А. Рањ. 74. 3дат. 84. Апдр. пџтт 3. госпоје Ст. ппс. 3, 183. 266. 4. 359. А. Рањь. 6б. Вран. жів. 54. - песрнће Стар. 3, 271. 3ор. 24. - доршс Стеф. 11. Ст. пис. 1. 236. 5, 259. Збор. 149. Стар. 4, 113. - богородице Апдр. дев. 179. божнце Злат. 76б. братнце 3бор. 25б. дапце Ст. пис. 3,266 . диклице Ст. ппгс. 2, 114. дјевпце Ст. пис. 3, 415. 5, 44. 3Аат. 102. Гуч. 132. дивице Врап. жив. 9. Јерж. 16. кражице Ст. пис. 5, 44. Злат. 102. Јерк. 15. Апдр. пут 94. крунице Ст. пис. 2, 51. кћерце Ст. пис. 4, 411. Злат. 99. пјесапце Ст. пис. 3. 399. поглавице Збор. 100. прпјатељице Андр. пут 79. птичице Ст. пис. 4, 25. pозице Ст. пис. 2, 28. ружице Ст. пис. 2, 66. службенице Стар. 1, 221. стрелице Ст. пнс. 2, 369. царпце 3бор. 79б.

Како су у дргтим падежима (види пструментал јед.) оспове на ја прелазнде међу оне па чисто а, тако су ирелазиле и овдје, те у њих мјесто $е$ долази и $о$, и то од краја XV вијека: братјо Ст. пис. 1, 104. 119. 279. Н. Рањ. 13. 3бор. 28. Див. 3б. Њанд. 1. госпојо Каш. ІІІб. змијо Д. Рањ. 686. Марнјо Збор. 83б. Гуч. 179. Банд. 129. Џицилпјо Банд. 130. - жељо Ст. пис. 2, 110. 324. Крн. 15б. - дУњо Д. Рањ. 70б. - жеђо Ст. пис. 3, 120. - піћо Злат. 3. Банд. 38. несрећо Ст. пис. 2, 446. 4, 72. Д. Рањ. 72. песрjeћо Ст. пис. 4, 412. песрићо Ст. пис. 2. 415. Зор. 29. срсћо. А. Рањ. 98б. - хнжо Н. Рањ. 15б. - душо 3бор. 100. Ст. пис. 2, 512. 4, 413. 5, 82. Брн. 41б. Злат. 94б. Гуч. 135. Гунд. суз. II, LIV. Крн. 23б. Андр. пут 79. -.. богородпцо Кан. 121. 123. братицо 3бор. 25б. голубицо Андр. нат. 35. дпвицо Каш. 114. дје'Іпцо Ст. пис. 4, 475. кораб.ыпцо Ка пІ. 122. краљнцо Канг. 122. овцо Ст. пис. 3, 250. поглавпцо 3бор. 55. помоһницо Кап. 122. ружпцо Кап. 122. тамницо Д. Рањ. 90.

Кад кад се налази и номинатпв јед. мјесто вокатива, и то од XV вијека, како с основом на чисто а тако и на 
ја: Андрија Банд. 130. братја Ст. пис. 1, 119. Н. Рањ. $125 б$. војевода Андр. пут 175. Гојисава Ст. пис. 4,,321. Јела Злат. 63. 65. Кујача Ст. пис. 4, 329. Марпја Банд. 4. Андр. дев. 62. Гдав. 127.' Маруша Ст. иис. 5, 258. Микша Хект. 37. Николица II. 148. Сара Ст. пис. 4, 240. 248. слава Ст. пис. 2, 65. слуга Н. Рањ. 82. Тадија Банд. 130. Тома Банд. 140. хвала Ст. пис. 2, 65. - IIто још прпје има хрхіммахрнта Сав. стар. 4, 230. биће грчки облик.

У адјектива доблази номинатив јед. мјесто вокатива, и то само сложени: божја Збор. 74. немила 3.лат. 50. племенита 3лат. 84.

в) с основама које се такођер сврпгуу на ја, али у којима се $j$ не слаже с предним сугласним, него се са а, које је за њим, сажима у $е$, пред којим се самијем $x$ мијења у $u$ (Мише) и измецу кога и самогласнога које би се пред жим десило вијева ради додазп $j$ (Гоје); то бпва и у номинативу јед., ${ }^{2}$ али у изворима које унотребих долизи тако само овај облик, који се у такпх рпјечи јамачно замјењује номинативом: тако за женско: госие Ст. нис. 1, 212. 259. Кате Злат. 996. Cape Ст. пис. 4, 239. 241. 243. селе Ст. пис. 5, 207. І'оје Ст. пис. 4, 323. Кује Ст. пис. 4, 328. моје (мојемуга, т. ј. мајмун) Ст. пис. 4, 159. -- за мушко: лале Ст. пис. 4 , 325. ми.е Ст. пис. 4, 323. Мише ${ }^{3}$ С'. пис. 5, 327. ћaћe Ст. пис. 5, 293.

III. Основе на i. У жим се грајње $\mathbf{i}$ шири, те бива дуго i, које је у словенским језицияа кратко:

a) у мупких ријечи: господи М. 65 поүтн Стеф. 26. Али је тако само у најстарије врпјеме, јер како су те ријечи у другим падежпма прешле међу мушке с основом на а, прешле су и у овом, а како су се оне с основом на а мијешале у овом падежу међу оне с основом на и, тако се и између овијех помпјешанијех с онима налази у овом падежу XVI и XVII вијека и дану Злат. 28б. Пос. 436.

б) у женски : мдадости Вран. жвв. 27. радости Град. дух. 64. Андр. нут 106. сласти Ст. нис. 3, 328. смрти Ст. пис.

' Кашић грам. 37 велп: Marija vel Marije.

2 Види у мојој расправи која ће изаһи у 25. или 26. књизи Рада југосл. академије.

3 Ако није средњега рода, гоје не бих рекао. 
1, 114. дјети Н. Рањ. 127. Град. дјев. 176. дјети прилуда Ст. пnс. 4, 222. 5, 240. писми Зор. 13. 14. 60б.'

IV. Основе на сугласно :

a) у мушких ријечи: како су те рнјечи ! другим падежнма прелазиле међу ријечи с основом на $\mathbf{i}$, прелазиле су п у овом. те је у старом словенском језику: кхиєин; али како су мупке ријечи с основом на $\mathbf{i}$ у сриском језику пенле међу мушке с основом на а. пмају и ове с њима једнако: камене Гунд. суз. III, XXXVIII. Андр. нач. 46. тако и које прешпвпи онамо одбацују у основи крајње єн: п.аме Андр. нач. 47.

б) у средњих се овај падеж замјењује номинативом: Фране Хект. 426.

в) у женских се такођер' замјењује номинативом: мати 3бор. 26. кћи Н. Рањ. 87. Стар. 3, 322. хћи Н. Рањ. 169. љуби Ст. иис. 2, 477. - али како су ријечи с оваком основом шрелазиле у другим падежима међу ријети с основом на i, прешле су онамо и у овом све осим прве: тако од XVI вијека: кһери Ст. пис. 5, 113. Злат. 46. Андр. пут 222. ьубави Збор. 97б. Ст. пис. 3, 328. 4, 305. Злат. 97б. Андр. пут 25. тако и друге које су у неким падежима задржавале основу на сугдасно: крви З.лат. 64б. Андр. дев. 108.

\section{ИНСТ Р УМЕНТА Л ЈЕ ДНИНЕ.}

Два су наставlia за тај облик: дуго а, које је у словенским језицпма кратко, и bhi, којему у словенским језицима bh гласи м а $\mathbf{i}$ слаби у ь, те цио гласи мь.

I. Основе на ш. Крајње и у основи слаби у словенским језицима те постаје т, ка којему приступа наставак мь: стиъ-иь; даље види под II. A.

II. Основе на а:

А. У ријети мункога и средњега рода : крајње кратко а слаби у словенским језицима у о, које у основама на ја прелази у $e$ предњега г.ласа радп: наставак је мн: у мушких рпјечи: рлко-мк, крак-мь; - у средњих : дмо-мь, покк-мк. - Али задње самогласно у основи слаби и да.ље у старом словенском је-

' Kaшићу је грам. 41 вокатив: sladost. 
зику, те постаје т, које се у основама на ја предњега гдаса радіг мијења на ь: у мушких рнјечи: когъ-мь, отыјь-ми, у средњих : дық-мь, хныь-мь.' - На овај се пошљедњи начин основе на а изједначују с основама на $\mathbf{u}_{2}$ алн су и своје 0 тувале оне прве па како су ријети.с основом на и прелазиле у другим падежима међу ријечи с основом на а, прелазиле су и у овом, те мјесто свога п у овом падежу имају п од овиjeх о: скмо-м. Тако је у старом словенском језику. А ! срнском језику основе су се на и тако помјешале с овима на а да у овом падежу не додазе осим црквенијех књига друкчије него са $о$ на крају гред наставком: снжо-м. М. 11. а основе на а такође имају своје 0 , које у основама на ја прелази у $e$ :

a) с основама на чисто а: $a a$ ) мушке ријети: троүдомь М. 4. гладом Злат. 28. што на једном мјесту стоји станькьм М. 7., јамачно ће бити погрјешка; - бб) средње: кожкством ь М. 311. здом Хект. 28.

б) с основама на ја: $a a$ ) мушке ријечи: зпонем Зборн. 52б. Саиьдаяеми М. 236. кралем Н. Рањ. 71. Сохьжемь М. 483. ножем Н. Рањ. 103. крижем Ст. пис. 3, 320. плачем Н. Рањ. 37. Ст. пис. 4, 27. Вран. жив. 110. мачем Вран. жив. 31. мјесецем Ст. пис. 2, 71. венцем Ст. пис. 5. 349. јагањцем Град. дјев. 170. кнеземь М. 222. пмдемк Стар. 4, 84. дажјем Јерк. 70. монастырюек М. 74. посподаремь М. 469. 525. пхремь М. 242.307. 391. - бб) средње: грьмсмь М. 346. копјем Ст. пис. 3, 465. кокемь М. 20. ужем СТ. пнс. 4, 366. срьдыјеми М. 22 . криоцем Cт. пнс. $3,396$.

- Тако је било и у адјектива с основом на а и на ја за мушки и средњи род: квгарскомь М. 44. векнкоми Стар. $4,136$. 138. прькеноми Стар. 4, 84. смешеноми Стар. 4.84. махоми Пб. 129. кожнемь М. 4. 104. Али је то у самом почетку врло ријетко, него се замјењује сложеним обликом; а пто и XV вијека има божшем М. 427. то пде међу с.ложене облике замијењене прономиналним: види даље код сложенијех облика.

Основе на ја изједначују се с онима на чисто а, те мјесто редовнога $e$ имају и $0:$ у мушки ријечи које у основи

1 Миклошић vergl. gramm. III. 12. 13. 32. 
пред ја имају $p$ jom XIII вијека: паром М. 44. чешће XV

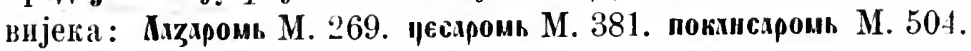
господаромя М. 527. типароми II. 127. І посдије: госнодаром Н. Рањ 27б. Хект. 27б. отаром Н. Рањ. 23. Каш. 13. Банд. 13. царом Збор. 27. Мрн. 36. Каш. 24. лонгаром Ст. пис. 3, 212. динаром Ст. пнс. 2, 432. рнбаром Радн. 89. тако пзмеђу онијех које у основ п нед а пмају з прем да је још XV вијека често києзсм. М. 289. 300. 305. 367. 377. 402., инак јон од XIV внјека долазп и кнєзомь М. 237. 288. 300. 305.341. 367. 370. 376. 382. 403. од XV вијека и птнеzомь М. 400. пнмеzомь М. 449. Радн. 61. кнтезом. М. 497. између онијех које у основи прел $а$ имају $и$, пма од XV вијека стржиоми (стрицом) М. 249. послије п у других рнјечи : братцом Ст. пис. 3 , 71. брацом Ст. пис. 4, 466. впјенцом Ст. лис. 4, 229. дијевцом Град. дјев. 170. зецом Злат. 39б. мисецом Хект. 18. Банд. IX. мјесецом Д. Рањ. 120б. соколцом Зор. 48б. судцом Г!нд. суз. предгов. танцом Ст. пнс. $2,86.5,235$. Од XVI вијека и у осталијем приликама, т. ј. кад је иред крајњим самог.дасним у основн само $j$ илп је у друте гасове сливено са предњн сугласним: бојом Вран. жнв. 66. вапајом Вран. жин. 36. знојом Пос. 21. крајом Ст. пис. 3, 17. обичајом Пос. 33. пернвојом Ст. пис. $4,343$. нокојом Ст. пис. 2, 222. 242. Гунд. суз. III, XCI. - гиљом Ст. пис. 2, 273. кораљом Ст. пис. 2, 78. прпјатељом А. Рањ. 36б. Град. дух. 43. Радн. 29. пепријатељом Злат. 41. створите.ьом Град. дух. 26. Андр. 380. Радн. 40. - воњом Град. діев. 14. Вран. жив. 66 . - мачом Гунд. суз. III, LXI. нлачом Ст. пис. 4, 27. 5, 168. Орб. 108. І'унд. пІс. 25. Гунд. суз. III, XIII. Бун. 25. - крнжом Град. дјев. 36. мужом Ст. пис. 5, 276. - мишом Д. Рањ. 79. тако и даждом Д. Рањ. 79. Злат. 66б. - У рнјечи средњега рода рјеђе прелазе основе на ја меңу оне на чисто а, п нстом од XVI впјека: копјом Ст. пис. 3, 138. 326. 350. - присто.ьом Ст. пис. 4, 362. лицом Ст. пнс. 2, 131. срцом Ст. ппс. 4, 426. Андр. дев. 26. у.ьацом Ст. пис. 3, 36. - бнтјом Радн. 42. - наслађењом Радн. 12. - Још види ниже под V с доданим $e$ на крају.

Од овога мијенања основа на ја с основама на чисто а долази те и основе на чисто а прелазе међу освове на ја, те имају у овом падежу п $e$ мјесто свога $о$, али много рјеђе, 
и то истом XVI-XVII вијека и само у мупाкх ријечи: мраморем Ст. пис. 2, 423. јадем Ст. нис. 4, 465. уздем 3ор. $66 б$. образем Андр. дев. 36. оцтем Андр. дев. 130. 161.

Између ријечи средњега рода на -нє налази се једном $\mathrm{XV}$ вијека $e$ изједначено с предњим гдасом, а но том оба $u$ сажета у једно: покемини М. 469. Види и поминатив јед.

Б. У женских су оба наставка: дуго а и ми; у основи је крајње а кратко, те у словенским језицима гдаси 0 , које у основама на ја прелази у "; до основе додази наставак и, пред који се да не буде зијева умеће $j$; иза тога наставка додазп наставағ ш, коме отияда ь, те му се $\boldsymbol{м}$ с наставком а, који је пред њим, слпјева у ж, које у српском језнку г.ласп $y^{\prime}:$ теното-ю М. 3. вратиє-ю Стеф. 2. адјектив: кожнє-ю М. 20. - Јамачно само писарском гријенком стоји ь мјесто о: ннстниьу М. 9.

Али су у српском језигу од најстаријн времена од којнх има сиоменика књижевних нзједначене у овом падежу основе на ја с онима на чисто а, не мијењајући $o$ у $e$, а изиеңу основе и наставка нзбачено је $j$, те је пза њезина самогласнога o самогласно $y$ ностало сугдасно $в:$ а) с основом на а: кқрось М. 2. 22. 36. 43. Батнновь М. 11. Бртнокь М.

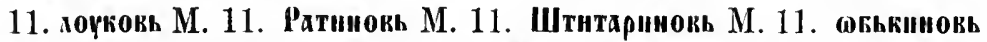
М. 19. 22. жозокь М. 20. гвсовь М. 23. шракинокь М. 23. гавовь М. 48. у адјектива којима је овај обдик изједначен са сложеним, те нема разлике: правоки М. 2. 22. 28-29. даноки М. 4. срьвьскокь М. 4. ұакхопнтокь М. 11. чрьноки М. 11. градьскокь М. 19.22. докровь М. 43. - б) с основом на ја: кококь М. 2. 22. zеикокь М. 4. покеконь М. 2. 22 . пекохокь М. 24. Струоки М. 11. у адјектива само на једном мјесту XIII впјека $e$ мјесто $o$ на крају основе: кожнєки М. 20. пначе је у њих $o$ и прије тога времена и послије: ванокь (= бањов) М. 2. кожнюкь (читај божијов) М. 4 (два пута). вожновь М. 45. 69. 70. Тако је са в само до друге половине XIII вијека.

Али од ночетка XIII вијека, дакле док је јон тако било, замјењнвало се је в гласом м јамачно једначећи се са

1 Тако ІІлајхер сотр. стр. 562-4. А Мнклошић vergl. gram. III. 6-7 мисли да је ту само први иаставак, па му се дуго a у словенским језициа замјењује гласом is. 
завриетком мушких и средыи ријечи: XIII вијека: пюкомь М. 10. Үрнновь рткомь М. 11. Үехниомь М. 11. водомь М. 17. праковь керомь М. 29. कпькиомь М. 35 . скокодомь М. 50 . ІІо том само тако до данас: a) с основом на чисто а : пканнмомь M. 111. 138. снкоиь М. 120. Фақиомь М. 180. керомь М. 208. конскомь М. 210. гакомь М. 210. госнодонь М. 210. ккетконь М. 218. посокниомь М. 230. у адјектива: поповомь М. 10 . пкрвгжомь М. 11. кралекомь М. 13. докромь верокь М. 36. старомь M. 95. малом (,mallom“) Злат. 79б. - б) с основом на ја: соүдномь М. 68. метохїоь М. 145. кепахномь М. 162. Аорояїмь М. 189. госпоюиь М. 189. госпонюмь М. 221. 236. вратномь М. 193. тефауншмь М. 222. тепауномь М. 230. 236. - кокомь М. 120 . 234. покекомь М. 217. 220. покекюмь (читај повељом) П. 74. мегомь М. 95. - двшомь М. 218. Дакншомь Пб. 34. - крахнцомь М. 60. 236. ШІтнтарнцомь М. 93. Рьжаннџомь М. 95. котоввннцомь М. 192. у адјектива псто тако: кожномь М. 209. гожьюмь М. 381. кожьющь (читај божјом) М. 453. божјом Вран. жив. 29. велјом Ст. пис. 2, 259. А. Рањ. 18б. вељом Ст. пис. 2, 195. 3, 142. 371. 4, 20. третјом Ст. пис. 2, 510. Орб. 82. третом Хект. 6. Буд. 56. Вран. жив. 92. Мрн. 45. Стар. 3, 259. магаретјом Радн. 32. већом 3лат. 5. векиом 3ор. 18. мањом Ст. пис. 1.4. лјепном Здат. 44б. славнијом Град. дјев. 160.

На једном мјесту XV вијека пма прнинстею М. 316 . које мислим за пијело да је допно од туда пто је писар, који већ пије имао ! том облику ни $e$ ни $j !$, хтно пнсати према црквеним књигама а нје знао гдје према њида треба $r$.

Стари заврпетак -оjy, од кога је на речени начни постало ов, избацивни $j$ могао се и сажети у $y$ (к чему је послије у садапюих кајкаваца још једном према другим ријечнма додано м): тако се осим -ом налази и $-y$ у једном споменику писану по свој прнлици у оном крају: вонску Стар. 3, 232. 241. 260. 268. 270. 288. 292. 299. волю 253. 261. дитцу 251. 282. заставу 272. персидском землю 268. наредбу 246-7. царицу 280.' тако јонг ! једног књижевнпка: врсту

1 Овај облик на $y$ могао је и другачије постати. У старом словепском мјесто ож има и само ж: ржкж. Миклошиһ vergl. gram. III 7. помињућп то вели да је ту к завршетку основ а дошао наставак мь, на ь отпа.ло а $\Perp$ се са $a$ слило у $љ$, 
Мат. 25. и у адјектива: ведику Стар. 3, 254. малу 233. негову 282. 324. персидску 252. Има и у друга два споменика XV и XVI вијега у адјектнва: кожню М. 359. 548. али прво мјесто инје поуздано, јер је у нотиису, па лако може битн да није добро прочитано; а друго је мјесто у нисму писану на турском двору.

III. Основе на i :

А. У мушких ријечи: крајње гратко і у основи г'даси у словенским језицима $e$, на које долази наставак мь: пжте-мь; то е у старом словенском јон слаби у $\mathbf{~}$, те има и ижть-иь. У сриском језику осим црквенијех књига није било друкчије него са $e$ : господе-мь М. 49. гладемь Стар. 4, 77. зетемь М. 62.97. крељу'тем Брн. 17. поүтемь М. 87. 123. 410. попљедња се ријеч тако одржала свега времена до данас: путем Н. Рањ. 29. Ст. пис. 1, 153. 4, 112. 341. Збор. 39б. Д. Рањ. ІХб. Хект. 39. Чубр. 13б. Вран. жив. 38. Див. Х. Кан. 15. Радн. 19. Али од XVI вијека и та рнјеч и остале изједначиле су се с онима у којих је основа на а: путом Ст. пис. 4, 115.238. 5, 165. Град. дјев. 84. Хект. 3. Зор. предгов. Буд. 67. Злат. предгов. Гуч. 307. Вран. жин. 17. Гунд. суз. II, VII. Банд. 18. Мрн. 12. Ђам. 5. Андр. дев. 8. голубом Кан. грам. 27. гостом Ст. пис. 1, 306. Н. Рањ. 43. црвом Андр. 73. - И ријеч је дан свег' времена гласлда днєм П. 111. 117. Н. Рањ. 26. 1136. Ст. пис. 1,65. 2, 181. 4, 247. Мрн. 46. а од XVI вијека има као и у другим падежима (види генит. датив) к основи додано в, па до тога в добија завршетак основа на а: дневом Хект. 10б. 46б. Банд. 29. Пос. 26. од XVII впјека долази

н да се оно старо $\boldsymbol{M}$ сачувало у српском језику. Али bе тешко бити тако, једно за то ито би се тенко у српском језику сачувало $M$, којега нема у старом словенском; друго за то пто се $\boldsymbol{м}$ може и друкчије протумачити, како је ноказано напријед; треһе што је у српском језпку $о$ пред $⿻$ дуго у женским ријечима, а у мупким је кратко, гдје управо долази $\boldsymbol{M}$ до основе; најшослије и за то што се ржьљ може и овако лротумачити : од рывоњ постало је без $j$ : ржвож, тада се о пзједначнло са и: рықљи, поје такођер има у старом словенском; најнослнје се й сане.и у једно ю. Испоредіl у Гајтлера fonol. 67. Томе старом словенском облику може одговараті у нас онај на $y$. 
и без тога в нзједначена с ријечима у којих је основа на чисто a: даном Гунд. суз. II, I. Та рпјеч долази у том падежу и као женска с основом на $\mathbf{i}$ (вщди пгод Б.) узнмајући иза основе на речени начпн в а иза њега опет као рпјечи с основом на $\mathbf{i}$ добијајући $y$ том падежу $u$ : дневи Ст. пис. 4, 242. 247. 5,340. Гуч. 279. такоме опет се налази додано $\mu$ као пто се налази и $у$ женских рнјечи: дневпм Ст. пис. 4, 247. - а од свагда је біло и као у ријечп женских даюу у значењу у ком се и данас тако говорн.

Б. у женских се крајње i у основи инри y ai, ша се сажима у дуго $\mathbf{i}$, које у словенскп језнциа постаје пратко й, а наставка додазе оба (а и мь) те се међу собом и с основом стављају онако као у женских ријечи с основом на а (вндп напрпјед под II. Б.): помөкн-ю М. 4. датню М. 12. дамню Стеф. 6. чьстню М. 168. тако јоши и XV вијека: вєстию II. 55. жамостню М. 518. микостию М. 301. пвтню М. 317. чєманю II. 31. рвхню II. 158. Јопा од XIII вијека пвбацује се $u$ : Фкмастью М. 15. XIV вијека: кмагодттю М. 133 . zапокадю Шб. 42. корнстю М. 106. пхметьо М. 217. помоцю М. 233. ревностю М. 134. тепхостю М. 134. ХV вијека: втстью ПI. 75. детю М. 259. заповдһью П. 160 . пакомостю М. 299. пхкомостью М. 342. паметю М. 519. псуатю М. 294. поноко М. 418. пртазаню М.

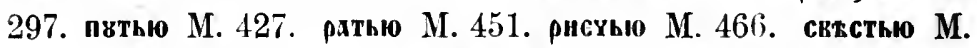
425. хнтростю М. 287. чемадью М. 286 . хекадю М. 298. тапо и до гіраја XVII вијека: болјезанју Н. Рањ. 115. болизанју Банд. 115. болесту Гуч. 169. в.ластју Н. Рањ. 32. горкостју Ст. пис. 2, 21. зучју Н. Рањ. 93. Ст. пис. 1, 200. жучју Каш. 46. кобју Здат. 86. гостју Ст. пис. 2, 112. крипостју Ст. пис. 5, 300. мндостју Ст. пис. 2, 197. Д. Рањ. 91б. Банд. 20. Каш. 84. мисалју Н. Рањ. 157б. Ст. пис. 1, 87. 3, 314. 3ор. 28б. Вран. жив. 112. мпслју Врн. 27. моһју Хект. 10б. наглостју Гуч. 14. Мик. 175. ноћју Хект. 11б. обнлностју Гуч. 21. обителју Ст. пис. 1, 71. паметју Ст. иис. 1, 100. Гуч. 146. пеһу Стар. 4, 114. помоћу д. Рањ. VIIб. путју Хект. 32б. ријечју Н. Рањ. 196. ричуу Ст. пис. 2, 25. Злат. 28б. Гуч. 32. Банд. 22. Мик. 496. Радн. 94. сјенју Н. Р’а. 44б. смртју Н. Рањ. 184. Чубр. 10. Вран. жпв. 31. Банд. 37. стварю Збор. 7. - Од друге подовине XV вијека налази се али врло ријетко $j$ од $j y$ са- 
стављено са сугласним које је пред вим по закону по ком се истина и сада саставља али по ком се је прије састављало само онда кад није нигда прије било растављено од вега гдасом $u$, прем да како се из горњих примјера види кроза све вријеме $j$ и остаје за се: скрьвмю М.518. сјењу (siegnju) Н. Рањ 162. мисаљу (misagliu) Буд. 43. 53. 64. Јамачно је само гријешком изостављено $j$ : михость М. 441.511. чељаду Буд. 59.

Од XIII вијека налази се и без $j y$, а тако һе бити постао самијем наставком а, који се са заврнетком основе i сажео у дуго $\mathbf{i}$, које је за словенске језике кратко: XIII вијека помоки М. 47. XIV вијека: овмастн М. 64. мнмостн М. 202. из XV и почетка XVI вијека не нађох ни једнога примјера, али је послије врдо обнчно: жалости Ст. пис. $2,436$. 3, 290. Злат. 94. жучи Кан. 63. заповиди Пос. 35. звири Ст. пис. 2, 429. Злат. 43б. зедени Ст. пис. 2 , 193. 3, 186. Гуч. 273. јакости Ст. пис. 3, 385. Град. дјев. 97. Гуч. г07. јесени Ст. пис. 2, 193. крјепости Ст. пис. 2, 11. 3, 389. 5, 300. А. Рањ. VIII. Злат. 84. Гуч. 120. дијености Ст. пис. 2, 47. Гуч. 289. љуб́езни Ст. шис. 2, 186. 3, 71. Злат. 41б. Каш. 42. масти Бун. 43. милости Ст. пис. $2,283.3,6$. Д. Рањ. 15б. З.лат. 44б. Гуч. 110. Ђам. 2. мисли Д. Рањ. 53б. Злат. 44. Гуч. 121. Пос. 2. младости Ст. пис. 2, 84. моћи Ст. пис. 3, 140. 5, 25. Гуч. 76. мудрости Д. Рањ. 13. Злат. 6. напасти Ст. пис. 5, 154. нарави Ст. пис. 3, 142. Злат. 23б. ноһи Злат. 66б. Гуч. 279. Бун. 43. обдасти Ст. пис. 3 , 5. Злат. 88. отрови Мрн. 20. памети Орб. 40. помоһи Ст. ппс. 5, 256. Град. дух. 8. Гуч. 12. Каш. 24. путп Ст. пис. 2, 168. А. Рањ. 7б. Гуч. 219. радости Ст. пис. 2, 115. 3, 146. А. Рањ. 145. Злат. 96. Гуч. 168. ричи Стар. 3, 315. свитлости Ст. пис. 2, 75. 3, 262. сини Ст. пис. 5, 65. сјени Гуч. 146 . сласти Ст. пис. 3, 74. сладости Ст. пис. 3,92. Д. Рањ. VII. смрти Ст. пис. $3,107$. Д. Рањ. 61. Град. дјев. 16. Іүу. 229. Див. 126. Мик. 728. ствари А. Рањ. VIIб. Злат. предгов. студени Гунд. суз. I, XV. цкврни І'рад. дјев. 63 . ћуди Ст. пис. 3, 374. части Д. Рањ. V. Злат. 21б. Гуч. 301. чељади Ст. пис. 5, 8. - Тацо се међу ријечима с основом на $\mathbf{i}$ налази и привари Гунд. пс. 14. 
lílто је тако пнструментал бно двојак, и један бно једнак с генитивом, јаманно је за то у једнога қњижевника -и пиструментал на $j y$ смијепан с гентивом те долази мјесто њега: од које иу драго стварју (-riu) Гуч. 38. 74. цјећа које стварjу (-riu) 101. ради које стварју (-riu) 106.

од XV вијека налази се овакоме обдику на и додано ", јамачно за то $А$ г би се мало изједначио с онима у којима је по закону $м$ : XV вијека: шстатнмь М. 481. 495. XVI вијека: смртим C'т. пис. 5, 73. знирим Д. Рањ. 16б. путим 7б. ричим 100. драгостим І'рад. дјев. 48. јакостим 158. корнстим 40. милостим 104. мислим 61 . наравим 11.0бластим 128. отровим 138. наметим 46. путим 46. радостим 110. смртим 137. содим 155. тихостим 153. хрлостим 87. цкврним 61. частим 167. чељадим 151. моћим Град. дух. 18. свјетдостим 25. сладостим 47. трстим 57. XVII вијека: сјеним Гунд. суз. II, XI. харностим Гунд. суз. предг. милостим Бун. 7. ијесним 21. помастим 32. смртим 20. болестим Андр. пут 38. жучим 408. јакостим 16. креностим 4. милостим 102. моһнм 16. паметим 8. помоһим 38. радостим 101. ријечим 64. свјетдости 111. частим Андр. нач. 57. испогијестим Андр. дев. 37.

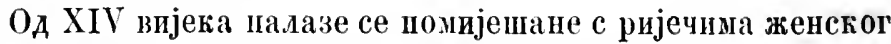
рода у којнх је оснона на а, помијешане тако да су к своме инструменталу па $u$ јоп узеле од тијех ријечи цијели заврпетак њихова инструментал -ом, пред којим знјева ради долази $j$, а по том се $u$ пред $j$ пзбацује, а тада је могло j y познатијем прнликама и пснадати: XIV внјека: чьстиомь М. 161. 164. мнхостном М. 165. рддостиоми М. 178. XV внјека: пехатномь М. 482. мнхостномь М. 523. речомь (јамачно речјом) М. 555. XVI нијека инло би овамо: завидошћом Зор. 31б. али гласова ић ради томе ће примјеру бити номнн. завндонћа. X VII внјека: исповиједјом („нспоєдюм“) Мат. 27. мисалјом („мисхюм“) Мат. 44. 67. мидостјом („мнмостюи“) Мат. 15. помоћом Мат. 37. ноһом Каш. 18. моһом Мик. 263. криностјом Глав. 42. 43. паметјом 50. помоћом 43. рнчјом 109.

Многе су са свијем прешле у овом падежу као и у другима међу женске с основом на а тако да су заврішетак основе па і одбациле: писмом 3ор. 17. тако има и: с добром 
кобом Зор. 39б. Неке су прешле меһу мушке с основом на а: дланом Ст. пис. 3, 378. сјеном Гуч. 253. Андр. 204.

IV. Основе на сугласно прелазе у овом падежу међу оне на $\mathbf{i}$; и то:

А. Мушке и средње рнјечи прелазе међу мушие с осповом і: мушпі о камемемь; - средње: пмемемь М. 59. 113. 266. 314. патиетемь М. 98. Аидретеми М. 287. Ккинетемь М. 287. Грукетемь Пб. 8. - А како су мушке ријечп с основом на $\mathbf{i}$ препле међу ријечи с основом на а тако су с њима и ове с основом на сугласно шрешле онамо:

a) мупке од XV вијека: камсмомк М. 378. Н. Рањ. 65. СТ. пис. 2, 97. 333. 410. Каші. 10. пламеном Н. Рањ. 22. Ст. пис. 1, 118. 2. 133. 333. 5, 57. тако и ријеч која се ни у номинативу јед. не налази другачије него с основом на $\mathbf{i}$ : кореном Вран. жив. 25. - Ірешавши међу оне с основом на а налазе се и без крајњега ен: прамом Ст. пाис. 4, 130. Тунд. суз. II, X. пламон (гдје се крајње $м$ промијенило на $н$, као пाто и сада по неким крајевима бива) Андр. 83.

б) средње јоіг до XIV : вртменомь II. 3. 83. 125. 144. Пбб. 126. врименом Ст. пис. 1, 8. Хект. 40. врјеменом Ст. пис. 2, 438. 4, 44. Злат. 40. временом Ст. пис. 4, 17. Див. Х. брименом Хект. 40. имсномь М. 207. 248. 431. 474. Н. Рањ. 18. Ст. пис. 1, 118. 2, 315. 4, 111. Хект. 38б. Град. дјев. 173. 3ор. 9б. Злат. 38б. Гуч. 20. Гунд. суз. предгов. Каш. 2. племеном Стар. 3, 254. Збор. 97б. Злат. 40. сјеменом Н. Рањ. 156. Гуч. 143. сименом Мрн. 97. Жоретомь ІІб. 41. Хияретюм М. 347. II. 106. Докретомь М. 304. Ккнметомь М. 347. М(омп)ретомь М. 287. лапнетом Зор. 37. тако једном у пјесми у слику и чудесом Ст. пис. 2, 49. - Основе на - $е c$ прелазе међу оне на а и окрњене, т. j. без крајњега $-\epsilon c$, и неке између њих прелазе тако од првијех времена: скокюмь М. 128. 'Ђам. 8. тххомь М. 14. Стет. 17. тијелом Н. Рањ. 131. Збор. 126б. Град. дјев. 9. Злат. 68. Радн. 63. тилом Ст. пис. 3, 416. Вран. жив. 16. небом Ст. пाнс. 4, 34.5, 178. Злат. 86. Вран. жив. 18. чудом Вран. жив. 38. Капі. 34. тако и колом (currus) Злат. 17. - Како су оваке ријечу неким падежима прелазиле међу оне с основом на $\mathbf{i}$, ријеч је небо прелазила и онамо овијем падежем одбацујући крајње -ес од основе и мијешајући се 
с онима којима се тај падеж свршује на $u$ (види напријед под III. Б.): неби Ст. пис. 2, 26. 425. 4, 455. 5, 50. 202. Д. Рањ. 3. Злат. 5. Мрн. 23.

Б. Женске прелазе међу женске с основом на i: м.хтсрню М. 13. матерью М. 283. мхтерю М. 316. Н. Рањ. 29. Збор. 9б. Буд. 59. Вран. жив. 66. Банд. 19. кћерю Збор. 45б. хћерју Вран. жиз. 78. џрьквїю М. 195. џр ькокӥю Зак. 33. поүвовню М. 3. хюкокию М. 190 . хюкокю М. 106. 134. 235 . пюковью М. 221. мювхкю М. 421. СТ. пис. 2, 54. 223. Збор. 115б. Вран. жив. 78. Крн. 3. Каш. 42. љубавьу Ст. пис. 2, 38. 192. крвју Н. Рањ. 112. Ст. иис. 1, 254. Зббор. 25б. Крн. 21б. Банд. 112. Kaшr. 13. ІІонљедње двије налазе се од XVI вијека и без jy као и остале у којих је основа на i: љубави Ст. пис. 2, 63. 87. 3, 150. 283. 307. 385. 450. А. Рањ. 1б. 75. Град. дух. 63. Злат. 2б. Гуч. 262. Чубр. 11б. Див. 39. крви Ст. пис. 3, 100. 461. 5, 14. А. Рањ. 194б. Злат. 34. І'ут. 11. Орб. 39. Див. 27. Андр. 37. и с додапим м: љубавим Ст. инс. 5, 24. Град. дјев. 15. 26. 54. дух. 36. Андр. дев. 161. крвим Ст. ицс. 4, 39б. 425. Грмд. дјев. 165. 174. Г'уч. 275. Бун. 43. Андр. пут 19. Неке добивпи овако основу на $\mathbf{i}$ предазиле су с вом као пг женске с основом на $\mathbf{i}$ меלу женске у којих је основа на a, и то од XVI вијека: күсрнон ІІІаф. pam. 1873. 112. матерјом Г'хав. 127. љубавјом („кюкикюм) Мат. 97. крвјом Гдав. 121. 125. Види напријед у овом падежу женске ријечи с осно. вом на $\mathbf{i}$.

Ірве четири рнјечи прелазе и међу оне женске којима се основа сврпчује на а, и то од XIV впјека оне двије којима се основа сврниује на в: ириквонь М. 111. 116. 134. 191. II. Рањ. 23б. пюквом М. 261. 324. 444. 457. II. 21134. Ст. пис. 1, 61. 101. 273. 2, 327. Зор. 21. Брн. 5б. избацивши в иза б: бубом Н. Рац. 221б. јметнувни $a$ међу б и в: бубавом Брн. 15. од XVI вијека и опе појима се основа сврнује на p: матером Н. Рањ. 29б. Злат. 7. Гуч. 14. Каш. 18. кћером Град. дјев 91.

V. У овом се падежу грајњему м додавало $e$ XVI и XVII вијека, кад иред и има о: у мушких: бороме Ст. пис. 2, 404. 4, 253. гробоме Бун. 52. домоме Ст. пис. 2, 490. 510. 4, 417. 471. Д. Рањ. 27. Вран. жнв. 54. Мрн. 27. јадоме Ст. пис. 
2, 455. кровоме Мрн. 154. дедоме Д. Рањ. 124. мраморкоме Чубр. 10б. Бун. 21. начиноме Д. Рањ. 144. снитоме Д. Рањ. 78б. тргоме Ст. пис. 2, 435. узломе Д. Ран. 32б. вијенцоме А. Рањ.91. норцоме Д. Рањ. 12. старцоне Д. Гањ. 39б. - у средњих: дјеломе Д. Рањ. 90. мороме Д. Г'ањ. 9б. срцоме Д. Рањ.88б. - у женских: бабоме Ст. пис. 5, 260. братјоме А. Рањ. 123. варкоме Н. Рањ. 89б. викоме 3бор. 126. вјероме Cr. пнс. 5, 95. војскоме Д. Рањ. IVб. главоме А. Рањ. 102б. Мрн. 165. гороме Ст. пис. 4, 414. 5, 19. дјецоме Ст. ппс. 4, 422. драчоме А. Рањ. 91б. душоме Ст. пис. 5, 299. त. Рањ. 14. жеЂоме А. Рањ. 20. злоћоме Ст. пис. 5,91. зороме Ст. пис. 2, 144. А. Рањ. 55. истиноле Н. Рањ. 204. Мрн. 162. кћерцоме Ст. пис. 4, 428. дажоме Ст. пис. 4, 483. молбоме Ст. пис. 5, 7. мрежоме Д. Рањ. 10б. мугоме Д. Рањ. 101. помњоме Мрн. 3. свптоме Н. Рањ. 184б. спломе Ст. пис. 5, 7. 298. Д. Рањ. 29. сјенцоме Ст. пис. 5, 316. службоме Ст. пис. 5, 17. совоме Д. Рањ. 87. тољагоме Мрн. 178. Тројоме Ст. ппс. 4, 469. тугоме Ст. пис. 4. 469. узоме Д. Рањ. 40б. химбоме С'т. пис. 4, 483. Мрн. 162. штетоме Д. Рањ. 94. - у адјектива за женски род: божјоме Ст. пис. 5, 256. Мрн. 27. великоме Злат. 1б. већоме Ст. пис. 1, 166. Д. Рањ. ІХб. вјечноме Ст. пис. 4, 391. врућоме Ст. ппс. 4, 418. горкоме Ст. пис. 2, 481. доброме Ст. пис. 5, 102. другоме Ст. пис. 2, 435. козјоме 3бор. 25б. лппоме Ст. ппс. $4,483$. људкоме Ст. пис. 4, 418. маломе Д. Рањ. 7б. мањоме Ст. пис. 5,5. жедноме Ст. пис. 3,146 . немиломе Мрн. 137. пособноме Злат. 37f. правоме Мрн. 4. притужноме Бун. 21. слишаноме Мрн. 3. тр(и)зноме Брн. 28б. турачкоме Мрн. 4. чнстоме Мрн. 4. Највише је овнјех примјера пзван слика, а доста их је и у прози.

Гдје гдје $м$ на крају г.даси $\mu$ : богон Ст. пис. $4,299$. законон Ст. пис. 4, 213. пламон Андр. 83. небон Град. дух. 50. веригон Град. дјев. 37. во.ьон Гуч. 206. Азарион Банд. 178. ноћин Крн. 7б. - у адјектива: веһон Гуч. 30. кренкон Град. дјев. 48. оби.нијон Град. дух. 47. 
ЛОКАТИВ ЈЕДНИНЕ.

Hac'rasak je i.

I. Основе на и. Крајње се и у основи шири у аи, а паставақ отнада. тада се аи немајуһи за собом самогласнога ! словенским језицияа опет сажима те гдаси y (оу): домон Стеф. 2. Сав. стар. 4, 231. М. 74. 78. помоү Стеф. ⒉ а.ди уз то још ! староме словенском језик! има и као у ријечи с основом на а; вНди под II.

II. Основе на а. у мунких, средњих и у женских завршетак а од основе и наставак i саставивши се гласе у словенским језицияа п, пред којим се гласови г. $\kappa, x$ мијевају на 3, и. $c$. а које се у основама на ја мпјења на $u$ предњега гласа ради:

A. ! мунких и средњнх:

a) с основом на 'исто а: XII и XIII вијека мушке:

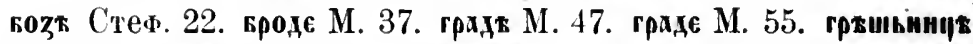

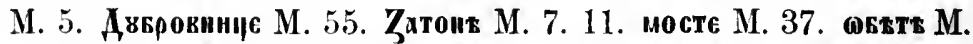
48. ПрнЗртит М. 6. Прндрене М. 55. Пртстоле М. 5. скете М. 23.

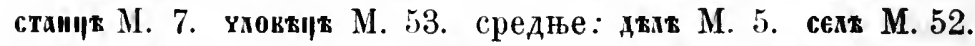
Хвостик М. 11. ХІV вијека мунике: градк М. 69. днаујс Пб. 21. Арагоскхкт М. 169. Двкровинии М. 101. 106. Двкровннит М. 185. ІІб. 22. жнкоть М. 112. жинотн ІІб. 23. конвне Пб. 25. моговет М. 169. ОБодй IIб́. 15. Прнзртин М. 135. прнестолн М. 104. Серн ІІб. 22. средње: крьд М. 154. мзстне М. 104. мтстк М. 143. Према крају тога вијека све је рјеђе тажо да се све више стеже на ријечи које су се мог.я дакие сачувати у старом обли"ју, као што су имена мјеста или ријечн које су прелази.ле нз књиге у књигу: нушке: поzе М. 201. квыс М. 216. пиквн М. 237. дворт М. 237. дворн ІІб. 39. Двкровннерн М. 243. двсн М. 233. прьстн М. 222. мнрн М. 221. мнре М. 235. скете М: 216. |алттат М. 217. средње: Авинт М. 232. месте Пб. 29. сөке М. 206. срєкрн Пб. 35. тако и ХV вијека: мушке: къцв М. 569. градт II. 94. 269. Аери II. 134. дкоре II. 160. Аверовннин М. 396. двсн М. 309. двсе М. 319. 418. Қаурн ПТ. 71. 72. Қадрт ПІ. 83. комвнн М. 416. Констандниопомк М. 525 . котарн П. 84 . котарь П. 87. крьстн М. 252. 273. 284. 290. 293. 305. ПI. 143. хнстє Пбб. 
124. мнрн М. 282. интропоонте М. 538. Ратн П. 129. рвсаzн М. 288. 336. свнтн М. 289. свттн М. 302. 346. 351. 357. Пб. 50. скети М: 365. ІІб. 116. скнетн М. 380. 384. 395. 432. ІІб. 92.109. скетн М. 473. ПІб. 57. (олаттн II. 60. Стефаны М. 268. Марнградн П. 47. Шикеннин ПІ. 40. средње: госпоџтки М. 288. господьсткк

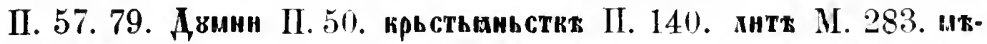

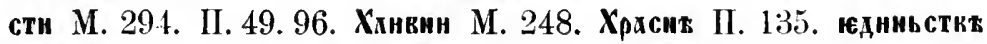
II. 155. на крају XV вијека и у почетку XVI у књигама по свој прилици преписиваним из старијих налазе се доста често: мушке: двори Стар. 3, 296. животи 263. закони 239. клобуци 267. обеди 320. сни 243. тако и у пјесмама тога времена: мушке: блуди Ст. пис. 3, 289. греби Ст. пис. 1, 65. двори Ст. пис. 1, 10. 2, 320.510. збори Ст. пнс. 1, 10. дузи Ст. пис. 1, 156. пакди С.т. пис. $2,328.3,297$. свити Ст. пис. 2, 26. свијети 3, 7. сни Ст. пис. 2, 56. 3, 150. столи Ст. пис. 1. 50. 3. 370. суди Ст. пис. 1, 161. средње: гр.ди Ст. пис. 2, 258. јутри Ст. пус. 1, 176. мисти ('т. пнс. 1.152. чели Ст. пис. 2, 36. 110.у познијим пјесмама истога (XVI) вијека све је рјеђи овај облик, и стеже се на неке ријечи (свијет. сан), тако да слабо која друга долази у том обличју. а мјесто ж додази $u$ и пјесмама које су писане јужнијем говором : двори Ст. пис. 5, 79. А. Рағ. Х. лови Зор. 30. пакли Ст. пис. 4, 13. свијети Ст. пис. 4, 18. 34 . 153. 190. 218. 297. 5, 4. 115. 124. свити Ст. пис 4, 204. 378. 444. 5, 3. 30. 230. Д. Рањ. VІб. Хект. 416. 3ор. 46. Злат. 8б. сни Ст. пис. 4, 57. 258. 5, 43.117. 182. А. Рањ. 121\%. Хегіт. 31б. 3ор. 4б. стани Хегіт. 27. столи Хект. 3б. Злат. 7. средње: јутри 3ор. 40б. Мри. 70. љети Ст. мис. 4,31. Д. Рањ. 48. мјести Злат. 30б. 37б. 96б. мести Чубр. 4. мисти Чубр. 10. т.ли Ст. пис. 3, 29. а.ди пошљедња ријеч има неке падеже (види акусатив п докатив мн.) п према ријечима с основом на $\mathbf{i}$, па јој п тај може бпти такн. А оспм пјесама од самога потетка XVI вијека једва се по која ријеч налазп у том об.иичу осим рпјечи сан: подвпзи Н. Раж. 103 (које може бити да је узето у женском роду. те не пде овамо?. впци Збор. 31б. врт.ли Брн. 66. греби Збор. 28. а сан налази се тако и у прози не само свега XVI вијека: сни Н. Рањ. 28. Збор 91. Стар. 1, 226. Град. дјев. 40. Брн. 69. него и XVII : сни Бран. жив. 19. Орб. 122. Банд. 9. 
Мат. 66. Мик. 638. осим те ријечи налазп се XVII вијека у пјесмама јоп само свити Гунд. ис. 37.

у адјектнва за мунко п средње XII і XIII вијека:

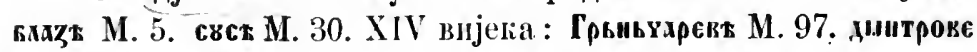

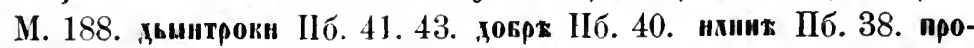
токистикарев ІІб. 23. XV вијека онако како је речено нанријед: иалк 11. 115. Попокн М. 256. пхунн М. 275. пвин М. 300. 313. 323. плтан М. 311. Хрнстекі М. 252. 273. Хрнстокн М. 256. 305. 10рюки М. 314. на грају пстога впјека или у почетку XVI а.ли у пњизи јамачно пренисаној пз старпје: Порови ('Talp. 3, 296.

б) с основом на ја: XIII вијена: мушке: отыри М. 48. манастнри М. 49. средње: срьдьюи М. 9. XIV вијека: мушке:

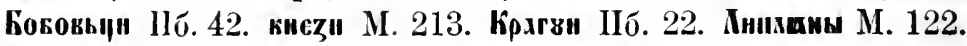
Минкаи ІІІаф. рап!. 1873. 102. монастирн М. 79. памагіорн М. 120. Үакнкн М. 97. средње: кмдаян М. 184. 247. Крапун П. 102. годмин М. 191. єканиемни М. 176. сканьћ̆емьи М. 222. Ұакрьши М. 101. морн М. 74. Норун М. 191. покн М. 64. прннорн М. 201. Скопн М. 156 . станн ІІб. 40. соүднин М. 60. Трхкнин М. 117. 146. 153. XV вијека Bobofci M. 385. Борчи М. 269. киеұи М. 268. ирєхни М. 295 . 307. прикан М. 310. 312. 314. 318. 324. 331. ПІб. 84. Ахzари М. 268. штыңн М. 309. 418. рохнтеки М. 268. царн М. 268. средње: заравни II. 79. морн М. 339. ІІб. 87. срьин М. 281. Һнин II. 176. - На крају тога вијека п.ли у почетку XVI у књизи по свој ирндпи преписаној пз старпје: кони Стар. 3.258. 277.322. Даъе се пе налази тани облик у ријечи мункога рода; пито има танци Ст. пис. 2, 77. 85. 86. 4, 111. може бити да је женскога рода с основом на а, види нанријед стр. 17. алп види јој и датив стр. 22. А средњега рода налази ce jom на крају XV или у самом почетку XVI вијека у пјесмама: мори Ст. пис. $1,153.3,164$. према.лити Ст. пис. $1,3$. срци Ст. пис. 2, 104.224. 240.426.' изван пјесама у почетку. XVI вијека само једном : вндјени Н. Рањ. 73. у другој подовини пстога вијека и $у$ пјесмама само једном! дици Зор. 45. у почетку XVII вијека само једном, и то без приједлога y речепици : годипһи деветом бише (т. ј. бјеше му девета година) Вран. жнв. 33.

' Без приједлога лок. (или дат.?) срци Ст. пис. 1, 210.258. 285. 322. 
Ријечи су с основом на ја прелазиле међу оне с основом на чисто а, те и у њих мјесто $и$ долази $\mathrm{s}$ : у мушких XV вијека: Коннів II. 102. ()ногоште II. 102. у средњих XIII вијека: морт М. 30.

У адјектива за мушки и средњи род само у овијех: XIIXIV вијека: кожін Сав. стар. 4, 231. господин М. 222. XV внјека: господин М. 293. 295. 307. 309. 310. 318. 324. 331. Пб. 84. господини М. 290. 305. 312.

Од XIII вијека почиње се овај падеж замјењивати дативом у рпјечи како с основом на а, тако и на ја, јамачно уз онее өсновом на и, којкх прави .окатив г.даск једнако с дативом овијех: тако XIII вијека: трнгоү М. 17. дмьгв М. 51. XIV вијека бива све чешћи: с основом на чисто а: у мушких: вроду М. 146. 162. Вакк8 М. 215. господння М, 215. грхду М. 62. 156. 201. ПІ. 5. Пб. 44. Аввровинкв М. 206. П. 1. законв М. 102. 170. Нzвору М. 194. крьств М. 238. кнсту М. 232. пирьгоү М. 80. Рикннкв М. 158. скету П. 1. Скадру ПІ. 2. Стефану М. 206. свду М. 206. трьгв М. 85. 120. чмокткв Пб. 37. ШІтнпоү М. 62. у средЊИХ крһду П. 7. Аунаву М. 194. кохнену М. 107. месту М. 205. нтств П. 10. - с основом на ја: у мушких: Кововыу М. 185. Гюргю М. 193. Даню М. 203. 204. адравню М. 99. Крвшекиу ПІб. 44. пару М. 206. 209. у средњих : вххданю М. 102. вкаданню М. 206. Қакрьшю М. 101. заравню II. 17. Пб. 31. нманию М. 216. морю М. 131. прнморню М. 201. 208. судннцв М. 230. спасеиї М. 126. 130. - XV впјека обкчнији је овај облик него правц локатив: с основом на чисто а: у мушких: Бвхкв М. 414. гмасв М. 288. 299. 342. госноднноү М. 271. грхд М. 302. 325. двор8 П. 35. Аввровинк8 М. 261. 290. П. 94. доркрокьчаннпоу М. 271. двху М. 366. жнвоту 478. II. 47. Қаваткв М. 281. закопв М. 112. комвну М. 298. 416. Пб. 81. котару М. 284. 289. Которв М. 446. крьсту М. 259. 261. 303. 413. жнсту М. 248. 251. поску П. 81. русагу М. 411. свнету М. 387. сктту М. 446. Пб. 70. Сококу М. 381. стхну М. 434. Стефанв М. 435. свдв М. 268. тестаменту ПI. 118. тетрагв Пб. 59. Трьноү М. 272. Шб. 61. Шарнграду П. 47. чмокткв Пб. 63. у сред-

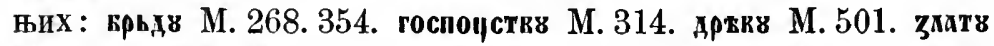
М. 386. колепв М. 258. крахекствв М. 305. мист8 М. 250. мзств М. 256. ПI. 77. прнательств8 М. 355 . секв М. 267. Смедерек8 М. 436. срекрв М. 403. - с основом на ја : у мушких Бхагаю М. 328. 
Бововив М. 398. 456. Борув М. 312. 325. 405. Қкечаю М. 283.

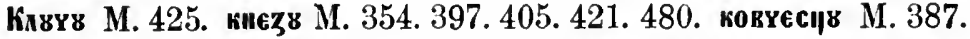
кракь М. 367. крхжв М. 276. 309. 316. крнжв М. 341. 401. 428. иєтню II. 159. бкнуаю М. 293. 310. прнатекю М. 250. роднтекю М. 435. Сепю ПІ.96. старџоү М. 279. пхроү М. 271. 354. 735. II. 47. у средњих: вхаданню ПІ. 35. М. 268. Врапув П. 102. кокю П. 149. Гроздью ПІ. 149. євамьекню М. 273. євапгекню ПІ. 107. евапгекью М. М. 293. заравью М. 43. морв М. 501. Невесняю М. 383. шгкавью М. 425. пнсаню М. 372. покю ПТ. 47. Похнџв ПІ. 112. посланью ПІ. 151. похтеню М. 289. прнморїв М. 268. прнморню М. 271. срьдыру II. 75. срыцв М. 281. станью ІІ. 90. свднцв М. 260. Трвьннв М. 256. Ћнів М. 489. - На крају XV впјека преобладао је са свијем тај облик тако да примјери напријед наведени за прави докатив из тога потоњега времена само су јоп трагови његови:' по ономе пто је напријед речено за те трагове разумије се да у истијем гњигама из којих су споменути још чешће додази датпв мјесто локатива: тако и танцу Ст. пис. 2,84. тако и у ријечи средњега рода: тлу Брн. 41б. само за ријечи свијет п сан, које су се, како је споменуто, најдуже држале у правом локативу, додаћу да у истијем књигама XV и XVI вијека долазі и свиту Ст. пис. 1, 39. 2,63. 3, 126. 5, 31. 319. Д. Рањ. IVб. Брн. 52. а сан ако и продире у XVII вијек у правом .окативу, опет у исто врпјеме има и сну Вран. жив. 39.47. 73. Кан. 93. 96.

У адјектива такође од XIII вијека: за мушко и средње с основом на а и ја: свхв М. $44 .^{2}$ XIV вијека: камову М. 102. по свху II. 12. дмнтровв ПІб. 28. XV вијека: господнвв М. 303. господну М. 316.347 .424 . господню М. 341.347 .383 .413 .456$. 471. Косоку ПТ. 47. маху М. 387. мнхолю II. 82. мегоку II. 118. хртстову М. 276. хрьстову М. 307. 431. II. 106. 107. по свхв М. 363. 410. по тапкв II. 121. Пб. 58. и послије кроза све вријеме: вегову Н. Рањ. 202б. Брн. 43б. Гуч. 47. Банд. 4. гнусну Ст. пис. 3, 79. славну Ст. пис. 3, 250. малу Ст. пис. 4, 417. докру Збор.

1 Кашиһ грам. 22 вели за локатив да га у једнини нема, него се мјесто њега говори датив.

2 Стоји с приједлогом по, те би могао бити датив, али у то вријеме долази по и с локативом у истом значењу: по свсь M. 30. за то не смета ништа мислити да је и овдје локатив. 
33. свету Град. дјев. 45. чисту Град. дјев. 45. зедену Град. дух. 12. тискну Хект. 31. крепку Буд. 126. добру Брн. 55. велику 3лат. 94. високу 3лат. 25. хитру Злат. 2. честиту Злат. 85. божју Вран. жив. 22. Давидову Банд. 11. велпку Каш. 7.

Б. У женских :

a) с основом на чисто а: XII-XIV впјека: Боснг М. 231.

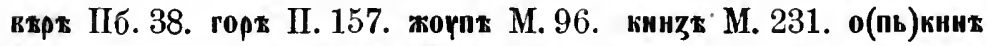
М. 7. иракдт II. 19. странж М. 7. Тару II. 22. XV вијека: Босмт

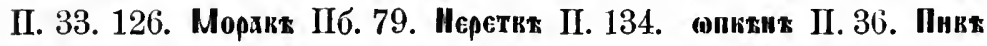

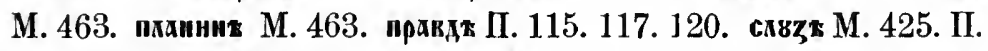
86. 146. 171. Пб. 49.52. сигртст М. 458. прем да нема сумње да није у сваком овом примјеру јужни говор него је у гдјеком само написано мјесто $e$ и мјесто $u$, опет за јужни говор имамо XV внјека: Арннте М. 544. киндне М. 465. а XIV и $\mathrm{XV}$ вијека долази и $e$ мјесто \$ онако како је речено напријед код датива: Боске М. 101.410. коқє Пб. 104. върє М.

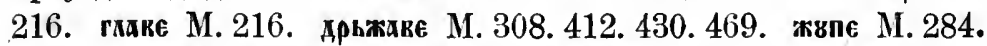
285. мание М. 268. Мораке М. 197. Ннкохе М. 261. правьде ПI. 4.

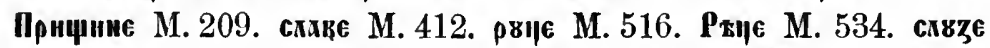
Пб. 104. 112. XVI впјека: Свчаве М. 557. трапеzะ М. 547. у нсто вријеме (XIV и XV вијека) долази и $u$ мјесто ₹ опет онако како је речено напријед код датива: Босмн М. 101. консюн М. 222. 235. втрн II. 16.22. гхаки М. 498. горн М. 301. ПI. 155. дрьжави М. 257. 312.336. ПI. 161. жвпн М. 289. 301. 302. II. 157. 176. Ұєтн М. 446.483. II. 2. кинұн М. 473. опћнян М. 283. прхвди Пб. 96. 121. равоти ІІб. 23. ртин М. 194. свнти Пб. 35. скавн М. 221. 235. 282. 300. сководн II. 17. сквзн ПI. 18. 95. Пб. 40. 85. Свтнсіџи М. 426. Пб. 37. Свторннн П. 11. пос.лије тога времена додази само $u$ у вњигама и западнога и јужнога говора (види напрнјед код датива): арци Н. Рањ. 116. Ст. пис. 4, 212. Іуч. 259. војсци Ст. пис. 1,55. 4, 415. Мрн. 59. војци (војсци) Ст. пис. 4, 440. Радој. 11. 19. 29. воћци Злат. 44б. дузи Ст. пис. 3, 291. 380. здраци С'г. пис. 4, 278. јабуци Ст. пис. 4, 210. Зор. 68. Радн. 21. јеци Бун. 21. јуси Мик. 250. њњизи Стар. 3, 237. Гуч. 81. колијепци 3бор. 2б. Бун. 47. дуци Злат. 13б. муци Н. Рањ. 135б. Ст. пнс. 2, 10. 221. 4, 94. Збор. 115. Д. Рањ. 8. нози Ст. пис. 3, 161. руци Н. Рањ. 52. Злат. 10. Вран. жив. 18. на сци (дасци) Збор. 133. сврсп Ст. пис.4,439. Орб. 304. Мик. предгов. 
снази 3лат. 75. соси Ст. пис. 4, 239. тузи Н. Рањ. 35. Ст. пас. 2, 36. 3, 265. 4, 117. 5, 307. Д. Рањ. 55. Злат. 6. Див. 5б. Андр. дев. 136. Радн. 26.

Ријетко остају гутурали непромијењени: XV вијека само пекн М. 380. XVI п XVII вијека: воиски Стар. 3, 225. 248. 257. 310. прилики Ст. пис. 5, 33. туги Ст. нис. 5, 304. дики Д. Рањ. 63. жеги Д. Рањ. 100. одлуки Буд. 148. 152. утихи Буд. 40. прилики Вран. жив. 44. реторики Вран. жив. 8. туги Крн. 18. 20. варки Бун. 8. брпги Мик. 254. книги Мик. предгов. Ауки Радн. 32. муки Радн. 3. опекн Радн. 9. војски Глав. 101.

б) с основом на ја: бдеги М. 61 . тоспогн М. 216. zеми ПГб. 81. покаун М. 387. доүшн М. 4. внекннци М. 384. вхкинци М. 473. Пб. 65. Хнининун М. 235. Үрьмьннцин М. 113. Юсемнин II. 20. - Оваке су ријечи XIV и XV вијека прелазвле међу оне с основом на а, иа су имале в (є) мјесто и: XIV впјека: деце М. 216. кекинје М. 238. 241. похауе М. 238. 241. XV вијека: канжекарне М. 463. Натокє М. 410. Ромамє М. 410. повекє М. 261. свинне М. 518. полаує М. 288. 296. 321. 348. 384. 391. 419. 431. Пб. 98. 109. Хочє Пб. 110. Ннкше М. 517. 536 . векмицє М. 288. 296. 316. 391. 419. 424. Пб. 109. внекннує М. 380. Пб. 92. Среврьннце М. 410. тканнце М. 415. Шнгинуе ПГб. 104. 124. код толиких прнмјера не треба сумњати да је тако и у овијем XV вијека прем да би могло бити да је у њима с само написано мјесто $u$ : вткмнцк М. 358. Пб. 68. Арауєвнц М. 404. ПІ. 145. Пвцшит П. 117. поковнца М. 462. Среврьмник П. 130. кнстоношт П. 69 . Бнньчх М. 263 . по паревн zемкт П. 22 . Даље нема тога. Види напријед и датив.

У адјектива се до краја XV впјека с основом на чисто а држи тај облик онако као у супстантива: срьдьяень М. 28. 33. пкьии М. 257. 381. Пб. 39. пвие М. 412. 430. 469. џркенн М. 498. кнрьин Пб. 40. чрьхени Пб. 49. 60. џькхемн Пб. 50. свноин Пб. 60. зекеии Пб. 73. ирахект М. 146. Мнхтшеве М. 334.

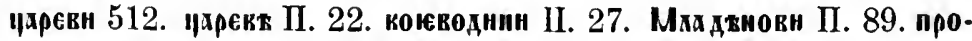
токнстнехреки Пб. 23. Юрнинин Пб. 98. негоке М. 261. 315. мегокт М. 565. П. 27. 34. 39. 41. 63. меговн П. 26. 29. ПГб. 119. с основом на ја: кожн 566 . кмежн II. 163 . такођер с основом на ја али као с осповом на тисто а (као папрнјед у супстантива) 
могло би бити : кожне М. 11. али лако може бити писарска погрјешка мјесто гожнен у сложеном облику. На крају XV вијека и свега XVI долази још доста често али само са $u$ мјесто ธ и код основа на чисто а и код основа на ја, и нонајвише у пјесмама особито у слику али не у свијех писаца: Александрови Стар. 3, 273. велици 274. висоци 300. влати 300. волуји 229. Пилатови Ст. шис. 1, 176. писани Ст. пис. $1,12$. свиони Ст. пис. 1 , 38. велици Ст. пис. 2, 505. гиздави 415. 501. горци 10. зелени 123. 505. љувени 24.132 .190 .232 .465 . пакљени 10. почтени 380. разлици 168. руси 351. трнови 340.363 . велици Н. Рањ. 180. Исукрстови 156. Јудини 174. његови 151. Абрамови Збор. 39б. велици 60. добри 3. материни 155. његови 29б. цесарови 132б. зелени Ст. пис. $3,66.192 .258 .388 .412$. 4, 52. 54. 58. 62. 100. 104. 109. 135. крвави 3, 393. очини 360. шакљени 3, 131. 279. 4, 219. студени 3, 182. 467. 4, 58. 98. 112. 144. 352. блажени Ст. пис. 4, 213. злати 113. крштени 219. љувени 218. приславни 133. славни 255 . танци 108 . црни 437. зелени Д. Рањ. 13. приљути 19. студени 126. дробни Зор. $30 б$. зелени Зор. 2б. злати 6б. незрили 70. нетлачени Зор. предгов. страшни 35. тврди 66б. исказани 66б. велици Буд. 117. добри 109. ведици Брн. 73. добри 42б. Исукрстови 19. вегови 58. сребрни 10б. свиони 10б. ташћи 67. чисти 73. XVII вијека врло ријетко: вегови Вран. жив. 49. цесарови Вран. жив. 93. били Крн. 4б. велнци Крн. 20. злати Крн. 12. огњени Гунд. пс. 45. У то га је вријеме замијенио са свијем сложени облик.

Без промјене грленпјех гласова долазе врло рпјетко адјектива, и то тек XVI вијека: велики Зор. 35. Брн. 72. плитки Зор. 35. трпіи 70.

III. Основе на i. Крајње се кратко i у основи шири y ai, oд кога постаје сажнмањем дуго $\overline{\mathbf{i}}$, које је у словенским језицима кратко, а наставак i, који би у словенским језицима могао ослабити у ь, отнада:

А. У мушких ријечи: до XV вијека: господи М. 122. пвтн М. 37. 93. 143. 162. а XV вијека, кад се је и у других мущких ријечи овај падеж у велике захјењпвао дативом, налази се и у ријечй аут мјесто овога падежа датив и то са св шред крајшим $u$ : пвтеки II. 13. 54. 151. Пб. 80. Како су оваке рпјечи у другим падежима прешле међу оне с осно- 
вом на а, тако су и у овом: ријеч аут пренавни онамо док су се датив и локатив мијешали, налази се XV вијека у локатпву од основе на чисто а али са $e в$, које је имала у дативу: пвтевь П. 157. а нмала је и прави њихов докатнв: поүтє Стар. 4, 67. таки облик а не прави докатпв од основа на і биће на крају XV п XVI вијека : пути Ст. пис. 2, 249. 4, 176. a још од XIV вијека пма и та ријеч тај облик према ријечима с основом на чисто а замијењен ьиховим дативом, какав је и у ње већ бно, п тако је остало свега времена: поүтоү М. 87. Пб. 120. Н. Рањ. 37. Збор. 91. Ст. пис. 3, 310. 4, 48. 241. 327. Ірад. дјев. 113. Вран. жнн. 46. Мрн. 73. тако и у других ријечи које су негда имале основу на $\mathbf{i}$ : лакту Гунд. суз. II, XXXVIII.

У ријечи дан било је такођер још XIV вијека као што прнличи рпјечима с основом на $\mathbf{i}$ у том падежу: дьми Пб. 28. а од XIV вијека и она је тај падеж замијенила дативом дмєкн Пб. 41. 43. М. 314. 441. тако и послије до данас: дневи Н. Рав. 71. Гуч. 277. Орб. 10. у том се обличју, т. ј. имајући у том пад. ев, помнјепала с рнјечима ! којнх је основа на а, па је најпослије добила завршетак правога њихова локатнва, и то XIV и XV вијека: дкєке М. 188. днєкне М. 312. днскх Пб. 28. 82. а посдије налазећи се међу тијем ријечима замијенила је тај падеж дативом онаким какав њима приличи: тако XVII внјека: дневу Вран. жив. 97. Банд. 20. 42. Гдав. 32. Оспм свега тога та је рнјеч јон у старом словенском језику гдасила у том падежу и дьнс (Миклошић vergl. gram. III. 53), тако се и у нас одржало свега времена: диє ПІ. 4 . 132. Н. Рањ. 13. 42. 77б. Ст. пис. 5, 58. 157. Збор. 25. 47. Град. дјев. 53. Хек'т. 20. Врн. 53. 59б. Орб. 167. Крн. 13. Гунд. суз. I, XV. Бун. 37. Каш. 83. Мик. 711. Андр. 101. ово пошљедње обличје налази се и окрњено XVI вијека с краја, без самогласнога $e$, те му је додано $a$ : онома дна Збор. 104.

Б. У женских: хти М. 46. заповнєдн М. 396. вдасти Н. Рањ. 41б. ријечй Н. Рањ. 32. писни Брн. 24. у писми од писан Врн. 236.

И женске су ријечи нагнњаде у овом падежу да пријеђу щеђу ријечи с основом на а (види и код датива женских ријечи с основом на i), те према тијем ријечима има XV 
вијека: заповєдє Пб. 98. 104. 108. заповнєдх М. 404. у пошљедњем примјеру може бити да је само нашисано мјесто $u$.

На два мјеста из XIV вијека иха заповъдв Пб. 34.36. алп за цијело мислим да је то или штампарска погрјешка и.ли је прегтсивач старо \$ 3 до читао в.

Ријеч је длан припадада некада међу ове ријечи, али је прешла међу ријечи мушкога рода с основом на а, па за цијело према њвма а не према овима пма XVI вијека длани Ст. пис. $3,126.355 .4$, 44. а у исто је вријеме према истијем ријечима и замјењивада овај падеж дативом: длану Хект. 23.

IV. Основе на сугласно. Ријечи с тијем основама још у старом словенском језику прелазе у овом пад. међу ријечи с основом на $\mathbf{i}$ :

a) мушке XII-XIV вијека: камєни М. 50. 70. 196. и између ријечи које су и у номинат. јед. прешле међу оне с основом на і : коржни Стеф. 12. Дом. 25.

б) средње: XIII вијека: колєсн Стеф. 5. некєсн М. 17. очесн Дом. 83. тасси Стеф. 22. текесн Стеф. 19. чюдесн Стеф. 24. тако може бити и ово на крају XIV вијека: Жоретн Пб. 40. а од ријечи небо налази се тако и XVI вијека небеси Стар. 1, 221. Брн. 6.

И у овијех се ријечи овај падеж замјењује дативом и то онаким какав осим редовнога може бити у мушких ријечи с основом на $\mathbf{i}$, међу које су прешле, и какав је напријед споменут и у овијех ријечи средњега рода: тако има XIV вијека мупко каменєви II. 19. у средњих се не налази тако. Али и мушке и средње од XIV вијека прелазе међу оне с основом на а, па као што оне замјењују овај падеж дативом, тако и ове мјесто докатнва имају датнв онаки какав је у онијех: a) мушке : кменя М. 131. Каш. 48. пламену Ст. пис. 3,411 . Банд. 45. тако и друге ријечи које су и у номинативу јед. прелазиле међу оне с основом на $\mathbf{i}$ : корння Пос. 20. прстену Гунд. суз. I, XLII. прешавши тако међу ријечи с основом на а надази се и без ен у основи: пламу Ст. пис. $3,60.353 .360 .454 .4,48.64 .71 .267 .-6$ ) средње: кртменв М. 337. 376. 422. пкемен М. 298. Пб. 77. тако и послије: вримену Ст. пис. 1, 26. Каш. 2. брјемену (tempus) Н. Рањ. 30 
рамену Н. Рањ. 52б. Збор. 99б. чељадету Орб. 227. дитету Каш. 20. Петрету Хект. 1. - Неке између онијех којима се основа свричје на $e c$ прелазећи међу оне с основом на а одбацују ес од првијех ремена: тако у правом локативу какав прилпчи тијем ријечима меһу које прелазе: тқх М. 43. тијели Ст. пис. 2, 292. 343. 3, 149. 303. 4, 43. 56. 122. коли Ст. пис. 2, 76. 77. 86. чуди Ст. пис. 1, 227. неби Ст. пис. 1, 226. 257. 2, 57. 3, 43. 176. 211. 406. 4, 18. 64. 74. 201. 231. 5, 86. 193. Хект. 45. Зор. 65. Брн. 56б. Гуч. 279. Гунд. пс. 44. Јерк. 25. тако и без ен: рами Ст. пис. 1,254 . а тај се правн докатив опет замјењује дативом као и у других ријечи: тијелу Н. Рањ. 296. Ст. іпгс. 3, 147. 360. 4, 70. Збор. 39. Вран. жив. 59. Орб́. 101. колу Ст. пис. 2, 86. небу Ст. пис. 3, 177. Град. дјев. 61. Вран. рјеч. 127. жив. 17. Мат. 15. раму Ст. пис. 3 , 283. 4, 83. 157. попљедњему може бити основа и на а.

Властита нмена средњег рода прелазе у овом падежу и међу женске ријечи с основом на а, као пाто чине и $\mathrm{y}$ номинативу, с цијелом својом основом: тако је XV вијека: Ћкетне М. 506. Ћкетн М. 504.

в) женске : матери Мик. 26. пюккн М. 520. Ст. пис. 2, 240. Брн. 6. с уметнутпм $a$ међу б н в: љубави Ст. пис. $1,46$. 2, 441. Н. Рањ. 210б. Хект. 44б. Брн. 27. Злат. 39б. Банд. 50. крви Н. Рањ. 106. Злат. 18. - Друга између овијех ријечи од XIII вијека прелази међу ријечи женске с основом на а: пюбьв: М. 33. повке М. 297. 355. хюквт II. 11. 20. - Тақо је и цркви Банд. 69.

\section{НОМИНАТИВ МНОЖИНЕ.}

Наставак је as, од којега s стојећи на крају отпада у словенским језицима као свако сугласно кад се деси на крају.

I. Основе на и. Крајње се и у основи шири у аu, које у словенским језнцима имајућ за собом самогласно од наставка гдасп ов, а наставак а гласи у словенским језицима $e:$ тако је било и у српском језику: сымок-е М. 59. симове 106. 215. 403. 407. 509. II. 92. ІІб. 127. сыновт М. 72. домове ПІІаф. pam. 1873.95. тако јон у првој половини XVI вијека: во- 
лове Збор. 26б. синове Н. Рањ. 26. 32. Збор. 26. 27. пошљедња ријеч у та оба извора долази тако у том облику врло често; $у$ другој половини истога вијека још само у једнога писца иста рнјеч: синове Буд. 126. Даље внди под II.

II. Основе на а:

А. У мупких ријечи: између крајњега самогласнога а у основи п наставка долази $\mathbf{i}$, с којим оно а слијевајући се у словенским језицима у слаби у $и$, за којим и а од наставка отпада, а пред којим се $2, x, x$ мијења у $3, u, c$ : тако је с основама на чисто а и на ја од најстаријих времена: а) с основом на чисто а: пртдвди М. 167. уабрн Пб. 64. векьннци М. 21. вкаси М. 24. хповзії. М. 137. 522. - б) с основом на ја: Скимыјн М. 11. свдырн М. 21. Тртвокнтнкы (-кы=ћи) М. 11. кметнкн (-ки=ћи) П. 3. - и послије тако свега времена: а) с основом на чисто а: роби Вран. жив. 74. бози Вран. жив. 80. дузи Ст. пис. 2, 364. брци Ст. пис. 5, 212. вуци Н. Рањ. 152. облаци Радн. 44. пуци Н. Рањ. 15. човјеци Збор. 37б. врси Ст. пис. 2, 427. гријеси Н. Рањ. 68б. петеси Ст. пис. 1, 82. б) с основом на ја: вапаји Кашг. 60. сужњи Ст. пис. $3,470$. 5, 161. дупежи Н. Рањ. 38. спужи Ст. ппс. 3,14 . јемачи Мик. 177. мударци Каш. 31. 38. мудраци Радн. 54. 81. парци Ст. пис. 4, 379. принлаци Радн. 67.

Врло ријетко грлени гласови стоје без промјене: у дру гој половини $\mathrm{XV}$ вијека у споменику писану на турском двору: дхьжникн М. 525. XVI вијека: дохотки Ст. пис. 1, 284. врутки Н. Рањ. 115б. чрчки Зор. 10б. XVII вијека: трги Мрн. 90. грихи Глав. 16. узроки Глав. 35.

-У адјектива је као у супстантива; а како у сложеном облику бива сажимање на крају, он се не разликује од номиналнога другачије него само акцентом у гдјекојим ријечима, за то ће међу примјерпма бити и таких у којима може бити сложени облик; акцентом се раздикује, јер је сугласно два пута написано: мали (malli) Н. Рањ. 34б. Град. дух. 80. Буд. 30. Орб. 26. - Грдени се гласови мијењају свега времена: тако до XVII впјека: вєкнцн М. 415. Ст. пігс. 5, 49. Град. дух. 40. Гүч. 33. висоци Град. дјев. 172. глуси Н. Рањ. 14. горсци Ст. пис. 3, 102. градыңн М. 39. дрази Н. Рањ. 59. Ст. пис. 3, 26. 439. 4, 30. Д. Рањ. 114. дрвъи М. 386. 545. Н. 
Рањ. 127. Збор. 13. Ст. пис. 5, 293. А. Рањ. 26. І'рад. дјев. 165. Гуч. 53. двкровауџн М. 102. 481. дузи С'. пис. 4, 399. Зор. 31б. иин М. 182. Збор. 122б. Ст. пис. 5, 129. кракевсін М. 14. кратци Злат. 96. краци Град. дјев. 181. кротци Гуч. 252. крстјансци Ст. шис. 3, 418. крхпцн М. 236. жубци Д. Рањ. 1146. мнозн М. 465. Н. Рањ. 15. С'т. пис. 1, 106. 3, 430. 4, 116. 5, 10. 146. Хект. 17б. Зор. 70. Злат. 9. Гуч. 3. Буд. 44. мвшци Шб. 65. нази СТ. пис. 4,51 . пласи Злат. 17б. поповьсци М. 98. разлици Ст. пис. 5, 49. Гуч. 3. рајсци Ст. пис. 3,422 , ријетци Ст. пис. 3, 276. рвсахшін М. 470. слаци Д. Рањ. 114б. свсп Збор. 52б. Ст. пис. 3. 30. оүвозн М. 15. Н. Рањ. 14. Ст. пис. 1, 106. ххьмьрн М. 45. ираьсрн М. 221. и свега XVII вијека: ведици Вран. жив. 39. Див. 31б. Банд. IV. Андр. 328. висоци Орб. 42. глуси Вран. жив. 114. дрази Див. 28б. Гунд. суз. II, X VIII. друзи Вран. жив. 104. Банд. IV. Гунд. суз. I, LXV. пс. 43. Мрн. 8. Радн. 40. двън Мат. 7. јаци Пос. 3б. једнаци Радн. 41. мнози Див. 31. Банд. IV. Мрн. 178. Каш. 39. Мик. 260. Андр. 7. Радн. 31. нази Орб. 284. разлици Гунд. ис. 43. Ђам. 4. сдаци Гунд. суз.'II, XVIII. слатци Орб. 32. тешци Андр. 328. вкозн Див. 36б. - Од XIII вијека долази и без промјене грлених гласова али ријетко: XIII вијека: шпькньски М. 39. ХIV-XV вијека: дввровьчкн М. 193. 478. 484. 516. 525. пхрьскн М. 438. 486. на крају XV и свега XVI вијека: горки Ст. пис. 2, 398. други Н. Рањ. 92. земаљски Град. дјев. 19. кротки Ст. пис. 4, 112. небески І'рад. дјев. 50. Зор. 54б. тихи Ст. пис. 4, 108. XVII вијека: велики Радн. 40. драги Радн. 10. други Орб. 57. дубоки Орб. 42. многи Радн. 10. сухи Радн. 22.

Али су се супстантива с основом на а помијешада c онима у којих је основа на и, те је $у$ њих било у овом падежу и онако као у онијех с основом на $\mathbf{u}$, као да је и у жих основа на и (впди под I): тако је у нас бвло од првијех времена до краја XV вијека: врагокв ( читај $e$ ) M. 35. попоке М. 98. 565. съдоке (vasa) М. 372. сьтоке ДОо. 109. тригоке М. 206. 209. 271. џкттове Стеф. 29. на крају XV и свега XVI вијека у пјесмама јоп доста често, али опет не у свијех писаца: валове С'т. пис. $1,153.3,125.164$. Хект. 46. вукове Ст. пис. 3,234 . градове Ст. пис. 3,285 . громове Ст. иис. $3,162$. 
јадове Ст. 3, 172. 470. 4, 203. давове Ст. пис. 1, 245. лугове Ст. пис. 4, 261. орлове Ст. пис. 3, 137. попове Ст. пис. $1,19$. 71. 84. 85. 243. столове Ст. пис. 1, 84. тријескове Ст. пис. 3, 162. Злат. 19б. изван пјесама од самога піочетка тога вијека врло ријетко: гробове Н. Рањ. 94. лавове Стар. 3, 253. попове Н. Рањ. 37б. Збор. 26. 27. Стар. 4, 116. Буд. 151. тако и с основом на ја, гдје се предњега гласа ради мијења ов на $e \theta: \mathrm{XV}$ вијека мвжєвє М. 465. и без промјене гласа o у $e$ иза з XIV вијека: кмеzоке М. 160. тако још и XV и XVI вијека: кнезове Ст. пис. 1, 41. 3, 210 - Види јон код вокатива мн. - Овај облик са $e$ на крају не прелази преко XVI вијека.

Али номинатив мн. на -ове и од основа на а и од онијех на $n$ губп своје $e$ на крају, па мјесто њега добщја $u$ од номинатива мн. који постаје начином показаним од основа на а не помијешаних с основама на $\mathbf{u}$; тако се тај облик од основа на и и од основа на а саставља у једно: од првога се узима цијели завршетак основе (ов ностало од и), који прелази и у основе на а, а од другога завршетак вегов, који га чини тпјем обликом; то се и у основа на а и у основа на и јавља још XIV вијека, прем да ријетко: с основом на a : поповы М. 122. и с основом на и: сннокн М. 240. ријетко је још XV вијека: с основом на а: хнстовн II. 102. али XVI вијека већ је обичније тако него са $e$ : с основом на а: богови Злат. 3. валови Ст. пис. 3, 470. вукови Ст. нис. 3, 372. 435. 5, 131. градови Здат. 96. гребови Збор. 28б. гријехови Ст. пис. 5, 78. духови Здат. 7б. ждрадови д. Рањ. 88б. крјесови Ст. пис. 3, 21. кумови Збор. 55б. понови Збор. 75б. тријескови Ст. пис. 3, 314. с основом на и: волови Збор. $26 б$. Ст. пис. 4, 418. синови Н. Рањ. 22б. 28. 39б. 62. 65б. $68 б$. 88. 115б. 116б. Збор. 93б. 96б. 122б. Ст. пис. 3, 115. 5, 74. Брн. 6. 19. 48. Гуч. 82. XVII вијека: с основом на а: валови Мик. 760. дарови Каш. 113. зракови Каш. 29. Мик. 859. попови Вран. жив. 22. Банд. 247. с основом на и: водови Банд. 70. синови Гунд. пс. 29. Банд. 12. Радн. 62. - и с основом на ја, гдје се ов мијења на $е в$, има тако XVI вијека: коњевп Ст. пис. 3,85 . а без те промјене иза з још прије: кнезовн 
Зак. 46. и XVII вијека: кнезови Орб. 255. по том и приштови Радн. 34.

Како је у овом падежу било на речени начин и -ове и -ови, а ово друго могло бити и без ов, узимало се да и оно прво може бити без ов: даре Стар. 3, 324. длане Ст. шис. 3 , 343. јаде Ст. пис. 3 , 468. даве Ст. пис. 3,234 . Види о том још ниже.

Међу основама на ја има их које су прије биле основе на i ; за то прем да још у старом словенском језику припадају меלу основе на ја, опет и у њему има и у српском је језику бно у ријечи с таким основама овај падеж као у ријечи с основом на $\mathbf{i}$ (види под III): таке су особито ријечи које се у номинативу јед. свршују на -тељ: тако до краја XV вијека: кхастекню М. 211 . мвчнтекне М. 316 . прароднтекне М. 116. пртродитекие М. 187. прароднтекие М. 233. прьвтекие М. 22. прнатекне М. 174. 352. 433. 445. 479. прнатекне II. 15 . II. 48. 53. 58. 66. роднтелне М. 89. 189. 316. 446. скетнтекне М. 15. 90. а и друкчије ријечи у којнх је основа такође на ја: крахне М. 13. кельможне ПI. 54. кокауне М. 98. нвжне М. 221. 235. 427. 486. 490. захтарне М. 98. покансхрне М. 117. покмнсарне $M$. 161. 231. 235. 304. 398. 399. 427. 486. 490. седхарне М. 98. оүанмрню М. 58. 59. 62. парнє М. 90.116. 133. 316. Од ријечи с основом на ја прешао је овај завршетак и на многе ријечи с основом на чисто а, и то од првијех времена из којпх имамо писанијех споменпка: архнєпискорпиє М. 13. пгоүменнє М. 13. нкономне Шаф. pain. 1873. 103. калвтерне ПІб. 30. катниї Сав. 13. мансторне М. 98. 144. пнскорине М. 13. стрһгорнне М. 98.

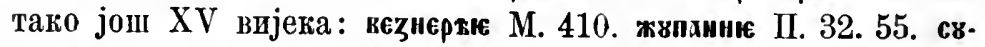
станЕ II. 48. хтнторїє М. 540. Хьтнторне М. 571. у то понљедње вријеме налази се и у ријечи које у основи пред крајњим а имају грлени глас, те се он мијења: вмьуыс Cтар. 3,62 . - У овом облику може $u$ пред к ослабивши у н испасти; то је бивало и у старом словенском јевнку, па је тако било и у српском од ирвијех времена: приттехе М. 35 . прнателе II. 21. 54. 55. 59. 104. 129. пртатекю М. 239. 258. 430. прнатек ые

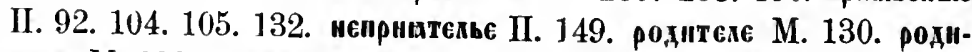
теле М. 239. роднтельс М. 254. 444. прароднтеле М. 239. скана-

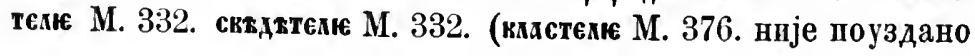


да овамо иде, јер у истом споменику често стоји є мјесто є: сє мјесто сє, менє мјесто менє, піа може бити да тај примјер иде меלу друге, који ће се ниже споменути). мвжьс М. 581. вуннауте М. 79. кметнке ПI. 8. покхнсарые М. 102. 307. 351. покансарье М. 292. 381. покансарюе Пб. 24. сусъдия II. 132. тако Һе бити и пнтропт М. 507. гдје је ₹ наппсано мјесто ю, а тако Һе бити и у ријечима које у основи на чисто а имају $и$ и $k$ пред тијем крајњим: нмострамиз II. 112. царнинц: II. 102.

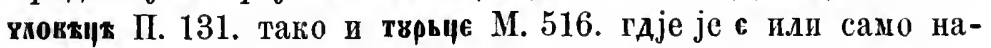
писано мјесто є или је $j$ пред с а иза " отпало.' - XVI вијека једва се траг налази томе обличју на -нє: из самога почетка тога вијека имам само један примјер : кокачнє Збор. 162. - Да ријечи с основом на ја имају у српском језику од самога почетка у овом падежу и само $u$ крају, показано. је напријед; овдје нека то још потврде примјери са свијем једнаки с торњима, у којима видјесмо є мјесто $u$ : прьвтекн М. 22. прнатехн М. 180. прнттекн М. 501. кметнкн ПІ. 3. покхнсарн М. 171. 184. 382. 481. и с краја XV и из XVI вијека: мужи Н. Рањ. 123. Збор. 122. цари Злат. 49. цесари Ст. пис. 1, 112. 3, 422. пастијери Н. Рањ. 21. Збор. 25б. Ст. пис. 4, 262. 3лат. 446.

Ријечи које постају наставком ин и.ди јанин одбацују у множини крајње ин, а тада им се основа свршује на сугласно, за то у множини не иду овамо него међу ријечи којима се основа свршује на сугласно ; али што осталијем облицима стоје међу ријечима с основом на а, I пाто су се у множини - по времену пзедначиде с вима, за то нека буду овдје споденуте. У њих у овом падежу к основи, која се реченим начином свршује на сугласно, долази наставак који у с.ловенским језицима гдаси $e$ : тако од најстаријих времена: ко-

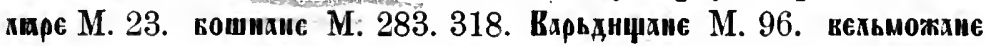
М. 273. кесможанє М. 318. внтахннане М. 218 . вхастекє М. 45. 54. 104. 157. 159. 161. 174. 176. 180. 207. 211. 219. 229. 231. 236. 273. 479. 486. 490. 557. II. 44. гратие М. 217. грагиане II. 37. 61 . 138. 145. Докродокане ІІІаф. pam. 1873. 102. двкровьуане М. 2. 31. 102. 157. 162. 205. 219. 267. 270. 434. 485. ПI. 8. ж8-

' Тако и сада: Божевце, Брадарце, Макце, Мипљеновце, Рановце, Жһабаре, Црниће. Милићевић, путничка писма 1868. 198. 


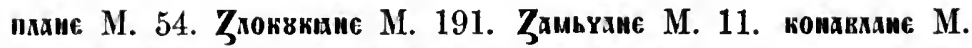
218. нраниаие М. 31. Корихране М. 63. квћане ІІб. 126. мекитаме (номин. јед. лскнтьнниь) Стар. 4, 142. көвите (номин. јед. певнтинь) Стар. 4, 140. Моруапе М. 92. мвсроманє (є читај є) М. 409.

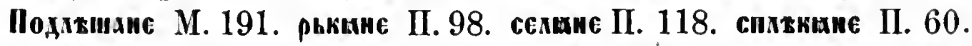

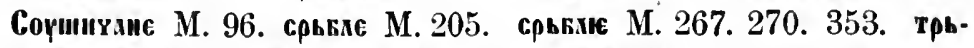
стеннуане М. 7. Оүхокане М. 93. хмьмкщие М. 34. тақо на врају XV и скоро свега XVI вијека y пјесмама: блаһане Cт. пис. 3, 215. властеле Ст. инс. 1, 32. 2,336. 3, 22. 206. грајане Ст. пис. 1, 5. дворане Ст. иис. 4, 291. дубровчане Ст. пис. 3, 208. жидове С'r. пис. 1, 19. 67. 169. 185. Ирудјане Ст. ппс. 1, 338. крстјане Ст. ппс. 3, 49. 83. 312. мишһане Хект. 44б. погане Ст. пис. 1, 243. рим.бане Ст. иис. 3, 39. сељане Ст. пис. 4, 292. стражане С'т. пис. 1,52. и изван пјесама у првој половини XVI вијека доста се находи: агаране 3бор. 159б. бабилоњане Н. Рањ. 81б. властеле Збор. 36б. грађане Н. Рањ. 203. дворане Збор. 27б. египтане Н. Рањ. 72. иеиптане Збр. 25б. иећпптане Збор. 26. жпдове Н. Рањ. 51б. 80б. Збор. 39. жудије Н. Рањ. 75. калдеане Н. Рањ. 122. крстныме Збор. 158. крстинс Збор. 90б. Стар. 1, 227. 4, 115. кућане Н. Рањ. 203. римьане Н. Рањ. 86. Збор. 79. али га од тада нестаје тако да на свршетку XVI вијека долазе у прози само у једнога књижевиика ове двпје ријечи: градјане Буд. 151. миићане 152.' - Ријечи с таком основом у множини прехазе као н друге у којих је основа на сугдасно међу ријечп с основом па $\mathbf{i}$ (које внди), и тада се изједначују с рнјечнма у којих је основа на а, те пмају као и оне у том падежу на крају $и$ : то почнње у нас XIV вијека: кмастекн М. 117. 189." Горнким ПІІат. раm. 1873. 102. двкрокуанн М. 157. Автуани М.

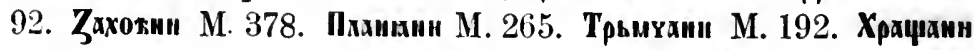
IIIаф. pam. 1873. 102. XV вијека: Қагвкаин М. 439. Ђаховни М. 378. срьви M. 270. 434. Зак. 43. на грају XV и свега XVI внјека : асиријани Ст. пис. 1, 26. бетулијанп Ст. шис. 1,6. бои (milites) 3бор. 14. болари Збор. З6б. воји (milites) Стар. 1, 223. грајани Ст. пис. 1, 26. 29. 247. грађани Н. Рањ. $220 б$ Збор.

' Али и сада гдје гдје у имснима мјеснијем: Брежаве. Милићевић, нутничка ншсма 1868. 198.

2 може бити и од властељ. 
31. А. Рањ. Vб. Злат. 53б. дубровчани Ст. пис. 3, 226. жіпдови Н. Рањ. 47б. 72б. 74б. 80б. 81б. Ст. пис. 2, 340. жудији Н. Рањ. 78. крстанн Збор. $60 б$. Ст. пис. 3,59. мјештани Д. Рањ. V. Злат. 18. римљани Збор. 13. 89. Ст. пис. 5, 34. себанп Ст. пис. 4, 318. стањани Ст. пис. 4,312. стражани Брн. 21б. тројани Ст. пис. 3, 203. 5, 34 .

Уз номинатив мн. са $e$ на крају долазе друге ријечи неколико пута тако да би се могдо мис.ити да су ријечи у таком облику узете као да су женскога рода или да им је узет акусатив мјесто номинатива: тако јоп XIV вијека: ако сте nаше прнттекне ІІб. $15 . \mathrm{XV}$ вијека: говорнше нхмь маше вка-

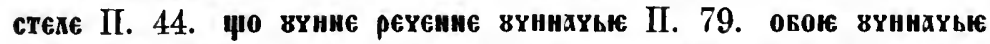
внкьши на сквпх II. 79. XVI вијека: да нмъ вахстеке дввровауке пошкю какову мнкостикю М. 557. гди су све јадове Ст. пис. 3, 470. гдје ти длане шупље стоје Ст. пис. 3,343 . даре частне многе придоше Стар. 3,324 . али мислим да ту нема ништа друго него је од супстантива завршетак $e$, по што му се значење веһ слабо осјећало, преношен и на друге ријечи које уз њих стоје у истом падежу.

Б. У ријечи средњега рода: пред наставком отпада завршетак основе, а наставак бива дуго а, юоје је у словенским језицима кратко: скк М. 14. помка М. 106. уста Ст. пис. 2, 16. Буд. 124. Злат. 39б. уда Злат. 72б. Вран. жив. 44. ледја Рад. 27. 47. - С тим је падежем једнак акусатив множине; за то ово вриједи и о вему.

Ријеч мунгога рода посао додази једном у овом падежу као да је средњега рода: безбројна посла Орб. 51.

- Ријеч језеро, која је и у другим падежима предазила међу мушке ријечи (види номинатив), налази се тако и у овом падежу: језери Мрн. 29. - Али још неке ријечи средњега рода додазе у номинативу мн. као да су мушкога рода на крају XV вијека: дили (позрив наши дили, ки су умиљенства) Ст. пис. 1, 27. лити (по све лити) Ст. пис. 1, 17. сели (сели тере двори паљиху се) От. пис. 1, 15. уди (сви уди) Ст. пис. 1, 181. и у акусат. мн. XVII вијека: уди Мрн. 23. тако има често и усти, на крају XV, свега XVI и у почетку XVII вијека: у номинативу мн.: усти љувени гди нису с умора Ст. пис. 2, 78. танци су ве усти Ст. пис. 2,348. у акусат. 
мн.: поносит' усти мој(и) Ст. пис. 2, 266. мени дарова усти свој(и) румени Ст. пис. 2, 269. тој рпјечи придјевена ријеч има на крају и $e$ и у номнн. и у акусат. као да је женскога рода: у номинат.: ово ти ме усти и љувен њих целов Ст. пис. 2, 278. устн твоје Гуч. 191. ове ме усти Злат. 46 . усти ове Ст. шис. 4, 430. грешне усти Ст. пис. 5, 55. моје усти І'унд. пс. 21. усти, ке мњах да мед хране, чемером су отроване Іунд. суз. II, XXI. без прпдјевене ријечи: усти Бун. 24. у акусат.: не млати све усти С'т. пис. 1,108 . кад усти отвараш пуне све радости Ст. иис. 2, 15. отвори све усти Ст. пис. 2. 277. гди усти отвори пијешости све пуне Ст. пис. 2, 295. на моје усти Ст. пис. 2, 433. моје усти Ст. пис. 5, 78. усти своје Гунд. пс. 14. усти опрхле Г'унд. суз. I, XXX. моје усти Бун. 33. уз таки облик стоји придјевена ријеч и у средњем роду у множини : устп ње сама смамише жнвот мој Ст. пис. 2, 25. усти ње. ка н.лову Ст. пис. 2, 112. једна лијепа усти Д. Јањ. 3б. Уз правнлно уста налази се придјевена ријеч и у женском роду: ваше уста да занијеме Ст. пис. 3,37 . налази се и у вокат.: усти Бун. 24.

у адјектива је као у супстантива: тужна Злат. 47. послједња Н. Рањ. $45 б$.

В. У женских рпјечи: прсд наставак у словенским језицима додази $\mathbf{n}$; по том отпада наставак, а додано се $\mathbf{n}$ слаже с предњйм гласом онако као у генитизу једн.': с основом на чисто а п на ја: жоүпе М. 13. паше М. 11. тако ноздре Ст. пис. 4, 169. ноздрве Вран. рјеч. 64. обрве Збор. 35б. Крн. 22б. јаспре Радн. 87. тако је било и мравље Ст. пис. 4, 84. 85. 165.167.

Налази се у другој подовини $\mathrm{X} V$ вијека као у мушких ријечи, али у спомепику писану на турском двору: мон вюїкодн М. 526. мон сувашн М. 526.

У пјесмама се налази као у рпјечи с основом на $\mathbf{i}$ : ливади Ст. пшс. 1, 17. тако и коси Ст. пис. 2, 36. 77. 116. Чубр. 7. уз обитно косе Ст. нис. 2, 28. 36. Злат. 69. тако и усни Ст. пис. 4, 119. 192. а.и попььедње може бити остатак од

1 IIL овога падежа, него мјесто ьега да долази акусатив мн. 
двојине. Тақођер остатак од двојине рекао бих да је конакаи М. 188. II. 173. мјесто тега послије додази Конхка М. 486. 428.

У адјектива је као у супстантива: бијеле Н. Рањ. 66. ведје Ст. пис. 3, 446. боље Вран. жив. 55.

III. Основе на i. Kрајње се i у основп шири у аi, те се сажима у дуго $\mathbf{i}$, које је у словенским језицима кратко, a по том

А. У мушки ријечи долази наставак гласећи у словенским језицима $e$ : гостиє М. 206. 208. 268. гостню М. 271. 354. 435. sвтрї Стар. 4, 74. кметню М. 249. 333. 531. пвтїє Сав. 4. пудне М. 21. 42. 317. 471. кюдню П. 6. 20. 145. тако још у почетку XVI вијека пвдп Збор. 28б. у пошљедњој ријечи и ос.дабивши у в отпада од XIII вијека: пвдье М. 44. 45. 379. 410. 510. пюдыє М. 126..173. тако ће бити и гост: М. 508. гдје

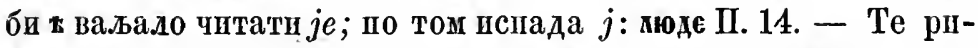
јечи од XIII вијека прелазе међу мушке с основом на а: roстн М. 510. кьметн М. 28. поүтн Сав. 5. Н. Рањ. 43. Ст. пис. 4, 300. луди М. 525. људи Ст. пис. 1, 21. Збор. 27. Д. Рањ. 81. Брн. 43. Каш. 11. тако и поктн Збор. 35б. а неке прешавши онамо добиле су од жих по ов пред $и$ од XIV внјека: поүтовн М. 87. Јерк 100. татови Ст. пис. 2 , 403. А. Рањ. 40б.

У ријечи дан било је такођер дыню, али се пा она изједначила с ријечима у којих је основа на а: дни Збор. 27. Ст. пис. 5, 36. Град. дјев. 39. Зор. 53. Злат. 97. Гунд. пс. 25. Банд. 11. Радн. 65. а од њих је добнла п њпхово ов, сачувавши основу на $\mathbf{i}$ само толико што је ов обратила у $е в$ : дневі Радн. 7. 70.

Б. У женских отпада наставак: Дхьжн М. 242 . шисми 3ор. 3. рнчи Пб. 21. Н. Рањ. 161б. ствари Злат. 41. свирали Ст. пис. 4, 493. звири немиле Ст. пис. 4 , 454 . тако је било и обрви Ст. пис. $3,273.4,55$. похкн Пб. 49. тако и ријечи које су само у множини у обичају : гвскн Збор. 23. јасли Мик. 175. пошљедње обје додазе у том падежу и с основом на а женскога рода: гусле Вран. рјеч. 19. јасле Мик. 175. Радн. 5. 63. пошљедња је прелазила п међу ријечи средњега рода с основом на а: јасла Зор. 58. (испореди номинат. јед.) Међу ове ријечи прелази и мрави (све) Ст. пис 4, 84. 85. мрави ОватII 
лијепе Ст. шис. 4, 165. мрави те Ст. пис. 4, 166. Између ријечи које су овамо ишле прелазила је међу ријечи женске с основом на а: сјене Андр. пут 234.

IV. С основом на сугласно:

А. У мушки ријечи: к основи приступа наставак, који у с.довенским језицима гласи $e$ : кмєне М. 130 . али како ове ријечи од првијех времена прелазе међу оне с основом на i, прелазе и у овом падежу, а тада се опет изједначују с онима у којих је основа на а: кхисн М. 70. 386 . према томе и ријечи које и у номинат. јед. прелазе меңу оне с основом на $\mathbf{i}:$ јелини Ст. пис. 1 , 13. стремени Ст. пис. 4, 167. прелазећп међу ријечи с основом на а могу и одбацити крајње eн у основи: илами Ст. пис. 2, 446. 5, 324. Андр. пут 324. прами Бун. 24.

Б. Женске ријечи прелазе од првијех времена међу женске с основом на $\mathrm{i}$ : кћери Н. Рањ 28б. Ст. пис $3,115$. 4, 362. І'рад. дјев 56. Банд. 18. Радн. 100. хћери Н. Рањ. 105. ирькви М. 111. и та ријеч и друте прелазе и међу ријечи женске с основом на а: қћере Н. Рањ. 143. Брн. 58. Банд. 155. хћере Ст. пис. 1, 113. Вран. жив. 42. Банд. 157. Крн. 6. матере Врап. жив. 9. Див. 38б. Радн. 35. црикве Радој. 44. тако и свекрве Андр. 83. у које је такођер негда била основа на 6 .

В. У средыл: од наставка а бива дуго, те у словенским језицима остаје кратко: тако је и у номинат. и у акусат. мн. : брјемена (onus) Н. Рањ. 39б. врјемена Ст. пис. 3, 6. 4, 90. 5, 40. 352. рамена Ст. пис. 4, 110. - джсса Стеф. 22. дртвєсх Стар. 4, 65. колеса Ст. пис. 1, 13. Вран. рјеч. 13. небеса Н. Рањ. 18. Ст. иис. 5, 191. Вран. жив. 23. Каш. 37. оуесх М. 194. сковеск Стеф. 13. М. 110. твкес Стеф. 17. телеса М. 100. Ст. пис. 1, 197. 2, 168. Н. Рањ. 94. Збор. 56б. Ст. пис. 3, 27. 4, 232. 5, 36. Град. дјев. 65. Буд. 143. Брн. 186. Вран. жив. 24. Орб. 100. тјелеса Ст. пис. 4, 175. тилеса Ст. пис. 1, 221. Банд. 213. оүшєса М. 72. унеса (vušesa) Г.яав. 127. үюдеса М. 9. Стет. 24. чудеса Н. Рањ. 84. Хект. 28. Буд. 54. Вран. жив. 109. Бун. 46. Каш. 34. - Неке прелазе међу ријечи средње с основом на а одбацујући крајње $e c$ у својој основп од првијех врехена : дық Стеф. 24. кода Н. Рањ. 1176. 
128. Вран жив. 13. ока (у мрежи) Хект. 5. сковх М. 144. тых М. 44. 45. уха Каші 46. чуда Ст. пис. 5, 142. Хект 5. 9. Јерк. 45. 97.' очи п уии види код двојине.

\section{ГЕНИТИВ МНОЖИНЕ.}

Наставак је am, којему је а дуго и који у словенским језицима сливајући се у глас д слаби у з, а по том остаје т у староме словенском језику а у другима отпада.

I. Основе на и. Крајње се и у основи пири аи, које у словенским језицима пред самогласнијем наставком гласи ов: сниокь М. 373. тако свега вренена: синов Н. Рањ. 26. Ст. пис. 3, 148. 4, 461. Град. дјев. 166. Хект. 26б. Брн. $26 б$. Банд. 16. волов Н. Рањ. 147. Збор. 26б. Врап. рјеч. 14. Мик. 93. 175. Али још у првој половини XIV вијека почиње му се додаватп на крају $a$, које п послије пма свега времена: сивова М. 107. 380. 463. 465. 501. Пб. 92. Н. Рањ. 46б. Збор. 25б. Ст. пис. 4, 410. 431. Банд. 36. комокх М. 102. 443. Збор. 266. Брн. 21б. Вран. жив. 50. Мик. 405.

Али се ријечи с основоч на $\mathbf{u}$ и у овом падежу пзједначују с ријечима у којшх је основа на а (види под II), те се налази и без ов још XIII вијека: сынь М. 28. тако XVII вијека: вол Вран. жив. 65. а с доданим $a$ још XV вијека снних Пб. 92.

II. Основе на а. Крајње а од основе са а од наставка сажима се у једно a, с нојим $\mathbf{m}$ од наставка сливајући се у - слаби у т, по том се т у основа на ја предњега гласа ради мијења на $九$, које се у старом словенском језику држи илі отпада као у номпнат. јед. а у српском отпада и т и и: тако је п у мушких и у средњих пा у женских:

A. У мушкाх :

a) с основом на чисто а: од XII до XV вијека: апвстокь М. 371. Биетькь М. 115 . кхахь М. 13. дукаать М. 339. комать ПГб. 55. бвань ПI. 17. посахь II. 74. ровьь Стеф. 25. скомхкь Пб. 74. сусиєдь М. 362. до краја XVI вијека: ангел

1 Кашић грам. 35 вели: nebesa vel neba vel nebi; slovesa vel slova vel slovi; tilesa vệ tila vel tili; čudesa vel čuda vel čudi. 
Град. дјев. 168. апостол Град. дјев. 69. бок Н. Рањ. 166. вјетар Ст. пис. 3, 13. врутак Н. Рањ. 88. дил Ст. пис. 1, 106. 3, 369. дукат Н. Рањ. 27. гдежан Ст. пис. 3, 99. Мрн. 32. греб Збор. 53б. гријех Ст. пис. 3, 259. жудјел Град. дјев. 182. здотвор Ст. пис. 3, 387. зуб Ст. пис. 1, 236. Н. Рањ. 222б. језик Ст. пис. 3, 455. мождан Ст. пис. 3, 393. народ Ст. пис. 3, 314. облак Ст. пис. 3. 132. особак Град. дјев. 136. посал Град. дух. 28. пророк Град. дјев. 154. псалам Н. Рањ. 177. раб Брн. 11. салам Ст. пис. 5, 54. синак Ст. пис. 3, 29. стабар Н. Рањ. 89. таленат Н. Рањ. 60б. уломак Н. Рањ. 151б. усионик Град. дјев. 154. узрок Град. дух. 18. и XVII вијека: Бнетак Мик. 265. дшл Вран. жив. 48. крмак Мнк. 746. начин Банд. V. ован Банд. 73. порат Мик. 266. узал Мик. 299. чавал Банд. 144. на крају стојећи $\pi$ кад кад и отпада: чава Cтар. $4,113 .{ }^{\prime}$

б) с основом на ја: од XII до XV вијека: кран М. 250. ПI. 74. 94. оүанн М. 62. - крахь М. 180. 345. окрьмнтекь ПІ. 119. прхроднтекь М. 187. 313. пртытекь М. 258. прнттекь М. 404. 507. роднтежь М. 100. 235. 382. 412. саквхь М. 407. - комь М. 14.135. ПI. 22. Фгань М. 149. сужань ПІ. 49. - Анмарь Пб. 25.ІІ. 49. пастмрь М. 62. ґарь M. 103. 180. 288. 300. 338. - мхсєџь M. 147. 170. 209. 436. П. 137. штаць М. 105. 219. 240. штаaןь М. 371. скоқхарь Пб. 74. трьговаць II. 7. 140. - п послије до XVII вијека: научитељ Град. дјев. 8. непријатељ Ст. пис. 1, 70. Град. дух. 49. Брн. $27 б$. прпјатељ Хект. 35. родитељ А. Рањ. 120б. Град. дјев. 87. Злат. 5. воњ Град. дјев. 114. коњ Н. Рањ. 117б. динар Н. Рањ. 926. Ст. пис. 5, 126. цар Стар. 3, 258. лупеж Ст. пис. 3, 215. проводич Град. дјев. 137. пинез Буд. 67. Град. дјев. 139. Хект 3б. Зор. 53. Буд. 67. Брн. 51. витез Ст. пис. 3, 45. зденац Ст. пис. 1, 29. злочинац Н. Рањ. 132. јагањац Н. Рањ. 84б. јунац Н. Рањ. 84б. младјенац Ст. пис. 3, 311. Збор. 102. младенац Буд. 92. мудрц в.ди мударц (mudarc) Н. Рањ. 210б. отац Н. Рањ. $18 б$. Збор. 7б. Ст. пис. 4, 384. Град. дух. 9. светац Ст. пис. 5, 158. - и XVII вијека : ненријатељ Банд. 235. родитељ Вран. жив. 85. пјенез Бун. 31. венац Врап. жив. 18. врабац Банд. 246. вребац Банд. 238. здочинац Мик. 175. м.даинац Вран. жив. 73. отац Вран. жив. 22. Банд. 7. Јерк. 77. пјешац Мик. 787. прасац Мик. 479. светац Банд. 19. штндац Банд. IV.

' Тако $\lambda$ отпада и у part. praet. act., гдје види. 
Ријечи с основом на а и оне с основом на и помијешале су се у овом падежу тако да је од овијех с основом на и прешло њихово ов и $\kappa$ онима $Y$ којшх је основа на а, и то још од првијех времена: а) с основом на чисто а: XII - вијека: чсстьниковь M. 2. сьпордовь М. 6. и даље XIII-XV вијека: апдековь М. 302. апостококь М. 303. апвстококь М. 452. втсовь Стеф. 25. грзхюки Сав. 7. даровь Сав. 10. дұкатовь М. 380. II. 176. Пб. 71. Ахьговь ПІ. 118. зхконовь М. 176. ниопкеменнковь М. 379. анстовь П. 151. пхоүгокь М. 98. поповь М. 13. пванzовь II. 96. снровь М. 139. парнннковь II. 2. юихковь II. 48. - на крају XV и свега XVI вијека: апостолов Н. Рањ. 154б. богов Злат. 296. валов Н. Рањ. 13. Ст. пис. 2, 383. Злат. 87б. впков Хект. 31б. виноградов Буд. 104. војников Ст. пис.1, 18. вртлов Буд. 104. врхов Н. Рањ. 15. вуков Ст. пнс. 3 , 156. 4, 101. градов Ст. пис. 1, 18. Н. Рањ. 35б. грихов Ст. пис. 1, 121. Хект. 40б. Буд. 4. Вран. рјеч. 126. гријехов Н. Рањ. 124. грјешников Н. Рањ. 97б. гробов Д. Рањ. 148б. даров Хект. 35б. даталов Н. Рањ. 88. духов Н. Рањ. 154. Ірад. дјев. 19. зидов Ст. пис. 3, 148. камиков Зор. 70. кинов Збор. 162. клеветников Буд. 54. лавов Н. Рањ. 82. намирников Хект. 35. народов Н. Рањ. 191б. папреваков Хект. 11б. плодов Н. Рањ. 144. попов Ст. пшс. 4, 357. цророков Н. Рањ. 91б. противнпков Н. Рањ. 144б. пуков Н. Рањ. 162б. разбојников Рањ. 44. Зор. 75. сакраментов Буд. 86. службеников Н. Рањ. 18б. траков Збор. 167. узроков Буд. 16. учеников Н. Рањ. 88. фнложофоф Стар. 3, 239. цршквењаков. Буд. 57. - и XVII внјека: ангелов Банд. 12. апостолов Банд. 208. боков Банд. 5. вирников Банд. 153. вуков Банд. 206. градов Банд. 26. Мрн. 20. гребов Банд. 88. грпхов Банд. 8. Глав. 12. дијелов Див. 9. доктуров Банд. 249. идолов Банд. 63. језпков Банд. 233. јунаков Мрн. 41. козаков Мрн. 45. комаров Вран. жив. 100. крухов Банд. 33. давов Банд. 71. можјанов Мрн. 26. мучеников Банд. XII. народов Банд. 18. начпнов Глав. 97. немоћников Банд. 39. постолов Банд. 3. плотов Банд. 32. прагов Банд. 102. пророков Банд. III. разбојников Банд. 35. сребрњаков Њанд. 84. скутов Банд. 43. судов Банд. 21. талентов Банд. 51. узроков Глав. 3. учепиков Банд. 2. Јерк. 45. - б) рпјечи с основом на ја добнле су такођер ов од онијех с основом на $\mathbf{u}$, па се о од ов предњег гласа ради промијенило у $e$ : 
али се оне тако јављају тек на крају XIV. внјека: покжнсрєвь М. 232. XV вијека: краєкь II. 58. 66. 71. kraglief М. 279. крапекь М. 285. 288. 298. 300. 448. 489. ПІ. 107. покрикачекь ПГб. 49. 56. покинсарекь 329.350 .432 . ПГ. 93 . на крају XV и свега XVI вијека : боев Стар. 3, 261. бенифицијев Буд. 12. официјев Буд. 250. краљев Н. Рањ. 17б. родптељев Буд. 58. учитељев Буд. 83. научптељев Буд. 14. огњев Стар.. 3 , 232. бичев Ст. пис. 5, 60. дупежев Зор. 75. мужев Град. дјев. 107. царев Стар. 3, 260. и XVII вијека: краљев Банд. 6. Мрн. 10. научитељев Банд. 20. коњев Мрн. 45. у таким ријечима додази у гдјекојега између истијех писаца XVI и XVII вијека 0 и непромјењено у $e$, и то не само иза з, гдје је и сада $о:$ витевов Ст. пис. 1, 246. кнезов Ст. пис. 1,246 . него и пза других гласова: непријатељов Гдав. 152. родитељов Гдав. 14. гусдаров Банд. 14. пастиров Зор. 36б. Банд. 11. царов Стар. 3, 254. 263. 296. Мрн. 170. тако и у странијем ријечнма, у којима се пзбацује у основи $j$ још у старом словенском језкку, те се ни $о$ не мијења у $e$ : калдеов Н. Рањ. 18. Банд. 7. фаризеов Банд. 3.

Ако овај облик од основа на а (прави без ов и начињени према оном од основа на $y$ са ов) и допире у XVII вијек, инак још у првој подовпни XIV вијека почпне му се додавати на крају $a$, које и данас пма: а) правн генитив мн. од оспова на а или на ја (т. ј. без ов): XIV вијека: апвстола M. 105. у то су се вријеме мјесто х ппсала и два нь: момастирьь М. 167. бтырь М. 82 . споүдьь М. 139. соүродннкь М. 81.

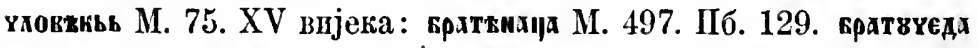
М. 453. внекх М. 285. 338. внећннка М. 370. Вкатковнћа М. 538. дниарл М. 295. 364. 390. ППб. 60. 76. П. 48. 108. дхьжннка ПГ. 119. двжинка ІІб. 120. двката М. 390. 443. 501. ПІб. 96. жиякакх Пб. 125. кхивгерл М. 463. комада IІб. 110. 112. копна М. 443. аткара II. 93. моринарх II. 38. пожа М. 498. отаух М. 456. покмопхуа II. 408. пхиеzа М. 369. пюнеза Пб. 113. 115. пненеза ПІб. 116. покхада М. 389. 392. покхнсхра М. 511. поставах М. 400. прнговора М. 501. ирнттека М. 517. Пб. 125. разлога П. 74. 169. роднтема М. 398. 470. роднтекь ПI. 147. трьгокара М. 484 . юнака ПI. 48. 49: 161. XVI вијека много чешће додази овако са $a$ него без њега: ангела Н. Рањ. 22. Д. Рањ. VІб. анђеда Збор. 93. апостода Н. Рањ. 140б. апвстока Збор. 159. карвна Збор. 84 . внкнега Збор. 
526. внсквпа Збор. 104. бога Н. Рањ. 122. Ст. пис. 3, 363. 4, 31. бојника Д. Рањ. VI. вераза Злат. 36f. вјетара Гуч. 202. витеза Н. Рањ. 184б. Ст. пис. 3, 252. влададаца Н. Рањ. 84б. Гуч. 72. власа Ст. пис. 2, 82. 3, 472. Злат. 69. војника Ст. пис. 3, 53. врабаца Н. Рањ. 209. врага Ст. иис. 3, 171. гласа Збор. $102 б$. гојтана Ст. пис. 3, 10. горштака Злат. 80. града Н. Рањ. 202. гријеха Н. Рањ. 51. Ст. пис. 3, 79. Збор. 4. Град. дјев. 56. Гуч. 13. грјешника Н. Рањ. 91. 195. грешника Ст. пис. 5, 116. Град. дух. 43. Гуч. 4. Грка Збор. 81б. Злат. 13. гусара Злат. 56б. дара Град. дух. 19. Гуч. 160. двора СТ. ІІис. 3, 464. дникамх Збор. 56б. дијела Н. Рањ. 71. Збор. 24. днетнћа Збор. 7Зб. динара Н. Рањ. 85. Збор. 55. Град. дјев. 141. дуката Н. Рањ. 27. духа Н. Рањ. 45. Ст. пис. 3, 448. Збор. 93. житничара Збор. 27. жудјела Н. Рањ. 181. Збор. 54. Ст. пнс. 3, 319. завидника Д. Рањ. 67б. закона Злат. 66б. злочинаца Н. Рањ. 150б. знанаца Н. Рањ. 29б. зуба Н. Рањ. 166б. Ст. пाис. 3, 466. 5, 187. 3бор. 103. Град. дух. 13. Гуч. 215. језика Ст. ппс. 3, 76. Злат. 37f. Чубр. 5б. юнака М. 553. књижника Н. Рањ. 97б. конаца Н. Рањ. 187б. коннка Збор. 76. кошица Н. Рањ. 70б. краља Ст. пис. 3, 464. 4, 118. 5, 4. крвника Ст. нис. 3. 385. Злат. 6. круха Н. Рањ. 70. лава Ст. пнс. 3, 436. Злат. 50б. кећичи Збор. 103. ловаца Ст. пис. 2, 205. Збор. 44б. манхстнра М. 545. Град. дјев. 7. манастијера Гуч. 28. мача Збор. 164. мендиканата Гуч. 96. мјесеца Н. Рањ. 61б. Збор. 79б. младића Злат. 51. мртаца 3бор. 82. мудрца или мударца (mudarca) Н. Рањ. 197б. Збор. 143. Д. Рањ. VIIб. Гуч. 173. мужа Ст. пис. 4, 9. народа Н. Рањ. 48. наука І рад. дух. 9. начина Збор. 11б. Град. дух. 35. Здат. 57б. немоһника Н. Рањ. 47. непријате.ба Н. Рањ. 170б. невјерника Н. Рањ. 217. нораца Ст. пис. 4. 270. облака Ст. иис. 2, 376. 3, 309. 4, 257. Збор. 14. образа 3бор. 162. ораха Ст. пис. 4, 252. осала Збор. 5. отаца Н. Рањ. 126б. Злат. 4б. Гуч. 42. оченаша (пет) Гуч. 43. паса (canis) Cт. пис. 3, 305. 4, 327. 3бор. 21. Д. Рањ. 55. пастијера Н. Рањ. 21. Злат. 36б. пастира Д. Рањ. 50. пјенеза Д. Рањ. Уб. пјешаца Збор. 76. предикатура Гуч. 63. пријатеља Н. Рањ. 214б. Д. Рањ. 88. Здат. 22. пророка Н. Рањ. 219б. Ст. пис. 3, 311. псалама Гуч. 19. птића Ст. пис. 2, 410. раба Збор. 29б. разговора Гуч. 126. реда Град. дјев. 141. рога Збор. 50. родјака Здат. предгов. 
2б. родитеља Н. Рањ. 29б. сағрамената Гуч. 310. сана Ст. пис. 4, 403. 404. свјета (sviyeta, consilium) Град. дјев. 175. слијепаца Н. Рањ. 63б. стара (мјера) Н. Рањ. 152б. ступаја З.лат. предгов. 1б. стараца Н. Рањ. 63. суда (vas) Н. Рањ. 62. суда (judicium) Град. дух. 82. судаца Н. Рањ. 67. Збор. 54б. сужана Ст. пис. 5, 161. сусједа Н. Рањ. 62. тетријеба Ст. пис. 4, 271. трговаца Н. Рањ. 187б. труда Ст. пис. 3, 24. Д. Рањ. 100. узала Злат. 62 . узрока Злат. предгов. 3б. ученика $\mathrm{H}$. Рањ. 14. Збор. 84. тратара Гуч. 28. хкнека Збор. 71. худаца Ст. ппс. 3, 398. чавала Н. Рањ. 130. страно: тарнзеа Н. Рањ. 15. - XVPI вијека тако често долази са $a$ да је према њему ријеткост што долази и без $a$; навешћу само по који примјер од свакога писца: брпста Мик. 28. вика Вран. жив. 46. витара Радн. 49. вдадалаца Каш. 3. власа Вран. жив. 11. војника Мик. 153. грнјеха Див. 3. Орб. 29. Апдр. дев. 16. гриха Јерк. 75. Каш. 2. Пос. 1б. гроздака Мик. 123. дара Јерк. 9. Андр. пут 218. днла Мик.66. дитића Јерк.28. зуба Орб. 34. Гунд. суз. II, LII Мнк. 860. Радн. 17. јавора Мик. 174. јагањаца Андр. пут 212. јунака Мик. 36. козлића Банд. 35. коња Мик. 230. костања Мик. 585. кравосаца Андр. пут 376. дупежа Мик. 286. љубовника Бун. 5. мисеца Каші. 91. мјесеца Андр. пут 4. народа Каш. 5. непрнјатеља Банд. 118. Јерк. 26. Мик. 833. Радн. 3. опанака ІІос. 37б. ораха Мик. 724. отаца Канг. 5. Радн. 64. пава Мик. 405. пакала Андр. дев. 54. паса Радп. 99. пастира Каш. 83. Радн. 45. посала Орб. 1. Каш. 29. Мпк. 460. пришта Мик. 457. пука Мик. 422. разлога Мик. 555. родитежа Орб. 31. Гунд. суз. предгов. сакрамената Мат. 93. светаца Kaш. 41. себара Мик. 34. стабара Каш. 19. судаца Мат. 45. Каш. 3. узала Андр. пут 188. фратара Вран. жив. 71. чавала Банд. 144. - б) начињени према основама на $\mathbf{u}: \mathrm{XV}$ вијека: кроқова Пб. 111. квмова Пб. 106. XVI вијека: богова 3лат. 3. валова Ст. пис. 3, 284. 5, 47. вукова Н. Рањ. 205. 3бор. 51б. Ст. пис. 3, 436. 4, 96. Злат. 72б. Гуч. 214. градова Н. Рањ. 154б. Ст. пис. 3, 39. 4, 214. Здат. предгов. 3. гребова Збор. 28б. гријехова Ст. пис. 5, 16. 39. 49. 86. гробова Ст. пис. 3, 341. дарова Н. Рањ. 135. Гуч. 21. дубова Злат. 43. јадова Ст. пис. 3, 7. 30. 388. 409. 4, 322. краљева Н. Рањ. 24б. Збор. 54б. Д. Рањ. IVб. Гуч. 287. кријесова Cт. 
пис. 3, 21. мостова Збор. 59. орлова Ст. пис. 3, 255. попова Ст. пис. 3, 318. постова Гуч. 3. пукова Гуч. 154. робова Ст. пис. 3,100 . синеговх Збор. 102. станова Ст. пис. 5, 17. целова Злат. 37. XVII вијека: валова Банд. 1. Мик. 162. впкова Вран. жив. 38. 69. 111. вукова Андр. пут 332. гребова Вран. жив. 23. грнхова Банд 28. Каш. 13. зубова Пос. 20. краљева Банд 43. попова Мик. 186. послова Радн. пут 45. робова Мик. 701. судова (vas) Капा. 98. судова (јudicium) Радн. пут 15. Како напријед са ов а без $a$ има ријечи у којшх би данас тешко било ов, тако се налази п у такпх рпјечи додано $a$ : XVI п XVII вијека: анђелова Вран. жив. 23. идолова Вран. жив. 19. 42. мвхеннкова Збор. 126. Пос. 5б. народова Банд. 44. обдакова Банд. 120. Радн. 44. ученикова Банд. 103.

Ријечи које постају наставком ин нли јажин и у множини одбацују крајње ин, њима у множини остаје основа на сугласно, те иду у овом падежу међу рнјечи којима се основа свршује на сугласно, и он им онако постаје (внди мало ниже); али ријечн с основом на сугласно прелазе од давнина и у том падежу као и у некима другима међу ријечи с основом на $\mathbf{i}$, па с њима п ове ријечи у множини одбацивши ин и тако добивши основу на сугласно прелазе међу ријечи с основом на $\mathbf{i}$, те им овај падеж постаје као оншма (внди даље под III) тако XIV вијека: Мквкиин М. 93. Папракими М. 92. XV вијека: вмастекн М. 362. двкровханн ПГб. 127. Гинкихин М. 263. квканн Пб. 107. квћани Пб. 126. omišani M. 279. тако још XVII вијека у властитом имену: Дечанмн М. 558. тако би могло бити што има и на крају XV вијека : бетулијани Ст. пис. 1,26. крстјани Ст. пис. 1, 246. али што има XVI вијека србљи А. Рањ. IV. 6. п XVII вијека грађани Вран. жив. 41. то ће бити дошло другим путем, који hе се споменути ниже. Али таким ријечима постаје овај падеж п онако како постаје ријечима с основощ на сугласно (види даље под IV), међу које пришадају у множини, а тада је апо не постањем а оно гласом једнак с правијем генитивом мн. ријечи мушких с основом на а, и то од првијех времена: тако XIII-XV вијека: кокарь М. 20. вмастекь M. 15. 160. 171. 230. 250. 350.456. с промјеном гласа $\lambda$ на крају у $о$ (од XIV вијека) вкастсо М. 230. 259.-508. 522. Кофамвкь ПІаф. 
pam. 1873. 110. срьвьхь М. 270. ерьвахь II. 75. 104. турхкь М. 285. 344. II. 48. втарь II. 176. Храцань М. 87. XVI вијека: граҺап Град. дјев. 23. Злат. 100. жидов Н. Рањ. 34б. Ст. пис. 3, 314. 4, 206. крстјан Ст. пис. 3, 51. Град. дух. 49. поган Град. дјев. 48. турак Ст. нис. 3,129 . и с доданим а: XV внјека: вмастека М. 445. 477. 478. 495. 502. 512. 537. 544. грагана ІІб. 128. дввровуана ПГб. 128. квћьанх М. 473. срьваха II. 138. 175. XVI вијека: жндова (пом. јед. жндовин) Н. Рањ. 75. жудија (ном. јед. жудијин) Н. Рањ. 95б. 182. латина Злат. предгов. 3б. мјентана Злат. 36g. погана Ст. пис. 3, 129. XVII вијека: дворана Мик. 93. жидова Андр. дев. 140. јудија (ном. јед. јудијин) Банд. 68. крстјана Каш. IV. према осталијем ријечима налази се и са ов, али тек XVII вијека: Грков Банд. V. жндовов Банд. 56. жуднјов Банд. 64. кристјанов Вран. жив. 72.

Како је номинатив мн. у неких ријечи с основом на ја бивао и онаки какав имају ријечи с основом на i (види напријед код помннат. мн.), тако п генитив мн. у таких ријечи осим редовнога обличја, које је напријед показано, долази и у обличју које има у ријечи с основом па $\mathbf{i}$ (внди ниже под III), те се свріпује на нн $(u j)$, које је разједначивањем моr.ло гдасити и си: тако XIV вијека: конен М. 63. монастырен М. 137. п послије према старијим књигама: моүжен Стар. 4, 141. али је и прије и послије било и без те промјене, па се је од нн $(u j)$ крајње " $(j)$ у српском језику одбацивало као и у ријечи с основом на $\mathbf{i}$ : тако XIII внјека: роднтекн М. 26. џррн М. 35. XIV вијека: дннхрн М. 222. 236. Пб. 25. XV вијека: схквпін М. 406. дннарн М. 283. 285. 295. 389. 428. 492.504. II. 155. ІІб. 91. 106. конднерн М. 407. перьперн М. 285. 297. 432. ПІб. 108. Пнемезн М. 286. 290. 297. пнмеZн М. 345. Пхнеън М. 370. 506. II. 64 . 130. 152. 176. IIб. 71. 81. пенеzн М. 399. 400. на крају XV и свега XVI вијека додази у више ријечи него ирнје: завезаји Град. дјев. 96. стуньаји Брн. 2. жиљи Ст. пис. 1, 78. краљи Ст. пис. 1, 15. 270. Брн. 67б. пријатељи Стар. 4, 115. Брн. 63. родитељи Брн. 8. 47. ступаљи Стар. 4, 112. бадњи Ст. нис. 1, 78. коњн Ст. пис. 1, 14. 37. 3, 297. 311. Стар. 3, 229. 262. 263. сежани Збор. 119б. Стар. 3, 282. цесари Ст. пис. 1, 15. динари Н. Рањ. 92б. Хект. 16. ликари 
Ст. пшт. 1, 144. одтари Ст. ппс. 1, 95. поклисари Ст. пис. 1, 10. моүжїн Стар. 4, 67. мужп Ст. пис. 1, 221. Стар. 3, 297. Н. Рањ. 66. 156. 160б. Ст. пис. 5, 83. 245. Стар. 4, 115. мышн Стар. 4, 71. мечи Ст. пис. 1, 21. 62. Стар. 3, 261. рваги Ст. пис. 3 , 241. витези Стар. 3 , 250. дворци (у слику) Ст. пис. 2, 507. мисеци Стар. 1, 229. XVII вијека: накладаји Банд. 109. краљи Вран. жив. 79. пријатељи Банд. 242. родитељи Банд. 194. 242.' монастири Вран. жив. 67. мужи Вран. жив. 29. 50. Банд. 56. Крн. 19б. товарнши Вран. жив. 32. обручи Мпк. 242. пинези Банд. 74. Радн. пут 78. 87. пјенези Мик. 209. 416. 569. 701. мисеци Врап. жив. 54. Банд. У. Мик. 256. Да све ове ријечи имају и прави овај падеж од основа на а, показано је напријед. - Уз оваке ријечи с основом на ја прелазиле су у овом падежу и оне с основом на чисто а међу рпјечи с основом на $\mathbf{i}$ : то се појављује од почетка XV вијека : ангелн М. $297 .^{2}$ коматн Пб. 53. комадн Пб. 57. вратвчедн M. 453. на крају XV п свега XVI вијека: амазони Ст. пис. 1, 72. амонити Ст. нис. $1,5.22$. глпби Ст. нис. 3,476 . дарн Ст. пис. 1, 293. Хект. 27б. ${ }^{3}$ Брн. 6б. елементи Н. Рањ. $25 \sigma$. закони Ст. пис. 1, 209. зуби Ст. пис. 1, 295. Зор. 9. крати Ст. пис. 5, 19. лави Ст. пис. 1, 169. легиони Н. Рањ. 91б. мпди Стар. 4, 260. моабити Ст. пис. 1, 70. можданп Н. Рањ. 72. народи Н. Рањ. 182. плоди Стар. 3, 315. Чубр. 5б. прозори Хект. 5. суди Ст. пнс. 1, 92. 295. сусједи Ст. пис. 3, 226. свитн Ст. пис. 5, 30. 81. труди Ст. пис. 1, 302. цвитп 3ор. 46. чавли Ст. пис. 5, 144. часи Буд. 54. чини Буд. 149. XVII впјека: апоштоли Банд. 210. дарн Мат. 93. зуби Вран. жив. 62. Банд. 22. Мик. 62. Радн. пут 71. дисти Вран. жнв. 9. рукави Мик. 127. скотп Банд. 116. скорпијун Банд. 246. таленти Банд. 247. часи Банд. $149 .^{*}$ и кад је у основи пред крајњим а грлени гдас, те се мијења: бози Вран. жив. 19. - Овај завршетак долази и кад према основама на и пма већ ов: по-

' Бандулавић често прем да не свагда у оваком облику са $u$ ппше још $h$ на крају. Види о том даље под V.

${ }^{2}$ Овај примјер долази у властитом пмену кахвгернць свєтє марнє шдь ангем, па може бити да је тако речено талијански.

8 Али има и у генитив. јед.: такове дари Хект. 286.

* Кашић грам. 28. вели vitrov vel vitara vel vitri. 
пови Ст. пнс. 1,58. даровп Банд. 153. а долазп п у ријечи с основом на и кад је према основама на а без свога ов: воли Ст. пис. 1, 14. биволи Ст. пис. 1,14 . и у рпјечи које постају наставком ин или јанин па у множини одбацивши крајње ин пмају основу на сугдасно: србљп Д. Рањ. IV. 6. крстјани Ст. пис. 1, 246. Вран. жив. 57. бетулијани Ст. пис. 1, 26. градјани Вран. жив. 41. Банд. 72. самаритани Банд. 57. жудији Банд. 75. 219.

Б. У ријечи средњега рода на чисто а и на ја: кнеть M. 101. мнсть М. 347. мксть М. 350. сать М. 104. 506. тако фдо краја XVI вијека: бедар Н. Рањ. 16б. годишт Н. Рањ. 164б. Ст. пис. 2, 400. годиш Ст. пис. 3, 99. 4, 72. Град. дјев. 139. дил Н. Рањ. 164. добар Н. Рањ. 223б. Ст. пис. 5, 14. Град. дјев. 16. Буд. 138. Злат. 5б. језер Н. Рањ. 115б. Ст. пис. 5, 47. дјет Ст. пис. 2, 160. 3, 49. 4, 2г6. Злат. 35. очац Ст. пис. 3, 102. сат Н. Рањ. 85. Гуч. 29. срдац 168б. уст Н. Рањ. 19. Ст. пис. 2, 56. Злат. 86б. и XVII вијека: бедар Банд. 5. годишћ Вран. жив. 6. годишт Банд. 31. добар Гунд. суз. I, XXII. Банд. 69. Јерк. 9. колпн Банд. 216. лит Вран. жнв. 67. мист Банд. 34. сат (пецат, т. ј. пет сат) Мик. 63. Бун. 31. (девецат, т. ј. девет сат) Андр. 293. срдац Банд. 8. тал Вран. жнв. 82. уст Вран. жив. 33. Банд. 5. с промјеном гдаса $\boldsymbol{\lambda}$ на крају у $0:$ дио Ст. пис. 1, 283. ирема чему ће били гријешком писарском доданом такоме 0 на ново $\pi$ : сеюмь М. 234.

Рпјечи с основом на ја, које пред тијем завршетком у основи имају $u$, пак су се у овом падежу сврпивале на $u j$, могле су у ирва времена у овом шадежу мјесто иј разједначивањем имати и еј: тако је покекъпе Стеф. 15. - У таким је ријечима од давна у свијем падежпла $u$ од $-и ј$ - ослабивши у ь испадало; а тада би се у овом падежу десила на крају два сугдасна, од којнх је задње исто $j$ од $-и j$, па би се тада међу два крајња сугласна као и у другим таким -приликама уметнуло $a$ : тако од ријечи које су у номинат. јед. гласпле на речени начин колје (од старнјега копије) в зелје (од старијега зелије) има XVI впјека генит. мн: конај Стар. 3,244 . зелај 3ор. 65б. види тако и у женскпх рпјечи (ладај). али се је то и помијерало у псто вријеме: основа кака је бнвала по пто се избацнло $u$ од - $и$ - п по пाто се $j$ с предњим сугласним слијевало, прелазила је така и у овај падеж, и 
тада јој је опет приступао исти завршетак $a j$, премда је вегово $j$ веће једном стајало у основи: тако ина XVI вијека и биљај (bigliaj) Зор. 65. зељај (zegliaj) Зор. 75. 76.

И ове су ријечи као и оне мушкога рода добиле у овом облику на крају $a$, такођер од XIV вијека, када су се два ьь писала мјесто $a$ : секь ШаФ. рат. 1873. 100. XV вијека: годнца Пб. 120. зрьи М. 387. 406. 498. Пб. 72. пвтара Пб. 103. свкана II. 135. XVI вијека већ је обичније са $a$ него без њега: врата Н. Рањ. 47. Збор. 37б. А. Рањ. Уб. Злат. 21. годишта Н. Рањ. 80б. Збор. 44. Ст. нис. 3, 268. Злат. 84б. Гуч. 86. дјела Н. Рањ. 80. Збор. 176. Ст. пис. 3, 158. А. Рањ. 8б. Град. дух. 9. дјев. 72. Злат. 36е. Гуч. 8. добара Ст. пис. 3, 12. Збор. 97. Град. дјев. 16. Злат. 21б. Гуч. 27.' зала Ст. пис. 3, 374. 3бор. 9. Д. Рањ. 79. Град. дух. 49. јаја Ст. пис. 4, 331. језера 3лат. 42. колјена Н. Рањ. 228б. Гуч. 207. лита Ст. нис. 2, 153. 368. пнета Збор. 26б. Ст. пис. 3, 406. 4, 72. Злат. предгов. 2. мјеста Н. Рањ. 72. Злат. 59. могућства І'рад. дух. 71. мора Ст. пис. 3, 375. надахнутја Град. дух. 71. оћућенја Град. дјев. 113. писана Н. Рањ. 190. Д. Рањ. 119б. Гуч. 19. прибивалишта Н. Рањ. 143б. пристолја Н. Рањ. 228б. ироштенја Гуч. 38. рама Ст. шис. 4, 91. 93. срца Гуч. 104. стада Н. Рањ. 21. уда Ст. нис. 3 , 264. Брн. 24б. уста Ст. пис. 2, 64. 116. Н. Рањ. 16б. Збор. 23. д. Рањ. 34. Брн. 28. XVII впјека: благодатства Каш. 119. брда Мик. 8. величанства Гунд. пс. 39. весала Бун. 10. воћа Обр. 48. врата Банд. 248. Мик. 478. вретена М. 792. годишта Вран. жив. 39. Див. Х. Банд. 115. дјела Див. $15 б$. Гунд. суз. III, IX. Каш. ІІІб. дшла Банд. 69. добара Орб. 20. мат. 60. Кашl. 3. Андр. дев. 151. Радн. 5. достојанства Андр. 212. Радн. 40. дрва Бапд. 118. зала Банд. 281. Радн. 21. изискивања Радн. 7. јаја Банд. 290. кољена Банд 186. краљевства Андр. пут 172. Радн. 68. крила Мик. 259. ледја Радн. 50. лита Вран. жив. 47. миста Банд III. напастовања Пос. 41. непомства Андр. пуут 406. оћвћєи Мат. 93. оћућенја Радн. 49. писама Банд. 2. Каш. 31. помазанја Радн. 53. помилованја Kaш. 119. пријательства Радн. 27. прнказанја Јерк. 73. срдаца Радн. 25. срца Бун. 3. Радн. 5. стабала Банд. 81. Радн. 42.

' Долази тако додано $a$ и тад међу предша два сугласна није уметнуто XVI и XVII вијека: добра Н. Рањ. 79. Андр. пут 245. 
стареншнства Радн. 43. ћућења Мнћ. 786. уда Мик. 849. Пос. 15б. ужа Мик. 737. уста Див. 13. Банд. 124. Гунд. суз. III, XVIII. Андр. дев. 48. цријева Мик. 524. чнњенја Радн. 74.

Како су и гдјекоје мупке ријечи с основом на ја могле у овом надежу имати и онако као штго имају ријечи с основом на і (види напрнјед код мушких ршјечи), исто су тако и гдјекоје ријечи средњега рода с основом на ја могде имати и ирема ријечнма с основом на $\mathbf{i}$, на пме оне које у основи пред завршетком ја имају $u$ : у њих је у овом падежу као и у другима речено " у основн ослабнвши у ь отнадало, а од "ш (uj), које су у овом надежу према ријечима с основом па $\mathbf{i}$ имале на крају, отнадало је крајње " $(j)$ као и у ријечи с основом на $\mathbf{i}$; тако долази поуздано пстом XVI вијега: пристодјц Н. Рањ. 186. деапјп Буд. 121. дилованји Буд. 37. 157. одлученји Буд. 72. оћућенји Буд. 33. пригришенји Буд. 42 . чињенји Буд. 19. 37.' није поуздвпо зеки Стар. 3,258 , јер се може читати и зељи и зели и зелиј. XVII вијека: смилопанји Банд. $273 .{ }^{2}$ али се тога внјека и избацивало $j$ пред крајњим $u$ само за то пто је пред тијем гласом: пстнна пишу: govorenij Радн.56. pokolinij Банд. 124. помаћкканни ПОс 41. помкнкамїн Мат. 96. али се не може потврдути да се је $i j$ в ии читало $j и$ или иј, него мислим да обоје показује сано да је бнло једно дуго и. - Да су су оваке ријечи имале у овом падежу и онако као. остале,

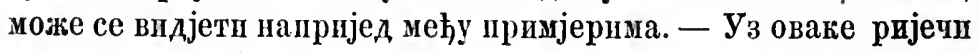
с основом на ја предазпле су у овом падежу п оне средњега рода с основом на тисто а међу рпјечи с основом на $\mathbf{i}$, као што су предазиле и мушке: таго нма на крају XV п свега XVI внјека: богатастви Стар. 3, 257. госпоцтви Стар. 3, 312. дили Ст. пнс 1, 8. 91. 115. Буд. 94. Брн. 2б. дјели Н. Рањ. 133б. дели Буд. 71. кољени Ст. пис. 4, 279. либри Ст. пис. 1, 7. дити Ст. нис. 1,23 . љети Ст. инс. $4,192.5,316$. њедри 3лат. 49. 61. рами Ст. пис. 1, 36. уди Зор. 336. Буд. 111. Брн. 186. усті Ст. пнс. 1, 48. 2 24. 226. 285. 394. 4, 90. 5, 36.

' Мјесто $j u$ нгтампано је латннски словпма gii, од чега $\mathrm{g}$ не нрипада к предњему $n$, јер кад нригада, онда не стојн g за њпм него пред вим: "cignengii“. Два $i$ мпслим да не

стоје за гласове $i j$ него за једно дуго i.

2 наштампано је латинским словима smilovanyii. 
55. 112. 178. А. Рањ. 59. Хект. 39б. 45. Злат. 37б. 64. Чубр. 10б.' тако поред споменутога напријед тал има и тли Ст. пис. 5 , 39. алп та ријет има и друге падеже према основама на i. - XVII вијека: богастви Пос. 21. богатстви Радн. 5. 43. дели Глав. 4. достојанстви Радн. 41. 54. усти Гунд суз. I, XXVIII. III, XVI. пс. 14. Бун. 45.

Што су се средње ријечи не само у овом позајмљеном облику једначиле с ријечима мушким, него што су и у правом свом генитиву мн. и готово у свјема другим падежима једнаке с мушким ријечима, то их је јамачно навраћало да се још' више с њима изједначе у овом падежу, те се п ! вих налази у овом падежу ов као у пушких према основама на $\mathbf{u}$, али доста ријетко и само у неких књижевника и пстом од свршетка XV вијега: днлов Брн. 5б. 56б. 72б. Банд. 295. кодов Стар. 1, 222. Вран. жив. 13. кољенон Н. Рањ. 201б. мистов Буд. 116. 138. ${ }^{2}$ Зор. 59. перов Зор. 70. селов Зор. 23.75. словов Стар. 1, 220. стадов Зор. 52.3 и с доданим $a$ XVI вијека: блатова Ст. пис. $5,47 .-$ И у ријечи која има основу на $\mathbf{i}$ али је прелазнла меלу средње с основом на а има и јаслов Стар. 1, 234. - Што има и удов Ст. пис. 1, 56. Банд. 222. Мрн. 149. може бити да не иде овамо јер је та ријеч и мушшога рода и гласи у номин. јед. и уд.

В. У женских с основом на чисто а и на ја: до краја XV вијека: вадақакь М. 408. көльможь П. 122. воєводь М. 538. господь ІІ. 1. 60. 69. 107. жкнрь Пб. 125. земахь М. 104. 258. 261. 234. ПI. 25. Пб. 84. земхь ПI. 10. коүћь М. 481. ххжнир Пб. 102. кнтарь М. 488. 504. Пб. 49. пешравадқ М. 448. бжнуь Пб. 49. 56. опrï̈ М. 195. оригн(н) М. 225. снроть ПI. 77. скугь М. 382. судїн М. 434. суднн ПI. 134. тисвћь М. 500. 503. 509. виауь М. 488. Пб. 49. форамь М. 408. - на крају XV п свега XVI вијека: вериг Град. дјев. 76. вил Ст. ии́с. 2, 87. висин Ст. пис. $3,352$. волать Збор. 72. 88б. гор Н. Рањ. 15. господпчан Ст. пшс. 3, 274. госпођ Ст. пис. 2, 43. госпој Ст. пис. 3 , 74. 4, 461. 5, 178.

' Долази и кад је женскога рода: од усти, ке бјеху јак роза Ст. пис. 2, 316. од усти, ке - Злат. 46.

2 Овамо би мог.ло ићи и чоменуто на стр. 70 бенефицијев, офнцијев.

3 Каши грам. 34 вели: źlatov vel zlata vel zlati. 
А. Рањ. 6б. густеран Ст. пис. 1, 30. дасак Вран. жив. 26. дјевиц Ст. пис. 2, 404. 3, 74. 4, 101. 306. Ірад. дјев. 46. дивиц 3лат. 86. дјевојак Злат. 40. дубип Ст. нис. 3, 382. думаш Град. дјев. 126. душ Н. Ран. 131б. жен Н. Рањ. 160б. Вран. жив. 82. ж九ивин Н. Рањ. 116. звизд Ст. пис. 1, 40. Н. Рањ. $211 б$. земаљ Н. Рањ. 42. здоб Град. дух. 79. змиј Стар. 4, 112. нгар Злат. 16б. карат Ст. пис. 3, 118. катндар Стар. 4, 117. књиг Буд. 83. косиц Ст. пис. 2, 36. краљиц Ст. пис. 5, 44. дикариј Буд. 39. дисиц Ст. пис. 3, 467. модитав Ст. пис. 1, 37. А. Рањ. 74. Буд. 120. молитвиц Град. дух. 65. мраваљ Ст. нис. 4 , 85. 165.' мркијенат Ст. пис. 3, 124. 470. мук Град. дух. 82. Буд. 5. наредаб Буд. 87. нево. Град. дјев. 38. Здат. 6б. недјељ Н. Рањ. 143б. неправад Ст. пис. 1, 238. 5, 66. Брн. 73. нечистоћ Н. Рањ. 73б. овац Н. Рањ. 42. Ст. иис. 3, 9. пелен Здат. 52. пожуд Град. дјев. 10. покор Буд. 34. понистар Стар. 4, 116. правад Ст. пшс. 1, 89. Буд. 130. првин Н. Рањ. 143б. птиц Ст. пис. 2, 81. Вран. рјеч. 11. пуњестар Ст. пнс. 5, 188. ран Буд. 12. рнб Н. Рањ. 174б. Ст. пис. 5, 37. робињ Град. дјев. 165. рук Ст. пис. 1, 254. Н. Рањ. 1616. 3лат. 6. светковин Град. дух. 36. свит Н. Рањ. 93б. слуг Н. Рањ. 27. службениц Н. Рањ. 143. Град. дјев. 116. специј Ст. пис. 5, 102. старпц Ст. пис. 2, 16. старјешин Г'рад. дух. 29. стотин Злат. 100. стран Зор. 66б. Злат. 1б. суз Ст. пис. 2, 20. 3лат. 76б. тисућ Н. Рањ. 167б. Д. Рањ. IVб. усан Ст. пис. 1,62. Н. Рањ. 16б. Брн. 44. хаљин Град. дјев. 87. хвал Буд. 40. худоб Град. дјев. $156 .^{2}$ с промјеном гласа $\iota$ на крају у о:

1 Та је ријеч и у старом словенском језику припадала међу женске ријечи с основом на ја, те је гласила у номин. јед. мрхвни и мрхвна, у геннт. мрлвнх (види у Миклошевиһеву рјечниюу); и қод нас је била међу тијем ријечима (впди ном. мн.) па је избацивши $u$ добила $\lambda$ међу $в$ и $j$, као што бива и $у$ другим таким прпликама.

2 IІрем да се у то вријеме уметало $a$ међу врајња два сугласна, опет се налази ІІ без тога $a$ : нешравд Брн. 726 . ламп Ст. пис. 3, 97. пукш (пушака) Буд. 90. тако вад се стеку три сүгласва на крају, од којпх је прво $j$ а друго и треће $c k$, налази се јметнуто $a$ само међу прво и друго: војаск Ст. пис. 1, 59. 72. 247. Н. Рањ. 163. 164. IІІто има: велик педјешс достојан је А. Рањ. 6. псдјепс Злат. 7б. на оба мјеста 
сио Ст. пис. 1, 36. 41.-XVII вијека: вод Банд. 14. дасак Вран. жив. 26. Мик. 59. дивиц Банд. ХХIII. драгам Банд. 271. жен Вран. жив. 82. зема.б Банд. 63. књиг Банд IV. кросан Мик. 30. кућ Банд. 102. думбарад Мрн. 63. Мариј (десет здравих Мариј) Јерк. 8. молитав Банд. 183. недиљ Банд. 182. неправад Гунд. пс. 33. ног Банд. 174. обрв Вран жив. 10. овац Банд. 15. палам Банд. 82. перал Јерк. 79. притак Мик. 89. рожиц Вран. жив. 19. рук Вран. жив. 91. Банд. 18. Јерк. 26. свић Банд. 194. сестар Вран. жив. 55. Банд. 66. слуг Вран. жив. 7. смокав Мик. 779. тмин Банд. 8. Јерк. 26. труба.љ Јерк. 76. унач Мик. 729. усан Банд. 5. 176. устан Банд. 228. 248.

На исти начин како је речено напрпјед за средње ријечи у овом падежу: копај, зелај (види напрпјед стр. 76) било је и у женске ријечи која у номинат. јед. сада гласи лађа а прије ладија, у овом падежу XVII вијека ладај. Рад југосл. акад. 16, 166.

Али ако се тако находи још и XVII вијека, опет још од XIV вијека додаје се на крају а онако као и у мушких и у средњих ријечп: жвпа М. 218. п са два ьь мјесто а: раБоть IIIаф. pam. 1873. 100. 103. XV вијека : аспрх(?) Пб. 49. 56.

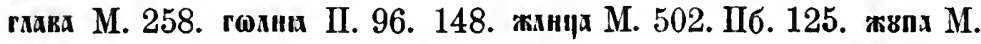
449. зднека Пб. 102. земала М. 369. 370. 528. кука М. 357. 361. 365. Пб. 84. крвгыха М. 372. хаднца М. 372. 394. пажнца М. 408. питарх М. 372. 380. 384. шправа ПI. 70. перама М. 498. пеух М. 498. пхоуа М. 406. правада Пб. 127. работа Пб. 80. рота М. 447. скнта Пб. 112. Пб. 125. сманніן М. 408. слугх М. 473. 485. II. 85. Пб. 110. страна М. 474. судна Пб. 44. П. 105. 111. 134. 136. свдьк М. 256. тирьгы ПI. 125. теұна М. 408. тнсвкы М. 298. 350. 356. 364. 372. 390. П. 56. Пб. 86. внхух М. 372 . хнхкда М. 407. уаша М. 372. чашніја Пб. 125. четх М. 443. 501. - На крају XV и свега XVI вијека: бесједа Ст. пис. 5, 8. Град. дух. 35. брига Град. дјев. 41. вида Ст. пис. 2, 26. 4, 101. внөмх Збор. 123б. висина Н. Рањ. 40б. Збор. 49б. Ст. пис. 3 , 379. Гуч. 5. вода Н. Рањ. 24. Ст. пис. 3, 126. Град. дјев. 172. Злат. 87. волата Збор. 11. глава Ст. пис. 2, 9. 3, 100. 4, 299. Збор. 50. годнна М. 546. гора Ст. пис. 1, 221. Н. Рањ. 426. Ст. пис.

може се мислити да је супстантив узет у мупком роду и да стоји у акусативу јед. 
5, 31. А. Рањ. 4б. Злат. 62б. госпоја Ст. пис. 2, 348. 3, 76. 3бор. 90б. Гуч. 136. госпођа А. Рањ. 25б. Чубр. 5. грана Злат. 80б. гусака Ст. пис. 4, 270. гуштерица Ст. пис. 3, 30. днекних 3бор. 34б. Ст. пис. 3, 131. Гуч. 21. доброта 3бор. 14. држава Ст. пис. 3, 76. Злат. предгов. 1. дубина Н. Рањ. 112. Ст. пис. 1, 30.. 3, 477. дубрава Злат. 50б. думана Туч. 28. душа Н. Рањ. 129. Збор. 100б. Град. дух. 12. Злат. 84. Гуч. 11. жежа Ст. пис. 2, 411. жена Н. Рањ. 137б. Збор. 19. Ст. пис. 3, 57. 416. 4, 366. 5, 13. 116. А. Рањ. 13. Ірад. дјев. 59. Злат. 29. Гуч. 72. жила А. Рањ. 38. живина Н. Рањ. 199б. Злат. 39. забава Град. дух. 28. зкшеза 3бор. 50. Ст. пис. 3, 421. Град. дјев. 65. Злат. 1б. звизда Ст. пис. 2, 57. Д. Рањ. 1б. Чубр. 15. зима Н. Рањ. 187б. злоба Н. Рањ. 46б. Ст. пис. 3, 262. 4, 384. 5, 36. Град. дух. 79. Злат. 36. Гуч. 11. злоћа 3бор. 7. змпја Н. Рањ. 153. Ст. пис. 2, 365. јабука Злат. 50б. јаребица Ст. пис. 4, 271. камиља Н. Рањ. 28б. капаља Ст. пис. 3, 60. клетава Злат. 6. књига А. Рањ. IX. Злат. 84б. кокопица Ст. ппс. 4, 270. кражица Ст. пис. 3,413 . крнвнна 3бор. 78б. крушака Ст. пис. 4, 252. куна Ст. пис. 3, 467. кућа Н. Рањ. 106. Збор. 87. литара Н. Рањ. 111б. Збор. 83. молитава Гуч. 88. мраваља Ст. пис. 4, 157. 165. мрва Н. Рањ. 46б. мука Н. Рањ. 207б. Збор. 126. Ст. пис. 5, 54. Д. Рањ. 70. Град. дух. 13. Гуч. 42. неком Збор. 97б. невоља Гуч. 110. неподоба Н. Рањ. 59б. нога Н. Рањ. 23. Збор. 83. Ст. пис. 3, 399. Ірад. дух. 56. оваца Н. Рањ. 140б. оправа 3лат. 36е. паља Ст. пис. 5, 185. папа Гуч. 10. патрпјарага Гуч. 4. пета Ст. пис. 2, 342. 3, 149. Збор. 72. планина Н. Рањ. 183. Гуч. 169. пловака Ст. пис. 4, 270. поглавица Збор. 75б. препелпца Ст. пис. 4, 271. прилика Збор. 114б. Град. дух. 9. привара Д. Рањ. 88. промјена Н. Рањ. 60б. пाсовака Ст. ing. 5, 101. птица Н. Рањ. 115б. Збор. 21. Ст. пис. 3, 9. А. Рањ. VII. Злат. 45. птичица Н. Рањ. 116б. пчела Ст. пис. 2, 71. 3, 144. 3бор. 2. раба Н. І'ањ. 141. работа Н. Рањ. 225. рана Град. дух. 61. раскоша Град. дјев. 11ј. Гуч. 266. риба Н. Рањ. 150. 3бор. 119. Д. Рањ. Уб. Злат 45. рубица Н. Рањ. 151б. ријека Н. Рањ. 79. Ст. ппс. 5, 47. Град. дјев. 182. рика Здат. 56б. рука Н. Рањ. 67б. Збор. 162. Ст. пис. 2, 416. 3, 454. 4, 480. 5, 54. Град. дјев. 22. Злат. 7б. Гуч. 171. рвсх Збор. 122. Гуч. 21. сабаља Ст. пис. 3, 60. свита Н. Рањ. 100б. Збор. 115. Злат. 
91. сестара Н. Рањ. 77. Збор. 108. Гуч. 28. снла Ст. пис. 3, 386. снрота М. 557. слуга Ст. пис. 2, 70. Н. Рањ. 49. Збор. 10. Ст. пис. 5, 237. Д. Рањ. 5. Град. дјев. 165. Злат. 3. старјешина Н. Рањ. 91. Гуч. 83. страна Н. Рањ. 213б. Збор. 51. Ст. пис. $3,10.4,203$. Злат. 11. стрила Ст. пис. 2, 39. стријела Ст. пис. 3,145 . Злат. 39. струна Ст. пис. 3,475 . суза Ст. пис. $2,463$. 3, 16. 4, 73. 5, 109. Збор. 26. А. Рањ. 71б. Град. дјер. 162. Злат. 20б. тамница Збор. 101. Ст. пис. 3, 315. танчнна Град. дјев. 63. таштипа Град. дјев. 77. тетака Ст. пис. 5, 246. тисућа Н. Рањ. 60б. Збор. 74б. Д. Рањ. IVб. трава Злат. 47б. туга Ст. пис. 2, 116. Град. дјев. 35. Злат. 3. тужица Ст. пис. 3 , 397. уза Ст. пис. 3, 438. ура Град. дух. 55. усница Н. Рањ. 218. хаљина Збор. 57б. Ст. пис. 5, 16. четина Ст. пис. 4,192 . шибика Збор. 36б. - XVII вијека: бритава Андр. пут 254. буха Мик. 32. висина Јерк. 82. вода Банд. 113. Јерк. 18. војвода Мик. грам. 6. Радн. 25.' волата Андр. дев. 49. врба Мик. 796. врста Мик. 797. гњнда Мик. 102. година Мик. 112. госпоја Вран. жив. 14. гора Орб. 166. Гунд. суз. III, XI. Банд. 3. груда Мик. 124. дасака Мик. 456. дјевица Орб. 27. длака Мик. 27. дубина Гунд. пс. 31. душа Див. 26б. Радн. ІІб. ъемија Мрн. 111. жена Вран. жив. 29. 36. 58. 60. 67. 82. Орб. 25. Ванд. 99. Каш. 2. Мик. 464. живина Мик. 701. звијезда Банд. 46. Мик. 862. здпла Мпк. 381. земаља Банд. 34. Кашг. 25. здоба Јерк. 75. Андр. дев. 30. здоћа Банд. 112. капаља Андр. пут 272. карата Мик. 137. књига Мик. 109. Радн. ІІІб. кодудрица Вран. жив. 56. кривина Андр. дев. 75. кучина Мик. 220. доза Мик. 428. масдпна Мик. 724. мекнна Мик. 399. Радн. 20. молитава Орб. 129. Андр. пут 120. дев. 138. нач. 32. мрва Банд. 38. мука Див. ХVб. Јерк. 66. Андр. дев. 70. невоља Мик. 22. недиља Банд. 183. неправада Банд. 62. оваца Банд. 34. Каш. 84. Радн. 44. опека Мик. 153. палама Каш. 40. паља Мик. 219. патријарака Кашг. 3. перала Андр. нач. 38. п.анина Банд. 34. Бун. 21. плоча Мик. 444. погдавица Банд. 85. погрда Див. 13б. приварака Андр. пут 403. прилика Банд. 24. псовака Каш. 50. Андр. дев. 142. птица Вран. жив. 20. Банд. 116. Мпк. 105. Радн. 42. пгела Мик. 567. рана Вран. жив. 39. Банд. 45. Мик. 535. рнба Радн. 42. рука Мик. 420. Андр. нач. 38. свиња Мик. 134. свита

1 Каши грам. 38 вели: vojvod vel vojvodaa. 
Банд. 48. сестара Каш. 41. сирота Мик. 26. слуга Вран. жив. 23. Гунд. суз. I, XVI. Банд. 29. Андр. пут 26. сова Мик. 777. старишина Банд. 91. стијена Мшк. 120. страна Банд. 38. Мрн. 61. Мик. 580. стрида Крн. 8б. суза Орб. 65. Гунд. пс. 4. Банд. 295. Бун. 36. Мик. 567. тисућа Вран. жнв. 50. тмнна Банд. 97. трава Орб. 48. Банд. 291. трнца Мик. 698. трубаља Каш. 63. туга Мик. 22. удица Мик. 711. удовица Орб. 27. ура Банд. IX. усана Радн. 56. хиљада Мрн. 41. штака Мик. 587.'

Како је у некнх ријечи мушких и средших с основом на ја овај падеж бно и према ријечима с основом на $\mathbf{i}$ (види напријед стр. 74. 78.), тако је бно и у некпх женскпх с основом на ја, па им је завршетак $и ј$ који би тада у том падежу имале могао у прва времена разједначивањем гласити и еj: тапо је било єпискоүпнєи М. 15 . а тада је крајње $j$ пза $e$ могдо и отпасти или се није свагда писало: зємкє М. 22. 38. тако је непромијенивши $u j$ на $e j$, него од $u j$ (ин) одбацивши крајње $j$ било XV внјека: тнсвкн Пб. 91. ${ }^{2}$ тако и шослије: тисући Ст. пис. 1, 12. 293. Стар. 3, 259. 276. 291. Вран. жив. 50. тако XVII вијека: пдаһп Див. XIV. гревји Орб. III. ${ }^{3}$ и избацивши j испред и: цреви Андр. 299. таке су ријечп с основом ја повукде за собои и друге ријечи с основом на чисто а, као што је било и међу мушкима и средњима: $\mathrm{XV}$ вијека: аспри М. 407. 525. 527. Пб. 97. П. 86. асырт Пб. 59. мвсафи М. 409.

' Прем да међу два сугласна уметнуто $a$ остаје и кад је за вима додано на крају $a$, како показују горви примјери, опет се налазе некп између самијех тијех иримјера а и другп без $a$ међу два сугласна као и напријед аспра: XVI вијека: вечерва Гүч. 89. ворабља Гуч. 32. мравља Ст. пис. 3, 356. наредба Град. дјев. 133. 134. сељанка Злат. 53б. трубља Град. дјев. 39. XVII вијека: искра Мик. 141. магла Орб. 260. патријарка Андр. дев. 93. сумња Орб. 1. 30. тужба Гүнд. пс. 27. шиндра Мик. 444. и гдје се стичу три сугласна, прем да се међу ирва два уметало $a$ кад се на крају вије додавало $a$ (впдн напријед стр. 80 ), опет долази без $a$ међу сүгласнима кад се на крају додавало $a$ : XVI и XVII вијека: војска $A$. Рањ. VIб. Гуч. 102. Гүнд. суз. предгов. Каш. 109.

2 Hије поуздано: декеть тнсвкн седамь схть ІІб. 67. јер може бити да је погрјешка мјесто тнсвкһ и ссдамь.

Наштампаво је плаһщи, сrevyij, али на крају стоји $и и$ и $i j$ 8а једно дуго $u$. 
на крају XV п свега XVI вијека: аспри Ст. пис. 5, 185. беспди Ст. пгис. 1, 84. злобп Ст. пис. 5, 39. коси Ст. пис. $2,18$. 79. Злат. 11. 53. магли Н. Рањ. 112. папи Буд. 148. стрили 3ор. 31. сузи Ст. пाс. 2, 168. Брн. 41. усни Ст. пис. 2, 409. XVII вијека: воиски Пос. 416. иасшри Пос. 20б. Радн. 88. коси Гунд. суз. I, XXXI. Бун. 6. 13. карби Радн. 63. палми Банд. 77.81. помњи Радн. 86. служби Див. XIV. срчби Радн. 59. стази Крн. 14. 20б. стрили Крн. 7. ури Вран. жив. 64. 65. 105. хвали Банд. 290. 293. 297. хиљади Мрн. 45. 55.

Г. У адјектива је за сва три рода било једнако, и то као у супстантива с основом на а у правом впховом том падежу, али само у прва времена: ддовь Стеф. 7. снрьь Стеф. 18. поєкь Стар. 4,64. а у исто се доба замјењпвао сложенијем обликом, који види.'

III. Основе на i. Крајње се i у основи шири те бива дуго, а у словенским језицима опет кратко, између њега и наставка да не буде зијева умеће се $j$, за којим наставак поставши у словенским језнцим в отпада, а тада и $j$, које се у старом словенском језику пише ", стојећи на крају п имајући пред собом $и$ у српском језику отпада:

А. У мушких ријечи: до краја XV вијека: кьиืети М. 29. кмети М. 30. 339. 345. 422. пуди М. 6. пюудн М. 367. пвтн М. 264. и даље свега времена: буди² Банд. IV. Банд. 198. Каш. 86. Мпк. 464. пути Н. Рањ. 193б. црви Ст. пис. 1, 315. 316.333 3бор. 1236. Орб. 163. Андр. пут 360. Пос. 186. Радн. 36. 43. И у ријечи је дан овака основа, те је и она у овом падежу гласпла свега времена: дьнн М. 165. 190. 257. дни II. 62.101. 140. Н. Рањ. 41. 3бор. 26б. Ст. пис. 3, 266. 5, 12. 117. Злат. 2. (dnij) Банд. X.

У старије вријеме могло је ни на крају разједначивавем гласити и єн: мюдєи Стеф. 8. поктен М. 331.

Али су све оваке ријечи оспм људи прелазиле међу ријечи с основом на a, неке ранпје неке позније; у ријечи дан тако је још у старом словенском језику (Миклошић, vergl.

1 ІШто има: велик педјепс достојан је Д. Рањ. 6. споменуо сам да hе то бити акусат. јед. мушкога рода.

2 Уесто латинским словима стоји на крају $i j$ или $\ddot{i} i$, али мислим да је то само мјесто једнога дугога $i$. 
gram. III. 53), а у нас се палази од XV впјека кроза све вријеме: даи ПI. 117. дни II. 137. дан Н. Рањ. 27б. Ст. пис. 1, 3. 5. 266. 2, 433. 438. 3, 263. 4, 167. 206. 5, 17. 29. Град. дух. 49. Хект. 2б. 18. 35б. 45. Буд. 138. Вран. эиив. 87. Банд. 98. Крн. $4 б$. тако и.дакат Н. Рањ. 115. Збор. 52. нохат Ст. пис. 1, 51. нокат Мик. 333. пут Ст. пис. 5, 189. с доданим $a$ на крају такођер од XV вијека: дашх М. 380. Збор. 8. Ст. пис. 3, 10. 63. 79. 350. 4, 36. 49. 219. 371. 5, 74.99. 161. 165. Град. дух. 55. Злат. предгов. 2. Гуч. 39. Див. 4. Вран. жив. 24. 52. 83. Орб. 10. Банд. 11. Гунд. пс. 28. Мат. 29. Мрн. 61. Каші. 16. Мик. 55. IIос. 43. Радн. 26. дагата Н. Рањ. 115б. Збор. 34б. Орб. 197. 219. Банд. 7. Кашг. 50. ноката Орб. 210. пута Н. Рањ. 43б. $46 \sigma$. Див. 29. Мат. 8. Капг. 96. Мик. 62. Андр. дев. 1. Радн. 31. неке су прешле онамо тако да према ријечима с основом на и пмају и ов: тако бп бнло још XIII внјека господокь М. 26.' тако је XVI вијека п послпје: голубов Н. Рањ. 175. путов Зор. 27б. Банд. 35. и с додани $a$ : путова Банд. 119. Мат. $16{ }^{2}-$ Између женских ријечи с основом на $\mathbf{i}$ постала је мушкога с истом основом па је с таким ријечима прешла међу мушке с основом на а, те има као оне: длана Ст. пис. 4, 111. тако је и мрав пзмеђу ријечй с основом на а (мравпја, мравља) прешао међу женске с основом на $\mathbf{i}$, а оданде међу мушке с основом на $\mathbf{i}$, тс је пмао у овом пад. као п остале ријечи једнако са женскима : мрави Ст. пис. 4, 165. 271. Радн. 9. али је с такн ријечима опет препао п међу мушке ријечи с основом на а те има у овом падежу п мрава Ст. пис. $4,164$.

Б. У женских : до краја XV вијека: рнеун М. 542. стварн IІб. 130. и иослије кроза све врпјеме: голијени Н. Рањ. 111. звијери Ст. пис. 3, 405. 4, 282. звири Хект. 22. Чубр. 4б. Гунд. суз. III, LV. Андр. пут 383. кости Збор. 113б. Ст. пис. 5, 154. Гунд суз. II, XXXIV. Радн. 74. дажи Буд. 92. напасти Гуч. 209. ноћи Н. Рањ. 44б. Банд. VII. охоласти Гуч. 209. пјесни Здат. 85. писмп Зор. 5б. Брн. 65б. погибили Каш. 112. погибли Радн. 57. ријечи Н. Рањ. 80. Град. дух. 35. Мик. 726. уши Ст. пис. 5,332 . п ријечп које се највпше говоре само у множини : гусли

1 Али би то па том мјесту могло бити и пиструментал јед. према номинативу господа.

${ }^{2}$ Кашић грам. 27 вели: golubov vel goluba vel golubi. 
Н. Рањ. 122. Мик. 238. јасли Град. дјев. 180. Гуч. 145. прси Н. Рањ. 24. Збор. 113б. Ст. пис. 1, 329. 4, 39. 5, 24. 148. Каш. 91. Андр. дев. 49. тако п дпнли Злат. 62б. - Ријеч отров била је женскога рода с основом на $\mathbf{i}$, те је у овом падежу било: отрови Ст. пис. 3, 110.

У ријечи средвега рода алеће, око узима се стари номинатив двојине ллећи, очи као да је номинатив мн. женскога рода с основом на $\mathbf{i}$, па према томе има и у овом падежу као у тијех женских ријечи: плећи Ст. пис. 3, 463. 5, 137. очи Ст. пис. 5, 247. 326.

И у овијех је ријечи као п у мушких у старије вријеме у овом падежу грајње ни могло разједначивањем гласити и єІІ zапоктден М. 9. ноцен Стеф. 28. вххстен М. 63. страстен Aом. 218.

Неке су између овијех ријети прелазиле и у другим паделима међу женске с основом на а, па су прелазиле и у овом: гусал Зор. 12б. пиисан Брн. 11. 19. 23б. 24б. Вран. жив. 108. само један пут п то у слику налази се тако п кост Зор. 14.' Ријеч јасли, која је прелазнла међу средње с основом на a, споменута је у том падежу код њих.

IV. Основе на сугдасно. $\mathrm{K}$ основп приступа наставак поставши у словенским језпцима $\mathbf{~}$, које у српском језику отнада:

А. У мушких ријечи с доданим $a$ на крају : камена Мик. 184. 444. тако пзмеђу ријечіг које су у номинат. јед. прешле међу ријечи с осповом на а: грумена Банд. 124. препавши онамо налази се и без крајњег ен у оспови : пдама Гунд. суз. II, XIII. Андр. 221. између ријечи које су пгрешле онамо надази се и са ов према ријечима с основом на и: еленов Стар. $3,221$.

Те су ријечи још у старом словенском језику предазиле у том падежу међу ријечи с основом на $\mathbf{i}$, по том је и у нас бнло још XV вијека: камепи М. 386. а према томе и XVII вијека: грумени Банд. 111. 113.

Б. У ријечи средњега рода: кркмєнь М. 532. кржмень ПІб. 84. вримен Банд. V. рамен Град. дух. 58. дктеть II. 1. колес

1 A Кашић грам. 41 вели да је у овом падежу sladost vel sladosti vel sladosta. 
Ст. пис. 1, 247. небес Ст. пис. 1, 336. 2, 201. 3, 355. 5, 118. 299. Н. Рањ. 146б. Збор. 28б. Град. дух. 50. Злат. 94. Банд. 24. см0вссь М. 17. телес Брн. 27б. Мрн. 60. хюуєсь М. 100. - С доданим на крају $a$ као п у других ријечп: бримена (onus) Радн. 43. врјемена Ст. пис. 3, 10. вримена Д. Рањ. VIII. времена Ст. ппс. 4, 265. Див. IX. Мпк. грам. 44. имена Ст. пис. 3, 378. рамена Ст. лис. 3, 474. колеса 3бор. 36. небеса Н. Рањ. 135. Ст. пис. 2, 350. 3, 289. 4, 296. Збор. 54. Ст. пис. 5, 118. 134 Злат. 58б. Гуч. 7. Див. 32. Обр. 23. Гунд. суз. I, III. Бун. 5. Јерк. 89. телеса. Ст. пис. 3, 335. Збор. 68б. Орб. 95. Каш. 32. тилеса Радн. 64. чудеса Ст. пис. 2, 73. Кашг. 34. Андр. нач. 48. Радн. 64.

Изједначујући се с ријечима средњега рода у којих је основа на а, неке у овом падежу као и у другима крње основу одбацујући јој крајње сугласно п пред вим самог.ласно: кола Н. Рањ. 117б. Збор. 13. Брн. 8. Злат. 2. Буч. 238. слова Див. XIII. Банд. IV. Ђам. 4. Мик. 183. чуда Јерк. 76. Андр. нач. 14. да су неке од овпјех прешавши тако окрњене међу ријечи с основом а пмале у овом падежу и ов према основама ка $\mathbf{u}$, споменуто је напријед код ријечп средњега рода с основом на $а$.

Неке су онако као п мушке и средње и женске с основом на а прелазиле у овом падежу с цијелом основом међу оне у којих је основа на i, али тек од XV вијека: вримени Буд. 54. 148. времени Див. ІХб.' рамени Ст. пис. 3, 395. 463. 3ор. 45б. симени Мрн. 24. небеси Ст. пис. 2, 111. 5, 27. 304. Гунд. пाс. 34. суз. III, XXXIX. Бун. 4. тако су предазнле и одбацивши у основи крајње сугласно и пред њим самогласно: коди Ст. пис. 3, 321. Вран. жив. 71. тпјели Ст. инс. 3, 120. неби Ст. пис. 2, 441. 443. 4, 437. 5, 8. 43. 114. 329. Злат. 6. 18б. 24б. 956102. Гунд. пс. 5. суз. I, LXIII. Мрн. $20 .^{2}$

В. У женских: матерь Сав. 5. кькерь М. 364. прькькь М. 243. - и с доданим $a:$ матера Орб. 216. 248.

Неке су у овом падежу предазиле још у старом словенском језику међу оне с основом на $\mathbf{i}$, по томе је и у нас: кюен М. 356. 360. Пб. 76. кькєрп М. 364. кьћерн М. 373. Пб. 67. хћери

- Кашиһ грам. 33 велп: vrimen vel vrimena vel vrimeni.

2 Кашић грам. 35 вели: nebes vel nebesa vel nebov vel nebi. 
Н. Рањ. 82. Вран. жив. 41. вћери Ст. пис. 4, 419. Град. дјев. 80. Банд. 209. - Ријеч ирква прешла је међу оне с основом на а: цркав Н. Рањ. 212б. Град. дјев. 183. Банд. 26. и с доданим $a$ : цркава Н. Рањ. 35. 145. Гуч. 12. 67. 88. Андр. пут 429.

V. Мјесто генитива мн. додази кад кад локатив мн. јамачно поводећи се за прономиналнијем обликом, који за оба падежа једнако гласи, али до XVI вијека долази тако ријетко да је тешко мислити да је та замјена била у самом језику, него hе у њој бити сазо погрјешке писарске: тако још XIII вијека: а) у ријечп с основом i : бдь вьсехь хю.д ријечи с основом на сугласно и у овијех које добивају основу на сугласно у множини одбацивпи крајње ин, или ушраво опет у ријечи с основом на $\mathbf{i}$, јер оне и једне и друге узимају

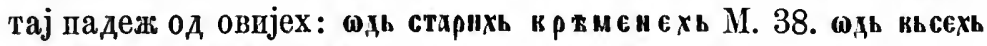
подехь краниаиехь М. 31 - - в) у нушке ријечи с основом на a, која у том падежу може бити да је такођер прешла међу ријечи с основом на $\mathbf{i}$ имајућп $є$ мјесто $\mathbf{~ : ~ „ о ~ и к н и с х ь , ~ ю д ь ~ м к н и с к ь ~}$ M. 38. тај се је облик (локат.) ријечи с основом на $\mathbf{i}$ још XIV вијека замјевивао обликом ријечи с основом на $\mathbf{a}$, те се је XIII вијека јамачно већ слабо осјећао, а тијем су лакше могли писари гријешити не знајући шта ће с њим и тако га узимајући мјесто генитива. - XIV вијека, из кога су спомендци много обнлатији, не находим ни једнога примјера у ком би генитив мн. био замијењен докативом. - XV вијека налази се локатив мјесто генитива само у ријечи женских с основом на а, а будућп да се тада већ додавало тенитиву мн. $a$, те се локатив у многих ријечи само тијем разликовао -од генитива што је пмао на крају $x$, дако је могао гдјекоме мјесто генитива са $a$ на крају доһи на ум докатив: и допста само у онијех ријечи женскога рода долази локатив мјесто генитива, у којих се та два обдпка разликују само

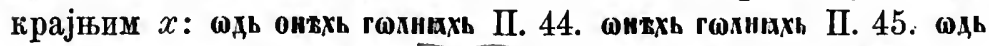
тахь расотахь ПI. 85. вьстхь суднахь II. 109. деиахь монхь М. 528. од узах Ст. пис. 1, 21. од јацих руках Ст. пис. 1, 21. - XVI внјека осим ријечи с основом на $\mathbf{i}$ п онијех у којих је у то врпјеме био генитив мн. према тијем ријечима, врдо ријетко у другима: тако између ријечи мушких с основом на a само: ирије дионицијех твојијех (Јевр 1,9) Н. Рањ. 22. из- 
међу рнјечи женских с основом на а само: од уздаха и молбах мојијех l'уч. 305. чешће у ријети с осповом на $\mathbf{i}: \mathrm{y} м \mathbf{~}$ шких : од људех 3ор. 41. у женских : окод заповндех божјшх Буд. 51. између мушких у којих је истина основа на а али које су у овом падежу предазнде међу ове: ван оних казех Буд. 56. и кад је у рпјечи с основом на $\mathbf{i}$ пзједначен докатив мн. с докатпвом мн. рпјечп мушки у којих је основа на a: заповеднх Брн. 72. ричих Брн. 48. стварих Брн. 21. - у другіх ријечи, које су у то врпјеме прелазиле у генитиву мн. међу ријечи с основом на $\mathbf{i}$, те им се од тога падежа разлпковао локатив мн. само крајњнм $x$ : између мушких с осно-

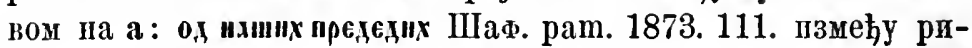
јечи средњега рода с основом на а: насрид вратих Зор. 9. од дилих Буд. 63. добрпх дилпх Брн. 26. четири ста дитих Стар. 3,225 . уз оваки докат. није бндо тешко и другоме са $о$ гред $x$ у ријечп средњега рода доћп на мјесто генптива: од устох твојих Брн. 446. - XVII впјека, кад је по неким крајевима било ослабило $x$, неки су га писци често пзостаљали гдје би требало а писали гдје не треба, тако има без $x$ п. пр. исвпрстовнс Днв. ХІІІб. на врати Мик. 790. а пма $x$ гдје не треба н. шр. neumiohstva Банд. 254. kojih (помннат. јед.) Банд. V. вдих (т. ј. уда) ІІос. 15. техомог Пос. 13б. хоногі (онога) Пос. 4. њех (акус. мн.) Пос. 8б. sveh (акусат. мн.) Радн. 2. svih (номин. мн.) Радн. 3. kaharbi ('т. ј. карбн) Радн. 63. У тијех књнжевнпка кад за гентпв. мн. додази облик са $x$ на крају, ако се таки облик не разликује од гёйтива мн. Нитим други него само онијем $x$, не може се узети да је доиста .окатив употреб.ен мјесто генитпва, него је такп обдик доиста генитив, коме је невјештином њиховом додано $x$. Тако није докатив мјесто теннтива, него је генптив мн. на $u$, који смо напријед вндјели, па му је гријешком додано $x$ : у мушких рпјечи с основом на а и на ја: родштељих Бапд. 194. мужнх 56. мисецих V. дарових 153. часих 149. тако у ријечи која у множпни одбацује ин: жудпјих Банд. 219. и која је између ријечн с осповом на сугласно прешла међу ове: грумейх Банд. 111. у ријечи средњега рода с основом на а п па ја: говореијих Њанд. 169. дилованјих 123. евангелјих 1. з.аменјих 21. гра.љевствих 107. милосрдјих 40. очитованјих 26. 
пожелинјих 26. приступљенјих 171. - у ријечи с основом на i: у мушких: од старих дних Банд. 177. будпх Банд. 14. Мик. 37. црвих Мик. 53. у женских : заповнеднх Див. 8. рнхнх нсвкрстовне Див. ХІІІб. стварнх Див. 16б. властих Банд. 107. жалостих 243. заповидих 249. костих 121. мислих 63. моћих 170. ноћих 36. печалих 26. стварих 138. јаслих 179. прспх Јерк. 93. - у женских рнјечи с основом на а, које су, како смо нацријед видједи, генитив мн. пмале и према ријечима с основом на $\mathbf{i}:$ оне још особито потврђују да ни у предњим примјерима пије локатив, јер у женских рпјечи с основом на а не може бити спомена о логативу на $u x$ : тако: војских Банд. 263. неправдих 38. 39. палмих 76. патријаркшх III. узих 238. 239. урих VII. хвалих 5. јасприх Радн. 95. ништа друго него су таке погрјешке и у оваким примјерима какви су много рјеђи: душах Банд. 291. аздијах Пос. 13. твојнје грихах Пос. 3. наПаствовањах Пос. 41. само пाто Вранчић има једном рожицах Вран. жив. 19. могао би бити догатпв мјесто генитива, јер Вранчић још добро зна за $x$ : њему је бно много обичнији генитив мн. без $a$, па употребнвши га са $a$ могао се дасно поместн помисливши да му. још треба $x$ као у локативу. А у рнјепи у којих се докатив разликује и другачије а не сампјем $x$, риједак је и XVII впјека локатпв мн. мјесто генитива, па је и тада јамачно прономннални облик помагао мнјешати их; а како долазе помијешани само у два књижевнпка, јамачно су само књнжевници мијешали: у рнјечи мушких с основом на а: огуљенијех власијех Мик. 363. од чланцијех Мик. грам. 4. од осталијех намисницијех Мик. грам. 11. у ријечп сред̆њега рода с основом на а: богатствнје Радн. 68. 78. 79. 80. 83. 84. 85. у. ријечи с основом на $\mathbf{i}$, које су у то вријеме и још прије прелазиле у локативу мн. међу ријечи мушке с основом на а, у такшх мушких ријечн : од свијех вриједнијех људијех Мик. предгов. људије Радн. 29. 72. 74. у женских: разбијенијех костијех Мик. 547. од њекијех оштријех ријечијех Мик. предгов. од ријечпјех смншнијех Мнк. 584. од ријечијех безреднијех Мик. 33. од мнозијех стваријех Мик. 255. од твојијех властптнје грппостије Радн. 34. болестије 75. жалостије 51. вспразностије 13. крипостије 30. дудостије 62 . обитилије 76. псостпје 30. ства́рије 12 . свитлостије 35 . и ријеч 
која је и у номинативу мн. прелазнда међу рпјечп с основом на i: јасприје Радн. 91.

ШІто у једном споменику XIII вијека пма шдь монхь пю„не, о.қ монхь внвчє М. 29. мислим да је ту генитиву мн., који се свршивао на $и j$, додано $e$ онако како се додавало у инструменталу јед.

На грају XVI вијека налазп се у једнога писца мјесто овога падежа генитив двојине у једне ријечн женскога рода с основом на і: светнјех отајностију Гуч. 25. од којијех отајностију Гуч. 25. - А у једнога писца XVII вијека налази се пстпјем обликом замијењен овај у ријечи средњега рода с основом на а, али само у слику, п јамачно њега ради: литу Мрн. 60.

\section{ДАТИВ МНОЖИНЕ.}

Наставак је за сам датив bhjam и за множину s, дакле bhjams; од тога у словенским језицика bh гласи $\boldsymbol{м}$, a

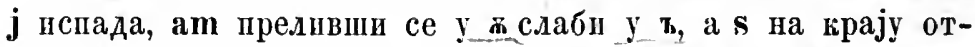
пада: тако наставак гласи у словенскпм језпцима мқ, којему у старом словенском језнку остаје $\mathbf{~}$, а у другима отпада.

I. Основе на и. Ријечи су с таком основом шрешле још у старом словенском језпку у том падежу међу ријечи мупике с основом на $\mathbf{a}$; види под II.

II. Основе на а:

А. У ријечи мушкога и средњега рода: крајње а у основи кратко будући гласи у словенским јелицима 0 , које у основама на ја прелази у $e$ предњега гласа ради:

a) с основом на чисто а до краја XV вијека: мушқе:

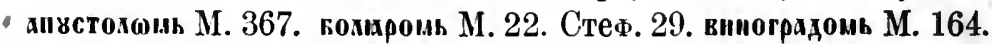
ктконь СТеф. 18. М. 176. кеконһ М. 481. кигомь М. 488.' внкин-

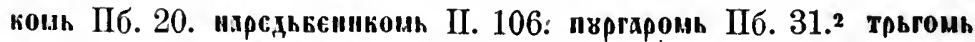
М. 19. храмоия М. 540. чкокткоиь М. 4. 42. - средње: дтомь

' IIIто има викви M. 328. биће писарска погрјешка.

${ }^{2}$ Наптампано је пврраромь, алп бпвшп у Аубровнику потражих оригинал те се увјерпх да је пвргироми; а то је пурrap=bürger, како се и сада говори око Зигреба. 
Стеф. 14. мастомь М. 129. мнстомь М. 304. сепомь M. 144. оүстоиь M. 110. - На крају XV и свега XVI вијека: мушке: антелом Ст. пис. 1, 270. 2, 75. Н. Рањ. 22. Град. дјев. 19. апостодом Н. Рањ. 154б. апустолом Буд. 9. бисаком Ст. пис. 4, 162. војником Ст. пис. 3 , 318. вуком Ст. пис. 1 , 159 . гарленхкомь Збор. 56б. градом Н. Рањ. 17б. грешником Ст. пис. 5, 33. Гуч. 83. гријехом Ст. пис. 5, 151. Гуч. 252. дугом Буд. 117. дужником Ст. шис. 3, 369. Град. дух. 87. Вран. рјеч. 127. завидником д. Рањ. 67б. зубом Н. Рањ. 32. идодом Н. Рањ. 46. инквиситуром Буд. 145. јархибискушом Буд. 132. јунаком Д. Рањ. V. калуђером Град. дјев. 131. крвником Ст. пис. 3, 386. Злат. 2. љубовником Град. дјев. 159. мучеником Гуч. 13. народом Н. Рањ. 14. Ст. пис. 3, 461. Град. дјев. 87. немоћником Гуч. 54. псом Н. Рањ. 46б. Стар. 3, 338. Д. Рањ. 69б. пуком Н. Рањ. 67б. Град. дјев. 87. путником Град. дјев. 75. учеником Н. Рањ. 25. Град. дјев. 73. Гуч. 247. чловиком Буд. 48. - средње: вратом Н. Рањ. 158. Ст. Ігис. 4, 192. 200. Брн. 24. Злат. $30 б$. дилом Ст. пис. 1, 303. дјелом Н. Рањ. 84. Злат. 32. пророчанством Гуч. 218. устом Ст. пис. 1, 94. 2, 104. Н. Рањ. 111. Хект. 27. Зор. 28. Брн. 44. Злат. 46. - XVII вијека: мупке: анјелом Орб. 227. ангелом Каш. 30. апостолом Каш. 78. апоштолом Радн. 24. богом Вран. жив. 10. војником Мик. грам. 4. гравраном Мрн. 36. требом Вран. жив. 21. гришником Јерк. 82. дужником Радн. 61. законом Вран. жив. 48. жудјелом Радн. 42. давом Радн. 10. народом Див. 10б. немоћником Кашт. 34. псом Вран. жив. 52. Банд. 38. Радн. 99. пуком Радн. 98. путником Вран. жив. 48. разумником Вран. жив. 11. редовником Див: 11. родјаком Мат. 61. ученнком Орб. 250. Банд. 1. Радн. 21. - средње: богатством Радн. 87. вратом Вран. жив. 93. Банд. 172. Радн. 49. дилом Банд. 73. Радн. 45. колином Банд. 125. устом Банд. 106.

б) с основом на ја: до краја XV вијека: мушке: прњштекемь М. 106. прнатекемь М. 483. вкеми М. 62. кнеzемь М. 25. 88. 146. 162. мхиастыремћ М. 115. покансаремь М. 85. ПІ. 152. оүмыхремь М. 58. прремь М. 67. 174. - средње: оүхениемь М. 73. На крају XV и свега XVI вијека: мушке: пријатељем Ст. пис. 1, 159. Злат. 9. коњем 18б. витезем Стар. 3, 323. кнезем Буд. 59. владдаоцем Злат. 8б. отцем Н. Рањ. 22. старцем Н. 
Рањ. 44. судцем Н. Рањ. 68. трговцем 3бор. 27б. парємя М. 547. тако је било и мрављем Ст. пис. 4, 85. - средње: помањканјем Іуд. 37. - XVII вијега: мушке: непријатељем 0рб. 240. родитељем Орб. 32. Кан. 21. мужем Вран. жив. 74. жетеоцем Банд. 71. злочинцем Мик. 232. оцем Кап. IIбб. пришлацем Банд. 190. трговцем Див. 11. - средње: дилованјем Банд. 100.

Тако је бнло и у адјектива за мушии и средњи род: с основом на чнсто а : докомиой Стеф. 24 . с основом на ја : вмдин чьнсиь М. 4. али само у најстарија времена, а послије долази само сложени обдик.

Из падежа у којнма основе на и тај крајњи глас свој пред самогласнијем наставком мпјењају на ов, и у којпма је од такнх основа прешло њихово ов и у рпјечи мупке с основом на а, из тијех је падежа прешло ов и у овај у ријечнма муниим с основом на $\mathbf{a}$, ако му се и не почиње паставак самогдаспијем, ша је к основи, која се тада свршује на ов, додан на пово заврнетаґ њезин, капо гласи у словенским јевнцима, т. j. o; a ғако су се рпјечи с основом па $\mathbf{u}$ помијепале с рнјечима у којнх је основа па a, све је речено преніло п г њима; ретено ов у основа на ја гласи жао и у другим падежима предњега гласа ради $e s$; тако се налази у нас од XIV вијека: с основом на чисто а п на $\mathbf{n}$ : грлдоконь М. 175. 233. сниокон М. 106. XV вијега с основом на чисто а и на и: вккюкомь М. 333. грхуокони М. 304. синокоць М. 373. 394. 403. 497. 510. храмокомь М. 540. с основом на ја: врхскомь M. 487. на крају XV и свега XVI внјека: с основом на чнсто а и на и: боговом Злат. 7. вадовом Ст. пис. 3, 12. вуковом Ст. пис. 4, 478. 5, 395. гријеховом Ст. пис. 5, 36. духовом Град. дух. 5. дјев. 31. јадовом Ст. пис. $3,73$. поповом Ст. пис. 5, 290. Стар. 3, 323. спновом Н. Рањ. 486. 3бор. 18б. Ст. пис. 3, 474. 4, 366. 393. 4, 471. 482. 5, 9. 21. Град. дјев. 28. с осповом на ја : краљевом Збор. 50б. Ст. пнс. 5, 46. Гуч. 301. мужевом Д. Рањ. 28. XVII вијека: с основом на чисто а н на и: боговом Орб. 273. градовом Банд. 6. дуговом Радн. 41. киновом Мик. 193. синовом Банд. 37.

Рнјечи с осповом на ја мушке и средње нзједначујући се с опима у којнх је оспова на чнсто а имају кад кад и $о$ мјесто $e$ : у мушки : XIII вијека иритекомь М. 28 . али је то 
једини иримјер у ком би тако рано стајало $о$ иза $љ$, за то може бити каква год погрјешка: на крају XIII или првијех година XIV вијека иза гласа $p$ : пхстыромь М. 61 . XIV и XV вијека иза 3 и $p$ : кияzонь М. 133. монхстиромь М. 167. нокистронь М. 218. 220. 480. гокаромь М. 485 . катвихрюиь М. 485 . на крају XV и свега XVI вијека већ не само иза поменута два гласа: витезом Ст. пис. 4, 423. кнезом Ст. пис. 1, 46. Збор 12. пинезом Ст. пис. 1, 156. Буд. 67. пјенезом Ст. пис. 5, 6. пастиром Ст. пис 5, 192. пастијером Злат. 72б. 3ор. 7б. морнаром Ст. пाг. 2, 439. царом Ст. пис. $3,45.56 .314$. него и иза других: пријатељом Ст. пис. 4, 423. А. Рањ. 43. ненријатељом Гуч. 272. родитељом І'рад. дјев. 78. 92. 139. владаоцом Ст. пис. 2, 441. дпјевцом Град. дјев 27. зецом А. Рањ. 114. младијенцом Ст. пис 4, 223. славицом Ст. пис. 2, 506. спјеваоцом А. Рањ. 145. тако п XVII вијека: витевом Вран. жив. 14. зидаром Вран. жив. 112. овчаром Каш. 10. пастиром Банд. 10. Капг. 11. Ради. 63. обичајом Радн. 77. краљом Радн. 75. 77. кукудрнљом (крокодил) Кашг. 96. научитељом Орб. 275. непријатељом Орб. 64. Радн. 18. 26. 32. 43. Глав. 59. роднтељом Г'дав. 101 . тако XVI и XVII внјека у странијем ријечима у којима се још у старом словенском језику избацивало $j$ : фарнсеом Н. Рањ. 159. - У таких ријечи и мјесто $е в$, кад га имају у том надежу, долази ов иза 3 XV вијека: кисzокоми М. 489. II. 161. - У средњих је врло ријетко о мјесто $e$ на крају XV внјека: дичцом Ст. пис. 2, 280. XVII вијека: болованјом Радн. 75. наслађенјом Радн. 13. попштенјом Радн. 13. 38.

Рпјечи које ностају наставком $и н$ и јанин, кад у множинй-одбаце крајње ин, онда имају основу на сугдасно І изједначују се с ријечима у којих се основа свршује на сугдасно (види под IV): у њих наставак мъ приступајући к основи налази пред собом глас $н$, тада се $\boldsymbol{н}$ изједначује с гласом који је за пим, т. ј. с гласом $м$, те и само постаје $\mu$, а тада се од два $м$ једно избацује: тако је у нас било XII XIII и XIV вијека: грағын М. 1. догровьчам М. 2. 17. 53. Дттьчхиь М. 92. а и послије долази мацедонам Стар. 3, 268. - A како су ријечи у којих је од постања њихова основа на сугласно у овом падежу препле међу оне у којих је основа на $\mathbf{i}$, тако су с њима прелазнле онамо и ове, гоје реченнем начнном добивају основу 
на сугдасно; по томе је у нас било до краја XV вијека: вмстекем М. 34. 43. 54. 157. 174. 185. 218. 220. 221. 255. 300. 340.

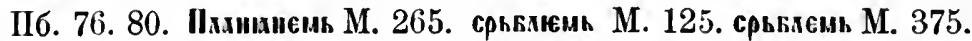
али како су мушке ријечи с основом $\mathbf{i}$ а с вима и оне с основом на сугдасно прешле међу мушке с основом на а, тако.су и ове с њима прешле онамо; по томе имамо још од XIII вијека: кастєкомь М. 24. 25. 27. 28. 41. 42. XIV до краја XV вијека: кмастепомь М. 117. 156. 158. 169. 403. 414. 450. 518. 545. Пб. 85.

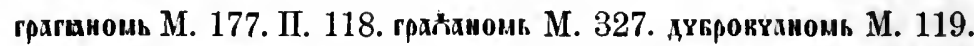
146. 157. Коцаманомь IIIаф. pam. 1873. 110. жоүхиемь М. 447. на крају XV и свега XVI вијека: кмастекомь 3бор. 27. жидовом Ст. пис. $1,184.3,318.5,133$. нећинтаномь 36ор. 26. крстјаном Ст. пис. 5,110 . Гуч. 1. мишћаном Хект. 27б. поганом Ст. пис. 3, 58. римњаном Ст. пис. 1, 70. тако жудпом Н. Рањ. 48. Збор. 76б. XVII вијека: бусдоманом Мрн. 40. жудиом Банд. 30.

Како су у другим падежима гдјекоје ријечи мушке с основом на а предазиле међу оне с основом на і (впди напријед стр. 37. 69. 74), тако су прелазиле и у овом падежу; по томе се налазп још XIV вијека зкконсмь ПI. 11. 12. XV вијека: везирень M. 460. цо томе и кад основа добпје ов XVI вијека: градовемь М. 550. киезокемь М. 552. тако и кад је у основи пред завршетком грлени гдас, који се мцјења у номинативу мн. па се мијења п у овом падежу XVI вијека: отоџємь М. 526.

И у овом се шадежу као п у генитиву мн. додаје па-крају $a$; тако додази још XIV вијека: до виеки кнекомх М. 106. до

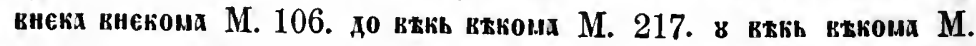
217. в внке внкомх М. 능. XV вијека: викв внкома М. 249. внекв вккона М. 459. тако XVII впјека и попома Вран. жив. 37. Таком се облику додавао на грају на ново наставак падежни на крају $\mathrm{XV}$ нли у почетку XVI впјека : по вијеке вијекомам Ст. пис. 2, 442. а.$\mu$ на крају г.даси п $н$ XVI вијека: у вијеке вијекоман Н. Рањ. 148б. 158б. 199. 201. ४ ске киеке виекоман Збор. 226.

Ірем да се овај падеж у овпјех ријечи, како видјесмо, држао кроза све вријеме, опет јоп на крају XIV вијека додази мјесто њега инструментал мн.: кь свонмь прихтем П. 24б. то је једини прнмјер до XVI вијека, а тога су вијека чешћи: у мушких рпјечи: свршио си онпјеми, кп у те уфају, чловјечијем 
синовми, ки ти се ирндају, љувену сву радост Ст. пис. $3,455$. вапим закони слика није и ваш глас Ст. ппс. 4, 424. к твојима отари Злат. 31б. протива пођи овијем ножи бод.бивијем Злат. 71б. у средњих: к врати Ст. пис. 4, 325. 369. допустит' теби и удми твојима Ст. пис. 5, 90. да (бог) дава то вишу cpeћу вашијем висоцијем дјели Злат. предгов. 3б. к твојим ирислатким уди Злат. 61б. - На супрот находи се датив мн. мјесто инструментала, прем да врло ријетко: у почетку XVI вијека: учинивши с тежаком од динара посла вих у внноград свој (Мат. 20, 2) Н. Рањ. 34. и XVII вијека: прид свијем својим дворником Ради. 90. - Много су се виши мијешала та два падежа у других ријечи, особито у женских с основом на а и у прономина дичнијех, чему је највнше узрока бнло у гласовпма које су имале на крају, како һе се код њих видјети. кад је то мијешање бнло пај јаче, опда се ипструментал мн; у ријечи мушких и́ средних с осповом на а у ведике мијењао добивајући мјесто самога $u$ на крају ими пли окрњепо им; од тога је мијенгња додазндо те су се оба падежа п пзједначивала, а изједпачивала су се тијем што се у дативу мн. ирајње самогласно у основи пред м истискивало п на вегово мјесто продира.ло из инструментала $u$, које је у њега било пред његовијем $м$ у реченом завршетку ими или окрњеном им. По томе имамо датив од самога почетка XVI вијека: старцим Н. Рањ. 69. истога вијека: гријесим Ст. пис. 5, 33. Гуч. 10. дарим Град. дјев. 55. духовим Град. дјев. 9. дух. 46. коњим Д. Рањ. 114. оцим Град. дјев. 31. ругаоцим Ст. пис. 5, 17. синовим Ст. пис. 4, 393. XVII вијега: брацим (братащ) Бун. 51. гријесим Бун. 3. Андр. дев. 77. дворим Бун. 13. доброчинцим Андр. пут 215. кладенцим Андр. пут 403. краљим Гунд. суз. II, XII. навјесницим Бун. 52. научнтељим Андр. пут 155. непријатељим Андр. пут 133. прасцим Гунд. суз. I, XI. пријатељим Андр. пут 214. родјацим Андр. пут 214. словинцим Мик. предгов. ученицим Бун. 51. Андр. дев. 140. Тако и у средњих: X VI вијека: дјелим Д. Рањ. 118. XVII вијека: вратим Андр. пут 226. 266. устим Андр. дев. 8.

Као птто се овом облику још док није бно овако помјерен додавало на крају $a$ (види мало напријед стр. 96), тако се дода и помјереном: XVI вијека: млацима (мдадац) Д. Рањ. 30.105. XVII вијека: грешницима Андр. пут 125. непријатељима 
Андр. нут 136. оцима Андр. пут 156. спновима І'унд. пс.28. трудима Андр. пут 147. чарима Мик. 826. тако и у средњпх: XVI вијека: сатима (сто)Н. Рањ. 154б. устима Д. Рањ. 75. Здат. $86 б$. XVII внјека: дјелима Орб. 9. 300. либрима Орб. 70. наслађењима Радн. 6. наслађинањима Радн. 7. устима Каш. 70.

По што се $а$ таго дода, стаде се $u$ пред $м$ избацивати, али истом XVII вијека, и тада јоп врло ријетко и само иза гдасова $x$ и ж: у мушких: пријатељма Радн. 14. у средњих: поштењма Радн. 6. хотењма Радн. ІІб.

Како се овај помјерени облик својим $u$ пред м веома прнближно сдоженом дативу мн. у адјектива, који се још од прије замјењнвао прономиналним обликом, налази се таки облик од адјектива пренесен на супстантив средњега рода, ади истом у другој половини XVII вијека и само у једпога иисца: богатствијем Радн. 81.

Средње су ријечи кад кад прелазиде у овом пад. међу женске с основощ н $九$ a, и то од XIV вијека али веома рвјетко ; тако свега XIV и XV вијека има само по један примјер: секаи М. 111. вхаданнтм М. 282. XVI вијека: мєстми М. 550.

Б. У женских ријечи: крајње је а у основи дуго, те у словенским језицима бива гратко, а наставак до њега долази: тако до краја XV вијека: женамь М. 14. свдырань М. 54. Конактиь М. 413. на крају XV и свега XVI вијека: висинам Ст. пис. 3, 352. војеводам Злат. предгов. 3. врстам Буд. 51. дјевојкам Ст. пис. 5, 261. Злат. 37. дјевицам Град. дјев. 27. думнам Град. дух. 3. дупам Н. Рањ. 177б. Буд. 12. женам Град. дјев. 12. звиздам Ст. пис. 2, 121. 3, 429. злобам Гуч. 10. змпјам Ст. нис. 3, 207. играм Здат. 17. канљам Ст. пис. 3, 429. књшгам Злат. 85. кораб.бам Ст. пис. 4, 466. наредбам Град. дјев. 129. Буд. 87. ногам Н. Рањ. 85. овцам Н. Рањ. 25б. птицам 3бор. $13 б$. сестрам Град. дјев. 3. слугам Н. Рањ. 31. Град. дјев. 51. старјенинам Н. Рањ. 23. Град. дјев. 78. сузам Ст. пис. 4, 414. тугам Ст. пис. $4,413$. Злат. 4б. убојицам Ст. пис. 3,322 . худобам Гуч. 143. чавкам Збор. 8б. XVII вијека: бесидам Вран. жив. 18. војводам Мик. предгов. 6. главам Банд. 29. госпођам Андр. пут 347. дивицам Вран. жив. 33. душам Вран. жив. 49. Каш. 2. Андр. пут 215. женам Врап. жив. 64. Каш. 78. књигам Банд. 175. кућам Мик. предг'ов. 6. мајкам Аидр. пут 174. мукам Вран. жив. 
45. Каш.45. Андр. пут 118. молбам Андр. дев.171. наредбам Див. 3. ногам Вран. жив. 23. поглавицам Банд. 13. потриоам Банд. 21. приликам Вран. жив. 3. рукам Бапд. 47. сестрам Вран. жив. 53. сиротам Врап. жив. 25. слугам Див. 38. Банд. 21. І'унд. суз. III, XXX пс. 26. стријелам Андр. пут 115. удовицам Вран. жив. 48. - и колективне ријечи долазе у том облику до краја XV вијека: кратїми М. 517. 536. 540. господами М. 442. 448. ІІб. 63. д취амь II. 104. 143. 156. XVI вијека: гослодами М. 556.

И у адјектива је бнло тако за женски род, али у српском језику долази само сложени облик.

Како су се у овијех ријечи датив мн. и инструментал мн. слабо разликовали у српском језику један од другога имајући оба $м$ од наставка и ннструментад пмајући још само $u$ иза тога $м$, од туда је долазнло те су се оба неко вријеме замјењивала један другим: тако је мјесто датина долазпо инструментал на крају XV или у почетку XVI вијека: жељами разумит' Ст. пис. 2, 121. XVI вијека: воде ногами мојими нијеси дао Н. Рањ. 189. к десетима дјевщцами Н. Рањ. 222. к женами Ст. пис. 4, 337. божнцами трема одсуди Ст. пнс. 4, 447. вим чело уресите вашнм гореким тим вилами д. Рањ. 51. прима свнм диним виламп А. Рањ. 7б. душами А. Рањ. 2. добит' мир жељами $A$. Рањ. 51. женамп тко злима гре служит $\not$. Рањ. 28. згодами $Д$. Рањ. 124. муками $Д$. Рањ. 78. сузе нијесу лијек тугамп $Д$. Рањ. 46б. слугами Град. дјев. 76. к овнјем књигами 3лат. предгов. 2б. слугами Злат. 59. стрилами Здат. 75б. тугами Злат. 17б. дружбами Гуч. 70. допуштено реченијем кадудрицами и думнами Гуч. 89. крстјаном и крстјашками Гуч. 59: свој брати и сестрами Гуч. 54. 55. 71. мојијема слугами зло чинити Гуч. 290. таптинами Гуч. 174. XVII вијека: душами Орб. 96. 120. 144. 152. 227. 247. женами Орб. 35. с'тарјешинами Орб. 86. худобами Орб. 247. реде женами Банд. 132. замчицу сакрили јесу ногами мојими Банд. 75. злобами Бун. 14. агами Мрн. 117. душами Пос. 41б. гробницамн Радн. 74. г долинами Радн. 29. живинами Радн. 12. к злоћами Радн. 13. невољами Радн. 75. поглавицами Радн. 14. к прнликами Радн. 54. птнцами Радн. 68. слугами Радн. 44. старепинами Радн. 46. тугами Радн. 3. - Тако је и датпв мн. долазио мјесто инструментала мг. (види код шега). - То се мијешање 
сврпи најпос.ије тнјем пто пнструмента. одбаци своје крајње $u$ те се изједначи с дативом и оба добпше на крају $a$ : таки датив мн. долази од XV вијека, али доста ријетко: XV вијека у рпјечи која је између онијех с основом на сугласно прешла овамо: прькким М. 534. XVI вијека: тугама Ст. пис. 4, 398. 410. 443. косама Злат. 88б. XVII вијека: главама Мрн. 129. тугама Мрн. 129. 138.

III. Основе на i. Крајње кратко і у основи гласн у словенскнм језцима $c$, па које приступа наставак:

А. У мушких : госполем М. 88 . гостень М. 25. Пб. 91. sвтремь Сав. 1. хюдень М. 21. 43. чрьктиь Љет. 57.' У рнјечн људи држи се тако кроза све врнјеме: иа крају XV и свега XVI вијека: људем Ст. иис. 1, 45. Н. Рањ. 13. Збор. 27. Ст. пис. 2, 32. 3, 22. 4, 5. 5, 5. 1. Рањ. 60. Хект. 2. Зор. 5б. Буд. 137. Злат. 37б. Гуч. 143. XVII вијега Вран. жив. 16. Аив. XIII. Орб. 34. Банд. 4. Гунд. суз. II, XI. Јерк. 25. Каш. 4. IIoc. 12.

Таке ријечи предазе међу мушке с основом на а од краја XV вијека: гостом Н. Рањ. 176. Стар. 1, 232. црвом Ст. пис. 1, 18. 115. Збор. 143. Орб. 46. Пос. 19. Радн. 74. чрвом Вран. жив. 84. нохтом Мрн. 160. и са:ов ирема другим надежима с осповом на а: путовом Радн. 57.

Како је рпјечима с основом на а дошло у овом падежу $u$ на крају основе, тако је дошло и овнјем, и то од почетка XVI вијека: „удим Н. Рањ. 202б. и с доданим $a$ на крају такођер XVI вијека: .удима А. Рањ. 114. XVII вијека: људима Орб. 119. Мик. 130. црвима Гунд. суз. I, XXVIII. Андр. пут 346. тада се и избацује $u$ : људма Радн. 7. 9. 14. 18. 20. 33. 37.61.97.

Б. У женских : стрхстсми М. 78. шеуахем М. 244. постемь дом. 116. тако до краја XVI вијека: заповидем Ст. пис. 1, 4. Буд. 7. звнеремь Збор. 25. звирем Ст. нис. 2, 174. 317. кокошем Ст. пис. 5, 185. костем А. Рањ. 61б. Буд. 57. крипостем Буд. 33. мислем Буд. 37. моћем Н. Рањ. 167. Буд. 57. напастем Ст. пис. 1, 290. Буд. 26. пјеснем Д. Рањ. 150б. Злат. 96. прсем Злат. 3б. ричем Ст. пис. 1, 43. 2, 319. 3, 284. Стар. 3, 239. Хект. 27. Зор. 1. Брн. 26б. ријечем Здат. 86. стварем Ст. пис. 2, 23.36ор. 20. А. Рањ. 1206. тварем Н. Рањ. 157. хитростем Стар. 3, 226.

1 у старом је словенском језику могло још и с ослабитп у מ: пюдынъ Миклошиһ, vergl. gramm. III. 45. 
XVII вијека: заповиједем Див. 3. 4б. 32б. заповидем Банд. 186. запоксқмь Мат. 89. костем Банд. 121. грниостем Банд. 127. навем Банд. 281. стварем Див. 38.

И у њих је из других падежа прешло $u$ у овај, те истиснудо е: тако XVI вијека: заповиједим Град. дух. 28. костим д. Рањ. 63. крјепостим Град. дух. 62. милостим д. Рањ. 79б. Град. дух. 17. 78. дјев. 55. напастим Град. дух. 11. 17. 37. XVII вијека: заповиједим Андр. пут 56. крепостим 6.

У исто вријеме кад се јавља овако помјерен, јавља се и с доданим $a$ на крају: XVI вијека : ијеснима А. Рањ. VI. 133. рпчима Злат. 91. XVII вијека чешће: болестима Андр. пут 118. Ради. 23. заповндима Вран. жив. 45. зановнједима Орб. 35. Андр. пут 27. нспразностима Радн. 6. греностима Андр. пут 147. прсима Kaп. 9. 75. у то се врпјеме и избацује $u$ : XVI вијека: ричма Брн. 60б. XVII внјека: звнјерма Г'унд. сув. III, LXVIII. испразностма Радіг. 38. 80. грнпостма Радн. 45. ријечма Радн. 45. стварма РадіІ. 4. 5. 11. 17. 41. 70. 79. 80. 82. 83. 84.

Те су рнјечи прелазиле у том падежу међу женске с основом на а XVI вијека: правам' Буд. 132. ричам Буд. 6. 39. 123. Стар. 1, 221. стнарам Буд. 53. 57. 74. и XVII вијека: сладостам Каші. грам. 41. стварам Мат. 53. а тада му се и додавало на крају $a$ : звирама Вран. жнв. 5. ригама Мрн. 138.

Налазе се те ријечи изједначене у овом надежу и с мушким ријечима у гојих је основа па а, такође XVI вијека, али ријетко: заповидом IjpI. 22б. 68. напастом Брн. 28.68б. прсом 3ор. 33б.

Као у женских с основом па а (види напријед стр. 99). тапо и у овијех долази кад кад и инструм. мјесто дат.: XVI вијека: ријечми вјерова'т' С'т. пис. 5, 18. супротива стварми Град. дух. 73. стављам се ричми тнм Злат. 35б. XVII внјека : стварми Пос. 8. тако и номјерени инстр. (види код њега) долази мјесто датива: XVI вијека: ириправи мјесто у срцу слаткијем пјесни Ст. нис. 4, 448. XVII вијека : сущротива свијем напасти 0рб. 85. друзијем ствари мучнијема Орб. 54. тријема крености богословнима Орб. 294. велицијем погибнли Радн. 42.

IV. Основе на сугдасно. Мушке и средње и неке између женских ријечи с таком основом прелазе у овом падежу међ!

' Bндіг у акусатпву мн.:- -равп Буд. 132. 
ријечи с основом на $\mathbf{i}$, а друге женске предазе међу женске с основом на а:

a) мушке: кхсшсмь. Види још напријед међу мушким ријечима с основом на а.

б) средње: скокссєь М. 9.17. Сав. 9. үюдесемь Стеф. 26. Али су препле меһу ријечи с основом на а: тағо још од првнјех времена: киоүстон Стеф. 14. на крају XV и XVI вијека: сјеменом Н. Рањ. 156. небесом Ст. пис. 2, 75. 410. Н. Рањ. 135. Збор. 45б. Ст. пис. 3, 389. 4, 23. 161. 297. 317. 5, 43. 53. 169. А. Рањ. 34б. 128б. Здат..67. Гуч. 158. чудесом Ст. пис. $2,87$. XVII вијека: небесом Див. 35. врименом Капг. 80. прелазећи онамо неке су п одбацивале крајње сугласно и пред вим самогласно у основи: XVII вијека: колом Вран. жив. 73. Радн. 47. словом Банд. IV. - Према ријечима међу које су прешле помјерио им се овај падеж и даље: с њима су у овом пад. добивале $a$ пред наставком, прем да врло ријетко: небесам Ст. пис. 4,297 . обичније је $u$ : словим Мик. предгов. и с доданим $a:$ словима Мик. предгов.

в) женске: неке су прелазиле међу женске с основом на і : керемь М. 356. 360. кькереиь М. 364. 373. ккеремь М. 395. тако још XVI вијека: ћерем Н. Рањ. 68б. - Али и та и друге прешле су међу женске с основом на а: тако од првијех времена: црьквхиь М. 26. 125. Пб. 117. на крају XV впјека и послије једнако: матерам Ст. пшс. 1, 244. Стар. 3, 289. кћерам Ст. пис. 1, 244. Град. дјев. 28. Банд. 115. црквам Н. Рањ. 196б. Банд. 227. - п вима се додавало $а$ на крају: тако XV вијека прь. ккхх М. 534. а долазио је XVII вијека и инстр. мјесто дат. као и у ријечи међу поје су препле: црквами Радн. 92.

V. Мјесто $м$ на крају палази се кад кад и $н$ од краја XV вијека : у мушких: вирникон Банд. 110. надбарон Банд. 96. у средњих: вратон Н. Рањ. 76. устон Ст. пис. 1, 188.

\section{АКУ С АИВ МНОЖИНЕ.}

Наставак је као за псти падеж једнине ат, којему за мпожну прнступа јоп $\mathbf{s}$, а тада се $\mathbf{m}$ пред s мијења на $\mathbf{n}$, и тако наставак гласи ans, од којега $\mathbf{s}$ стојеһш на крају у словенским језицима отшада. 
I. Основе на и. Од наставка отнада а, а са и од наставка саставља се крајње кратко и у основи те од њих бива дуго и, које у словенским језпциа бива м: тако је у старом словенском језику смит; а у српском су језику рнјечи с таком основом прешле међу мушке с основом на а; внди под II.

II. Основе на а:

А. 'у мупких п женскпх ријечи : од наставка отиада а, па се крајње а у основи саставља са $\mathbf{n}$ од наставка онако као у генитиву јед. женских ријечи с основом на а (види напрнјед стр. 16.) п у номинативу мн. пстијех ријечи (внди напријед стр.

64), те у словенским језицима

a) у ријечи с основом на чисто а бпва т, које замјењујући се гласом $и$ долази у старпје вријеме и у нашим књигама: у мушких ријечи: чхокькы М. 4. "ракы М. 4. в кекн М. 29. 312. закосни М. 180. - у жепских ријечп: қадикм М. 4. спмн М. 9. - Међу мушке ријечи с оваком основом прелазиле су у овом иадежу и ријечи с основом на и, ша су примале завршетак овога шадежа од овијех ријечи, а крајње и у својој основи пирпле у ов, као и у номинативу мн.: тако је бнло доноки М. 125.

б) у ријечи с основом на ја бива које у сршском језику

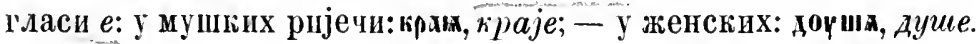

Али су се у сриском језику ријечи и мушке и женске с основом на чисто а изједначиле у овом падежу с онима у којих је основа на ја прнмивши њпхово е мјесто свога т, и то од најстаријих времена (види и генитив јед: женских ријечи с основом на а и номинатив мн. истијех ријечи):

1. мушке ријечи:

a) с основом на чисто а: колар М. 21. броде Мик. 119. кпєке М. 261. Злат. 51. вике Вран. жив. 12. власе Ст. пис. 4, 272. Здат. 93б. вуке Н. Рањ. 179б. гхасе П. 25. граде Мрн. 20. грихе Буд. 4. гробе Банд. 121. дијеле Н. Рањ. 110б. диле Мик. 65. двге М. 232. ждрибе Глав. 62. элюон М. 180. зубе Мик. 547. кусе Злат. 73. хисте М. 379. II. 101. мосте Збор. 77. пруге Ст. пис. 4, 270. пуке Н. Рањ. 28б. раке Мик. 534. реде Буд. 85. свјете Злат. 24. Град. дјев. 120. српе Н. Рањ. 15. столе Н. Рањ. 52. суде (јudiсіа) Н. Рањ. 46. суде (vasa) Н. Рањ. 62. туђине Ст. пис. 4, 88. узме Н. Рањ. 102. тако п у ријечи која је између рпјечи средњега рода с основом на суг.ласно (т) прелазнла овамо: копиле Ст. 
шис. 4,49 . - Међу ријечи мушке с основом на а прешле су и оне с основом на и: доме Вран. жив. 69.

б) с основом на ја: орхиє М. 62 . нєт (мјесто нетије) II.

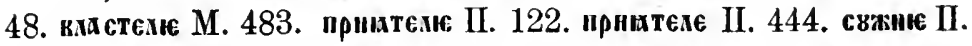
53. Косорнкє М. 138. пиплиће Н. Рањ. 23б. Банд. 13. муже Ст. пис. 1, 69. Стар. 3, 248. маче Н. Рањ. 15. лемјеше Н. Рањ. 15. венце Ст. пис. 2, 399. долце Зор. 30б. зхєиє М. 565. зајце Гхав. 103. ммџє ПI. 99. прншлаце С'т. пис. 4, 62. мударце Каш. 15. витезе Вран. жив. 65 . кпезе М. 4. ппєеєє М. 345. пинезе Ст. пис. 1, 117. Буд. 90. дниаре М. 532. П. 77. 3бор. 55. Ст. пис. 5, 17. 134. Мат. 69. љекаре Гуч. 12. манастире Г'рад. дјев. 136. покисаре М. 207. Буд. 130. пхре М. 4. 100. - Види и нижке.

Tаго је и у адјектива: с основом на чисто а: мхнастир нске М. 6. с основом на ја : радоскакме М. 45. кожне М. 456. и послије једнако: противне Буд. 33. - Види и ниже.

Из облика у којима се у ријечи с основом на и крајње и у оспови пред наставком мијења на $о в$ и у којнма је то ов прешшло пा $\mathrm{k}$ ријечияа с основом на a, из тијех је облика прешло ов и у овај: тало с основом на чисто а XIV и XV вијека : гхсокс II. 25. 68. грхдоке II. 136. дароке М. 190. двогоке М. 410. дхьгоке М. 525. двгоке М. 527. II. 175. „ћлоюке М. 341. II. 130. хнстове М. 358. II. 80. рококе II. 10. стоүпоке М. 531. свдоке (vasa) М. 393. и послије: брјегове Ст. пис. 3,62 . вукове Ст. пис. 3. 42. гласове Збор. 87б. Град. дјев. 105. Злат. 5. гријехове Ст. пис. 5, 34. гробове Злат. 8. дарове З.лат. 16б. Гуч. 221. дворове Збор. 82. дугове Радн. 41. зракове Кап. 42. Мик. 859. зубове Злат. $72 \sigma$. јадове Ст. пис. 4, 163. Злат. 3б. класове Радн. 97. давове Ст. пис. 3, 51. дугове Ст. пис. 3, 234. мостове 3бор. 59. овнове Здат. 52б. паукове Радн. 82. пругове Андр. пут 348. робове Ст. пис. 3,100 . стигове Ст. пис. 3. 215. трјескове 3лат. $36 \mathrm{k}$ - тако је и у рпјечи с основом на и, које пренавни у овом падежу међу ове ријечи и примајући њихов заврністак задржавају из других својих падеяк своје ов у основи, и то од првијех времена : қонокс Стеш. 7. волове 1І. Ран. 63. С'т. пис. 3 , 148. синове Брпг. 9. - и с осповом на ја, гдје се ов предњега гласа ради мијења па $е в$ : XIV пијека: свжнккс M. 171. и послије: враљеве І'рад. дух. 21. І'у. 303. сужњеве Ст. пнс. 5, 25. мачеве Радн. 57. а без те иромјене иза гласа 3 тагођер XIV ви- 
јека: києзокс M. 160. а XVI вијека налази се прем да вр.ло ријетко без те иромјене и иза других гласова, као што је бивало и у другим падежима: мужове С'т. пис. 4, 423. І'рад. дјев. 45. зецове Ст. шис. 5, 184.

Како ријечи које постају паставком ин и јанин у множини одбацујуһи крајње ин добивају основу на сугласно, а мушке су рнјечи у којих је од постања основа на сугласно предазиле у овом падежу меלу ријечи с основом на $\mathbf{i}$, прелазиле су онамо $\mathrm{c}$ нима и ове: XIII вијека команы' М. 21. кмстелы М. 24. кхмстеки М. 43. XIV внјека: кмастеки М. 205. 242. Cтхьмханы M. 144. XV вијека: кмхтем М. 367. 376. 400. 430. 461. 462. 470. II. 104. 112. Дехани НІб. 117. ирьстьан II. 50. а како су мушке ријечи с основом ша i прелавиле овамо међу ријечи с основом на а, предазиле су и ове и ту остале до данас: тако XII вијека у ријечи у којнх јаматно нигда није ни било другачије: грнке М. 4. оргес М. 4. и послије: срькме М. 203.

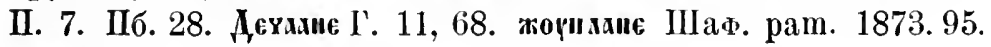
кристјане Вран. жив. 78. тако п јеврије Н. Рањ. $112 б$.

Како су неке ријечи с основом на ја прелазпле у другим падежима мн. међу рпјети с основом на i, прелазиде су и у овом: XIV вијека: ирнатем М. 241. XV вијека: пркатеми М.

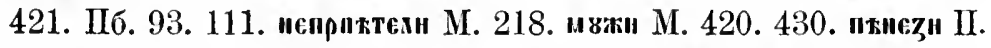
146. Пб. 113. - То је свега поменутога времена, како се види, било рнјетко, али је послије узело мах у неком крају, те додази у неких писаца врдо често а у неких кад кад, а у највише њих и не долази: тако на крају XV и свега XVI внјека : јереји Буд. 3. обичаји Буд. 137. родите.ь Буд. 59. калежп Буд. 86. зеци. Зор. 30. прасци Зор. 30б. нинезп Буд. 117. динари Ст. пис. 1, 286. XVII вијека: пријате.и Вран. жив. 33. родитељи Вран. жив. 98. Андр. иут 309. братићи Мрн. 20. кључи Вран. жив. 68. мејапи Мрн. 12. венци Вран. жив. 19. знанци Вран. жив. 29. отци Мрп. 65. сасци Вран. жив. 64. стражци Вран. жин. 44. ударци Врап. жнн. 61. удорци Мрн. 24. витези Вран. жив. 40. пинези Ради. 91. 98. ушерези ${ }^{2}$ Бун. 12. - За ријечима

1 држим да м стоји гријешком мјеспо "; повеља је писана тако чистијем народнијем језиком да не могу вјеровати да у тој рпјечи ш одговара староме словепском т.

2 Наптампано је ушересн. 
с основом на ја поводнле су се и ријечи с основом на чпсто a, те су п оне прелазпле у овом падежу као и у другим (впди генитив мн.) међу ријечи с основом на i: тако XIV вијека: змд1 М. 106. XV вијека: екхиьекисти М. 273. екангемстн М. 312 еваиАехнсти М. 324. пирн М. 381. тако ће бити и нетн (т. ј. метин) II. 47. чепће на крају XV и свега XVI вијека, али само у некпх писаца као п предње ријечп : абити Буд. 142. бискупи Буд. 130. бори Ст. пис. 1, 17. бравп Врн. 22б. буси Ст. пис. 1, 13. в.даси Ст. пис. 2, 108. Зор. 17б. гласи Ст. пис. 1, 334. гњини Ст. иис. 1, 296. дари Ст. пис. 1; 221. Стар. 3, 296. Буд. 76. Брн. 63. двори Ст. пис. 2, 466. 5, 54. дланін ${ }^{2}$ Ст. пис. 1, 193. заклопи Ст. пис. 1, 38. заступи Ст. пис. 1, 11. здамени Зор. 2. зубп Зор. 17б. јади Ст. ппс. 1, 188. казп (casus) Буд. 127. кастели Ст. пис. 1, 245. Зор. 71. легати Буд. 130. лови Зор. 38. народи Ст. ппс. 1,205 . начнни Зор. 1б. одтари Ст. пис. 1,244 . поклони Ст. пис 1, 59. пости Буд. 89. посто.ии Ст. пис. 4, 282. потпдати Ст. пис. 3, 109. прсти Ст. пис. 2, 500. редн Буд. 79. руби (vestes) Ст. пис. 1, 48. скути Ст. пис. 1, 29. 2, 245. суди (judicia) Ст. пис. $1,55$. судп (vasa) Буд. 86. трудн Ст. пис. 1, 180. укорн Ст. пис. 1,319. узли Зор. 62б. чемери Зор. 13б. ч.ъани Буд. 81. XVII вијека: анјели Вран. жнв. 16. бискупи Вран. жив. 67. вали Вран. жив. 10. витри Вран. жнв. 10. власи Вран. жив. 71. Банд. 71. Кап. 111. гласи Вран. жив. 43. Мрн. 154. гради Мрн. 12. греби Вран. жив. 38. грми Мрн. 19. дари Вран. жив. 9. двори Мрн. 26. закони Вран. жин. 48. Мрн. 51. зиди Мрн. 21. зуби Вран. жув. 62. Крн. 4. лави Вран. жив. 5. листи Вран. жив. 84. медвиди Вран. жнв. 5. одговори Вран. жив. 60. Мрн. 99. посли Вран. жнв. 74. Мрн. 28. ности Банд. 29. прсти Крн. 5. свити Вран. жпв. 81. суди (vasa) Банд. 21. суди (judicia) Андр. пут 260. табори Мрн. 35. труди Мрн. 142. угљени Вран. жив. 72. фратри Вран. жив. 75. хљьби Вран. жив. 107. хртп Мрн. $48 .^{3}-$ у таком се облику пред крајњшм и мијењају грлени гласови: тако на ьрају XV и свега XVI вијека: грисп Буд. 7. жњижници Стар.

1 Та би рнјеч (murus) могла бити и женскога рода с освовом на $\mathbf{i}$, те не би ишла овамо.

2 Прем да је у те ријечи основа на $\mathbf{i}$, али је јамачно у то вријеме већ била препгла међу ријечи с основом на $а$.

${ }^{3}$ kашић грам. 28 вели: vitri vel vitre. 
1, 221. дузп Буд. 117. еретици Буд. 139. исповидници Буд. 3. дузи Зор. 30б. обдаци Зор. 41. оружници Ст. иис. 1, 183. отроци Буд. 156. поддожници Буд. 78. покорници Буд. 41. противници Буд. 163. страси Зор. 1б. XVII вијека: бози Вран. жив. 31. боци Вран. жив. 114. виреници Вран. жив. 70. војнцци Мрн. 64. врси Мрн. 135. гриси Вран. жвв. 10. Мрн. 23. гришници Вран. жив. 8. друзи Вран. жив. 29. дузи Крн. 7б. јунаци Вран. жив. 58. облаци Мрн. 136. облоци Вран. жив. 112. пгтоци Мрн. 135. гутници Вран. жив. 25. раздози 8. родјаци 29. свидоци 24. свитваци 68. врдо се ријетко и само у једног писца XVI вијека налазе ти гласови непромјењени: данки 3ор. 3б. дреки Зор. 68б. - Оваки облик на $u$ налази се и са ов пред и: на крају XV вијека: попови Ст. пис. 1, 63. XVII вијека: братови Мрн. 20. гласови Мрн. 99. - С ријечима У којнх је основа на а овако су и ријечи с основом на и прелазиле у овом падежу међу оне с основом на $\mathbf{i}$ на прају XV и XVI и XVII вијека: воли Ст. пис. 1, 148. поли Ст. пис. 4, 29. 356. 5, 42. 301. сини Ст. пис. 1, 174. Вран. жеив. 60. Мрн. 115. - И ријечи које у множини одбацујући крајње ин добивају основу на сугдасно, па су предазиле међу ријечи с основом на $\mathbf{i}$ (види напријед), а одавде прешле међу ријечи с основом на а, опет су с тијем ријечима у истијех писаца прелазиле међу оне с основом на і: XVII вијека: градјани Вран. жнв. 25. крстијани Вран. жнв. 55. крстјани Вран. жив. 75.

Од сушстантива, којасу се овијем иачином у овом падежу свршпвала на $u$, прелазило је $u$ и на адјектива: тако XV вијека: zа почтени " станокнтн имастеке М. 297. дасно су ұоке зиате и свдоке -срекрьнн М. 393. како је послије оваки облик ! супстантива узео мах, тако је било и у адјектива: на крају XV и XVI вијека: жидовскп сини Ст. ий. 1,174 . верни 188. чемерни јади 188. бисерни усти Ст. пис. 2, 216. велики дари Стар. 1, 221. разлици нути и разлици начини наслидовах 3ор. 1б. дивји прасци прпварајући 30б. гриси смртни Буд. 7. за дари божји 71. људі редовни 142. пријад реди свети 159. XVII вијека: велики дари Вран. жив. 9. њихови гршси 11. свети божји свидоци убнјаше 24. не држиш нас за разумни 25. добри г.даси чујем 43. кроз тихи зарови Мрн. 18. цареви двори 26. кроз мнозн таборн 35 . војнички закони 99. дробни зуби Крн. 4. 
тако је у истијех писаца бнвало и у прономина, юод којих he ce споменути.

Између ријечи с основом на ја неке су у овом иадежу враћајући се између ријечи с основом на $\mathbf{i}$ међу ријечи с основом на а шрелазиле заједно са завршетком овога падежа, па према ријечима с основом на а опет добијале и њихов завршетак у овом падежу (види и ријечш с основом на $\mathbf{i}$ ): тако

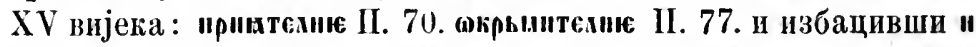

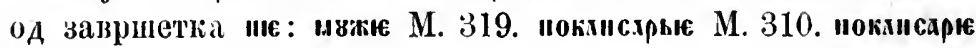
M. $367 . '$

Једном ријеч вијек додази у овом падежу као да је средњега рода: сва вика Ст. нис. 5, 44. у с.дик.

2. У женских ријечи с осповом на чисто а и на ја: ковмхе М. 6. Ржке М. 4. нетохие М. 16. покеке М. 202. тако асире ПІб.69. јаспре Радн. 85. Конккс М. 428. осе Злат. 52. Вран. жив. 64. мрав.ље Ст. нис. 3, 20. 4, 84. 165. обрве Ст. пис. 2, 44. Збор. 110б. Ст. шис. 4, 176. Кан. 111. хоругве Мрн 100.

IIIто има скоподне M. 411. томе hе номин. јед. бити слободија, јер има и локат. мн. скоподикх М. 411.

Тако је и у адјектпва: дуге Н. Рањ. 52б. мале (malle) Буд. 37. господие М. 9. пзрискамс М. 92. ведје Ст. пис. 2, 191. А. Рањ. 8 б.

Неке и од наведенијех предазе међу ријечи с основом на i: XV вијеса асири М. 329. Конхки М. 413. послије особито y нених књикевиика: стопи Ст. пис. 1, 38. хвали Буд. 94. у других књижевиика у нјесмама и коси Ст. иис. $2,25.31 .108$. 270. 348. 3лат. 39б. 64. 64б. тако у ријечи која је и у номинат јед. прелазила меһ! рпјечи с основом на $\mathbf{i}$ : страни Мрн. 124. Од сунсантива је прелазило $u$ и у адјеєтнка : прси бијели Ст. ппс. 2, 31. руси госи Ст. нис. 2, 348.

Б. У ријечи средњега рода једнаг је овај облик с ионинативом мн., гоји вндн. $-У$ ријечи кољено палази се једном XVII вијека, и то у схику, као у венских ни мушки ријечн: тве кољене Бун. 30. - У ријечи тло оснм редовгога: па тла Вран. жив. 52. 65. у тла Глав. 50. налази се и према ријечнма

1 IIIто има XIV вијека окмтхрю M. 65. то не нде овамо нето је од основе ја па се држи $j$ пза $p$; а што има XV вијека

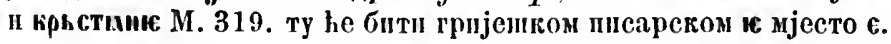


с осповом на i: XVI вијека: на тли Ст. пис. 3, 8. 325. 335. 4, 120. 287. 380. и према рнјечима женским нли мушим с основом на а: на крају XV и свега XVI и XVII вијека: на т.ле Ст. пис. 1, 223. 4, 267. 280. 287. 5, 129. 3лат. 2б. Kaıा. 19. 44. 46. по т.ле Ст. пис. 2, 282. Бун. 28. Апдр. нач. 42.

III. Основе пг i. Од наставка отпада a, а пред његовијем $\boldsymbol{n}$ продуљује се крајње $\mathbf{i}$ у основи, те у словенским језицима бива кратко, по том и остатак од наставка отпада:

А. У мушких ријечи: до краја XV вијека: гостн М. 398.

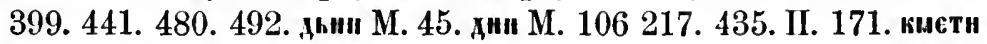
М. 531. жюди М. 6. 46. 492. II. 6. 73. 169. ІІб. 109. поүти Сав. 9. II. 5. тати Зак. 38. на крају XV и свега XVI вијека: гостп Хект. 5. дши Ст. пис. 1, 58. Н. Рањ. 15. Ст. иис. 2. 94. 44 Т. 3, 8. 4, 11. 451.5 , 3. 42. 54. 119. 299. Збор 32б. А. Рањ. ІУб. Град. дјев. 62. Хект. 17б. Зор. 26. Куд. 56. Злат. 4б. Гуч. 29. Чубр. 9. жуди Ст. иис. 1, 246. Н. Рањ. 70. Збор. 5. Ст. нис. 3, 43. 4; 172. 227. д. Рањ. VII. Ірад. дух. 22. дјев. 20. Зор. 7б. Буд. 132. Брн. 27. Злат. 41. Іуч. 2. лакти Збор. 34б. нокти Ст. пис. $3,16.130 .4$, 385. пути 3ор. 1б. црви Ст. пис. 4, 120. - XVII вијека: дни Вран. жив. 55. Аив. 9б. Орб. 1. Гунд. суз. III, LV. Бапд. 3. Мат. 47. Мрнг. 183. Кашा. 32. Андр. нач. 6. Нос. $4 б$. људи Вран. жив. 17. Орб. 7. Мрн. 180. дакти Вран. жив. 53. пути Мрп. 22. - тако прешавши меלу ове ријечи и мрави (све мрави, ки дазе) С'т. пис. 4, 165.

Ријеч дан прима и $е 6$ у основи на крају као у другим падежима остајући иначе међу овијем ријечима у овом падежу: XVI и XVII вијека: дневи С'т. пис. 5, 239. Д. Рањ. V. З.дат. 226. 37. Іуч. 106. 174. KaшI. 112. ${ }^{1}$

Ове ријечи предазе међу мушке с основом на a, a предазећи онауо у овом падежу најпрпје су неке заједно са завршетком овога падежа прелазиле па према онијем ријечима још добијале завршетак њихов у том падежу: тако XIII вијека: хвднс М. 45 . XIV вијека: пюдыє М. 210. XV вијека гостє М. 429. гдје је иди испало $u$ пред є или є треба читати ије. А послије су прелазпле п редовно, т. ј. без завршетка који имају у овом падежу с основом на $\mathrm{i}$ : тако XIV вијека: мюдс ПI. 26. XV вијека: пюдє ПГ. 42. Пб. 68. поүте М. 326: XVI вИ-.

' Што има дпиве Ст. шис. 2 ; 13. јамачно треба читати дни ве. 
јека: госте Хект. 32б. Злат. 26б. дпе Злат. 36g. Чубр. 11. људе Буд. 135. 137. 138. Брн. 27. похте Стар. 3, 246. Хект. 226. покте Ст. пис. 4, 150. 385. 477. путе Н. Рањ. 15. 64. 79. С'т. пис. 4, 13. 263. 266. 5, 46. Хект. 35б. XVII вијека: госте Андр. пут 349. длапе Каш. 95. дие Каш. 38. жуде Апв. 12б. Банд. 15. 260. Мрн. 163. ІІос. 32. Радн. 14. црве Пос. 13б. Радн. 59.' - Pпјеч дан прелазећ п тако међу ријечи с основом на а добивала је и ев на крају основе као у другим падежима: XVII внјека: диеве 1'ади. 8. а ријеч је шут добивала ов пе мијењајући о на $e:$ XVII вијека: путове Радп. 12.

b. У женских рнјечн: чссти М. 6. чтн М. 217. ирназии М. М. 444. п послије једнако: голпјени Н. Рањ. 111. голини Ст. ппс. 1, 189. деспп Гупд. пс. 9. кобп Зор. 32. звијери Ст. пис. 4, 87. 172. 263. мисли Н. Рањ. 19б. моһи Ст. пис. 1, 241. ости Ст. пис. 4, 19. Хект. 33б. ријечи Н. Рањ. 30. части Буд. 67. тако је било и обрви Ст. пис. $1,76.2,71.3,267.358 .4,192$. пјесні Ст. пис. 2, 1. 4, 12. Збор. 100б. Злат. 1б. писми Зор. 1 . Брн. 55. Банд. 151. Бун. 37. Андр. дев. 10. прави Буд. 132. рати Орб. 223. свирали Н. Рањ. 58б. Ст. пис. 4, 335. оклопи Гунд. сузе I, XXXIX. Апдр. пут 35. нокрови Ст. пис. 4, 363. - тако и У ријечи гоја је међу ове прешла: мрави (злате све мрави, пе лазе по трави, хотил бих сабрати) ('т. пис. 4. 163. мрави Ст. пис. 4, 86.157. - тако и које су пајвпше само у множини у обнчају : гуслп Н. Рањ. 122. Ст. пнс. 3, 66. 71. јас.ди Н. Рањ. 21. прси Н. Рањ. 37б. Ст. пис. 2, 29. 3, 323. 5, 152. Злат. $70 б$. Вран. ж九ив. 59. према пима и дипли Ст. пис. 3, 245. 306. 419. 4, 117. 185. 335. 5, 242.

Рнјетш гусли и јасли долазе од XVI вијека и међу ријечима женским с основом на а: гусле 3ор. 59. 72б. Банд. 14. 232. Мик. 125. 126. јасле Стар. 1, 234. 235. Банд. 9. 11. Радн. 63. ношьедња се налази у исто врнјеме и међу ријечима средњега рода с основом на а: јасла С'тар. 1, 234.

Ади оспм поменутијех ријечп гоје се и сада у том падежу говоре и с осповом на а, и осим рнјечи које су у свпјем падежима прешле онамо, као XVII вијека у истом падежу: нєсиє Мат. 67., ирелазиле су п друге међу рнјечи женске с основом на а као у другим падсжима (внди п датпв и докат. мн.)

' Kaшић грам. 27 вели: golubi vel golube. 
и јахачно уз њих, али врло ријетко: XVI вијека: риче Брн. 63. XVII впјега: дваре Mpп. 112. прсе Радп. 4. стваре Крн. 20. MpII. 138.'

IV. Основе на сугдасно. Ни у мушінх ни у желских рнјетш није било овога падежа од таке основе, него

А. Мушке су ријечи прелазиле у том падежу међу мушке рвјечи с основом па $\mathbf{i}$ : кмєш" у старом словенском језику; a у српском како су пупке ријечи с основом на $\mathbf{i}$ прешле у том падежу међу мушке с основом на а, препле су с њима и ове: пламене Ст. пис.5, 170. Мрн. 19. Каш. 42. 66. тако у ријечи гоја је и у номинат. јед. још у старом словенском прешла међу ријечи $\mathbf{c}$ основом на $\mathbf{i}$, па је $\mathbf{c}$ њима у српском језику опет прешла међу ријечи с основом на а: єкск Дом.9. - Неке прелазе онамо и одбацујући крајње суг.ласно п пред њим самогласно у основн: праме Гужд. пс. 43. Вун. 13. пламе Андр. пач. 48. - А капо су онет мушке ријечп с основом на а прелазиле у неком крају у овом надежу међу ријечи с основом на $\mathbf{i}, \mathbf{c}$ њима су се и ове опет онамо враһале: пламени Мрн. 122. корени Буд. 40. па тако и без крајњега ен у основи, у слику : прами C'т. пис. $2,467$.

Б. Женске су ријечи такођер прелазиле у овом падежу међу женске с основом на $\mathbf{i}$ : у старом словенском ихтери и дтиттерн, а по том је било у нас: прьккн М. 111. покки М. 444. прва је између њих прешла међу женске рпјечн с основом на a: матере; друга је и данас још жеђу ријечима с основом на i : кћери, али је прелазила и међу женске ријечи с основом на a: xhepe Ст. пис. 1, 89. гћере Банд. 115.

B. У средњих је тај падеж једнаг с номннативом мн., који -види.

Како су неке између тақих ријечи нрелазиле и међу мушке с основом на а, налази се у њих и у овом падежу према истијем мушки : нлемене Мрн. 143. 157. а у слику и бримене Мрн. 157. \ како су неке мушке ријечи с основон на а шредазшле међу мушке с основом на $\mathbf{i}$, уз њих су прелазиле онамо и оваке, које су биле међу њих препле: племени Мрн. 73.

' И мушке и јкенске ријечи налазе се у веких пшсаца у овом падежу и са $x$ на грају, алш врло ријетко: користих Брш. 68. sудих Мрн. 135. 


\section{В ОКАТИВ МНОЖИНЕ.}

Особита облиға за вокатив ми. нема, него се у свијех ријечи замјеьује номпнативом ми,, којн види.

I. C основом на и : смноке у старнје вријеме, а нослије према основама на а: синови Вран. жив. 101.

II. C основом на a :

А. у мушких ријечи: пуци Н. Рањ. 182б. синци Ст. пис. 4, 308. - Према ријечима с основом на и: банове Ст. пис $3,46$. кнезове Cт. пис. 3,46 . а но том онет као у ријечи с основом на а: боговн 3.лат. 10. витезови Ст. пис. 3, 252. - Ірема основама на $\mathbf{~}$ само у старије врнјеме (види номинат. мн.): привтекье М. 426. "рнатскис II. 96. прнитске ПI. 170. - ПІрема основама на сугдаспо (внди номинат. мн.): комарс Сав. 5. вмстеле М. 42. 483. христиане Стеч. 16. крстјапе Ст. нис. 1, 255. 293. 2, 341 . дворане Ст. пис. 3,154 . а послије као у ријечп с осповом на а: властели Ст. пис. 4, 3. блаһани Ст. пис. 3, 216. дубровчани Ст. пис. 3, 230. крстјани Ст. пис. 3, 327.

Б. у ријечи средњег рода, види номинатив мн.

В. у женских ријечп : жене Злат. 9. госноје Ст. пис. 3,243. У адјектива је као у супстантива с основом иа а и на ја. III. $\mathrm{C}$ основом на $\mathbf{i}$ :

А. у мупких ријечи : господнє М. 81. тако само у старпје врчјеме, а послпје као у ријечи мушких с основом на п; види номинат. мн. у мушких ријечи с основом на $\mathbf{i}$.

Б. у женских ријечп: звијери земаљске Ст. пис. 4,318. IV. С основом па сугдасно: види им номинатив мн.

\section{ИНСТРУМЕНТАЛ МНОӜИНЕ.}

Наставак је као у истом падежу једнине bhi, само му још долази с краја за множину гдас $\mathbf{s}$, дакле bhis; y c.ловенским језицима s стојећи на крају отнада, a $\mathbf{i}$ ce продуљује те у словенским језицима бива кратко, a hh гласи у словенским језицима и; тако наставак гласи у словенским језицима ин. 
I. Основе на и. Крајњи глас у основи и слабећи у словенским језицима бива т као у номинатпву јед., па до њега до. дази наставак: тако је у старом славенском језику а тако је било и у српском до XVI вијека: смньми М. 34. сынин М. 564. сипми Ст. пис. 1, 316. али су још у старом словенсгом ријечи с таком основом прелазиле међу оне с основом на а; впди II. А.

II. Основе на $\mathbf{a}$ :

А. У мушиих и средњих ријечи гдас м од наставка испада а крајњи глас у основи кратко а слабеһп у словенскнгјезицима ностаје т као у номипативу јед. мушких рпјечи, па се то т од основе са и од наставка саставља у ж, које у основа на ја предњега гласа роди прелази у п т r.saci $u$ :

a) с основом на чнсто a до краја XV вијака: мушіе: вратвусди М. 454. 456. ираги М. 44. граии М. 46. дари М. 221. 282. zаписи М. 329. котари М. 284. нетехи М. 486. овнети М. 329. свъдоки Пб. 26. трнги М. 19. чшти П. 48. средње: дрккы М. 11. дти II. 93. диекн М. 365. секни М. 172. оүстн М. 5. - На крају XV и свега XVI вијека: анђели Ст. пис. 2, 348. Гуч. 233. апостоли 3бор. 54б. бедеви Злат. 17. вепри Злат. 51. вјетри Ст. пис. 3, 377. вдасп Н. Рањ. 77. дарп Злат. 3. закопи Ст. пияс. 4, 444. Злат. 36f. занори Ст. пис. 4, 201. засторн Ст. пис. 1, 50. затвори Д. Рањ. 84б. зуби Н. Рањ. 161. Збор 158. Ст. пис. 3, 251. Стар. 4, 112. дави Ст. пис. 3, 52. мири Ауч. 102. народи Н. Рањ. 37б. Ст. пси. 3, 299. начини Н. Рањ. 22. Ст. пис. 3, 360. Буд. 35. Гуч. 7. псп Ст. пис. 5, 15. свјети Злат. 9. туђини Злат. 20. узми Хект. 44. щвити А. Рањ. 92. чавли Ст. пис. 3 , 321. Гуч. 221. чини Буд. 57. јастреби Збор. 53. средње : весли Д. Рањ. 73. Хект. 24. врати Ст. пис. 4, 202. Хект. 40. Злат. 19. дили Ст. пис. 1, 24. 121. 4, 425. Буд. 35. дјели Злат. 16б. Гуч. 83. дрвй Ст. пис. 4, 296. копити Ст. пис. 4, 180. крили Збор. 21. дитп Хект. 4. рами Ст. ппс. 1, 53. уди Ст. пис. 5,42 . усти Ст. пис. 4, 402. Хект. 30. Злат. 86б. - XVII впјека: анјелп Орб. 15. бнскупи Орб. 103. гдаси Каші. 59. днавли Див. 30. зуби Вран. жив. 92. Орб. 34. Банд. 13. Мрн. 50. начини Орб. 89. образи Орб. 163. реди Орб. 253. сни Радн. 43. целови Мрн. 175. чавли Орб. 92. Каш. 46. штапи Банд. 25. средње : богатстви Радн. 10. 81. господстви Банд. 132. днди Вран. жив. 25. 
Каш. 113. Шос. 39. дјели Див. 7б. Гунд. пс. 20. суз. III, LX. кољени Орб. 268. писми Крн. 4б. платнв Банд. 106.

Тако је и у ријечп с основом на и по што су се $\mathbf{c}$ овима помијенгале: XIV вијека : сини М. 219. XVI вијека: сини Буд. 59.

б) с основом на ја: до краја XV вијека: мушке : ги М, М. 494. нрахи М. 458. иртродитекин М. 100. прародитеки М. 562. приктехи М. 367. II. 57. 145. родитеми М. 14. 187. 210. 317. 382. 412. 421. 468. 486. оүчнтем М. 561. кони Стеф. 29. Орахокичнкн М. 92. мхуи II. 48. покрикхуи Пб. 56. кникии М. 427. мхсери М. 55. ииєпези Пб. 115. пхстыри М. 57 - 58. покхнскри М. 304. 345. 422. 544. ормитаї М. 58. пари М. 99. 100. 458. средње: везакони Стеф. 19. zасекь" М. 439. єүаигеки М. 11. помп М. 449. мхнинци M. 494. пашпци М. 138. пртходнци М. 494. - На грају XV и свега XVI вијека: зман Збор. 129б. краљи Ст. пис. 4, 218. 425. научитељи Гуч. 167. Буд. 14. непријатељи Збор. 6б. Ст. пис. 3, 225. обрањитељп Н. Рањ. 25б. пријатељи Н. Рањ. 59 Хект. 21б. родитељи Брн. 21. коњи Ст. пис. 1, 36. Н. Рањ. 60б. Злат 12. птићи Злат. 4. мечи Ст. пис. 1, 16. са мчп Збор. 80. мачи Ст. пис. 3,311 . мужи Брн. 61б. товариши Н. Рањ. 18. вјеначци Ст. ппс. 3, 359. владавци Н. Рањ. 19. мудраци Гуч. 171. знанцп Н. Рањ. 67б. Гуч. 169. витези Стар. 3, 272. Злат. 16б. овчарп Ст. пис. 4, 302. пастирп Ст. пвс. 3, 456. 4, 278. 5, 205. Д. Рањ. 134б. цари Стар. 3, 322. средње: копји Ст. пис. 1, 36. копи Стар. 3, 295. Ст. пис. 4, 468. дасканји Стар. 1, 218. зелји Ст. пис. 1, 3.3ор. 21 б. зели Стар. 3, 257. воһи Ст. пис. 1, 66. годиптп З.ат. 86. кљпићи Стар. 4, 114. крноци Ст. пис. 3, 404. дици Стар. 1, 218. 3.лат. 81. личци СТ. ппс. 2, 75. - XVII вцјека: мушке: жиљи Вран. жив. 19. жраљи Банд. 192. Мрн. 4. обраните.ьи Банд. 15. прпјатељи Вран. жив. 74. Орб. 286. родитељи Банд. 58. учитељи Каш. 97. коњи Вран. жив. 46. бпчи Вран. жив. 22. Банд. 109. мачи Банд. 85. Каш. 50. старци Банд. 14. клинци Див. 26б. мударци Јерк. 37. дунежи Јерк. 64. витези Вран. жив. 14. средње: перји Вран. жив. 18. пристолји Банд. 134. диловањи Пос. 39. пожелшнји Бапд. 172. поштењи Радн. 10. срци Банд. 13. прнбивалишти Каш. 8.

Тако је било и у адјектива за мушки и средви род, те сө налази још на крају XV и XVI вијека у пјесмама, особпто 
у слику, али врло рпјетко; тако има изван слика: хитри Ст. шис. 1, 24. писани Ст. пис. 1, 50. гвоздени Ст. пис. 4, 202. у слику дедепи Ст. ипс. 3,124 . љути Ст. пис. 3 , 321. гвоздени Ст. пис. 4,199 . непокојни Хегт. 44 . а.ии се пи тада тај облик у адјектива није разумијевао него се писао само као остатак од старнне, јер додази п ондје гдје би требао сложенп облик : тими жутки воһи Ст. пис. 1, 66. и не само то, него до.дазп и за женски род, како ће се споменути мало даље код женскп рпјечи. Мјесто тога облика узео је мах од давнина сложени.

Из падежа у којима се у основама на $\mathbf{u}$ крајшп глас шири у ов пред самогласнијем наставком, прешло је то ов и у овај, пред завршетак вегов т, као штто је прешло и у друге падеже у мушких ријечп с основом на а, па каго су се с овијем ријетима помијешале оне у појшх је основа па и, прешдо је опет то ов у овом падежу од ријечи с основом на а к ријечима у којих је основа на и: тако је у нанем језнку бпло од најстаријшх времена у мушки ријечи с основом на qисто а и на и: до краја XV вијека: градовы М. 4. градови М. 400. даровн М. 168. 172. хнстокн М. 329. 403. 433. поүгови М 449. 494. миниоки М. 191. сынюкы Дом. 165. сшиоки М. 180. 262.377. 563. - XVI вијека: брјегови Ст. пис. $3,161.167$ вукови Ст. пис. 3, 52. 75. 318. Злат. 1б. гробови Ст. нис. 3, 29. дарови Злат. 11. Гуч. 301. дубови Злат. 43. духови Гуч. 131. јадови Cт. пис. 3, 76. 108. 463. сњегови Ст. пис. 3, 161. - XVII вијека: дарови Каш. 23. зубови Пос. 19б. попови Вран. жив. 16. постови Радн. 71. синови Банд. 202. Пос. 11б. - Како је исто ов прелазнло и к рнјечнма средњега рода у некни падежима (види стр. 79), налази се и у овом XVI внјека један пут: блатови Злат. 52б.

Како м од давна у српском језику гласи $u$, претварају се пред вим у овом падежу гласови $2, x, x$ у $3, u, c$; алп то бива истом од прве подовнне XIV вијека, и свега је тога вијека јоп доста ријетко: засемин М. 113. 141. 143. 191. 242. засеюџи М. 234. тврџи М. 223. - XV је вијека већ тако често да су примјери без те промјене врло ријетки (види напријед с'тр. 113):

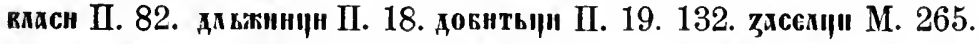
zасеори М. 284. 296. 301. 305. 340. 346. метеси М. 494. опкеннирн М. 401. 414. отропи П. 147. прхведниџи Пб. 40. размози М. 445. 


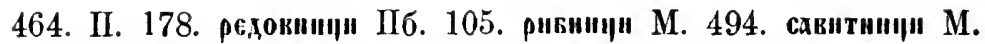
469. стронинџи М. 459. 470. тркz" М. 410. 436. 445. вгодинип М.

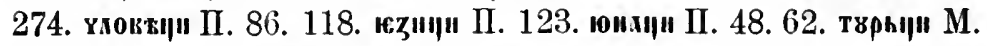
525. од тога времена й не долази другачије него с том промјеном (осим неколика примјера из XVII вијека, које һу на по се споменути) кимєзи Збор. 75 бисаци Ст. пис. 4, 309. бози Н. Рањ. 64. бријези Ст. пис. 4, 76. врази Ст. пис. 1, 116. С'тар. 4, 113. вуци Ст. нис. 4, 131. Зор. 36б. грисп Ст. ппс. 1, 39. Брн. 28б. грјешници Н. Рањ. 219. грешници Гуч. 174. Орб. 168. гришницп Буд. 28. грци Здат. 13. друзи Зор. 26б. Банд. 7. језици Н. Рањ. 138. Банд. 27. јупаци Д. Рањ. 20. камици Вран. жпв. 16. круси Радн. 57. мисници Гуч. 89. наредбепици Н. Рањ. 19б. насљедници Орб. 7. науци Здат. 93. Стар. 1, 222. Орб. 121. немоћнпци Кап. 26. обдаци Ст. пис. 3, 406. одвитници Банд. 15. покорници Гуч 232. помоһници Банд. 183. разбојници Јерк. 78. разумници Гуч. 114. редовници 3бор. 21б. родјаци Н. Рањ. 67б. Хект. 35. Банд. 20. тежаци Банд. 24. ученици Н. Рањ. 70. Ст. пис. 5, 120. Банд. 75. уздаси Град. дјев. 90. Злат. 81. здаси Зор. 2б. 37. - Како свега XVI и XVII вијека нема другачије него с промјсном грленпјех гласова, онда што се гао највећа ријеткост XVII вијека палазп воски Банд. 113. и грихи Глав. 27. не ће бити стари остатак него hе бити одступање од новога правила и вршједиће онолико колшіо врнједи што се кад кад налазе и у номин. мн. ти гласови непромјењени; пспореди још даље.

Како су неке ријечи с основом на ја шредазиде у номинативу и у генптиву мн. међу рпјечи с основом на $\mathbf{i}$ (впди. стр. 60.74), тако су прелазнле и у овом падежу те су та имале п онако као оне. т. ј. с цијелијем наставком ми састављеним с основом онако као у њих (вцди натраг под III): так $\widehat{0}$ је било XII вијека: кр.хьин М. 4. парьми М. 4. Које од такшх ријечи које од онијех с основом на и (видш под I) дошдо је те су и ријечи с основом на чисто а гласиле тако у том падежу : XIII вијека: миногрдин М. 46. дарьии Стеф. 13. тако п даље не само с основом на ја него и на чисто а: XIV и XV вијека: врхтвуедьми М. 451. 452. 455. градин М. 288. 424. грхдими М. 299. 321 дирьмн М. 241. дарми М. 242. 317. 412. 486. заком ьин П. 161. коньми М. 63. конии М. 191. II. 91. котарни М. 494. кракьип 
П. 161. хнстьми М. 330. II. 102. ІІб. 39. 65. 72. 77. маниин М. 494. пниезми М. 285. пєнезими II. 154. покаис.рмн М. 325. прлродитекин М. 129. прародитехьми М. 282. прнставьеии II. 79. привтехьми М. 176. 315. 458. 508. II. 75. 98. 122. родительми М. 63. 562. оүммн М. 563. 565. пррьми II. 161. На крају XV и свега XVI вијека: ангелми Н. Рањ. 214б. власми Здат. 2б. гласми Збор. 99. дарми Ст. нис. 3, 239. 243. 297. 309. Буд. 54. Гуч. 130. жу.ьми Ст. пис. $1,266$. законми Ст. иис. 5, 352. зубми Н. Рањ. 23. Збор. 27. Ст. пис. 4, 47ь. 5, 99. кључми Збор. 105. кнезми Ст. пис. 1, 38. коњми Стар. 3, 251. Гуч. 238. иужми Ст. нис. 1, 271. Н. Рањ. 160б. Стар. 4, 142. оглавми Ст. пис. 5, 59. подвезми Ст. пис. 1, 38. рукавми Ст. пис. 2, 252. сакраментми Буд.56. скорупми Ст. пис. 5, 194. ушерезми Ст. пис. 1, 37. шаторми Збор. 75. И XVII вијека: апоштодми Банд. 137. власми Банд. 66. гласми Банд. 99. жудјелми Радн. 91. кључми Мрн. 3. коњми Банд. 51. краљми Банд. 79. научптељми Банд. V. прнјатељми Банд 49. - Тако и онда кад је у основи пред задњим самогдасним грлени глас; он се на.дази непромијењен од XIII до XV вијека : гржым Стеф. 22. М. 562. 530. али се од XIV вијека и мијења: трязин М. 229. П. 5. 7. 17. 22. 26. XV вијека: пвзьми М. 449. хвіьми' ${ }^{\prime}$ II. 48. трьзми II. 63. 70. 112. XVI вијека: јездцми Н. Рањ. 36.1386. розмнје ${ }^{2}$ Н. Рањ. 117. узроции Буд. 40. XVII вијека: боцми Банд. 17. вразми Банд. 272. розми Банд. 118. Пос. 19б. - Тако и кад поменутијем начином прелази ов из других падежа $у$ овај у ријечи с основом на а и на $\mathbf{u}$, али тек од XV вијека: градокмн М. 348. дирокьин М. 524. хнстокьен М. 357. хнстовми М. 361.-365. 374. Пб. 87. синокиш М. 403. стхновым॥ II. 91. XVI внјека: даровми Збор. 36б. синовми Н. Рањ. 53. 62. 65. 676. 1746. Ст. пис. 4, 445. 448. 474. XVII вијека: гласовми Банд. 112. даровми див. 6. зидовми Банд. 293. синовми Банд. 44. 52. 192. 217. - Мушке су ријечи повукле за собом и средње (ади ов није у њих продрло у овом падежу), али тек од XIV вијека: дрьвин М. 234. сскьмн М. 116. 234. XV вијека: вратьин ПІ. 133. дрьвмп М. 296. 305. дртеьми М. 284. на крају XV и XVI вијека: вратми Ст. пис. 5, 159. Буд. 156. Злат. 4.

1 Наштампано је квицини.

20 крајњем $ј е$ внди стр. 122. 
дрнекми 3бор. 75. Ст. пис. 5, 102. кљишћми Стар. 4,'114. кодннми Ст. пис. 1,43 . крилми 3бор. 8. устми Ст. пис. $1,4$. Н. Рањ. 63б. Буд. 22. Злат. 87б. усми Н. Рањ. 220. Град. дјев. 71. Гуч. 44. XVII вијека: вратми Банд. 45. Каш. 18. колинми Глав. 50. устмп Банд. 2. Капг. 29. устни (т. ј. устми) Вран. жив. 45.

Ријечи које постају наставком ин и јанин па у множпни одбацују ин, добивају основу на сугласно, те се пзједначују с рпјечима у којих се основа свршује на сугласно: ако се тада у жих основа свршује на $九$, тај се г'дас као и у дативу мн. кад до њега дође наставак ми, пзједначује с гласом м од наставка, те постаје $\mu$, по том се једно од два м избацује: тако имамо још XV вијека: сонихми М. 440. дввровухмн М. 375. и послије мацедонами Стар. 3, 251. 282. Како ријечи којшма се основе од постања свршују на сугдасно предазе у овом падежіу међу рпјечи с основом па i. с њима предазе онамо и ове, те у овом надежу гласе и онако као оне: тако XIV п XV впјека: кхастекьн М. 143. 189. 211. кхастеюмн М. 444. а како опет ријечи с основом на $\mathbf{i}$ прелазе меһу оне с осповом на а, таго с њима прелазе онамо и ове, у којих се у множини основа сврпује на сугласно, те се изједначују с ријечима мушким које имају основу на а: тако од XIII вијека до краја XV: комхрм М. 22. Сав. 13. комхап М. 22. вмстекм М. 34. кмастеки М. 44. 146. 156. 210. 255. 311. 431. 508. 544. двкровуани М. 205. 434. срьва М. 205. 353. 434. и послије: грађанп Гуч. 305. жндовп Ст. пис. 3, 318. индијани Ст. пис. 3,230 . римшани Ст. пис. 1,48 . (тако са ж).

IIто је глас ж, на који се сврпивао овај падеж, у српском језпку гласпо и, пред којим су се и грлени гласови мијењади, и птто и у старом словенском језику код основа на ја мјесто т стоји $u$, те се тај падеж у тијех ријечи мупкога рода пзједначно с првијем пад. мн., а у других се ријечи, које су имале цијели наставак ми, добро разликовао, с тога да би се разликовао п у њих према овима другима, не само се мијешаху у овом падежу ријечи у којих је основа на а $c$ ријечпма у којпх је основа на $\mathbf{i}$ (како је речено напријед), него се и самоме правом инструменталу ријечи с основом на а додаваше још једном наставак ми, које особито дако могаше бивати уз рпјечи у којпма се чуваше наставак ми: тако на- 
Ходимо XIII вијека: моншн вохаршин М. 28. свонмн воларнми М.

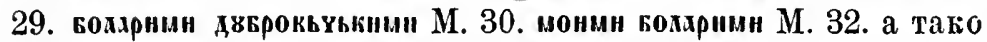
је без сумње и XIV вијека: прароднтехнин машнин М. 241. (гдје је гријешком наштампано прародитеми мн нхшнин). таlо и XVI вијека: керстнхннми Шаф. pam. 1873. 111. за мушким су ријечима пристајале средње: тако од прнлике $X V$ вијека: устими Стар. 1, 221. и XVI вијека: устими Брн. 55. Оваки се је облик XVI вијека већ мијењао (како һемо одмах видјети), за то не долази чешће; истом се XVII вијека опет јавља у неких књижевника доста често, а тада hе га бити пзазвао нов узрок, како һе се одмах видјети: бнчими Каш. 46. 56. винцими Каш. 77. гдасими Кашт. 55. годубићими Каш. 16. даровими Каш. 95. конопцими Каш. 50. 57. дпстими Мрн. 178. мирими KaшI. 11. мирисимп Мик. 254. мрцнми Kaш. 118. пјенезими Мик. 278. пинезими Капг. 95. послими Мрн. 112. прасцими Каш. 31. уреснми Каш. 77. чавлими Каш. 46. тако и у средњпх ријечи : дилими КапI. 103. дјелими Капг. IIIб. копјими Каш. 50. проклетствими Радн. 65. Оваки се облик находи и у рпјечи с основом на $\mathbf{i}$ и на сугдасно: видп их ниже IIOд III II IV.

Таки се облик само крајњнм својим $и$ разликоваше од датива мн., какав узимаше мах XVI вијека, а сврх тога оба падежа бјеху у то вријеме ослабила не само у овијех ријечи него и у других. те се мијешаху и један другим замјењиваху (внди код датива мн. мушкшх ријечи с основом на а инструментал мјесто датива и датив мјесто инструментада; види и код женских ријечи с основом на а датив и инструментал мн; види исте падеже у замјеница личних); што дакле разлика међу пима већ бјеше слаба и што се замјењиваху, за то се и изједначише са свијем, а изједначише се тијем што се оваком инструменталу мн. са завршетком ими одбаци крајње $u$ : тако је врло често XVI вијека: у мушких: анђелим Ст. пис. 5, 111. Град. дјев. 11. апостолим Град. дјев. 161. бисацим Ст. пис. 4, 309. боцим Град. дјев. 176. валим Ст. пис. 4, 434. гдасим Ірад. дух. 12. гријесим Град. дух. 15. гусарим Град. дјев. 75. дарим Град. дух. 19. дпнарим Ст. пис. $5,155$. законим Ст. пис. 4, 460. змајим Ст. пис. 5, 16. зубим Ст. нис. 4, 476. А. Рањ. 119б. јадим А. Рањ. 6. језпцим Град. дух. 49. 
калуђерим Град. дјев. 126. каноницим Град. дјев. 127. кумшањим Ст. пис. 5, 287. мирим Ст. пис. 4, 423. Град. дјев. 153. мужнм Ст. пис. 5, 254. начиним д. Рањ. 84б. Град. дјев. 112. народим Град. дјев. 160. науцим Град. дјев. 4. непријатељим Ст. нис. 5, 56. облацим Д. Рањ. 134. палим Ст. пис. 4, 199. патријарцим Град. дјев. 173. повојим Ст. пис. 4, 222. поповпм Град. дјев. 127. постим Град. дух. 16. пријатељпм Ст. шпс. 5, 20. Д. Рањ. ІХб. пророцим Град. дјев. 173. разлозим Град. дјев. 123. сакраментим Град. дух. 24. сатирим Ст. пис. 5, 223. синовим Ст. пис. 4, 437. старцим Ст. пис. 4, 362. Град. дјев. 173. трудим д.Рањ. 8. уздасим Д. Рањ. 81. Град. дух. 16. ученицим Град. дух. 52. чавлим Град. дјев. 140. шиљцим Град. дјев. 90. у средњих: дилим Ст. пис. 4, 483. дјелпм д. Рањ. 37б. Град. дјев. 21. кољеним Ст. пис. 4, 462. Град. дух. 32. копнм Ст. пис. 4, 478. крилим Град. дух. 67. пророчанствим Град. дјев. 154. устим Д. Рањ. 60. - XVII впјека: у мушких: анђелпм Андр. дев. 25. бичим Андр. пут 78. благосовим 122. блудим Гунд. суз. II, IX. валовнм Андр. нач. 36. гласим Андр. пут 125. грнјесим 69. грешницим Андр. пут 419. даждим Бун. 36. дарим Гунд. пс. 41. Андр. пут 77. дев. 14. дуспм Андр. пут 73. двораним 144: завезајпм Гунд.суз. I, LXIV. зрацим Гунд. пс. 43. суз. III, XXIX. кладенцим Андр. пут 19. лавим 436. латиним Ђам. 21. лупежим Бун. 45. начиним Андр. гут 353. дев. 21. научитељим Андр. пут 274. невјерпицим Андр. дев. 14. негријатељпм Гунд. пс. 4. образим Андр. пут 375. одметницим 403. писаоцим Ђам. 46. погледим Гунд: суз. II, ХХ. пријатељим Андр. дев. 59. разумницим Андр. пут 155. редовницим 177. родјацим Андр. дев. 59. свецим Андр. дев. 25. трннм Бун. 41. угризајим Мик. 717. уздасим Андр. пут 322. целовим Бун. 27. чавдим Бун. 33. Андр. иут 408. дев. 42. средње: вратим Андр. пут 257. дјелим 140. достојанствим Андр. дев. 180. нач. 23. жвалим Гунд. пс. 9. кољеним Андр. пут 14. напастованим (-nijm) 368. свједочанствим 368. устим Андр. дев. 119. нач. 36. пут 155. - на крају м гдаси гдје гдје и $н$ : коларинин Град. дјев. 104. - IIто се овако овај падек изједначпо с дативом, с тога се XVII вијека покушавало да се опет разлик ује враћајући му на крају и; примјере видп мало напријед. 
Таком облику додаје се још $a$ на крају као у генитиву мн. и у дативу мн., и с тијем се додатком појављује још прије него без њега, а то свједочи да се $и$ одбацивало прије него што се тај облик без њега у књигама находи ; тако нмамо са $a$ још на крају XV вијека: синокиних М. 531. мачима Ст. пис. 1, 11. XVI вијека: вијенцима А. Рӓњ. 107б. воњима А. Рањ. 63б. г.ласима Ст. пис. 4, 449. даждима Д. Рањ. 124. дарима Д. Рањ. V. Злат. 31б. дјетићима Ст. пис. 4, 255. дубима Д. Рањ. 118. зубима А. Рањ. 68б. јадима Д Рањ. 46б. лијецима А. Рањ. 146. мирна Д. Рањ. 88. мразима Д. Рањ. 140. ступима Д. Рањ. 9б. трацима Д. Рањ. 77. чавдима Ст. пис. 5, 136. у средњих : воћима Д. Рањ. 28б. дјелима Д. Рањ. 28б. устима Ст. пис. 5, 69. 255. Д. Рањ. 23б. Злат. 80. - XVII впјека: у мушких: анјелима Орб. 227. бисерима Мик. 722. бичима Бун. 41. бозима Вран. жив. 61. грпјесима Орб. 40. даждима Бун. 36. дарима Андр. пут 179. даровима Мик. 85. дусима Андр. пут 90. зубима Мик. 586. језицима Радн. 54. краљима Орб. 103. лијецима Андр. пут 198. лонцима Радн. 85. љубљеницима Радн. 9. мирима Мик. 119. мирисима Мик. 181. науцима Ђам. 21б. пјенезима Мик. 116. планетима Орб. 11. прутима Мик. 525. разговорима Андр. пут 307. разлозима Орб. 79. Мик. 554. Андр. путт 387. розияа Мик. 17. ру кавима Мик. 571. синовима Андр. дев. 139. свидоцима Радн. 2. уздасима Гунд. суз. II, XVII. црипима Вран. жпв. 113. штитима Мик. 37. у средњих: бдењима Радн. 71. дјелима Орб. 13. 60.145. Андр. пут 127. 139. 145. 180. Радн. ІІб. добрима Радн. 53. езем пдима Орб. 166. једрима Мик 178. устима Андр. пут 82. цаб.има Мик. 46.' - Што толиким прпмјерима $у$ наточ пма без промједе грлених гласова: острогима Мик. 343. редкима Мик. 560. то ће бити онако као напријед стр. 116 у два примјера без ма.

Обдик тако раширени гдасом $a$ додази и без $u$ пред $\mu$, али тек XVII вијека: у мушких : пастирма Радн. 42. киповма Радн. 36. у средњих: изнашастма Радн. 100. крилма Радн. 70. мистма Радн. 30. поштенма Радн. 12. устма Радн. 19. 22. 42. 56. 71. 86. чињењма Радн. 74.

У средњих ријечи долази тај облик и према женскима с основом на п као кад кад у дат. мн., али врдо ријетко:

${ }^{1}$ Кашиһ грам. 28 вели: vitrimi vel vitrima и на стр. 34: 7latima vel zlatimi vel zlati. 
тако још XIII и XIV вијека: засекнкин M.11-12.59. на крају XV шли у почетку XVI вијека: воћами Стар. 3, 266. крилами Ст. шис. 2, 408. 436. и XVII вијека: богатствами Радн. 83. 93. достојанствами Радп. II. у исто вријеме и без крајњега $u:$ богатствам Радн. 81. доброчинствам Мик. 85.

Птто се и у нушких тако налази у једнога писца на крају $\mathrm{XV}$ вијека два пута у слику: врхами Cr. Iпс. 1, 10. дугами Cr. пис. 1,57 то һе бити јамачно само слпка ради; изван слика додази само један пут: другами Ст. пис. 1, 275.

У овога се падежа налази само једном додано на крају $e$ XVI вијека: розмије Н. Рањ. 117. а штто XVII вијека има: у мупких: зуковије Радн. 37. и у средњих: днлије Радн. 57. мастилије Радн. 37. ту је инструментал помијешан с локативом и вим замијењен; нсто је тако у исто вријеме замијењен докативом, који је добио на крају м од инструментада иомијешавпи се с њим (внди код докатива): у средњих: вратијем Андр. пут 257. богатствијем Радн. 81. 83. створенијем Радн. 83. Андр. 263.

Да се кад кад у овијех ријечи налази пнструментал мјесто датива и датив мјесто инструментала, поменуто је код датива мн.; а да се кад, кад налази докатив мјесто инструментала, споменуће се још код локатива мн.

Б. У женских : у основи је крајње а дуго, те у словенским језшцима бива кратко; к њему приступа цијели наставак ин: тако до краја XV вијека: веснєдми М. 420. вєкьможкан М. 272. мевин М. 218. медии М. 301. тако је у то вријеме и у кодегтивних ријечи: врхтихин М. 63. 278. 564. господами М. 201. II. 27. 33. 39. 57. 161. дттырами M. 63. 564. -- На крају XV и свега XVI вијека: блшжиками Н. Рањ. 23б. бухами Ст. пис. 5, 15. веригамп Збор. 55б. водами Ст. пис. 3, 354. Град. дух. 50. Злат. 10б. војсками Рањ. ІХб. гиздамн Ст. пис. 2, 89. дјевицами Гуч. 233. дубравами Гуч. 273. душами Ст. пис. 3, 445. Гуч. 279. жељами Злат. 86. женами Н. Рањ. 16б. Ст. пис. 5, 16. Град. дјев. 175. звијездами Ст. пис. 2, 58. 3, 146. 5, 113. злобами Ст. пис. 3, 388. змпјамп Д. Рањ. 129. књигами Гуч. 77. косами Ст. пис. $2,11.5,119$. молбами Злат. 4б. Гуч. 6. молитвами Гуч. 22. мрвами Гуч. 266. ногами Ст. ппс. 3,121 . Град. дух. 42. Злат. 51б. ножццами Н. Рањ. 108. овцами Ст. пис. 3 , 
74. 5, 242. па.лцами Н. Рањ. 91б. потрјебами Н. Рањ. 30б. ранами А. Рањ. 149. Гуч. 199. рибами А. Рањ. 114. риками Хект. 106. руками Н.Рањ. 64. Збор. 46. Ст. иис. 2, 210. 3, 377. Град. дјев. 156. светковинами Гуч. 90. сестрами Збор. 9б. етаришинами Буд. 59. стријелами Ст. иис. 3 , 182. сузами Ст. иис. 2, 281. 3, 76. 4, 392. 5, 195. А. Рањ. 90б. Град. дјев. 88. Злат. 4б. Гуч. 102. тминами Здат. 90. тугами Ст. пис. 3, 459. Д. Рањ. 2. уздами Злат. 20. тако и у ријечи која је сада мушіога рода: мрвљами Ст. пис. 4, 84, 158. XVII вијека: веригами Бун. 24. виками Орб. 108. водами Див. 6. војсками Орб. 84. врућинами Орб. 167. гатками Пос. 2б. грдобами Радн. 16. грлицами Каш. 16. дивицами Вран. жив. 16. душами Орб. 219. женами Орб. 255. Банд. 5. Јерк. 15. заклетвами Мик. 264. засједами Гунд. суз. II, XXVI. згодами Андр. пут 74. здобами Бун. 29. Мрн. 24. јаглами Крн. 5. клетвами Мик. 52. косами Бун. 32. краљицами Орб. 103. купами Мик. 444. дажами Андр. пут 373. молбамп Вран. жив. 16.Мрн. 26. Мик. 264. модитвами Орб. 121 . муками Орб. 34. Каш. 9. направами Бун. 6. ногами Мик. 449. Андр. пут 40. пеленами Бун. 47. пеленицами Каш. 9. приварами Радн. 24. приликами Радн. 5. птицами Банд. 114. пукшами Мрн. 45. рудинами Мик. 570. руками Орб. 42. Мик. 420. Андр. 6. Радн. 3. сабљами Мрн. 45. стазами Банд. 3. сузами Вран. жнив. 17. Бун. 3. Каш. 46. Андр. пут 339. тминами Вран. жив. 22. травами Орб. 4. трубљами Орб. 227. уздами Гунд. пс. 9. хвалами Гунд. пс. 28. шаками Мик. 409. птетами Радн. 49.

Тако је бндо и у адјектива за женски род: многхми М. 11. хрнстовмин М. 11. врахіїаи Сав. 7. жеквзнами Стеф. 10. али само у прва времена, а послије је мах узео сложени облик. На крају XV вијека тако је веһ бцо заборављен овај номинални облик у адјектива да мјесто њега долази облик мушкога рода и то само у пјесмама: изван слика: бритци сабљами Ст. пис. $1,12.36$ у у слику: свилами разлици От. пис. $1,41$. руками прибили Ст. пис. 2, 30. 240. 259.

Ако се и држао овај облик у супстантива свега времена, ошет не раздикујући се од датива мн. ничим осим свога крајњега $u$, мијешао се је с њим тако да је и он додазпо мјесто датива (впди код датива мн. у женских ријечи с основом на a) и датив мјесто њега или да је своје $u$ на крају губио: 
тако на крају XV и свега XVI впјека: бесједам Cт. пис. 5, 19. Злат. 59. божицам Злат. 5. геригам Град. дјев. 37. вилам Ст. пис. 2, 68. 422. 4, 469. галијам Ст. пис. 5, 102. грлпцам Ст. цис. 2, 360. 373. дивицам Ст. пис. 2, 361. дјевицам Град. дјев. 101. дикдам Ст. пис. 2, 90. дјевојкам А. Рањ. 11. добротам Град. дјев. 55. 68. душам Г'рад. дјев. 31. 33. заклетвам Злат. 72. занчнцам Град. дух 81. звиздам Ст. пис. 2, 47. 75. 235. Г'рад. дух 15. зракам А. Рањ. 46. Град. дух. 25. јестојскам Град. дух 15. косицам Ст. пис. 2,30 . дукијернам Град. дјев. 177. молбам Ст. пис. 4, 417. 5, 36. Град. дух. 46. Здат. 82б. модптвам Г'рад. дјев. 88. Гуч. 7. мукам Ст. пис. 2, 400. Град. дјев. 75. З.лат. $82 б$. нашоменам Град. дух. 1. направам А. Рањ. VIII. наредбам Град. дјев. 123. ногам Град. дух. 32. Злат. 11б. оготам Ст. пис.5, 254. приликам Ірад. дјев. 8. 84. 153. птицам Ст. пис. $2,361.4,434$. птичицам Ст. пнс. 2, 361. разбдудам Град. дјев. 112. раскошам Град. дјев. 111. регудам Град. дјев. 132. рожнцам Ст. пис. 2, 89. рукам Ст. пис. 4, 368. сестрам Злат. 32б. славам Гуч. 125. слугам Град. дјев. 87. службеницам Град. дјев. 87. сузам Ст. пис. 4, 316. Град. дух. 16. Злат. 21. тугам Злат. 25. тужпцам Ст. шпс. 2, 418. хвалам Злат. 95. пиббгам Град. дјев. 182. X VII вијека: гиздам Гунд. суз. I, XXXVIII. гдавам Банд. 87. Андр. пут 208. гозбам Бун. 25. грешницам Андр. пут 419. дворкињпцам Бун. 7. драчам Андр. шут 139. душам 340. заушницам Банд. 92. звијездам Андр. пут 182. злобам Андр. нач. 21. косам Бун. 30. крунам Андр. пут 360. молбам 223. молитвам 173. мукам Гунд. суз. II, XLVII. Андр. пут 232. наредбам 89. ногам 106. невољам Андр. дев. 107. овчицам Андр. пут 332. ошекам Мик. 542. приликам Андр. дев. 115. ранам Бун. 44. раскошам Гунд. суз. II, VII. Андр. ІІут 83. росам Бун. 36. рукам Андр. пут 354. слугам Гунд. суз. III, LIII. стријелам Андр. пут 42. сузам Гунд. суз. III, LXXI. Бун. 17. 24. 36. Андр. дев. 73. нач. 49. тугам Андр. дев. 108. хаљинам Андр. нач. 21. хитринаж Андр. пут 387. чесвннам Гунд. суз. I, IX.

Таком облпку са сугдасним на крају додаје се као и у дативу мн. и у другим приликама па крају $a$, и то од XV вијека: гокнхих П. 96 . zемким М. 551. на крају XV и свега XVI вијека: бесидама Буд. 32. вилама Ст. пис. 2, 349. 378. 403. 405. женама Буд. 23. 83. 87. Вран. рјеч. 128. звиздама Ст. пис. 
2, 377. звијездама Ст. пис. $3,205.416 .5$, 44. змијама Ст. пис. 2, 405. јизбама Буд. 94. юњигана Буд. 137. косама Ст. пис. 2 , 10. 71. 5, 57. ликарпјама Буд. 35. милостнњама Буд. 59. мирама Буд. 91. наредбама Буд. 132. од.укама Буд. 132. светшњама Буд. 56. свићама Буд. 157. сестрама Ст. нис. 5, 147. силама Буд. 54. слугама Стар. 1, 218. стри.лама Ст. пис. $2,145$. сузама Ст. пис. 2, 8. 282. 366. 437. 4, 244. 392. 393. 427. 430. 439. 443. 444. 470. 5, 76. 94. Д. Рањ. 30. Град. дјев. 157. З.лат. 43. тугама Ст. пис. 2, 366. 403. 405. 4, 433. А. Рањ. 30. З.лат. 19. узама Буд. 85. уздама Ст. пис. $5,59$. химбама Буд. 91. XVII вијека: водама Орб. 10. главама Мрн. 134. дружбама Мрн. 21. заушницаща Мик. 822. кочијама Мик. 789. крајинама Мрн. 3. купама Мнк. 222. мирама Мпк. 175. папама Мрн. 131. пет.ыама Мнк. 825. ружпцама Мик. 572. рукама (нашима) Мрн. 134. Андр. дев. 140. свићама Мрн. 177. струњама Мнк. 172. сузама Врап. жив. 41. 54. хаљннама Радн. 51. 72. химбама Мрн. 133. шакама Мик. 584.'

На.лазп се XVI вијека према основама на $\mathbf{i}$, али само у два примјера : петми Ст. пнс. 4, 171. рукми Брн. 15. Једном има и према мушким рпјечнма с осповом па а : zеми М. 38.

III. Оснфве на i. Наставаг долази цио ми, а у основи крајње кратко і слаб̆ у словенским језицима те бпва п тако је бнло и $у$ мушких и у женских:

a) у мушких до краја XV вијека : диьми Стар. 4, 134. пудьии М. 44. модми М. 46. 296. мюдыни М. 211. П. 6. 91. 135. на крају XV и свега XVI вијека: људми Ст. пис. $1,36$. Н. Рањ. 30. Збор. 55. Ст. пис. 4, 234. 401. 460. Буд. 62. Злат. 23. Гуч. 122. црвми 3бор. гвоздми Збор. 88б. п XVII вијека: људми Банд. 20. Каш. 83. Іос. 32.

Али од XV вијека изједнатују се ове ријечп и друге с оваком основом с рпјечима мушким у којпх је основа на а, т. ј. додазе са $u$ мјесто ми: гвозди Стар. 1, 223. гости Ст. пис. 1, 47. људи Ст. пис. 1, 185. Стар. 3, 251. 248. 281. А. Рањ. 86. 119б. Хект. 30б. Вран. жпв. 61. 93. Див. 33б. 38б. Орб. 281. Крн. 2б. Каш. 22. 26. Пос. 32. нокти Ст. нис. 3, 131. 456. 4, 49. 482. Крн. 22б. Мрн. 70. Пос. 19б. нохти Ст. пис. 4, 112. Вран.

' Кашић грам. 38 вели: vojvodami vel vojvodama. 
жпв. 111. Мрц. 50. пути Н. Рањ. 48. Стар. 1, 229. Банд. 40. Мрн. 72. Г'хав. 23. црви Ст. пнс. 1,320. - Изједњачују се с вима и даље узимајуһи као и оге к томе иромијењеном облику још једшом наставаг ми: гвоздими Стар. 1,222 . и по том крајње и одбацујући, и то од XVI вијега: људим Ст. пис. $5,156 . \mathrm{H}$. Рањ. 40. Град. дјев. 118. дух. 21. путим Град. дјев. 112. Бун. 13. Андр. пут 353. црвим Андр. пут 291. к таком се обдику још додаје $a$ XVI п XVII вијека: људима А. Рањ. 13. Орб. 118. ноктима А. Рањ. 77.' па се и пред м може и избацити: људма Радн. 14. 30. 36. 46.

б) у женских : до краја XV вијека : бкирьшьми М. 11. птсиьми

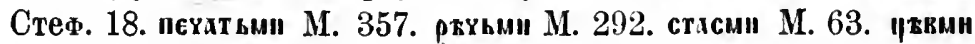
M. 498. хастьми М. 221. иа крају XV и свега XVI впјека: бодестми Збор. 51б. зановидми Буд. 60. звнермп Збор. 10. Ст. пис. 4, 180. грељутми Ст. иис. 1, 17. грипостми Ст. иис. $1,165$. Буд. 54. милостми Н. Рањ. 51. 1уч. 134. мнсалми Ст. пис. 3, 316. печатми Стар. 3, 267. помоһми Буд. 24. прсми Ст. пис. 3, 307. 4, 320. ричми Ст. пис. 1, 43. Д. Рањ. 90. Хект. 18. ријечми Н. Рањ. 155. Збор. 34. Ст. пис. 4, 417. 481. 5, 307. Злат. 456. Гуч. 81. свиралми 3бор.102б. свјетлостми Н. Рањ. 111б. сласми Збор. 155б. стварми Ст. нис. 1, 321. Збор. 119. Злат. 3. ћудми Брн. 61. и XVII иијека:крепостмп Див. 6. кришостми Гдав. 41. напастми Банд. 218. паметми Банд. 110. ријетми Див. 29. Мат. 90. ричми Банд. б0. Каш. 7. свит.лостми Банд. 32. трстми Јерк. 56.

Али једнаке будући у том падежу с мушюима у којих је основа на $\mathbf{i}$ мпјењају с шима и тај облик: најприје према мушкима у којшх је оспова на а: тако се јавља на крају XV и свега XVI вијека: ${ }^{2}$ заповиди Брн. 44. кости Стар. 3, 236. крипости Стар. 1, 235. Хект. 38б. Брн. 15. І'уч. 300. 306. мндости Гуч. 78. напісти Ст. пис. 5, 75. пјесни 3бор. 79б. Ст. пис. 4, 448. Злат. 83. Гуч. 241. пиесми Збор. 102. ричи Зоран. 16. 27. 28. 32. 47. ствари Н. Рањ. 218. Хект. 25. 3ор. 66. части д. Рањ. IVб. Зор. 1б. Злат. 10. чељусти Злат. 68б. тако и

' Капић грам. 27 вели : golubimi vel golubima vel golubi.

2 IIIто има XIV впјека: пехатн M. 107. 229. и по том XVI впјева печати Н. Рањ. 199. може бити да је ријеч већ у мушком роду, као што и има веһ XIV впјека: пхиниь печатом M. 176. тако Һе бити у стасн у мом рјечпाку код ријечи стась. 
XVII впјека: болести Јерк. 58. изврсности Каш. 31. крипости Вран. жив. 112. Кан. 119. милости Кан. 27. Пос. 25. мисли Вран. жив. 81. Пос. 40б. напасти Орб. 81. Капг. 98. пемоһи Орб. 125. области Банд. 79. писми Врап. жив. 71. ногибнли Радн. 46. помоһи Орб. 126. шсости Вран. жив. 42. радости Каш. 79. ријечи Див. 29. ричи Вран. жив. 11. 13. 37. 42.61. Каш. 28. 49. сатвари Вран. жпв. 113. ствари Див. 6. 22б. Орб. 46. Мат. 72. КаІІr. 32. 76. 109. ІІос. 5. 29. - Таком се облику опет додаје наставак ми: тако још XV вијека: частии М. 317. користим М. 494. прсими Ст. пис. 1, 172. XVII вијека: криностими Каш. 117. мастими Каш. 111. писними Каш. 79. - По том без крајњега $u$ XVI вијека: жалостим Град. дјев. 75. крепостим Град. дјев. 55. 68. 95. мндостим Град. дјев. 159. мислим Д. Рањ. 89. Град. дјев. 47. 88. 89. 98. моћим Град. дух. 17. ирсим Ст. пис. 4, 320. раздикостим Град. дјев. 55. ријечим Ст. пис. 4, 483. Град. дух. 47. дјев. 8. 21. 61. стварим Д. Рањ. 24б. XVII вијека: болестим Андр. пут 408. дев. 6. химбеностим Андр. пут 373. радостим 96. 373. ричим Пос. 36. с.лабостим Андр. нач. 21. стварим Андр. дев. 59. хридим Бун. 16. - С доданим $а$ на крају XV и XVI вијека: костима $A$. Рањ. 7б. мислима Д. Рањ. 125б. остима Ст. пис. 4, 19. 20. пјеснима Д. Рањ. 118. 127. ричима Ст. нис. 1, 8. Д. Рањ. $7 б$. 56. ријечима Ст. пис. 5, 8. 19. А. Рањ. 37б. Злат. 34б. стварима Д. Рањ. ІХб. частима Злат. 10б. XVII вијека: бодестима Орб. 66. Андр. дев. 40. Радн. 75. врстпма Орб. 182. испразностима Радн. 73. крепостина Андр. пут 70. дажима Радн. 24. 40. милостима Орб. 204. Андр. дев. 14. пут 77. мислима Андр. дев. 86. напастима 52. немоћима Орб. 7. помоћима Андр. нач. 60. прсима Радн. 13. 61. радостима Андр. пут 83. ричима Вран. жив. 34. 75. 113. 114. ријечима Орб. 84. Мик. 161. 385. 442. Андр. пут 53. сатварима Вран. жив. 33. слабостима Андр. 435. химбеностима Андр. 268. частима Мик. 275. - По што је додано на крају $a$, долази п без $и$ пред м XVII впјека: болестма Радн. 71. 73. жалостма Радн. 71. заповиједма Радн. 49. испразностага Радн. 10. јаностма Радн. 53. крипостма Радн. 71. рпјечма Гунд. пс. 20. Мат. 49. 58. 59. Радн. 5. 21. 39. рнчма Банд. 51. стварма Радп. 22. 30. 32. 
Налазе се од конца XV вијека оваке ријечи изједначене у овом падежу п са женскима у којих је основа на а, и то не само оне које су пијеле прелазиле онамо као: тусдами Зоран. 22. писнами Банд. 82. пего п друге: прсами Ст. пис. 1, 14. пестами Мпк. 17. рнчами Мрн. 91. 136.' и са $a$ мјесто крајњега $u$ као и у ријечи међу које су прешле: XVI вијека: ричама Стар. 1, 222. Буд. 17. 24. 25. 30. 58. 67. 84. стварама Буд. 116. 129. тварама Буд. 4. і XVII вијека: ричама Мрн. 12. 133. 138.

IIIто па једном мјесту има: niedniema krjepostiu Гуч. 5. 6иhе гријешком и мјесто $\mathrm{n}$ а то мјесто $\mathrm{m}$.

IV. С основом на сугласно. Од таких основа нема овога падежа ни у староме словенском језику, него ријечи с таком основом предазе међу друге:

А. Мунке ријечи предазе међу мунке с основом на $\mathbf{i}$, те имају овај падеж као оне: камєнь-иі у старом словенском језику, а у српском како су ријечп мушке с основом на i прешле међу мушке с основом на а, прешле су с њима и ове: тако XV вијека: сь четнри пхмєп! Пб. 56. М. 386. XVI вијека: гамени Ст. пис. 3, 75. Хект. 25б. пламени Злат. 206. 86б. и у њих се таком облику па пово додавао наставак ми: XVII внјека: пламеними Каш. 79. тада се крајње $u$ одбацивало и додавало а: каменима І'унд. ис. 42 . тако предазећи онамо и одбацивале су у основи крајње сугдасно и пред жим самог.дасно: плами Ст. пис. 2,505. Гунд. суз. III, XXX. и тада вм се на ново додавао наставак ми, $0,\{$ кога се крајње $u$ одбацивало: пламим Град. дух. 82. прамим Бун. 26. а тада се додавало $a$ : прамима Бун. 27. како су ријечи с основом на а прелазиле у овом пад. међу ријечи с основом $\mathbf{i}$, тағо ријеч јелен, којој се основа свршује на сугласно, алп која је и у воминат. јед. још у старом словенском језику прелазила међу ријечи с осшовом i, прешавши одапде меһу мушке с осповом на a, има.да је у овом падежу као мпое пзмеђ њих опет према ријечима с основом на i XVII впјека: јелинми Банд. 215.

Б. Ријечи средњега рода прелазе међу средње с основом на а; по томе је било п $у$ нас кроза све вријеме: бри-

' Кашиһ грам. 4] вели: sladostami vel sladostima vel sladosti. 
мени Радн. 49. вримени Мрн. 139. нмени М. 192. 219. дыссы Стар. 4, 131. пекеси Стеф. 1. Ст. пис. 2, 463. 3, 354. 363. 375. 415. 5, 298. Гуч. 11. Чубр. 14. Орб. 227. смокеси Сав. 4. М. 128. телеси С'r. пис. 3, 105. 268. 354. 377. Орб. 118. тнлеси Мрн. 48. чвқссн М. 133. Ст. пис. 2, 111. Гуч. 291. Вран. жив. 6. Пос. 5б. - Kaко су средње ријечи с основом на а предазпле у овом пад. међу ријечи с основом на $\mathbf{i}$, с њпма су прелазиле и ове, те је бпло XVI п XVII вијека: телесмп 3бор. 55б. чудесми Каш. 32. 117. - И у тијех се ријечи иравоме инструмента.лу мн., који су имале према основама на а, додавао још једном наставак мн, од гога је отпадало крајње самогласно: XVI п XVII вијека: чудесим Град. дјев. 148. Андр. нач. 39. пут 173. именим Андр. пут 415. а таком се облику додавало а XVII вијека: именима Мик. грам. 4. колесима Мрн. 63. телесима Орб. 249.' - Неке прелазећи међу ријечи с осповом на а могле су и одбацити у основи крајње сугдасно и пред њим самогласно: тако од краја XV вијека : коли Н. Рањ. 60б. Гуч. 238. Злат. 17б. Врап. жњв. 13. неби Ст. пис. 5, 300. (испореди стр. 43-44). слови Ст. ппс. 2, 92. Хект. 18. Вран. жшв. 18. Дпв. ХІб. Каш. 7. тнли Ст. иис. 1, 117. - Тапом се облику наново додавао наставак ми, од кога је трајње $u$ отпадало: колим Град. дјев. 183. Мик. 789. словим 'ам. 15. Андр. нач. 38. чудим Андр. пут 182. тада му се додава.ло $a$ : словнта Ђан. 1. 3. Мик. предгов. Како су ријечи с осповом на а пмале овај пад. п према ријечима с основом на $\boldsymbol{i}$, тако су с пима имале и ове с основом овако окрњеном: словмн Н. Рањ. 105. Банд. 170. - Како су средње ријечи с основом иа а пмаде тад кад овај падеж према женским рпјечима с основом на а, тако се налази и у овијех: колами Ст. пnс. 1, 23.

B. Женнске су једне предазпле међу рнјечи с основом i, а како су ријечи с основом на $\mathbf{i}$ промгјенпле тај падежі према мушкима с основом на а, тако је бнло пा у овијех: ьрви Ст. пис. 5 , 152. а с њима су и на ново узеле наставаг ми, од кога је крајже $и$ отпадало па се додавало $а$ : XVII вијека: кћерима Андр. пут 45. и избацивши $u$ : кћерма Радн. 81. - Аруге су ријечи а с шима и та прешле међу женске ријечи

1 Капић грам. 33 вели: vrimeni vel vrimenima. 
с основом на а: матерами Див. 38б. прьквхмн Зак. 31. Ст. пис. 4, 437. Гуч. 35. и одбацивши крајње $и$ : кћерам Град. дјев. 74 .

\section{ЛОКАТИВ МНОЖИНЕ.}

Наставак је su, од кога се у словенским језицима $\mathbf{s}$ мијења на $\boldsymbol{x}$, а и с.лаби у т, те постаје хъ.

I. Основе на и. Крајње и у основи слабп у словенским језицима у т: тако је у старом словенском сынъ-хъ; али су се још у старом словенском језику ријечи с таком основом помијешале с онима у којих је основа на а, те имају у том падежу и као оне, а у српском и немају другачије него као рнјечи с основом па а. Внди под II. А. 1. 2.

II. Основе пг a:

А. у жушкпх је пा у средњих ријечи било двојако:

1. У основа на чисто а крајње је кратко а гласи.ло У словенским језицима $о$ као и у дативу мн., те је наставак хқ приступао к тому гласу: тако је било п $у$ нашем језику: мушких рпјечи: трьгохь М. 52. инюкохь М. 332.568 . свечениониокохь М. 332. 543. Стар. 4, 233. окхакбхь М. 332. одрохь Стар. 4, 76. у средњих: сккохь Зак. 30. тако у средњих још на крају XV и XVI вијека: вратох Ст. пис. 1. 28. 35. 50. 3ор. 68. и XVII вијека: устох Див. 13. т.лох Јерк. 63. - Тако су имале и рпјечп с основом на и помнјешавши се с овима: домохь Сав. стар. 4, 231. М. 65. - Како се внди, то је бнло веома ријетко, нити се могло одржкати уз друти начнн:

2. Основа на чпсто а и на ја добива до крајњега краткога а гдас i, па се та два гласа у словенским језицима слијевају у в (које је у сриском језику гдасило како је поменуто под докатпва јед.), пред којим се гдасови $2, x, x$ мијевају ! з, и, $c$, п које у основа на ја предњега гласа ради прелази $у$ :

a) с осповом на чисто а : до краја XV вијека ! мушких ријечи: ктақzвхь М. 217. кельzїєк М. 532. brevelezih М. 279. кнпоградихи П. 24. конииџтхь М. 15. крьсвхь П. 149. граднхи М. 328. градехь М. 418. дкорнхь М. 220. дхьзахь П. 118. Пб. 48. доктхк Пб. 20. дукатиехь М. 403. законехи М. 38. 288. ПI. 12. 23. 26.62. 95. законћхь М. 187. 188. законнхь М. 221. 236. закомехь П. 5. 
zаконнехь М. 489. законнехь Пб. 120. запнсехь М. 307. 314.422. II. 161. запнснехь М. 307. 382.389 .412 . zаписнекь М. 460. zаписнхь М. 393. хистнхь М. 242. хистехи Шб. 41. хистххь М. 300. шистихь М. 305. пистиехь М. 413. ммниехь М. 38. пародехь ПІ. 140.

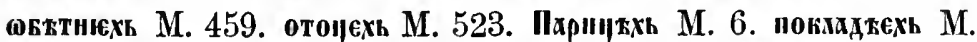
404. покадаехь М. 404. поскахқ М. 54. поскиехь М. 323. поскехь М. 295. понснеки М. 425. свдехь М. 372. тетраzиехь Пб. 93. трь3\$хь ПI. 160. вкћтехь М. 188. ПI. 110. вкктихь М. 221. взмвхь М.

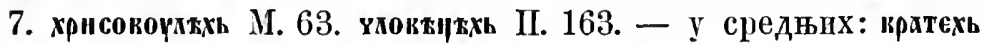

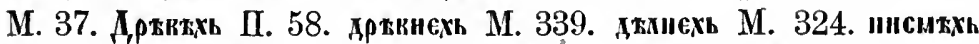
М. 217. секъхь М. 37. М. 32. секнхи М. 249. оүстбхи М. 9. чеднхь М. 260. чєлиек М. 342. 371. чєдехь М. 534. - На крају XV и свега XVI впјека: у мушких: апостолијех ${ }^{1}$ Град. дјев. 69. биљезијех Д. Рањ. 59б. Злат. 37. Бнецијех Ст. пис. 5, 322. Злат. І. боцих Ст. пщс. 1, 152. глибијех Ст. пнс. 3, 468. грнјесијех Н. Рањ. 75б. Ст. пис. 3, 431. 4, 358. 5, 35. 114. Гуч. 11. даршекь Збор. 166б. Гуч. 134. дарих Град. дух. 15. дворпјех Ст. пис. 4, 7. законијех Н. Рањ. 198б. зборијех Град. дјев. 126. зборпх Злат. 22б. зглобијех Ст. пис. 4, 17. зламених Н. Рањ 144. зубијех Ст. пис. 3, 94. језицијех $А$. Рањ. VII. лијецијех $А$. Рањ. 8 б. дистпјех Д. Рањ. 162б. І'уч. 74. лузих Ст. пис. 2, 434. Злат. 37. лузијех Ст. иис. 4, 285. мпрнјех Град. дјев. 166. народпх Н. Рањ. 162б. науцих Буд. 89. облацијех Збор. 35. Ст. пис. 3, 78. оборијех Ст. пис. 4, 291. оковијех Ст. пис. 3,100 . послих 3ор. 27. пос.лијех Град. дјев. 51. постијех Град. дјев. 182. празијех (ираг) Н. Рањ. 194. пророцијех Н. Рањ. 20. проропих Град. дух. 79. роднх Н. Рањ. 143б. сних Брн. 69. снопијех Ст. пнс. 3 , 445. станијех Ст. нис. 3 , 11 . тестаментих Буд. 80. трудијех Град. дјев. 182. уздасијех Град. дух. 14. чавлијех Ст. пис. 5,140 . тако и у ријечи с основом на и: домпх Стар. 3, 236. - у средњнх: брдијех Ст. пис. 4, 262. вратих Ст. пис. 1, 40. Злат 30б. вратијех Збор. 1. Ст. пис. 4, 201. 5, 133. Град. дјев. 48. Злат. 26. дјелијех Н. Рањ. 21б. Ст. пис. 5, 12. Град. дјев. 69. Злат. 52б. Гуч. 164. дјелих Град. дух. 58. делих Буд. 59. дилих Брн. 19б. добријех Гуч. 125.

' И XVI се впјека пише ије највише тако да се може читати i camo je. 
ко.ьенијех Н. Рањ. 93. Збор. 9. Град. дјев. 157. Г'уч. 96. дибрвјех Град. дјев. 8. мистих Буд. 137. њедријех Ст. пис. 4, 283. Злат. 47б. писмијех Н. Рањ. 20. Збор. 68. Ст. пис. 5, 121. Гуч. 262. ребријех С'т. нис. 4, 168. стадијех Ст. пис. 3, 9. 5, 215. устијех Н. Рањ. 16б. Град. дјев. 30. Злат. 47б. Гуч. 216. устих Н. Рањ. 101. Ст. пис. 4, 422. челих Н. Рањ. 24. челијех Град. дјев. 169. - XVII вијека: у мушках: гријесијех lунд. пс. 18. зглобих Ка пा. 46. народпх Банд. 2. пителих Һанд. 249. послијех Мик. 826. послих Канг. ІІІб. прозоријех Мик. 764. пророцшх Банд. 18. Кашг. 5. са.ипјех Орб. 56. са.1мпх Банд. 23. трудих Банд. 25. уздасијех І'унд. пе.' 23. чданих Мик. 44. ч.данцијех Мик. грам. 3. - у средњих: вратих Гунд. суз. I, LXIV. дјелијех Орб. 7. 234. дјелих Гунд. шс. 42. дилих Банд. 11. мјестпјех 0рб. 161. Мат. 14. мистих Банд. 37. Каш. 51. отајствнх Ванд. 8. селијех Мик. 591. селих Мик. 461. устпјех Мик. 250. челих Банд. 14.

Једном без промјене гутурала XVII впјека: грихих Гдав. 14. Види о гом код номинатива мн. и инструментала мн.

б) с основом на ја: до краја XV вијека у мушких ријечи: коннхи М. 191. Нстнинкихь М. 96. трьговинхь М. 174. џарнхь М. 171. 205. 266. - у средњих: Граднщнхь М. 494. - На крају XV и XVI вијека: у мушких: крајих д. Рањ. ІХб. коњвх Ст. пис. 1, 11. вепих З.1ат. 37б. пастирнх Зор. 10. у средњих: дупьих Ст. пис. 4, 280. по.љих Ст. пис. 2. 159. 361. Зор. 36б. здамењих Буд. 54. ошнцијих Буд. 121. ппсањих Буд. 54. плеһпx 3ор. 70. посветилиштых Н. Рањ. 17. срцих Н. Рањ. 163б. срдачцих Зор. предгов. - XVII вијека: у мушких: коњих Мрн. 45. крижих Кан. 71. меяпих Банд. 14. удорцих Банд. 25. - у средњих : мидосрдјих Банд. 42. весељих Кап. 119. по.ьих Банд. 221. Каш 40. здаменјих Банд. 158. мученјих Каш. 51. тутованјн К:нI. 104. 119. лицих Кап 51. срдцих Банд. 25. срцих Каш. 29. посветилиштпх Банд. 5. ирибивалиптих Банд. 177. грговнітет Банд. 44.

У адјектива је бшло као у супстантива за мушки н средши род: крхюкћхь М. 147. али од XIV инјека додази ирономинални облик једнак с овијем замјењујуһи сложени, те he ce споменупи међу сложенпјем облицима.

Из других падежа, у које је од ријечи с основом на и прешло њихово ов и $к$ ријечима с основом на а, прешло ия 
је и у овај падеж, и то мушкима с основом на чисто а, али истом од XIV вијека: тако имамо до граја XV вијека: гх-

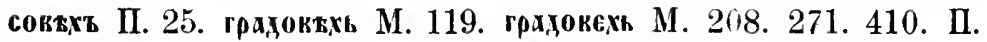
81. 96. дискокнхи Пб. 91. хистокехи М. 285. свдокнеки М. 372.403. 425. судокекь М. 407. 411. ІІб. 99. трьговекь М. 271. 435 . трьговъхь М. 271. на крају XV и свега XVI вијека: валовијех Ст. пис. 3, 288. врановијех І'рад. дјев. 146. градовијех Н. Рањ. 41. Збор. 53б. Д. Рањ. VII. тробовијех Н. Рањ. 226. дуговијех 3бор 43б. ностовијех Іууч. 164. XVII вијека: гробовијех Орб. 124. градовијех Орб. 20. даровијех Орб. 24. даровнх Банд. 5. - Од ријечи с основом на а пренло је опет ово ов у овом иадежу и к ријечима с основом на и: тако XVI вијека: домовијех Н. Рањ. 14. синовијех Г'уч. 145.

Рнјечи с основом на ја предазе међу оне с основом на чисто а, али између многих примјера ма.10 је поузданијех: поуздани су XV вијека: динхиехь М. 403. покнсхриехь М. 323. 403. 508. 509. бкотџћєх М. 425. неноуздани су у којшх је на крају вхь, јер може бити да је само написано мјесто и: тако пма још XIV вијека: қинхти П. 20. XV вијека: покмсхртхь ІІб. 85. М. 429. 491. 506. неноуздани су такођер у којих је на крају єхь, јер с може бити не само по источном говору мјесто в и по јужном само наппсано мјесто $j e$, него може бити и право с према ријечима које ће се сиоменути ниже: тако има XV вијека:

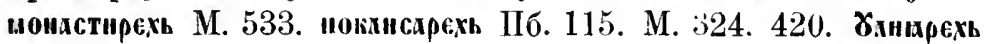
М. 228. Пакмокиєхь ІІб. 82. трьгокиехи М. 363. 411. пенєзехи Пб. 113. порхиекь I. 96. XVI вијека са свијем су поуздани празониса ради примјери јужнога говора: перивојнјех Гуч. 21. научитељијех Град. дјев. 161. коњијех Збор. 76. глезњијех Ст. пис. 3, 99. вијенцијех Ст. пис. 5, 174. мударцијех Збор. 8. пјешцијех Збор. 49. манастиријех Град. дјев. 126. 138. манастијеријех Г'уч. 35. тако и у средњих XVI вијека: полпјех 3бор. 43б. Ст. пис. 4, 467. прибивалинтпјех І'уч. 126. срцијех Збор. 117. Град. дјев. 109. XVII вијека: оћућенијех Орб. 187. тако би мондо бити XV вијека: скрокпрвьь М. 300. а.ди може бити да је в само нанисано мјесто и. Будући да у западном

' И у таким се примјерима ије пише тако да се може читати и само je. 
говору ₹ гласи $u$, за то сви примери наведени напрпјед за мушке и средње рпјечи с основом на $j a$ од краја XV до краја XVII вијска може бити да само за то онако гласе што су по западном говору, те могу припадатп овамо, а јамачно hе тако бити и XV вијека: покисарихь М. 397. 441. 503.

Како су пеке ријечи с основом на ја у другим падежима прелазиле међу опе с основом на $\mathbf{i}$, тако су прелазпле и у овом, те пмају као оне, п то од XIV вијека: копски $M$. 63. XV впјека мвжсхь Пб.93. а како су у другим падежима уз ријечн с основом на ја пристале и многе с основом на чисто а, јамачно су тако пристале и у овом падежу, и тако ће бити још XIV вијека у споменику у ком сс добро разлп-

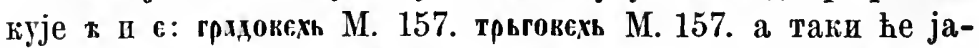
мачно бити п многи између примјера паведепих напријед, у којнма је є. мјесто т, као јоп XIII вијека имиехь М. 38. ади писма ради нијесу поуздани; али се поуздано показује ово прелалење XVI вијека у нњпrама које су писане латинским словима: тако има тога вијека у ријечи с основом на ја и на чисто а: варошех Буд. 151. версех Буд. 101. владаоцех Н. Рањ. 29. дарех Н. Рањ. 17. Град. дух. 36. законех Буд. 117. 137. затворех Буд. 142. кипех Буд. 149. казех (casus) Буд. 153. мјесецех Н. Ряњ. 107б. народех Н. Рањ. 13б. 20. $181 б$. натпиех Буд. 52. пјенезех А. Рањ. Уб. послех Буд. 124. постех Н. Рањ. 41. редех Буд. 85. снех Н. Рањ. 20б. 29. танцех Ст. пис. 2, 65. 515. трудех Н. Рањ. 41. узмех Буд. 19. шаптех Злат. 86б. из XVII впјека нађох само: постех Банд. 25. за мушкима су тако прелазиле и средње: XIV впјека: ормжнцехь ШаФ. pam. 1873. 101. XV вијека: знинштехь П. 82. скровицсхь М. 281. 337. 346. тако hе јамачно бити истога времена (ако бп се правописа радп и могло сумњатп): дымех II. 45. 46. 54. 151. 173. икстсхь II. 11. 12. 37. 37. 96. 146. поуздано је опет у књигама које су писане латинским словима XVI внјека: бенефнцјех Буд. 85. њедрех Злат. 50б. официјех Буд. 146. прибивалиптех Н. Рањ. 143б. срцех Н. Рањ. 23. 143.145. 150б. 165б. 166б. 190. устех Д. Рањ. 63. 82. 106. 122. числех Буд. 101. тако XVI и XVII вијека н тлех Cт. иис. 3, 24. 309. 313. 321. 338. 345. 4, 170. 476. 5, 131. 138. 146. Збор. 776. 826. 95б. Град. дјев. 132. Злат. 81. Банд. 166. Гунд. суз. II, XXXIV. 
III, LXXXV. Мрн. 80. Каш. 40. 94. Јерк. $45^{\prime}$ тако бн могло бити и пољех Н. Рањ. 192. Ст. пис. 2, 386. прибивањех Н. Рањ. 162б. чињенјех Д. Рањ. IVб. али се завршетак може читатн и ијех.

Ријечи које постају наставком ин и јанин одбацујућп у множини ин добивају основу на сугласно: тада се у овом падежу члас $\mu$ на крају основе изједначује с г.дасом $x$ од наставка II постаје $x$, па се једно од два $x$ избацује: тапо је било још XIV и XV вијека: Кнсоуахь Пб. 89. грагахь Пб. 93. Авчахь М. 96. Дечахь М. 567. Zиворахь М. 220. Комхрахь М. 97. Папракахь М. 96. Храцахь М. 568. тако по свој прилицп и Тврахь М. 249. - Али како су ријечи с основом на сугласно прелазнле у овом падежу међу оне с основом на $\mathbf{i}$, прелазнле су и ове, па су имале овај падеж и онако као рпјечи с основом на і (види под III); тако бп мог.ло бпти што се находи до краја XV вијека: арьванассхь М. 363. кхастекехь М. 306.487. 516. 535. Горуанехь М. 415. грагіамехь ПI. 163. дукрокуанехь М. 31. врхнихиехь М. 21. погансхь II. 140. стрхиниехь II. 140. хрьватехь II. 96. али ти ирихјерп нијесу поуздани, јер у њима може бити да с стоји мјесто а те пду меһу примјере који ће се одмах споменути; поуздано је: срькмжь М. 140. 354. 435. II. 153. срькєхь М. 363. јер кад би бнло с основом на а. било бп " мјесто є ради предњега гласа; а како су у сриском језику ријечи с основом на i прешле у овом падежу међу оне с основом на a, c вима су онамо препле и ове: по томе пмамо од XIII впјегіа: вахстельхи М. 15. 157. камстемнхь М. 441. 447. вмастекнехь

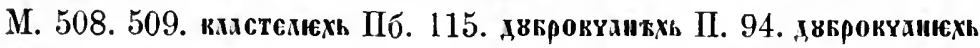

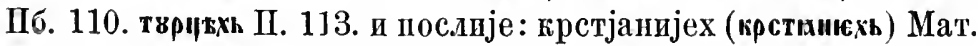
6. тако п према основама на ја: срькихь М. J18. 206. 209. 268. и послије: јудијих Банд. 25. таки могу битп п они мало час споменути прнмјери са -єхь, за које рекох да су непоуздани.

Од почетка XVII внјека кад је $x$ већ бндо ос.лабило додази и дока' мн. без вега: у мушких : гриесие Пос. 35. дворовије Радн. 63. Млетцие Див. ХІб. - у средњих: на врати Мик. 790. диелие Див. 8б. 34б. добрие Див. 26б. достојан-

' ІІошљедњи писац има једном локатив јед. тлеху Јерк. 63. као да би ном. био тлех. 
ствпје Радн. 44. дунљије Радн. 64. ледп Радн. 51. поштени, непоптењи Радн. 29. сүцие Див. 38. устије Пос. 6. Радн. 43.

Средње су ријечи прелазиле кад кад у овом падежу sеbу женске с основом на а (нспореди дат. и инстр. мн.): тако још XIII вијека у ријечи која је пзмеђу ријечи $с$ основом на суг.ласпо препла овамо: теках М. 37. XIV впјека сьзда-

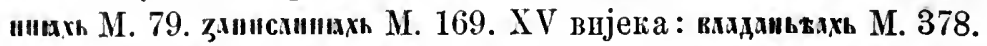

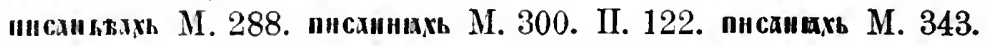
иристхищихи II. 149. сомихахь М. 529. XVI вијека: срцах Стар. 1, 225. водогритах Іууч. 62. XVII вијека: брдах Мик. 114. водогрнттах Џанд. 20. ледиах див. 25б. 36. приствпхихи Мат. 30. оңнадамицахь Мат. 16.

Кад су ријечи с основом на а п на ја имале генитив мн. према рпјечима с основом на $\mathbf{i}$, па им се од тога надежа раздиковао локатив мн. само крајњим $x$ у западном говору, те им је локатив додазно мјесто генитива (внди ген. мн. напријед стр. 74. 75). тада им је и таки генитв додазио мјесто докатпва, и то у писаца за које се не може реһп да су пзостављали $x$ не говорећи га: тако у мушви ријечи XVI вијека: листи Буд. 124. но ових начнни Буд. 158. чини Буд. 121. 146. члани Буд. 52. русази Стар. 1. 218. по оннх чавли Стар. 4, 113. XVII вијека: вали Вран. жпв. 22. гради Вран. жшв. 77. греби Вран. жив. 17. у својшх двори Вран. жив. 7. 11. по својих светпх евангелисти Вран. жив. 16. жи.љ Вран. жив. 19. у осталих науци Вран. жив. 8. но његових честих уздисаји Вран. жив. 34. тако гробн Банд. 269. премда тај писац није са свијем ноуздан у писању слова $x 0^{1}-$ у средњих: XVI вијека: у свих својих деанји Буд. 93. у деанји црквених Буд. 123. у светих дилованји Буд. 159. у тацих дели Буд. 90. у оних дугованји Буд. 125. у исноведанји велицих Буд. 46. у тих светих мисти Буд. 57. п њихових мисти Буд. 78. у обранји Буд. 144. у велицих иригришенји Буд. 48. у очитих проклетстви Буд. 49. селп Буд. 151. у срци њихових Буд. 35. на ноли Стар. 3, 307. у светих дили Брн. 15б. у добрнх дили Брп. 18б. 24б. у худих днли Брн. 71. XVII впјека: по обћенитпх мисти Вран. жив. 114. у усти Вран. жив. 32. по

1 Кашић грам 28 вели: vitrih vel vitri. 
твојих усти Вран. жив. 21. у свих дн.ди Крн. 9б. - уз оваки генитив на $u$ налазп се п прави мјесто локатива XVII вијека у мушких: у ових валов Јерк. 82. (види и код женских ријечи с основом на а). - Што XVI вијека има у слику: у јадови Ст. пис. 2,417 . на врати Ст. пис. $4,191.207$. по сели Ст. пис. 4, 292. ту је јамачно само слика ради изостављено правом докатнву $x .^{\prime}$

Налази се докат. мјесто инструментала, али врло ри-

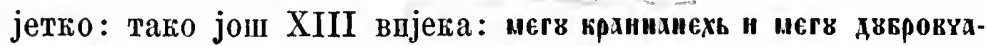
пехь М. 31. XV впјека: над г.лезњпјех Ст. пис. 3, 99. за својих родитељих Брн. 9.

Како је од давна додазпо кад кад докат. мјесто инструментада, како се лоқат. замијењени генитивом на $и$ изједначивао с инструменталом, како се п изгубивпи крајње $x$ изједначнвао у западном говору с пнструменталом, и како је у једнини бно изједнатен с дативом, с тога се XVII впјека изједначи с инструменталом, какав је тада био, и у томе пшто му се дода његово $и$ а тијем се пзједначи и с дативом мн., какав је тада у велике био: у мушки : градовнм Ђам. $2 б$. гријесим Андр. дев. 88. 130. пут 22. 223. 318. дарим Андр. дев. 13. 15. 37. нач. 45. пут 72. 282. јадшм Андр. пут 271. законим 208. казим Ђам. 25. мирнсим Андр. пут 350. науцим Ђам. 66. облацим Андр. нач. 10. разговорим Андр. дев. 129. пут 307. сакраментим Андр. пут 96. 359. судпм 229. трудшм 373. часим 102. - у средыих : вратпм Андр. нач. 55. дјелим Андр. пут 55. 105. дев. 159. добрим Андр. дев. 60.176. мјестим Ђам. 2б. Андр. нач. 3. надахнутим Андр. дев. 45. нас.лађеним Андр. пут 232. прогоњеним 198. у овијем размшшљаним Андр. дев. 129. Кад облик тако добн на крају $м$, још му се дода на крају $a$ као у дат. и инстр.: у мушких : вјетрима Андр. пут 165. напредцима 96. перивојима Радн. 2. посдима Андр. дев. III. пословима Радн. II. 2. разговорима Андр. пут 344. у средњих: дјелима Андр. пут 96. 107. 143. добрима 257. дибрпма Ђам. 4б. морима Андр. пут 293. насдађењима Радн. 2. отајствима Андр. пут 387. но.биа Радн. 2. поштењшма Радн. 6. смилованјима

1 У примјеру: при ловди и хрти Ст. пис. 4, 350. биће ари пюгрјешка мјесто шрид. 
Андр. пут 61. устпма 74. 292. - По што се тако додало $a$, долазп п без $u$ пред $м$ : Һућењма.

У средњпх и кад им је тај облик према женскима с основом на а (види напријед стр. 136) налази се као п у женских у овом падежу на исти начин додан на крају наставак од инструмештала мн. цио: у богатствами Радн. 6 и окрњен ади с доданим $a: \mathrm{y}$ добрама земаљским Радн. 1.

Б. У женских: у основи је на крају а дуго, те у словенским језицима бива кратко; до њега долази наставак: до праја XV впјека: гюхнихь II. 96. Конхвххх М. 229. 298. 301. 370. р8кахь М. 369. рнкахь II. 20. смободахь М. 410. слвғахь ПГб. 110. скоконихи М. 411. - На крају XV в свега XVI вијека: бесједах Гуч. 107. водах Н. Рањ. 88. Ст. пис. 5, 47. дубравах Ст. пис. 3, 245. дунљах Ст. пис. 3, 100. rорах Н. Рањ. 42. 3лат. 13б. же.бах Ст. пис. 2, 17. женах Град. дјев. 93. Злат. 29. жнлах Ст. пис. 3, 358. забавах З.лат. 37б. звијездах Н. Рањ. 13. Злат. 92б згодах Злат. 21. здобах Ст. пнс. 3, 440. Гуч. 107. зраках Град. дух. 69. играх Злат. 2б. књигах Ст. пнс. 5, 312. Буд. 124. Гуч. 18. Конавлах Ст. пис. 5, 332. косах 3бор. 6. пуках Ст. пис. 3, 445. кућах Град. дјев. 87. Злат. 37. модитвах Град. дјев. 7. Гуч. 12. мрвах С'т. пис. 3 , 391. муках Ст. пис. 3, 80. 5, 150. Злат. 42б. Гуч. 95. невољах Н. Рањ. 41. Град. дјев. 181. Гуч. 125. његах Д. Рањ. 129. Гуч. 146. палицах Ст. пис. 5, 231. потребах Град. дух. 53. Іууч. 4. правдах Н. Рањ. 39. приварах Злат. 35. прнликах Ірад. дух. 74. Гүч. 143. ранах Н. Рањ. 34б. Град. дјев. 182. раскошах Ст. пис. 1, 112. руках Н. Рањ. 41б. Ст. пис. 2, 265. Град. дјев. 127. Хект. 25б. 3ор. 38. Злат. 2б. русаљах Гуч. 69. сањах 3ор. 16. Буд. 54. свадах Н. Рағ. 39. сестрах Град. дјев. 152. слугах Град. дјев. 165. стијенах Ст. пис. 3, 15. 4, 264. странах Ст. шис. 2, 59. Д. Рањ. IV. Злат. 5б. стрнјелах Н. Рањ. 209. сузах Ст. пис. 3, 76. І'рад. дух. 4. Злат. 5. сушротивах I'рад. дух. 44. таштинах Град. дух. 17. тминах д. Рањ. 7. трјесках Ст. пис. 4, 444. тугах Ст. пис. 5, 11. Д. Рањ. 45 б. Град. дјев. 182. Злат. 4б. Гуч. 125. тужбах Ст. шис. 3, 445. уднцах Н. Рањ. 41. Чубр. 11. узах Ст. пис. 1, 21. хаљпнах Град. дјев. 142. хвалах Гуч. 133. - XVII вијека: вечерах Банд. 44. годинах Мик. 768. ropax Каш. 40. долинах Орб. 55. 
душах Орб. 172. женах Мик. 223. звиздах Банд. 1. земљах Мик. 132. књигах Див. 6. Банд. 8. Јерк. 9. Мик. 191. молитвах Вран. жнв. 4. Орб. 134. Каш. 2. жуках Див. 30. Орб. 132. Банд. 45. невољах Гунд. суз. III, XI. ногах Мик. 287. планинах Мик. 114. погибијах Каш. 114. постељах Банд. 1. руках Орб. 85. Гунд. суз. I, XXXI. Мик. 728. светковинах Банд. МІ. скупштинах Банд. 13. сликах Каш. 5. стопах Мик. 80. странах Орб. 116. сузах Гунд. суз. I, I. Бун. 21. таштинах Орб. 45. тугах Банд. 25. узах Банд. 2. устнах Банд. 228. хвалах Гунд. cyз. III, XXXV.

XVII вијека кад је $x$ бнло ослабило долази овај падеж и без жега : вода Радн. 61. књига Пос. 4. Радн. 22. кућа Радн. 65. невола Радн. 27. нечистоћа Пос. 5. срамота Радн. 4. туга Радн. 3. 26.

Налази се једном мјесто овога падежа датив још XVI вијека: у протившћинам Брн. 15. Али по што је $x$ ослабнло и отпало, а у другпх се ријечп овај падеж изједначио с инструменталом, пзједначи се п у овпјех узевши онаки какав бјеше без $x$ наставак од инструмента.да ције.ли ми или огрњенп као што п $y$ њега бјеше $м$, и то узе мах у другој половини XVII вијека: водам Андр. нач. 9. пут. 293. гнусобам Андр. пут. 403. гозбам Андр. иут 232. дубинам Андр. пут 272. душам Андр. дев. V. забавам Андр. пут 344. згодам Андр. пут 58. молбам Андр. пут 156. молитвам Андр. дев. VI. мукам Андр. пут 13. невожам Андр. пут 101. ногам Андр. дев. 65. одлукам Андр. пут 96. нотребам дев. 75. приликам Андр. пут. 375. пучинам Андр. пут 272. ранам Андр. пут 198. раскошам Андр. дев. 25. рукам Андр. пут 39. сдавам Андр. пут 344. сликам Андр. пут 383. слугам Андр. пут 10. сумњам Андр. пут 153. супротивам Андр. дев. 98. таштинам Андр. дев. 17. тминам Андр. пут 75. тугам Андр. дев. 5. урам Андр. дев. 101. хитринам Андр. пут 41. цревљам Андр. пут 299. - много рјеђе с цијелијем ми: на твојијем руками Андр. пут 154. по разлнцием странами Андр. пут 346. у хвалами Андр. пут 344. у п.леменштинами Радн. 2. у хаљинами Радн. 72.

У овом су падежу прелазпле неке рнјечи међу оне с основом i, алп врло ријетко: зсикехь М. 37. 253. и XVI вијека: тмех Н. Рањ. 22б. 209. тако једном у слику п јамачно само слика раді: 
пјесанцех Ст. пис. 2, 65. - прелазиле су и међу мупке с основом на а такођер у слику: цистих Ст. пис. 1, 57.

Мјесто овога падежа долази генитив мн., ади вр.о рпјетко, јамачно уз рнјечи мушке и средње које су у генит. мн. пмале на крају $u$, те им је тагі генит. мн. долазпо и мјесто локатива (види шапријед стр. 136): XVI вијека: у књиг Ст. пис. 5, 9. по разликих држав Зор. $57 б$.

Да је овај падеж додазио кад кад мјесто генитива мн., споменуто је код генитив мн.

У адјектива је било као у супстантива: господипахь $\mathbf{M}$. 9. господынахь Стеф. 9. озихиеихи М. 140. али не сеже прего XIV вијека, него се замјењује сложенијем обликом, који се опет замјењује прономиалнијем, како hе се поменути међу прономиналним облицима.

III. Основе на i. Крајње гратко і у основи гласи у словенским језицима $e,{ }^{\prime}$ ка којему прнступа наставак хқ у мушких и у женских ријечи:

a) у мушких: до краја XV вијека: „қиекь II. 32. 45. мюдехь M. 13. 217. 387. 411. 443. П. 85. 163. nокьтекь Стар. 4, 74. пвтекь М. 37. П. 124. на крају XV и свега XVI вијека: људех Ст. пис. 1, 303. 2, 337. 5, 6. Збор. 24б. Град. дјев. 12. Зор. 41б. ноктех Ст. пис. 2, 27. 104. путех Н. Рањ. 35. 79. З.лат. 63. 79. XVII вијека: људех Банд. 279. Мат. 94.

б) у женских: до краја XV вијека: вранскь Стеф. 15. дмнехь Стар. 4, 234. zапоктдекь М. 9. шнхостехь М. 101. woћекь М. 176. 183. 248. шимстекь М. 62. шехакехь М. 24. 34. шкхкехь II. 60.

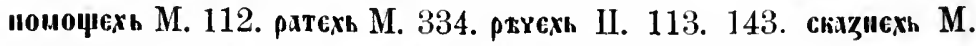
532. скрьвехь М. 244. сы.ирьтекь М. 332. ств.рехи, Нбб. 130. искехь М. 58. на крају XV и свега XVI вијега: болестех Збор. 1096. деснех Ст. пис. 4, 191. жалостех Ст. пнс. 2, 343. заповиједех Н. Рањ. 46. заловидех Буд. 72. исповндех Буд. 19. јаслех Ст. пис. 3, 302. Г'ч. 302. костех Ст. ппс. 3, 263. 3лат. 44б. мислех Ст. пис. 2, 405. 3, 99. 4, 45. 3бор. 66. А. Рањ. ІХ. Злат. 61. Гуч. 286. напастех Н. Рањ. 102б. наравех Буд. 7. немоћех Н. Рањ. 35б. ненавидостех Н. Рањ. 13. остех Ст. пис. 3. 263. отровех

1 у старом је словенском језпку млого јоп и у и ослабити: хюдьхь Микл. vergl. gramm. III. 45. 
Стар. 3, 323. пјеснех Н. Рањ. 33. Ст. пис. 2, 47. 519. 5, 343. 350. Збор. 199. А. Рањ. Зб. Злат. предгов. ппснех Хект. 43. пропастех 3бор. 95б. прсех Ст. шис. 2, 349. 3, 130. 4, 407. Д. Рањ. 95б. Злат. 41б. Гуч. 153. рпчех Ст. пис. 1. 126. 3ор. 16. Буд. 71. рпјечех Н. Рањ. 107б. 3бор. 112б. Злат. 52б. силостех Стар. 3, 281. слабостех Н. Рањ. 35б. стварех Н. Рањ. $104 б$. 3бор. 19б. Д. Рањ. 162б. Буд. 8. Брн. 15. тамностех Збор. 936. тварех Буд. 125. ћудех Брн. 11. частех Д. Рањ. IVб. XVII вијека : жалостех Банд. 33. заповидех Банд. 38. јаслех Банд. 10. навех Банд. 278. нанастех днв. 39. Банд. 96. немоћех Банд. 26. прсех Див. 36. Банд. 14. пустошех Банд. 244. ричех Банд. 102. стварех Див. 13. Банд. IV. гамностех Див. 35.

Мушке а за њима и женске, једнаке будућп у гом падежу с вима, прешле су међу мушке с основом на а: тако између мушких још XIV впјека узевпи и ов од ријечн с основом на а али му $о$ промијенивни на $e$, као у номинативу мн. (који види): пвтекъхь M. 85. а на крају пстога вијека и у том попустивши и узевши ов мјесто ев: пвтовехь ПІ. 2. тако XVI вијека: пвтокехь М. 551. XVII вијека: путових Радн. 96. у ријечи дан држало се ев још XVII вијека: дневнх Банд. 149. Без ев долазе исте мупке ријечи и женске од краја XV вијека изједначене у том пад. с ријечнма мушким у којих је основа на а: мушке XVI вијека: путијех Н. Рањ. 40. Град. дјев. 182. дних 3ор. 51. XVII вијека: људих Каші. 32. 62. 118. ьудијех Мні. 424. путих Бапд. 25. 40. 238. путијех Бун. 37. дних Банд. 177. 228. - экенске: на ғрају XV и свега XVI внјека: болестих l'рад. дјев. 42. драгостих Грал. дух. 14. заповидих Брн. 23. звпјеријех Ст. пис. 4, 175. исиовндих Брн. 71. користих Брн. 68. крепостих Град. дјев. 113. дудостих І'рад. дух. 16. мплостих Град. дух. 15. жис.дијех Ст. пис. 4, 347. 350. Град. дјев. 53. мислих Ст. нис. 4, 315. Брн. 7. напастих Град. дух. 44. немоћих Брн. 2. печалих Зор. 20. Брн. 46б. пјесннјех Н. Рањ. 166б. ('т. пис. 2, 404. 4, 436. 5, 87. 327. Град. дух. 63. дјев. 172. пјесних Ст. пис. 5, 174. писних Брн. 11. 22. писмпх Зор. 67. прсијех Ст. пис. 4, 407. І'уч. 146. прсих Ӟор. 69. рнјечијех Ст. пис. 5, 14. Град. дјев. 154. Гуч. 194. ријечих Град. дјев. 32. смртпјех Град. дјев. 182. стварих Град. дух. 22. стваријех l'уч. 274. XVII вијека: бодестијех Орб. 163. болестих Каш. 66. жалостих Каші. 29. заповидих 
Вран. жив. 112. Банд. 63. јасдих Јерк. 28. костијех Гунд. пс. 12. криностих lian. 59. иемоһпx Kan. 35. печалпx han. 114. писиих Вран. жив. 70. прспјех Гунд. суз. I, XXXI. прсих Јерк. 85. Каш. 102. рнчих Каш. 21. смртих Банд. 25. стварих Мрн. 186. тампостих Банд. 69.

XVII пијека како је $x$ било осдабидо, додази овај падеж и без њега: у мушких : путови Ради. 97. у женских : жалости Пос. 11. испразностије Ради. 59. 68. крппостије Радн. 52. 72. 77. прси Ради. 25. 40. стиари Радн. 4. тако и ирави докатив са $e$ па грају основе: при јас.ле Мик. 86.

Као пाто у мушких и средњих с осиовом иа а мјесто овога падежа додази генитн мп. кад се сврпује на $u$, тако долази и у овијех мушких и женских: у мушких: XVII впјека: прп .туди Врап. жив. 67. у женских чешһе: XVI впјека: о ствари мин!hијех Ірад. дјев. 51. у свијех ствари І'рад. дух. 71. области Буд. 146. у врнмених твари Буд. 95. XVII внјека: у твојих зановнди Вран. жив. 83. у својпх прси Вран. жпв. 16. о божанствених ствари Вран. жив. 19. у тих стварп Вран. 101. по ријечи, Давндовнјех Орб. ¿27. у ових заповнди Банд. 174.'

Како се ! дрчrих ријечи овај падеж изједначио с шнструмента.ом и жим се замијенио (внди паприед), тако је и ! овнјех : ! ночетк! XV инјека додази мјесто њега инстр.: в прхкния М. 24-. тако XVII ппјека: у стпарми Ђам. 5б. тако је мјесто локатива јираво пиструментал какан је онда био: о осталијем ствари (роб. 235. истога вијека.10катив изједначен с инструменталом какав је онда бно: ! мунких : птим Андр. п! 179. 257.301. у женских : ! болестим Андр. иут 135. 375. исновијестим Іидр. дев. ј). иа ми.1остим Андр. дев. 13. 45. ! мислим .Іпд]. п!т 105. 207. немоһим Апдр. "уг 11. У пјесним Андр. пут 344. у стварим Аидр. пут 96. 101. таком се об-

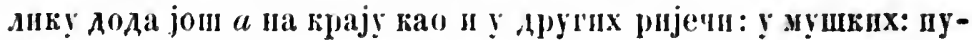
тима Аидр. пут 157. у бо.естима Андр. дев. 98 . 151. пут 11. 92. 99. 198. 392. У жалостиа Андр. пут 156. зановиједнма Андр. пут 31. нспразноетнма Радй. 8. костима Андр. пут 371. миАостима Андр. дев. 15. 37. пут 202. 226. 418. напастима Андр. пут 92. 370. педрагостима Андр. пут 11. шрноовјестима Андр.

' Kamuh грам. 27 вели: golubih vel golubi. 
пут 343. прсима Андр. пач. 37. дев. 50. пут 159. радостима Андр. пут 232. ријетима Ђам. 86. 9. 12. 13. 16. 17. 216. 27. слабостима Андр. дев. 124. стварнма Андр. Муг 287. Но што се додадо а долази и без $и$ иред $м$ : у мунких : људма Р'идн. 7. 51. криностма Р'ади. 77. стварма Радн. 6. 8. 15.36. у многије стварха Ради. 60. у овије стварма доғијем Р'адн. 49.

Ilpenamun sel,y myнke c ocnosor na a nasasn ce rao у њих и са о пред $x$ : прсох C'rap. $3,311$.

jiencке су ријечи предазиде у овом пад. и меһ, женске с осноном на а као у дативу и инструменталу мн., и то не само оне које су сада и у осталијем надежияа изједначене са женскича у којих је основа иа а, као иричах Н. ''ањ. 36.' јаслах Ірн. 52. писнах Банд. 2\%. нисмах Банд. 161. и без $x$ : пјесна Радн. 81., него и друге: XVI вијека: немоһах liуд. 20. Врн. 70. печалах Зор. предгов. ричах Вуд. 53. 58. 95. скрбах Зор. 20. стварах Буд. 14. 59. 86. XVII инјека: печалах Вран. жив.

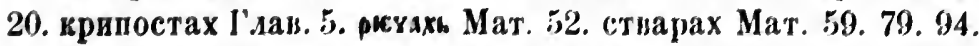

Мјесто овога падежа иалази се и докатив двојние: XVI вијека: по обитилију Н. Рањ. 107б. XVН вијека: на "рсију Враи. жив. 68.

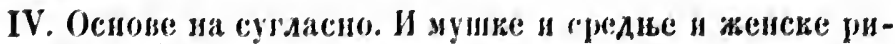
јечи иредазияе су у овом падежу јоп у старом словенском језику међ! ријечи с основом на 1 , пити су га Аругауије имале: тако н. шр. ! средњих: вринснехи. М. 39. - Али у иас како су ријечи с основом на $\mathbf{I}$ прелазиле мең, мушие и средње с основом иа а, тако су с нима и ове:

а) муние: XV инјека: кхиенияь М. 386. XVI вијека: пма. menuсхи 3бор. 14. тако и рнјеч воја је и ! номинат. јед. јон у старом словенском пренда меhу ријеуи с основом на $i$,

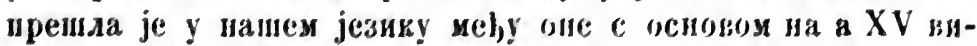
јека у овом падежу: ирьстешнсхь М. 425.

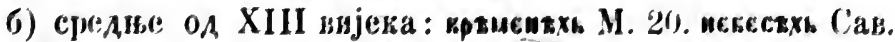
14. иа крају XV и свега XVI вијека: вримених Буд. 54. paменијех Г'У. 207. водесијех Збор. Збјб. эрн. 8. небесих Ст. нис. 1, 195. 3ор. 72. Lрн. 5. Вјан. рјеч. 127. пегесијех Н. 'аat. 39. 40. 3бор. 74. Ст. пис. 4, 110. 5, 81. Іүуад. ајев. 18. І'уч. 3.

' Исти писац ика у иокин. јед. шрнтач Н. Ран. 33. 
чудесих Ст. иис. 1, 197. Н. Рањ. 144. XVII вијега: вримених Банд. 67. пменпјех Гунд. суз. предгов. небесијех Див. 33. Орб. 100. небесих Вран. жив. 20. Ванд. 44. Крн. 8б. Каш. 10. 80. те.леспјех Орб. 172. тилесих Банд. 203. чудеспх Банд. 73. Средње неке прелазе онамо и тако да одбаце крајње сугдасно II пред њим самогдасно од своје основе: колпх Стар. $3,316$. колијех Град. дјев. 160. Гу'ю. 238. чудијех Орб. 140.

У средњих мјесто овога падежа додазп и генитив мн. кад се завршује на и (као и у мушких и средњнх с основом на a п у мушких и женских с основом на $\mathbf{i}$, види стр. 136. 142.) XVII вијека: на својих рамени Вран. жив. 86. рамени Мрн. 141. тако и над се од основе одбаци крајње сугласно и пред вим самогдасно: коли Вран. жнв. 71. 73.

XVII вијека кад је $x$ бнло ослабпло долази овај пад. и без њега: у средњих: небеспје Радн. 77. 84. чудесије Радн. 38. п одбацивни у основи крајње сугдасно п шред вим самогласно: ко.ли Мик. 789.

И у овијех се ријечи као п у других на пстп начин (види стр. 135. 142) овај падеж у пошљедње врнјеме изједначио с инструменталом какав је онда већ бно: у мушких: пламеним Андр. иут 222. у средњих: на раменијем Андр. дев. 142. а свршујући се на м добнја $a$ на крају: словима Ђам. 7б. 16. Андр. нач. 18.

в) женске неке прелазе још у старом словенском језику међу женске с основом на а: тако и у нас: ирьккххь М. 98. 108. Н. Рањ. 23б. Ст. пис. 5, 150. Д. Рањ. УІб. Гуч. 32. у нашем су језпку пре.азпле онамо и друге: XVI вијека: кћерах Град. дјев. 91.

Да се и у овијех рнјечи с основон на суг.асно налази овај падеж мјесто генитива мн.. споменуто је код генит. мн. 


\section{ОБЛИЩИ ПРОНОМИНАЛНИ И CJ0ЗЕНИ.}

Облицима се разликују од имена а међу собом се слажу замјенице (pronomina) које имају сва три рода и тко и ито.

Основе се свршују у једнијех на чисто а, као у сам (основа: сама), а у других на ја, као у мој (основа: моја). Неке се у неким облшцима шире: основа ка, од које су облици за сва три рода, шири се у некнм облицима тако да мјесто заједничкога краткога а имајући у словенским језицима $o$, и по том гласећи жо предази међу основе на ја те гласи која; то бива и у оспове кьсака; основа сја шири се у некшм облицима тако да јој $j$ лостаје $u$, пза којега ошет зијева ради добива $j$, те остаје међу основама на ја, а у којим се облицима не шири, у онијема избацује $j$ остајући међу основама на ја; основа кьсја такођер одбацује $j$ остајући међу основама на ја, али у неким облицима прелази међу основе на чисто $а$.

Сложени су облици у адјектива одређенпјех, и постају кад-се номинални облик њихов састави с обликом замјенице којој је основа ја, а номинатив јед. мушкога рода и, женскога њ, средњега є, али којој је номинатпв бво у обичају само сложен с рнјечцом жє: нжє, а иначе се замјењивао номинативом других замјеница.

Нека су адјектива ирешла међу замјенице, те имају оспм шрономиналних облика неке п номиналне п сложене. И неке замјенице имају од некога времена гдјекоје облике с,дожене, особито номинатив јед. мушкога рода, јамачно уз друге падеже прономиналне, с којима су се у српском језику изједначили сложени. 


\section{НОМИНАТИВ ЈЕДНИНЕ.}

Постаје за сва три рода као у имена.

A. За мушкн род:

а) од основа иа чисто а: кьски М. 32. 98. ксакь М. 312. 314. ІІб. 27. Вран. жнв. 77. свак Ст. пис. 1, 11. 2, 11. 347. 4, 76. 395. Збор. 13. А. Рањ. 5б. Град. дјев. 128. Злат. 16б. Гуч. 27. Крн. 5б. Радн. 43. свак час Ст. пис. 2, 45. свак дан 118. свак чловјек Ст. чис. 3, 405. свак час 130. Град. дјев. 174. Злат. предгов. 3б. Гуч. 260. у сложеном облику од XIII вијека: кцсаки М. 14. ксхки М. 102. 394. 458. П. 10. 13. 70. вхсхкн Пб. 35. всаки Юуд. 127. 156. Вран. жив. 29. скаки М. 220. 225. 394. 462. 499. 509. Ст. пис. 1, 11. 57. 115. 2, 8. 16. 72. 3, 130. 284. 4, 87. 152. 267. 380. 5, 110. Град. дјев. 36. Зор. 1. Буд. 127. Вран. рјеч. 70. 87. Злат. 87. Гуч. 39. Анв. 3. Банд. III. Крн. 10. Глав. 12. из друтих иадежа у којима се ова основа инри прешла је рапирена и у овај од XV вијека: кскон П. 30. скхкон М. 497. свакојп Ст. пис. 5, 72. види ниже кши. кьсакошки види Ііод генит. мн. - пиь М. 18. 135. 354. од XIII вијека у сложеном облику: ши М. 10. иньин М. 21. ини М. 219. 351. 361. 365. 374. 411. II. 24. 72. Пб. 27. 87. Ст. шис. 1, 81. 113. Н. Рањ. 49. Ст. пис. 2, 93. 358. 3, 443. 4, 401. 5, 10. Злат. 27. Мик. 140. јнни Зор. 8. Вран. рјеч. 6. - нсть М. 25. од XV вијека у сложеном облику: исти М. 502. П. 118. Пб. 98. 128. А. Рањ. 94. Буд. 40. Злат. 37б. Аив. 4б. Орб. 59. Гунд. суз. I, XIV. Банд. 12. Бун. 49. Канг. 41. Мик. 148. Андр. нач. э. јис'и Вран. жив. 46. - єдни Сав. 6. М. 58. 144. 178. Ст. пис. 5, 81. од XV вијека у сложеном облику: єдннын (вокат.) М. 277. једини Ст. пис. 4, 213. 300. 4, 461. 5, 128. Вран. жив. 41. Андр. дев. 177. једихни Ст. пис. 4, 391. 472. - єдьмь М. 6. 149. ндань II. 9. 39. сложено са жи: ниєдань Пб. 95. Ст. пис. 4, 111. Д. Рањ. 22б. нъдань ПІ. 1. 6. 94. 99. Пб. 87. пюдань М. 298. ПI. 118. нидан С' пис. $2,29.410 .4,369$. и у сложеном облику XVII вијека: ниједни Каш. 109. - кмк Стеф. 11. 18. - кхкокь Сав. 14. Ст. пис. 1, 83. Каш. 46. Глав. 13. какав Андр. дев. 29. п у сложепом облику сложено са ни: никаквп Каш. 90. - помик Сав. 3. М. 512. Ст. пис. 3, 80. 137. Град. дјев. 
120. Јерк. 22. - котори (у сложеном облику) Стеф. 25. М. 14. сложено са ни: никоторнже М. 5. - кт- од основе ка, кад нема другога рода осим мушкога, у овом падежу додази само с доданим на крају то: іьто М. 2. кто М. 2. 10. 30. 52. 113. 161. 268. 353. 458. 479. 535. Буд. 24. 82. 85. 118. сложено са нт: нвкто Стеб. 20. М. 69. искьто М. 29. сложено са ни: инкто М. 53. 135. 362. пошледње с доданим на крају жс, коме се у срнском језику мијења ж на $p$ : пиктоке М. 15 . пикторс М. 30. никторе Ст. пис. 1, 9. окрњено: инкторь М. 491. с додан пм зи: мнктоz" Зак. 41. од XIII вијека додазе гласови кт преметну'ти: тько М. 30. тко М. 42. 51. 101. 105. 135. Ст. пис. 1, 19. Н. Рањ. 151б. Збор. 8б. Ст. пис. 2, 13. 3, 5. 4, 227. Д. Рањ. 2. Град. дјев. 62. Зор. 17б. Злат. 4б. Гуч. 10. Див. 3б. Орб. 112. Гунд. суз. I, XXII. Банд. 33. Крн. 2. Бун. 50. Радн. 37. сложено са нх: инстко Збор. 3б. њетко Ст. нис. 4, 59. 5, 103. Ђам. 5, 23. нитко Вран. жив. 104. Банд. 37. сложено са жи: ннтко М. 111. 204. 256. 363. II. 15. Ст. шис. 1, 111. Н. Рањ. 19. Збор. 7. Стар. 3, 219. А. Рањ. 8. Див. Х. КапI. 24. Радн. 39. пошљедње с доданим на крају жк, коме се у српском језику мијења ж на $p$ : питкоре Н. Рањ. 82. 3бор. 26б. Ст. пис. 4, 32. 160. 357. 420. 464. 5, 8. 133. Д. Рањ. 28. Гуч. 215. Вран. жкив. 67. Банд. 7. Радн. 39. са $u$ мјесто $e$ у ре: ниткори Ст. пис. 4, 259. окрњено: инткорь М. 256. 467. ПІ. 20. Пб. 40. Ст. пис. 1, 15. Н. Рањ. 34. 72б. Ст. пис. 4, 47. 442. 5, 15. Град. дјев. 24. Хект. 18б. Зор. 55. Злат. 3б. Вран. жив. 36. Банд. 45. сложено са $и$ : иткоре Ст. пис. $5,11.223$. окрњено: иткор Н. Рањ. 75. од XV вијека отнада с приједа т, прем да, како се види, свега времена долази и цијело: ко ПІ. 79. 127. Ст. пис. 4, 116. 209. 223. 5, 28. 41. Д. Рањ. 30. 122. Хект. 46. Вран. жив. 30. 34. 36. Гунд. суз. III, LIV. Јерк. 34. Каш. гран. 48. Андр. нач. 55. тако у сложено са пк: веко Ст. пис. 4, 104. нико Вран. рјеч. 6. сложено са ин: пнко Пб. 118. Ст. пис. 4, 240. пошљедње с доданим на крају же, којему се щијења ж на $p$ : никоре Вран. жив. 18. 38. окрњено: никор Ст. пис. 1, 262. 4, 442. Вран. жив. 12. 39. према томе и свако Брн. 23. од XV впјека налази се гдје гдје и гд мјесто кт: gdo М. 280. Стар. 1, 227. 3, 226. Зор. 26. Крн. 12. Глав. 122. нигдор Стар. 3 , 222. Крп. 24, - од оспове ка нерапирене, кад пма сва 
три рода, за мунки род нуа сложени номип. јед.: кын Стеф. 18. кн М. 7. 34. 107. 120. 293.306. 378. 546. II. 99. 113. 153. 177. Пб. 91. кьн II. 82. кіг Ст. иис 1, 131. 2, 19. 365. Н. Рањ. 27. 33.87. 90. 102б. Ст. пис. 3, 467. 469. 4, 42. 113. 413. 5, 8. 34. 114. 232. Д. Рањ. 5б. 17. Град дјев. 22. 65. дух. 49. Буд. 60. Банд. 9. 17. Јерк. 40. 83. сложено са ик: нккн М. 31. нюкн П. 11. веки Ст. ппс. 2, 31. (gnieki) А. Рањ. 34. 89. (nieki) Ст. пис. 4, XI. (nieki) А. Рањ. 12. І'рад. дјев. 112. Злат. 14. пз других падсжа, у којнма се основа пнри, шрешла је раширена и у овај јошl XIII вијека, а је лп тај облик с таком основом био Ірономинални нди сложени, т. ј. је ли гласио кој или који, пе може се поуздапо знати правописа радп до краја XV вијека: кон М. 14. 101. 261. Пб. 54. ПІ. 82. пешоуздано је и XVI внјека у највише писаца, јер пишу пстина коіј Н. Рањ. 24. Град. дјев. 19. Злат. 84. Гуч. 2. али њихово іј гдасп и $j$, као што шину и у средњем роду: toij Н. Рањ. 16б. Град. дух. 119. оvоіј Град. дух. 21. поуздано бнва од краја XV вијека у пјесмама гдје број слогова показује да је гласило који Ст. інис. 1, 8. 18. 114. 2, 3. 43. 94. 96. 100. 142. 211. 229. 487. 3, 70 . 217. 303. 4, 29. 67. 108. 200. 211. 344. 418. 440. 5, 17. 33. 110. 114. то потврђује XVI вијека п правопис неких писаца: сhоуі Хект. 3. 41б. chogii Буд. 30. коуі Вран. рјеч. 87. тако п XVII внјека: kоуіј Вран. жнв. 19. коуі Банд. 3. Мрн. 109. Каш. 8. chogi Јерк. 77. kоiј Бун. 52. Андр. нач. 19. kојі Мик. 31.' сложепо са нт: некон М. 31. пткон М. 546. ПІ. 107. 164. Г. 11, 190. нјекоји Н. Рањ. 98. А. Рањ. 64б. њекоји А. Рањ. 89. Ст. пис. 5, 58. никоји (nichogi) Буд. 41. сложено са жи, и на крају му додано же, којему ж у срнском језику гдаси $p$ : ннконе М. 10. без ре: мнкон Зак. 39. 一 окакокь види код датива јед. окхын у сложеном облику, с доданим на крају жде, које у српском језику гласи ђе: оклигє М. 251. 359. 409. - окь М. 274. $3 \varepsilon 0.460 .509$. II. 105. 142. Шб. 60. ов. Ст. пис. 1, 9. 18. 20. 2, 20. 92. 233. 316. Хект. 7б. Зор. 54. Буд. 152. Мрн. 86. 111. Глав. 5. с доданим на крају зи: юкьзн М. 457. 478. с доданим $a$, по пто је гласа ь нестало, од XV вијека, прем да је,

' IIто иза: кој Ст. пис. 2, 472. 505. 4, 200. 218. јамачно је само стиха ради изостављепо $u$. - Гријешком има гдје гдје ткоји Ст. пис. 4, 443. у дну. 
како се види, и даље било без њега: юва Пб. 60. Ст. пис. 4, 469. Злат. 71. к тому се још додаје $j$ од XV вијека: юван М. 400. 523. 556. П. 132. Пб. 121. Град. дјев. 14. тако ће бити само написано ь мјесто $a$ : окьн М. 521. крајви су се гдасови $а ј$ преметали XV вијека: ока М. 384. 409. 410. 415. Пб. 100. 102. 103. 105. Фкьм Пб. 106. 108. 115. 116. 121. од XIV вијека долази и у сложеном облнку и послије је обнчније тако него другачије: юкн Пб. 26. ІІ. 22. М. 251. 387. 425.443. П. 29. 68. Пб. 53. 65. Ст. пис. 1, 18. 20. 26. 91. 2, 50. 58. 388. 455. Н. Рањ. 30. 43б. 50. 58б. Збор. 26. 93. Ст. пис. 3, 11. 80. 4, 48. 98. 407. 440. 5, 60. 110. А. Рањ. 29б. 80б. Град дјев. 11. 28. Хект. 10б. Буд. 5. Вран. рјеч. 44. Злат. иредгов. 2. Гуч. 10. Вран. жив. 4. Див. 10. Орб. 36. Гунд. пс. 29. Банд. 2. Мрн. 99. Јерк. 11. Канг. 8. Ђам. 3. Андр. дев. 8. Радн. 14. Гдав. 86. с доданим зи: шки" М. 522. Збор. 40. - онањ види генит. јед., послије само у сложеном облпку. - онь: бнь крхамниь

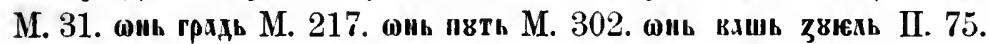

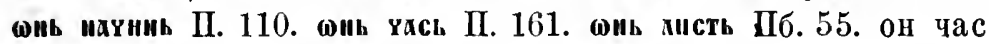
Ст. пис. 1, 24. он киі 103. он дан 314. он ход Ст. пис. $2,17$. од дан 40. он гдас 92. он уздах 268. он цвитак 322 он свит 421. он час 433. оп свијет Ст. пис. 3,5 . он крај 58. он плач 452. он свијет Ст. пис. 4, 25. он час 287. 5, 139. Н. Рањ. 39. он свијет Н. Рањ. 79б. он дан 134. он Збор. 9. он крај $А$. Рањ. 73. он пут 147. он властелин Хект. 11. он витар 3ор. or 8. он покорник Буд. 18. он дан Брн. 41. он час Вран. рјеч. 102. Злат. 99б. Іууч. 42. и XVII вијека: пемили он чловнк Вран. жив. 44. тко је он, који ће издати тебе Банд. 14. дух јест он, ки свидокује Банд. 144. он час Бун. 21. он дан Мрн. 45. он велнки криж Јерк. 61. он Гдав. 14. с доданим зи:

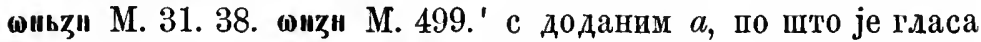
ь нестало, XV вијека: ших М. 499. к тому је још додано $j$ XV вијека: омхи М. 426. 458. 487. а гласови су се $a j$ преметали: шик М. 409. од XV вијека у сложеном облику чешће него друкчије: оснн М. 340. они М. 346. 507. II. 32. 45 . Пб. 60. Ст. пис. $1,24.40 .2,42.456 .5,118.121$. 151. Н. Рањ. 17. 24. Збор. 1. Ст. пис. 3, 6. 399. 4, 14. 334. 427. 5, 33. 37. 94. 278.

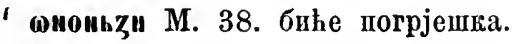


Д. Раш. V. Град. дух. 10. дјев. 19. Хект. 17б. 28б. Буд. 38. З.лат. предгов. 2. Гуч. 5. Вран. жив. 18. Див. 19. Орб. 33. Бапд. 3. Мат. 19. Бун. 29. Јерк. 15. Каш. 2. Андр. дев. 2. нач. 10. Шос. 2. Радн. 7. І'лав. 14. с доданшм на крају жде, које у српском језику гдаси ђе: ониђе Н. Рањ. 171б. к тому се још додавадо жс, којену се пијења же на $p$ : ониђере Н. Рањ. 153. и огрњено: ониђер Н. Рањ. 22. - схи М. 23. Ст. нис. 4, 441. Буд. 23. Злат. 17б. Вран. жив. 3. п у сложеном обдику смиї 1'. XI, 66. сами Злат. 65. Käl. 6. - тми Сав. 6. М. 24. 34. с доданим зи: тхкиз' М. 41. п у сложеном об.1ику : тхкн ІІб. 39. Ст. ппс. 5, 160. с доданим жде, које у срнском језику гдаси ђе: такиге II. 88. - таковь II. 135. Ст. пис. 1, 83. Мат. 9. и у сложеном облику: тхкокын М. 10. тхкокн М. 14. 459. с доданим жъс, које у сриском језику гласи ђе: таковигє II. 18. 25. - тодик Ст. нис. $3,137.4,60.215$. Вран. жив. 59. и у сложеном облику: толики Ст. пис. 4, 200. - ть Стеф. 3. с доданім $a$, по што је гласа ь нестало, а мјесто њега се писало II hh й кад кад $\epsilon:$ тh ('тет. 3. ІШат. pam. 1873. 100. тє М. 46. та Ст. пис. 1, 20. 2, 365. 3, 215. 4, 8. 169. 362. 381. 387. А. Рањ. 62б. Хект. 40. Зор. 2б. Буд. 11. Вран. жив. 10. Банд. 20. Мрн. 40. Јерк. 33. Мик. грам. 14. ГАав. 18. с доданим ждє, које у српском језніу гласи $ђ e$, те се мјесто $ђ$ иисало и $д$ : тьжде Сав. 6. тьде М. 7. тажде М. 103. таће М. 462. с доданим зи: тхзи М. 185. с доданим $j$ : тан М. 232. 426. 459. 462. 496. 502. 507. II. 149. 151. ПІб. 60. 83. 103. тако ће бити само написано и мјесто а: тын М. 521. Пб. 12. 23. 64. 66. 77. 82. тај Н. Рањ. 88б. 90. 214. Ст. пис. 2, 91. 323. 363. 3, 29. 97. 164. 462. 487. 4, 60. 84. 158. 177. 214. 225. 326. 387. 5, 121. 338. Збор. 4б. Д. Рањ. 19б. 60б. 81. Град. дух. 55. Хект. 45. Здат. 7б. Гуч. 152. Јерк. 38. од XIII вијека и у сложеном облпку: ты М. 15. П. 30. тн М. 402. 493. П. 176. Пб. 77. Ст. пис. 1, 41. 2, 85. 4, 210. 226. 321. 371. 420. 443. 5, 129. 131. 201. А. Рањ. 32б. Град. дјев. 64. Хект. 29б. Гуч. 2. Див. 17. 19. 20. Банд. 23. Мат. 12. Андр. нач. 5. Радн. 9. 15. 21. 39.

б) од основа на ја : кись М. 10. кась М. 106. 319. ПI. 56. По́. 35. вас Н. Рањ. 37. Ст. пис. 2, 55. 3, 10. 4, 17. Збор. 8б.

\section{' Наштампано је тхкірн.}


Хект. 29б. Злат. 22. Гуч. 99. Вран. рјеч. 107. жив. 31. Банд. 10. Јерк. 7. Каш. 41. Мик. 764. Радн. 41. с преметнутим консонантима XV вијека: савь М. 508. - кашь М. 24. једном и у сложеном облику XV вијека: вхшн ПІ. 103. - двој Вран. рјеq. 13. - од основе ја, од које би овај пад. у словенским језицима био јъ, али се оба гласа састављају у и, те сложено са же бива у овом пад.: ике М. 3. - сь М. 14. с доданим $a$, по пто је нестадо гласа ь, а мјесто $a$ писало се испрва и hь: chb M. 66. сх Стар. 3, 270. Брн. 67. Вран. жив. 22. с доданим $j$ : сан М. 102. 238. 388. 403. 471. 480. Пб. 34. 111. Ст. пис. 1, 66. Н. Рањ. 22б. Ст. пис. 2, 48. 351. 396. 3, 10. 4, 5. 30. 251. 445. 5, 4. 34. 111. 214. 253. Збор. 28. Д. Рањ. 2. Град. дјев. 180. Зор. 11. Здат. 14. Гуч. 104. Вран. жив. 80. Орб. 19. Гунд. суз. I, LXXII. Јерк. 27. од исте основе раширене: сн М. 13. 20. 33. 425. Пб. 108. Ст. пис. ', 36. 351. 355. 4, 459. 5, 42..' Збор. 161. 3дат. 2. с доданим зи: снз" М. 29. 31. 53. 147. - свој. - твој. ${ }^{2}$ - чни М. 271. које је данас у сложеном облику.

У сложеном се облику номинатив од прономина " (који се налази у сложеном нже) саставља с номиналним номинативом од адјектива тако да пред внм завршетак номиналнога облика -т бива -т, а -ь бива -н, на се онда тн и нн сажима у српском језику у дуго $u:$ a) ка’д је у адјектива основа на чпсто а: дигехьски М. 4. крьстнаньскы М. 5. гртшьни М. 9. хрьин М. 11. б) кад је у адјектива основа на ја: кекн М. 1. векни M. 9. доны M. 197. говеки M. 199.3

Б. За средњи род :

а) од основа на чисто а: кскко М. 9. 339. 487. II. 16. 94. IІб. 35. скхко М. 285. 346. 384. 420. 537. П. 28. Ст. пис. 4. 163. Злат. 6б. Вран. жив. 67. и сложени облик: кьскою Стеф. 17. - свакојако Крн. 1. - нмо М. 249. Злат. 15б. јино Вран. жив. 42. с доданим $j$ : иној Д. Рањ. 30б. - нихко ПI. 1. јинако Вран.

1 Наштампано је sij.

2 ШІто има тоіі Град. дух. 20. svoij Град. дух. 19. не свједочн да се читало моји, твоји; види напријед стр. 148 код који.

* Налази се п с доданим fe: дрвгнгс М. 433. и у споменидима пнсанијем на иностранијем дворима с доданим $e$, које може бити да је мјесто ђе: кекне М. 548. кехкїє М. 550. снкнне М. 548. 550. веронхине М. 556. 
жив. 36. - исто Злат. 88б. јисто Зор. 16. Вран. жив. 6. єдино М. 538. - једно Злат. 17б. сложено са ни: ннедио М. 487. Злат. 12б. Јерк. 40. пв.по М. 361. нидно Ст. пис. 2, 394. 4. 373. - како, сложено са жи, а на крају му додано же, које у српском језику гдаси ре: никакоре Банд. 19. - какоко Сав. 4. - ко М. 290. 423. Н. Рањ. 8. 119. 144. 154. Ст. шис. 2, 57. 3, 247. 4, 31. 116. 240. 430. 5, 119. 326. Буд. 25. Злат. 3. 23. 39. Вран. жив. $64 .^{1}$ сложено са шт: њеко Ст. пис. 3, 210. $5,170$. од раширене основе: коє М. 22. конє М. 480. Н. Рањ. 21. Збор. 111. Ст. пис. 4,436 . Вран. жив. 10. Орб. 87. сложено са нะ: некою II. 70. сложено са жи, а на крају му додано же, које у српском језику гласи ре: пнкоєрс М. 45. сажето: ке (3.0, ке ју ће скончати) Ст. пис. 4, 450. (јаје, ке буде ставити) Д. Рањ. 101. - колико Злат. 52. сложено са пะ: некокнко П. 134. Злат. 36f. Орб. 1. без слога ли: коко С'т. пис. 1,19 . никоко Ст. пис. 1, 13. Хект. 16. -- котороє (с.ложени облик) М. 4. окмко, с доданим ждє, које у српском језику гдаси $ђ е$ а $ђ$ по некпм крајевима гласп $j$ : өвхкоє Шб. 60 . - ово М. 40 . Н. Рањ. 9б. с доданим зи: окози М. 69. с доданим $j$ : окоп М. 105. Н. Рањ. 21. Ст. нис. 2, 49. 4, 470. Град. дјев. 4. с доданим ждс, које у српском језику гласи $ђ е$, а $ђ$ по неким крајевима гласи $j$ : шкоє М. 417. с доданим $j$ и зи: бвовзи (где һе бити само написано мјесто $j$ ) М. 417. - оно М. 545. с доданим зи: онози М. 53. 478. с доданим $j$ : онон М. 106. Збор. 23б. с додания жде п рє: прво гдаси у српском језику ђе, а друго се може и огрњитн: онођер Н. Рањ. 34. - само Злат. 80. тако, с доданпм же: такоже М. 15. с доданим $j$ : такоп М. 461 . Н. Рањ. 13б. - такоко Сав. 11. М. 274. п у сложеном облику: такокоє М. 89. - толико Злат. 52. с доданим жде, које у српском језику гласи ђе: тохнкос М. 30 . токнкоге М. 240.261 . а $ђ$ гдје гдје г.ласи $j$ : толикоје Ст. пис. $1,228.4,116$. с доданим $j$ : тохнкон М. $422 .^{2}$ без слога ди: токо Ст. пис. 1, 20. 49. Хект. 24. с доданим жлє, које у сршском језику гласи Ђе а но неким крајевима и је: токоје Ст. пис. 1,24 . - то М. 13. 55. с доданим на крају ждс, које у српском језику гдаси ђе а гдје и $е$ : тожде II. 39. тоге II 162. тоје Ст. пис. 1, 24. 200. к тому се

1 Гришјешком тко (мјесто ко) Мрн. 25.

2 Налази се и тулико Глав. 128. 
додаје јоп жє, којему се ж мијења у српском језику на $p$, а $e$ и отпада: тођере Н. Рањ. 13б. тођер Ст. пис. 2. 52. Д. Рањ. 13. 121б. Град. дјев. 24. 49. 63. с доданим зи: тозн М. 21. с доданим $j$ : тон М. 15. Н. Рањ. 16. Ст. ппс. 3, 123. 4, 162. 205. 5, 120. А. Рањ. Уб. Град. дјев. 4. Злат. 10б. Гуч. 21. с доданим $j$ и зи: төнзн М. 104.

б) од основа на ја: ксе М. 17. 240. 289. 306. 314. 365. 401. 420. 500. Ст. пис. 1, 168. Вран. жив. 18. ввсе М. 219. ске М. 238. 276. 285. 307. 419. Ст. пис. 2, 163. 3бор. 7. А. Рањ. IX. Хект. 2б. Зор. 23 Злат. 6б. Гуч. 22. Вран. жнв. 87. Крн. 26. Јерк. 27. Каш. 49. Глав. 26. - ваше. - двоје Злат. 13. - од основе ја, сложено са же: южє М. 15. єжє М. 3. промијенивши жа $p$ : єрє М. 13. єрє М. 6. - моје, и сажето: не Ст. пис. $2,119.3,459.4,353$. - се М. 24. 116. II. 93. Банд. 9. с доданим $j:$ сен М. 375. 412. Ст. пис. 5, 102. 163. 339. Злат. 96. Гунд. пс. 34. од раширене основе: сиє М. 2.6. 116. сию М. 13. с доданим $j$ : сисн М. 467. - твоје, и сажето : тве Ст. пис. 2, 102. 4, 63. 237. 431. Злат. 6б. Гуч. 240. - үне М. 52. Ст. пис. 4, 481. с доданим но: чнсно М. 34. 3бор. 2б. сложено са жи, а на крају му додано жє, које у српском језику гласи ре: пнчєрє М. 249. окрњено ннхнер М. 126. свачије Град. дјев. 123. - од основе уа као за мушки род чь долази само с доданим на крају то: хьто, и с њим се слажу друге ријечи као да је средњега рода: чьто М. 6. что М. 13. 54. 261. Буд. 7. 67. ћако је нестало гласа ь, мијења се $\boldsymbol{u}$ пред то на $и$ од најстаријнх времена: чо М. 2. 13. 46. 50. Сав. стар. 4, 231. Н. Рањ. 14. 16. 29. Збор. 4б. Ст. пис. 2, 9. 11. 3, 138. А. Рањ. V. Град. дјев. 4. Хект. $4 б$. 5. 6б. 10. 19. 21. 48б. Брн. 61б. Вран. рјеч. 86. Злат. 2б. Гуч. 9. Див. 21. Вран. жив. 8. 14. 21. 61. 65. 100. 111. Банд. 18. Мрн. 108. Јерк. 14. Каш. 40. Андр. пут 430. сложено са нт: итуто М. 15. ничто Вран. жив. 3. икчо М. 462. II. 18. Ст. пис. 3, 237. Град. дјев. 141. Злат. 56б. Орб. 181. ништо Хект. 8. Вран. рјеч. 6. жив. 17. сложено са ни: инүьто М. 46. инцо М. 147. 153. 161. 175. Ст. пис. 1, 43. 2, 137. 331. 3, 104. 4, 45. 375. 5, 6. д. Рањ. 100б. Град. дјев. 88. Вран. жив. 17. пошљедњему се додаје на крају жс, којему се ж мијења у српском језику на $p$ : инутоле М. 263 . щщцоре М. 37 . Ст. пис. $3,340.4,91.195$. 262. 274. 470. 5, 150. 341. Хект. 13. 36б. окржено: мнцорь II. 
6. 36. М. 367. Н. Рањ. 19б. 22б. 29. 36. Збор. 2б. Ст. иис. 3, 10 108. 4, 158. 253. 5, 8. Д. Рањ. 32. Град. дјев. 4. 39. Хект. 21.28. Стар. 3, 304. Злат. 10б. 15б. Гуч. 183. Банд. 15. сложено са $u$ : вштор (ни га ће иткор привари', од њега иштор сакрити) Град. дух. 13. према томе и: свашто Радн. 87. од XIII внјека додази и окрњено, т. ј. без крајњега $o$, те је иза сугласнога на крају додано а као и у других ријечи, највише кад је сложено са $и$, али и кад није сложено, како у номинативу тако и у акусативу, и у порицању, кад обично додази генитив мјесто акусатива; сложено са жи: да нмь ннцх не нснакости М. 16. 53. дх нмь не вzме пнци М. 120. да "е пхате ищца М. 203. да ниь ннтко ннциа не заваки М. 204.

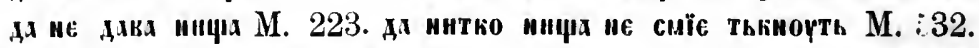

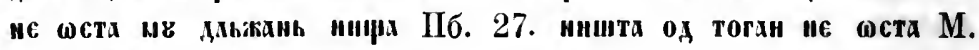
507. ништа Н. Рањ. 5. Збор. 38б. Ст. шис. 2, 115. 4, 202. 402. Д. Рањ. 5. 1'рад. дјев. 92. Злат. 8. Гуч. 144. Див. 30. Каш. 43. ничта Буд. 12. било би све ништа Ст. нис. 2 , 122. ништа ти није тешко Андр. пут 296. ништа се не губи Ради. 37. тако и с приједлогом у акус.: за ништа Ст. пис. 4, 132. Андр. дев. 24. по ништа Ст. нис. 4, 132. у ништа Ст. іпс. $5,83$. Злат. 27. Гуч. 144. с доданим же, које у српском језику гласи ре: да се ие кое инираре М. 21. да тн не нспакости ницире М. 22. ие дасте кнцир: М. 42 . ништаре Ст. пис. 1, 17. 124. 155. Н. Рањ. 91б. Збор. 5б. Банд. 15. Јерк. 22. Радн. 34. за ништаре Стар. 4, 114. и окрњено : ништар Ст. пис. 1, 28. 54. 108. 138. тој ми се мни ништар Ст. пис. 2, 215. нгш'гар Н. Рањ 186. 25. 36б. Хект. 2. 21б. 28. Зор. 33. Брн. 2б. Орб. 259. Банд. 8. Јерк. 22. за нпптар Ст. пис. 4, 357. у ништар Каш. 39. тако и сложено са $u$, на му се и тада додавало на крају ре: иштаре A. Рањ. 10. за иштаре Мрн. 101. у сложеном са жи налази се и ufie мјесто ито од XV впјека у неких шисаца: нишіе Ст. пис. 1, 34. 121. 327. Вран. рјеч. 66. жив. 5. 18. 19. 64. Крн. 19б́. Мрн. 77. Јер. 41. додази тако са $a$ и кад није

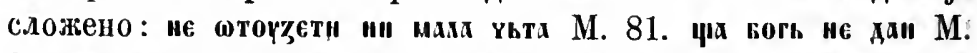

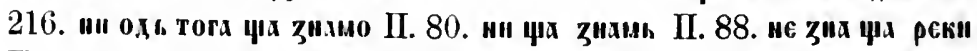
II. 97. нотьнити се иоткорити ңіх оть иего Г. XI, 137. шта жена зда носи и химбе у свој скут Ст. пис. 2, 331. од XV вијека долази и без цјелога то, а тада му се ни и не мијења на $и$, 
тако додази сложено са жи, и у акус.' с приједлогом, а и еамо, и то не само у онијех које сада по тој ријечи зову чакавцима него и у других, као што у онијех долази и ито; сложено: мну (?) П. 89. у нич Злат. 23. у акус. иза ириједлога: ва ч Стар. 3,288 . кроза ч Ст. пис. 2, 4. 99. 107. за ч Н. Рањ. 176. 87. 88. 101. 160. Ст. нис. 2, 4. 102. 347. 434. 3, 4. 212. 4, 25. 58. 115. 133. 150. 214. 5, 218. 298. 330. Д. Рањ. $15 б$. Вран. рјеч. 86. Здат. 3б. 6б. 86б. Мрн. 22. кад стоји само, ни сложено ни с приједлогом, додаје жу се на крају $a$, као и другим ријечима: ча Ст. пис. 1,7 . Н. Рањ. 19. 163. Ст. шис. 2, 355. 385. Стар. 1, 219. 3, 241. 4, 111. Хект. 26. Буд. 26. Брн. 61б. Вран рјеч. 86. жив. 3. Крн. 2б. Јерк. 14. Глав. 26.

У сдожен о м облику номинатив од прономина є (које додази у єжк) састав.ьа се с номиналним номинативом од адјектива без промјене: чмоктүхскою М. 133. древнєє М. 131. само се тада у српском језику сажима оє у дуго о, а єє у дуго $e$ од првијех времена: свсто М. 2. маме М. 297.

В. За женски род:

a) од основа на чисто а: всакаа (у сложеном облику) М. 477. скак М. 531. Ст. пис. 1, 8. Н. Рањ. 19б. всака Буд. 147. - јина Ст. пис. 1, 232. - нст. М. 329. - једина Ст. иис. 4, 449 - пнедма М. 281. индих М. 281. Д. Рањ. 22б. Јерк. 22. - к М. 30. 274. Н. Рањ. 16. Ст. пис. 4, 95. 152. 255. 5, 74. д. Раш. VІб. Град. дјев. 6. Здат. 1. Банд. 39. с доданим $j$ : кај Ст. пис. 1, 337. сложено са п: њека Ст. пис. $2,125$. Д. Рањ. IV. Град. дјев. 174. Злат. 3. и од раширене основе: кок Сав. стар. 4, 231. М. 240. 297. Н. Рањ. 16б. Ст. пис. 2, 136. 4, 206. 436. 5, 34. 74. Збор. 4. Злат. 76б́. Вран. жив. 9. Банд. 20. Андр. пут 415. сложено са пт: мекои М. 39. 33. неком II. 125. ннеков М. 418. Злат. 6. - клка М. 7. - колика Гуч. 48. и без слога ли: кога Ст. пис. 1, 86. - которл М. 14. Вран. жив. 105. - овака, с доданим j: овакај Ст. пис. 2,69. - ова Злат. 16. с доданим $j$ : шкхи М. 416 Збор. 8. Град. дјев. 81. с додапим $j$ п зи: овајзи Н. Рањ. 89б. - она Н. Рањ. 76. с доданим зи: онхұзи М. 117. с доданим $j$ : онми М. 275. Ст. пис. 2, 48. - сам M. 14. - така, с доданим жс, које у српском језику гласи ре: тахре М. 181. - томнк М. 239. с доданим j: толніан М. 238. Збор. 49б. п без слога ли: тока Ст. 
пис. 1, 86. - та Вран. жив. 64. с доданим зи: тазн М. 16. с доданим $j$ : таи М. 101. Ст. пнс. $3,122.4,60.177 .415$. Гуч. 33. с доданим жпс, које у српском језику гдасп ђе, а гдје гдје и је: таје Ст. пис. $4,49 .^{\prime}$

б) од основа на ја: всх М. 315. Пб. 109. сва М. 452. 772. II. 116. Ст. пис. 1, 104. 2, 104. Хект. 29б. Злат. 9. - моја Андр. 415. и сажето: ма Ст. пис. 2-151. 4, 163. 243. 5, 42. Злат 6. - си Стеф. 1. тако с раширеном основом и без а на крају као у неких супстантива (види напријед стр. 9) али и са $a$ : сих М. 22 . сї М. 49. с основом нераширеном долази истом XVI впјека, јамачно уз друге ријечи: са Зор. 15. с доданим $j$ : сај Хект. 8б. Злат. 4б. - твоја, и сажето: тва Ст. пис. 4, 248. Злат. 996.

у сложеном се облшку номинатив од прономина м (које долази у сложеном кжс) саставља с номиналним номинативом од адјектива без промјене, само се тада у српском језику сажима ах у дуго $a$ : пртүнста М. 241.

\section{ГЕНИТИВ ЈЕДНИНЕ.}

А. За мушки и средњи род. У основи крајње а кратко будући гласи у словенским језицима 0 , које се.у основама на ја мијења на $е$ предњега гласа ради. Наставак је sјa, у ком је од sј постало у словенским језицима га у једној ријечи $\varepsilon$ (чссо, ном. чһто) начнном довољно још не иротумачедпм, а крајње а кратко будући у словенским језицима гласи $o$, мјесто којега је у српском а кад кад и у староме словенском језику $a$ начнном који такођер још није довољно про-

' Гријешком је наштампано та је.

${ }^{2}$ Моде бити да је 2 постало од туда пाто се у sj изједначило $\mathbf{s}$ с гласом $\mathbf{j}$, па од $\mathbf{j}$ постало г, као пто би било $\mathbf{y}$ строүгх мјесто строүх: пто у странијем ријечима пма 2 као шхрхскекгин, вије поуздано да је у њшма 2 словенско (види Старине 3, 56. 57); пто се за пријелаз гласа $j$ у 2 помиње генит. мн. ги (Рад 17, 184), ту не Һе бити 2 постало од $j$, иначе бп било и гим мјесто им, него је 2 постало од $x$ па се преметвуло: ги од иг мјесто $u x$; а $c$ може бити да је постало што се $\mathrm{g} \mathbf{s j}$ изједначило $\mathbf{j}$ с гласом $\mathrm{s}$ : тако би се нашао и узрок за пшто се у -со није о промијенвло на $є$. 
тумачен:' наставаю дакле гдаси у словенским језицима го п za а у једној ријечи $c 0$ и $c a$.

Ca o на крају наставка допире у XV вијека: вьского Сав. 2. Стар. 4, 234. скакого М. 258. пного М. 15. 269. 534. єдНного Стет. 25. кого М. 269. когожде М. 4. ни ють когожде Сав. 1. оного Стет. 10. самого М. 75 . того M. 278. 306. 311. єго М. 5. 304. 307. него М. 289. 295. 305. 307. 315. него ПI. 14. 143. и окршено го М. 63. 64. 132. коюго М. 319. моєго М. 288. ихшего М. 260. 275. 285. 297. 307. 316. 387. 418. 423. 432. Пб. 59. 77. cero М. 5. 9. 10. II. 2. скоего М. 5. ткоего М. 9. чесо М. 253. 569. - ІІІто и XVI вијека има у једнога иисца: когогод Буд. 139. 148. чесо Буд. 122. јамачно ће бити из црквениjex кіњига.

Са $a$ мјесто о на крају наставка долази од првијех времена у српском језику:

a) од основа на чнсто $a$ : ксхкогх М. 4. 22. скхкогх М. 211. 307. Н. Рањ. 14. Буд. 11. Вран. жив. 42. Див. 24б. Јерк. 19. Гдав. 33. од рапирене основе: свакојега Ст. пис. 5, 77. - шиога М. 211. - истога Злат. 92. - єдога М. 81. 99. 240. сложено

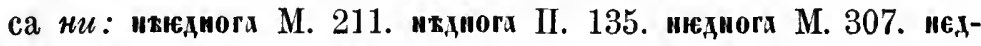
пога М. 346. ниянога М. 432. Ст. пис. 2, 302. ниједнога Г.ав. 41. - од, основе на, кад има само мушки род (тко): кога Сав. стар. 4, 231. М. 27. сложено са "к: нкког М. 81. сложено са

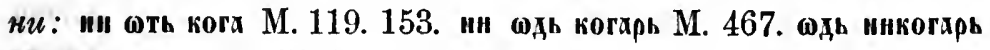
М. 473. никогар Н. Рањ. 79б. Ст. пис. 5, 181. Град. дјев. 68. Вран. жив. 95. никогаре Вран. жив. 4. 42." - од основе ка, кад има сва три рода, нераширене : кога М. 48. 101. с доданим pe: когаре М. 23. сложено с жи: ннкогаре М. 22. ин бдь когарь М. 258. пнкога М. 61. од основе раширене: конга М. 111. сложено са нт: "хкоєга М. 144. сложено са жи: инкостаре М. 46. у обдику од раширене основе пзједначује се єс предњим гласом, по том се оба о сажимају те нестаје раздике између та-

- Да би отпало о, пак се додало $a$, као пшто у српском језику бива у другпм прпликама, тепко је мислитп за то што се и у староме словевском кад кад налази $a$ мјесто о, види Миk.nomnha vergl. gram. III. crp. 64.67.

2 Гријешком уз номинатив пма ткога Мрн. 129. Ст. пис. 4, 405. у дну. 
кога облика и облика од нераширене основе: од XV вијека: коюгх М. 367. 369. кога Буд. 120. Злат. 1б. Андр. пут 392. сложено: нјекога Злат. 10. - окога М. 38. Злат. 38. с доданим зи: швогазн М. 522. с доданим $j$ : шкогм М. 251. Н. Рањ. 216. Ст. пис. 3, 247. 3бор. \&. Гуч. 118. - wњога М. 22. 37. 275. Град. дјев. 82. Злат. 74. с доданим зи: оногяз М. 117. с доданим $j$ : шноги М. 208. Н. Рањ. 24. Гуч. 243. с доданим $j$ и зи: смогандн М. 254. с доданим fe и ре окрњено: оногађер Банд. 285. - самогх М. 22. Каш. 81. Радн. 44. - тогх М. 13.19. 23. 81. с доданим fе (жде) и ре (же): тогиере М. 98. с доданим зи: тогми М. 81. с доданим $j$ : тоган М. 156 . Ст. пис. 2, 114. 5, 115. Град. дјев. 129. Гуч. 217. -- такогај Град. дјев. 76. с доданим $j$.

У поминалном облику налази се: XV вијека: опхки ПI. 167. XVII вијека: сама Радн. 23. 26. свакојака Радн. 84. којима п приличе номинални облици, налазе се тако још XVI и XVII вијека: селика Ст. пис. 1, 203. толнка Ст. пис. 4, 117. 456. гхкок II. 168. Мрн. 37. Каш. 14. 46. Јерк. 8. никакова Див. 13. каква Радн. 28. никаква І'уч. 24. Радн. 4. а по томе и у сложеном облику од ирвијех времена: таковаго М. 9. такомхаго М. 87. 278. - у сложіеном је облику бнло пи инаго М. 29.

б) од основа на ја: кьсегх М. 2. 47. 79. 138. 357. 458. всегх М. 219. скега М. 404. 479. 509. 516. Пб. 113. Ст. пис. 1, 21. Г'рад. дјев. 125. Гуч. 11. Вран. жив. 20. 27. 36. всега Вран. жив. 18. с доданим ђе и ре, окрњено: всеганерь М. 482 - до пегх М. 81. юљи иегх М. 211. без приједлога: мега М. 274. 301. нега М. 310. ІІ. 150. ІІб. 39. Н. Рањ. 17б. окрњено: га Сав. стар. 4, 231. М. 7. 13. 42. 46. 52. 117. Н. Рањ. 1226. - моєга М. 19. 373. сажето: нога М. 183. 193. 203. 274. номга М. 368. 369. 458. мога Н. Рањ. 80б. Банд. 5. - мхmега М. 21. 22. обојега Ст. пис. 1, 3. - сег М. 10. 23. 276. 395. II. 71. 118. Ст. ппис. 1, 21. 43. 103. 129. 4, 414. 435. Град. дјев. 85. Буд. 53. Вран. жин. 21. Крн. 11. Мрн. 23. 146. Јерк. 2ง. 50. с доданим $ђ е$, које гдје гдје гдаси и је: сегя Пб. 41. сега М. 453. с доданим $j$ : сеган М. 212. 510. Ст. пис. 1,60. Н. Рањ. 39. 796. Збор. 3. Ст. пис. 2, 380. 5, 57. 321. Злат. 766. Гуч. 28. Бун. 14. Каш. 91. с раширеном основом: снегх М. 87. 189. 571. ПІаф. pam. 1873. 96. с доданим j. спсган М. 105. 
Збор. 161б. - сконгх М. 233. сажето: скога М. 36. 112. 206. 286. П. 117. скошга М. 366. 370. Н. Рањ. 19. Злат. 79. - твоска М. 22. Гуч. 108. сажето: ткогх М. 30. 47. - чесх М. 53. 102. 211. 247. 458. 500. М. 49. 60. 97. Мб. 51. Ст. пис. 1, 39. 120. 133. Н. Рањ. 126б. 165б. Ст. пис. 2, 6. 237. 5, 221. 323. Град. дјев. 5. Хект. 10. Брн. 4б. Злат. 85. Гуч. 132. Вран. жив. 74. Орб. 3. Гунд. суз. I, LXVIII. Банд. 74. Бун. 22. Kaпr. 55. Ђам. 25б. Глав. 3. Андр. пут 285. сложено: печес М. 18. пичесх М. 477. 479. 3бор. 39б. Ст. пис. 4, 249. А. Рањ. 4б. Каш. 28. Андр. пут 203. с доданим ре: инчєсаре М. 20. Град. дух. 48. Банд. 266. Глав. 36. окрњено ничесар Ст. пис. 5, 61. Вран. жпв. 47. $\mathrm{XV}$ вијека налази се и у те ријечи г мјесто $c$ : чєга M. 467. али само на том ијесту, нити из других извора имам примера. Али и поменуто напријед код номинатива шта долазп мјесто генитива, и то не само кад генитив стоји мјесто акусатива, као у негацији (впди напрнјед стр. 154), него и иначе:

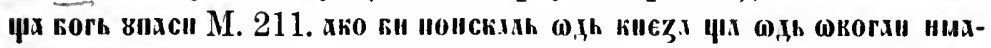
пїх М. 477. тако и иза приједлога: б,ц цих когь вкоип М.

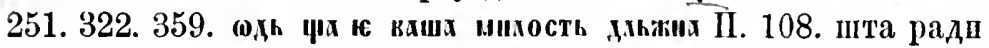
погубио овај (Мат. 6,2 8) Н. Рањ. 89б. од пта Ст. пис. 2, 99. 3, 27. 4, 441. 5, 175. Збор. 110. Д. Рањ. 7. 32. Злат. 35. $71 б$. ода шта Радн. 19. 34. птта радн Радн. 32. 77. од ништа Збор. 55. Ст. пис. 5, 83. Канг. 84. Јерк. 34. Андр. дев. 24. Радн. 52. ни ода піта Радн. 6. од ништар Брн. 4. Kani. 13.

Према основама̄ на ја налазп се $e$ мјесто 0 п у неких на чисто а XVI и XVII впјека: тега Ст. пис 4, 271. 281. 368. 406. 5, 69. 103. 262. А. Рањ. 98. Хект. 10б. Злат. 8б. 10. 43. 73б. 76. Андр. дев. 3. 59. 165. нач. 7. пут 52. 240. с доданим $j$ : тегај Ст. нис. 2, 362. Злат. 5б. 17б. - овега Ст. иис. 5, 262. Гуч. 122. 281. Вран. жив. 23. Орб. 336. Бугі. 26. Јерк. 15. Андр. пут 84. с доданим $j$ : овегај Вуч. 156. - онега Ст. пис. 5, 43. 104. Јерк. 15. 19. 27. тако и кад оспова пред крајњим самогласним има $\boldsymbol{\kappa}$ од краја $\mathrm{XV}$ вијека, али веома ријетко: кега Ст. пис. 1, 40. свакега Јерк. 39. - према томе и твега Ст. пис. 1, 40. од твога сажетога од твојеzа.

Окрњено, т. ј. без крајњега $а$, налази се само једап пут свега времена и то XV вијека: нашегь M. 405. 
У сло же н о облику кад к номиналном прпступа замјепнца у генитиву єго, њезнио се є изједначује крајњнм гласом $a$, до кога долази, те и само ностаје $a$, но том се оба $a$ caжимају у једно: тако је допнрало у XV вијек: стрлшннано $\mathrm{M}$.

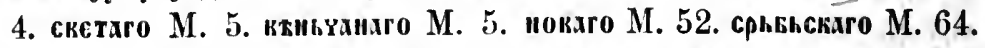

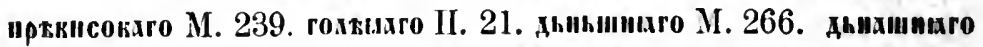
II. 17. данашимаго IІб. 44. чхсиаго М. 299. когохювикаго М. 406. старшаго IIб. 39. - IIто пма XVI впјека у једнога писца: светаго Буд. 134. виньњаго 39. то је из црквенијех књига. - А.ди од ирвијех времена из којих имамо нисанијех споменика овај је сложени облик пзједначен с прономнналпијем, мјесто -л- које реченим пачином постаје од -sє- имајући 0 , које се у адјектнва с основом на ја мијења на $c$ нредњега гласа ради, а у доданога је прономпна крајње о допирало у XV вијек: скттого М. 35. скетого М. 37. 134. 176. 265. 317. 358. 414. Пб.

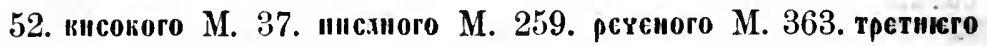
M. 84. 228. пожїско М. 182. али од самога ночетка мјесто крајњег'а о долаз п $a$ као п у прономина: а) кад је у адјек-

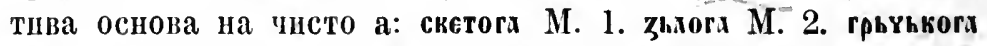
M. 5. Yucrora M. 23. воcutckora M. 24. cxakbsora M. 35. coprora M. 68. жикогх М. 79. ирьткога М. 79. вехинког М. 92. б) вад је у адјектива оспова иа ја: векисга М. 4. 5.24. кемьега М. 39. вељега Ст. иис. 4, 102. 348. shncmnera M. 22. дhnьmnera

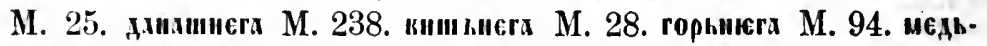

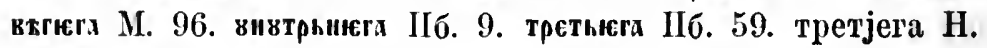
Рањ. 35. Град. дух. 26. Гуч. 72. Банд. 24. трећега Пос. 34. - оба адјектива кекни и трсти прелазнли су и међу оне с основом на чисто а одбацујући крајње шн: велога Хент. 23б. Мрн. 121. Радој. 18. третога Буд. 37. Вран. жнв. 13. Гдав. 101. пре.азнло је онамо п тантога Пос. 37. - А из онијех с основом на ја прелазило је њихово $e$ и к онима у којих је основа на писто а XVI и XVII вијека, али ријетко: давнега Зор. 19. певољиега Јерк. 54. осталега Јерк. 100. тужнена Јерк. 54.

Сложени овај облик налазп сс окрњен, т. ј. без крајњега самогдаснога, али нстом XVII вијека и тада само једнох: прндратог Андр. дев. 49.

b. За женски род. Основа је онака капва је у мушком и средњем роду, алп на крају добнва $\mathbf{j}$, које је остатак од sj, а то 
опет од smi (које внди код датива јед.); к такој основн са $j$ на крају иристуна паставак as као у имена, a $\mathbf{u}$ које добивају у том падежу женска имена с бестовом на а долази иза а од наставка, те се с њим а он с предњим $j$ слаже као у имена женских с осонвом на ја (внди стр. 16): тако је било од основа на чисто а: шноє М. 10. юnоє Стеф. 18. шное М. 530. тоє М. 530. од основа на ја:

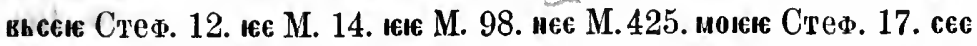
Сав. 3. - Али је у српском језику од првијех времена тај облик изједначен с номиналнијем, те онако ностаје:

а) од основа на чисто а : всхкс М. 22. 481. сваке М. 308. 531. Ст. иис. 1, 10. Буд. 25. Вран. жив. 39. Гдав. 40. и од раширеке основе: вьскоє ${ }^{1}$ М. 2. скиою П. 7. СТ. пис. 4, 421. Д. Рањ. 3. - пнє М. 18. - исте Злат. 90б. јисте Вран. жив. 3. - једне Злат. 61. педие М. 410. пжли ІІ. 19. 132. нидне Ст. шис. $2,215.429$. - од основе ка раширене: које Град. дух. 62. сдожено: инкоюре М. 13. инкосре М. $16.20 .^{2}$ сажето: ке Ст. пис. $2,56.4,159.261 .5,217$. с доданпм $j$ и зи: кејзи Ст. пис. 2 , 377. од исте основе нераширене, сложено: веке Ст. нис. 2, 336. Д. Рањ. 131б. - ове Н. Рањ. 165. Злат. 18б. с доданим $j$ : овеј Град. дјев. 69. с доданим $j$ и зи: овејзи Ст. шис. $2,179 .^{3}$ - шкаке М. 545. никакве Град. дјев. 64. - оне Вран. жнв. 24. с доданум $j$ : юнсн II. 45. с доданим $j$ и зи: онејзи Ст. пис. 2, 33. - таке Злат. 20. - те М. 64. Ст. иис. 4, 191. с доданим зи: тези М. 60. с доданим $j$ : теј Ст. шис. 2, 194.

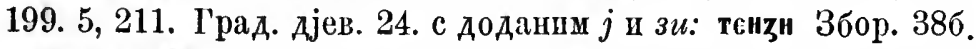
- толике М. 216. избацивши ли: токе Ст. пис. 1, 22. - Неке су долазнле и у сложеном облику: такые М. 58. таковынє М. 81. икокиє Стар. 4, 234. пньторї̈ М. 18.

б) од основа на ја: кс: М. 13. 369. 487. все М. 10. ске М. 295. - є М. 274. је Ст. иис. 2, 1С4. Гуч. 180. mе М. 98. иє М. 225. 274. ње Ст. пис. 1, 221. 222. 2, 102. Н. Рањ. 16б. Збор. 47б. Град. дјев. 70. Зор. 12б. Злат. 2б. Гуч. 18. Гунд. суз. I, XLIV. Банд. 9. Андр. пут 160.' - мое М. 9. мок 89. сажето: ме

' Могло би бити и према стар. слов. кьсакоњ, али вшди ту ријеч и у другим падељима.

2 IIorpjeпка he бити шпкоре М. 13. 14.

${ }^{3}$ Мјесто доданог $j$ налази се и ји: овеји, такеји Ст. пие. $1,60$.

- Ilрем да је тако од шрвијех времена, онет се налази на крају 
Злат. 18б. - имшє М. 5. - се Ст. ппс. 1, 48. с доданим $j$ : сеј Ст. пис. 2, 417. 446. Злат. 40. од исте основе раширене: спє М. 13. 23. 141. - ткок М. 91. сажето: тве Злат. 9. - троје Буд. 3.

У сло ке н ом облику генитив замјенице єе, српскп єке, прнстушајућп к номаналном облику губи први слог свој: кад је у адјектива основа на чисто а: скетню М. 5. догрнє Стеш. 17. срыпские М. 104. тенхне М. 110. вгрнскїе М. 335. хрыные М. 538. кад је у адјектпва основа на ја: дохинєе - У пошљедњих се оба крајња кєє сажнмају у једно дуго: домию; па је из овнјех крајње є прешло и у оне прве мјесто њихова мє, и то од првијех времена: грняьске М. 4. мориске М. 4. срнвске М. 45. ноихвхьске М. 217. хвнске М. 249. кад кад стоји и ке мјесто с (као и у другим прплпкама): хунске М. 283. вос.иChe M. 470 . арвге М. 482.

\section{ДАТИВ ЈЕДНИНЕ.}

А. За мушки и средњ род: основа до крајњега својега a, које кратко будући у словенским језицима гласп 0 , па у осповама на ја прелазп у $e$, добнја sma, од којега отпада $\mathbf{s}$ у словенски језицима: од оспове тако састављене постаје овај обдпк као у имена мункога рода у којих је основа на а (внди панрнјед стр. 21. под II. А. 2):

а) од основа на источ а: ксакоия М. 306.545 . вксакомя М. 517. касакоцоү Пбб. 35. suachomu М. 279. скакомв М. 315. 524. Збор. 12. Ст. пис. 4. 194. Зор. 37. Буд. 128. Гуч. 23. Крн. 2б. Гдав. 5. - пстому Мрн. 154. - једному А. Рањ. IXб. сложено : ихдноия II. 18-19. пєдномя Пб. 114. нидному Д. Рањ. 75. - од основе ка, кад има само мушки род: комоү М. 13. Мик. 59. слодено са пs: нєком М. 31. њекому $\mathrm{H}$. Рањ. 90. сложено са ни: шнкомоүре М. 6. Н. Рањ. 41. 49б. Град. дух. 87. Вран. жив. 93. Банд. 21. окрњено: пикомоүрь М. 338. Н. Рањ. 31. Ст пис. 5, 229. 318. Хект. 26. Зор. 13б. без pe: никому Ст. пис. 4,455 . сложепо са $u$ : нкомур (али се не

$\mathrm{XV}$ и XVI вијека а једном и XVII вијека: њеје Ст. пис. 1, 20. 38. 40. 46. 54. 76. 83. 160. 36ор. 56. Хевт. 28. 31. 3ор. 63. 72. Буд. 83. 84. 153. Мрн. 144. - IIIто има svojee (не svojeje) Буд. 5. tvojee Вран. жив. 12. našee Врав. жив. 4. пјее Врав. жив. 5. за цијело стоје два ее за једно ауго. 
находи да је икомур допустио) Град. дјев. 125.1 - од основе ка, кад има сва три рода, од основе раширене, сажето: кому Ст. пис. 2, 84. Град. дјев. 41. - овому Гуч. 73. с доданим $j$ : юконвн М. 102. - оному Злат. 34б. с доданпм зи: юмомузи М. 146. с доданим $j$ : юномвн М. 267. Збор. 2. Ст. пис. $3,371.4,349.5,187$. - самон М. 22. Ст. шис. $3,380$. 4, 190. Гунд. пс. 18. Андр. дев. 18. Радн. 15. - томоү М. 230. Вран. жив. 53. с доданим $j$ : томв" М. 107. Ст. пис. 3, 21. 4, 161. 328.

У номиналном облику додазп: "ткакоү М. 91. окхкокв М. 215. такокв ПI. 36. тохикоу Саз. 8. и од XVI вијека: саму Брн. 57б. Град. дјев. 34. Радн. 7. 15. 26. 31.

б) с основом иа ја: кьскосмя М. $203 .{ }^{2}$ сажъето: всакоюмя М. 368. 376. - ксем М. 209. 487. Вран жіив. 18. кисємв М. 365. скем(в) М. 285. скемв М. 413. 511. Н. Рањ. 13. Ст. пис. 2, 445. - ємоү М. 5. са $н$ и без приједлога: иєм М. 107. немх М. 211. 510. Злат. 18б. без првога слога од ирвијех времена: моү М. 6. 17. Н. Рањ. 15. с доданим зи: мвзн М. 474 . - моємя М. 2. Вран. жив. 44. сажето: момв М. 108. 385. 3ор. 39. Гуч. 103. Банд. 22. Андр. пут 18. - пашемв М. 320. - обојему Мрн. 155. - своєив М. 547. Град. дух. 71. сажето: сконв М. 461. скоюмв М. 461. Н. Рањ. 65б. Збор. 36б. Гуч. 4. семоү М. 5. с доданим $j$ : сємвн М. 207. Збор. 29. с доданим зи: семвъи М. 55. од исте основе рашине: снешоү М. 100. 111. 272. 278. 436. 534. с доданим зи: спєнвъи М. 180. - ткосмв М. 22. Ст. ппг. 2, 199. сажето: тком М. 35. Н. Рањ. 38. - чему Ст. ппс. 4, 308. 5, 195. Канг. 51. сложено: пиченвже М. 156 . генитив чєсо узима се за основу другим падежима, тако ш овом: хссомоү Стет. 28. пичесонв М. 213.

Према основана на ја налази се $e$ мјесто о п у основама на чисто а од краја XV вијека: тему Ст. пис. $1,46$. 233. Ст. пис. 4, 249. Ђам. 5. Андр. дев. 53. овему Ст. пис. 5, 8. Буд. 93. Мрн. 80. 124. Андр. нач. 3. онему Андр. дев. 1. нат. 22. пут 33. једнему Мрн. 48. - тако и од сажетога твому: твему Мрн. 19. 28.

' Грјепюом: твому Ст. пис. 4, 400. у дну. Мрн. 89. нитьому Ст. пис. 4, 333. у дну.

2 Гријешпом всаконм М. 567. 
Окрњено и изједначено с локативом налази се од XV вијека: вьсєюь II. 103. пашемь II. 104. 120. кхшемь ПI. 113. 133. 167. твоњи II. 143. скакоми М. 420. нь немь Стар. 4, 142. једном Н. Рањ. 208б. мом Ст. пис. 1, 63. 2, 94. 397. 466. 474. 5, 59. 65. 298. Андр. дев. 19. твом Ст. пис. 1, 247. 5, 33. 87. Злат. 9. Андр. дев. 135. свом Ст. пис. 5, 18. 65. папем Град. дјев. 16. пстом Град. дјев. 9. дух. 71. Д. Рањ. 38б. ПІос. 36. Вун. 35. ниом Д. Рањ. 3б. Андр. дев. 29. том Злат. 52. ком Ст. пис. 5, 35. Гунд. пс. 14. сваком Див. 11б.' њеком Бун. 8. толиком Ст. пис. 4, 489. ванем Бун. 51. од сажетога: мем Злат. 63. - '’ако је и уз неке прнједлоге још од XIV вијека: по томкє

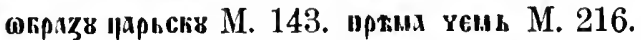

Тако окрњеном опет се додаје на крају $e$ од XV вијека: исис М. 494. томе Ст. пис. 1, 36. једноме Ст. пис. 1, 184. твоме Мрн. 36.

У сложе ном облику датив од ироломина ємон прнступајуһи к номинадном облику пзједначивао је своје є с крајњим гласом његовијем, те је бндо догроүормоү, послије се оуоү салимало у оү: кториюомоү М. 91. нли прелазило у оо, које се сажимадо у о и тако остајало и кад се адјективу основа сврнгје на ја, те се пा у напим старијим књигама налазп: имақтнюоюү М. 48. Али је овај сложени облик као и генитив у српском језику јоп од првијех времена изједначен с прономпналпим тако да мјесто оүоү или реченога о, које би стајало и код основа на ја, има $о$, које се у осповама па ја мијења на $e$ предњега гдаса ради: а) кад је у адјектива основа на чисто а: двкрокьчькомв $M$. 7. пракомв М. 7. похтеномоү М. 157. верному Ст. пис. 4, 344. беспаметному Град. дјев. 10. худому Здат. 14. небескому Гуч. 5. големому Вран. жнв. 45. славному Мрн. 84. другому Мик. 175. божьанственому Радн. 73. - б) кад је у адјектива основа на ја: кемемоү М. 5. третїєеоү М. 48. мхадвншемя М. 48. садашпенв М. 240. поскедпенв М. 240. кохємоү ПІ. 23. старнемв Збор. 12б. Вран. жив. 73. Банд. 80. најдражему Злат. 11. третјему Н. Рањ. 27. - Адјектива кекин и трєтни долазе и без иј прешавии међу основе на чисто а: ведому Ст. пис. 1, 215. Хект. 22. Мрн. 67. третому Ст. нис. 1, 206. Глав. 4.

' ПІтампарска је погрјешка: сваком Ст. пис. 4, 337, 
Од XV вијека додази сложени облик без крајњега самогласнога, изједначен с локативом: XV вијека: кекєнь I. 36 (два пута). речєнонь ІІб. 63. 69. 70. XVI вијека: вишњем Ст. ппс. 4, 404. 5, 24. 65. вјечном Ст. пис. 5, 80. искрњем 13. поштеном 312. худом 33. човичком Ст. пис. 4,484 . реченом $A$. Рањ. 58. ангеоском Град. дјев. 19. беспаметном 14. 22. грешном 73. земалском 9. небеском 22.26 . осталом 9.10 . 17 . божанственом Град. дух 76. духовном 75. божјем Брн. 20б. брзом Злат. 16б. ведиком 52. коњском 16б. навидном 10. нејаком 16. 27. оићеном 11. XVII вијека: скиком М. 5t0. вишњем Бун. 4. светом 47. почтованом Ђам. 2. правом Мик. предгов. вјечном Андр. дев. 122. ъубеж.ьивом Андр. дев. 166. рајском 175. вирном Радој. 30.

Тако окрњеном додаје се на крају $е$, и то још XIV внјека, али у примјеру једином тога времена, те може бити погрјенка: двкровьннянкомє ІІб. 45. мало је поузданије XV вијека, али опет само један примјер: рстєпонс Пбо. 69. XVI вијека опет само један примјер: убогоме Н. Рањ. 39б. и у вему може бити погрјешка, јер је погрјешка у самом мјест гдје се находи: „разломи дачному крух твој, п убогоме годне (мјесто: убогога кога гоне) уведи у кућу твоју (Иса. 58, 7).

Б. За женски род: основе, којима је крајњи глас као у мушком роду, добпвају на крају smi, од чега у словенским језицима остаје само $j$, иза тога гласа наставак аi, који би се сажео у i, отнада:

a) с основом на чисто а: всккои М. 563. с доданим зи: свакојзи Ст. пис. 2, 75. 3, 437. 4, 287. 5, 175. Гуу. 174. - њекој"Ст. пис. 5, 159. - овој, с доданшм зи: овојзи Ст. шис. 3 , 208. 4, 121. - оној, с доданим зи: онојзи Ст. пис. 2, 198. -нидној А. Рањ. 7. 19. - свакојакој Вран. жнв. 71. - таковој Јерк. 9.

б) с основом на ја: кьсен М. 47. Пб. 20. са т мјесто є ва.ьа да невјештпном писарском: кски М. 27. кьски М. 41. 54. скен М. 363. - ен Сав. 5. пен Стар. 3, 224. 309. - моен М. 30. 225. - сєи, и са т мјесто с: сти М. 13. и од раширене основе: спен М. 13. - скоен М. 54. Пб. 22. - твоє॥ М. 22. твоє॥ ПІ. 25. 144. - Али још од XIII впјека основе су се на ја изједначиле с онима на писто а: ксон М. 25. 174. 300. 383. 413. 
кьсон М. 49. всош М. 66. скон М. 280. 420. 470. Шб. 117. Д. Рањ. V. - вашон II. 14. с доданнм зи: вашојзш Ст. пис. 3, 230. 4, 125. - шюш М. 225. пон М. 387. Пб. 95. шн М. 251. 358. П. 57. јој Ст. пис. 2, 74. Злат. 7б. са $н$ и без приједлога: пон М. 419. 503. П. 30. Стар. 1, 220. Ст. пис. 2, 100. Каш. 91. с доданим зи: њојзи Ст. пис. 5, 188. Гуч. 120. - којој, с доданим зи: којојзи Ст. шис. 2, 79. 117. 225. 3, 71. А. Рањ. 35. и сажето : кој Ст. пис. 5, 138. 317. Каш. 83. Јерк. 50. - моюи М. 228. Пб. 58. с доданим зи: мојојзи Ст. пис. 2, 69. 100. 3, 182. 4, 299. А. Рањ. 36. Злат. 95б. и сажето: мон М. 545. - панон М. 190. Пб. 117. нхшоши М. 177. с доданим зи: нашојзи Ст. пис. 4, 351. 5, 167. - својој, с здоданим зи: својојзи Гуч. 168. твојој Град. дух. 21. с доданим зи: твојојзи Ст. пис. 2, 194. 5, 153. А. Рањ. 56б. сажето: твој Ст. пис. 5, 143. - свачпјој Град. дјев. 123.

Налази се кад кад п без крајњега $j$ : тако још XIII вијека: вьсе М. 28. према томе и нослије: јо Злат. 26б. 456. 46б. жојо Див. 5б. Види стр. 167.

XVI и XVII вијека долази по један пут и у номиналном облику : своји Злат. 88. мјесто својој у слику; тако: рече и (мјесто јој) Вран. жив. 59.

Налази се и пнструментал мјесто датива: души мом ,Ст. пис. 5, 51. мјесто мојој. Видй и докатнв.

У сложено м облику кад к номналном прнетуна датив од замјенице єи, отпада, му є: иртскетьн М. 5. срьпьсыни М. 136. христїхијсн М. 244. пртүнстьи М. 569. п без промјене грденијех гдасова: ұстьсксн М. 17. рашьктн М. 47. и без крајњега $j$ : понорьске М. 47. које бп могдо бити и у номиналном облику, али стоји до примјера који је пред њим споменут.

Ади је у српском језику овај сложени облик још од ирвијех врехена замијењен прономиналним тако да мјесто његова завршетка вн кад је у адјектива основа на чисто а, п мјесто ни кад је у адјектива основа на ја, додази као у прономина $о j$, чему се уз основе на ја мијењало о на $e$ : а) кад је основа на чисто а: скетон М. 6. грхдьскон М. 7. 25. прьвон М. 14. двкровьуькоІ М. 29. чрьнон М. 561. срькьскон М. 142. помбрскон М. 143. пртунстоп М. 159. дрвгоп М. 215. хнпмхискон М. 563. веговој Збор. 8Зб. Здат. 62. небогој Ст. 
пис. 4, 261. - б) кад је у адјектива основа на ја: кожнєи М. 10. вожнен II. 18. А тақо су у самијех прономина основе на ја изједначене с онима на чисто а, дошло је њихово ој у овом облику и у адјектива у којих је основа на ја: кожнон M. 223. домиоп II. 155. старшщоп М. 545. вељој Ст. пис. 2, 76. 4, 33. трєтнои Збор. Зб. ч.ловечјој Ст. пис. 3, 155. дивјој Бун. 16. најлипшој Ст. пис. 1, 117. бољој Буд. 15. мањој Д. Рањ. 6б.

Налази се кад кад без крајњега $j$ : вожиє М. 11. вожк М. 28. то би могао бити пн номинални облик (внди напријед стр. 23-24), али пма и кожно М. 327. а према томе и послије божјо Ст. пис. 4, 219 (у слику). очино Див. XVI. Види стр. 166.

Сложеном се облику додавало зи од XVI вијека: другојзи Ст. пис. 2, 42. славнојзи 78. вичнојзи Ст. пис. $3,441$. грјешнојзи 393. схртнојзи 94. тмастојзи 173. бистројзи Ст. пис. 4,140 . женскојзи 176 . морскојзи Ст. пис. 5 , 57. вјечнојзп д. Рањ. 53. љувенојзи Злат. 49. жеговојзи Гуч. 22. Гунд. пс. 44.

Налази се и инструментал мјесто датива: људском Ст. пис. 5, 55. мјесто ьуд"кој. Внди стр. 166.

\section{АКУСАТИВ ЈЕДНИНЕ.}

Постаје као у имена истијем наставком, који се на исти начин саставља с основом; само је за средњи род био наставак $t$, қоје је стојећи на крају отпало као и $\mathbf{m}$ у имена.

А. За мушки род: но што је наставак отпао, једнак је тај облик с номинативом, код кога п примјере види. Од основе ја био је овај облик и кад није сложена са жє: како крајње а у словенским језицима слаби у т, које иредњега $j$ ради прелазп у ь, кад би акусатнв стајао без прпједлога сам о себи, тада се слијевало јь у $u$, те је гласио н М. 4. а кад стоји иза приједлога те се има на што наслонити, тада од јн бива друго: бнва исто ппто бива у имена: $j$ се са предвим сугласним, а то је $\boldsymbol{t}$, које се умеће између приједлога и овога прономина, слијева у један глас, у ъ, које се писало ", те је иза њега и ь остајало: тако је свега времена: за иь М. 162. ПІ. 157. за ш Ст. пис. 5, 183. Туч. 8. Мрн. 107. мимо ш 3бор. 38. Зор. 37. Крн. 3б. их ши М. 427. Ст. пис. 2, 70. Н. Рањ. 154б. Хект. 18. Злитт. 13. Чубр. 10б. Гунд. суз. II, 
XXVII. нада ж Н. Рањ. 156. ш шь М. 344. 36ор. 4. "о "ь 3бор. 39. пода нь М. 439. ирида њ Ст. пис. 4, 456. Г'уч. 301. Вран. жин. 34. Банд. 35. про њ (т. ј. кроза в) Бун. 23. у в Н. Рањ. 77. Ст. пис. 5, 317. Хегт. 17б. Зор. 29б. І'уч. 30. Bран. жив. 98. Гунд. суз. II, XXVI. уза њ Ст. пис. $1,46$. Збор. 4. Д. Рањ. бб. Злат. 17б. Орб. 112. - Али кад је без приједлога, замијењен је акусатив ове ријечи у српском језику још од првпјех времена генитивом, и.то не само кад стоји за жнво што, кад се и у других ријечи замјењује акусатив генитивом: єго М. 16. Стеф. 13. го М. 64. 132. га М. 7. 13. 42. 52. 53. 87. 147. 183. Ст. пис. 1, 72. Хект. 25б. Здат. 56. њега Ст. нис. 4, 219. него и кад стоји за пाто мртво: го М. 63. гх М. 64. 108. 117. 189. 215. 565. 322. 359. 387. 394. Ст. шис. 2,60 . шега ПI. 11. 92. Иза приједлога премда се држи акусатив једнако (види мало више), ипак долазп и генитив мјесто њега од XIV вијека: на пєь М. 88. за пєех М. 147. ПІ. 99. шх пег М. 295. II. 128. 145. Н. Рањ. 87. Ст. пис. 4, 263. 5, 194. Kauı. 58. Глав. 42. у њега Ст. нис. 5, 3. Каш. 98. Пос. 35б. уз вега Ст. пис. 4, 485. под вега Ст. пис. 5, 140.

Од основе та акусатив ть, по што је нестало гласа ь, долази и без доданога $a$ иза приједлога, на који се наслања: ва т Стар. 3, 316.

Од прономпна који у ном. јед. гласи тко, нема акусатива, него се замјењује генитивон.

У сло жен о м облику саставља се акусатив од прономнна ॥ с номина.лни обликом као у номинативу, код кога и примјере впдн.

Б. За средњи род: по пाто је наставак отпао, једнак је тај облик с номинативом, код кіога и примјере впди. Од оспове ја палази се тај облик и кад није сложен са же и допире у XV вијек: є М. 4. ю М. 499. с приједлогом:

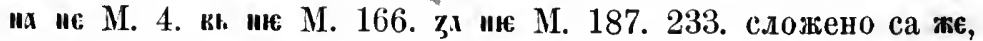
које у сриском језику гласи $p e$ : по коми ки с, сре хокете М. 42. с уметшутим ва међу є и ре: по искаре М. 20. А послије га нема, него мјесто акусатива долази од XV вијека у те ријечи генитив : гх (т. ј. сребро) II. 105. (катметкзо) М. 245. (срдашце) Ст. пис. 2, 45. 46. (пме) А. Рањ. 122б. (бдаго) Буд. 108. (тијело) Банд. 94. (ухо) Каш. 49. (пме) Каш. 110. (добро) 
Глав. 79. вега (т. ј. слово) Ђам. 18б. а иза приједлога замјењује се акусатив средњег рода акусативом жушкога рода од краја XV вијека: у в ('т. ј. море) Ст. пис. 2, 354. (гнијездо) Збор. 8. (дрво) Ст. пис. 5, 16. (зрцало) Град. дух. 19. (море) Гунд. суз. III, LVI. за в (т. ј. днјете) Ст. пнс. 4, 316. на ж (грдо) Ст. пис. 4, 301. (дјевство) Град дјев. 25. 30. (свићало) Хект. 33б. (небо) Орб. 265. XVII вијека додази и генитив мјесто акусатива пза пријед.лога: у њега (т. ј. краљевство) Радн. 55. - Акусатив ове ријечи средњега рода додази XV вијека мјесто акусатива мушкога рода: $є$ (т. ј. тестахенат) М. 496. Пб. 128.'

Сложени је акусатив средњега рода једнак с номинативом, код кога и примјере види.

В. За женски род: у свијех је као у имена, осим два, код којих hе се споменути: a) с основом на чисто а: кьскио Стеф. 13. всакв М. 308. касккв М. 309. 315. сваку Ст. пис. 1, 41. Гуч. 60. Глав. 5. од исте основе рапирене: свакоју д.Рањ. 186. - једину Ст. пис. 4, 306. - једну, сложено: мддн П. 63. нидну Ст. пис. 2, 323. Д. Рањ. 76. идну Ст. иис. 2, 371. какв М. 56. - кодику Град. дјев. 26. - ку Н. Рањ. 89. Ст. пис. 2, 68. 124. 154. Ст. пис. 4, 74. 90. 254. 306. 5, 34. Град. дјев. 35. Злат. 6. с доданим $j$ : куј Ст. пис. 1, 43. сложено са пв: некв П. 87. Ст. пис. 2, 70.4, 221. Д Рањ. 36б. Град. дјев. 73. Злат. 14. Андр. нач. 4. од исте основе раширене: коју Ст. пнс. 1, 101. Н. Рањ. 21б. Ст. пис. 4, 230. Радн. 27. сложено са ит: њекоју Ст. пис. 2, 197. никоју Ст. пис. $2,320$. сложено са жи: ин за коюре М. 274. - ову, с доданим $j$ : шввн М. 210. Н. Рањ. 26б. Ст. шис. 3, 434. 5, 122. Град. дјев. 76. Гуч. 154. - ону М. 7. с доданим $и$ : шивзн М. 23. с доданим $j$ : онви М. 177. с доданим ђе: шивге М. 311. юпвяе М. 313. - оваку, с доданим ђе п ре, које се и крњи: овакуђер Град. дјев. 105. - онаку, с доданим Ђе: онакгє М. 311. с доданим pe: онакврє М. 313. - таку с доданим $j$ : такуј Ст. ппс. 5, 135. тоү Сав. 5. М. 61. Вран. жив. 7. с доданим жпє, које у српском језику гласп ђе: торалє Сав. 10. тоүге М. 113. туђе Н. Рањ. 97б. с доданим зи: тоңз М. 98. с доданим $j$ : тоүи

1 Kапиһ грам. 73 ставља за акусатив тој ријечи у три рода: њега, њу, оно. 
М. 167. туј С’. пис. 1, 43. 3, 97. Град. дјев. 73. Гуч. 208. таку Ст. пис. 4, 308. с доданим ђе, које тдје гдје гласи и је: такује Ст. пис. 1, 130. с доданнм : тмкон Сав. стар. 4, 231. Ст. иис. 2, 314. томнкоң М. 19. с доданнм $j$ : томнівн М. 261. избацивни ли: току Ст. пис. 1, 8. Хект. 10. - б) с основоз на ја: кьсв II. 143. ксв М. 493. касв ІІб. 34. сву Ст. пис. 2, 28. Зор. 21. Злат. 3б. Вран. жив. 14. - вашу Злат. 85. - 10 3бор. 9. Ст. инс. 2, 178. 4, 274. Д. Рањ. 137б. Хект. 43. Злат. 47. Гуч. 261. иза приједлога: њу Збор. 1. Д. Рањ. $137 б$. 3лат. 75. Врап. жнв. 9. тако и без ириједлога: њу Н. Рањ. 60. Збор. 91. Ст. пис. 2, 61. Злат. 10. Вран. жив. 8. Каш. 89. c. додания $j$ : њуј Ст. пис. 1, 85. у те рнјети од XVI нли XV вијека често долази генитив мјесто аюусатива: да hе је учииити цесарнцу Стар. 1, 222. кад би је видно Ст. пис. 4, 274. хоћете заплат' је Ст. пис. 4, 418. кад му је ставиш Ст. пис. 5, 196. њему је поклонив Д. Рањ. ІХб. змије је млијеком хранише Д. Рањ. 45б. јере би је настанио Град. дјев. 150. становито бисте је имали Ірад дјев. 101. виђу је Здат. 14б. с којом је растави Злат. 14. ако је узимат' буде Гуч. 29. којијем је је заслијепио Андр. пут 186. једа је пристраши Андр. пут 394. - моју, и сажето: му Ст. пис. $2,465.4,444$. А. Рањ. 4б. - обоју страницу Мрн. 32. - своју, и сажето: сву Ст. пис. 4, 429. - твоју, и сажето: тву Ст. пис. 4, 433. - хню М. 424. чню М. 323. 342. 371. 414. нн zі чнюре М. 274. - од основе сја раширене: сню, с додашим зи: спюзи М. 158. с доданим j: сшюн М. 102. од XIV внјека додази од нераширене основе: съ Ібб. 34. Ст. пис. 1, 48.68. 182. Мрн. 185. с доданим зи: свзи ІІб. 34. с доданим ј: суј Ст. пис. $1,46.81 .65 .2,445$.

У сло женом се облику апусатив прономина ю састављао с номиналним обдиком без пкаке промјене: пртинствю М. 9.' А.ли у срлском језику од ирвијех времена долазе оба крајња сдога оүю сажета у у: скетоү гороү М. 6. дроүгоү М. 167.

\section{ВОКАТИВ ЈЕДНИНЕ.}

Замјењује се номинативом јед. и у прономина и у адјектива у сложеном обдику.

1 Погрјешке су: срьдьухиою М. 292. пожхствикю М. 260. ьожАCтвеню М. 275. 


\section{ИНСТРУМЕНТАЛ ЈЕДНИНЕ.}

А. За мушки и средњи род: основа се пири добивајући на крају $\mathbf{i}$, које се с њезинијем крајњим а слијева у $\mathbf{~}$ пред којим се кмијења на $u$, а к се у основама на ја предњега гласа ради мијења на $u$; за тијем додазн наставак као y имена:

a) с основом на чисто а: всхитмь М. 265. всаинмь М. 305. всхинемь М. 367. ксициеки М. 457. сзартмь М. 455. ПГ. 46. свацијем Гуч. 1. 91. Ђам. 16. 19. п без промјене грленога гласа од XV вијека: всккем М. 308. свакијем Гуч. 99. 119. 156. 300. Банд. IX. у сложеном облику: ксхкниь М. 5. од раширене основе од XV вијека: скхкони II. 36. ксхконмь II. 40. - нньмь М. 14. нинемь М. 485. Ст. пис. 2, 376. 5, 14. - истијем Гуч. 22. Андр. пут 40. - єдиикм. М. 22. - єІитми М. 52. єдиниь М. 248. єдинемв М. 498. Н. рањ. 44б. Ст. пис. 4, 335. 5, 22. Д. Рањ. ІХб. Град. дјев. 16. Орб. 5. инедниемь М. 509. Банд. 7. - од основе ка, кад има само мушки род, у сложеном облику: книь М. 297.' сложено са ни: инкынь М. 144. у прономиналном облику без промјене гласа $\kappa$ : кијем Ст. нис. 5,9 . клекнути пред кијем Мик. 194. држати с кијем год Мик. 86. с.дожено са ни: никпјем Ст. пис. 5, 17. - од исте основе, кад има сва три рода, такођер у сложеном облику: сложено са ни: инкниь копцемь М. 27 . и без ни: ким Ст. пис. $4,392$. 420. пут, ким је кум куму сламу крал 3ор. 65б. начнн, ким бисмо небеса напуњали Г'рад. дјев. 21. од раширене основе од XIII вијека сложено са ни: ннконме М. 23. сложкено са "в: нккони М. 59. од основе нераширене у шрономиналном облику без промјене гласа $к$ : кпјем Ст. пис. $2,427.3,407$. 4, 36. 159. 392. 5, 10. 336. ономузн, с кнемь гокорншь Збор. 24. начин, ьнјем би се плодили Град. дјев. 21. кијем 3лат. 36f. 74. - каквим Ст. пис. 2, 49. каквијем Андр. нач. IV. - комнцнемь М. 366. Гуч. 157. колицим Ст. шис. 1, 231. Брн. 59. бвтиь П. 52. бкемь М. 230. 238. 402. бвиемь М. 380. Пб. 92. Див. ХІІІб. с доданцм зи: овємии М. 188. - опнемь М. 394. Град. дјев. 4. опемь Пб. 105. с доданим зи: шнгмьзи М. 112. с доданим ђе и ре: онимђере Н. Рањ. 155б. - самијем Андр.

' С промјеном крајњега $м$ у. 
нач. 19. - тьи М. 134. тнешь М. 417. Ст. пис. 4, 178. 204. 233. Злат. иредгов. 2б. Іунд. суз. III, LXV. тим Буд. 28. Вран. жив. 11. с доданим зи: тьмьзи М. 94. с доданим Ђе и ре: тьuнrepe Г. XV. 275. 283. М. 270. - тминсин 3бор. 88. Град. дух. 81. Гуч. 124. тацих 3лат. 23б. тлюень Мат. 38. без промјене грленога г.иаса: таким Каш. 46. такијем Андр. дев. 5 . 114. онакијем Андр. нач. IV. - толицим Ст. пис. 1, 231. Брн. 59. 3лат. 9. толицијем Ст. пис. 4, 9. І'рад. дјев. 15. Гуч. 124. и без промјене грленога гласа: толикијем Ст. иис. 4, 263.' у прва времена у номиналном облику: токнком Д. 121. -

б) с основом на ја: двојим Хект. 27. - имь, иза приједлога са $н$ : шни М. 146. Н. Рањ. 17б. и без приједлога: ниць М. 192. 284. 305. 343. - мојим Зор. 6б. - обојим Ст. пис. 1, 76. - симь М. 13. - својим, и сажето : скиь М. 286. твојнм Андр. пут 28. и сажето: твим Ст. пис. 4, 463. чнмь М. 13. Буд. 4. сложено: ничимре Зор. 29б. 一 од основе на ја. која у овом облику одбацујуһи $j$ прелази меלу оне на чисто а јон у старом словенском језику: кския М. 134. всинь М. 255. ксиємь М. 312. скисми М. 106. скемь М. 296. скти П. 65. свијем Н. Рањ. 31. Ст. пис. 2. 444. 4, 178. Град. дјев. 24. свим Ст. пис. 2, 122. Зор. 11б. Вран. жив. 11. Банд. 116.

Све основе па ја прелазе у овом облику међу оне на чисто а, осим инструментала щмь, и то од XIII вијека: ихшень М. 30. тако каштмь II. 81. 167. нашемь М. 137. 230. 340.

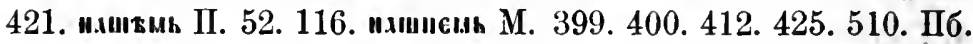
94. пхшннен М. 458. монеми М. 461. 3бор. 10. Ст. пис. 2, 447. Гуч. 142. Андр. дев. 76. сконємь М. 311. 461. Пбб. 92. скосмь М. 380. скоюи М. 421. Пб. 105. својијем Ст. пис. 4, 144. Град. дјев. 45. Гуч. 4. Див. 30. IІос. 15б. твојнјез („tvoiem\&) Н. Рањ. 18. Ст. нис. 2, 469. Див. 8. тронем закононь Збор. $5 б$. чијем (што) Ст. пис. 3, 269. 357. 438. 4, 5. 17. 323. 5, 118. 218. Град дјев. 150. Злат. 8б. Див. 20б. Орб. 274. Гунд. суз. III, IXI. Буг. 20. 'Бам. 21б. Андр. дев. V. Радн. 39. ничијея С'т. пис. 4, 241. Злат. 28. тако и семь поүтемь С'тар. 4, 56. - и основе на чисто а, које се раширене свршују на ја: сва-

' С промјеном гласа $о$ у $y$ : куликшм - туликим Ст. пис. 1, 231. у дну. 


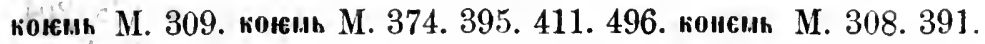
Збор. 24. Ст. иис. 4, 13. 70. 375. 5, 152. Град. дјев. 14. Злат. 53. Гуч. 20. Банд. 236.'

Овом се облику додају на грају гласови $a, e, u$ :

1) $a$ од XIV вијека: ткма Пб. 41. тнма Пб. 36. $43 . \mathrm{XV}$ вијека: тхих ІІ. 127. тних П. 127. сл сктих П. 176. и нослије: тима Вран. жив. 13. са свнма Ст. пис. 1, 40. 155. 5, 339. А. Рањ. 2. Зор. 1. до чима Ст. пис. 1, 194. томе доданом глас! јоіп се додавало $j$ XIV вијека: тнихн IIб. 42.

2) $е$ од првијех времена алп с доданим $j$ на крају: тsнен Сав. стар. 4, 231. XIV п XV вијека: твмєн M. 128. II.

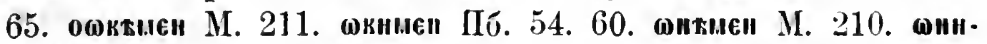
ємє॥ Пб. 120. и XVI вијека: тимеј Ст. пис. 2, 411. само $c$ XIV вијега: пньє М. 191. "' пиме II. 1. 2. и послије једнако: свиме Ст. пис. 1, 90. 325. 2, 74. Гунд. пс. 40. Крн. 2. Мрн. 128. Јерк. 22. свијеме Ст. пис. 2, 74. Злат. 34. - свакпјеме Ст. шис. 4, 394. свакиме Јерк. 28. - вашиме Д. Рањ. IX. ші пиме II. 53. М. 553. с раз.ичнијем ирпједлозима и без при једдога: њиме Н. Рањ. 24. 42б. 93. 138. Збор. 12б. Ст. пис. 2, 444. 496. 511. 3, 142. 298. 302. 334. 350. 4, 121. 200. 455. 5, 6 . 11. 26. 141. А. Рањ. 27б. Град. дјев. 15. 101. Буд. 11. Злат. 35. 97. Гуч. 2. 52. Чубр. 5б. Вран. жив. 36. Див. 18б. Орб. 56. 227. Банд. 6. Мрн. 75. Ђам. 9б. 19. Андр. дев. 84. нач. 6. Радн. 6. 26. Глав. 25. Радој. 26. - истиме Мрн. 166. - једниме Буд. 159. Мрн. 4. 181. - кијеме (тко) Ст. пис. 4, 78. 394. Гунд. суз. I, XXII. никиме Брн. б2б. - киме (којн) Ст. пис. 4, 457. Д. Рањ. IVб. 79. 162б. Буд. 4. Мрн. 21. кијеме Мӓт. 30. њекиме Д. Рањ. 125б. којпме Ст. пис. 4, 488. Мрн. 12. којијеме Ст. пис. $4,488.5,79$. - мојияе Ст. пис. 4, 482. А. Рањ. 47б. - нашиме Злат. 98б. - Фвниє Пб. 60. Вран. жив. 20. Мрн. 136. овијеме Н. Рањ. 183. - ониме Буд. 30. Вран. жив. 39. Мрн. 93. - својине Ст. пис. 4, 395. А. Рањ. 12б. Злат. 88б. - тиме Ст. пис. 1, 242. 243. 2, 240. 4, 366. 396. 463. 472. Д. Рањ. ІХб. Хект 8. 22. Брн. 9. Чубр. 9. Вран. жив. 9. Крн. 23. Мрн. 60. Јерк. 17. тијеме Ст. ппс. 2, 299. Град. дјев. 174. - такиме Д. Рањ VІб. Злат. 62. - тво-

' С промјевом крајњега м на ж: ннчннь ПГб. 24. скоянһ ПІб. 109, 
јиме Ст. пис. 5, 93. Д. Рањ. 37. Мрн. 22. твпме Гунд. ІІс. 35. - чиме Ст. пис. 2, 411.498. 3, 17. 4, 482. Д. Рањ. 12б. 22б. 69б. Врап. жив. 13. Мрн. 28. 78. ПІос. 19б. Радіг. 62. чијеме Н. Рањ. 152б. Ст. пис. 4, 373. Гуч. 189. Бун. 37.

3) $u$ XV и XVI внјека, али доста ријетко: тьми Пб. 91. тимн П. 50. тинин М. 439. 440. окши Пб. 51. онијеми Н. Рањ. 127б. својијеми (хином) Гуч. 29. тако ће бнти п тник Стар. 3,51. - Том се додатку опет давао поменути додатак e: тншиє М. 426. два пута.

Облику тако раширеном и помјереном доданијем $e$, додавао се паново наставак XV впјека: тинси М. 533. а по том се додано $e$ мпјешало с гласом к, који припада том облику пред наставком, те се њим замјењивало: тпмијем Ст. пис. 2, 374. 3, 116. 372. Збор. 35б. 37. Гуч. 299. тијемијем Ст. пис. 4, 52. 67. 129. 142. 234. окнемнемь Збор. 154. овимим Д. Рањ. 102. онимим Ст. пис. 2, 32. ониниемь 3бор. 84. 85. 86б. Гуч. 9. - И томе се опет додавало $и$ на крају XIV вијека: (окнแмим Пб. 40.

Находи се од почетка XVI вијека зи пе само додано на крају, како је већ показано, него и уметнуто пред наставак, а тада се његово и замјењивало гласом т, који има овај облик пред наставком: овпјезијем l'уч. 5. 106. Орб. 23. окизиемь Збор. 10. 85б. Град дјев. 112. онијезијем Н. Рањ. 1996. Гуч. 9. Орб. 31. онизијем Град. дјев. 49. тијезијем Ст. пис. 5. 319. Д. Рањ. Уб. Гуч. 157. 271. Орб. 52. тизијем 3бор. 56. Ст. пис. 5, 312. Град. дух. 13. тизим Ст. пис. 5, 331. Банд. 48. 128. у пошьедњој рпјечи мјесто , за којим је дошло зи, налази се и $e$ (јамачно према падежнма у којима се у те ријечи о замјењује гласом $e$, те би зи било додано к основи): тезпјем Ст. пис. 5, 12. 252. Орб. 154. Ђам. 9б. Андр. дев. 8. пут 39. - И тада се додаје на крају $e$ : тијезиме $Д$. Рањ. IX. 90. 100б. 107. 126б. тезијеме Ст. пис. 5, 63.'

У сло жен о о облику кад приступа инструментал замјенице ш⿻ь ж номиналном облнгу, отпада наставак номиналном облику, а основа му се тада свршује као у номинативу

' Гријешком има датив мјесто инструментала: прида војему Вран. жиив. 44. мјесто: прнд којим. Види још код сложенога облика. 
јед. па се с њом слаже шмь пао што се у номинат. јед. слаже н: тако је у нас од почетка али све рјеђе: кад је у адјектива основа на чисто а: оүсрьдьнинь М. 10. прткьзооркхенимь

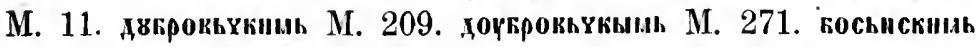

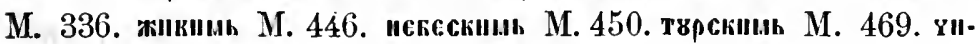
стим М. 526. тако и даље: његовим Н. Рањ. 14. Ст. пис. 1,51. острия Ст. пис. 1,19 . анђелским Ст. пис. 2, 356. рајским Ст. пис. 4, 447. тискним Ст. пис. 4, 112 . медведним Зор. 42б. тастним Вуд. 13. светим Вран. жив. 6. рајским Гунд. суз. III, IV. пратарским Мрн. 33. великим Банд. 7. Кашг. 33. - и кад је у адјектива основа иа ја: отьчни М. 9. гожінни Стар. 4, 233. доњим Ст. пис. 1, 40. - Али ако се и находи тако свега времена, ншак се још од XIII вијека сложени облик замјењује прономиналним добивајући в пред наставком мјесто ми, које се у српском језику сажима у $u$, и мијењајући пред в гласове $2, \kappa, x$ у $3, \imath, c$, а такп облик може бити да је и у гдјеком између горњих прнмјера имајућп по занадном говору $и$ мјесто $\mathbf{~ , ~ а ~ њ и м ~ с е ~ у ~ и с т о ~ в р и ј е м е ~ з а - ~}$ мјењује и номинални облшк; тако XIII вијека: гржшьнњь М. 15. хистти М. 22. 25. чистси М. 28. 38. XIV вијека: кехщемь

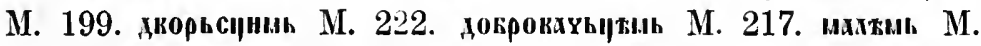
87. югокты М. 96 . пареккиь II. 25. и послије тако узима мах да је много обичнији од другога: XV вијека: косаисцемь М.

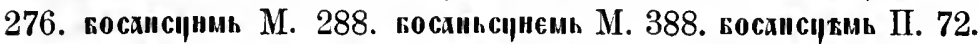
векниния М. 293. керовхинеи М. 372. 390. 394. 508. Пб. 95. втровапнемь М. 399. керокхиеиь Пб. 9. керокхиемь М. 393. Пб. 115. Внсоџтмь П. 50. 167. доврнешь М. 462. докрнешь М. 508.

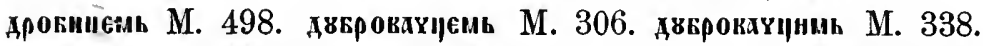

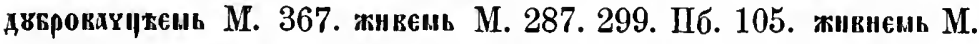
325. 414. жнвтми М. 342. 383. жикнемь М. 457. западыпемь М. 411. zемахмемь М. 309. змаекемь Пб. 121. нменованнемь М. 497. нстохьнемь М. 411. костеннень М. 498. михостивнеми М. 457. некеснемь М. 307. новемь М. 421. пегокеми М. 372. 390. 402. Пб. 96. пеговнень М. 503. рнмьсүкиь М. 381. скетемь М. 230. 259. 287. 321. 431. скетисин М. 342. 383. 414. скетлиемь М. 412. скетовинемь М. 367. скавнемь М. 306. скавннемь М. 311. 382. 412. скавнжмь II. 79. срьчанемь М. 261. 418. турсітмь М. 381. вгарсџтмь М. 381.

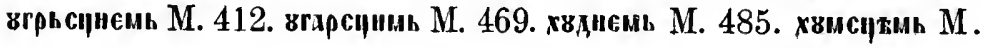


454. „спеи М. 526. тако је и послије, а само hy по који примјер навести од раздичнјех писаца: мнозим Ст. пис.' $1,3$. велицијем Н. Рањ. 23. вјечнијем 24. велицим Ст. пис. 2, 225. велпцием 468. горцијем 384 . веселијем 444. тужнијем Ст. пис. 3. 11. присуспјем 259. блазпјем 46 I. дразијем 461. велпцијем (т. пис. 4, 34. велици 419. дразим 467. друзијем 277. злијем 297. рајсцијем 447. злијем С квдиси Збор. 22б. ксхиниень 5б. дразпјем Д. Рањ. V. велнцим IVб. божанственијем Град дјев. 12. дрчзијем 60. дијевијем 20. велицијем Злат. 3. таштијем 35. тудиијем Злат. предгов. 1б. блазијем Г'уч. 110. велпцијем 238. достојнијем 10. друзнјем 101. дубоцијем 134. обилнијем 13. правијем 14. друзпјем Дпв. 38. дуднјем 29б. откривенијем Орб. 113. светијем 43. слацијем Гунд. суз. II, XXV. велицим Банд 5. велицијем 13. друзим 19. новнјем 107. велицим Кан. 70. друзијем Мик. 534. приблазнјем Андр. дев. 11. дразијем 172. тијеснијек Радп 6. - п без промјене грленијех гласова од XV впјека, али врло ријетко: XV вијека: првгем М. 474. XVI вијека: апостоличанскијем Град. дјев. 80. небескијем Град. дјев. 45.91. Гуч. 7. XVII внјека: велнгијем Див. 5. дратпјем 15б. нејакијем XIII. словинскијем ХІб. земаљскијем Орб. 23. тихијем Гунд. суз. I, XXVI. благшјем Андр. дев. 94. небескијем 89. бриткијем Андр. пут 22. зема.ьскијем 404. рајскијем 36. разликпјем Андр. нач. 30. великијем Радн. 44. - А како су се прономин с основом на ја помијешала у овом облику с онпма у којих је основа на чнсто а, добнда су и адјектива с основом па ја у овом сложеном облику т пред паставком мјесто $u$ од $\mathrm{XV}$ вијека: кожиєм' М. 427. кожьемь М. 449. кожїємь М. 530. 533. пожнень М. 560. Н. Рањ. 14б. 24б. Ст. пнс: 5, 27. Д. Рањ. УІб. Гуч. 10. Див. 4. Орб. 290. већијем Ст. пис. 5, 168. мхинен Збор. 24. јачијем Ст. пис. 4, 415. вишвпјем Бун. 38. највећнјем Алдр. пач. 42. - а вєкии налазп се без ин у основи: көлки ПІ. 158. 166.

И с д о же н о се облику додавадо на крају с од свршетка XV вијека: друзиме Ст. пис. 1, 317. друзијеме Ст. пис. 5, 13.

1 Могао би бити и номинални облик, као што је и бъо у старије вријеме (види вапријед стр. 35), али ту веһ није. 
мртвиме Ст. пис. 5, 10. вишњиме Д. Рањ. 28б. здатиме 60. злиме 60. тамниме 101б. чудниме 29. 37 . другиме Буд. 75 . задиме 75. химбениме 75. пाкодниме 75 . вјечнијеме Злат. 48. дразијеме 95. мртвијеме 35. притамнијеме 48. великиме Вран. жшв. 36. умрлиме Гунд. суз. II, XVII. милосниме Бун. 40. малиме Мрн. 163. славниме 88. худиме 163.1

Б. За женскп род : постаје као у имена (види напријед стр. 37) и онако се у српском језику промијенио: било је всакою М. 22. кьсею Стет. 13. ноєю Пб. 51. скоюю Пб. 55. а од тога: ксакокь М. 22. ксокь М. 22. сковь М. 31. єдиокь М. 22. конкь М. 20. сконокь М. 2. скоюкь М. 22. 48. од основе нераширене: сєю М. 72. п од рапирене: снювь (читај сијов) М. 4. - а по томе : а) од основа на чисто а: ксхконь М. 50. скакомь П. 29. М. 500. Злат. 21. од исте оспове рапирене: свакојом Гуч. 119. - єдиомь Г. ХV, 306. ниједном Ст. пис. 1, 4. Град. дјев. 97. - од основе ка раширене: көюм. М. 18. којом Ст. пис. 4, 202. којон (с промјеном крајњега $м$ на н) Хект. 456. І од нераширене : комь М. 275. 286. Н. Рањ. $70 .^{2}$ Ст. пис. 4, 159. 5, 8. Кан. 61. Мик. 231. -- кхкон М. 24. - оном Вран. жив. 70. - тмкомь М. 24. - б) од основа на ја: всомь М. 36. всомь М. 191. 218. всоюмь М. 367. свомь М. 433. 451. Ст. шис. 1, 18. 3, 140. Град. дух. 20. Брн. 24. Вран. жив. 27. Див. 3. Банд. 40. - вашом Ст. пис. 3, 220. - пом ПI. 29. њом Злат. 45. с доданим зи: њомзи Ст. пис. 5, 242. - моюмь М. 178. 193. Пб. 53. 71. моюиь (читај мојом) Пб. 69. мојом Ст. пис. 4, 202. - машомь М. 176. 218. - скоюмь М. 120. свонюи М. 176. 210. Пб. 55. - од основе раширене: снюи М. 217. 220. с доданйм зи: снюмьзи М. 145 . - твојом, с доданим зи: твојомзи Ст. пис. 2, 47. и сажето: твом Ст. пис. 4, 189.

Налази се и са $y$ мјесто ом онако као у имена (впди напрнјед стр. 38): са всу потрибои Стар. 3, 246-7. са всу вонску 270. ші њу 224. с војску моју 268. с књигон моју 294 . своју вољу 261. са заставу своју 272. с царицу своју 280. с војском своју 279. 282. главом своју 265. с матерју своју 251.

- Гријешком има једном датив мјесто внструмевта.ла: меу пуку неверному Вран. жив. 10. Види и напријед код прономивалнога облика, стр. 174.

2 Написано је "kоom" јамачно само за то што је било дуго. 
Крајњему м додаје се $e$ од XV вијека: најприје долази иза тога $e$ још додапо бе илп $j$ : томеге Пб. 107. томен П. 74. 131. Пб. 79. окомен П. 158. ононеи Збор. 41. а послије п само e: свакоме Ст. пис. 2, 490. - своме Ст. пис. 2, 504. - пстоме Мрн. 75. - једноме Р. Рањ. 128. 151. Ст. пис. 2, 497. 4, 346. 427. Д. Рањ. 55б. Мрн. 162. 178. Андр. 79. - њоме Ст. пис. 1, 149. Н. Рањ. 66. Ст. ппс. 2, 491. 3, 5. 463. 4, 133. 347. 455. 5, 39. 53. Збор. 45. Здат. 36k. Гуч. 28. Вран. жив. 12. 54. 89. 105. Орб. 74. Мрн. 143. Јерк. 18. Андр. нач. 9. пут 7. Радн. 57. - коме Ст. пис. 4, 457. Д. Рањ. 4б. 18б. 77б. Буд. 4. Чубр. 10б. Мрг. 49. векоме Д. Рањ. VІб. којоме Ст. пис. 4, З95. 5, 25. 34. А. Рањ. 9б. Гуч. 199. Вран. жив. 42. - мојоме Ст. пис. 4, 395. 427. 449. 5, 91. 193. Д. Рањ. 94. Злат. 64б. - овоме Ст. пис. 4, 471. - ономе Орб. 235. - својоме Ст. пис. 5, 19. Д. Рањ. 10б. - томе Ст. пис. 2, 114. 487. 4, 393. 407. Д. Рањ. 9б. Мрн. 173. - твојоме Ст. пис. 2, 477. 491. Д. Рањ. 10. 19. Иза овога доданога $e$ још се једном додавао падежни наставак: томем Ст. пис. $3,5.31 .38$.

Сложени се облик не разликује од номнналнога.

\section{Л КАТИВ ЈЕДНИНЕ.}

А. За мушьп и средњи род: основа као у дативу добива .. од sma, на то долази наставак in, којему $n$ отпада a $\mathbf{i}$ слабби у словенским језпцима у $\mathbf{b}$ :

a) од основа на чисто а: вьсконь Стеф. 17. ксаконь $\mathrm{M}$. 14. 407. Вран. жпв. 74. сваком Ст. пис. 1, 10. Град. дјев. 5. Брп. 19б. од псте основе раширене: всакосмь М. 288. всакоњмь М. 300. - ниомь М. 160. Буд. 85. - истом Град. дјев. 81. једном Вран. жив. 21. пкуномь II. 10. пндмомь М. 281. - овакомь П. 6. - овом Буд. 59. Брн. 5б. Вран. жив. 59. - ономь М. 6. Злат. 74. пх номь М. 23. - самом Град. дјев. 50. - таком Злат. 18б. - томь М. 10. А. Рањ. 54б. Здат. 2б. Вран. жив. 23.

б) од основа на ја: вьсемь ПI. 19. М. 442. всемь М. 420. 446. П. 12. васемь Пб. 34. скењь М. 230. 420. 517. П. 28. Н. Рањ. 41. Ст. пис. 1, 93. 2, 86. 3, 327. 4, 242. Збор. 10. Град. дјев. 126. Хект. 38. Зор. предгов. Злат. 8б. Гуч. 95. Вран. жив. 114. 
Орб. 281. Андр. пут 318. - нєиь М. 146. 264. 498. Н. Рањ. 16б. Ст. пис. 1, 93. 2, 71. 429. 3, 326. 4, 287. 5, 6. Збор. 4 . Град. дјев. 6. дух. 4. Хект. 5. Злат. 22. Вран. жив. 110. Орб. 167. Ганд. 46. Мрн. 33. Андр. нач. 22. - од основе ка, кад има сва три рода, рапнрене: коємь М. 16. коєнь М. 297. П. 18. Вран. жир. 107. сажето: кеюи М. 337. комь М. 422 . Пб. 121. Ст. ппс. $1,52.2,66.3,421.4$, 204. Злат. 1б. нјеком Д. Рањ. 19б. - мојем Ст. пис. 2, 80. сажето: момь М. 183. 247. Ст. пис. 2, 475. - пашємь М. 251. П. 81. - своємь М. 251. сажето: своиь М. 452. - од основе сја нераширене : сємь М. 251. 301. 356. 448. Ст. пис. 1, 64. 332. 2, 411. 417. Гуч. 263. Банд. 43. с доданпм зи: сєинзи М. 53. и од раппрене основе: снемь М. 46. 459. снемь М. 76. 83. 124. Пб. 78. Збор. 31б. чень М. 160. 500. ПI. 19. Збор. 32б. Ст пис. 2, 512. 5, 13. Град. дјев. 83. Хект. 27. Злат. 36. Орб. 281. Мрн. 92. Андр. 361. Рад. 26. "и их чеиьре М. 184. у ничем Град. дјев. 148. Злат. 30.'

Прежа основама на ја налази се $e$ мјесто 0 п у онијех на чисто а од XV впјека: овєиь М. 313. 478. Брн. 40. Јерк. 7. 14. 27. Андр. нач. 4. дев. 71. - тємь М. 517. 537. Пб. 29. Ст. пис. 2, 498. А. Рањ. 12б. 42. 49. 125. 143. - таковем Јерк. 45. 59. 65. - тако од сажетога мом: мем Злат. $15 б$. Види још даље.

Крајњему $⿻$ додаје се :

1. а: тоша М. $42 .^{2}$ оноча дне Н. Рањ. 67. Град. дјев. 81. по сєиа сега М. 117. 165. на овеуа дару Андр. пут 214. али ће на пошљедњем мјесту прпје бпти штампарска погрјешка $a$ мјесто и.

2. $е$ од првијех времена, алп најшрије с додавим $j$ пза е: снемен Сав. стар. 4, 231. бзонен М. 369. 421. Пб. 107. ононен М. 434. Пб. 78. Н. Рањ. 205б. и са ђе иза $e$ : ономеђе Н. Рањ. 77. са самијем $e$ : свакоме Мрн. 133. једноме Вран. жнв. 21. у њеме Н. Рањ. 196б. коме Ст. пис. 1, 241. 3, 408. Буд. 21. Мрн. 136. 155. овоме Н. Рањ. 19б. Вран. жив. 21. Мрн. 35. wноме М. 370. Вран. жив. 29. Мрн. 136. таконе М. 474. тиоме

1 Крајње се $\mu$ гдје гаје мијева ва $\mu$ : кон Ст. пис. 1, 52. Брв. 25. У свен Брн. 69. у чен Зор. 15. Брн. 47. 63. 68.

2 На том мјесту није јаспо да је локатив: "ь " тома, по что

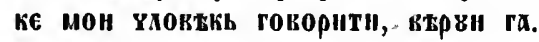


А. Рањ. 21. 23б. тоне ПI. 9. М. 280. 500. Пб. 119. 122. Ст. пис. 5, 256. А. Рањ. 7б. Хект. 4б. 18б. Зор. 28. Вран. рјеч. 27. жнв. 34. Мрп. 188. тако и кад је е мјесто о у основама на чисто а: окемс М. 311. онеме Вран. жив. 58.

Иза дометнутога $e$ налазп се на ново додан наставак од XVI вијека: томем Н. Рањ. 108. Ст. пис. 2, 159. Збор. 156б. 159. 170б. овомем Н. Рањ. 34б. 77. 210. Збор. 151б. Ст. нис. 5 , 298. ономем Н. Рањ. 142. семем Гуч. 102. и кад је $e$ мјесто о у основи на чисто а: овемем Ст. пис. 5, 42.

Налази се од XIII впјека инструментал мјесто докат.; али врло ријетко: XIII вијена: при конмь сект М. 52. XIV вијека: ни у чнмь крнки ІІб. 18. 20. ХV вијека: на инмь Пб. 45. нх ким иссть М. 518. XVI вијека: по свпјем свијети Ст. пис. 3,241 . у чијем Ст. пис. 5,314 . 317 . тако би могло бити $\mathrm{XV}$ вијега и в нвиь II. 57. в кашкиь господьсти II. 62 . али ту може дако бити да је п само написано мјесто є. Види још даље код женскога рода.

OA XIV впјека долази датив мјесто локат., али испрва врло ријетко : XIV впјека само једном : ш нашемоү спасенію $\mathrm{M}$. 126. ${ }^{1} \mathrm{XV}$ вијека: по том (за вријеме) М. 297. в томвзи ПI. 77. по ювомвн М. 484. в кехком почтеню М. 481. у вашемв Пб. 91.

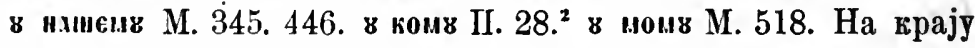
$\mathrm{XV}$ и свега XVI вијека врло често иза свакојаких приједлога: вашему Н. Рањ. 78б. Збор. 78б. Злат. предгов. 1б. свак ому Ст. пис. $1,14.161 .227 .3,158.355 .420 .4,79.254 .259$. 426. Збор. 166. А. Рањ. 32б. Хект. 32. Брн. 19б. Злат. 76б. Гуч. 89. - свему Ст. пис. 1, 33. 46. 103. 107. 160. 196. 213. 328. 2, 406. 441. 517. Н. Рањ. 20б. Збор. 27. Ст. шис. 4, 237. 425. 5, 5. 29. 61. 74. 81. 104. А. Рањ. IX. 57. 67б. Хект. 17. 18б. 276. 33. 36б. Зор. 72. Брн. 19б. Злат. 71б. Гуч. 17. всему Буд. 45. - иному Ст. пис. 1, 248. Збор. 122. Здат. 36f. - једному Н. Рањ. 227. Ст. пис. 3, 370. Збор. 158. А. Рањ. 39. Здат. 69б.

' Истога би впјека било: 10 реуеномь машему сквът Пб. 42. али пруједлога по ради може бити и датив на свом мјесту. Истога бі вијека било: о нашемв М. 130. оү жемв М. 131. али је тако у пријепису врло непоуздану.

${ }^{2}$ Непоуздано је в комв Пб. 111. јер лако може бити да би требало qитати в коми м., 
Гуч. 6. - њему Ст. пис. 1, 56. 78. Н. Рањ. 146б. 153б. 165. $199 б$. Ст. пис. 2 , 70. 402. 4, 149. 287. 5, 12. 174. Збор. 88б. А. Рањ. 43. Град. дјев. 37. дух. 35. Хект. 7. 11б. Буд. 49. Брн. $14 б$. 3лат. 286. Гуч. 21. - кому Ст. пис. 1, 66. 82. 105. 151. Н. Рањ. 1576. Ст. пис. 2, 82. 90. 125. 342. 440. 3, 145. 391. 4, 71. 149. 410. 5, 36. 56. 95. 118. Збор. 115. А. Рањ. VIIб. 3б. Град. дјев. 119. Хект. 32б. 36. Злат. 36f. Гуч. 17. никому (векому) Хект. 46б. којему Хект. 46. Гуч. 113. - мојему Ст. пис. $1,215$. 2, 402. Н. Рањ. 192. мому Н. Рањ. 17. Ст. пис. 2, 41. 106. 443. 474. 3, 103. 345. 474. 4, 250. 225. 5, 40. Збор. 34б. Д. Рањ. 82. Хект. 2б. Зор. 16. Злат. 100. Гуч. 119. - нашему Н. Рањ. $21 б$. Збор. 39б. Ст. пис. 3, 76. Хект. 35б. Буд. 96. Гуч. 91. с доданим $j$ : нашемуј Ст. пис. 2,65 . - овому Ст. пис. 1,151 . Н. Рањ. 27б. Збор. 91б. Ст. пис. 3, 9. 126. 205. 301. 4, 104. 364. 377. 5, 29. 31. 40. Д. Рањ .18б. Град. дјев. 4. Хект. 20. 276.32. Буд. 55. Злат. 36f. Гуч. 21. Чубр. 16. овомуј Збор. 19. Ст. пис. 3, 227. 5, 344. овему Ст. пис. 5, 28. Д. Рањ. 97. Злат. 36б. Гуч. 42. -- оному Збор. 54. Ст. пис. 4, 231. 5, 50. 103. А. Рањ. VIII. Град. дјев. 21. Хект. 36. Буд. 16. Гуч. 20. Злат. 61. ономуј Н. Рањ. 41. 3бор. 100. онему Гуч. 194. - самому Н. Рањ. 2026. 3бор. 163. Град. дух. 65. Брн. 4. Гуч. 169. - сему Н. Рањ. 96б. Ст. пис. 5, 50. Град. дјев. 45. дух. 10. Хект. 39б. Брн. 52. Стар. 4, 112. Злат. 37б. семуј Ст. пис. 2, 337. 361. Збор. 1556. - својему Збор. 6. Хект. 146. Буд. 25. свому Ст. пис. 1, 5. 42. 54. 2, 355. 442. Н. Рањ. 21б. 30. 47. Збор. 21. 24. Ст. пис. 3, 138. 316. 4, 394. 5, 13. Д. Рањ. 796. Град. дјев. 79. Хект. 9б. Буд. 12. Брн. 2б. Злат. 47б. Гуч. 6. - тому Ст. пис. 1, 156. 2, 135. 259. 445. 3, 75. 145. 172. 203. 271. 426. 4, 32. 5, 124. 307. Збор. 8]. А. Рањ. Уб. 42б. Град. дјев. 26. 108. Хект. 9б. 21б. 27. 33. Буд. 18. 20. 67. Стар. 1, 222. Злат. 35б. 84б. Гуч. 24. томуј Н. Рањ. 21. Збор. 31. Ст. пис. 3, 76. 110. 4, 184. 5, 307. Злат. 70. тему Ст. пис. 5, 28. 295. Хект. 46. темуј Ст. пис. 3, 326. твојему Ст. пис. 1, 215. Збор. 30. Чубр. 15. твому Ст. пис. 1, 208. 2, 62. 305. 493. Н. Рањ. 67б. 148. Збор. 32б. Ст. пис. 3, 126. 325. 444. 4, 189. 254. 462. 5, 17. 37. Хект. 48б. 53б. Зор. 40. Брн. 3б. Гуч. 124. - чему Ст. пис. $3,441.5,93$. Хект. 11. Буд. 34. у ничемур Ст. пис. 1, 179. Зор. 2. Брн. 47. ни у чему Ст. пис. 3,441 . у ничему 3лат. 75б. - XVII вијека : вашему 
Див. 23. Банд. 32. Бун. 35. Каш. III. - свакому Див. 4. Банд. 17. Јерк. 14. Каш. 104. Пос. 14б. Радн. 4. - свему Вран. жив. 15. Див. 26. Банд. 33. Бун. 42. Мрн. 60. Каш. 16. Андр. дев. 7. Радн. 13. - иному Мрн. 24. Мак. 534. Андр. пут 318. пстому Див. 5б. Орб. 259. Банд. 67. Мрн. 67. Каш. 11. Пос. 5. јистому Вран. жив. 7. - једному див. IX. Банд. 19. Мат. 33. Андр. дев. 163. Пос. 34б. - једпному Каш. грам. 38. Андр. дев. 128. - вему Вран. жив. 4. Див. 18. Орб. 9. Банд. 7. Крн. 10. Мрн. 9. Јерк. 37. Каш. 4. Мат. 80. Андр. дев. 63. Пос. 14б. Радн. 12. Гдав. 36. - кому Вран. жнв. 89. Гунд. пс. 4. суз. III, LXXXIII. Банд. 23. Мат. 35. Мрн. 156. Јерк. 14. Каш. 15. Андр. нач. 16. дев. 58. Пос. 26. Глав. 21. у никому Крн. 19б. којему Вран. жив. 12. Банд. 190. Јерк. 10. - мојему Вран. жив. 36. 59. Банд. 5. 95. Глав. 97. мому Див. 8. Орб. 40. Гунд. пс. 13. Банд. 77. Мрн. 56. Јерк. 50. Каш. 68. Андр. дев. 42. нач. 15. нашему Орб. 70. Гунд. суз. предгов. Банд. 3. Мат. 12. Мрн. 90. Ћам. 6. Глав. 12. - овому Вран. жив. 11. Див. 2. Орб. 2. Банд. 8. Мат. 64. Мрн. 105. Јерк. 7. Каш. 12. Ђам. 4. Пос. 24. Радн. 23. Глав. 3. Андр. пут 21. овему Јерк. 42. Кашг 119. Андр. нач. 19. дев. 57. пут 8. - оному Вран. жив. 55. Див. 19б. Орб. 256. Банд. 11. Мат. 42. Јерк. 44. Каш. 12. Радн. 18. Глав. 18. с доданим ђе п ре: ономуђер Банд. 264. онему Андр. дев. 57. 61. пут 126. - самому Орб. 114. Банд. 34. Јерк. 21. Каш. 67. Андр. нач. 11. пут 228. - својему Вран. жив. 3. Банд. 114. Гдав. 112. свому Див. 6б. Орб. 82. Гунд. нс. 6. суз. II, XLIX. Банд. 6. Мат. 62. Крн. 4б. Бун. 22. Мрн. 120. Каш. 4. Ђам. 5. - свачијему Андр. нач. III. - тому Вран. жив. 7. Орб. 7. Гунд. суз. III, XVIII. Банд. 100. Крн. 12. Мрн. 80. Каш. 9. Ђам. 3. тему Бун. 31. Ђам. 14. 20. Андр. дев. 7. нач. 37. пут 55. - такому Радн. 20. - твојему Вран. жив. 43. Банд. 151. твому Гунд. суз. I, VI. Банд. 44. Крн. 7б. Јерк. 82. Кашг. 35. Андр. дев. 87. пут 235. Радн. 4. Гдав. 23. толикому Јерк. 75. - чему Див. 19. Банд. 25. Крн. 16. Мат. 101. Мрн. 122. Јерк. 103. Капі. 30. Ђам. 2б. Андр. дев. 35. пут 278. Шос. 31б. Радн. 22. у ничемуре Вран. жив. 4. Банд. 238. у нпчему Банд. 176. Андр. пут 234.

У сложеном облику локатив замјенпце ємь пристунајући ћ номиналном облику изједначује своје є с веговијем 
задњим вокалом, те у основа на чнсто а од -тю- бива -st, а у основа на ја од -нє- бива -нн-, по том се два једнака гласа сажимају у један: таки је облик у нас риједак, ипак долази од почетка п допире у XV вијек: кад је у адјектива основа на чисто a: свтткмь М. 4. хрнстодаровантми М. 5. попокьсџжмь М. 14. пвстемь M. 18. светогорьсітиь М. 48. рехепиемь М. 201. хасьнимь М. 273. вьтортиь М. 278. странитиь М. 278. светниь М. 418. инхнмь M. 534. XV се вијека додавало на крају $u$ : скстсмн М. 343. - кад је у адјектива основа на ја: жнкотворєцинь М. 273. соүдоүцниь М. 278. похнкшнми М. 354.' - Али је још од првијех времена у српском језнку овај сложени облик као п други замијењен прономиналним, т. ј. мјесто његова г пред нь долази из пронопина $о$, које се у основа на ја мијева на $e$ : а) кад је у адјектива основа на чисто а: XII вијека: страшьноь M. 6. XIII вијега: дроцгоми М. 10. дүховномь М. 14. шгориеньскомь М. 14. вьторонь М. 27. XIV вијека: строүинхьскомь М. 64. монхстнрьском М. 80 . zиатопеххтионь М. 131. џхрьскомь М. 156. схавиоми М. 156. 237. стхронь М. 170. светоми М. 176. чхсномь М. 222. XV вијека: порлчкоюнь М. 399. довронь М. 293. П. 79. zетьскоиь М. 538. Новомь М. 354. скетонь М. 309.347. 424. славномь М. 293. стомионь М. 250. стономь М. 375. 450.491. страшионь М. 534. часпюиь М. 261. п послије једнако: младом Ст. пис. 1, 3. једанаестом Н. Рањ. 34. хокпсханскомь 3бор. 2б. духовном Град. дјев. 45. његовом Хект. 41. божанственом Зор. 65. римском Буд. 131. небеском Брн. 55б. добром 3.ат. 15б. реченом Гуч. 88. - б) кад је у адјектива основа на ја: до краја XV вијека: ввдоүцсмь М. 10. иних(ш)нкь (гдје ће т бити само наиисано мјесто є) М. 10. божюнь М. 238. 383. божьемь

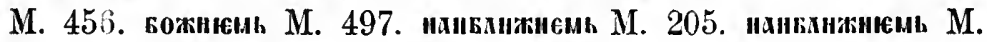
267. 353. Вмьусми М. 272. Вмьчнсы Пб. 61. тако и послије једнако: окхмь Збор. 37. вељем Ст. пис. 3, 436. доњем Ст. пис. 4, 309. Зор. 40. туђем Злат. 3б. третијем Град. дјев. 114. третјем Орб. 254. Оба су адјектива кєми и трєтни и одбацивала крајње ин те прелазила међу оне с основом на чисто a: ведом Мрн. 34. третом 3ор. 23. Брн. 54.

1 He ће бити остатак од тога него погрјешка XVII внјека: на руским крају Мрн. 38. 
Крајњему се $\boldsymbol{м}$ додаје $e$ од $\mathrm{XV}$ вијека: скавномє $\mathrm{M}$. 495. пакленоме Брн. 28. другоме Орб. 6. свитломе Мрн. 35. смитноме Мрн. 182.

Како су се у прономина основе на чисто а мпјешале међу оне па ја, тако се палазп п у адјектива, али врло ријетко: подниженем Гуч. 124. Види и ниже.

Од XIV вијека долази датив мјесто локатива као и у прономина: их писанонь П. 19. XV вијека: po otvorenomu M. 280. по бтворсионя М. 449. ва светоюмв М. 366. в скадарскомя

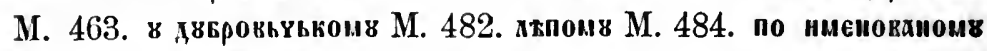
М. 496. о инивтонв М. 538. прп реченомв П. 52. Ф комеия П. 58. по киетхуькомв П. 83. по дртвсконя П. 90. в кивьшемв П. 155. XVI вијека: божјему Ст. пис. 1, 215. многому 47. божјему Н. Рањ. 137б. 175б. драгому 202б. другому 157. жидовскому 29. небескому 178б. почтеному 224. морскому Ст. пис. $2,414$. Божнемв Збор. 98 . крнедионя 24б. змоня 49б. миепомв 64 . пекескомв 125б. стрхимомв 125. блацкому Ст. пис. 3,218 . великому 322. вјечному 62. 445. горкому 103. драгому 168. женскому 84. живому 380. псходвему 322. осмому 177. оптрому 364 . правому 360 . светому 325 . свијетлому 75. славному 231. смртному 129. сухому 166 . тамному 158. тихому 408. трудному 447. чемерному 318. великому Ст. пис. 4, 223. верному 455. вјечному 71. 225. 328. плачному 311. светому 231. царскому 426. вељему Ст. пис. 5, 14. божјеиу Град. дјев. 113. другому 142. светому 62. тијескному 75. јуначкому Хект. 146. реченому 35б. рибарскому 36. тихому 18б. задарскому Зор. 39б. .убвеному 2б. слободному 57б. божјему Брн. 50. божанственому 57б. светому 24. старому 22б. тилесному 51. чловичјему 5. земаљскому 29б. присвијетлому Злат. иредгов. 16. другому 76б. божјему Гуч. 259. божанственому 159 . великому 35. дивијему 214. изврсному 114. небескому 193. невољному 40. светому 39. XVII вијека: пекомомв М. 560. божјему Вран. жив. 109. женскому 59. залому 97 . монастирскому 74. светому 38. великому Див. 7. горному 14. господњему 6б. небескому 6. светому 20. старому 10. тужному 24б. божјему Орб. 300. другому 57. замаљскому 19. људскому 295. опћеному 232. садањему 14. смртному 44. вјечному Гунд. пс. 15. милому 10. нечистому Гунд. суз. III, LXXI. применому I, XLI. божјему 
Банд. 2. воденому 204. воштеному 113. господњему 121. доброму 27. духовному 185. небескому 22 . новому 110 . светому 20. третјему VI. угодному 50. већему Мат. 7. смртному 57. другому Мрн. 12. приписаному 12. турачкому 13. ведому 57. третому 23. небескому Јерк. 94. славному 7. главному Каш. 11. жестокому 13. пуному 5. рајскому 85. светому 11. спромашкому 5. третјему 44. чдовичанскому 12 . латннскому Ђам. 9. пређвему 9. словинскому 9. мушкому Мик. грам. 3. болесному Андр. дев. 57. грешному 152. жестокому 61. живому 49. тврдому 145. црљеному 88. другому Пос. 35. светому 236. божјему Радн. 45. светому 6. великому Гдав. 68. верному 12. малому 68. смртному 24. умрлому 3. - према основама на ја: у осталему Јерк. 76 .

Б. За женски род: основе као у дативу јед. добивају smi, од чега у словенским језицима остаје само $\mathbf{i}$; наставак је am, пред нојим i шрелази у $j$, а сам наставак аm слива се $\mathrm{y}$, које ослабивши у қ отпада иза $j$; тако је тај облик гласовима које је сачувао једнак с дативом:

а) с основом на чисто а: свдкон М. 362. Здат. 27б. - сднон М. 498. ниједнојзи А. Рањ. 10б. - овој Злат. 29б. овојзи Ст. пис. 4, 186. - оној Злат. 43. - тој, с доданим зи: тонзи М. 165. Ст. пис. $4,210$.

б) с основом на ја: кссн М. 221. П. 14. јамачно ће бити само написано ₹ мјесто є: кстн М. 4. кьстн М. 19. - иєи М. 4. воюе М. 16. коєн М. 218. - ноєи М. 183. Пб. 29. - пхшеи М. 481. - своєи М. 4. своєн II. 14. - твоюн II. 45. - сеј Ст. пис. 1, 35. и од раширене основе: снсн М. 23. 25. - Као у дативу тако и у овом облнку основе су се на ја изједначпле с основама на чисто а: всон М. 171. 235. П. 9. 121. свои М. 306. 430. - ноп М. 217. 294. 305. Шб. 49. њојзи Ст. шис. 5, 153. А. Ран. 76б. Гуч. 7. - мојој Злат. 2. - нанон М. 270. - свонюи М. 210. - од раширене основе снон М. 191. 219. - од раширене основе: коншн М. 176. Ст. пис. 2, 57. Буд. 115. п од нераширене основе: кој Н. Рањ. 145. Ст. пис. 2, 85. 4, 222. Злат. 21б. Банд 22. KaІr. 34. Гдав. 24.

У некшх је био и номннални облик мјесто овога: по шнь

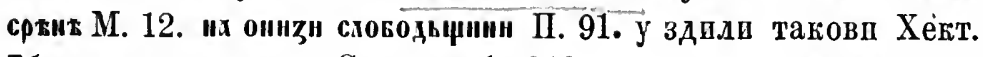
7б. у тоднци славп Ст. пис. $1,213$. 
Налазп се и без крањега $j$, гоје може бити да само није паписано: свако Н. Рањ. 14б. којо Див. 21б. једно Див. 20. Внді и датпв.

Долази и ниструментал мјесто локат. ади врло рнјетко: земља, по гом ходе Ст. пис. 1, 154. зрака, при ком свјетлос свака остаје обдачна Ст. пис. 3,353 . Видп и напријед код мушкога рода.

у сложен о се обдику саставља прономен с адјективом као у дативу, и таки облшк у сриском језику допире у

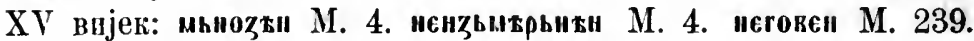
303. прекен П. 21. докреп М. 415. скете॥ М. 539.'

Али се од првијех времена овај сложени облик као и датив замијенио ирономиналншм (внди датив): а) кад је у адјектива основа на чисто а: XII вијека: скетон М. 6. XIII виjesa: горскои М. 12. пастырскои М. 61. срьпьскон М. 52. XIV

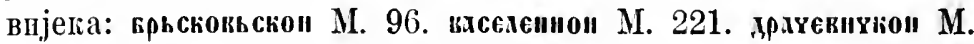
201. двгрокьчко" М. 241. жегаговскон М. 143. жекъъиоп М. 148. 163. zхтринхвскон М. 91. "zақранон М. 241. конхвахьскон М. 218.

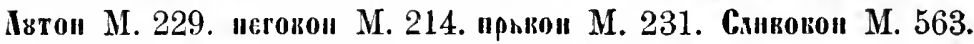

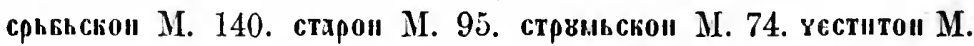
222. XV вијека: косхискон М. 288. посьисноп М. 336. вехнкон

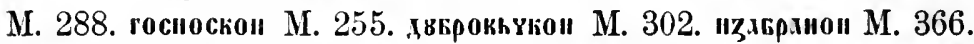
нонхкхоскош М. 284. краснон М. 297. "стокон М. 295. пхиьнон М. 415. сптткон М. 275. хинкинскон М. 248. херџегокоп М. 474. парєкон М. 513. ФАгодион П. 571. и послије једнако: ведикој Ст. пис. 1, 116. 3, 380. горкој Злат. 25. густој Ст. пис. 3, 352. зеленој Ст. пис. 3, 66. Зор. 63. љутој Злат. 28. његовој Збор. 46. Гуч. 81. Вран. жив. 33. Банд. 36. путеној Н. Рањ. 226. Јаковљевој Банд. 4. - б) кад је у адјектива основа на ја: кожнен М. 21. 252. 268. кожиєи М. 71. П. 43. божюи М. 415. твюен М. 147. туеп Стар. 3, 280. алшсу се таке основе изједначиле с оніма на чисто а као и у прономина, и то од XIV вијека: кояноп М. 105. 250. ПI. 59. тв'он М. 228. донон М. 301. тако и послије: божјјој 3ор. 67. Див. 之8б. вељој Ст. пис. 3, 393. 4, 70. 210. доњој Ст. пис. 3, 268. туђој Злат. 27. телетјој

' Гријешком има и мєнъьрекомиєн II. 14. 
Банд. 67. третјој 'Бам. 25. у кекнн могдо се и одбадити мн: велој Ст. пис. 4,210 . Хект. 8. 45.

Налази се додано зи: добројзи д. Рањ. VІІб. - Надази се и без крајњега $j$ (види и датпв): кожнє М. 32.193. четврто Н. Рањ. $40 б$.

\section{НОМИНАТИВ МНОЖИНЕ.}

С основом се саставља наставак као у имена, којима се основа свршује на чисто а и на ја, те се и грлени гласови у основи онако мпјењају:

А. За мупки род: ваши Н. Рањ. 144б. - всаун М. 117. сваци Ст. пис. 3, 229. - вси М. 24. 319. 400. Вран. жив. 71. ски П. 10. М. 273. 414. 432. 496. Пб. 109. Ст. Пис. 1, 44. 185. Н. Рањ. 14. 22. Ст. пис. 2, 111. 4, 273. Збор. 7б. Хект. 3. Брн. 5. Стар. 1, 227. Гуч. 53. Вран. рјеч. 25. жнив. 16. Гунд. пс. 13. Банд. 3. Мрн. 90. - кохии М. 122. Н. Рањ. 22б. Ст. пис. 2, 52. Град дјев. 64. Хект. 8. Гуч. 170. Див. 11б. Каш. 93. Андр. пут 8. иткомии ІІ. 7. 13. 134. Орб. 12. николици Мрн. 178. - шкоп М. 189. 370. - ови Н. Рањ. 68. - оваци Злат. предгов. 2б. - они Н. Рањ. 14. - си М. 45. Ст. шис. 5, 37. Злат. 94б. ти Н. Рањ. 14. с доданим ђе, које гласи п је: тне М. 429. таци Град. дух. 70. - тагови Радн. 44. - толици С'т. пис. 4, 228. 442. Андр. дев. 53. - У основи ка, кад није сложена, не мијења се $\boldsymbol{\kappa}$ од првијех времена: тако с доданим ре: кнрє М. 2. без тога додатка: кі М. 274. II. 60. 102. Ст. цис. 1, 27. Н. Рањ. 18. Ст. пис. 4, 14. 51. 165. 341. 421. 5, 121. Д. Рањ. IV. Град. дјев. 15. Хект. 5. Гуч. 8. Орб. 5. Банд. 12. кад је сложена са ик, мијења јој се $\kappa$ : "тіן II. 42. Стар. 4, 76. њеци Г. Рањ. 87б. Ст. ппс. 4, 273. ници Ст. пис. 1, 245. Хект. 8. Буд. 14. Брн. 43. Мрн. 171. али се налази и без те промјене од XV вијека: "кии П. 61. Н. Рањ. 98. Ст. пис. 5, 130. Орб. 22. Глав. 25. ники Хект. 8. Банд. 68. Кашг. грам. 52. иста се основа и шири у овом облику према другима: кон М. 34. којн Н. Рањ. 14б. Ст. пис. 4, 204. 341. 5, 113. Град. дјев. 64. Хект. 13. Буд. 5. Банд. 12. векоји Ст. пис. 2, 135. - Тако се и у другім рнјечима грдени глас, прем да се свега времена мпјења, налази п нешромјевен: каки Хект. 21б. таки Хект. 47б. Андр. дев. 53. кодики Банд. 49. 
Једном има с доданим $e$ па крају: кою П. 135. види и ншже.

У сл о е н м облпку номин. мн. од замјенице $и$ пршступа к номпналном облику без пкаке промјене, па се у српском језику оба $u$, юоја тада буду заједно, сажимају у једно дуго, п тако се сложени облик изједначује с поминалним разликујући се само акцентом. Види код номиналнога номннатива мн. - Налази се додано $е$ на грају (види ном. јед.) ретє uнe M. j 49 .

Б. За средњи род: свака Злат. 24б. Вран. жив. 10. нhса М. 310. нса М. 398. васх М. 282. скх М. 230. 309. 492 . Пб. 95. Ст. пис. 2, 347. Зор. 69. Злат. 7. Гуч. 2. - ина Буд. 23. јина Вран. жив. 40. - моја, и сажето: ма Злат. 15. - ова Буд. 23. - шкох М. 187. - она Н. Рањ. 15. - сама Вран. жив. 13. - та М. 4. Буд. 2. с доданим $j$ : ть» (чптај тај) II. 114. тај Град. дјев. 108. 3.ат. 16. Гуч. 254. - трох Збор. 13. - од основе ка нераширене: ка М. 440. Н. Рањ. 44. С'т. нис. 4, 300. 456. Буд. 49. Злат. 36е. према другим падежима долази и од раширене основе од XVI вијека: која Н. Рањ. 21. Ст. иис. 4, 300. Буд. 124. - од основе сја раширене: сит М. 11. сим М. 15. алп и без $a$ : си М. 10. Стеф. 10. 13. и од нерашпрене: сл Ст. пис. 1 , 125. с доданпм $j$ : схи М. 230. Ст. пис. $1,49.5,325$.

У сложеном облику пма: всауьска. М. 9.

У сложен о се облику саставља номин. мн. замјенице п с номпналним облпком без промјене: размичнхт М. 5. али се у сриском језику аи сажима у једно $a$, те је сложени облпк једнак с номшналним разлнкујуи се само акцентом. Виду поминални номинатив мн.

В. За жеиски род: ске М. 107. 296. Злат. 41. Врац. жив. 88. - ине Н. Рањ. 100. - є.иє М. 498. Пб. 74. - моје Злат. 59. сажето: ме Ст. нис. 4, 43. 125. 160. 220. Злат. 29б. - ове Злат. 21. с додапим $j$ : овеј Д. Рањ. ІХб. - овоє свдыје М.46. шкою стрхне II. 79. - те, с доданим $j$ : теј Ст. пис. 4, 227. 25". Гуч. 18. - тзоје, и сажето: тве Ст. иис. $4,126$. - од основе кіи нераширене: кс М. 13. 15. Н. Рањ. 105. Ст. пис. 4, 154. 211.384. 5, І60. Д. Рањ. 13. њеке Ст. нис. 4, 211. 270 од исте основе рашпрене: које Н. Рањ. 105. А. Рањ. VII. никоје Ст. пис. 4, 441. - од основе сја рашпрене: сиє М. 13. и од нераширене: с доданим $j$ : сеј Злат. 22б. Гуч. 286. 
У сложеном се облику састав.ьа номнг. мн. ь, српскп є, с номиналпим обликом без промјене, а како и номинални обдик у срнском језику има на крају є не само од основа па ја него и на чисто а, санима се єю у једно є, те је сложенг облик једнак с номиналии разлпкујһи се само апцентом. Вшди номинални номинат. мн.

\section{ГЕНИТИВ МНОЖИНЕ.}

Једнак је за сва три рода. Основа добија на кјају i, с којим јој се крајње а слијева у словенским језнцима у т, пред којим се грлени гласови мијењају, а од којега у основа на ја бнва и предњега г.ласа ради; наставак је sam, којему глас $\mathbf{s}$ у словенским језицима прелази $\mathrm{y} x$, a $\mathbf{a m}$, којему је а дуго, слијева се у словенским језицима у ж, које слаби у қ, а т у српском језику као и у другим сдовенским осим старога словенскога отпада.

а) од основа на чпсто а: свацијех Н. Рањ. 138б. Збор. 1066. Гуч. 160. свацих Гунд. суз. I, XII. Каш. 18. и без промјене грленога г.ласа: свакијех Гуч. 7. -- свакомикхь М. 501. п без промјене грленога гласа: всакојаких Вран. жив. 3. инехи М. 166. иннехь М. 350. 501. 36ор. 10. Мпк. предгов. иних Злат. 21. - нстие Радн. 41. - нелнехь Збор. 13. Д. Рањ. VIб. - комиџхк М. 357. кодицијех Град. дјев. 147. колицих А. Рањ. 31. Каш 42. њеколицијех Н. Рањ. 64б. Злат. предгов. 26. - овтхи М. 392. швєек М. 423. овијех Н. Рањ. 43. Збор. 52. Ст. пис. 4, 206. 231. 238. Град. дјев. 122. Злат. 716. Гуч. 136. Орб. 104. ових Ст. пис. 1, 79. Зор. 32. Вран. жив. 73. Банд. 198. Мик. грам. 16. - овацијех Град дух. 65. Ђащ. 13. без промјене грленога гласа: овапијех Ст. пис. 5, 134. - wитх М. 23. онијех Н. Рањ. 44. Ст. пис. 3, 467. 36ор. 13. Град. дјев. 163. Злат. 42б. Андр. пут. 44. оних Н. Рањ. 44. Буд. 148. Вран. жив. 28. с доданим зи: Фиехзн М. 267. онацијех Злат. 166. - самххь М. 79. самијех Ст. пис. 3, 309. - техь М. 27. тнехи М. 373. тєхь М. 423. тнјех Ст. пис. 4, 165. д. Рањ. IX. тих Ст. пис. 1, 89. - тадијех Ст. пис. 4, 348. А. Рањ. ІХб. Орб. 95. тацих Ст. пис. 1, 4. 41. 5, 199. Буд. 54. - тодицијех Ст. пис. 3, 259. 4, 436. Град. дух. 12. дјев, 35. толицих Ст. пис. 4, 410. 442. 445 . 
У сдоженом обдику додази: шиыхь М. 79. комккхи М. 558.

б) од основа на ја: двојих Ст. пис. 4, 428. - ихь М. 9. нх Ст. пис. 1, 22. јих Ст. ппс. 1,22. Хект. 31б. с приједлогом: шуи инхь М. 6. и без приједлога: инхи М. 236. Н. Рањ. 229. Ст. шис. 5, 49. А. Рањ. VII. Град. дјев. 13. Здат. предгов. 3. Гуч. 144. Банд. 9. Каші. 7 . $^{1}$ - мојцх Ст. пвс. 1, 174. Злат. 7б. - пишхь М. 341. - спх Ст. пис. 1, 3. 33. 4, 219. - својшх Бапд. 12. - твојих Ст. пис. 1, 20. Хект. 39б. - од основе која предази у овом облику међу основе на чисто а пзбацујуһи $j$ joш у старом словенском језпку: вснск М. 104. исияки М. 438. ксєхи М. 393. всих Буд. 9. Вран. жив. 74. васнхь М.

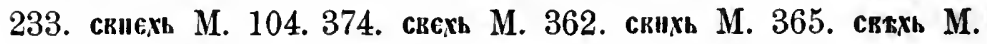
403. 553. свнјех Н. Рањ. 22. 3бор. 116. Ст. пис. 2, 25. 3, 9. 409. 4, 4. 62. 142. 257. 5, 4. 37. А. Рањ. IV. Град. дјев. 66. Злат. 1б. Гуч. 7. Орб. 241. Гунд. суз. I, LIV. Мик. 580. Андр. дев. 44. свих Н. Рањ. 17. Ст. пис. 2, 56. 4, 210. Хект. 25б. Зор. 7. Вран. жив. 20. Банд. 38. Јерк. 19. КапI. 28. - од основе ка нераширене пма прономинални облик без промјене гдаса к: кћхь ІІ. 144. 160. Пб. 49. 74. кехь Пб. 110. кијех Ст. пис. 3, 101. 4, 144. 175. 5, 9. Град. дјев. 37. Гунд. пс. 21. њекијех Гуч. 61. Орб. 94. 111. г с шрохјеном гласа $\kappa$, сложено: ницих Ст. иис. 1, 243. и сложени облик: њеких Град. дјев. 37. а из других падежа дошла је у овај и раширена основа: вонхь М. 401. Ст. пнс. 1, 114. 4, 341. Банд. 149. Андр. пуут 277.

Основе на ја прелазе међу оне на писто а: кашқь П. 11. 118. ваншєк Пб. 93. Н. Рањ. 43б. Збор. 105. Ст. пис. 5, 237. Град. дјев. 4. Злат. $36 \mathrm{~g}$. Гуч. 11. Див. 26б. - схь М. $427 .{ }^{2}$ внјех Орб. 33 (два пута). Мик. грам. $33 .^{3}$ - моюкь М. 107. монсхь М. 311. нопехь М. 459. Н. Рањ. 85б. Збор. 10б. Ст. пис. 3, 256. 472. Злат. 97б. Гуч. 107. Гунд. пс. 9. суз. I, XLIV. Mик.

1 Једном се налази 2 мјесто $x$ : њиг Банд. 261. а што једном пма hi (мjесто ih) Банд. 261. не мислнм да су тласови преметнути, вего he бити певјештнном шишчевом стављено $\mathrm{h}$ гдје не треба. Обоје може бити и штампарска погрјешка.

2 Није поуздано на том мјесту, јер има у истом спомевпку I Epathentuh M. 428.

3 Тако hе бвти у слику с приједлогощ без уметнутога $\boldsymbol{H}$ и без $x$ на крају : од јије Ст. пис. $1,85$. 
грам. 15. Андр. дев. 75. пут 30. - шхшехь М. 35. 237. 258. 259. 297. 306. 431. Пб. 111. пхшехь М. 258. пхшнехь М. 404. 412. 429. 485. 517. пишїех М. 532. Н. Рањ. 51. Збор. 68б. Ст. пис. 2, 168. 3, 60. 4, 112. 310. 5, 46. Злат. 3. Гуч. 20. तІв. 33. Орб. 31. - сиехь М. 414. Н. Рањ. 124б. Ст. нис. 2, 444. 3, 10. 63. 79. 165. 364. 444. 4, 36. 49. 155. 371. - своєхь М. 240. ПГб. 105. свонєхь М. 459. свонехь М. 501. Н. Рањ. 14. Збор. 5іб. Ст. иис. 3, 268. Град. дух. 17. Гуч. 19. Орб. 53. својије див. 13. Радіг. 44. - твовхь II. 10. Н. Рав. 38б. Збор. 29б. Ст. пис. 5, 36. Здат. 1б. Гуч. 135. Див. 33. Орб. 30. Гунд. пс. 29. Миг. грам. 15. Андр. пут 27. твојије Радн. 34. - од основе ка рапгирене: поюхь М. 285. жонекь М. 404. коехь М. 498. конекь Збор. 10. Ст. пис. $3,40.325 .435 .4$, 76. 5. 140. Гуч. 3. Мик. грам. 14.

Мјесто свијех долазп п генитив двојине на крају XV п XVI вијека у слику: свију Ст. пис. 1, 83. Хект. 19б. 29. XVII вијека и изван слика: свију Радн. 21. 35. 40. 50. 87. Истога впјега додази тако и од основе она: онију Радш. 3.

На крају се додаје: 1) а XVII вијека: њиха Мрн. 36. 38. - 2) e с доданим $j$ од XIV вијека: текен М. 101. тнехен М. 416. Пб. 122. овнхен М. 471. овпјехеј Н. Рањ. 204. 208б. онпјехеј Н. Рањ. 207б. и без $j$ од свршетка XV вијека: онихе Ст. пис. 1, 302. Вран. жив. 39. свихе Буд. 105. вихе Буд. 130. Вран. жив. 48. - 3) и од XIV вијека: тнхн М. 234. 469. тьхи М. 459. овнхи М. 414. овијехи Н. Рањ. 177. 208. Фнтхи М. 443. онијехи Н. Рањ. 105б. 225. 225б. - Мјесто такога $e$ или јоп прије мјесто $u$ налази се написано в: тяџыхт Стар. 3, 51.

На дометнуто $е$ додавао се још једном падежни наставак у почетк у XVI вијека: тијехех Н. Рањ. 216. овијехех Н. Рањ. 366. онијехех Н. Рањ. 21б. 24. 25. 26. 30. 35. 70. 78. 82б. 95. 1136. 299. онпхех Н. Рањ. 41. тада се дометнуто $е$ узимало и као да је завршетак основе те се њим замјевивало: тнхнек 3бор. 37б. оннхнекь Збор. 3б. - $И$ на дометнуто $и$ налази се још једном додан падежни наставак: овихих Ст. пис. 2, 382.

Налази се зи уметнуто пред наставак, а тада се његово $u$ замјевује гдасом \$, који основа има пред наставком: тпјезијех Н. Рањ. 228. Ст. шис. 2, 442. овијезијех Н. Рањ. 156. Гуч. 76. Орб. 94. онпјезијех Гуч. 21. 228. Орб. 7. 29. по за- 
падном говору на оба мјеста $u$ : тизнх Банд. 129. овизих Банд. 27. мјесто к пред з налази се п $u$ јамачно из номинатива мн.: тизијех С'т. ппс. 3, 462. 4, 165. 261. 3бор. 44б. Град. дјев. 41. Мик. грам. 4. тизи(х) Радн. 4. овизијех Ст. ппс. 2, 447. Збор. 112б. Мик. грам. 16. овизије Пос. 3. онизијех Збор. 116. Град. дух. 7. Мат. 8. Мик. предгов. онизије ІІос. 1б. Радн. 2. 5. гојизпје Радн. 38. мјесто т пред з налазп се и $e$ (види инструм. јед.): тезијех Ст. пис. 4, 2262. Ст. пис. 5, 202. 219. онезијех Гуч. 42. Орб. 156. овезијех Орб. 156. тацезијех Ст. пис. 5, 237.

У сложен ом облику саставља се генитив мн. од замјенице ихь с номиналнијем обликом као пाто се саставља у номинативу јед., па у срнском језику од ми й ин сажимањем бива једно дуго $u$ : кад је у адјектива основа на чисто а: манастнрьскихь М. 6. светмхь М. 11. рашкихь М. 22. zемахинхь М. 103-4. двкровьхкнхи М. 159. 514. речешихь М. 258. прьхеннхь М. 386. посиискиих М. 448. 489. п тако свега времена: пуних Н. Рањ. 143. злих Ст. пис. 1, 116. њихових 324. свезаних Ст. пис. 2, 506. небеских Ст. пис. 4, 231. Злат. 29б. праведвих Cт. пис. 4, 231. мудрих д. Рањ. IX. вегових VIб. Зор $66 б$. Вран. жив. 18. Банд. 26. дијепих Злат. 46. разликпх Вран. жив. 3. -- кад је у адјектива основа на ја: жвпаних М. 6. ивтриихь М. 308. најмањих Н. Рањ. 196б. старијнх Ст. пис. 1, 3. средњих Ст. пис. 3, 359. дивјих Хект. 22. божих Гунд. суз. II, LVI. третих Ст. пис. 2, 347. - Али је п овај сложени облик изједначен с пропоминалния, мјесто -и- постадога $о д$-ти- добивши од прономуна ь, пред којим се $2, x, x$ мијења на 3 , и, ', и то од XIII вијека, те се вим замјевује и номиналнгі: стирехь М. 31. XIV вијека, ,окрьхь М. 241. дувро(ва)чсіихь М. 232. 236. шиозихь II. 1. пегокехь М. 238. прь-

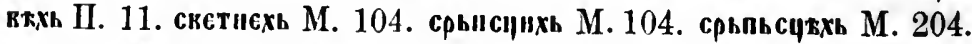
старєхь М. 237. П.рентхь II. 10. XV вијека: вимехь М. 372 . вє-

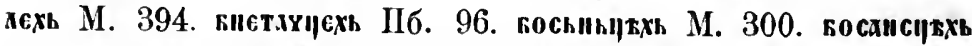

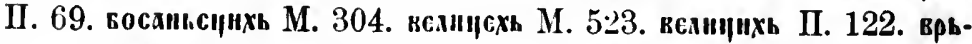
ховиєхь М. 299. деке.їехь М. 532. докрьхь М. 501. докрехь ПІб.

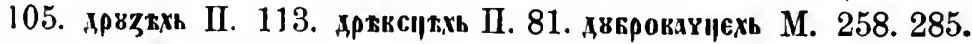

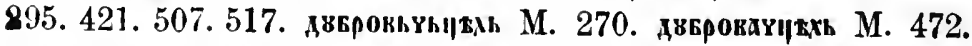
двкровауьцихь М. 283. 290. 364. 451. 491. 537. двгровауцисхь М.

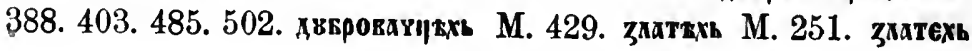


М. 390. 495. заатиехь М. 492. 500. ұхехь М. 346. ндакранехь М. 287. 413, мххехь М. 523. инозехь М. 518. мнозьхь II. 118. иеговехь М. 295. негоктхь М. 310. ПІ. 105. пегокнехь М. 312. шсталехь М. 431. писапиюехь М. 458. пкакетинехь М. 386. подпакениехь М. 372. почтепехь М. 478. прьктхь М. 310. прькехь М. 319. прькиехь М. 341. 412. ра-

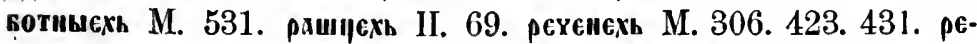
уеннехь М. 350. рехенехь ПІб. 106. светехь М. 261. 413. 456. светнехь М. 312. 383. скет пхһ М. 312. сководиехь М. 570. сахинхх

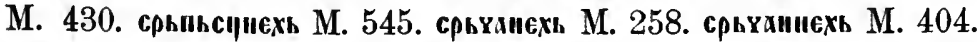
старехь М. 258. стартхх М. 444. старїехь М. 532. тврсцћхқ М. 338. вгарсієхк М. 285. вгрьсџћхь М. 338. вгрьсџнхк М. 339. XVI вијега : анђелсцијех Ст. пис. 1, 211. апђелсцих 230. велицијех Ст. пис. 3, 391. 4, 286. Збор. 4. Град. дјев. 72. Гуч. 19. висоцих Буд. 71. вјечнијех Ст. пис. 3, 397. Град. дјев. 56. воденијех Ст. пис. 4, 188. глуспјех Н. Рањ. 17б. горцијех Ст. пис. $2,474$. горсцијех Ст. пис. 3, 110. господиновијех Н. Рањ. 192б. грчцих Ст. пис. 4, 465. губавијех Н. Рањ. 156б. дадецијех Ст. пис. 5, 223. добријех Ст. пис. 5, 10. Град. дјев. 68. Злат. 36е. Гуч. 85. дразијех Ст. 2, 496. 3, 29. 4, 76. Злат. 34. дразнх Ст. пис. 2, 97. друзијех Н. Рањ. 60. Збор. 4б. Ст. пис. 4, 358. 5, 18. Град. дјев. 134. Злат. 70б. Гуч. 25. друзих Ст. ппс. 2, 152. 4, 460. Хект. 36. Злат. 69. дубоцијех Н. Рањ. 115. дузијех Ст. пис. 5, 165. жестоцијех 3бор. 48б. Д. Рањ. 59б. зема.ссцијех Н. Рањ. 89. Ст. пис. 3, 264. Град дјев. 20. здатијех Ст. пис. 4, 165. злијех Ст. пис. 3, 374. Град. дух. 9. издраелсцијех Н. Рањ. 61. источннјех Ст. пис. 4, 337. јацих Ст. пис. 1, 21. јечменијех Н. Рањ. 70. хупешцијех Збор. 101. мнозијех Н. Рањ. 24. Ззбор. 6. Ст. пис. 3, 159. 5, 120. Град. дјев. 6. Злат. 40. Гуч. 3. мнозих Ст. пис. 1, 27. 4, 218. 5, 313. Хект. 35. 3ор. 71. морсцијех Ст. пис. $3,438.4$, 57. мртвијех Ст. пис. 3,380 . Збор. 29. Гуч. 11. небесцијех Н. Рањ. 89. Збор. 40. Ст. пис. 3, 379. 4, 124. Град. дјев. 19. пеговијех Н. Рањ. 35. Збор. 9. Град. дјев. 118. планннсцијех Ст. пис. 4, 111. празнијех Н. Рањ. 62. првијех Ст. пис. 3, 297. Град. дјев. 136. разлицијех Ст. пис. 4, 11. Д. Рањ. VII. Гуч. 42. раздицих Д. Рањ. IX. Буд. 89. свјетовнпјех Ст. пис. 4, 4. сдацијех Ст. пис. 5, 8. слијепијех Д. Рањ. 17б. старпјех Ст. пис. 3, 311. Збор. 50. Злат. 16. сусијех Н. Рањ. 47. тешцејех Гуч. 72. тисих Ст. пис. 1, 37, 
труднијех Ст. пис. 4, 52. турсщијех Ст. пис. 3, 3i5. убозијех Н. Рањ. 16б. Збор. 53б. убозих Ст. пис. 1, 119. XVII вњјека: велицијех Орб. 42. велицих Банд. 141. глусих Вран. жив. 114. Банд. 6. добрпјех Див. 33. Гунд. суз. III, IX. Мик. грам. 9. дразијех Гунд. суз. предгов. друзијех Орб. 1. Мик. 117. друзнх Банд. 35. Кап. 88. каменијех Банд. 21. крацијех Гунд. суз. I, VI. мнознх Вран. жпв. 70. Банд. 14. мнозијех Банд. 16. Ђам. 2б. Мик. 255. опацијех Орб. 25. Андр. дев. $14 \%$. првијех Орб. 31. путенијех Андр. пут 231. разбијенијех Мик. 547. суспх Банд. 39. светијех Мнк. 262. телеснијех Андр. дев. 8. тешцих Каш. 96. - и без промјене грленијех гласова долази од XV вијека: хитискехь М. 408. дрвгтхь М. 474. двБрокауһкехь М. 522. Пб. 130. „вБрокауькиехи Пб. 130. Бенетһхкехь М. 528. срьв ьсктхь ПІб. 82. вгрьсктхи ПІб. 82. тако п послије: сухпјех Ст. пис. 3, 243. морскијех Ст. пис. 4, 270. мушкијех 215 . планинскијех 121. сухијех 112. тројанскијех 465. датинскијех Ст. пис. 5, 165. земаљскијех Град. дјев. 18. небескијех 16. грчкијех д. Рањ. VIIб. морскијех V. крстјанскијех Гуч. 32. љуцкијех 126. људскијех Орб. 197. датинскијех Ђам. 5б. другијех Мик. грам. 14. морскијех Мик. 162. жарғијех Андр. пут 221. земаљскпјех 83. небескијех 436. прпјекпјех Андр. дев. 142. - Од основа на чисто а прешло је ово $\leftleftarrows$ п к основама на ја, као и у прономина, и то од XV вијека: долитхи М. 250. ПI. 78. 94. ,омьнтхи II. 66. ПоскеАнехь М. 259. пожехи М. 287. 299. 424. көжиехь М. 312. 460. 463. божехь М. 456. госноћинехь М. 493. кельхь II. 81. XVI вијека. божијех Ст. пис. 3, 204. Град. дјев. 19. Брн. 11. Гуч. 3. кншнехь Збор. 12. винњијех Ст. пис. 3, 289. 4, 44. 58. 61. 187. Д. Рањ. VІб. Здат. 89. кражиехь 3бор. 164. Ст. пис. 5, 254. горијех Н. Рањ. 60. горњијех Ст. пис. 4, 319. господњијех Град. дјев. 145. дивијех Ст. пис. 4, 270. дјавољијех Ст. пис. 3, 438. дјављијех Гуч. 181. довијех Ст. пис. 4, 206. млађијех Град. дјев. 69. З.лат. 54. најмањијех Н. Рањ. 43. прашчијех Ст. пाс. 4, 192. садаппјех Ст. пис. $3,10.444$. сињнјех Ст. пис. 3, 294. старијех (compar.) Град. дјев. 69. туђијех Злат. 27. XVII вијека: божијех Гунд. пс. 39. Андр. пут 258. дпвпјех Гунд. суз. III, XI. 
Без $x$ на крају налази се једном XIII впјека јамачно грпјешком писарском: паши прьви М. 41. XVI впјека у слику и јамачно вега ради: повити (кад цвити повити златом и бисером - китицу поскити ручицом ве хитром) 3ор. 46. XVII вијека кад је $x$ у самом говору било ослабило: његови Вран. жив. 33. апоптоскије Див. 11. госпиније XV. злије 33. мнозије 1б. морскије 5б. обранпје 36б. мали Мик. 153. незрш.ии 724. мањn 654. многије Пос. 27б. опације 8б. властптпје Радн. 34. друзије 25. другпје 46. злије 2. људскпје 30. разликије 51.

\section{ДАТИВ МНОЖИИЕ.}

Једнак је за сва три рода. Основа добпја на крају $\mathbf{i}$ које се с крајњим самогласним њезинијем слаже као у генит. мн.; а наставак је исти којим постаје и у имена псти падеж:

a) од основа на чисто а: шщемь М. 101. 185. 455. шинємь М. 457. 548. - сдишть М. 88. - слить ПІ. 88. једнијем Д. Рањ.

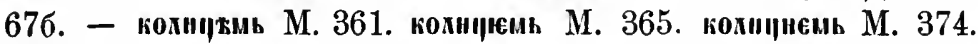
Ст. пис. 5, 34. Злат. 55б. Гуч. 59. Андр. пут 258. колицим Стар. 3, 317. Кашг. 21. пикокнцниь М. 545. - бвтиь М. 197. ювємь М. 373. овнјем Злат. 85. Орб. 96. - овацијем Гуч. 157. - опемь М. 260. онијем Н. Рањ. 13б. Ст. пис. 5, 9. Град. дјев. 22. Гуч. 109. Ашв. 33. оним Буд. 137. - схмхы М. 23. - тацијем Ст. пгис. 4, 202. Андр. нач. 50. - тењь М. 216. тьемь М. 219.' - тодицијем Град. дјев. 54. Орб. 54. - без промјене грленога гласа: коликијем Бун. 14. такође без промјене тога гласа или у сложеном облику: коликим Ст. пис. $1,329$.

б) од основа на ја: ниь М. 2. gim М. 280. јим Ст. пис. 1, 116. 5, 56. 57. Хект. 35б. Брн. 58. Вран. жнв. 102. им Орб. 247. 250. с приједлогом: к вим Банд. 134. и без приједлога: пнми М. 193. 255. 281. Н. Рањ. 31. Ст. пис. 1, 11. 5, 151. Гуч. 126. Вран. жнв. 19. Каш̈. 15. - мојим Вран. жив. 33. - шашнмь П. 32. - юкошиь М. 553. 554. - својим Вран. жив. 97. - твојим Вран. жив. 18. - од основе која предазн у овом облику међу основе на тисто а (као и у ин-

' Према овијем, онијем налази се с доданим сприједа о XVII вијека: к отијем Радн. 53. 
струменталу јед. и у генит. ин.): всъи М. 25 . вснми М. 377. вснень М. 457. всияна М. 466. всим Вран. жав. 76. свемь М. 239. 394. svim М. 279. свни М. 451. 494. свтми М. 455.485. свнемь М. 538. Н. Рањ. 20б. Ст. пис. 3, 45. 4, 5. 116. Град. дјев. 5. Д. Рањ. VІІб. Іуч. 1. Орб. 85. Андр. пут 118. свим Н. Рањ. 14б. Ст. пис. 4, 264. Вран. жив. 29. Каш. 21. Глав. 14. - од основе ка нерапирене има прономинални облик без промјене гласа $ж$ : кијем Ст. пис. $4,49.5,6.33 .120$. Град. дјев. 49. с промјеном гласа $\kappa$, сложено: њецијем Н. Рањ. 154. п без промјене пиєкнєи 3бор. 2. њекијем Радн. 75. и облик сложени: ким Ст. пис. 1, 79. Град. дјев. 23. никии Ст. пис. 1, 243. Брн. 43. њеким Д. Рањ. 1226. и раппрена је основа дошла из других падежа у овај: којпм Ст. нис. 2, 218. 4, 214. 268.

Основе су на ја преплл међу оне на чисто а: ємь $\mathrm{M}$. 428.' - мокми М. 280. нонеи М. 312. Н. Рањ. 85. Град. дјев. 3. Андр. пут 353. - пашнемь М. 106. Пб. 91 . пашнемь М. 457. 458. 483. нашємь M. 167. 295. 343. паштиь М. 217. 219. II. 4. 8. 22. 55. мхшєеь М. 402. напнјем Н. Рањ. 22. Ст. пис. 3, 369. 5, 36. Гуч. 10. Радн. 61. - съиь М. 219. - своємь II. 23. Н. Рањ. 13. 62. својијем Раді. 1. - твонмь II. 94. твојијем Андр. 147. - од основе ка раширенс: којијем Ст. Inc. 3 , 40. 259. 384. 431. 4, 20. 74. 229. 449. 5, 34. 113. Злат. 5. Банд. 62. 'Бам. 186.

На крају му се додаје:

1) а од свршетка XV вијека: вима Ст. пис. 1, 25. 204. А. Рањ. 54. Град. дјев. 84. Злат. 9. Гуч. 41. Орб. 6. Мрн. 74. Каш. 10. 15. 33. Мик. грам. 11. Андр. дев. 134. нут 81. Шос. 16. 25. Радн. 9. 12. 40. Радој. 12. има Пос. 8. - свима Ст. пис. 1, 8. 4, 405. 413. 427. А. Рањ. 38. Вран. жив. 8. Гунд. суз. II, XLVII. Мрн. 181. КашI. 34. 79. 80. Радој. 13. свијема Ст. пис. 4, 405. 448. А. Рањ. 146. Гуч. 102. Орб. 81. - тима д. Рањ. 16. - ниједнима Злат. 76. - колицнјема 0рб. 88. векодицијема 0рб.94. - мојима Ст. пис. 4, 416. - својпма Ст. пис. 4, 427. 466. Д. Рањ. 118. Злат. 8б. својијема Орб. 255. Андр. пут 174. - твојима Ст. пис. 4, 463. 5, 12. 90. Д. Рањ. 4.

' Тај примјер вије поуздав; види код генит. мн. 
3лат. 31б. твојијема Ст. пис. 4, 463. сажето: твима Гунд. пс. 26. - нашима Ст. пис. 4, 449. Мрн. 137. нашијема Ст. пис. 4, 449. - векијена Орб. 8. којијема Гуч. 12. Орб. 119.'

2) $e$ с доданим $j$ од XV вијека: бктиен М. 371. Н. Рањ. 206б. онимеј Н. Рањ. 204. послије само $е$ без $j$ : пиме Д. Рањ. 43. Вран. жив. 71. 95. 97. Јерк. 60. - тиме Ст. пис. $1,323$. 325. 327. Буд. 134. - ониме Ст. пис. 1, 58. Вран. жив. 15. 109. - једниме Мрн. 48. - свијеме Ст. пис. 3, 326. свиме Д. Рањ. 151. Хект. 8. Вран. жив. 21. Гунд. суз. III, XXIV. - снемє Збор. 27. - нашиме Д. Рањ. 79. - твојиме Ст. пис. $5,95$. - којиме Ст. пис. $5,49.51$.

3) $и$ од XIV вијека: тнмн М. 401. - онтмн М. 456. нашеми М. 518. онијеми Н. Рањ. 14. 26б. Гуч. 245. оними Ст. пис. 2, 310. овпми Злат. 3, 61. вими Ст. пис. 5, 11. 30. 70. 84. Град. дјев. 145. Злат. предгов. 3. 62. Гуч. 260. Чубр. предгов. 2б. ${ }^{2}$ мојијеми Злат. 9б. - У другим се падежима (вдди инстр. јед. и гевит. мн.) престало XVI вијека додавати $u$, с тога ваља мислити да се у то врнјеме престало додавати и у овом падежу, а што се и послије ғалази, то да је инструм. мн. узет мјесто датива: инструментад мјесто датива додази и XVI вијека: воде ногами мојими нијеси дао Н. Рањ. 189. свршио си онијеми чловјечпјем синовми Ст. пис. 3,455 . за то и у гдјеком између наведенијех примјера тога времена може бити да је и инструментал; а XVII је вијека тако: њими Орб. 91. к вими Банд. 46. дај њими 25. рече вими. 20. жпми Пос. 30. 33б. нашими Мрн. 138.

На додано $e$ још се једном додавао падежни наставак од почетка XVI вијека: овијемем Н. Рањ. 34б. 66. 716. 79. а тада се $e$ мијешало са завршетком основе у том облику и вим се замјењивало: онпјемијем Н. Рањ. 217. онимијем Ст. пис. 3 , 371. 461. Збор. 29. 40. 46. окиємнемь Збор. 177. тимим Ст. пис. 2, 272. онимим Ст. пис. 2, 52. 272. Д. Рањ. VIII. 6.

Налази се зи уметнуто пред наставак, а тада се његово $u$ замјењује гласом који основа има у овом облику пред наставком: онијезијем Гуч. 55. 89. онијезијема Гуч. 47.

1 у двојнни би могло бнтн: ногама мојнма Н. Рањ. 866. вима CT. пнI. $5,12.57$.

2 Iредтовор није Чубрановпћев. 
Орб. 8. овијезијем Орб. 221. (но западном говору:) онизим Банд. 17. мојизим Ст. нис. 4, 410. мјесто у у основи налази се и $u$ (види код генпт. мн.): окнъисык Збор. 50б. онизнјем Град. дјев. 28. Пос. 9. 26. налази се и $е$ мјесто (види инстр. јед.): тезијем Ст. пис. 5, 131. 210. онезијем Ст. иис. 5, 21. 79. Град. дјев. 94. Гуч. 54. онезим Каш. 30. 36. онезима Каш. 6. 53.

Сложени је облик једнак за сва три рода; датпв ин. од замјенице им саставља се с иоминалнијем обликом као у пнструменталу јед. мушкога рода: а) кад је у адјектива основа на чисто а: двкрокьчькни М. 16. 24. 120. 177. „вкроваукищ М. 185. 516. вожксткенши М. 134. подвихкскниь М. 205. подвихвьскынь М. 266. пркинь М. 288. срьчашимь М. 426. рете-

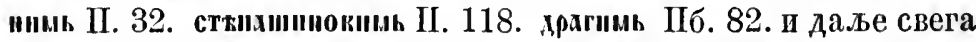
времена: пздраелским Н. Рањ. 143б. жидовским Н. Рањ. 176. верним Ст. пис. 1, 7. околним Ст. пис. 2, 31. горским Ст. пис. 4 , 478. прнслатким Злат. 61 б. осталим Вран. жив. 3. другим Банд. 47. његовим Банд. 47. добрим Мик. грам. 9. - б) кад се адјективу основа свршује на ја: дошиь М. 231. 253. 385. 486. посксдитм М. 295. мањим Д. Рањ. 98. старијим Стар. 4, 112. Каш. 21. - И овај је сложени облик од XIII вијека изједначен с прономпналним (види инстр. јед. и генит. мн.) те се њим замјењује и поминани: XIII внјега: джликмь М.

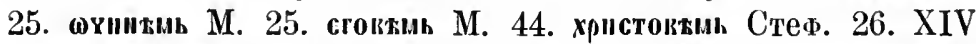

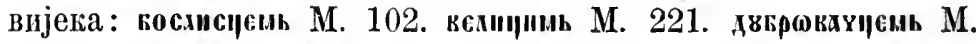

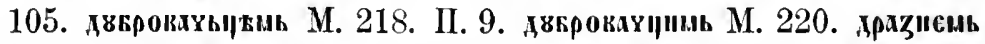

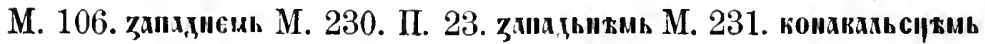
II. 19. имозтық М. 244. повокрьдьсџтыь Пб. 31. петовемь М. 106. 240. пеговтыь М. 143. скеттиь М. 134. срьчхисиь М. 193. тревиньсџты II. 19. хвиьсџень М. 102. XV вијека: госаньсџниь М.

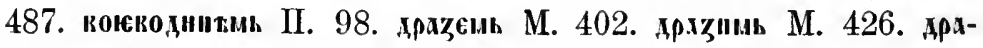

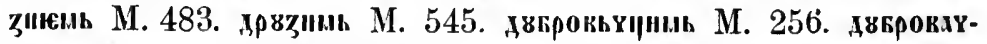

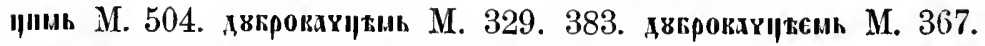

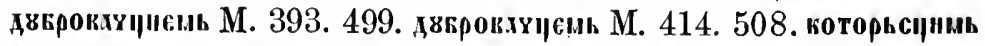

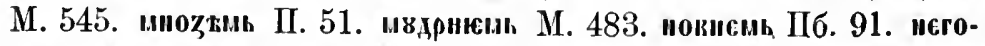

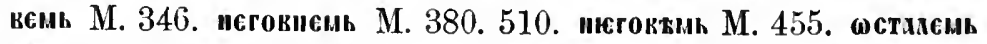

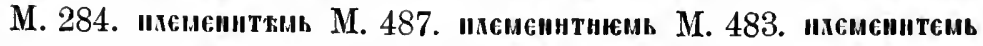
Пб. 114. правжми ПІ. 79. прьвтиь М. 300. прьвснь М. 343. рстспесиь М. 285. речепемь М. 297. речепиемь М. 373. скакиьыь Пб. 84. 
смавнемь Пб. 114. срьуамемь Пб. 113. старнемь ПІб. 91. хунсинемь M. 459. од краја XV и свега XVI вијека: ангео(с)цијем Град. дјев. 9. бдазијем Ст. пис. 5, 17. бдаженијем Ст. ппс. 4 , 12. Гуч. 247. богољубнијем Град. дјев. 3. Гуч. 1. бодљивијем Злат. 71б. вјернијем Гуч. 59. добријем Ст. пис. 3,380 . дразим Злат. 9. придразим Ст. пис. 4, 427. друзим Ст. пис. $2,50.4,246$. Д. Рањ. 25б. Хект. 29б. Зор. 69б. дрвънєн Збор. 2. Ст. пис. 4, 175. 351. 5, 6. 8. Злат. 68. друзим Ст. пис. 5, 335. живијем Злат. 28б. злијем Ст. пис. 3, 22. израелсцијем Н. Рањ. 48б. кротпнемь Збор. 23. дудијем Злат. 47б. миоземь М. 545. ммозшм М. 552. мнозим Ст. пис. $1,120.2,80.4,435$. Брн. 41б. мнозијем Ст. пис. 5, 14. 49. Град. дјев. 6. небесцијем Ірад. дух. 5. михиємь М. 550. праведнијем Ст. пис. 4, 233. светијем Ст. пис. 5, 116. Гуч. 13. труднијем Ст. пис. 4, 20. тужнијем Ст. пис. 3, 29. Гуч. 189. убозијем Н. Рањ. 79. Ст. пис. 5, 8. убозим Ст. пис. 1, 119. Град. дјев. 86. Буд. 80. XVII вијека: велицпјем Вран. жив. 79. глусијем Андр. пут 289. друзијем Орб. 54. Андр. пут 65. друзим Банд. 24. Кап. IV. Мик. предгов. јацијем Банд. 126. мнозим Вран. жив. 3. Мик. предгов. мнозијем Гунд. суз. I, LIX. Андр. пут 33. обилнијем Андр. пут 403. опацијем Андр. пут 156. осталпјем Банд. 26. светијем Андр. пут 156. тужнијем Орб. 45. убозим lанд. 90. Каш. 83. убозијем Радн. 94. - И'без промјене гутурала долази од XIV вијека, али испрва ријетко: XIV вијека: двкроклукиень М. 106. двкрокауькти М. 218. XVI вијека: прниорскиси М. 548. израелскијем Н. Рањ. 63. јевре(ј)скијем Н. Рањ. 80. небескијем Ст. пис. 3, 352. ангеоскијем Град. дјев. 31. земаљскијем 9. XVII вијека: бриткијеж. Андр. пут 115. рајскијем 266. непријатељскијем Андр. дев. 109. другијем Радн. 13. 33. 46. многијем 20. - Од основа на чисто а прешло је у у овом облику и к онима на ја као п у ирономина, и то од XIV вијека: допень М. 102. 280. по-

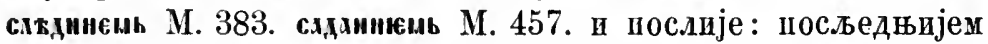
Н. Рањ. 34б. стхрнем (compar.) 3бор. 11б. доњијем Ст. пис. 3,123 . вишњијем С'г. пис. 4, 161. божијем Див. 3. горијем Андр. дев. 22. млађијем Радн. 48.

Од XVI вијека додаје се на крају $a:$ злима Ст. пис. 4, 444. мртвима 413. тужнима 413. 448. тужнијема 448. друзијема Ст. пис. 5, 102. друзима 185. живима - мртвима 17. 
мудријема 3. добрима Д. Рањ. 131б. друзима 9б. 100. 116. злима 28. крацима Злат. 76. мртвима 8б. кроткијема Гуч. 252. реченијема 55. турскијема 32 XVII впјека: блаженијема Орб. 227. добријема 42. друзијема 193. живијема 139. злијема 93. мучнијема 54 . осујенима 144 . подложнијема 255. убозијема 113. умрлијема 45. многима Банд. 222. умрдима Бун. 10. дру3пма Мрн. 138. ноћнима 63. богатима Каш. 119. домаћима 83. друзима 61. мнозима 75. убозима 83. друзијема Андр. IIyT 76.

У исто се вријеме додавадо п $e$, а.ли много рјеђе: XVI вијека: друзиме Ст. пис. 5, 92. А. Рањ. 79. мнозијеме Ст. нис. 5, 51. 66. људскиме Злат. 45. XVII вијека: друзиме Гунд. піс. 42.

Налази се и $и$ додано, чим се овај падеж пзједначивао с инструменталом мн.; до краја XV вијека могдо је $u$ бити додано дативу, а послије ће битн инструментал узет мјесто датнва (види напријед код прономина): XV вијека: вмастекошь двкровуџтин Пб. 62. XVI вијека: изабранијеми гостом Н. Рањ. 176. бог ће вратити праведнијеми Н. Рањ. 190б. супроћ обранијемп божпјем Н. Рањ. 204. правими Ст. пис. 1, 36. да вам

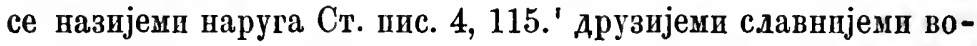
јеводам и господи Злат. предгов. 3. да погађаш јацијеми 9б. мнозими 10. мојијем м.лађијеми допушта $36 \mathrm{k}$. дарива вјерними својими 38б. допуштена свијем осталијеми дружбами опћено Гуч. 70. XVII вијега врдо ријетко: до коле хоћеш се супротивити заповидима цесаровими Вран. жив. 45. како се иристоји светими Банд. 50.

\section{А УСАТИВ МНОЖ⿱一兀甘Е.}

Постаје као у имена, те је једнак за муши и женски род, а у средњем је роду једнак с номинативом мн.:

А. За мушки и женски род налази се у старије вријеме са н на крају према старом словенском т од основа на чисто a: Фкн М. 4. нки М. 4. тн Пб. 15 . али је као у имена дошло $e$ и мјесто ш :

1 Ту би могао бити и инструментал на свом мјесту вао: гдје се мном наруга Ст. пис. 4, 115. али би онда вам било мјесто инструментала. 
a) од основа на чисто а: всхке М. 412. сваке М. 470. Злат. 91. од исте основе раширене: ксхкон М. 427. 486. - вскиолаке М. 413 . - ние М. 17. Н. Рањ. 154. - исте Буд. 156. - кокнке М. 393. жеколиге Град. дјев. 69. - ове Н. Рањ. 159б. с доданим $j$ : овеј Д. Рањ. ХIII. - оваке Злат. 63. - оне Н. Рањ. 123. с доданим $j$ : онеј І'рад. дјев. 20. - те.М. 137. с доданим fе и ре, а ирви додатаг гласи и je: тепере М. 449. с доданим $j:$ теј Ст. пис. 4, 246. - таке Буд. 129. с доданим $ђ е$ и $p e$, које се пошљедње и крњи: такоперь Збор. 114.

б) од основа на ја: ксе М. 413. 421. Стар. 3, 234. Вран. жив. 74. ске М. 261. 295. 307. 413. 424. 456. Пб. 69. Ст. пис. 3, 373. Град. дух. 21. Злат. 16б. Вран. рјеч. 87. - моє М. 443. и сажето: ме Ст. пис. $5,34$. - є М. 4.226.331. П. 7. 170.є М. 2. 36. 60. 218. 252. 305. с приједлогом : иє : М. 53. 248. 421. 422. 564. П. 58. 138. и без ириједлога: иє М. 328. XVI и XVII вијека врло је ријетко без прпједлога: XVI вијека: је Буд. 69. 127. Брн. 20. Стар. 4, 113. ње Ст. пис. 1, 27. 36. 79. 155. 3ор. 32б. XVII вијека: је Вран. жив. 75. Мат. 7. боље се држи уз приједлог све до краја XVII вијека: ње Ст. пис. 1, 13. 23. 48. Н. Рањ. 141б. 196б. Ст. пис. 2, 390. 4, 485. 5, 73. 75.94. Д. Рањ. 4б. 120б. Град. дјев. 119. 128. 138. 164. Хект. 22б. Зор. 69. Буд. 59. 107. Злат. 51б. 75б. 76. Гуч. 10. 40. Вран. жив. 60. Банд. 81. Бун. 33. Мат. 54. Андр. дев. 55. пут 59. Пос. 7. Глав. 35. излазећи тако из обичаја акусатив тој ријечи замјењује се генитивом без приједлога и с приједлогом, и то од XIV вијека: без приједлога XIV вијека: жа пхи подаде М. 108.

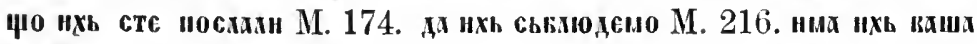
мнхость II. 9. покоде ихь II. 10. XV вијека: пхи М. 285. 339. 346. 366. 368. 400. 405. 432. 470. 570. 515. II. 28. 31. 37. 42.44. 47. 55. 58. 63. 73. 77. 82. 86. 96. 107. 110. 160. Пбо. 69. 83. 94. 95. 110. на грају XV и свега XVI вијега: јих Ст. иис. 1,5 . 20. 23. 34. 48. 70. 5, 71. 87. Хект. 5. 23б. 27б. 31б. 32б. Стар. 1, 229. 4, 111. пусти их Н. Рањ. 151б. шрниесоше шхи Збор. 35б. хоће их покести Збор. 51. мртке ихь вҮнин Збор. 76б. их Ст. пис. 2, 27. 41. 219. 428. 3, 143. 4, 223. 5, 6. 7. 110. Стар. 3, 224. 232. учећ их Д. Рањ. VIII. 68. извршујући их Град. дјев. 132. чтили их су Злат. предгов. 3б. достојне шх чини Гуч. 73. њих 
Ст. пис. 1, 91. посла њих Н. Рањ. 34. да искусим њих Н. Рањ. 88б. остави њих Н. Рањ. 91. пихь ди кикв Збор. 25б. взамь шихь 3бор. 38. њих Ст. пис. 5, 8. Стар. 4, 115. вих видеһи Град. дјев. 151. њих Злат. 7. њих ухватише Гуч. 289. XVII вијека: их Вран. жив. 24. Гунд. суз. III, LX. Банд. 40. Каш. 36.47. Андр. пут 63. јих Мрн. 3. њих Вран. жив. 22. поче њих молити Вран. жив. 58. ту ћу њих судити Орб. 230. уздитне њих Банд. 6. посла њих Банд. 156. њих Див. 28. Каш. 37. 102. Мик. грам. 11. Пос. 8б. тако и с приједлогом XIV вијека:

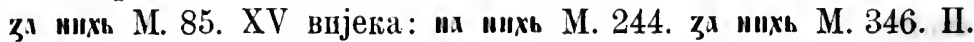
54. 82. и послије са свакојаким приједлозима: на крају XV п свега XVI вијека: њих Ст. нис. 1, 43. Н. Рањ. 17. 40б. Збор. 6. Град. дух. 68. 87. Хект. 18. Буд. 163. Злат. 126. Гуч. 85. XVII впјека: њих Вран. жив. 50. 58. 73. 113. Банд. 75. 121. Мрн. 65.' - Од основе ка нераширене, која кад није раширена принада меלу оне на чнсто а: ке М. 54. 399. Ст. пис. 4, 144. 201. Ірад. дјев. 9. Злат. 6. Ванд. 38. пикке Збор. 105. Ст. пис. 4, 167. А. Рањ. VI. Град. дјев. 85. Гуч. 154. Орб. 3. Андр. пут 301. с доданим $j$ : кеј Ст. пис. 2, 328. и од основе раширене: које Ст. пाс. 4, 203. Вран. жив. 8. њекоје Н. Рањ. 138. - од основе сја рапирене: спю М. 10. од псте основе нерашпрене: сс М. 567. съ (гдје һе ж бити само написано мјесто с) II. 171. се Ст. пис. 2, 459. 5, 54. с доданим $j$ : сеј Ст. пис. 2, 192. 358. 391. 411. Гуч. 286. за женски род додази и само си: киигы си М. 84. тако и в вьси скете М. 28. 33. за мушки. У неких писаца додази номинат. мјесто акусатива уз пмена мушкога рода с основом на а кад је и у њих узет но-

1 Kamић грам. 74. за акусатив мн. овој ријечи не ставља ништа друго него „они, оне, она“; Микаља грам. 11. ставља само "њих." - И у Аругих се прономина доста често замјењивао акусатив генитивом, али се пије изуубо: пожеже онијех $\mathbf{H}$. Рањ. І8. молите за онијех 396. онијех свак часті 3.лат. 916. нод проклецтво ставља свијех онијех Град. дјев. 83. оних Вран. жив. 38. КапІ. 89. оздравц једнијех Д. Рањ. VIб. мозк ихи скиски номициехь 3бор. 102. свнх Н. Рањ. 17. Ст. пис. 2, 56. 4, 258. Хект. 256. Кіаш. 89. за свијех Гуч. 159. Орб. 240. кпјех Н. Рањ. 95б. Град. дјев. 137. пицих Ст. пис. 1, 243. познам њеких Град. дјев. 37. кошхь М. 401. којијех Ст. пис. 3, 40. Гуч. 311. којшх Банд. 149. Андр. пут 277. 
минатив мјесто акусатива или уираво кад у акусативу предазе међу ријечи с основом на $\mathbf{i}$ (види напрнјед стр. 106-107) и уз ријечи с основом на $\mathbf{i}$, и то од краја XV впјека: заповиди моји Ст. нис. 1, 8. сваки труди 180. сви своји верни 188. моји труди 314. олтари твоји 244. гласи моји 334. власи свој(и) Ст. пис. 2, 108. они дни Зор. 26б. јини раздики кастеди 71. сви данки своји 3б. ти корени Буд. 40. они гриси 38. родитељи своји 59. пзрече ки годир гриси 25. ти разлози Вран. жив. 8. хоћете они исти венци пријати 74. сви посди чнњаше 87. гриси своји носећи 23. за наши гриси 10. за ваши бози 113. који штује цесар 40. сви зиди Мрн. 21. своји сини 115. напии војнгци 64. ки гласи 154. ако носите који одговори 99.

Б. За средњи род једнак је овај падеж с номинат. мн., који вндн. - Од основе ја налази се само у књигама писаним црквенијем језиком: а Стеф. 7. а кад га је нестало у српском језику, замјењивало га је кад кад акусатив мн. мушкога рода, докле се и он држао: ње (т. ј. лица) Ст. пис. 2,63. кроза ње (т. ј. врата) Г'рад. дјев. 34. та добра јесу онога, који напал је јест Буд. 107. ако је (т. ј. дјела) кто не чини Буд. 124. за ње (т. ј. добра) Буд 13є. а како се и у мушком роду замијенио акусатив мн. генитивом, замијенио се је п у средњем: та добра могу се датп убози(м), или да их држи за се Буд. 108. - Од основе сја раширене било је сна М. али и без $а$ : сн Стеф. 13. сип М. 10.

У сложеном облику саставља се акусатив мн. од прономина за женски род к, српски ю, а за средњи ис номиналним обдиком без промјене, те је било за мушки и женски род: дроүгне М. 4. чьстьныс М. 91. бковхинс М. 91. за средњи: рақанчьнах М. 5. али како у српском језику номинални облик мушкога и женскога рода има на крају $e$ не само од основа на ја него и на чнсто а, сажима се єє у с, а у средњем се роду сажима их у а, и тако ти сложени облици бивају једнаки с номнналншма, које впди, само птто је у сдоженима крајње самогдасно дуго.

\section{ВОКАТИВ МНОЖИНЕ.}

Замјењује се номинативом множине и у прономина и у адјектива у сложеном облику. 


\section{ИНСТРУМЕНТАЛ МНО ЖИНЕ.}

Једнак је за сва три рода. Основа добија на крају $\mathbf{i}$, које се с крајњим самогласним њезннијем слаже као у генит. мн.; наставак је исти којим и у имена постаје исти падеж, и остаје цио:

a) од основа ша чисто а: свацими Каш. 27. од исте основе раширене: ксхконин М. 289. - ники М. 11. ПІ. 36. нмени М. 230. нинеи М. 458. иними Буд. 59. Каш. 49. истијеми Град. дјев. 18. истими Каш. 42. - једними Н. Рањ. 18б. пиєдинми М. 458. - овими Буд. 51. Злат. 61б. Вран. жив. 113. Мрн. 98. Каш. 49. - овацими Буд. 17. Каш. 104. оваковими Вран. жив. 37. Мрн. 12. - онки II. 6. 91. Фнемїн М. 434. онєии М. 455. онијемп Ст. пис. 5, 133. оними Буд. 51. Вран. жив. 72. с доданим зи: шиємнии М. 205. 208. 267. - санын М. 14. - твмн М. 51. П. 135. темн М. 402. тими Ст. пис. 1, 66. Буд 132. Мрн. 44. - тацимп Ст. пис. $1,15$. Буд. 13. - тақовкии ПІ. 23. 98. 114. - толицијеми Н. Рањ. 70. Орб. 52. тодици Јерк. 75. Каш. 46. - И без промјене грленога гласа од XV вијека: ксхкмн М. 288. всхкєип М. 424. свакнјеми Див. 6. 26б. тақими Хект. 30б. толикими Банд. 112.

б) од основа на ја: вашими Банд. 17. - нмн М. 14. тако само у старија времена, а послије као с приједлогом; с приједлогом: ипмн М. 4. 99. 147. II. 72. Н. Рањ. 29. 3бор. 2. Ст. пис. 3, 416. 4, 224. 5, 20. Буд. 13. Злат. 26. Гуч. 98. Вран. жив. 19. Банд. VII. Мик. 249. без приједлога: њими Н. Рањ. 27. Ст. шис. 2, 28. 107. Стар. 4, 232. Буд. 63. Гуч. 22. Гунд. пс. 27. - мојими Н. Рањ. 189. Хект. Зб. Злат. 23. Банд. 183. - пашнии М. 382. Банд. 195. - својими Ст. пис. 1, 53. Банд. 13. - твојими Вран. жив. 19. Банд. 31. сажето: твими Мрн. 177. - снмн М. 259. Ст. иис. 1, 31. - од основе која у овом облику као п у дат. мн. прелази међу основе на чисто а: кьстмн М. 218. вснии М. 255. кснемн М. 312 . нсени М. 414. всеми М. 255. свеми М. 259. 284. 321. 431.' свијеми Н. Рањ. 31б. Ст. нис. 3, 299. 406. 4, 168. 5, 113. Гуч. 230. Див. 25. Орб. 84. свими Ст. пис. $3,146$. Хект. 17б. Здат. 3б. Вран. жив. 88. Мрн. 35. Банд. 21. Каш. 29. - од основе ка нерапирене

1 у једном сиоменику има и ксии М. 255. 
има облик сложени: кими М. 402. Ст. нис. 2 , 48. ншкими Ст. пис. 1, 3. и промпнални без промјене грленога гласа: кијеми Ст. пис. $3,433.4$, 154. Збор. 9б. с промјеном грленога гласа, сложен са пт: ницими Мрн. 4. од псте основе раширене види ниже.

Основе су се на ја и у овом облику изједначпде с онима на чисто а: наинсин Збор 115. монеми Збор. 83. 95. манени М. 238. 403. 422. пхинеин М. 403. 412. пиштин М. 403. 458. ПI. 91. пхиюми П. 10. Пб. 107. пашијеми Ст. пис. 3, 268. Див. 38. Банд. 153. сконсин М. 312. 485. Н. Рањ. 62. 69б. Збор. 18. Ст. пис. 2, 26. Орб. 7. скоњин М. 364. 387. ІІб. 92. скосин М. 380. твонени Збор. 58б. Ст. пиис. 4, 168. 5, 20. Брн. 2б. сиеми М. 312. стии (а.ли ту може бити да је т написано мјесто ") М. 243. од раширенијех основа: ксхкоњи М. 321. конєми М. 459. Ст. ппс. 3, 385. Див. XV.

Налази се зи уметнуто пред падежни наставак, а тада му се $u$ замјењује гласом ₹ који основа има на крају у том облику, а оспова мјесто п добија или $u$ (види нашрпјед стр. 192. 198): тнзиеми Збор. 45. овнъиеми Збор. 83. 98б. Стар. 3, 219. оннзнеми Збор. 54. 55. 80. 115. онизнми Банд. III. 120. или $e$ (види напријед стр. 174. 198): тезими Каш. 30. онезпми Каш. 42. - Од зи могло се $u$ и одбацнти: тезми Ст. ппс. 1, 38.

Од XIV внјека долазп обдик и окрњен, без крајњега $u$, и тако изједначен с дативом мн.: ищхм П. 19. вснм М. 104. пошљедни примјер није поуздано тога вијека, јер је из познијега пријеписа. XV вијека: колнјњы II. 61. 159. скемь М. 455. скони П. 30. и послије једнако: инијем Ђам. 4. Мат. 52. истијем Град. дјев. 102. Орб. 219. Бун. 36. Ђам. 22. Мик. грам. 4. једнијем Радн. 19. ниједним Здат. 4б. овацијем Град. дјев. 89. 157. овијем Н. Рањ. 218. Злат. 31б. Гуч. 109. Орб. 147. Ђам. 14б. 15. Андр. пут 42. Радн. 27. 43. 46. овим Ст. пис. 4, 432. Злат. 4. 80. онијем Ст. пис. 5, 132. 330. Град. дјев. 14. Зор. 69б. Злат. предгов. 1б. Орб. 108. Ђам. 13б. самијем Злат. 42. Радн. 27. самим Радн. 13. тим Ст. пис. 4, 427. 449. 463. тијем Ђам. 3. 4б. 5. тацијем (тхюмь) Мат. 52. такијем Андр. пут 70. толицијем Н. Рањ. 111б. Град. дух. 19. дјев. 95. Орб. 184. Андр. дев. 25. пут 80. тодицпм Ст. пис. 2, 168. 4, 439. тодикијем Пос. 21. Радн. 22. - вашијем Бун. 
25. Радн. 93. свијем Н. Рањ. 31. Ст. пис. 3, 43. 377. 4, 58. Град. дјев. 68. Гуч. 22. 275. Орб. 84. 168. 182. 281. Бун. 25. Андр. дев. 120. Пос. 25. Радн. 14. 69. свим Ст. пис. 2, 227. 349. 405. 4, 417. 426. 5, 19. 56. 75. Злат. 13. Банд. 173. мојијем Злат. 36k. Орб. 84. Бун. 29. Андр. дев. 137. мојим Ст. пис. 5, 56. 69. Зор. 2б. Злат. 63. Гунд. пс. 4. напијем Ст. пис. 2, 18. Орб. 286. Радн. 36. сим Ст. пис. 4, 416. својијем Н. Рањ. 170б. Ст. пис. 5, 75. Град. дух. 16. Злат. 62. Анв. 29. Бун. 26. 36. Андр. дев. 14. Пос. 39. Радн. 47. својим Ст. пис. 5, 118. Бапд. 87. твојијем Град. дјев. 183. Гуч. 181. Андр. дев. 139. нач. 36. пут 40. Пос. 11б. Радн. 25. твојим Ст. пис. 4, 462. 476. 487. 5, 255. Злат. 58б. Гунд. суз. III, LXXX. Банд. 128. Андр. пут 154. од основе ка нераширене: кијем Ст. пис. 4, 436.' Бун. 24. ким Злат. 88. Гунд. суз. I, XXIII. векијем Здат. предгов. 2б. Орб. 121. и од раширене: којим Ст. пис. 2, 422. којијем Ст. иис. 5, 76. Град. дјев. 23. дух. 8. Злат. 7. Гуч. 266. Див. 26б. Гунд. пс. 43. Ђам. 1. 4. Андр. дев. 70. 86. Радн. 31. свакојим Ст. иис. 5, 64. - тако и кад је уметнуто зи: онијезијем Н. Рањ. 180. Гуч. 133. овизијем Град. дух. 8. Пос. Зб. тезијем Ст. пис. 5, 147. Андр. 121. тизијем Радн. 30.

Тако окрњеном облику додаје се $a$ од XIV вијека: ш мима ПI. 22. тако и пос.дје: пнима Д. Рањ. V. истијема Гуч. 38. ниједнијема Гуч. 5. овијема Ст. пис. 4, 481. 482. Орб. 263. овима Ст. пис. 4,482 . Крн. 4б. онима Гуд. 36 . Пос. 32 . онијема Орб. 220. такима Злат. 95. тима Ст. пис. 4, 402. Д. Рањ. 286. - вашима А. Рањ. IХб. свима С'т. пис. 1, 17. 2, 44. 463. 4, 466. Д. Рањ. 57б. 134. Хект. 8. 17б. Брн. 49б. Вран. рјеч. 39. 88. Чубр. 15. Гунд. пाс. 4. Мрн. 44. свнсмх Збор. 6б. Ст. пис. $3,205.4,466.5,155.179$. Гуч. 232. Орб. 40. иниа М. 445. тако с пријед.огом и без пријед.лога : њима Ст. пис. 1, 22. 31. 4, 257. 465. 482. 5, 154. Д. Рањ. IVб. Х. 19. Град. дјев. 43. 56. 116. 140. 141. 157. дух. 25. 50. 88. Злат. 326. 86. Гуч. 174. Орб. 89. 102. 183. 214. Гунд. суз. I, LVII. Бун. 3. 24. Мрн. 3. 46. Ђам. 5. 9. Мик. грам. 16. Пос. 11б. 32. Радн. 13. 15. Андр. пут. 224. 232. мојијема Ст. пис. 4, 449. Гуч. 290. мо-

1 С промјеном крајњега м на $\varkappa$ : кијен Град. дух. 36. 
јима А. Рањ. 82б. 1.18. нашијема Гуч. 102. напима Мрн. 134. својима д.. Рањ. ІХб. 62. 144б. Злат. 80. својијема Ст. пис. 5, 120. 121. 127. 254. Гуч. 77. 206, 240. Орб́. 252. твојијема Ст. пис. 2, 408. 4, 476. Злат. 9. твојима Злат. 93. Банд. 137. Мрн. 140. сажето: твима Гунд. суз. II, IX. од основе ка нераширене: кима Ст. нис. 2, 356. 398. 416. Чубр. 4б. кијема Ст. ппс. 5, 247. и од раширене: којима Ст. пис. 5, 19. Злат. 93. Орб. 73. 142. којијема Гуч. 154. Орб. 21. 36. 50. Андр. нач. 1. 3. 4. - и кад је уметнуто зи: тијезијема Гуч. 306. овијезијема Орб. 263. онијезијема І'уч. 1. Орб. 88.

Додавало се је и $e$ : вапиме Ст. пис. 4,490 . свиме Ст. пис. 1, 13. 4, 445. А. Рањ. 39б. 67. свијеме Ст. пис. 5, 99. кијеме Ст. пис. 5, 313. киме Буд. 60. Брн. 49. којнјеме Гуч. 101. њпме Радн. 66.

На додано е на ново се додавао падежни наставак, а тада се додано $e$ замјењивало гласом ₹ који основа има у том падежу: тимиеми Ст: пнс. 3, 99. опнинии Збор. 121. а тада је опет крајње и отшадало, па се додавало 1 : конємине Збор. 80.

У сдоженом облнку за сва три рода пструменталмн. од прономина нмн саставља се с номиналним обликом мупкога рода без промјене, само се тын и ни, које тада буде пред наставком ин, сажима у срнском језику у једно дуго и: исскврьними М. 5. хвтинын М. 12. пегокшии М. 210. поскнгинии М. 236. вожнии М. 308. таго свега времена: јерусолимскими Н. Рањ. 19. многими Ст. пис. 1, 36. драгими Хект. 25б. добрими 38б. јадовними Зор. 37. острими Буд. 58. светими Брн.26. пуними Злат. 91б. сдаткими Вран. жив. 113. нечистими Гунд. суз. I, LXIV. небескими Банд. 114. сухими 112. живими Мрн. 134. царскимп 129. гвозденими Каш. 46. мехкими 9.

Од XIII је вијека овај облик као и други (вуди инструментал јед.) изједначен с прономиналнијем, а таки могу бити по западном говору и гдјекоји између горњијех примјера, па се вим замјењује и номинални облик: XIII вијека: еговтын M. 44. XIV вијека: вогодарованемн М. 230. восапьсүтмн II. 7. зиатнеми М. 107. ниеновантин М. 219. крьститмн М. 219. мноzнин М. 230. пеговтын М. 176. скетиемн М. 104. сктткеми 
М. 104. XV вијека: кисерьнсни Пб. 104. восаньсинии М. 255 . косхиспєми М. 307. кекиџтыи II. 33. ктрованиеми М. 403. кс: рованеми М. 433. пмситиеми М. 321. докркми М. 311. П. 92.

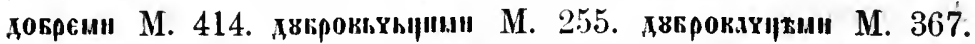
двкровауџени М. 508. "zакрансыи М. 276. 431. "zакраписеип М!

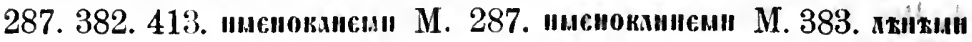

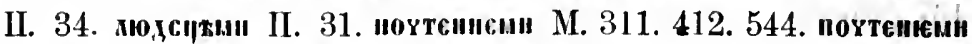

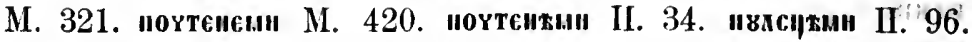
ретенисин М. 382. скетемн М. 259. 431. скетнеми М. 309. 312.

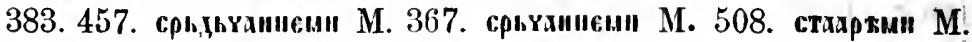
367. XVI вијека: ангеосцијеми Н. Рањ. 36. блаженијеми 217. издраелсцијеми 65 . мнозијеми 22. његовијеми 18 . пуиијеми 88б. горцијеми Ст. пाпс. 2, 500. грознијеми Ст. нис. $3,383$. добрпјеми 443. дразијеми 75 . жељнијеми 133. новијеми 360. слатцијеми 354. тужнпјеми 108. бијелијеми С'т. пис. $4,109$. друзијеми 27. здатијеми 109. злобнијеми 46. злијемп Ст. шис. 5 , 11. оптријеми 19. плачнијеми 50. көминем 3бор. 91. жєсторнени 124б. ниодиемн 1. скетнеми 118. минени 75. мнозими 3ор. 26б. вриднијеми Злат. 16б. грознијеми 81. дразими 97. дробппјеми 4. јапијеми 6. мнозијеми 68б. живнјеми Гуч. 74. мнозијеми 153. веговијеми 305. писанијеми 77. XVII вијека: мнозими Вран. жни. 112. Банд. 92. Мрн. 57. Кашт. 32. добријеми Див. 25. лажљивијемн 21. живијеми Орб. 152. лијенијеми 52. мнозијемп 204. велицимп Банд. 112. друзимп Мрн. 4. дузими 178. разлицими Јерк. 25. привелицимп Каш. 32. - п без промјене грленијех гласова од XV вијека: двьровьчькеин М. 535. градьсктин ІІ. 162. келикнемн Збор. 32. ІІрніслаткијеми Гуч. 241. српскијеми Див. ХІб. небескијеми Орб. 84. - Kaго су се у прономина у овом облику помијешале основе на ја међу оне на чисто а, тако су се номијешаде и у адјектива у овом сложеном облику од XV вијека: посмеднкин М. 238. вгаднвшнеми М. 457. божијеми Н. Рањ. 149. туђијеми Н. Рањ. 64. врућијеми Ст. пाис. 3, 462. 4, 27. заджпјеми Ст. пис. 4, 166. дражпјеми Злат. 11.

Од XIII вијека до.лазн и тај облик окрвен, без крајњега самог.даснога, изједначен с дативом мн.: XIII вијека: прєинсанниь М. 28. XIV вијека: пнсиним М. 234. XV вијека:

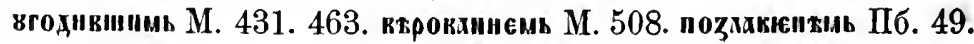


речєиеми Пб. 115. XVI вијека: грсцим Н. Рањ. 105. жидовсцијем 105. гокиетасписми 3бор. 826. билим Ст. пис. $2,77$. дразим 314 дразијем 405. дробним 361. жељним 281. здатим 25. дијепим 28. осталим 361. отајним 418. пригрозним 366. прихитрим 89. разлицим 89. смртним 405. бојним Ст. нис. 4, 468. гвозденијем 201. достојним 443. дразим 423. изврсним 437. линим 417. плачним 416. слатким 448. најслађим 417. тамним 404. худим 449. честим 434. чистнм 434 . злијем Ст. пис. 5,16 . пзбранијем 23 . првавијем 43 . славнијем 42 . слацијем 8. велицим Д. Рањ. IVб. дразим 20б. здијем 28б. мнозим V. немилим 107б. тужним 107б. блаженијем Трад. дјев. 65. добријем 101. духовнијем 68. живијем 122. земаљскијем 18. злочестијем 128. кренцијем 66. лијепијем 8. мртвијем 122 . његовијем 77. осталијен 68. праведнијем 33. светијем 31. страшнијем 62. умрлијем 178. блаженим Злат. 91. велицим $36 \mathrm{i}$. гнусним 51б. горијем 86 . достојнијем 84 . јацим 11. крацим 826 . крвавијем 87б. малим 44б. мнозим 11б. мнозпјем 16б. мртвим 11. нејация 51б. планинским 51. разлицим 63. свијетлијем 2. тесалскијем 17. учињенијем 83. цијелим 17б. апостолскијем Гуч. 98. бдаженијем 279. грознијем 182. густијем 273. замјернијем 291. мнозијем 78. његовијем 66. осталијем 22. разлицијем 11. славнијем 7. XVII впјека: друзијем Орб. 96. изабранијем 252. мнозијем 34. његовијем 64. осталијем 126. раздицијем 7. светијем 15. придразијем І'унд. пс. 42. свијетлим 43. худим 4. добријем Гунд. суз. III, LX. неумрлим III, XXIX. новијем I, XXXVIII. свитлим III, XXX. уреснијем III, XXX. хитрим II, XXVI. грознијем Бун. 17. друзијем 6. дворнијем 7. мнозијем 6. оптријем 16. тврдијем 47. мнозим Мрн. 24. друзијем Ђам. 9. датинскијем 3. новијем 19. виховијем 5 . реченијем 7б. садањијем 4б. старијем 4б. готовим Мик 116. дијепим 161. пуним 178. раскораченим 539. узети 419. бдаженијем Андр. дев. 154. бременитием 37. гвозденијем 144. љуцкијем 139. небескијем 25. разлицпјем 21. светијем 120. телеснијем 115 . највећијем 145 . анђеоскијем Пос. 39. другијем 30б. злочестијем 32 . мнозијем 446. његовијем 25. осталим 10. паметнијем 32 . разлицим 29 . богатијем Радн. 72. божијем 36. великпјем 63. властитијем 53. добријем 36. другим 11. земаљскијем 1. пзвањијем 84. коздетијем 
39. будскијем 54. малијем 51. мнозијем 13 . многијем 48. туђнјем 73.

Тако оцрњеном облику додаје се $а$ од краја XV вијека: мпогма Ст. иис. 1,31. страшнима 31 . тмастима 17. XVI вијека: друзима Н. Рањ. 163б. неумивенијема руками 64 . златима Ст. пис. 2, 11. 445. љувенима 505. грознима Ст. пис. 4, 427. грознијема 445. дразима 448. грвавима 402. лииима 483. слаткима 481. светима 444. добријема Ст. пис. 5, 13.15. пебескима 13. светијема 320 . сиједијема 57. боднима Д. Рањ. 129б. веселима 105. грознима 90б. друзима 18б. здатима 130. злима 69. малима 60 . мнозима ІХб. новима 89. оштрима 41. плачнима 78. русима 23б. разлицима 92. слаткима VIIб. цвјетнима 107б. већима Злат. 86. прутима 20. мртвима 316. разбијенима 59. скдаднима 86. сметенима 59. апостолскијема Гуч. 38. велицијема 130. гвозденпјема 214. друзијема 77. небескијема 131. његовијема 130 . телеснијема 103 . чуднијема 134. XVII вијека: безбројнијема Орб. 81. велицима 125. вјечнијема 167. гдасовитијема 227. добријема 60. друзијема 34. духовнијема 126. жестоцијема 179. живијема 107. злијема 255. људскијема 34 . мртвијема 124 . невјернијема 88. његовијема 267. осталијема 222. раздијељенијема 118. раздицијема 253. смртнијема 254. старијема 21. блаженијема Гунд. пс. 41. једнацима Гунд. суз. II, XLVII. грознијема Бун. 26. жестоцима 33 . мекахнима 47. обилнима 36. оштрима 41. придразнма 27. војнима Мрн. 158. краткима 120. мнозима 137. светима 26. сдаткима 175. друзијема Ђам. 9. датинскијема 1.'

Додавало му се и $e$ XVI и XVII вијека, али рјеђе: влажниме Д. Рањ. 77б. жудниме 57. здиме 6. мртвиме 996. туђне 38. пудниме 9. пудскиме Злат. 3. вишњиме Гунд. суз. II, XLVIII. жалосниме III, XVII. његовиме Гунд. пс. 28. мнознме Мрн. 179. принростиме Радн. 51.

На додано е додавао се је опет падежни наставак, а тада се $e$ замјењивало ғласом који има основа у том падежу: XVI вијека: грдимнми Збор. 161б.

' Кашић грам. 46 вели: svetimi vel svetima. 


\section{Л0КАТИВ МНОЖИНЕ.}

Једнак је за сва три рода. Основа добнја i, које се с крајњим самогдасним њезинијем слаже као у генит. мн. и као у докативу мн. мушких и средњих имена с основом на a, а наставак је исти којим постаје исти облик и у имена:

a) од основа на чисто а: ксаџв, М. 26. скаинхь М. 236. Каш. 82. и без промјене грденога тласа: всакъь II. 173. имехь Пб. 130. М. 410. иних Буд. 137. - истијех Град. дјев. 152. Аив. 6б. - комнџтк II. 116. кодицих Банд. 93. ннекохнинек Збор. 10. - ових Ст. пис. 1, 37. А. Рањ. IV. овијех Град. дјев. 168. Злат. 36g. Орб. 134. овије Див. 5. Радн. 36.

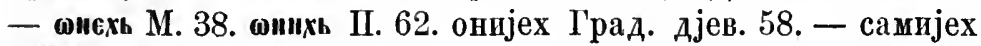
Град. дјев. 41. - тијех Гуч. 133. тих Буд. 57. - тацијех Злат. 31. тацих Буд. 90. - момнықь ПІ. 87. толицијех Ст. пис. 4, 432. Град. дух. 36. Здат. предгов. 3. Орб. 218.

б) од основа на ја: вашихь М. 24. Н. Рањ. 23б. - вь пнхь М. 5. Н. Рањ. 18б. Збор. 5б. Ст. нис. 1, 142. 2, 30. 388. 3, 124. 5, 130. Град. дјев. 27. Хект. 25б. Буд. 157. Гуч. 26. Вран. жив. 49. Див. 37б. Орб. 53. Банд. 7. Каш. 21. - мојих Ст. пис. 2, 243. - пхшихь M. 242. А. Рањ. ІХб. - сихь М. 233. - твојих Вран: жив. 21. и сажето: твшх А. Рањ. 83. - од основе која предази у овом падежу међу оне на чисто а (као и у генит. мн.): васнхь М. 233. ксихь М. 324. скехь М. 397. 410. Пб. 95. свих Н. Рањ. 165. Ст. пис. 2, 388. Д. Рањ. V. Град. дјев. 69. Гуч. 32. Банд. 40. свпјех А. Рањ. VII. Банд. 14. Бун. 37. свије Див. 26б. - од основе ка нераширене-сложени облик: ких Ст. пис. 1, 7. 2, 39. 102. 144. Хект. 30. Злат. 35. никих Банд. IV. п прономннални без промјене гласа к: кијех Ст. пис. 4, 153. 5, 37. 292. Злат. $36 \mathrm{k}$. њекијех Орб. 161. Мат. 70. с промјенощ грленога гласа: ппџєхь Мат. 14. и од рапирене: кощхь II. 151. Ст. пис. 2, 71. 5, 189. А. Рањ. У б.

Додази и у с.доженом облику: инихи М. 98. кскконкнхь М. 161.

Основе на ја прелазе међу оне на тнсто а: ваштхь П. 49. вашехь М. 517. 535. вашијех Н. Рањ. 33. Збор. 117. Банд. 13. моєекь Пб. 91. мојијех Н. Рањ. 16б. 35б. 229. Збор. 94. Ст. пис. 5, 68. Град. дјев. 152. Див. 25б. Орб. 85. пхшсхь М. 
260. 288. 295. 422. нишисхь М. 491. 506. 508. машьхь ПТ. 55.82. 96. шашијех Н. Рањ. 56. Град. дјев. 39. Гуч. 21. напије Див. 8б. съхь ПІ. 45. сшсхь М. 382. 413. скоєхи М. 387. 459. својијех Н. Рањ. 20. Град. дјев. 169. Злат. прегов. 1б. Гуч. 6. својнје Радн. 52. тконскь 3бор. 64. Ст. нис. 3, 256. 343. од основе ка рапирене: коєхь М. 386. Пб. 113. којнјех Ст. пис. 4, 88. 5, 349. Злат. 36g. Гуч. 1. Бун. 44.

Додаје му се на крају $e$ од $\mathrm{XV}$ вијека, и то јоги с доданим $j$ : сихси М. 470 . са самијем $e$ : овихе Буд. 164.

На таки додатак јоп се једном додавао надежни наставак, а тада се додано $е$ замјењивало гласом који у овом облику нма основа на крају: тнехнехь Збор. 157. $166 б$.

Налазп се уметнуто зи пред наставак, а тада му се $u$ замјењује гласом ₹ који има основа у овом облпку на крају: овъзъхь М. 475. овизшх Банд. 270. овизујех (окнзєхь) Мат. 13. онијезпјех Гуч. 102. тада основа може мјесто - имати и $u$ : онизиехь Збор. 94. Мик. грам. 3. и $e$ (види напријед стр. 174. 198. 205.) овезијех Ст. шис. 5 54. 100. 102. Гуч. 313.

у почетку XV вијека налази се датив мн. мјесто локатива: в книь скииь М. 249. свега тога вијека до краја XVI вијека нема више ни једнога примјера, а на крају XVI вијека долазн опет датив мјесто локат. један нут с доданим $a$ на грају : којијема Гуч. 10. и инструментал мн. којим се тада датив замјењивао (види код датива): на свијеми Злат. 16с. а.ли XVII вијека већ доста често долазн датив мјесто докат.: инијем Андр. дев. 47. пут 10’. пстијем Андр. пут 337. овијем Ђам. 6б. 7б. 9. 12. 15. Андр. дев. 98. 129. 141. Радн. 8. овацијем Ђам. 8. 24. онијем Андр. нач. 53. дев. 25. пут 101. тијем Ђaм. 27. такијем 'Андр. 58. толицијем Андр. дев. 15. пут 418. - свијез Ђам. 17. 24. Андр. дев. 37. пут 100. Радн. 95. мојијем Андр. дев. 45. нач. 37. пут 74. нашијем Андр. дев. 5. својијем Андр. дев. VII. пут 32. твојнјем Андр. дев. 142. нач. 55. пут 17. којнјем Ђам. 23б. Андр. дев. 69. пут 313. п с уметнутим зи: овезијем Андр. пут 256. онезијем Андр. пут 312. овизијем Радн. 6. онизијем Радн. 7. - с доданим $a$ : вима Ђам. 11б. Андр. дев. 45. нач. 18. пут 76. Радн. 24. 33. 65. мојијема Андр. пут. 344. твојнјема Андр. пут 160. овацијема Ђам. 12. којпјема Андр. пут 18. Радп. 8. њекијема Ђам. 25б. 
У сдоженом обдику, који је такођер за сватри рода једнак, саставља се локат. мн. замјенице ихт с номиналнијем обликом као у дативу мн.: кад је у адјектива основа на чисто а: старнхь М. 23. прьвнхь сиетнхь М. 171. срьдауинхь М. 281. вегових Н. Рањ. 101. А. Рањ. VІб. раздиких Зор. 27. добрих Буд. 89. речених Гуч. 52. проклетих Орб. 7. старих Банд. 177. - кад је у адјектива основа на ја: вишњих $Н$. Рањ. 21. госнодњих Банд. 221. - Али је и овај сложени облик изједначен с прономиналнијем јоп од XIV вијега:

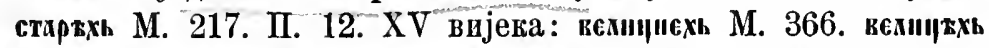
M. 444. докрнехь М. 324. добр вхь М. 459. догрехь М. 496. Арузехь М. 362. двкровауыриехь М. 403. zападиқхи М. 363. замтиехь

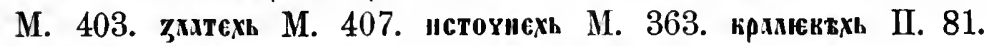

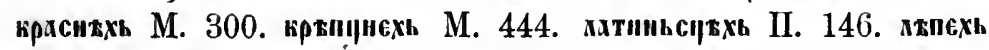
II. 143. пюквениехь М. 444. хюдьсПвхь II. 113. пеговнехь М. 443. ппдобннюек М. 459. почтенехь М. 516. почтеинехь Пб. 93. пракнєехь М. 459. прькехь М. 422. рехенехь М. 275. реуєннехь М. 403. реченехь М. 420. скетқхь М. 397. скакнтхь II. 161. срьдауитхи М. 300. срьдауинехь М. 337. срьврьиехь М. 411. срегрьииехь М. 425. старєхь М. 261. старжхь II. 95. XVI вијека: жидовсцијех Н. Рањ. 29. издраелсцијех 42. краљевијех 14. праведнијех 216. светијех 20. вскнинсхь Збор. 8. мнозиєхь 47. иекесүнєхь 124. рнисінехь 8. скетиєхь 97. мнозијех Ст. пис. $3,435.5,68$. морсцијех Ст. пис. 3. 288. труднијех 139. друзијех Град. дјев. 72. граљевсцијех 88. мнозијех 8. огњенијех 160. разлицијех 8. светијех 113. велицих Буд 46. друзијех Злат. 37б. лијепијех 50б. пакљенијех 5б. храбренијех 1б. боголубнијех Гуч. 156. добријех 164. друзијех 78. затворенијех 126. мнозијех 97. огњенијех 238. нисанијех 46. разлицијех 65. смртнијех 13. XVII вијека: пакленијех Див. 30. велицијех Орб. 132. Давидовијех 271. друзих Банд V. мнозих 25. сусих 37. светијех Бун. 19. дузих Каш. 35. тешцих 35. реченнје Див. 11б. добрије Радн. 65. и без промјене грленијех гласова од XV вијека: мокьсквк М. 529. XVII вијека: слаткијех Мик. 584. другије Пос. 35б. високије Радн. 44. многије Радн. 60. - како су у прономина у овом падежу основе на ја прешле међу оне на чисто а, тако су препле и у адјектива: „омьнхь М. 222. квдвксхь М. 299. кожнехь Збор. 38. винњијех Ст. пис. 
3, 97. Град. дјев. 184. господынјех Град. дјев. 44. доњијех Орб. 289.

Од XVI вијека додази датив мн. мјесто докатива, али тога вијека има само један иримјер, п он је с додапим $a$ : блаженпјема Гуч. 272. пз почетка XVII вијека има једном инструментал мјесто локатива: при осталими Вран. жив. 78. а послије се замјевује дативом без доданога $a$, а с датпвом је већ био изједначен п инструментал: мнозијем Ђам. 5б. осталијем Ђам. 12. 13. 17. 24. разлицијем 2б. реченијем 16. штампанијем 4б. бременитијем Андр. дев. 176. пут 257. вјечнијем Андр. дев. 176. пут 285. највећпјем Андр. дев. III. добријем Аидр. дев. 54. пут 55. друзијем Андр. нач. 3. пут 318. духовнијем Андр. дев. 45. пут. 96. придразијем Андр. дев. 50. даживијем Андр. пут 343. мнозијем 10. веговпјем Андр. дев. 180. пут. 232. светијем Андр. дев. VI. пут 96. добријем Радн. 6. доњијем 49. њнховијем 8. светијем 51. и без промјене грленшјех гласова: горкијем Андр. пут. 13. дјевичанскијем Андр. дев. 60. пут. 159./жестокијем Андр. пут 312. земаљскијем 41. морскијем 272. иебескијем Андр. дев. 60. другијем Радн. II. изванскијем 43. многијем 2. 


\section{ДОДАЩИ.}

\section{ЗАМЈЕНИЩЕ БЕЗ РОДА.}

Но ми нат и в једнине. У том облику за прво дице има племе пндоевропско особиту рпјеч, још доста не пстумачену, која у старом индијском језику гдаси аһam (постало од аgаm или agham), а у старом словенском азт, и с доданим сприједа $j$ : мзъ; ирема томе је и у српском језику било хъь М.

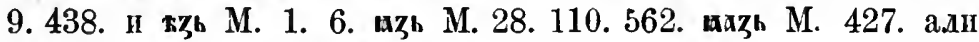
јої од првијех времена долазп окрњено, без крајњега зь, као данас: М. 1. а Сав. стар. 4, 231. М. 21. ва М. 30. - За друго је лице у старом пндијском језпку tram (постало од tuam), чему је најприје исшало а, по том $\mathbf{v}$ вративши се $\mathbf{y}$ u постало дуго $u$, а за вим $\mathbf{m}$ отпало, а дуго и постало у словенским језпцима т, те тај облик гласи у старом словенском језику тж, чему у српском језику одговара ти. Рефлексивно нема номинатива.

Генит ти в једнин е. Основе су у овом падежу и у остадијем падежима једнпне за прво дице та, за друго tva, за рефдексивно sva; али се у овощ падежу основе удвојавају a наставак падежни as као и у имена отпада: за прво лпце основа удвојена на првом мјесту остаје ma, а на другом се мјесту мијења у словенским језицима $\mathbf{m}$ на ", а самогласно a на оба мјеста постаје є: мснє М. 2. на једном мјесту XIV вијека јамачно писарском гријешком мнс М. 183. тако ће и у мемє М. 376. бити само написано єє мјесто є; и једном у слику, јамачно слика ради: менје Ст. пис. 2, 391. - За друго лице основа tva удвојена на првом мјесту губи $\mathbf{r}$, а на другом губи $t$, a $\mathbf{r}$ постаје к начнном још доста не протумачения, а самогласно а на оба мјеста гласи є: текє Сав. 4 . - 
Исто бнва и у основи за решлексивпо: удвојеној осповн sva на првом мјесто нспада $\mathbf{v}$, a па другом испада $\mathbf{s}$, a $\mathbf{v}$ постаје к, и самогдасно а на оба мјеста гласи є: сєк. М. 59. - За енклитички генитив узима се акусатив ме, те.

дати в једи ине. Постаје као у женских ријечи с основом жа а. Основе су удвојене као у генптиву и онако се мијењају, само им се а на другом мјесту у словенским језицпма с наставгом-і слијева у $\mathbf{k}$, а за прво лице још и на првом мјесту слаби у т, које у српском језнку отиада: иьт М. 5.

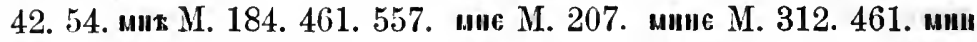
М. 281. 314. Ст. иис. 1, 180. 2, 5. 167. 445. међу два сугласна уметало се $a$ XV-XVI вијека: ман М. 274. 385. 445. Ст. пис. 1, 184. 2, 161. 354. 380. Стар. 3, 226. 227. 235. ман М. 460. 461. манпе Стар. $3,234.235$. али још од XIV дошло је међу два сугдасна $e$ јамачно из генитива: менє М. 233. мсии Пб. 43. М. 290. 443. 495. Пб. 124. мент М. 302. 337. 339. 341. 349. 370. 398. 403. 492. II. 103. 146. men!e M. 441. 501. 507. uєn!e M. 461. мсшт, М. 500. менє Пб. 104. 113. тако са је допире у XVI вијек: менје Н. Рањ. 15. 16б. 25б. 31. 42. 43. 52. 71. Збор. 25б. 29. 34б. 172. Ст. пис. 2, 136. 285. 311. 333. 365. 3, 181. 4, 239. 5, 181. 186. 221. 243. 254. али у исто вријеме узима мах $u$ па крају: мени Н. Рањ. 16. 19б. 22. 26б. 27. 43. 85. 88. 168. Збор. 32б. 36б. 39. 43б. 54б. Ст. пис. 2, 396. 3, 381. 4, 76. 5, 52. 298. Злат. 2. Гуч. 132. - За друго дице: тект М. 1. 22. II. 24. 143. 157. теке М. 237. 239. 260. теки М. 292. текте М. 500 са je на крају допире у XVI вијек: тебје Н. Рањ. 15б. 16б. 24. 31. 42. 71. Збор. 32. 172. Ст. иис. 2, 487.3, 351. Д. Рањ. 77б. у слику: тебије Ст. пис. 2,262 . у исто вријеме узима мах $u$ на крају: тебп Н. Рањ. 89. 118б. 143. 185. Збор. 2б. 25. 36. 84. Ст. пис. 4, 12. 304. Злат. 1б. Гуч. 131. - За рефлексивно: сек М. 2. 461. ПI. 112. 148. секе М. 343. 422. секи М. 248. 444. II. 50. 51. 162. секи М. 373. секте М. 493. тако са је на крају допире у XVI вијек: себје Н. Рањ. 30.72. Збор. 2. 7. 8. а у то вријеме узима мах $u$ ша крају: себи Збор. 10б. 33б. 35. Ст. пис. 4,304 . - У енклитичком су облигу основе само један пут, и без $\mathrm{v}$ за друго дице и за рефлексивно, а завршетак основе a с наставком i, саставља се у т, које слаби у н: ми М. 2. Сав. стар. 4, 231. ти М. 9. сп M. 2. 11. 26. 
Акусатив једнине. Основе се у том облику узимају само један пут, п другом дицу п рефдексивном без $\mathbf{v}$; наставаг је као у имена, завршетак основе гласећи условенским језицима е, саставља се с наставком у ж, које у српском језику гласи $e$ : за прво дице: ме М. 4. 208. Н. Рањ. 196б. мимо ме Ст. ппс. 2, 422. 481. 4, 346. Здат. 72. - За друго дице: те Н. Рањ. 16. - Рефлексивно: се Ст. пис. 2, 379. налази се и окрњено у прози: спћи с начепе Стар. 3,272 . у једном споменику XVI впјека налази се рефлексивно са $a$ мјесто $e$ по говору у ком и у другим прпликама кад кад ж гдасп $a$ : обита са Брн. 6. опи са Брн. 29. - Мјесто апусатива додази и генитив: менє М. 9. менє М. 376. вндјећете мене Н. Рањ. $138 б$. у мене Ст. ппс. 4, 160. теке М. 9. 43. обујми тебе Н. Рањ. 16. у тебе Ст. пис. 5,80 . себе Ст. пис. 4,64 . у себе Ст. ппс. $4,454$.

Вокатив једнине захјењује се номинативом јед.

Ин н трумен та.. је д ди и не. Постаје као у женских ријечи с основом на а. Основе се удвојавају као и у другим падежима, и сугдасна им се онако мијењају, а самогласна другачије: за прво дице самогласно а на првом мјесту слаби у словенским језицпма као у дативу у т, које у српском језику отпада, а на другом мјесту слаби у о: иною М. 4 . ПІб. 121. од тога у сриском језику као у имена најщрије: инок М. 27. 33. а послије: мнон М. 174. 186. 193. 281. 461. Пб. 34. 83. 112. Збор. 5. Ст. пис. 2, 105. 359. 4, 189. 217. 5, 134. А. Рањ. 47. Г'рад. дјев. 166. Злат. 5. Гуч. 134. Орб. 250. Банд. 25. Бун. 38. Каш. 60. Андр. пут 40. по неким крајевима умеће се $a$ међу два сугдасна од свршетка XV впјека: маном Ст. пис. $1,176$. 226. 3, 288. 3ор. 486. 70. Вран. жив. 11. 14. 23. Глав. 122.' 3а друго лице и за рефлексивно самогласно а на оба мјеста кратко будући у словенским језицима гласи 0 : токою, од тога у српском језпку најприје: токою, па тококь М. 22. 23. а послије: тобом Злат. 73б. Вран. жив. 31. сокюиь М. 458. Н. Рањ. $157 б$. Вран. жив. 47. - Крајње $м$ гдје гдје гласи и н: тобон Гуч. 119. собон Ст. пис. 4, 208. - Од почетка XVI вијека налази се и с доданим на крају $e$ : мноме Н. Рањ. 191. Ст. пис. $2,448$. 455. 491. 3, 21. 62. 451. 4, 11. 23. 26. 5, 185. 206. 254. А. Рањ. 21.

' Кашић грам. 69 вели: mrom vel manom. 
22. 82б. 99. Хект. 13. Злат. 1б. 13б. 18б. Вран. жив. 21. Крн. 23. Мрн. 23. 36. Јерк. 71. Андр. дев. 59. тобоме Н. Рањ. $15 б$. Ст. пис. 2, 420. 448. 490. 3, 87. 104. 368. 4, 72. 74. 97. 5, 60. 74. 105. 325. Д. Рањ. 90. Буд. 48. Злат. 27б. Гуч. 240. Вран. жив. 13. собоме Н. Рањ. 147б. 1566. 157б. Ст. пис. 2, 497. 3, 129. 4, 244. 455. Вуд. 33. 62. Вран. рјеч. 95. жив. 7. 23. 29. Мрн. 135.

Аокат и ј једн и не. Једнак је с дативом јед. и постаје као у имена женских с основом на а: за прво лице: мьи $\mathrm{M}$. 5. инт М. 337. инн М. 415. Пбб. 121. тако допире у XVI вијек: мни Ст. пис. 1, 7. 37. 46. 85. 238. 2, 5. 343. 351. 394. Стар. 3, 231. 284. 301. Зор. 16б. Брн. 4. 15. 42б. а од XV вијека умеће се као и у дативу $e$ међу два сугласна: мєи М. 416. IIб. 122. и је на крају држи се у јужном говору још у почетку XVI вијека: менје Н. Рањ. 15. Ст. пис. 2, 40. Збор. 92. али у исто вријеме узима мах $u$ : мени Н. Рањ. 14. 180б. 203. Ст. пис. 2, 351. 416. 454. Град. дјев. 114. Злат. 8. 40. - За друго лице: тект П. 148. тако са је још у почетку XVI вкјека: тебје Н. Рањ. 153б. Збор. 73. у исто вријеме узима мах $u$ : тебн Н. Рањ. 153б. Злат. 9. Гуч. 131. - Рефлексивно : секе М. 286. Пб. 109. секик М. 391. 403. секие М. 402. секи М. 441. 448. 492. Пб. 116. сек М. 492. са је па крају допире у XVI внјек: себје Н. Рањ. 226. Збор. 14б. 153. Ст. пис. 2, 303. 3, 194. у исто вријеме узима мах $u$ п у јужжом говору: себи Н. Рањ. 152б. 188б. Збор. 10. Ст. пис. 4. 45. Град. дјев. 21. Злат. 2. Гуч. 261.

Номинатив множине. Основе су за све падеже у множини као у једнини: за прво лице ma, за друго tva; само у множини основи за друго дице отнада $t$ у свијем падежима, а за прво дице у свијем падежпма осим номинатива мијења се у основи $м$ на н, може бити за то пто је основа прије била удвојена па се у удвојеној то обоје учннило као и у једини, а послије се основа огрьнла с приједа до друге иоловине. Ретлексивно нема множине. Основе свршујуһн се па а изједначују се с основама женских ријечи на а. Iо томе номинатпв ми. постаје као у тијех ријечи, а т, које тада постаје на крају, остаје у српском језику гласећи $u$ (као у номин. јед. мушких ријечн с основом на $\varkappa$, види стр. 11) а не замјењујућш се гдасом $e$ као у имена и у других за- 
мјеница женскога рода (гдје је дошдо од одснова на ја): за прво дице: ми Н. Рањ. 27б. - за друго лице: ви Н. Рањ. 20.

Генитив мн о жне. К основама на п ва приступа наставак којим постаје тај падеж и у других замјеница (види напријед стр. 189), само му се $\mathbf{s}$ не мијења $y$ $x$ него остаје с: за прво дице: ияск М. 510. - за друго лице: вхсь М. 20.

Дати в мо ки е. $\mathrm{K}$ основама на и ва пристуга наставак којим тај падеж постаје и у других ријечи: за прво лице:- пиь ПI. 71. за друго лице: вхмь М. 2. и иза приједлога: к нам Ст. пис. 3, 379. ка нам Вран. жнв. 18. ка вам Вран. жив. 17. к вам Банд. 36. крајње м гласи гдје гдје и ж: нан Бапд. 280. ван Н. Рањ. 38. 134. Стар. 1, 234. Ст. пис. 4, 308. 310. - Од XV вијека додазп п с доданим $a$ на крају, али ријетко: пхма П. 151. Мрн. 131. КапI. 5. 13. 16. 21. 22. 27. 30. 42. кхих II. 135. Збор. 78б. КапII. 58. -- XVI и XVII додази често инструментал мјесто датива без приједлога и с пријед,логом: памн М. 553. Ст. пис. 4, 360. 5, 25. 28. 32. 35. 48. 72. 85. 92. 95. намн оставн Д. Рањ. VI. намп дан не освита 52. гди нами све ствара жесток вај 93. почетак временитога живота нами бише Град. дјев. 17. нами се сличап учини 18. нами свјетова 77. к нами Град. дух. 81. да нами није моћ' имати пријатеља Злат. 22 . нами 82б. 101. к нами 97. нами потрјебан Гуч. 3. која се прпстојаше нами 31. објави их нами 135. проћ нами тужнијем 189. оставивши нами своје тијело Орб. 61. нами чине 247. даје нами 42. нами Гунд. суз. II, XLI. III, XXX. нами не потрибује Банд 23. дај нами 29. нами Бун. 48. Мат. 97. Мрн. 107. 111. 116. Мик. 16. грам. 10. Андр. дев. 180. нат. 27. пут 157. Пос. 16. 19. Радн. 48. к намиі Банд. 45. Мрн. 34. Ђам. 17. Радн. 49. - вами посидам Д. Рањ. IV. благо вами 50. г вами IXб. ја ћу дат' вамп мјесто Град. дјев. 167. једа се вами мни Здат. 14б. вами велин 31б. вами Гуч. 143. 240. није вами дано Орб. 193. јаох вами 284. к вами 150. рече вамп Банд. 21. вами дан јест 26. дадох вами 101. вами Бун. 15. Мат. 8. Мик. грам. 10. Пос. 7б. Радн. 10. Андр. пут 20. Радој. 32. к вами Банд. 45. Андр. дев. 60. Пос. 25б. - Енклитички облик за прво дице: им Стеф. 18. Сав. 13. М. 23. ин М. 41. 177. 190.269.302.399. 403. 435. 470. 479. 481. 535. II. 1. 17. 25. 69. 71. 152. Брн. 29б. 
за друго лице: вм М. 4. 25. ки М. 29. 42. 175. 417. 476. 501. 536. 545. 555. II. 1. 7. 69. 131. 132. Ст. пис. $3,214.4,109.5,212$. 330. Гуч. 143.

Акусати в но жине. К основама н $а$ и $в a$ приступа наставак којим исти падеж ностаје у других ријечи, а т, које тада постаје на крају, остаје и у српском језику гласећп $u$ као и у ном. мн.: за прво дице: им Стеф. 18. М. 23. 54. "I Сав. стар. 4, 231. II. 9. - за друго дице: вы М. 4. 19. 25. ви М. 506. 517. 545. II. 13. 55. 95. 131. 148. 161. Н. Рањ. 96б. Ст. пис. 2, 403. - Што данас има же, өе (види уे Обдицима срг. јез. 26), то ће бити у најновије вријеме изједначено с акусативом мн. других ријечи. - Од XV вијека додазп генит. мјесто акусатива: такон сє " вздхите в мась $M$. 517. да нас продијене Н. Рањ. 19б. помирује нас с богом Буд. 36. ако нас видише Вран. жив. 20. за нас Вран. жив. 8. вогь єе вась почтикь ПI. 122. прими вас Н. Рањ. 13б. молим вас Вран. жив. 66.

Вокатив множин замјењује се номинативом.

Инструментал множине. К основама жа и $6 a$ додази наставак као у женских ријечи с основом на я: за прво лице : нхи" М. 305. II. 2. Ст. пис. 3, 43. 360. 4, 32. 434. 5, 211. А. Рањ. 5. І'рад. дјев. 63. Хект. 7. Злат. 13. Гуч. 21. Вран. жив. 25. Орб. 134. Мик. 110. Андр. пут 256. - за друго дице вхмы М. 2. ками ПІ. 55. Н. Рањ. 19. Ст. пис. 2, 83. 4, 306. 5, 135. Град дјев. 142. Хект. 7. Злат. 36g. Гуч. 84. Вран жив. 4. Орб. 84. Банд. 3. Мик. 814. Пос. 43. Андр. пут. 416. Радн. 45. - Од XIII вијека додази п окрњен, те изједначен с дативом, пли њим замијењен: XIII вијека: сь нам М. 29. 33. XV впјека: с пами II. 41. мегю вхмь М. 43. сь вами II. 72. XVI вијека: међу нам Ст. ппс. 2, 430. меју вам Ст. пис. 3, 207. с вам Ірад. дух. 5. XVI вијека: с нам Банд. 73. меу вам Банд. 216. прид нам Ђам. 216. - тако окрњеном или изједначеном с дативом додаје се $a$ од XIV вијека: с мхмх II. 11. с камх ІІ. 1. 2. 4. 5. 9. 15. 20. и послпје: пхих М. 308. 309. 319. 445. 446. II. 66. 143. 15 1. 156. 157. Ст. Іпис. 3, 204. камх II. 49. 52. 54. 67. 72. 80. 88. 148. 157. 170. Ст. пис. 1, 294. $2,360.363 .377$. 


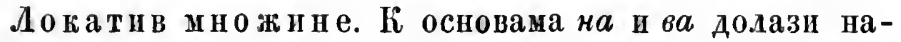
ставак юојим постаје тај падеж и у других ријечи, само му ce не мијева $\mathbf{s}$ на $x$, него остаје $c$ : за прво дице: пксь $M$. 87. 105. 329. Пб. 123. Ст. пис. 1, 151. Н. Рањ. 147. 149б. 1586. 159б. Збор. 31. Ст. пис. 4, 157. Д. Рањ. 52. Град. дух. 83. дјев. 109. Брн. 50. Банд. 41. 160. Каш. грам. 69. - за друго дпце: вась II. 49. 122. Ст. пис. 1, 248. Н. Рањ. 138б. 2020. 203. 205. 210. Збор. 27б. 120. Д. Рањ. 132б. Град. дјев. 39. 167. Брн. 14. Вран. жив. 49. 54. Банд. 21. 83. Каш. грам. 70. - XVII вијека прем да се још налази, ипак се замјењује иструменталом: у нами Андр. дев. 113. пут 256. Радн. 4.32. у вами Радн. III. послије одбацивши крајње $u$ п пзједначивши се с дативом добио је на крају $a$.

II

\section{ДВОЈИНА.}

НОМПНАТНВ АКУСАТИВ ВОКАТНВ.

Наставак је дуго a.

I. Основе на и. Крајње се кратко и у основи сажнма с наставком у Ауго и, које у словенским језнцима бнва т, а ы у српском језику гласи $и$ : по .к. кохи М. 14. 15 . ма пом М. 462. Н. Рањ. 69. - Али су ријечи с таком основом прешле међу мушке с основом на а, те имају као оне (види ниже под II. A): смих Сав. 4. два сшна Н. Рањ. 189б. иа пола Н. Рањ. 68б. Ст. пис. 5, 105.

II. Основе на a:

-А. У мушки ријечп: крајње а у основи сажпма се с наставком у дуго a, које у словенским језпцима остаје кратко:

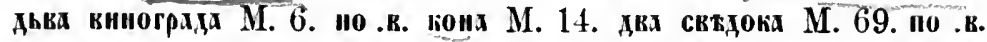
димара М. 193. два днка М. 249. .к. вмастелних М. 256. .к. храста М. 264. к. храстика М. 264. иа дкл итсеңа М. 351. два деката М.

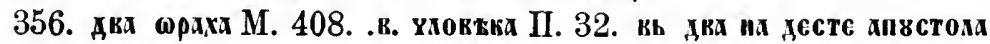
М. 275. - Тако и у адјектива: .к. властекния двкровьчкх М. 256. два козлића најбоља Н. Рањ. 56б. - Тако и у прономина: .к. ваша чмовтка ПІ. 32. он. Пб. 22. с доданим $j$ : онаи Збор. $115 б$. овај Н. Рањ. 189б. тако је било п у прономина у кога је основа ја: акус.: и Сав. 4. али како је тој ријечи нестало 
акусатива у једнини и у множини, нестало га је још прије у двојнин. Тако постају и бројеви: два (који је веһ наведен) ІІ оба М. 14. шка да Н1б. 116. М. 507. 509. 556. Н. Рањ. 148. Хект. 15б. Вран. жив. 25. Орб. 99. Мрн. 165. - Тако је било п у личнијех прономина, али за прво лице само акусатив: па (номинатив види ниже под Б) а за друго и номинатив и акусатив: ва Сав. 5. алп само у пајстарнје врпјеме, а послије долази у множини: акус.: срјете ви ч.довјек Н. Рањ. 96б. или мјесто акус. геннтив мн.: нас, вас, а неко вријеме и генитив двојине, који види. - у адјектива у сложеном обдику саставља сс прономинални облик а с номиналним обликом: крника М. 134. мјесто иртпкм, а у српском се језику сажима ли у дуго а: вь.к. апвстолх ирьхоких М. 460.

Б. У ријечи средњега рода: основа добива на крају $\mathbf{i}$, које се с прајњим њезинијем а саставља у ћ, пред којим се гласови $2, \boldsymbol{\kappa}, x$ мијењају на $3, u, c$, а које се у основа на ја мијења на $u$ предњега гласа ради: а) с основом на чисто a: до граја XV впјека: компи Стеф. 13. окт сск Г'лас. 15, 304.

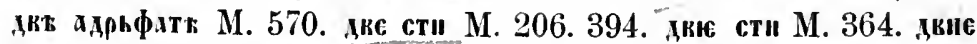
сти М. 373. Ани стн М. 489. 537. дкН сть М. 247. Анне стье М.

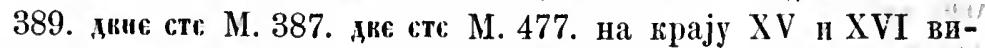
јека: рами Ст. пис. 1, 30. кољени Ст. пис. 3,24 . дви коли Стар. 3, 230. а до краја XVII вијека само: двје сти Н. Рањ. 127. Гуч. 17. Орб. 104. дви сти Банд. 140. - б) с основом на ја: до краја XV внјека: годмин ІІб. 9. М. 369. 397. и послије у пјесмама: лици Ст. пис. 1, 42. 92. Зор. 45б. 46. личци Ст. пис. 2, 24.62. 82. 165. 216. 316. а изван пјесама до краја" XVII внјека само: шлећи Ст. пис. 1, 154. 3лат. 87б. Крн. 2б. Андр. 169. али се та ријеч у том облику узима као да је женскога рода с основом на $і$ у номин. ми.: шлећи се њихове згрбпле Андр. пут 169.' (внди и генит. локат. дв.) Основе на ja као да су прелазиле међу оне на чисто а: zа дкє годшис ІІб. 113. - У адјектива је бндо као у супстантива јон XVI вијека у пјесмама: личци рунени Ст. пис. $2,24$. 82. 165. 216. 316. Анчци уресни Ст. пис. 2,62 . лици румени

' Како су ријечи женскога рода с основом иа $\mathbf{i}$ имале гдје гдје акус. мн. као ријечи с освовом на а (crp. 110-111) тако се налази и у ове: широке плеће Крн. 23. 
Зор. 45б. дшци му блшдили Зор. 46. - У прономина с основом на чисто а: зи бкше двие годнци М. 369 . и на ја: моп М. 9. уз ријечи охи и уиши свега времена (внди под IV) и у. оба броја, која су веһ сцоменута. - Тако и у прономина личнога за прво лице постаје номинат. од основе_ва: књ; акусатив види под А. - У адјектива у сложеном облику састављао се прономинални облик п с номпналним без промјене: срьчьצњnти М. 9. доүшекшт М. 88. а.ли само у најстарије вријеме. - Али још од XIII вијека взједначују се овп облици у свијех ријечи средњега рода с истијем облицима мушки ријечи: дке сти М. 31. XIV вијека: .к. годнца Пб. 35 . XV вијека: за

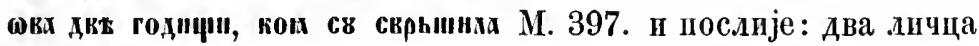
румена Ст. пис. 2 , 53. два дичца весела Ст. пис. 2,67 . два суначца Ст. пис. 2, 382. гиздава два ока Ст. пис. 2,490 . два уха Ст. пис. 4, 116. п.лећа Хект. 47. меју плећа Хект. $14 б$. дза годишћа Вран. жив. 69. колина оба два Мрн. 172.

В. У женских ријечи основа таґођер добива $\mathbf{i}$, те бива $4+i=\ell$ шго и у ријечи средњега рода: а) од основа на чисто а: до краја XV вијека: позь Сав. 4. дке пози М. 408. рвци М. 236. 252. 318. 428. 488. по авн страни М. 236. бкне странћ М. 328.

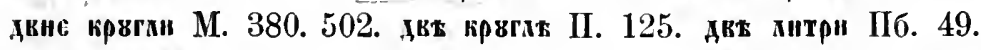

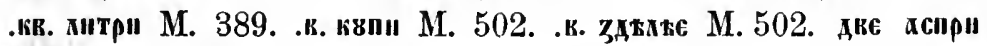
M. 527. на крају XV и XVI вијека само у неких ријечи: руци Ст. пис. 1, 64. 2, 23. 24. 25. 36. 82. 110. 130. 212. 353. 5, 79. 3лат. 61. усни Ст. шис. 1, 239. 3, 273. 329. Гуч. 108. ријетко

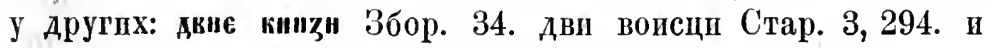
без промјене грленога гласа: дви воиски Стар. 3, 292. - б) с основом на ја: до краја XV вијека: бкт Нкани М. 11. „кт тнсоркн М. 50. 232. 397. двше тисвћн М. 428. 504. двт квкіи М.

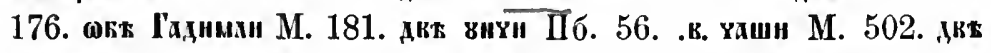
чвпшџ" II. 18. и до половине XVI вијека: дкне мвшпџн Збор. 36б. дви врнћи Стар. 3, 237. основе на ја као да су предазиле међу оне на чисто а (види дат. и лок. јед. стр. 23-24. 52.): пепенит юкт М. 13. - У адјектива с основом на чисто

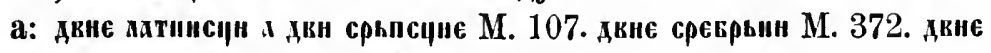

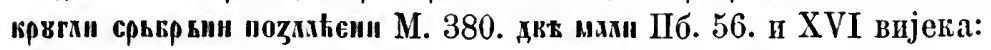
руци гиздави Ст. пис. 2, 293. руци прибијели Ст. пис. 2, 110. дви врпһи велици Стар. 3, 237. - У прономина с основом 
на чисто а: тк, с доданим зи: ткци М. 176. онте М. 544 . с

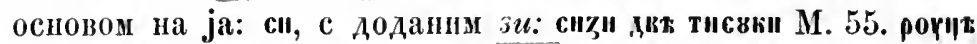
скон Сав. 10. руци мој(и) С'т. Іинс. 2, 258. и у оба броја, како је већ наведено. - У адјектива у сложеном облику прономинални се облик саставьао с номиналним без промјене: прти,стижи роүут Сав. 10. али тако само у прва времена.

А.ди се у свнјех ријечн осим оба броја (двије, обје) завршетак к и и замјењује гдасом $e$, тс се ни грлени гдасовн не мнјењају, јамачно према истијем облицима множине, и то у ријеши с основом на чнсто а од XV внјека а у ријечн с основом на ја јон од XIV внјека, п тако је остало до данас: а) с основом на чнсто а: в рвкс М. 326. в рвке моє

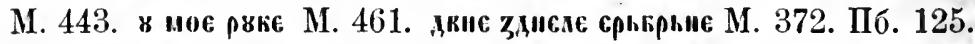

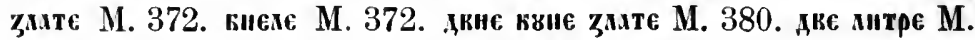

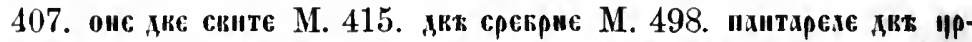
кене М. 498. дит аспре М. 525. zа дке годние М. 556. .к. кауве II.

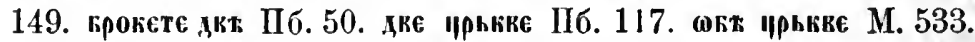
ове дви Ст. пис. 1, 50. двије жене Н. Рањ. 70б. дви звизде Ст. пнс. 2, 382. оби руке Ст. пис. 3, 317. моје двије друге Ст. пнс. 4, 153. двије муне Ст. пис. 4, 361. дви хиљаде Хект. $17 б$. обе руке Зор. 66б. усне Злат. 45б. Крн. 4. руке своје Вран. жив. 101. обе двије стране Ст. иис. 5, 18. обе дви дојке Вран. жив. 63. у адјектива п кад је сушстантив у иравој двојнни: руци прибнде Ст. пис. 2, 23. 353. бнле руцн Ст. пис. $2,83$. усни румене Ст. нис. 3,329 . - б) с основом на ја: динс покеке

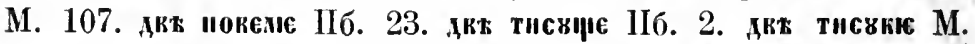

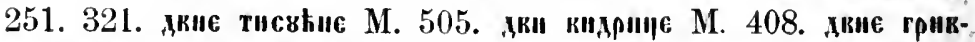

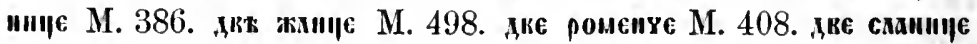
Іо. 102. обје двнје плавце Н. Рањ. 150. дкшс мвшиюе Збор. 36б. дви овце Банд. 71. у адјектива и кад је сушстантив у правој двојнни: „ке поз̆и орһмс М. 408.

III. Основе па i. Iрајњи глас од оспове сажима се с паставко у дуго $\mathbf{i}$, које у словенским језнцима бнва кратко:

А. У мущких рнјечи: юқх поути М. 93. два дни Н. Рањ. 77. Збор. 67б. Вран. рјеч. 13. Ст. пис. 4, 344. Орб. 125. Мнк. 92. Радн. 64. нонљедња је рнјеч остада тако до данас, а друге су препле међу ријени мушке с основом на а као и у другим облицима: у два пута Мнк. 713. у оба два пута Радн. 57. 
Б. У женских ријечи: двије заповиједи Н. Рањ. 159. тако у ријечи која сада већ није женскога рода, него је прешла међу ријечи мушке с основом на а, било је још XVI вијека: обје длани А. Рањ. ІХб.

IV. Основе на сугласно. Ријечи с таком основом шрелазе у' овијем облицима међу ријечи с основом на i:

А. мушие: канєи; али су у овом облику с мушия ријечима у којнх је основа на $\mathbf{i}$ ошет прешле међу мушке с основом на а, као и у другим падежнма: дка клмсна М. 126. два танка прамена Ст. пис. 2, 419.

Б. женске ријечи: .к. кєрн П. 171. али су прешле међу женске с основом на а, те је најирије било: дкнє кћєрлє $\mathrm{M}$. 544. а пгслије: ћере дви Зор. 9б.

В. ријечи средњега рода: имєн, али се у српском језику не находи тако, него су те ријечи прешле међу средње с основом на а; само се у двије ријечи сачувао таки облик, које одбацују од своје основе крајње $e c:$ очи и уии, уз које и придјевена ријеч стоји у двојини до краја XVI вијека: бхи мон М. 9. очи Н. Рањ. 17б. моји очи Ст. нис. 1, 166. свети очи 188. очи твојн при.липи 315. милосрдни очи твоји 334. гиздави очи Зор Зб. очи к зем.ы шригнути 17. очи његови Брн. 16 очи твоји 42. мили моји очи Стар. 3,223 . двије очи Здат. 90б. очи твоји Вран. жив. 27. очи моји 48. здрави очи 31. јере су видиди очи моји 110. моји очи Орб. 218. очи отешчаһ.ли Банд. 85. очи упиљени Мрн. 36. виднли очи моји Јерк. 30. очи лпјепи, очи криви Мик. 349. очи повезанп Андр. пут 191. оүши мон Стеф. 18. обје двије уши Град. дјев. 42. уши твојн.Вран. жив. 24. уши отпрти Банд. 6. - али се обје ријети у тијем облицима узимају и као да су женскога рода с основом на $\mathbf{i}$ (внди и код дат. ннстр. дв.): тако око свршетка XIV вијека: змє бун Шаф. lesek. 129. п послцје: очи ваше Ст. пис. 1, 4. Н. Рањ. 66б. видјели очи моје Н. Рањ. 176. очи твоје Н. Рањ. 28б. Збор. 33б. плачне очи моје Ст. пис. 2 , 425. тве очи приславне Ст. шпс. 3,472 . плачне очи Ст. пис. 4, 451. очи моје Гуч. 154. очи вапе Банд. 56. очи отешчале Банд. 91. црне очн створени Крн. 4. двије црне очи Бун. 5. уши своје Н. Рањ. 23. ошље уши Ст. пис. 4, 142. обје двије уши ваше Град. дјев. 42. уши твоје Гуч. 230. Гунд. пс. 31. 
гпи нијест чуде Орб. 297. тши своје Банд. 13. Обје рпјечи доlaze XVI вијега и ! облик! ријечи средњега рода, у којих је основа на а. нзједваqеном с обдиьом мушвих ријечв; впди напрпјед II. Б.

I EHกTHB I05ATHB.

Наставав је aus. од кога се аu ! словенскич језвцима cazпма $\mathrm{y}$ (оr). аз на врају отпада.

I. Оенове на и. Крајње и Г основи пред наставгоу orna, a: cunor. Bндіl jom nод $\mathrm{V}$.

II. Основе на а. Крајње а ! основи отпада пред наcrabeoy :

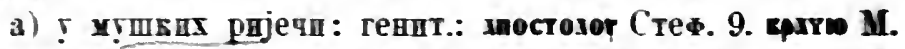

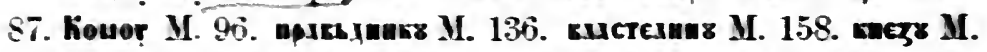

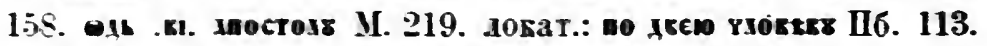

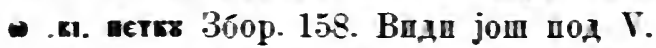

б) г рпјечп средвега рода: генит.: кризот твови М. 521. врхт п.ее! Ггч. 205. догат.: на волин! Ст. пис. 1, 10. на раху Cr. пис. 3. 283. по п.еһ! Ст. пис. 1. 57. на плеל! Ст. пnс. 1, 101. али се номпнатив двојине илећи узпма гао да је номн. мн. 0.2 основе на i. па се према томе ваходи генит. п догат. ун.. којп додазе п за двојнну : врх плеһи Ст. ппс. 3, 474. 4, 49.

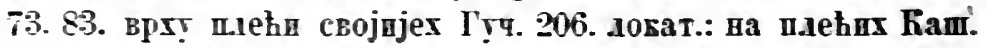
61. ва твојијем плећнса Андр. дев. 160. Внди још под $V$.

в) ! ршјечи денскога рода: генит.: иоки orctuor Cав. 9.

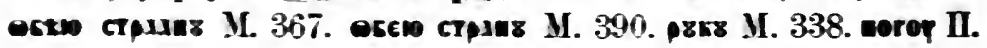

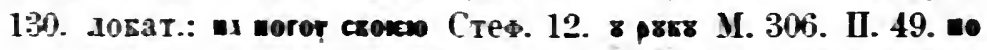
рзгв М. 349. 850. П. 94. - Г двпје рпјечи таво свега времена: p】в Н. Рањ 22. 3бор. 90. Радн. 69. ногт 3бор. 74. Врн. 45.

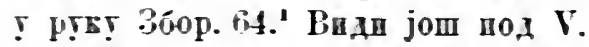

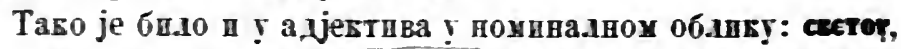

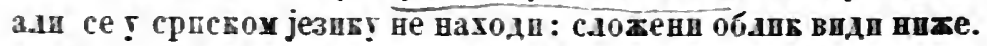

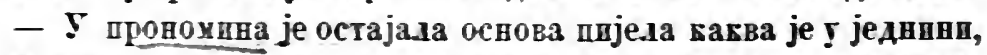

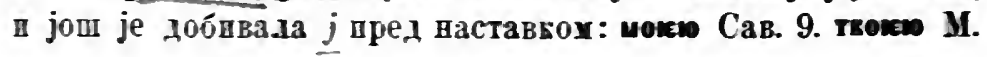

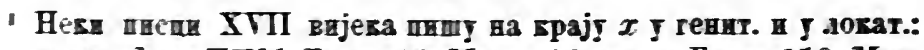
pzкzx Дав. XIII6. Банд. 65. М̈s. 126. ногуд Бавд. 156. Mir. 9. ва ногіх Банд. 111. Радн. 2. 
521. своксо М. 521. тапо је бв.10 и у броју: огою Стеф. 2. а.ии је у ирономина самог.дасно које имај! इ генит. и .окат. множине пред наставком продрдо и 5 ове облике пред вихов наставаг истиснувши пу из основе самогАасно, в то од свршетка XIV вијека: пню М. 219. 249. 356. 360. 364. 373. 393. 458. 462. 499. Пб. 22. 35. gnigiu М. 385. вију Ст. пис. 1. 83. пхшию Пб. 113. овију СТ. пис. 1.92. тако, преу да значи множину: свију Ст. пис. 1,83 . Хект. 19б. таво је и ! бројевима два и оба основа каква је у дативу и инструменталу црешда п ! ове облике од XV вијека: генитив за сва три рода: шгто IIб. 55. М. 367. ПІ. 147. шкен П. 85. А. Рањ. 27. Гуч. 42. окnв М. 505. Ст. пис. 1, 92. 2, 402. 412. Хевт. 5. Зор. 33б. Ћрн. 4. дкто Зак. 32. М. 570. двјеј! А. Рањ. 42б. Здат. 75б. двију Ст. пис. 1, 79. 83. 89. Н. Рањ. 5зб. 171. Збор. 92б. Зор. 32. Ггч. 136. Вран. хив. 73. Банд. (11. Мик. 215. Пос. 32. докатив за

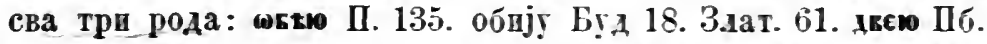
113. двпјг Н. Рањ. 55б. Банд. 83.' прем да се оба броја тако находе свега времена а и данас, опет кад је двојнна готово у свијех рвјечи взашла вз обпчаја те се у ве.ике зачјењива.ла множином, прелазнда су и та два броја XVI и XVII вијека ! множину шрономиналну, премда само двоје значе: у генит. и докат.: дбих. обих. и у новијем докат.: дбјема, види под V.2у адјектива у сложеном облику састав.ља се прономпна.1ни обдшк кею с вомнна.дни обдиком одбацивши први свој слог: светорю М. 87. 136. али је из с.ложенога генштива п доқатива множине самогдасно које имају цред наставком преш.10 п ! ове облвке встисвувии вихово ог пред ю. в то од XIII в.1в

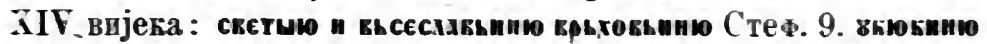
М. 158. одвирьтию М. 249. таки облик додазп XIII ввјева мјесто акусатива: скьти М. 35 . према томе је п XVI вијега: његовију Стар. $3,327 .-\boldsymbol{Y}$ дичнијех врономина основе за прво дице на, за дргто ва остају цијеле са завршетком $а$ шред

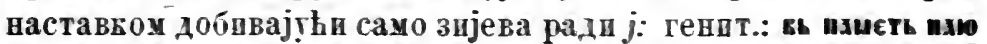

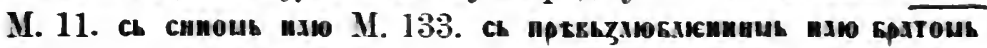

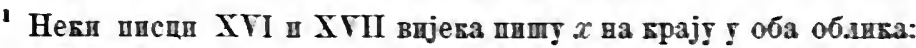
двијух Град. дјев. 136. Банд. 44. Мвк. 46.

2 Kатић грах. 57-5s ве.ии за генит. и .оқат.: drih rel drijø, obih rel obiju. 
М. 269. их окив имв потрикв М. 505. немој нају мајку зловобиті Хект. 126. до нају миле мајке Хект. 16. гмагояы мос да

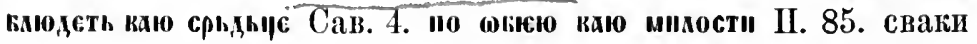
вају Хект. 5б. локат.: доңхь кожй да почїеть иа каю Сав. 5. Геиитив у двојнии долази и мјесто акусатива као што додази I у множнни, XVI вијека: пушћај нају Хект. 16. али и за мпонну долазе оба ова облику и то не само исте облике замјењујући множини него п друге, на крају XV и XVI вијека: за геннт. ми.: прид лицем вају свнх Ст. пис. 1, 86. однеси тај бич од нају 245. господиш нају 248. сазнајте дила вају 253. услиша нају молбе 338. кога вају во паде (Аук. 14, 5) Н. Рањ. 159. чудо видит' бише свим меу нами, гдй рика тецнше под нају ногами Хект. 8. свих нају душ Чубр. 15. за акус. мн.: брани нају Cr. пис. 1, 27. прпми свих нају 31. уфанје све моје постављам у вају 214. помилуј нају 244. жубнмо ми њих, они нају 204. за дат. мн.: против нају Ст. пис. 1, 22. плати'' hе бог вају 82. за инстр. мн.: ких се сад меу нају спомена сва згуби А. Рањ. 58. и XVII вијека надази се мјесто акус. мн.: нају Јерк. 7. 93.'

III. Основе на i. Крајње кратко і у основи бива дуго, те у словенским језицпма остаје кратко: обитилију Н. Рањ. 107б. отајностију Гуч. 25. прсију Вран. жив. 68. али на та сва три мјеста стоје ти облици за множину.

IV. Основе на сугласно. Наставак прнступа к основи: шкемє М. 248. али како су таке ријечи у другим надежима прелазиле међу оне с основом на $\mathbf{i}$, прешле су онамо и у овијем падежима двпје с окрњеном основом, т. ј. без крајњега ec: генит.: очшо Сав. 10. Ст. шис. 1, 174. Н. Рањ. $73 б$. 3бор. 17. Зор. 7. Брн. 27б. Злат. 97б. Вран. жнв. 18. Банд. 5. вщпю Збор. 10б. Њанд. 5. локат.: у очију Н. Рањ. 56. Банд. 47. Крн. 9б. Радн. 24. по очију Стар. 3, 264. Злат. 59. по ушију Ст. пис. 1, 263. на ушију Гунд. суз. I, XXXI. у ушију Банд. $213 .{ }^{2}$ обје се ове ријечи узимају у том облику и за множину: с тисућу очију Д. Рањ. 38. седам очију Банд. 232. али се

2 Кашиһ грам. 69 вели: $\mathrm{s}$ nami vel $\mathrm{s}$ naju.

${ }^{2}$ Неки писци XVI и XVII вијека пишу $x$ у оба облика: на очнјух Град. дух. 43. очијух Банд. 63. у ушијух Град. дјев, 39. Банд. 5. 
облици очи и уиии узпмају као да су номинат. мн. с основом на $\mathbf{i}$ женскога рода, па се према томе находп генитив и докатив мн., који долазе и за двојину: генит.: врх очи Ст. пис. 2, 467. од очи твојнјех Ст. пис. 3,456 . с очп слипих Ст. ипс. 4, 476. очи А. Рањ. 71б. из мојих очи Гуч. 278. дијеших ње очи Злат. 56. из очи Злат. 81. очи мојијех Гунд. пс. 9. из очи мојих Андр. пут 407. једном пма и ои Андр. пут 186. али би могла битп и погрјепка. локат.: по очих свих Д. Рањ. 83. и новијп локат.: у уппма мојијем Андр. пут 344.

V. Прем да су се ова оба облика двојине у неких ријечи догувала до данас, опет су се оба не само у других ријечи него п у тијех од $\mathrm{XV}$ вијека почела замјењивати друтим обдицима:

1. Мјесто оба ова шадежа, кад су с приједлогом, додази номинатив двојине с приједлогом од XV вијека, онаки какав је кад био: мјесто генитива: бдн мок два дам М. 532. ода два чдовјека Н. Рањ. 79б. од ова два начкна Орб. 90. 124. након два дни Орб. 196. з оба бока Мрн. 54. до дка годниа II. 103. с оба ока Ст. пис. 1, 184. s obi strani M. 386. од руци Ст. пис. 2, 467. руци ван Злат. 14б. с обје двије стране Ст. пис. 4, 440. с обе стране Мрн. 46. са дви стране Мрн. 50. од двије оштрнне Радн. 57. из двпје ствари Град. дух. 80. - мјесто докат.: в два саква М. 407. в тази ФБох лнста Пб. 55. на колини Ст. пис. 1, 209. у оба два творења Д. Рањ. VIII. в двт орьманнце II. 135. по два дни Н. Рањ. 89б. у ове двије заповиједи Н. Рањ. 159. тако уз број који стоји у генитиву или локатпву двојине налазп се у номинативу двојине рпјеч којој се број каже: од лицп обију Крн. 4. на обију колини Буд. 18. множине:

2. Оба се падежа двојине замјењују истијем падежима

а) број стоји у двојини, а ријеч којој се број каже у множини: за генит.: Фдь овтю страна П. 147. са страна обију Ст. пис. 2, 402. ОА двню старнехь свснеда Збор. 50. ОА двню вратненаца 92. дкию сткари 6. обију синак Зор. З3б. двију па-

1 у броју дванаест пा уза в почела су се оба ова облика губити јоіl XIV вијека: оть скстыхь .кі. апостояь М. 167. испореди додатак четвртэ. 
стиров 50. од овнх двију м.лади 32 веселпх двеју звизда Злат. 75б. од објеју реченијех дуга І'уч. 42. овијех двију светијех госпоја 136. оних двију братннац Вран. жив. 28. од ових двију м.ладинац 73. са обнју двију стран 37. тизнх двију дан Банд. 129. од двнју страна Мик. 215. от дкив трвгиє ствари Пос. 32. - за локат.: на ногах обију Злат. 61 . у двију рпјечијех Мик. $46 .^{\prime}$

б) број се не каже гззијеком, него ријеч којој се сачувала двојина стоји у двојинп, а придјевена јој додазй у множини: за генит.: изь пашихь рвкв М. 338. руку твојијех Н. Рањ. 22. ол рвкв анкеосинех 3бор. 90. ногу вегових Врн. 45. веговије руку Радн. 69. мојих очију Ст. пис. 1, 174. очију мојијех Н. Рањ. 73б. Злат. 97. очню твонск Збор. 17. очију мојшх Зор. 7. очију твојшх Брн. 27б. очнју његових Вран. жив. 18. очију мојих Јерк. 16. из очнју твојих Каш. 64. Фа монехь вшню Збор. 10б. - за локат.: в канњхх рвкв П. 49. в ткошсх рвкв Збор. 64. у очију пашијех Н. Рањ. 56. по очију жеговијех Банд. 64. у очију твојије Радн. 24. у ушију мојнјех Град. дјев. 104. у уинју мојнх Банд. $5 .^{2}$ у очију својнма Ради. 41.

в) број се не каже изријеком, него се мисли двоје, али се двојина замјењује множином: исгокихи синока М. 380. ро-

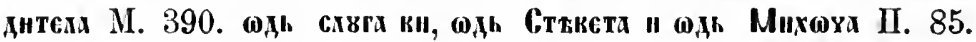
од усан својих Н. Рањ. 16б. од главе до иета Збор. 72. Ст. шис. 2, 342. мојијех рамепа Ст. пис. 3,474 . у усшам твојијем Андр. пут 160. таво се замјењивала двојипа множнном и у ријечи у којнх се сачувада двојина до данас: гепит.: твојих рук Ст. пис. 1, 20. рука његовијех Н. Рањ. 35. Град. дјев. 118. од твојнјех рук Ст. инс. 5, 79. од рук твојнх Хект. 39б. из рука мојшх 3лат. 7б. из твојијех рука Гуч. 266. божјих рука Гунд. суз. II, LVI. рука твојијех Бун. 19. Андр. дев. 29. рука Кан. 101. Мıк. 420. нрострв кодина пог Ст. пис. 1, 37. од главе до нога 3бор. 83. ног твојих Банд. 174. нога Каш. 66. Мик 421. - локат.: в пхшнхи рвкахи М. 369. у руках ових Ст. пис. 1, 37. у руках својијех Н. Рањ. 117. в рв-

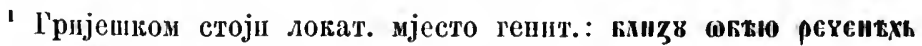
мист'хxh II6. 55.

2 у оба је пошљедња прпмјера наштампано ушпјух. 
кахь твонехь Збор. 63б. у руках мојих Ст. пис. 2, 243. у твојијех pуках Ст. нис. 3,454 . у руках својнјех Ст. пис. 4, 46. на руках му Хект. 25б. да ми те у руках имати Д. Рањ. 98б. у руках онога Буд. 111. у руках држећп не упусти Зор. 38. у руках држим те Злат. 26б. на руках својијех Гуч. 154. у руках иман Вран. жив. 110. у руках мојијех Орб. 85. у руках Гунд. суз. I, XXXI. у руках његових Банд. 144. на руках својнх Каш. 84. умријети кому на руках Мик. 728. на ногах Ст. пис. 1, 51. стонше пл погххь 3бор. 117б. на ногах Град. дјев. 147. Мик. 287. при ногах господњих Банд. 221. у твојијем рукам Андр. пут 17. 242.

г) број се изријеком кағе, али и сам прелазп у множину, прем да само двоје знати: тако само у некнх књнжевника XVI и XVII внјека: гепит.: двпх поражених Зор. 32. од двих вил 33. од првих двих 36. из обих рук 31. с обих стран 71 двих мисеци Буд. 137. 140. са двих стран Мрн. 53. обих 34. с обих стран 57. двих узроков Глав. 89. - локат.: у ових двих заповиди Бапд. 174. и новнјі локатив мн. изједначени с дативом и инструм.: у овијем двјема заповиједима Андр. пут 31.

\section{ДАТИВ ПНСТРУМЕНТА.}

Наставаг је за оба облшка bhjams као у дативу множине; али му је а дуго: bh гласн у словенским језнция $и$, а ј отнада, дуго а у словенским језицима бнва кратко, крајње s отнада, а за њим и $\mathbf{m :}$ тако наставак гдасп ма.

I. Основе на и. Крајње и у основи слабећи у словенским језицима постаје т, ка којему пршступа паставак: помт-их; али су рнјечи с таком основом пренле у та оба облика међу мушке ријечи с основом на а, те још у старом словенском језику има стио-м. Види II.

II. Основе на а:

А. У ријечи мушкога п средњега рода: крајње а у основи кратко будући гласи у словенским језицима $o$, које се у основа на ја предњега гласа ради мијења на $e:$ к такој основи прпступа наставак: a) у дативу: у мушикшх д о краја XIV вијека: кратоих М. 226. властекинома М. 156. го. сподиома М. 26. Комома М. 96. роднтекемх М. 26. XV і XVI 


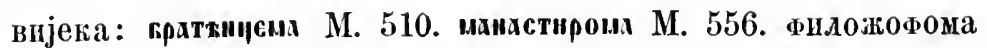
Стар. 3, 225. чловикома Стар. $3,306 .-$ б) у инструмепталу: у мупких: .кі. аностолома М. 225. 250. 379. .к. строниккома М. 459. пукома Стар. 3, 261. витезома Стар. 3, 230. налази се $a$ на крају основе, које је јамачно пренло из номинатива дв., ако је добро наштамшано: кондкрам Шб. 125. - између мупшких и средынх палази се на прају XIV и XV вијека према ријечима с основом на ॥ (виді I): .кь. аиястокьмх М. 450. чекьма II. 18. а у илеће, којему се помин. дв. алећи узима и као номин. мн. од основе на $\mathbf{i}$, јамачно према ријечима с осшовом на i (III) има у инстр. дв.: плећма Ст. пис. $3,173$. $5,70.271 .323 .324$. истој се ријечп п номинатив двојине $а л е ћ и$ узима за основу множнии, којом се двојниа замјењује (види и генит. локат. дв.): за плећияа његовијема орб. 267.

Б. У женских рнјечи: у основи дуго а на крају остаје у словенским језицима кратко: а) дат.: странхм М. 375. ногама Н. Рањ. 86б. ругама Злат. 61б. - б) нистр.: мхдниџмих М. 65. оүстьниа Стеф. 4. рукама Ст. пис. 2, 77. ногама Мик. 38. дивојкама Банд. 58. али од када и у множнни датив. и пнструментад имају на крају $а$ (внди папријед стр. 100. 124-5) од тада се у овијех облика не разликује двојина од множине. Једном се налази XVII вијека са $u$ (в) на крају основе, које ће бити узето из номпнатива двојине у инстр.: уснима Мик. 224. а једном без $a$ пред паставком XVI вијека: очицма. Ст. пнс. 2, 251.

у адјектива је у номпналном облику било за сваки род онако како је бнло у супстантива: за мушки и средњи: докромх, за женски: прозорхнвамх М. 72. сложене облике види ниже. у црономина су оба надежа једнака за сва три рода, а основа им се шири на крају онако као у множини у истијем облицима, а тако се ширп и бројевима два, оба: дат.: нма Сав. 4. Стеф. 13. М. 23. 158. 462. инма (с приједлогом и без приједлога) М. 248. 462. 513. Злат. 43. оконма II. 178. сима М. 134. и снема М. 156. твоних Сав. 9. нистр.: таих с доданим $j$ : тхмхи Пб. 125. сампма Банд. 58. инмх (с приједдогом п без ириједлога) Пб. 22. Град. дјев. 16. Зор. 27. Злат. 45б. Гуч. 136. кима Ст. пис. 2, 500. мојима Ст. пис. 1, 8. мшимх М. 530. оспове су на ја прелазиле и у двојини у оба 
падежа међу основе на чисто а као и у множини: мојијема Н. Рањ. 86б. сконемх Збор. 4б. твојијема Н. Рањ. 38. Ст. пис. 5, 75. Ђам. 2б. гојијема Гуч. 10. Андр. дев. 87. и у оба броја као у прономина с основом на чисто а: за сва три рода једнако у оба падежа: дкти краткпюмх М. 510. дкия мқдтинихих М. 65. бктих чекьм. II. 18. тако: двјема Н. Рањ. 69. 157. Збор. 4. 36. 110б. Д. Рањ. 26б. Злат. 25. Гуч. 10. Андр. пут 261. двима Ст. пис. 1, 45. 69. 91. 4, 294. Стар. 3, 306. Буд. 40. Вран. жив. 72. Банд. 58. 172. 211. Каш. 79. юкема М. 394. објема Н. Рањ. 189. Ст. пис. 3, 204. 383. 4, 91. 118. 162. 387. 5, 22. 146. 248. окима М. 375. Ст. иис. 2, 44. Зор. 32б. 42. Злат. 86. Вран. жив. 97. 114. Бун. 42. Мрн. 175. обнма двима Ст. иис. 1, 79. број два за мушки и средњи род додази XVII вијека и са $a$ на крају основе, које је прешло у ове облике јамачно из номинатива: двама учеником Радн. 44. двама господаром Радн. 44. меу двама аколити Банд. 81. с двама остадим Мик. предгов. другијем двама (инстр.) Радн. 38. двама словима Мик. грам. 5. обадвама Мик. 357. та су оба броја у овијем облицима прелазила и у множину као у генитиву и докат. (види напријед) XV и XVII вијека: двим, обим, двими, обими,' види под. V. - У адјектива се у сложеном облику саставља прономинални облик имл с номиналним као у множини, за мушки, средњи и женски род: доүхокиния М. 72. пюьазиних М. 72. скетынх М. 91. векнкима М. 134. достоикриима вгодиния М. 156. тако и пеговних М. 226. и према прономиналном: срьдчнтих ПI. 104. бпјелијема Ст. пис. $2,421$. -- У личнијех прономина основе за прво дице на, за друго ва остају щиједе са завршетком $a$ пред наставком: пхмх М. 301. кхих Сав. 4. али је датив био и с акусативом једнак: иирь вх воүдн Сав. 5.

III. Основе на i. Oд крајњега i бива у словенским језицима ь као у инструменталу множине, те к такој основи пристуша наставак: пжтьма, костьма; ади се ти облици не надазе у сриском језику у изворима које употребих. Види IV. V. IV. Основе на сугдасно. Прелазе у овијем обдицима међу основе на i: кћерма Збор. 4б. - Ријечи око и ухо ире-

' Капиһ грам 58. 59. има за датив само д6им, обим, а за инструментал: „s dvimi vel dviju“, „s obimi vel obiju." 
дазе такођер онамо, а.ии им у основи остаје $u$ на крају које пмају у номинативу, и мијењају средњи род на женскп: про-

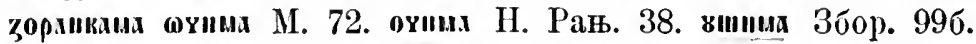
Стар. 4, 115. Вран. жив. 33. обје се ријечи у том облпку употребљавају и за множин: очима људскијем Радн. 29. очима умрлнјем Андр. дев. 119. сврбећими ушшма Банд. 17. основа коју имају у двојини узима се п за множину: очими мојима Ст. пис. 1, 8. п окрњено: прнд очнм д. Рањ. IX. Андр. нач. 50. пу' 159.'

V. Ова су се оба облика зампјеннда другнма онако као и генитив и докатнв:

1. Мјесто оба кад су с приједлогом долази поминатив двојине с приједлогом од XV вијека опаки какав је кад био: сь .к. пожа Пб. 73. са дка каменка М. 380. 384. Пб. 92. са дки кимєи ІІб. 103. спећи међу два витеза Н. Рањ. 184б. с два

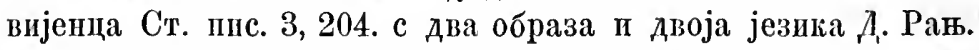
77. - з дие сти Збор. 75. с два срца Д. Рањ. 120б. - сь дкт исчи ІІб. 73. с дви рибе Ст. пис. 1, 80. с двије дјевојшце Н. Рањ. 67. с двије тисуће Ст. пис. 5, 281. 290. с двије поглавите врсте Злат. предгов. 1.

2. Оба се падежа двојине замјењују истнјем падежпма множне:

a) број стоји у двојини, а у множнии ријет којој се број каже, такођер од XV вијека: за дат.: тжы. дкмм трьгокпсмн II. 138. тим двима Ст. пис. 1, 91. двима њим 45. ким обима двнма 79. двјема госнодаром Н. Рањ. 157. двјема

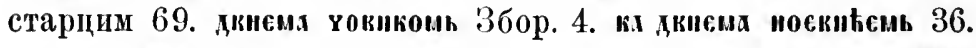
ка двнма бисним баком Вран. жиз. 6 . обима твојим родитежем 97. тако јим обнма гдаве одсиконе 114. двпма господпном Банд. 172. двима дупежем Каш. 71. двима учеником 79. двјема госпарнм Андр. пут 261. двама господаром Радн. 1. двама учеником 44. - дкисмх ссстрамь Збор. 110б. двисых женми 110б. војскам ратиим двима Стар. 3 , 262. којијем објема Г'уг. 122. - за пнстр.: двима гриси Ст. пис. 1, 69. опизиеми днеск вчеищи Збор. 115б. двима танци прами Ст. 2, 505. објема закони Ст. пис. 3, 204. с оними двима својнми друзи

' Налази се XVII вијека и локат. мјесто пнстр.: пршд очију kaII. 39. 45. 
Вран. жив. 72. меу двима војници Банд. 211. -- двјема грпли Гуч. 10. кољени обима Ст. пис. $5,19.3$ двима оними помањканји Буд. 40. с овијем двима словима Ђам. 13. с двјема словима 21б. - двјема веригами Н. Рањ. 184б. објема руками Ст. пис. $3,383.4,91.118 .162$. с двима самима дивојками Банд. 57. двима веригами 211. двјема хвалам Злат. 25. руками обима Мрн. 175. - мјесто инструментада датив, којим се и иначе замјењује инструментал: двама ухом Радн. 19.'

б) број се не каже изријеком, него рпјеч којој се сачувала двојнна стоји ? двојини, а иридјевена јој долази у множини од XIV вијека: дат.: свијетдијем очима Ст. пис. 5, 342. очима твојим Брн. 27б. ушима мојим Вран. жив. 33. твојијем очима Андр. дев. 172. - инстр.: рукама нејаким Ст. пис. 4,430 . мојими рукама Злат. 23. с јацим рукама Злат. 11. нашемн оунмх II. 10. плачними очима Ст. пис. 1, 172. Зор. 60б. очнма монемн Збор. 94б. плачнијеми очима Ст. пшс. 5, 50. прнд очима божпјими Брн. 67б. очима мојими Хект. 6. 44б. овим очима Злат. 80. прнд очима твојијем Град. дјев. 183. прнд очима веговими Буд. 12. очпма телеснијема Гуч. 103. твојими очима Вран. жил. 19. прид очима његовијем Орб. 64. прид очима господњими Банд. 247. овими очима Мрн. 31. очима твојими Јерк. 65. својнм очнма Бун. 10. прибистријем твојијем очима Андр. пут 87. твојијем очима Радн. 25. з двигиятиема вшим Збор. 99б. ушима нашими Банд. 195. овими ушима Мрн. 31 .

в) број се не гажке изријеком, него се мисли двоје, али се двојина замјењује множнном од XIV вијека: сь првкьзювменинми синови крамекьстия ми, Мхркоми " Аидржкансми М. 180. спнокомь М. 380. тако и у рпјечи у којих се сачувала двојнна долази и множина мјесто двојине: дат.: ногам мојнјем Н. Рањ. 85. ногам мојим Банд. 74. рукам његовим Банд. 47. рукам мојим Андр. пуут. 353. очнцам Ст. пис. 2, 393. - инстр.: својими руками Ст. пис. 1,47 . прихитрим рукамп Ст. пис. 2, 89. попесе га сконемн рвкаии Збор. 118. рвкани монеми 83.

' Пред инструменталом од сто налази се XVII вијека номинат. од два средњега рода: са дви стима својими јунаци Вран. жив. 12. са свимп дви стима витезн својими 12. тако је број пред сто престајао мијењати облике. 
руками твојијеми Ст. пис. 5, 176. руками твојнјема С'т. нис. 5, 75. руками својијема Г'уч. 240. мојим руками 3дат. 93. овим руками Злат. 27. својими руками Врап. жив. 75. твојијем руками Андр. дев. 93. ногами жеговијеми Н. Рањ. 156.

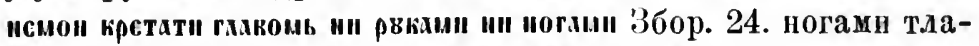
чин Вран. жив. 29. ногами мојими Қанд. 75. твојијем ногами Апдр. 40. за плећи његовијем Орб. 266. очими мојима Ст. пис. 1, 8. мјесто инструментала датив, којим се и иначе замјењује инструментал: пред ногам Исукрстовнјем Град. дух. 32. прид твојијем ногам Андр. пут 106.

г) број се пзријеком казке, али и сам ирелазп у множнну: дат.: разбојником обим Ст. пис. 1, 189. двим братом Мрн. 124. обим нам двим Мрн. 77. - инстр.: меј двими друзи Зор. 31б. колинми обими Ст. пис. 1,43 . обими рукамп 3ор. 32. мекв ,кисии зкиерми Збор. 69. обнми очнма мојим 3ор. $2 \sigma$.

\section{III}

\section{ТРИ ЧЕТИРИ.}

Имали су падеже у множини као ријечи с основом на i, и то за мушки род као мушке, а за женски и средњи род ка̄o женске:

Н о м н н а ти в. За мушки род до XV вијека: трїє сынове

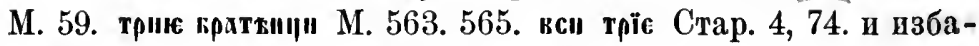
цнвши " XIV и XV вијека: трьє М. 99. Пб. 53. 57. без крајњега є од XIV вијека према рпјечнма с основом на а, међу које су прелазиле оне с основом на i: три кимн М. 130. три покси М. 408. три синоке М. 496. ски три М. 496. 544. ІІб. 128. кธніи три М. 498. трн Михоскићи М. 544. трп дхии П. 152-3. број четири и не додази са $e$ у српском језику: чєтири камсии М. 70. - за женски род: три кажіне М. 408. четнри тнсвке М. 339. 407. Пб. 69. - за средњш род: три стх М. 69. 229. чєтири ста М. 251. - тако уз оба броја ријеч којој број показују долази у номинатпву до половнне XVII вијека: три мисеци Ст. пис. 1, 64. мужи они три Н. Рањ. 123. трп коппири Збор. 45б. трп бози Ст. пис. 3, 430. трп дусп пакљепп Ст. пис. 4, 92. сви колищи трн завјети Град. дјев. 123. три начини алити три пути Град. дух. 7. три пастири 3ор. 60. трн слицц $60 б$. 
они три дјетићи Брн. 28б. три краљеви Гуч. 304. три младинци Вран. жив. 73. нијесу прошли три дни Орб. 19. ови три мужи Бапд. 126. три мудри краљп Каш. 95. ови три језици 65. три младићи вржени 88. четири дни ве су Н. Рањ. 78б. четири кони києки Збор. 13. четири госиодари Збор. 81 б. четири страси Брн. 4б. четири витези Вран. жив. 61. четири умори Орб. 73. четири мисеци Банд. 56. од XV вијека ријеч којој се број каже долази и у номинативу двојине: четнри комата Пб. 74. погдавита три завјета Град. дјев. 119. три су уреса Орб. 295. тако п् ријечи женскога и средњега рода: прћије али ти урешења јесу четири Орб. 295. три лита Банд. 112. четири дита Мик. 37. број четири од XV вијека крњи се губеһи на крају $u$ : четир стх П. 147. четир дести ПГб. 69. (пснореди акусатив).' тако окрњен још је избацивао $u$ шред $p$ : четр ста Ст. пис. 1, 22. 63. Гуч. 87. четр дести Град. дјев. 169. четр десет Банд. 14. (испореди акусатив). окрњеном четир биће додано $e$ : XVI вијека: четире лгта Стар. 1, 230. (испоредй акусатйв). тако ће додано $е$ имати: трије сти (300) Ст. шис. 3,464 . уз ријечи средњега рода долазп иетир са $a$ на крају у споменику XVI вијека, а то hе бити изједначено с осталијем ријечима средњега рода: четнра лита С'тар. $3,240$. 289. четира ста 225. 226. 234. што у истом споменику има и четира тисућа 293. биће и тисућа узето у средњем роду, као што има и три тисућа 320.

Ге н и т в. Мјесто генитива додазп од првијех времена докатив мијешајући се с прономинима у којих су та два облика једнака: тақо до XV вијека: тьрєхь свдь М. 25. трсхь ихсть М. 256. II. 72. трехh тневћь М. 389. трехи тневћхх М. 392.

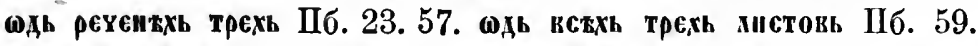
трехь краттихиа Шб. 129. шть четирехь еүангемисть М. 124. 132. шдь чстирсхь судь М. 256. таки облик у три не прелази преко $\mathrm{XV}$ вијека, а у четири налазп се п у почетку XVI вијека: четирех живнн Н. Рањ. 179. - Од свршетка XV вијека до краја XVII долази $u$ мјесто $e$ пред наставком, а то ће бити према прономиналном облику с основом на ја: лит трих Ст.

' IIIто има и трь хитре М. 372. ту һе бити ь само написано мјссто И, као што има на истој странп и Прькнсавь. 
нис. 1, 33. трнх дан Буд. 41. трпх виков Мрн. 22. нас трих (мјесто анусатнва) Мрн. 33. трих дан Гдав. 105. од четирнх састав Стар. 3, 316. од четнрих елемената Орб. 38. њих четирих Банд. 226. у иетири долази XVI вијека и ије иред шаставком, a то hе бити опет изједначено с ирономпиалим обликом с основом на чисто а: сх евнсхь четирнехи стран Збор. 27. овијех четиријех ријечијех Мик. грам. 33. таюо XVII вијека и у три: шть трюки (читај тријех) Мат. 93. - Од XVI вијека до граја XVII долази и у двојши : трнју Н. Рањ. 62. од овпзијех трију Н. Рањ. 156. трпю Збор. 4. Стар. 4, 112. трију главнијех неиријатеж, својијех Град. дух. 10. овијех трију завјета Град. дјев. 12:. од оннјех трију начнна 163. од трију њих Буд. 51. трију сил 33. од овнх трију ствари Брн. 40. од трпју краљи 69. од свенијех трију краљева Гуч. 302. трив Див. XV. Пос. 18б. од овизпјех трнју Мпк. иредгов. четирију живина $H$. Рањ. 197б. са свих четирију („е̌еtirju“) стран C'т. инс. 1, 243. од четпрнју годишћа Вран. жив. 47.' Од овога генитива двојнне, кад двојниа ослаби, поста на ново генитив множине одбацившп $j y$ (као генит. мн. очи према генит. дв. очију): XVI п XVII ппјека: од трп нраљева Гуч. 303. од овијех четирн мјеста Орб. 104. од осталпјех четири дијела бесједе - Мнк. грам. 46. од овијех четири врста Мик. грам. 16. - Како бива у двојшн, тако и овдје пза ирнједлога мјесто генитива додази номинатив а ријеч појој се број каже у номинативу двојнне онаком какав јест, и то од XV вијека: вез

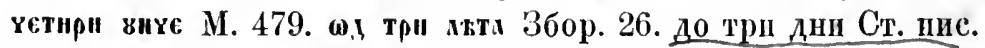
4, 92. од све три Ст. нис. 5, 280. с те три 271. накони три годишта Вран. жив. 74. од трндести и три годишта Орб. 17. од ова четири елемента Орб. 16. након три дни Банд. 88. од четнри струке Мик. 36. и окрњенг номпнат.: након четр дии KaIII. 39.

Датпв. До половине XVI вијева: трень вратепџемь М.

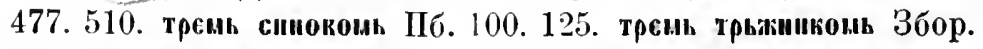

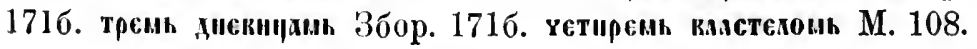

' Кашић грам. 59 вели: trih vel triju, а стр. 60 само четирих. - Неки писци XVI п XVII пппу $x$ на крају: тријух завјета Град. дјев. 120. 122. 144. ових трнјух Бапд. 170. од четиријух витар Банд. 121. а има н четприху Банд. 201. 
четирень квками М. 356.360 .373 .595$. Пб. 86. 89. Од XV внјека додавало се на крају а: трєих спновом М. 409.' тако и XVI вијека: божицами трема Ст. пис. 4, 447. онијем трема врстам Град. дјев. 84. мјесто $e$ пред наставком додази $u$ онако као у генитиву од свршетка XV внјека: трпм Ст. нис. 1, 124. трим чедом Чубр. 4б. трим Кашт. грам. 59. Гдав. 27. четирим саставом Стар. 3,316 . четирнм стварам Буд. 5. четирим ангелом Банд. 232. џ таком се облику додаје на кјају $a$, a то hе бити из двојине као у генитиву: четирима од витеза Н. Рањ. 184. четирима ангедом Н. Рањ. 200. трнма грихом Пос. 18б. овијем трима Пос. 18б. - у гри мјесто с додази и ик, које ћс бити прешло нз номннатива: трїень Cтар. 4, 78. и такі облик додази с доданим $a$ XVI II XVII вијека, а у то ће врпјеме ије бити према прономиналном обдику: онисмь трисмх ивжем Збор. 40. тријема Ст. пис. 4, 447. трпјема учеником Орб. 121. тријема крепости (sic) 294. - Мјесто датива додази и инстр. XV вијека: трєыл єиноком. Пб. 125.

Aк усатив. До краја XV вијека: три чкоктк М. 42. ша

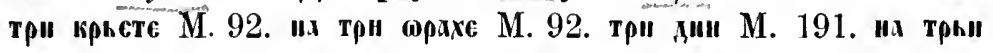
диеке М. 409. три двкате II. 108. на три номате ІІб. 61. чєтири еканкгекнсте М. 35. 275. 468. четири двкате М. 479. 504. четире: „михре II. 108. тако до граја XVII вијека долази уз број у агусатнву и ријеч којој се број қаже: три мисеце Ст. нис. 1, 5. три зиме 20. три дии 268. трн крухе Н. Рањ. 134б. три мјесеце 138. три народе 3бор. 13б. три граде 330. три краъье Ст. ппс. 3, 309. трн скоке 247. у три диједе Град. дух. 8. исте трн завјете 119. за три дни Д. Рањ. 74б. Хект. 3. три јуначке добре коње Хект. 12. на три дијеле Бри. 54б. трп краљеве Іуч. 303. за три дни Банд. VI. оне три краље Јерк. 25. на три диде Каш. 83. у три дни Мик. 746. за три разлоге Гдав. 25. и кад је у имена акусатив једнак с номинативом: у три дшли Буд. 4. чини три липш суди Вран. жив. 75. три облоци учине 112. - четири дијеле Н. Рањ. 110б. четири анђеле Збор. 54б. на четпри начине Глав. 27. - број

' Писарском гријешком има ь мјесто с: трьна Пб. 98. у истом споменику има и срькра Јбб. 97. 
четири крњи се губеһи крајње $и$ од XV внјека: четнрь димарє II. 108. тако окрњен још је избацивао и $u$ пред $p:$ но четр стране Ст. пис. $3,39$. облигу тако на један нли на оба начина окрњеном додавало се па крају $e$ : четире крнности C'т. нис. $1,100$. четире ноге Збор. 7. на четнре стране 68 . четире стуше Стар. 3, 259. по тетрье (četare) путе Брн. 12. 29б. четрье (čtare) Врай. жив. 22. - ОА XV вијека уз ове бројеве долази и у двојинй рнјеч којој број показују : Мароєве три крхта II. 152. у три дијела Гуч. 9. 113. у три уборка Банд. 24. вь .д. скаигекиста М. 295. 299. 316. ПГб. 95. их .А. несеңа ІІб. 114.

Инструментал. XIII и XIV вијека: трьми мвсери М. 55. четирьми єеканьгенисти М. 220. ирви број од XIV вијека додазп са $e$ пред паставком: трєми М. 172. Од XV вијека до гіраја XVII долазе оба броја са $u$ пред наставком онаго као у генитиву: трыми Стар. 4, 134. тримп начнни Буд. 158. трими кулами Мрн. 31. оними трнми напасти Каш. 98. чстирими М. 248. четирпми риками Стар. 3,285 . с четирими ручицами Зор. 45. оними четирими прћијами Каш. 77. четирими начини Г'лав. 27. Од почетка XVI вијека долазе оба броја и са a на крају мјесто $u$ јамачно према двојинп: четирнма Н. Рањ. 246. с трима редовници Хект. 7. прнд трима Вран. жнв. 23. с трима свићами Банд. 111. трима чав.и Јерк. 79. број три тако са $a$ на крају али још са $e$ пред наставком долази такођер XVI и XVII впјека: трема начиним Град. дух. 16. трема путим Град. дјев. 112. међу трема 135. с овнјем трема словима Ђам. 15. а XVII вијека и са ије пред наставком једначећи се с прономиналним обликом: окшема трнсма Див. 36 . и без нкакога вокала пред ма: прнд четирма живинами Банд. 14. четирма руками Банд. 128. - XV вијека у оба броја долази и номинатив мјесто инструментала а ријеч којој се број каже у инструменталу с пријед.логом или без приједлога: са четир॥ наме॥! М. 386. Пб. 50. 56. сь тр॥ сафини Пб. 56. с четнр॥ мапими Пб. 69. четири еканћекисти М. 446. са три дитићи Ст. пис. 1, 276. Од XVI впјека уз приједлог долазе бројеви у номннативу а рнјеч којој се број каже у номинативу двојине: с ове три Ст. шпс 5, 272. међу ова три завјета прво мјесто држи Град. дјев. 135. с четири слова Орб. 4. с четири ријечи 55. с четири истине 99. с четири прћије 295. 
Доват ив. До краја XV вијека : по трекь хнствхь II. 168.

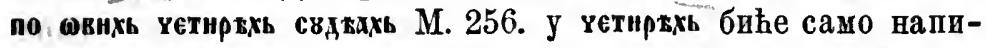
сано мјесто є. Као у генитиву тако п у овом падежу долази $u$ мјесто $e$ пред наставном XVI п XVII вијека: четирих ко.дих Стар. 3, 316. четирих Каш. грам. 60. долази и ије (вуди код генитива): в трюхь (читај тријех) Мат. 16. а три додази и У двојини XVII вијека: у трију киппх Вран. жив. 21.' Иза приједлога мјесто локатива додази номинатив а ријеч војој се број каже у номинативу двојнне од почетка XVI вијека: када бп по три дни Н. Рањ. 29б. уздржи се у три славе Орб. 279. стоји у три вијенца 280.

\section{IV \\ IIET-ДECET.}

Бројеви су шет-десет имади неге падеже као имена с основом на $\mathbf{i}$ а неке као имена с основом на сугдасно. У српском се језику номинатив јед. сачувао до данас; од осталијех су се падежа држали ови овако:

l'енитнв једнин е пза приједлога зампјенио се номи-

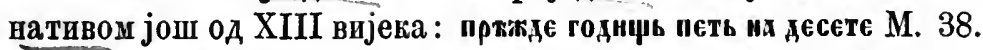
прне седамы киета Збор. 31б. шдь селамь дана 45. од седам годитт Град. дјев. 147. након шест дит Вран. жив. 67. од друге седам годишт Андр. пут 295. а тако и без пријед.дога XVI вијека: у похвалу седам пјесни покорнијех Ст. пис. 5, 104.

да тин је днин е замјевива 0 се дативом мн. прономиналним са $u$ пред наставком као у ирономина с основом на ја, те је г ријеч којој се број каже стајала у истом падежу: од XIV вијека допирућп у XVII: петнмь вмастекомь М. 108. седмим даром Буд. 33. к првим седмим заповндем 51. десетим дивнцам Банд. 253. од XVI вијека додавадо му се а на крају : к десетпма дјевицами Н. Рањ. 222. пестима Ст. пис. 5, 104. седмима црквам Банд. 227. од XVI вијека долази са ије мјесто $u$ као у прономина (с основом на ја стр. 196): седмијемга црквая Н. Рањ. 196б. десетијема дјевицам Н. Рањ. 173б. дєсетнєих коминкюи 3бор. 83. XVI вијека замјевивао се номинативом јед., а само

' Kaшиh .rpax. 60 велn: trik vel triju. 
се ријеч гојој се број каже узпмала у дативу: цет сатпма братји Н. Рањ. 154б. к седам заповидем Буд. 51. а најнослије на крају XVII вијека ни ријеч којој се број каже пије се узимала у дативу него у генитиву множине: к десет дјевнца Андр. пут. 257.

А к у сатив једнин е само у десет кад стојп иза приједлога у бројевима $11-19$ био је са $e$ на крају као у некшх ријечи с основом на суг.ласно (види напријед стр. $2 \varepsilon-29$ ): до почетка XVI вијека: єєа(ш) их хесетє М. 373. Н. Рањ. 125. єдих их дєсете Пб. 57. Авх их десете М. 372. Н. Рањ. 90. дкне их десете тис8ћи М. 349. трн "х десете М. 349. четнрн их десете М. 497. пєть нх десете М. 248. Н. Рањ. 115б. осли их „есете М. 406. Н. Рањ. 164б. хрвги их дєсєтє Пб. 85. тако је са $e$ на крају допирао у XVII впјек, али између $c$ п $т$ избацивпи $e$, и то од XV вијека: „ва их десте М. 273. 275. 372. 468. 510. Стар. 1, 222. Вран. жив. 12. Банд. 19. Каш. 64. єуш их десте внчу М. 389. шесть их десте М. 389. осхи их десте М. 273. Стар. 1, 218. четр на десте Вран. рјеч. 86. Банд. 26. Каш. 89. Гдав. 95. пет на десте Вран. жив. 67. Банд. 31. Каш. 10. једа(н) на десте Банд. 46. Кашт. 87. осам на десте Каш. 22. тако већ окрњеном још се и $д$ одбацивало, те се или уметало зијева ради $j$ : од XV впјека: пкаиюсте М. 372. двапајесте Н. Рањ. 29б. 53. вли је зпјев остајао: дванаесте Н. Рањ. 77б. 186. 200б. петнаесте Н. Рањ. 162б. 185б. или је $e$ пза на слабило у $j$ такође XVI вијека: Педхихнсте 3бор. 116. двхихисте 25. уєтрихисте 19. пстианстс 52. или је и то $j$ пспада:ло: четврти на сте Хект. 45. - али се налази десет п без $е$ у акусатпву у таким бројевпма од граја XIV вијека: дкх их дєсть Пб. 35. Вран. жив. 106. петь иа десєть М. 523. шест иа десет Вран. жив. 70. седам на десет 108. осам на десет 5 . п тада му се опет избацује $e$ између $c$ и $T:$ два на дест Ст. пис. 1,12 . тако окрњеном додавало се на крају $a$ : дна их деста М. 552. а тако окрњепом без доданога $а$ одбацује се и д: дванаест Н. Рањ. 36б. Град. дјев. 82. Ради. 98. четрнаест Н. Рањ. 35. петнаест 38. в без крајњега $т$ : једанаес Н. Рањ. 136. дванаес 229. петнасс Злат. 97. Гуч. 46. Орб. 57. тако окрњеном још се нзбацивало п $a$ од на: петнес Ст. пис. 5, 104. песнес 104. дванес Гуч. 180. - У овијем сдоженијем бројевима, кад је 
први број престао предазити у потребне падеже (испореди наведено: єлнв их дєсте вичз М. 389), те су се оба узимала као једна ријеч, прелазио је број десет и у друге падеже, ако и има пред собом приједлог на, XVI и XVII вијека: Петру и једанаестима Н. Рањ. 154. дванадестим апостолом Вран. жив. 23. алп је још од прије у сложеном броју остајао први у номинативу, и ако има род, у мушком роду, а други у акусативу, тако још XIV вијека: ють скетыхь .кı. апостокь М. 167. кь .вı. скетнхь врьховнихь апостожь М. 173. гдје истина број није исписан, али да је онако како рекох потврђује додани генитив мн.; тако : за .кі. гака М. 258. сда(и) иа десете внауа М. 272. два на десете кругала М. 372. са .кІ. зрна М. 386. у четнрн иа десете сокиноки М. 497. с један на десте апостола Н. Рањ. 140б. с дванес ученпка Гуч. 180.

Инструментад једнине замјењнвао се од XV вијека инструментадохмн. I то прономиналнујем онако као датив: седмими науци Ст. пис. 1, 218. петими главами Мрн. 121. петими Глав. 21. од XVI вијека са ије мјесто $u$ пред наставком и без крајњега $u$, које је отпа.до као и у других ријечи па је додано $a$ : седмпјема печатп Н. Рањ. 199. такође са $a$ на крају али са $и$ пред наставком: нетпма крусима Андр. пут 96. али још од XV вијека замјењује се и номинативом јед.: подь петь иа десете печатми М. 248. пет сик.иими КаII. 16.

А окатив једнине замјењивао се локатпвоп мн. од XVI вијека, прономиналнијем као п инструментал: в оспихь секих М. 249. у петих Глав. 19.

Номинатив и агусатив множнне. У оба падежа додази десет у бројевима 30 пा 40 , и оба су била као у ріјечи с основом на $\mathbf{i}$ : до половине XVII впјека: трн пєсєти $\mathrm{M}$. 390. четирн десети М. 407. задржавајући грајње $u$ крњно се је број десет онако као у акус. јед.: трн дести М. 504. Н. Рањ. 90. Збор. 25б. Ст. пнс. 5, 103. Д. Рањ. V. Орб. 47. Каш. 97. четири дестн М. 504. Н. Рањ. 34б. чєтир дестн Пб. 69. четр дести Н. Рањ. 41. Збор. 72. Град. дјев. 169. Орб. 261. Каш. 89.'- четрьести Орб. 197. 220. - Али од XV вијека захјењује

' Погрјешка Һе бити: четрдастп Орб. 265. 
се у оба облика множнна једнином: трн дєсєть М. 478. Вран. жив. 88. Мрн. 55. четирн десеть ПІ. 109. уєтнрь дессть П. 108. четр десет Вран. жив. 85. Банд. 34. Каш. 98. и окрњено као у акус. јед.: триес Каш. 97. 104. - оба су облика множине замјењивала и друге: с трн дссти тнсвћь 3бор. 81. наконь три „єсти даих Збор. 8. од три дести и три годишта Орб. 17. а тако ће бити и: до четири десет дан Н. Рањ. 81.

Номинатив и акусатив двојнне. У оба облика додази десет у броју 20, и оба су као у ријечи с основом на $\mathbf{i}$ (види стр. 224): дка десети М. 278. 506. задржавајући крајње $u$ до краја XVII вијека нзбацује $e$ између $c$ и т од од XV вијека: два дєстн М. 389. 504. Н. Рањ. 1146. Збор. 58. Ст. пис. 4, 385. Орб. 104. Каш. 83. Андр. пут 274. - Од XV вијека долази окрњено, без крајњега $u$ : двх „єссть П. 108. Хект. 24б. - истога вијека додази једном двојина као у ријечи мушких с основом на чисто а (види стр. 221): два крать нась два десета М. 248. - од XV вијека замјењивали су се номинативом и други падежи: пржд оними два десети и четирнми М. 248. 


\section{ОБЛИЩИ ГЛАГОЛСКИ.}

Гдаголи се по основама од којих им постаје инфинитив дијеле у шест врста:

I. с основама у којих нема наставка, а оне се дијеле у седам раздјела по гдасовима на које се свршују: 1 . на д, $\boldsymbol{T} ; 2$. на $, 3, c ; 3$. на $б, a, b ; 4$. на $2, x, x ; 5$. на $\psi, \mu ; 6$. на самогдасно, осим $p ; 7$. на $p$ и $\lambda$.

II. с осковама гоје постају наставком мю.

III. с основама које постају наставком $\mathbf{k}$; ти се г.даголи опет диједе у два раздјела по основама какве су им у садашњем времену: 1 . с основама које остају и у садашњем времену цијеле; 2. с основама које мјесто добивају у садашшем времену други наставак.

IV. с основама које постају наставком ".

V. с основама које постају наставком $а$; дијеле се у три раздјела по основама ганве су у садашњем времену: 1. с основама које остају и у садапшњем времену цијеле; 2. с основама које жјесто а добијају у садашњем времену други на ставак ; 3. с основама које у садашњем времену одбацују а, те добијају наставак други него оне другога раздјела.

VI. с основама које поостају наставком $y$ и $a$, пред којим се $y^{\prime}$ шири ов, те оба заједно гдасе ова пй према предњем гдасу ев

\section{ИНФИНИТИВ.}

Постаје наставком који у словенским језнцима гдаси $T u$; крајњи гдасови у основи, за којима дође, слажу се с његовијем $T$ по својим законима ;' у неким се основама мијења и самогдасно које им је у коријену, како ће се код вих на-

' Види у Облицима српскога нли хрватскога језика 1872. стр. 63. 65. 67. 69. 73-4. 85. ч у Раду југосл. акад. I. 112. 
поменути. Између глагола којима се у изворима налазп инфннштив, нека буду споменути само знатнији или који су сада мање у обпчају или су са свпјем изашли из обичаја:

I. 1. на д. вжюстн М. 188. Ст. пис. $1,55.2,11.5,48$. Д. Рањ. VIIб. Злат. 10б. бљуст' Ст. пис. 1, 57. повести Н. Рањ. 184. вест' Ст. пис. 1, 62. класти Ст. пис. 4, 28. Вран. рјеч. 83. укрести Вран. рјеч. 102. Зор. 76б. сести Ст. пис. 1, 226. Вран. рјеч. 97. систи Ст. пnс. 1,90 . сјести Гуч. 302. - на т: гњести Вран. рјеч. 35 . рести Ст. пис. 1, 111. Н. Рањ. 1446. Мрн. 29. расти Мик. 544. шгрьстн Шб. 63. срјести Н. Рањ. 2096. сусрести Град. дјев. 183.' цвасти Ст. пис. 1, 30. Вран. рјеч. 37. - у којих је у коријену вокал ь, пирили су га у и: чнстн Сав. 4. М. 84. 539. "зуисти Стеф. 24. почисти М. 3. и пзбацивши 6 иза $u$ : процисти М. 183. 203. - глагол треће врсте с основом ввд налази се и међу овима XIV вијека одбацивши крајње - (према садашвем времену): вктстн М. 186.

I. 2. на з: "зхтсти М. 447. виєсти Пб. 112. удјести Н. Рањ. 228. Ст. пис. 4, XI. А. Рањ. 59. Град. дух. 11. Здат. 50. Гуч. 276. Орб. 99. Андр. дев. 93. мусти Вран. рјеч. 63. - на $c$ : "zиссти М. 204. понести Н. Рањ. Ст. пис. 3, 261. поднести Ст. шис. 1, 261. Хект. 22. Град. дух. 82. Банд. 95. Каш. 70. однести Ст. пшс. 5, 37. Вран. рјеч. 48. пренести Буд. 143. Зор. 66. нест' Ст. пис. 1, 145. понест' 154. пасти Н. Рањ. 42б. Буд. 80. спасти Град. дјев. 142. Орб. 46. Банд. 176. Каш. 35. Радн. 9.Основа нес и одбацује крајње $c$, те шири $e$ у к од XV вијека: вижти II. 127. понкти II. 136. прнисти Пб. 84. однијети Н. Рањ. 1446. Бун. 50. понијети Н. Рањ. 52б. прннијети Н. Рањ. 203. похниети Збор. 6б. Ст. пис. 4, 73. 5, 77. Град. дух. 89. Злат. 23. Гуч. 160. Днв. 24. Орб. 233. Радн. 18. Андр. дев. 39. донити Ст. пис. 5, 35. Зор. 28. Банд. 116. поднити А. Рањ. 3б. Хект. 20. однити Буд. 78. Вран. жив. 42. понит' Ст. пис. 1, 119. Зор. 21б. понијет' Ст. пис. 2, 426. Гуч. 133.

I. 3. на б: дубсти Хект. 22б. Вран. рјеч. 18. скупсти Ст. пис. 4,302 . искупсти Бун. 9. - на $\underline{a}$ : сопсти (sugere) Вран. рјеч. 103. хропсти Збор. 174б. Вран. рјеч. 101. поцрпсти $Н$.

' Писарска hе битп погрјешка срит Ст. пис. 2, 172. мјесто срил, како пште слик. 
Рањ. 65б. зацрпсти Банд. 55. посути Вран. жив. 85. - на в: жнтн М. 74. ожпт' Ст. пис. 3, 407. шлити Вран. рјеч. 91. Миi. 421. - И пред уметнутпм $c$ пзмеђу основе и наставка могло је основи крајње б отпасти: скусти Зор. 29.

I. 4. на 2: покекн М. 208. поктки М. 267. врькй II. 115. сьврьћн М. 467. врћи Н. Рањ. 46б. Збор. 27б. Вран. жив. 5. Банд. 38. врћ' Ст. пис. 2, 223. 3, 173. 4, 98. Злат. 5. Гунд. суз. I, LXV. поврћи Ст. пис. 1, 140. одврћи Ст. пис. 1, 202. Вран. рјеч. 1. заврћи Орб. 75. Авики ПІ. 7. 16. Град. дјев. 185. дпћ' А. Рањ. 14б. жеки П. 149. раждећ' Д. Рањ. 28. Град. дух. 27. раждећи Андр. нач. 49. ждећп (сажећи) Орб. 220. хєк М. 416 ceћ⿰ М. 219. досеi! M. 183. 258. II. 102. досећ' Здат. 680. прпсећи Ст. пис. 1, 81. притећ' Чубр. 12. - на $x$ : обући Н. Рањ. 211. вући Вран. рјеч. 107. пореки М. 50. рећи М. 274. 447. Ст. пис. 1, 3. Н. Рањ. 58б. 67б. Ст. пис. 4, 78. 5, 168. Д. Рањ. УІб. Злат. 2. Крн. 8б. Банд. 35. рећ Ст. шшс. 2, 107. 4, 10. А. Рањ. 2. Злат. 12. пзрећи Збор. 99. Ст. пис. 3, 91. "зрећь Збор. 111. порећ' Гуч. 72. тућ' Ст. пис. 1, 156. тући Вран. рјеч. 78. У којим је основама самогласно $p$ или $y$, постало од $\lambda$, оне су се и ппрнде добијајући в иза $p$ и $\lambda$ : таго иза $p$ до половине XVII вијека: брџћп Ст. пис. 1, 279. выррьцн М. 110. врићи Ст. пис. 1, 151. Стар. 3, 328. Буд. 154. врић' Ст. пис. 1, 11. 143. одврпћи 61. разврићи 36. одврпћ' Крн. 15б. стртки М. 43. стрићи Ст. ппс. 1, 279. Стар. 3, 291. иза $\pi$ до краја XV

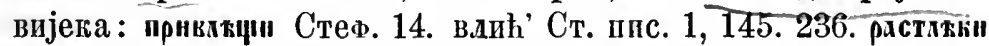
П. 166. т.ли' Ст. пис. 1, 236. натлић' Ст. пис. 1, 145. - Основа

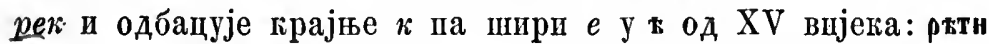
II. 111. 136. М. 509. 510. Н. Рањ. 214. Збор. 18б. Ст. пис. 4, 12. А. Рањ. Уб. Град. дух. 41. Гуч. 215. Орб. 306. Див. 15. Гунд. пс. 14. Мат. 13. Анд. дев. 135. изрпјети 3лат. 36k. Мик. предгов. изрити Ст. пис. 2, 115. ријет' Н. Рањ. 148. Ст. пис. 3, 101. 4, 265. 5, 35. Град. дјев. 98. Гуч. 4. Бун. 31. рит' Ст. пис. $2,72$. 3, 189. А. Рањ. VІб. Зор. 47.

I. 5. на $н$ : зачети Н. Рањ. 15б. Гуч. 118. почети Вран. рјеч. 48. почати Стар. 4, 118. Јерк. 9. зджсти М. 414. к.лети Н. Рањ. 92. Вран. рјеч. 28. прокљети Вран. жив. 43.' жети

' У једнога шисца гријешком уз садашње вријеме налази се један пут пренесено у другу врсту: купути Зор. 156. 
Вран. рјеч. 61. Радн. 42. Мик. 595. пожети Банд. 57. жњети Мик 595. - на м: задути Ст. пис. 4, 166. издути Мик. 153. ожети Ст. пис. 5, 7. јети Вран. жив. 67. шзети М. 204. П. 119. Збор. 46. Град. дјев. 125. Гуч. 68. изет' Злат. 42б. изнет' Ст. пис. 1, 324. 325. Фтети М. 195. Фтиетн М. 14j. пднети М. 327. Ст. пис. 1, 52. иријети Глав. 4. снет' Ст. пис. 1, 187. 270. снети Глав. 68. оүзети М. 15. ПІ. 87. Гуч. 25. Див. 14. Банд. 9. взеть М. 493. вазет' Ст. пис. 2, 8. 3, 440. 4. 46. 5, 37. Здат. 56. вазети Ст. пис. 4, 318. Вран. рјеч. 2. жив. 28. взети Стар. 3, 293. одузети Вран. рјеч. 27. обујети Вран. рјеч. 19. заујети Вран. рјеч. 69. иста основа гласи у интинитиву по неким крајевима и ја (као напријед поча-): јати Ст. пис. 1, 40. Вран. рјеч. 16. зајати Вран. рјеч. 64. објат' Ст. пnс. 2, 111. обујати Вран. жнв. 35. Јерк. 15. одујати Ст. пнс. 1, 10. примти М. 211. прыати М. 418. прпјати Ст. шпс. 1, 4. Хект. 36. Зор. 27. Буд. 79. Вран. рјеч. 10. жив. 13. Банд. 43.'

I. 6. на $a$ : дати М. 2. Н. Рањ. 104. zиати ПI. 18. стати М. 41. - па_ и: битв Буд. 99. брити Вран. рјеч. 88. обрити Вран. жив. 73. привити Буд. 99. пзгнити Вран. рјеч. 104. изгњити 84. геитн 39. 60. ${ }^{2}$ "тн М. 23. 206. 324. Ст. пис. 1, 152. Хект. 11. Вран. рјеч. 76. Мик. 150. пт' Ст. пис. 5, 35. Д. Рањ. 5б. Злат. 1б. о том гдагоду види још мало ниже. пити Н. Рањ. 65. впнтн П. 38. - на у: изути Мик. 166. обути 51. оплути 3ор. 556. ${ }^{3}$ рути Стар. 1, 232. Ст. пис. 3, 24. рут' Ст. пис. 4, 168. слути Ст. пис. 1, 54. чвти П. 10. - на ж: бити Н. Рањ. 72. кнть М. 323. П. 71. придобити Збор. 10. позабит' Ст. пис. 2, 371. покрит' Н. Рањ. 210. сакрити Вран. рјеч. 18. плити Чубр. 15. исплити Ст. пис. 3, 453. 466. ${ }^{4}$ (отьтрнти Стар. 4, 75. - на „: дјети Мпк. 69. задјети Ст. пис. 4, 21. дит' Ст. пис. 1, 45. додит' Ст. пис. 2, 314. одит' Ст. пис. 1, 154. раздит' Ст. пис. 1, 26. одити Вран. жив. 17. заодити Радн. 74. надити Мик. 276.

' Има п у других: прпјат' Ст. пис. 2, 225. пријатп Ст. пис. 3, 43. 372. 457. 4, 3. 307. 5, 9. А. Рањ. 84б. Град. дјев. 9б. али га оні узимају као глагол пете врсте, види код садапњега времена.

2 Гријепком је мјесто $u$ : тњетп Андр. иут 291. „izljeti“ Muк. 160.

${ }^{3}$ И са љ мјесто $\pi$ : прппљути Ст. пис. 3, 229.

- Грпјешвом са uе мјесто $u$ : ирнимети Збор. 1226. 
пјети 3бор. 56б. Ст. пис. 4, 8. Град. дјев. 140. Мик. 416. пјет' Ст. пис. 2, 163. 3, 111. 429. А. Рањ. V. Здат. 52б. Гуч. 32. спјети Ст. пис. 4, 5. спјет' Ст. пис. 4, 23. пет' Ст. пис. $1,7$. пети Ст. пис. 1, 75. Вран. рјеч. 16. - Инфинитив од основе и сложен с приједлогом који се свршује на сугдасно, додази без промјене до краја XVII вијека : изит' Н. Рањ. $217 б$. С'т. пис. 3, 468. Здат. 39g. изити Ст. пис. 2, 249. 4, 476. А. Рањ. 74. Гуч. 170. обити Ст. пис. 4, 146. отити Д. Рањ. 82. Злат. 11б. Вран. рјеч. 1. жив. 55. Мик. 150. сити Ст. пис. 4, 409. 5, 47. 79. Гуч. 84. унити Д. Рањ. 8б. кад је сложен са при добввши два $и$ једно до другога сажима их у једно: прнтн М. 413. Н. Рањ. 14. Ст. пис. 3, 439. 4, 98. Вран. рјеч. 2. Мпк. 505. прит' Ст. пис. 2, 43. 3, 197. 398. 4, 142. 5, 40. Д. Рањ. 1. 3лат. 2. сложен с другим ириједлозима, који се свршују на самогдасно, мијева своје $u$ ва $j$, али је то поуздано истом од XVI вијека, јер се дот.де у писму слабо разликује $u$ од $j$ : донти М. 256. 337. 361. 450. Н. Рањ. 179б. Ст. пис. 1, 43. 4, 205. Вран. рјеч. 8. дојт' Ст. пис. 1, 63. 4, 295 у дну. Јерк. 69. зајти Ст. пис. 3 , 423. мимојти Н. Рањ. 40б. Банд. 33. мхнтн М. 449. Ст. нис. $1,100.3,69.469 .4,45.295$. Зор. 6б. Вран. рјеч. 64. Чубр. 8. Банд. VI. Крн. 14. најт' Ст. пис. 2, 517. нұьнанти II. 28. взнајт' Ст. пис. 1, 100. юкьнхнти II. 87. ојти Ст. пис. $1,43$. понтн М. 22. 317. 327. 473. Ст. пис. 1, 9. Н. Рањ. 18. Хект. 9б. 3ор. 32. Вран. рјеч. 1. жив. 52. Банд. 3. Мрн. 33. појт' Ст. пис. 1, 13. 46. пројти Ст. иис. 1, 43. 4, 93. 112. Банд. 2. Мрн. 33. тако п кад се пријед.ог свршује на сугдасно али се између њега и основе умеће $a$ : изајти Вран. рјеч. 33 . Банд. 4. Крң. 14. вадајти Вран. рјеч. 103. обајти Ст. пис. 1, 110. одајти Вран. рјеч. 1. сајти 28. али ако се п налази тако до краја XVII вијека, опет се још од XIV впјека гласови $j r$, који у тијем приликана стоје заједно, слијевају у $ћ$ : доћн М. 211 . П. 6 . M. 414. 453. 473. 530. П. 6. 12. 42. Н. Рањ. 13. Збор. 13. Ст. пис. 2, 403. 3, 425. 4, 456. Д. Рањ. VIII. Град. дјев. 39. Злат. 3. Гуч. 2. Бун. 15. Радн. 41. доћ' Н. Рањ. 177б. Ст. пии. $2,14$. 3, 95. 312. 408. 4, 12. 440. 3лат. 2. Гуч. 29. заћи Ст. пис. 2 , 390. Град. дјев. 134. заћ' Ст. пшс. 2, 440. 3, 163. 4, 100. 5, 47. Злат. 87. мимоћп Гуч. 188. Банд. 186. пхки М. 363. наћи Н. Рањ. 43б. Збор. 13. Ст. пис. 2, 424. Д. Рањ. 9. Град. дјев. 5. Гуч. 
247. Див. 26. Орб. 35. Гунд. суз. I, LXIII. Апдр. дев. 83. Радн. 3. паћ' Н. Рањ. 188б. Збор. 22. Ст. пис. 2, 40. 344. 3, 112. 4, 42. А. Рањ. VIIб. Злат. 12. "зихи П. 6. 35. изнаһи Д. Рањ. VIб. Гуч. 12. Фкмхкн II. 87. оһи С'т. пис. 2, 151. 3, 27. Влат. 25. оћ' Ст. пис. 2, 339. 3, 40. 450. 4, 255. Д. Рањ. 122б. Злат. 6. поки М. 185. 418. II. 9. поћи М. 211. 467. 546. Н. Рањ. 27. 3бор. 8б. Ст. пис. 4, 436. Орб. 102. поћ' Ст. пис. 2, 17. 436. 3, 192. А. Рањ. 10. Злат. 3. проки П. 8. проћп Ст. пис. $4,452$. Злат. 66б. Орб. 192. проћ' Ст. іпс. 2, 32. 3, 163. 4, 42. 5, 59. 3лат. 17. ући Ст. пис. 2, 221. ућ' Ст. пис. 2, 20. тако и кад је сложен са ирн и ирт, али истом од XVI впјека: ирићи $\mathrm{H}$. Рањ. 15. Збор. 26б. Ст. пис. 4, 219. 224. Град. дјев. 5. дух. 60. Пос. 15. Андр. пут 48. прић' Ст. пиис. 2, 41. 3, 371. 5, 35. Злат. 2б. пријећи Радн. 62. из таких је сложенпјех прешло $ћ$ и у сложенс с шриједлогом који се свршује ша сугласно а нема уметнутога $a$ II у нес.ложени, али истом XVII вијека: надпћ' Гунд. суз. III, XIII. отићи Див. 8б. Радн. 9. 18. 55. ићи Радн. 47. 88. ІІос. 5б. по томе се XVII вијека налази иаписано и $\hbar$ и пред њим $j$ постало од $u$ : дојћи Каш. $5,35.44 .62$. дојћ' Крн. 6б. изајьи Банд. 19. најһи 71. 78. 237. Кан. 10. 57. појћп Каші. 31.

I. 7.' на $p$ : подрпјети Ст. пис. 4, 49. 203. издрити Ст. пис. 4, 439. одритп Вран. рјеч. 27. пожрити Ст. пис. 1, 47. Вран. рјеч. 27. Крн. 21. пождрпјетп Ст. пис. 4, 107. Радн. 78. прождријети Андр. пут 297. умрити С'. пнс. 1, 214. Вран. жив. 80. Каші. 72. Радн. 78. Глав. 13. умријетп Ст. пис. 3, 108. Андр. дев. 40. помријети Збор. 25б. умријет' Ст. пис. 4, 136. умрит' Ст. пнс. 5, 35. Злат. 20. вамрвт' Ст. пис. 2, 325. заприт' Ст. пис. 1, 214. одаприти Вран. рјеч. 89. подаприти 40. прострит' Ст. пис. 1, 214. Злат. 72. простријети Ст. пис. 3, 274. прострити А. Рањ. 73б. Канг. 65. разастрити Вран. рјеч. $33 .{ }^{2}$

(" Како се основа ширн, види у Об.лицима срискога или хрват. језика 1872 стр. 85 . а онако се тири и кад се сврпује на $\lambda$, само пाто се у глаго.иа с таком основом $\mathrm{t}$, које тада добија, изједначује с наставком к, појим иостају глаголи треће врсте, другога раздје.а, те је кратко.

2 Овамо би мог.ло ићн: перпти Ст. пис. 1, 107. али смпсао као да не допушта. 
без промјене у основп: потьрьть М. 424. потрти Ст. пис. $1,36$. Н. Рањ. 18. Банд. 95. трти Вран. рјеч. 85. трт Ст. пис. 4, 439. Злат. 95. затрти Ст. пис. 1, 115. Вран. рјеч. 16. Ванд. 44. растрти Ст. пис. 3, 77. стрт' Ст. пис. 2, 42. 3, 98.4, 410. Злат. 13. стрти Д. Рањ. 23. Вран. рјеч. 22. Врн. 44. сатрти Ст. пис. 4, 122. Іуунд. суз. II, III. Каш. 13. Андр. дев. 181. измеלу онијех којнма се основа пири долази и без пирева само у једнога писца, па п у њега само у слику: одрти Ст. пис. 1,10 . пожртп 10 . - на л: млити Вран. рјеч. 62. Мик. 261. самлити Зор. 75. Мик. 261.

II. погыпиорт Сав. 7. погнивтн М. 365. погнивть М. 357. Пб. 87. Акнгивти М. 252. Збор. 30. Брн. 18. Вран. рјеч. 107. Гуч. 237. Мрн. 28. Јерк. 7. Капг. 41. двигнут' Град дјев. 110. Орб. 43. подвпгнути Ст. пис. 3, 24. уздвигнут' Ст. пис. 3, 24. 5, 169. дигнутп Ст. пис. 5, 39. Банд. IV. Пос. 34б. Радн. 34. уздигнут' Ст. пис. 3 , 128. подигнут' Град. дух. 42. уздигнути Банд. 3. Бун. 19. Андр. пут 196. вщькнвть П. 39. панути Ст. пис. 5, 4. паднути А. Рањ. 47. упаднути Радн. 78. одьтиснвти М. 289. отиснути ІІос. 17. Радн. 87. потисивти М. 285. Буд. 135. стиснути Збор 12. Град. дух. 36. притиснути Зор. 31б. Брн. 15. затиснутп Каш. 34. Андр. пут 54. тиснути Мрн. 80. стискнут' Ст. пис. 3, 21. истискнут' Ст. пис. 4, 487. протискнут' Град. дјев. 34. тпскнути Вран. рјеч. 108. притискнути Вран. жив. 14.

III. 1. нитти М. 50. Пнети М. 29. нинтн М. 326. Ст. Пис. 1, 116. Хект. 20. Чубр. 9. Банд. 10. Јерк. 9. јимити С'т. пис. 1, 220. Зор. 37. умјети Мик. 726. развытть ПI. 35.

III. 2.' бдити Мпк. 11. велит' Ст. пис. 2, 116. висјети Гунд. суз. I, IX. врјети Ст. пшс. 3, 424. дрьжатн М. 2. зрьжать ПI. 32. жудјети Гуч. 242. жнитть ПІ. 76. живјети Н. Рањ. 146. 3бор. 33б. Ст. пис. 2, 402. Д. Рањ. 62. Град. дух. 17. Злат. 30б. Гуч. 248. Див. 10. Орб. 37. Андр. дев. 58. живити Н. Рањ. 155б. Ст. пис. 4, 439. Хект. 20. Брн. 72. Вран. жив. 54. Банд. 38. Јерк. 82. Каш. 87. Пос. 37б. Радн. 3. назрјет' Н. Рањ. 42. Ст. пис. 4, 12. зазрјетп Ст. пис. 2, 10. 3, 99. назрети

1 Како од $\$$ бива $a$, види у Облидима српскога нли хрватскога језика 1872. стр. 95. 
Андр. дев. 29. зрит' Д. Рањ. 2. каснити Вран. рјеч. 25. ускнит' Ст. пис 1, 221. пкниети Збор. 99б. цкњети Ст. пис. 5, 171. Град. дух. 14. дјев. 39. цкнит' Ст. пис. 2, 247. 4, 436. цкнити Ст. нис. 4, 446. 5, 35. Злат. 1б. Мат. 10. Пос. 9б. минети Збор. 54. Град. дух. 174. мњет' Ст. пис. 2, 58. мучати Вран. рјеч. 98. узрастити Бун. 9. свирити Радн. 44. сидјети Гуч. 173. Орб. 231. словјети Ст. пис. 4, 395. 469. словити Ст. пис. 2,63. 4, 395. 488. Злат. 90. снјети Н. Рањ. 143. стомт М. 206. Сq. нис. 5, 35. достојати Гуч. 193. стајати Радн. 13. 38. 64. исто сажето: стат' Злат. 8. стати Вран. жив. 11. тајати Ст. пис. 3, 261. 4, 348. хотеть М. 351. хотити Н. Рањ. 208б. хотјети Андр. Пут 233. хитетн М. 15. хтАти М. 69. хтьть Пб. 73. хтитИ А. Рањ. 36. хтјет' Д. Рањ. VIIIб. ктјет' 9б. процтјети Н. Рањ. 161б. Ст. пис. 4, 59. џтнєти Збор. 50б. цтјет' Ст. нис. 3, 199. процти'т' Ст. пис. 2, 75. процтити Ст. пис. 3, 186. процафтит' Н. Рањ. 17. процавтит' Ст. пис. 4. 302. процаптит' Ст. пис. 4, 302. почтвти М. 211. прочтвтн М. 496. 499. прочтать II. 74. чтtти ПІб. 129. хтнетн Збор. 1.

У ову врсту пришада пнфинитифом својнм и гдагод у кога је садашње вријеме бнло од самога коријена: оүвътвти Сав. 13. вะдити Пб. 23. индити М. 377. 409. иแдТТ М. 420. вндеть Пб. 25. "звкне,пети М. 374. "звкидиетн М. 361. "зввндитн М. 365. повндкть II. 58. повидјети Н. Рањ. 68. повидит' Ст. пис. 2, 438. повидити Хект. 7. повидјет' Злат. 37. zапо-

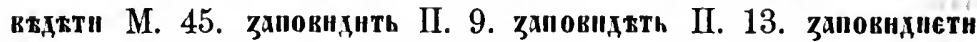
3бор. 2. псновидјети Н. Рањ. 147. Збор. 9. Орб. 64. Андр. дев. 16. Фповияти М. 467. сповидит' Ст. пис. $1,266.2,30$. А. Рањ. 102. Злат. 10. сповидјети Ст. пис. 4, 402. али му се XIV вијека налази инфинитив и по првој врсти у првом раздјелу, гдје види.

IV. примитн М. 218. 323. II. 9. 20. 117. Н. Рањ. 34. 36ор. 75б. Ст. пис. 2, 433. 3, 304. 5, 13. Град. дјев. 24. Злат. 50б. Гуч. 36. Радн. 97. примит' Ст. пис. 1, 190. однимит' Ст. пис. 1, 41. $2,441$. 3, 395. Д. Рањ. 76б. однимити Јапд. 47. снимити Банд. 94. слимпти KäI. 71. зајмпти Ст. пис. 5, 3. појмити Ст. пис. 3, 90. 4, 71 . појмит' Ст. пис. 3,110 . обујмит' С'т. пис. $2,126.3,270.4,459.5$, 3. обујмити Гуч. 120. нсти се глагол находи у истом значењу घ несложен: имити Стар. 4, 74. почтнтн М. 445. П. 69. Ст. пис. 
1, 48.4, 396. А. Рањ. Vб. Каш. IV. почтит' Злат. 21. поштити Ст. пис. 5, 20. чтитн Пб. 128. Ст. пис. 1, 3. 3, 327. Хект. 39. Злат. 59. Гуч. 1. Вран. жнв. 3. Орб. 6. Мик. 45. чтит' Ст. пис. 2, 254. Д. Рањ. 107. штет' Ст. пис. 1, 132. 153. штити Ст. пис. 5, 28. Буд. 42. Стар. 1, 226. Вран. жив. 16. Банд. IV. Мик. 45. прочтит' Зор. $53 б$. прочтити Вран. жив. 85. проштити Каш. 65. спасит' Ст. пис. 1, 267. спаситн Вран. жив. 105. Андр. дев. 22. пут 8. сритити (перфективно) Мрн. 72. тирит' Ст. пис. 2, 72. одтјерит' Ст пис. 3, 51. ударити Вран. рјеч. 76. удрити Вран. рјеч. 76. Мик. 31.

V. 1. ськмодати M. 4. жгати Ст. нис. 1, 16. Вран. рјеч. 24. сажгати 46. пмати М. 44. Ст. пис. 1, 48. Град. дјев. 37. Хект. 41. Гуч. 239. Орб. 246. јимати Вран. рјеч. 3. проклинат' Злат. 6. заклинати Банд. 86. споминати Див. 1. успомињати Пос. 12б. пјевати Андр. дев. 72. пспливат' Ст. пис. 3, 470. срјетат' Ст. пис. 2, 143. посндати Стар. 3, 236. сцати (mejere) Вран. рјеч. 60. шроцватат' Ст. пис. 2, 434. поцревати (имерф.) Н. Рањ. 65б. чрипати Вран. рјеч. 44. дочкати Ст. пис. 1, 123. дошкати Јерк. 62. прочнтать М. 253. птати Гдав. 3. назуват' Ст. пис. 4, 285. - Види још у VI врсти.

V. 2. скезать II. 34. двизати Ст. пис. 3, 284. Хект. 36. дерати Ст. пис. 4, 448. дрхтати Вран. рјеч. 108. дрхтат Банд 296. дртати Радн. 52. жерати Ст. пнс. 1, 116. Вран. рјеч. 44. нскать ПГ. 56. єиати М. 21. к.ати Град. дјев. 13. проклињати Н. Рањ. 201. заклињати Вран. жив. 99. распињати Ст. пис. 1, 175. носкать II. 72. М. 251. стерати Банд. 31. чесати Вран. рјеч. 39.

V. 3. брати Буд. 112. гмати М. 347.' одигнати Стар. 3, 238. жвати Стар. 3, 238. звати Н. Рањ. 20. одацрати Вран. рјеч. 1. разапрати 29. рват' се Ст. пис. 5,35 . вркатн М. 468. одрвати Гунд. суз. II, XXXI. ревати Андр. 123. ссат' Д. Рањ. 82. ткати Мик. 692. такати (ткати) Вран. рјеч. 106. - прокнати Збор. 28б. гријати Мик. 121. даватн М. 23. Вран. жнв. 48. продавати М. М. 47. II. 133. надијати се Хект. 13. Вран. рјеч. 70. кајати се Гуч. 106. ковати Ст. пис. 3, 271. смјејати се Н. Рав. 2296. Ст. пнс. 4, 321. А. Рањ. 107б. смијати се Вран. рјеч. 91.

У ову врсту припада инфинитивом и глагод који у садашњем времену прппада у четврту врсту: спати Буд. 124.

1 Налази се према садапњем времену и промијевено г у ж, па у $p$ : изарнати Банд. 176. 271. 277. Пос. 216. 
Истом у садапвем времену може се по ближе видјети који глаголи ове врсте прпшадају у који раздио, ондје ће се видјети и који припадају у два.

VI. втрокать II. 66. веровати Вран. рјеч. 24. Хект. 32. да-) роват' Ст. пис. 3, 392. даровати Андр. дев. 61. целовати Вран. рјеч. 72. почтокати М. 274. П. 154. Н. Рањ. 209. Ст. пис. 5, 54. Град. дјев. 168. Хект. 5. Гуч. 22. Орб. 57. чтовати Ст. пис. 1,68. Н. Рањ. 162. ттоват' Зор. 5б. штовати Н. Рањ. 17. Вран. рјеч. 21. жив. 19. Банд. 5. поштовати Каш. 48. Пос. 17б. Радн. 26. Г'даз. 23. сагрнховати Буд. 4. подпговати Банд. 46.' воњвать ПІ. 48. краљеват' Јерк. 82. прнатекекати М. 405. тако су многи до краја XVII вијека имали ова или ева, мјесто чега сада имају ива: ${ }^{2}$ пробуђеват' Град. дух. 35. освадјеватп Каш. 53. обадјевати Каш. 53. павјештевати Н. Рањ. 64б. навјештовати 49. навиштевати Банд. 101. узвишевати Каш. 113. Андр. 151. извршевати Гуч. 169. угашевати Н. Рањ. 49б. Банд. 41. погрђевати Н. Рањ. 49б. раздјељевати Збор. 77. ожнвљевати Банд. 171. изисковатп Кашг. 11. пазовати Хект. 12б. казоват' Мрн. 31. приказовати Град. дјев. 31. Банд. 15. скончевати 3ор. 2б. пскушевати Врап жив. 88. Банд. 4. окушевати Радн. 13. раздучевати Банд. 114. оддучевати Андр. пут 425. умпожевати Банд. 115. смућевати Збор. 43. исшитовати Каш. 6. испићевати (испитивати) Глав. 55. мхпаћекатн М. 501. пушћевати Стар. 4, 117. одпушћевати Банд. 179. заручевати Вран. жнв. 112. расадјевати Вран. рјеч. 83. посвећевати Н. Рањ. 112. поскаковати Н. Рањ. 176. наслајевати се Глав. 18. обслужевати Збор. 8б. Вран. рјеч. 3. Дпв. 10б. Банд. 38. Каш. 83. Радн. 12. осудјевати Банд. 161. утврђевати Н. Рањ. 29б. потврдјевати Вран. рјеч. 76. затпсковати Збор. 7б. захваљеват' Град. дух. 48. захваљевати Андр. пут 204. оћућевати Каш. 85. оћутјевати Андр. дев. 104. раширевати Бапд. 18.

Истина још од XIV вијека додазе оваки гдагоди и са ива (а неки још у старом словенском јевику), али како һе се код садашњега времена потврдити, прнадали су до краја

' Биће писарском гријепrом ь мјесто о: дарывати М. 240. а.ли се могло о и избацити: обпдватн Вран. рјеq. 81. Стар. 3, 293.

3 Види о том у Раду југосл, академије VI. 148. 
XVII вијека у пету врсту, у први раздио њезин. Предњих ради нека им инфинитив буде споменут овдје; а у инфннитиву долазе: XIV вијека: винснкать П. 20. XV вијека: юкриннкати M. 405. сказнкхти М. 439. XVI вијека: даривати Стар. 1, 227. з'рјешивати Збор. 162. казнвати Чубр. 5. спомениват' Д. Рањ. IVб. целиват' Ст. пис. 4, 118. XVII вијека: навјестиват' Андр. дев. 15. уврпђиватп Пос. 38. саграђивати Радн. 67. сагришивати Банд. 39. Пос. 3б. погрђшвати Пос. 11. Радн. 20. даривати Каш. 119. појављивати Гунд. суз. предгов. ґазивати Радн. 35. пригазнват' Орб. 235. прнказивати Банд. 143. указивати Радн. 56. Андр. пут 314. искушивати Радн. 96. смућивати Радн. 46. Андр. пут 374. спомениват' Орб. 243. Андр. 52. испитивати Радн. 96. припоручиваті Андр. нач. 8. посвеһнвати Глав. 48. просвјетљиватп Див. 35б. наслађнват' Радн. 30. прослиђивати Радн. 21. обслужнвати Радн. IІб. осуђивати Див. Зб. захваљивати Андр. нач. 45. зафа.бнвати Радн. 21. целивати Вран. рјеч. 102. Банд. 74. ишчекивати Андр. дев. 78.

У инфинитиву се крајње $и$ доста често одбацује, прем да се свега времена II држи, а почело се одбацивати на крају XIV вијека: примјери су тога времена: зихть II. 16.

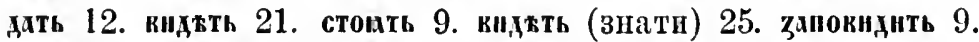
zапокндтть 13. пазать 25. писать 13. скттовать 17. вписикать 20. познији су већ наведени напријед, гдје ми се чвнидо потребно. - Ннфинитиву којп пред крајєнм $u$ има $c T$, по што се $u$ одбацнло, те остало па крају $c x$, могло се и $т$ одбацивати XVI вијека као и у другим приликама (види нацријед стр. 6. 10-11): привес' Ст. нис. 5, 67. упас' 36. Инфинитив чинити налази се у пјесмама не само тако без крајњега $u$ него п без онога нред т: чннт Ст. пис. $5,31$. А. Ран. 74б. 86. 101. 118. 130. 133. а по томе пред ћу одбацивало му се и $т$ : чинћу Д. Рањ. 4, 78. 117б. - ІІто има с наставком два пута стављеним: зајтит Ст. пис. 4, 241 (у дну), то је јамачно додатак прошлога нли нашега вијека; истина налази се п овај прпмјер XVI вијека: пзљеститће (мјесто изљести ће) Н. Рањ. 1076 алп је ту јаматно радп гласа $\hbar$ иисарском грнјешком написано и $т$, као што је и у примјеру XVII вијека: довритһу (мјесто доврић' ћу) Крн. $15 б$. 


\section{САДАШПФЕ ВРИЛЕМЕ.}

Основе су у садапњем времену двојаке:

А. Основе без наставка; таких основа има само пет: основа єс, од које је осим садашњега времена био још само партицип садашњега времена; - основа прве врсте првога раздјела мд, српскп јед (т); - основа прве врсте шестога раздјела да, која сс у садапњњем врехену удвојава, али на другом мјесту одбацује $a$, те гласи дад; - основа треће врсте, која у садашњем времену одбацује крајње ๘ ґоје има у инфинитиву, те гласи: въ; - основа исте врсте првога раздјела, која јоп у старом словенском језпку прелази и у пету врсту и добивши ондје а мјесто ₹ гдасп шма, па се одваја од основа и те врсте у садашвем времену задржавајући вихово $a$ али у осталом прелазећи међу предње четири.

Б. Основе с наставком, а наставак је двојак:

a) једнијем је основама наставак а, које се у словенским језицима у првом дицу јед. и у трећем дицу мн. слијева у један гдас с првијем сугдаснијем од дичнога наставка, а у осталијем дицима гласп $e$, пред којим се гласови $2, \pi$, $x$ мијењају на $ж, u, u$ : таки наставак добијају у садашњем времену основе од којих постаје интинитив у једнијех гдагола цијеле, а у других окрњене: ције.е га добијају у глагола прве врсте свијех осим онијех шестога раздјела; а окрвене, без крајњега самогласнога које имају у инфинитиву иред његовијем наставком, добијају га у глагола друге врсте и у онијех пете врсте трећега раздједа којима кад се окрње

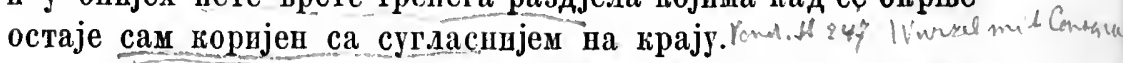

б) другим је наставак ја, у коме од а бива што је речено за наставак а, а $j$ се са суг.ласнијем које се пред вим деси слаже по својим законима: таки наставак добијају у садашвем времену основе цијеле у гдагода прве врсте шестога раздјела п треће врсте првога раздјела п пете врсте првога раздјела; а окрњене, т. ј. бсз крајњега самогласнога које имају у инфинитиву пред његовијем наставком, добивају га у тлагода пете врсте другога раздјела и трећега раздједа исте врсте оспы онијех за које је речено да добијају други настазак, и у глагода шесте врсте. Исти наста- 
ваћ добивају основс и у глагода четврте врсте без крајњега самогласнога које пмају у ппфинитиву пред његовијем наставком, али само у првом лицу јед., а у свијем осталијем лицима остаје им основа lika је у инфинитиву. А глагодп треће врсте друтога раздјела прнпадају у садапњем времену у четврту врсту, те имају основу онаку кака је у тијех глагола.

Гдјекоји гдаголи поједице прелазе у садапњем времену из једне врсте у другу или из једнога раздјела у други: тако хотјети прелази из треће врсте у пету, 'и то у други раздио њезин; глагол спати прелази из пете врсте у четврту. Гдјекоји се глаголп одвајају од свога друштва и тијем што у садашњем времену мјесто наставка а увпмају ја: таки су н. пр. глаголи прве врсте којн у иншнитифу гласе жети (жати), мљети (ммти). Гдјекојим се гдагодима у садашњем времену коријен шпри добнвајући међу диа сугдасна самогласно као брати: бере; мљети: меље; звати: зове; клати: коље. У којпх овако што или још друго што бива, паноменуће се код њих.

ІІРВО АНЦЕ ЈЕДНННЕ.

Постаје паставком пі, од којега за словенске језнке бнва u уз основе гоје немају наставка, а уз остале остаје само и.

А. Основе без наставка:лични паставақ додази до основе, која кад се свршује на $\not$ пзједначује тај члас са $м$ од дичнога наставка, а по том једап од оба једнака гласа отпада: ссиь М. 5. юсьн М. 81. ссан М. 274. огрњено долази од првпјех времена : сьм М. 2. сии М. 102. иза не пде цијело, и тада се е од не са є од основе слијева у п: нксий II. 76. инссиь М. 468. несы М. 518. нисам Вран. жив. 4. нијесам Андр. пут. 50. таго састављено налазп се XVI вијека и огрњено озад изван пјесама: нис Стар. $1,227.3,309$. Зор. 54. 64 б. види и друго лпце. -- пешь Збор. 176. јим Зор. 13б. Јерк. 14. Каш. грам. 120. пам М. 29. Н. Рањ. 42. Ст. пис. 5, 297. - вми Сав. 7. М. 547. инемь М. 500. Ст. пис. 2, 246. 413. 3, 7. 4, 3. вим Ст. пис. $1,32$. 2, 6. 5, 35. Д. Рањ. 65. Хект. 16. Зор. 13б. Злат. 10. Чубр. 13. Вран. жив. 31. Мрн. 31. покнем Збор. 3. Ст. пис. 2, 486. по"вщм Хект. 36б. Зор. 15. заповијем Н. Рањ. 182. Збор. 120. исповты Сав. 7. исповијем Са. пис. 3,278 . оновијем Ст. пис. 
5, 213. прнповеми М. 207. 268. проповијем Н. Рањ. 138. сповим Ст. пис. 2, 100. сповијем Ст. пис. 5, 271. - пман Стеф. 22. М. 27.44. 100. 173. 188. Злат. 4. Банд. 15. јимам Вран. жив. 9. иза же могло се прајње $e$ од те ријечи са $\underline{u}$ од основе слити у п: нимам Ст. пис. 2,26 . али и без тога слијевања: не имам Банд. 39. - Мјесто въми налази се и клдж Стет. 17. 22. које се држи за остатак особитога облика, који се у словенски језицима сачувао само у тога глагола (Миклошић, vergl. gram. III. 165). Истом облику квм додавало се XVI вијека $e$ на крају као и неким номиналним п прономиналним облицима: виме Ст. пис. $2,12.15$. 63. 66. 119. 120. 147. 242. А. Рањ. 85б. Тубр. 6. сповиме Чубр. 6. - Мјесто имам налази се и прсма гдаголима пете врсте првога раздјела, међу које тај припада инфинитивом, XIII вијека: нихю М. 24. - Којима се између овијех глагола основе у овом облнку свршују па $A$, у њіх је $\{$ из трећега дица мн., гдје је од свагда бнло, по што пм се то лице промијенило према глаголима прве врсте првога раздјела, прелазило I у остала дпца, те су се и у њима изједначивали с реченијем глаголима, али се то у овом лицу појавлује пстом у почетку XVII вијека, и свега је тога вијека врло ријетко: налази се само у једнога гдагода и само у једнога писца: подадем Вран. жив. 99. прндадем 104. види код других дица. - Глагол којему је у овом облику основа кћ стојећи у највише других облика међу глаголима треће врсте другога раздједа, а и у самом 3. дицу мн. садапњега вр. стојећи међу њима од свагда, шрелазно је међу њих и осталијем дицима тога времена од свршетка XV впјека (впди код 2. дица јед.), али му се 1. лище јед. находи тако истом XVII вијека: изувидим Вран. жив. 17.

Б. Основе с наставком: личному наставку mi отпада $i$, па се с веговнјем m крајње а у основп слијева у старом словенском језику у ж, које у сриском језику гласп $y$ (op); тако се налазп у нас свега времена, али што позније, то рјеђе:

I. 1. блуду Ст. пис. 5, 42. Злат. 18. изведу Н. Рањ. 42. доведу Ст. пис. 5, 216. греду Н. Рањ. 127. Збор. 38. Ст. пис. 5, 216. паду Ст. пис. 3, 336. упаду 465. преду Ст. пис. 4, 313. - I. 2. уљезу Н. Рањ. 52. донесу Ст. пис. 1, 22. - I. 3. живу Ст. пис. 2, 112. Д. Рав. 236. 826. 94. - I. 4. одвргу Н. Рав. 
97. вргу Ст. пис. 4, 17. А. Рањ. 104б. извргу Банд. 161. могв М. 42. Ст. пис. 2, 12. 5, 211. Мрн. 38. помогу Ст. пис. $2, \overline{194 .}$ 4, 120. узмогу Ст. пис. 5, 285. реку Н. Рањ. 24б. Ст. пис. $2,116$. 3, 389. 4, 268. 5, 213. Хект. 11. Див. 2б. Банд. 22. одрекв М.

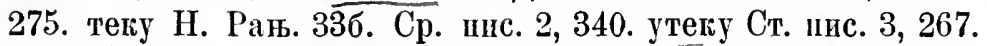
стеку 389. - І. б. књия М. 24. куну Н. Рањ. 84. Ст. пис. 5, 267. вчьнв М. 44. зачну Ст. пис. 2, 30. начну Ст. пис. 5, 268. почну 247. у тога г.лагола долази и $⿻$ мјесто $н$ од XV вијека: вчмв II. 174. узму Н. Рањ. 195. Ст. пис. 5, 269. изму Ст. пис. 5, 186. - I. 6. бију Ст. пис. 3, 385. впию 3бор. 26. у тога је глагола могло $и$ ослабивши у ь испасти : разкью II. 147. впдп и у других гдагола ове врсте код других лица. вапују Ст. пис. 2, 340. 3, 470. гњију Ст. пис. 4, 344. пролију Н. Рањ. 141. пију Н. Рањ. 91. Ст. пис. 3, 251. Зор. 22б. попију Банд. 103. исплпју Ст. пис. 3, 459. шију Ст. пис. 4, 313. чвю М. 44. Ст. пис. 3, 449. 4, 73. 5, 287. Д. Рањ. 3. Вран. жив. 64. дпју Ст. ппс. 1, 66. задпју Ст. пис. 1, 37. смију Ст. иис. 2, 83. 3ор. 13. у двије основе које се у инфннитиву свршују на $y:$ : $л y$ и слу, шири се тај гдас у сад вр. у ов: плову Ст. пис. $2,225 . \overline{3,445}$. види још код других дица. Основа која у инфннитиву гласи пт шири

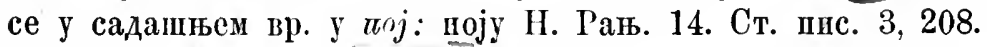
споју Ст. шис. 4, 47. Оспова која у интинитиву гласп ста предази у словенскп језнцима од свагда у сад. вр. у II врсту, види код других дица. Основа која у интинитиву гдаси у старом словенском језषку кт добија у садашњем вр. јим се т саставља у $\underset{\pi}{2}$ које у сриском језику гласи $y$, иза тога још добија на крају $д$ од коријена који је у глаголу дти, те прелази у први раздио прве врсте: буду Н. Рањ. 42. Ст. пис. 2, 329. 5, 180. Здат. 21б. добуду Ст. ипс. 3, 384. Хект. 4б. Злат. 2б. забуду Ст. иис. 2, 99. 5, 299. Основа која у инфинитиву гдаси $u$ добија исто $A$ у садашњем вр. од свагда те прелази у први раздио прве врсте: пду Н. Рањ. 139. Збор. 38. Д. Рањ. 95б. пзиду Ст. нис. 2, 100. прпду Н. Рањ. 24. Ст. пис. 4,327 . Банд. 39. сложено с щријед.логом који се свршује на самогдасно, мијења $u$ иза тога самогдаснога на $j$, које се са $\not$ које је за жим слијева у $\varnothing$ у овом об.лику од XVI вијека (у другим додази тако још прије): дођу Н. Рањ. 31б. зађу Ст. пnс. 2, 344. 5, 151. нађу Ст. пис. 2, 329. 4, 94. пођу Н. Рањ. 51. 
Збор. 25б. Ст. нис. $2,42.5,179$. тако и са ари сложено: прнђу Н. Рањ. 24. Ст. пис. 2, 29. 48. 349. 3, 460. Злат. 2б. и просто: иһу Ст. пнс. 4, 411. али ће пошљедње бити само слика ради. - I. 7. мру Н. Рањ. 58б. 72. Ст. пис. 2, 101. умру Н. Рањ. $56 б$. II. брнну се Ст. пис. 5, 308. вену Ст. пис. 2, 318. 3, 323. 4, 76. узвену Ст. пис. 5, 300. гнну 308. логину 92. издахну Ст. шис. 4, 301. ускрсну Н. Рањ. 97. макну Ст. пис. 4, 301. пану Ст. пис. 2, 218. спомену Ст. пис. 3, 434. 5, 300. посеги II. 147. стину Ст. нис. 4, 244. трну Ст. пис. 2, 109.

III. 1. же.лију Ст. пис. 1, 253. Зор. 13. умшју Ст. ппс. 2 , 83. овамо је прелазило XVI вијека и живију Зор. 13. III. 2. бјежу Ст. пис. 5, 297. боју се Ст. нис. 2, 60. 3, 386. 5, 277. 3ор. предгов. бо.бу Ст. пис. 2,115 . вељу Ст. пис. $2,37$. 244. 328. 5, 179. Град. дјев. 15. Хект. 11б. Зор. 67. З.лат. 286. Гуч. 171. Орб. "40. Андр. дев. 139. кнгю М. 518. Н. Рањ. 23. Збор. 25б.АТ. пис. 2, 6. 3, 460. 4, 411. 5, 270. Д. Рањ. 186. Злат. 12б. Банд. 13. Пос. 13. вију Ст. пис. 2, 78. Хект. 116. Стар. 3, 255. 4, 115. вишу Ст. ппс. 5, 128. вољу Ст. пис. $2,74$. Д. Рањ. 59б. дркжв М. 25. Ст. пис. 5, 111. Вран. жив. 23. жују Ст. пис. 2, 112. А. Рањ. 5. позру Ст. пис. 2, 30. јижју Хект. 16. мпу Ст. пис. 1, 243. 2, 12. 254. 5, 180. Д. Рањ. 2. Зор. 15. 3.ат. 10. мржу Ст. ппс. 2, 33. мучу Ст. пис. 2 , 44. стиђу се Н. Рањ. 1526. стою М. 28. Ст. пиис. 1, 75. 2, 314. 3, 359. 4, 210. 5, 308. достоју Ст. пис. 5, 110. тршљу Ст. нис. 2, 5. 42. ћућу Ст. пис. 2, 122. хофв М. 29. хокв М. 45. хоһу Н. Рањ. 18. Ст. пнс. 5, 175. Злат. 44. Гуч. 119. Вран. жнив. 61. п окрњено од XIII вијека: кв М. 50. 174. 241. ћв М. 47. Н. Рањ. 58б. Збор. 45. Ст. шис. 2, 43. 3, 392. Вран. жив. 92 . Банд. 4. могіло је о и ослабити у в а по том отпасти: хкю М. 69. челу (читај йтеђу) М. 247. овамо је прелазило у овом облику од XVI впјека из првога разајела ове врсте: жељу Ст. пис. 2, 118. 502. 3, 433. 5, 232. д. Рањ. 5.

IV. вкагодароү Стет. 12. пробуђу Н. Рањ. 77б. скагю се $\mathrm{M}$. 207. свару Ст. пис. 5, 266. нзвођу Н. Рањ. 79б. оүзвраштоү Сав. стар. 4, 231. крхкв М. 44. сврьше М. 193. гокору М. 389. Ст. пис. 1, 42. Н. Рањ. 136. 3бор. 38. Ст. пис. 2, 50. 3, 6. 4, 213. 5, 214. Град. дјев. 74. Хект. 35. Зор. 65. Брн. 47. Орб. 10. Банд. 2. Каш. 68. пзгоњу Н. Рањ. 59б. грнјешу Ст. пис. 5, 150. гу- 
бљу Ст. пис. 2, 105. погубљу Н. Рањ. 72. задав.иу Ст. ппс. 2. 465. разднјељу Н. Рањ. 36б. одрпјешу 15. эам М. 518. поздрав.бу Ст. пис. 5, 129. иримљу Н. Рањ. 102. искушу Ст. пис. 2, 251. окупу Ст. пис. 4, 210. пзлијечу Н. Рањ. 66б. прндожу 386. Ђуб, 139б. иншмо ПІ. 64. Ст. пис. 2, 42. моко М. 180. 518. Н. Рањ. 32. Ст. пис. 2, 116. 3, 16. 369. 5, 158. Д. Рањ. 24. Град. дјев. 60. Хект. 4Сб. Банд. 61. пошв П. 108. Н. Рањ. 197б. Ст. пис. 2, 224. 5, 281. пхкю М. 69. 208. прављу Ст. пис. 5, 129. пвцв M. 42. ризрекв М. 462. насдаһ, Ст. ппс. 4, 314. слнипу Ст. пнс. 3,449 . служу Ст. пис. $5, \overrightarrow{149}$. стављу 267. сторю М. 25. поткорв М. 193. отвору Ст. пис. 5, 268. тужу 306 . чңню М. 415. CT. IIIT. 5, 268.

V. 1. Фкекекаюо М. 25. постиккаю М. 70. прицияо М. 20. ирипақаю М. 9. пршхю М. 69. присеzаю М. 1. тако је у том раздједу само у најстарпја времена. - V. 2. обшру Ст. пис. 4, 361. вежу Ст. пис. 5, 189. вичу Ст. пис. 4,372 . движу Ст. пис. 5, 325. уздвпжу Ст. ппс. 2,410. уздипу Ст. ппс. 3, 17. 326. 447. Јерк. 22. раждижу Ст. пис. 2, 99. сазпьу Н. Рањ. 98. позпру Ст. ппс. 5, 178. шюв М. 275. сншів М. 52. пшту А. Рањ. 32б. ишћу Јерк. 48. калку Ст. пис. 5, 156. покалу Ст. ппс. 4, 213. зикишв М. 107. проклињу Д. Рањ. 103. лажу Ст. пис. 5, 260. дижу (лизати) Ст. пис. 3 , 398. намажу Н. Рањ. 62. мећу Ст. ппс. 3, 17. умиру Ст. пис. 2, 12. 5, 178. пашу Хект. 16. пшш М. 21. 518. Ст. пис. 5, 323. плачу (flere) Ст. пис. 2, 51. проплачу Ст. пис. 5, 119. оплачу (lavare) Н. Рањ. 61. Ст. пाис. 5, 119. пљежу Ст. пис. 4, 142. прппрежу Ст. пис. 4, 168. одричу Ст. ппс. 4, 372. шљу Ст. пис. 4, 438. 5, 320. Д. Рањ. 53б. палу Хект. 35. 37. пошљу Н. Рањ. 130б. Збор. 29. пошаљу Банд. 30. почињу Ст. ппс. $4,344 .-\mathrm{V} 3$ неке се основе пире добпјајућп међу два сугласна једне $e$, друге $o$, а основи која у ппфинитиву гдаси кова кад одбацп $a$, повраћа се ов у $y$ : беру Н. Рањ. 52. Ст. пис. 3, 398. зберу Ст. шис. 4, 102 перу Ст. пис. 3, 465. оперу 278. поженоү Стет. 24. зову Ст. нис. 1, 40. Зор. 14б. нзктю М. 71. даю М. 50. Пб. 84. Н. Рањ. 71. Збор. 121б. Ст. пис. 2, 135. 3; 434. 4, 220. 5, 343. Д. Рањ. 94. Зор. 62. Вран. жпв. 36. прпдају Ст. ппс. 2, 122. 3, 330. уздају Н. Рањ. 154. познају Ст. mic. 3 , 434. 457. 4, 28. Хект. 33 . Зор. :9. Брн. 41б. кају се Ст. 
пис. 3, 391. 431. спују Чубр. 14б. смпју се С'r. пис. 2, 206. остају Ст. пис. 3, 431. трају Ст. іnс. 4, 28.

VI. благују Н. Рањ. 56б. вјерују 161. 3бор. 30. Ст. пис. 3, 376. верују Ст. пис. 1, 50. Буд. 38. навјештују Н. Рањ. 21. дароүю Сав. стар. 4, 231. казују Ст. ппс. 4, 327. путују 261. запухују Ст. пис. 3, 16. свитују Грн. 55. потварююю М. 312. тугују Ст. пнс. 3 , 16. зихкаюю II. 173. схранују Н. Рањ. $80 б$. чтviу Н. Рањ. 8сб. 3ор. 76. сцјењују Н. Рањ. 85.

Од глагола који у садашњем времену имају основу без наставка (под A), те се у њих дпчни наставак једнако чувао цио, он је прешао и $\mathrm{k}$ другима: то се најприје догодпло онијем глаголна у којих се могло у првом дицу јед. без и какве друге промјене само замијенити крајње у дичнјем наставком на да се псто дпце не раздинује од осталијех (осим трећега мн.) ничим другим него само дичнијем наставком, као IIто се ни у онпјех првпјех нпје ничим другим раздиковало онда кад се то догађало; то су гдаголи у којнх основа садашњега времепа пред својим наставком има $a$, па се с тпјем гласом пзједначпьао наставак њезин у свијем днцима у којпма је стајао несмијешан с првпјем гдасом личнога наставіа гласећи $e$, т. ј. у свијем дицима осим 1 . јед. и 3. ми., па су се два аa постала од лю сажимала у једно $a$, и на тај се начни основа и $у$ тпјем лицима сврпивала пред лпчнијем наставдпма онако како се сврнивала у 1 . лицу јед. пред његовијем крајњим $j y:$ таки су глагоди пете врсте првога раздјела п глагол прве врсте знати. Од ХІІ вдјека додази 1. лице јед. тако промијењено у глагола V врсте, 1. раздјела: притын M. 21. рхкоташи М. 21. сткар.иь М. 56. XIV впјека: закинимк М. 76. 80. 81. 82. запртірхи 76. 80. 81. 82.180.

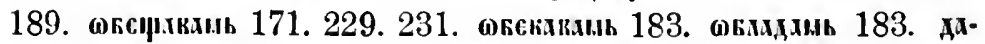

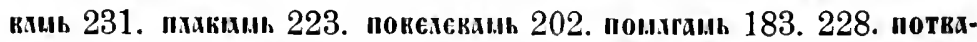

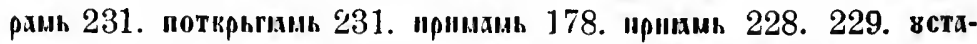

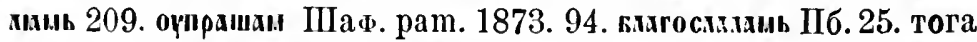
вијека долазп тако и у поменутога глагода прве врсте: змхи || М. 102. XV вијека: „макан М. 476. ІІб. 82. дарнками М. 449.

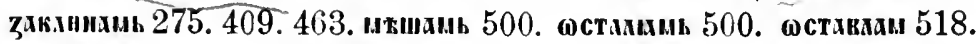
примани 274. 461. зихи 476. ПГ. 88. истом тога (XV) вијека дохвата се ова промјена и других гдагода, у којшх осим 
што се крајше $у y$ (или $y$ ) замјењује личнијем наставком, још и вокал қојц имају у другим лицима шред личнијем наставком прелази и у прво лице: најприје се то догоди глаголима четврте врсте и једнаким с вима у садашњем времену глаголима другога раздјела треће врсте, а п у њих је свега тога времена још ријетко: вхиниь М. 410. мохниь 483. 518. пхатнмь 489. жххни 518. кидим 515. истога вијека налази се једном и у глагола $\mathrm{V}$ врсте трећега раздјела: кьздасмь $\mathrm{M}$. 486. - Од свршетка XV вијека обузима та промјена све глагоде и напредује тако да XVII вијека већ ријетко дола̃зе без ње, осим онијех у које ни данас јоп није продрла:

I. 1. гредем Н. Рањ. 132. падем Ст. пис. 4, 399. ушадем Орб. 164. сретем А. Рањ. 82. мјесто гредем налази се од. свршетка XV вијека и као у глагола бев наставка у садашњем времену, и то у свијем дицима осим трећега мн.: грем Ст. Іис. 2 , 44. 317. 4, 241. 301. 5, 61. 182. Злат. 16. - I. 2. љезем Ст. пис. 4, 476. принесем Злат. 46. пасем Грал. дјев. 114. I. 3. живем Н. Рањ. 138б. Збор. 103б. Ст. шис. 4, 251. 420. 5, 291. Злат. 8б. Див. 10. Банд. 38. Јерк. 19. Кап. 36. Андр. 18. - I. 4. речемь Збор. 72б. Ст. пис. 2, 23. 5, 284. Злат. $28 б$. Вран. жив. 16. Орб. 264. Банд. 14. Андр. дев. 101. кад је промјена узимала мах, дохватала се и онијех глагола који су до данас остали без ње одбранивши се: можем Ст. шис. $2,98$. 165. 228. Буд. 46. Злат. 4б. 12. 15б. Чубр. 7б. Јерк. 21.' приможем Вран. жив. 87. узможем Ст. пис. 5,185 . Орб. 335. I. 5. почнем Ст. пис. 1, 219. 2, 417. узмем Ст. пис. 2, 470. вазмем Злат. 26б. Вран. жив. 92. измем Ст. пис. 3, 18. примем Јерк. 64. - I. 6. вапијем Ст. пис. 2, 470. 5, 93. упијем Јерк. 88. ${ }^{2}$ одкријем Вран. жив. 44. чујем Ст. пис. 5, 347. Злат. 3. с промјеном гласа у у ов: ндовем Ст. пис. 2, 231. 3, 393. сдовем Ст. пис. 2, 254. одијем Вран. жив. 105. у тога се г.лагола (кад није сдожен изначи говорити) може у основи крајње самогласно изједначити с предњим те се оба једнака гласа сажети у један: дим Ст. пис. 2, 3. 3, 63. 4, 181. 5, 34. Хект. 7. 9. Зор. Зб. Буд. 143. Брн. 54. Вран. рјеч. 49. Злат. 8.

' У Кашића је грам. 155: можем, морем, могу.

2 Види тај глагол и у четвртој врсти. 
Мик. 67. друге провјене које могт бити у тога гыагода, види код других дпца. сщщем Ст. пис. 2, 478. 3, 17. 4, 144. 243. 5, 37. 208. Д. Ран. 96. 3.1ат. 7. Бам. 2. и у тога се глагола основа сажима као ! предвега (од почетка XV вијека, впдп код трећега дица): смпм Ст. иис. 1, 32. 292. 313. 2, 21. 70. 78. 161. 227. 234. 267. 356. 4. 209. 214. 419. 225. 473. 5, 255. 3op. 4. Злат. 71б. Банд. 25. по том и напрпјед наведено смијем уоже бити и сажето. па је по јужном говору. од основе која се сажпуа од првпјех времена (впди код 2. дица јед.) а у овом липу, како је помепуто, од XIV вијека: знам Збор. 26б. Ст. пис. 2. 53. 5. 261. 3.1ат. 31. Вран. жив. 24. Повнам Ст. пис. 2, 513.4.418. Андр. дев. 56. тај гдаго. једначећп се са дам прпмио је од њега д у лицима ! појима га је он пмао, али f. 1. диу јед. истом XVII впјека: знадем Вран. жив. 19.26. 55. 61. 71. Мрн. 24. 37. 74. познадеу Вран. жив. 17. од двпје основе које се шире од свагда добпјајџһн, д, како је веһ споменуто: будем Н. Рањ. 42б. Мпк. 3. забудем ('т. пис. 2, 129. 5. 93. прпдобдем Вран. жив. 61. дојдем Јерк. 84. зајдем Ст. ипс. 3, 104. најдем 428.4. 42. Враи. жпв. 23. ојдем Ст. пис. 1, 226. појдеу Вран. жив. 55. пзајдем Ст. пис. 4, 8. 33. гла-

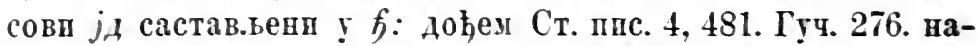
ђем Ст. пис. 4. 295. ЗАат. 81б. Гучч. 170. Бун. 52. ођем ЗАат. 44б. поқем Здат. 56. међу гдаго.е овога раздједа предазио је из четврте врсте: "тпјем Ст. иис. 5. 347 . - I. 7. мрем Ст. пис. $2,45.5,40.179$. трем Ст. пис. $2,44.4,431$. Бун. 30. стрем 3.1ат. 3. всти глагод с рашпреноя основом добпвши $e$ у корпјену: терем Ст. пис. 3. 71. глаго.д који су вз другога разjела треhе врсте прелазп.ли овано: врем Крп. 10б. позрех Ст. пис. 2, 10. 37. 359. 420. 455. узрем Ст. пис. 2, 101.

II. покнегисши Збор. 750 с свенем Ст. пис. 4,262 . вехнем Ст. пис. 2. 460. 481. двпгнем Град. дјев. 23. ускрснем Банд. 84.

III. 1. жемнем' Збор. 178. умијем Ст. ивс. 4, 242. 293. 348. 5. 111. 178. Град. дјев. 143. 3.1ат. 69. Андр. пут. 202. рхзвинешь Збор. 37б. Гуч. 103. З.1ат. ј4б. доспијем Андр. пут 210. надази се и пзједначен наставак основе с предњим гласом, ио том оба сажета ! један: қми Ст. шис. 1, 81. 2, 397. 4, 443.

' Внди га II у аругом раздјелу. 
Хегт. 9. 35. 3.лат. 4б. Мрн. 77. Јерк. 40. разумим Ст. пис. 2, 397. 442. З.ат. 4б. Гран. жив. 24. Мрн. 7б. п с промјеном крајњега м на $н$ : гмин Стар. 1, 234. таго сажето може бити и предње умијем, па̄ је во јүжном говорт. - III. 1. бјежим 3лат. $36 \mathrm{k}$. ве.лим Ст. пис. 2. 104.5, 182. 300. имциь 3бор. 39. Ст. вис. 2, 49. 4, 73. 5, 267. Гүч. 279. Орб. 13. драпм З.лат. 266. желим Ст. пис. 2 , 45. 326. 5, 308. Хегт. 36б. Зор. 13б. З.лат. 16. Врн. жив. 12. Крн. 21. Мрн. 81 Јерг. 22. живим Ст. пис. 2, 112. Зор. 13б. жудим Вран. жив. 28. позрим Ст. пис. 2, 479. 5, 63. 297. озрим Хект. 4Пб. узрим Злат. 5Зб. мним Ст. дис. 2, 19. А. Рањ. 90б. Злат. 16. цБвим Ст. пис. 4. 455. Андр. дев. 103. доцкним Андр. пут 77. поцвним Ст. пис. 4, 416. налази се и с доданим на крају $e$ (види напријед у глагола без наставка у основи): желиме Ст. пис. 2,341 . а.ли у слигу. Једначеһи се с гдагодом поји ฐ садапњем вр. нема наставка у основи и У 1. двцу јед. гласи по западном говорг вим. п у кога се из 3 . дица мн. разишло д и шо осталијем дицима. узимао је то д и г.лаго. ове врсте мним XVI вијега: мнидем Буд. 76. У г.дагола хотіети није се првога .ида дотағ.ло м.' IV. обратим Ст. иис. 2, 54. говорим Н. Рањ. 13б. Андр. дев. 54. згодим Ст. пис. 2. 12. дворим 51. скупим Н. Рањ. 42. бубим Ст. пис. 2. 341 . смис.1им Ст. ппс. 5, 315. молим Н. Рањ. 38. Збор. 34б. Ст. пис. 5. 233. З.1ат. 85. Вран. жив. 97. Пос. 13. смирим Ст. пис. 5, 293. подносим 298. иравпм 347. примим Ст. пис. 2, 470. Град. дјев. 104. чиним Ст. пвс. 5, 297. qтим Ст. пис. 5 , 347. упим Ст. пис. 2, 282. вапим Ст. пис. 2, 423. 5, 76. Злат. 90б. Андр. дев. 76. пут 26.

V. 1. сабирам. Ст. пис. 2. 93. разбирам Ст. пис. 3. 79. 4, 72. обећавам 9бор. 88. згдедам Ст. ппс. 5. 267. давам Ст. пис. 2, 446. 5, 34. Гунд. суз. I. XXXVIII. Орй. 64. Бүун. 34. Андр. дев. 86. раздирам Ст. пис. 2. 445. зазивам Н. Рањ. 18. назирам Ст. пис. 2. 148. познавам Ст. ппс. 2. 447. Злат. 8. Гуч. 107. спознавам Ст. ппс. 4,5 . вазимам Ст. пис. 4 , 324. закв.лам 305. зак.лапам Ст. нис. 5, 279. зак.инам Ст. пис. $4,324$. 5, Г̄73. Аив. 17. Банд. 215. прогдпнам Збор. 126. Ст. пис. 2.308.

' Cамо Kamвђ трам. 106 гма: да хоћем (relim) а на стр. 101 xohy (rolo). 
закљинам Вран. жив. 105. 109. помагамь М. 228. умирам Н. Рањ. 68. Ст. пис. 2, 66. 148. 310. 3, 330. Врап. жив. 52. Јерк. 21. оннам Ст. пис. 5, 270. опирам (прати) Ст. пис. 4, 72. педјепсам Злат. 6б. пуштам Злат. 16. посилам Н. Рањ. 23. Ст. пис. 4, 372. 5, 109. Д. Рањ. 4. Андр. иут 63. посиљам Ст. пис. 4, 305. окећиким Збор. 72. хирикхиь М. 449. Ст. пис. 2, 356. 448. 4, 304. Д. Рањ. 135б. Јрн. 4. З.ат. 51. Андр. пут 46. скончивам Крн. 15б. смутивам Андр. пут 39. споменивам Орб. 34. 219. ослободјнвам Вран. жнв. 6. захваљивам Орб. 27.' целивам Ст. пис. 4, 314. Злат. предгов. 4. глагол прве врсте јети, којему је $е$ гдје гдје гласило ја, прелазно је сложен овамо тако да му се $a$ узпмало као наставак којид постају основе у инфинитиву: пријам (примим) Ст. пис. 5,319 ? 'цријам (примам) 351. види и код других лица. - Што пма XVI вијека и несажето: пуштајем Злат. 65б. то hе бити шрема трећем раздјелу ове врсте (види код 2. дица јед.). - V. 2. обирем Радн. 75. свежем Н. Рањ. 42б. уздвижем Ст. пис. 2, 351. 3, 461. Јерк. 31. дижем Ст. пшс. 5, 40. 45. дрхћем Ст. пис. 5, 48. озирем Ст. пис. 2, 391. ишћем Ст. пис. 1, 3. Банд. 70. укақем Вран. жив. 22. проклйем Ст. пис. 2, 410. лијежем Пос. 16. умирем Ст. пис. 1, 227. пишем Банд. 251. плачем (flere) Злат. 26б. разрежем Ст. пис. 2, 127. шљем Град. Аух. 4. Злат. 15 б. Гунд. суз. I, XXXVII. шаљем Банд. 13. Мат. 3. понаљем Банд. 46. стењем Ст. пис. 3, 17. почињем Вран. рјеч. 20. - V. 3. с промјеном у коријену: перем Ст. пис. 3,465 . с промјеном гласа ж у $p$ : одренем Ст. пис. $1,81 .^{2}$ без промјене у коријену: дајем Ст. пис. 2, 495. Вран. жпв. 34. Банд. 45. Пос. 15. Радн. 3. познајем Банд. 4.

VI. верујем Вран. жив. 12. споменујем Андр. пут 52. уздахнујем Банд. 269. прикажујем Анд. дев. 20. промјенујем Ст. пис. 5, 154. захкахвнем Збор. 96б. захваљујем Андр. пут 74. чтујем Ст. пис. 5. 93. А. Рањ. 94.

1 С промјеном крајњега $M$ на $\%$ : захваљивав Стар. 1, 228.

2 Могло се у тога глагола и избациті $e$ које добпја коријев пирећи се: одагнем Андр. нач. 52. види и 2. и 3. лице јед. а налази се исти глагол и по ирвом раздјелу ове врсте на крају XV вијека, види код 2. лица јед. 


\section{ДРУГО АПЦЕ ЈЕДНННЕ.}

Постаје наставком si, којп и у словенским језицима уз основе без наставка Г'ласп си, а уз остале мијева му се 8 на $x,{ }^{\prime}$ које се опет пред н мијења нащ. те гласв щи.

Ғ. Основе без наставка: дични наставак сн долази до основе, која кад се свршује на дـизједначује тај глас с гдасом $c$ од дичнога наставка, по том од оба једнака гласа један отпада; тако и основи која се свршује на $c$ отпада тај гдас пред $c$ од личнога наставка: єси М. 9. оюрњено: сн М. 68. иза не како је речено код првога лица јед.: итсн. М. 270. пєси М. 208. нијеси Ст. пис. 2, 53. ниси Вран. жив. 64 . кад је тако састављено, или кад с приједа окрњено има пред собом ријеч гоја се сврпује на самогдасно, да би се могло на њу наслонити, налази се и без задњега $u$ не само у пјесмама: нис Ст. пис. 2, 434. нијес Ст. пис. $3,65.4,77$. 5, 97. 3лат. 70. ти ди с Злат. 31. него и изван пјесама: ти с Јерк. 16. види и прво дице јед. - исн Стар. 4, 68. - вьздасн Стеф. 17. подасп М. 278. - втсн Стеф. 11. Стар. 4, 234. свтсн Стеф. 22. - Само се у првога од овијех глагола одржао лични наставак си свега времена у српском језику, а остали су га промијенили шрема глагодима у којшх основа пма наставак: таки је наставак долазпо у старом с.1овенском језику к основи ших, која овамо прнпада, те је и у нас бпло: нмхшн Стеф. 9. а кад добише таки наставак, он им се крњио губећи крајње $u$ као у глагола од којих та добише: нмхшь Сав. стар. 4, 231. М. 22. 43. П. 88. Злат. 101б. остали гдаголи овога реда (осим првога) додазе с таким наставком од XIV вијека: ктшь П. 6. 30. вијеш Ст. пис. 4, 252. виш Ст. пис. 1, 101. $2,19.495 .5,40$. Хект. 19б. извијеш Ст. пис. 1,136 . повиш Хект. 19б. зипвкии ІІ. 59. заповиш Ст. пис. 2, 157. 495. Зор. 7б. 18б. псповијеш Збор. 163б. Андр. дев. 25. прошовијеш I. 122. сповијеш Н. Рањ. 31б. Збор. 63. - дашь П. 35. М. 500. Ст. пис. 2, 70. Д. Рањ. 34б. Злат. 2. Андр. дев. 150. - јиш Ст. пнс. 1, 46. објиш Ст. пис. 1, 224. - у свд трп гдагода којима се основа свршује на $\not$ налази се у овом дпцу $\not$ прешло из трећега дица мн. (види код 1. и 3. лица јед.)

1 Schleicher, compend. 657. 
те се пзједпачују с глаголима првога раздједа прве врсте, али истом XVII впјека у овом лицу: повндепи Рран. жев. 94. заповидеш 55. 91. 100. дадеш Вран. жив. 17. 114. Радн. 6. 38. подадеш Банд. 274. додадеп Радн. 2. јндеи Вран. жиз. 87. а у првога п према глаголима III врсте другога раздјела (како је речено год 1. лица јед.) па крају XV вијека: разувндиш Ст. нис. $1,85$.

Б. Основе с наставном: литин наставак гласећи мин додазп XIII вијегі још цио у споменпцима писанијем по

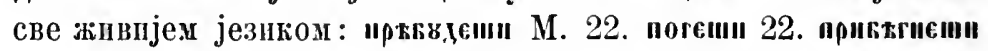

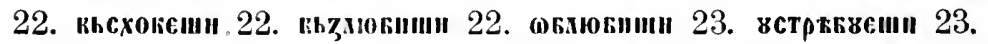
т.ихи" 53. хоксши 53. ПІто XVI вијека има у једпога нисца: шадеши Буд. 99. убијеши 60. поднесешп 47. јаматно је према црквенијем књигама. - Али од првпјех времена долази с окрњеним наставком, без гірајњега $u$ : тако XIII вијека:

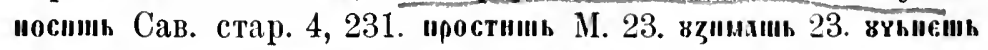
43. морсши 43. вұмєшь 47. п послије остаје тако:

I. 1. бљудеш Н. Рањ. 28. Ст. пис. 5, 96. збљудеш Ст. пнс. 4, 37.' тредеш Башд. 67. украдеш 22. донадеш Ст. пнс. 1, 130. упадеш 3ор. 67. Брн. 11. Вран. жнн. 35. Радн. 27. сједеш Збор. 32б. седен Брн. 55. 60. срштсшь Збор. 32. цватеш Хект 38б. чтен Ст. ппс. 1, 92. мјесто гредеи пма и према глаголнма без наставка у основи (видй 1. дице јед.): греш Ст. пис. 2, 55. 4, 296. Злат. 75. - I. 2. убезеи Н. Рањ. 31б. I. 3. живеш Ст. пис. 1, 144. 2, 319.4, 248. 450. Бріг 42. Злат. 95. Бапд. 30. Јерк. 82. Андр. пут 157. Радн. 2. - I. 4. одвржеп Вран. жив. 25. подвржеш Ради. 54. раждежеи Чубр.9. $\Lambda$ ндр. дев. 144. можен Ст. пис. 1, 131. 3, 444. Злат. 1. Вран. жив. 19. Радп. 20. поможені Ст. пнс. 5, 153. Злат. 54. Јерк. 22. Андр. пут 354. и с промјеном гиаса $\nRightarrow$ на $p$ у тога гйагола од XIII вијека: мюpєш⿻. М. 43. Ст. пис. 1, 219. Н. Рањ. 161. Збор. 149б. Ст. пис. 2, 3. 401. 3, 103. 4, 145. Град. дјев. 63. Хект. 20б. Брн. 45. Вран. зкив. 8. Банд. 128. Каш. гран. 155. Пос. 3. Гяав. 16. обучеп Ради. 93. речеші Ст. пнс. 5, 15. 122. Банд. 68. Јерк. 56. стечеш Злат. 54б. Мјесто можеи долази п огрњено, без личюга наставка п вокала пред њим,

' ІІІто пна у слику: бљудиш Ст. пис. 1. 242. биһс само слика радп. 
од XIII впјега: пожь М. 53. II. 11.61.66.68. 122. Ст. пис. 1, 36. 120. Збор. 26б. 35. 58. 63. Ст. нис. 2, 117. 142. 157. 4, 221. 420. 5, 30. 135. 206. Хект. 4б. 41б. 3ор. 2б. Брн. $60 б$. Злат. 8б. Орб. 163. Андр. Дев. 29. - I. 5. зачнеш Н. Рањ. 16. почнеш Кап. 114. вазмеш Брн. 43б. Злат. 57. измеш $\mathrm{H}$. Рањ. 148. пзнемен Стар. 1, 223. примен Ст. пис. 1, 43. 3, 444. 3ор. 55. од основе која добија наставак ја мјесто чистога a: жањеш Банд. 252. - I. 6. вапијеш Ст. пис. 2, 344. узвапнјеш Гунд. суз. III, LXXIX. у глагола иити могло је $u$ ослабивши у ь исшасти: олјеш С'г. пис. $2,453 .{ }^{2}$ пхиешь (natare) 3бор. 133. смијеш Ст. пис. 2, 485. сажето: смиш Мрн. 166. такођер сажето: диш Ст. пис. 1, 263. том се глаголу и удвојавао коријеп тако да му се на првом мјесту мијењало т на є а па другом отпадало, те је оспова добијала ја мјесто а ио другом раздјелу пете врсте: одеђеп Ст. пис. 4, 10. с промјеном гласа $y$ у основи у о6: пловеш Ст. пис. $3,326.4,39$. Мрн. 145. спокшь П. 121. с промјеном гласа ₹ у основи у ој: појеш Ст. пис. $3,67.4,25$. у глагола у кога од давнина бива сажимање (внди код 1. дица јед.) налази се несажето: zнасшь Стар. 4, 72. сажето: зихи II. 118. М. 515. Вран жив. 35. Банд. IX. познаш (т. пис. 4, 354. Злат. 45. Бун. 45. Каш. 68. Андр. нач. 57. у пстога глагола са $\not$, које му је допло како је речено год првога лица јед., истом од XVII вијека у овом дицу: знадеш Вран. жив. 17. 20. 24. 29. 30. Мат. 38. Мрн. 36. 42. 77. Радн. 20. 25. 41. 53. позшадеш Вран. жив. 104. Радн. 92. у глагода којима се основа шири од свагда добпвајући $А$ (внди код 1. лица јед.): будеш Ст. нис. $4,485$. добудеш Ст. пис. 2, 43. Зор. 76б. Вран. жив. 85. прпдобудеш Гуч. 107. забудеш Ст. пис. 1, 143. Хект. 41. Чубр. 7б. Јерк. 34. тај глагод сложен са до изједначивао се на крају XVII вијека с осталијем г.лаголима овога раздјела: добијеш Радн. 88. 98. идеш Ст. пис. 5, 244. пондешь II. 101. најдеш 3ор. 6б. у њега се $j_{д}$ саставља у $ђ$ од XIV вијека у овом лищу: ${ }^{2}$ догњшь ПІ. 6. 24. дођеш Ст. пис. 4, 438. Злат. 72. зађеш Ст. шис. 4, 175. нађеш Град. дух. 45. "зыхген М. 515.

1 Тако може бпти и gnје Ст. пис. 1, 223. изгиє 3бор. 28. "zaruc 3бор. $32 \sigma$.

2 Уз цијели лични наставаґ још XIII вијека: погєщи М. 22. 
ођеш Ст. пис. 5, 37. пођеш Злат. 40б. приђеш Ст. пис. 4, 220. тако постало 5 у слоненом прелази XVII вијека и у несложени: иһеш Радп. 5. 7. 25. Пос. 286. а по том и кад је сложен с приједлогом иза кога се не мијења $u$ на $j$ : отиЂеш Радп. 29. 49. - - I. 7. треш Ст. пис. 4, 413. стреш Ст. пис. $2,50.5,49$. у глагола гоји је из треће врсте прелазио овамо: поореш $А$. Рањ. 63. у глагола који ішире основу узимајући $e$ међу два сугласна: подереш Ст. пис. 4, 20. које би. могдо бити и по $\mathrm{V}$ врсти.

II. дпгнелі Д. Рањ. 79. уздвигнеші Брн. 5б. притиснеш Брн. 73. почихпеш Ст. пис. 2, 453. упинеш ПІос. $40 б$.

III. 1. вмиєшь Збор. 2. Ст. пис. 4, 429. 5, 18. Д. Рањ. 33. Злат. 9б. Андр. пут 31. разумпјеш Радп. 21. и сажето (види код 1. лица јед.) од XV вијека: вмвшь П. 60. умип Ст. пис. 1, 25. 101. 2, 3. Хект. 20б. разумиш Банд. 141. Мрн. 72. III. 2. бдпш. Ст. пис. 4, 33. везнш 313. кн,лшшь М. 515. Злат. 55. желип Ст. пис. 1, 99. 2, 66. Хект. 7. Орб. 238. живиш Ст. пис. 1, 138. позрин Ст. пис. 2, 10. 469. мниш Ст. пис. 5, 179. З.ат. 95. сједин Град. дух. 21. Орб. 250. оћутпі Вран. жив. 19. џхитниь Збор. 171б. цтипा Ст. пис. 2, 68. 472. цкниш Ст. пнс. 2, 45. Гуч. 243. Јерк. 22. Андр. дев. 24. с уметнутим д (видп код 1. лица јед.) XVII вијека у овом днцу: мнидеш Вран. жив. 30. 49. глагол којему је основа у интниттпв коть у свијем лицима осим 3. мн. стоји у другом раздјелу пете врсте: хоћеш Ст. пис. 1, 154. Гуч. 118. не хоћеш Ст. пвс. 2, 423. окрњено: кєшь II. 129. ћєшь М. 500. Ст. пис. 2, 112. 3, 139. А. Рањ. 143. Злат. 22. Гуч. 142. долази п озад окрњено без личнога наставка и вокала пред њим, од XV вијека: хюкь II. 115. 133. хоћ Ст. плс. 1, 154. Н. Рањ. 53б. 117. 3бор. 12. Ст. пाис. 2, 112. 225. 3, 136. 352. 1, 27. 442. 5, 10. 76. 297. 325. Хект. 10б. Брн. 5б. Стар. 3, 226. 295. 297. Злат. 3, 8. Мик. 174. окрњено и с пријед и озад иза ријечи која се свршује на самогласно, те се може на ву наслонити: не $九$ Ст. пис. 1. 107. Н. Рањ. 38. Збор. 62. Ст. пис. 2, 34. 112. 113. 3, 459. 4, 33. 103. 255. 381. 5, 298. Хект. 10б. Стар. 3, 223. Злат. 9б. ако һ Хект. 4б. гдје ћ мисли скупит Ст. пис. 4, 102. гдје ћ стада хранит 186 . ако ме ћ Ст. пис. 2,116 . посли 
ме ћ хвалити Злат. 23б. тој ди та ћ пролити Ст. пис. 4, 151. ако се ћ избавпт Ст. пцс. 4, 142.

IV. говиш Злат. 14б. пматншь П. 6. М. 501. пракнши М. 313. примиш Ст. пис. 5, 336. Злат. 22б. Андр. пут 85. пзнимиш Бапд. 161. цорип (ако што товору, бесједу му цориш) Д. Рањ. 34. чинипі Н. Рањ. 82б. вчниншњ М. 515. чтиш Ст. пис. 1, 125. 2, 3. 142. 266. Д. Рањ. 55б. штин Ст. пис. $1,125$. 144. Стар. 1, 226. Банд. 141. сумњиш Ст. пис 5, 197. вапинг Злат. 8. у глагода који инфинитивом ирппада у пету врсту: спиш Ст. нис. 2, 423. 5, 129.

V. 1. прајње аю у основи изједначивши се у ал сажима се у а од првијех времена (види и код других лица): тако XIII вијека: вънмашь М. 23. п послије: зоираш Збор. 8. давапI Ст. пис. 5, 5. Д. Рањ. 83б. Злат. 19б. продаваш Ст. пис. 5, 120. вазимаші Ст. пис. 2, 68. проглинапI Град. дјев. 103. помагаш А. Рањ. 146. Андр. пут 162. умираш Ст. пис. 5, 29. 190. надаші се Андр. пут 298. споминапा Див. 24. почвнаш Злат. 2. скш (чнтај сјаш) Стар. 3, 317. дариван Ст. пис. 3, 462.5, 221. Див. 216. Банд. 135. спомениваш Орб. 3. викапI Злат. 14б. рикаш Ст. пис. 4, 19. с окрњеном основом: глаш (гледап) Ст. пис. 2, 423. глагол који је из прве врсте предазио овамо како је речено код 1 . лица јед.: пријаш Ст. пис. 2, 417. 3, 379. Злат. 75б. штто се још XVI внјека налази и несажето у несвршенијех глагола: скончајеш Ст. пис. 2, 423. д. Рањ. 59. пуштајеш Д. Рањ. VIIб. 104б. у тијех he г.дагола бити основа у инфинитиву на $а в a-$, те hе бити прешли у трећи раздио ове врсте. - V.2. обежеші Злат. 72. сврћеш Ст. пис. 2, 52. удјељеш Андр. пут 15. интеш Злат. 6. ишћеш Зор. 31. Јерк. 9. пншєш ПI. 11. проричеш Злат. 6. шаљеп Радн. 91. потаљеш Банд. 45. Радн. 89. пошиљеш Град. дјев. 114. пстјечеп Злат. 3. почивеп Ст. пис. 4, 411. - V. 3. с промјеном у корпјену: опереш Вран. жив. 20. поженеш Ст. пис. 4, 38. у истога глагола и с промјеном гласа ж на $p$ : ренеш Ст. ппс. 5, 176. одренеш Јерк. 34. у њега се мог.до и избацити $e$ које добија коријен ширећи се: изарнеті Банд. 277. а тада се и повраћало 2: изагнеші Андр. дев. 29. а налази се и по првом раздјелу ове врсте од свршетка XV вијека: одагнаш Ст. пис. 1, 243. без промјене у 
коријену: жвеші Збор. 136б. ревеш Ст. пис. 4, 20. жаюши II. 94. Ст. шис. 2, 99. Брн. 41. Каш. 35. задајеш Злат. 101б. Вран. жнв. 108. познајеш Банд. 162. Јерк. 62. ІІос. 2б. Радн. 12. смнјеш се Д̆ив. 31б.

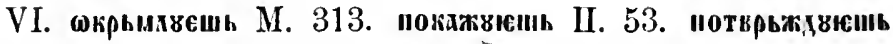
II. 4. верујеп Вран. жив. 47. мјенујеш Ст. пис. 4, 10. вегујеш Злат. 75. ттујеш Злат. 49.

\section{TPEЋЕ АИЦЕ ЈЕДНИНЕ.}

IІостаје наставком ti, у ком од i у словенским језицима постаје и, те гласи ть, а и у српском језнку отпада.

А. Основе без наставка: које се свршују на д, мијења им се $A$ пред т од дичнога наставка на $c$ : єсть М. 5. нест M. 463. стојећи на крају $т$ пза $c$ могло се и одбацити као и у друг'их ријечи (види стр. 6) од XVI вијека:' јес Н. Рањ. 69б. Збор. 14б. Ст. пис. 2, 15. 4, 165. 5, 52. 122. Злат. 1б. Гуч. 17. цијелому налази се XIV вијека додано на грају $e$, које се додаје и другим рпјечима : нсте Пб. 15 . саставља се са не каюо је речено код првога дица јед.: пћсть М. 62.532. шєсть М. 38. цијело без не одржало се, истина, свега времена, али енклитччки долази од првијех времена и окрњено озад тако да нема ни личнога наставка пи крајвега сугласпога у основи: є М. 6. є М. 10. 15. ию М. 464. је Ст. пис. 2, 51. тако од првијех времена и састављено са не замјењујући цијело: нк М. 6. 20. ше М. 205. пиє М. 101. 281. Ст. нис. 3, 13. Злат. 19. нс М. 55. 117. ин М. 255. Пбб. 53. Ст. пис. 1, 36. Н. Рањ. 18. Ст. инс. 2, 316. 5, 218. Хект. 19. А. Рањ. 8. Зор. 15. Буд. 35. Злат. 8. Вран. жинв. 4. Гунд. ис. 17. Кап. 90. Глав. 37. тако постало у источном говору не и у занадном ни шзједначнвши се с другим ријечима узимало је још једном є од XIV вијека: пє М. 154. пєс М. 550. пиє М. 249. пије Хект. 36. Буд. 26. Вран. жив. 8. Јерк. 54. - кжсть Сав. 3. пронтсть М. 10. још XV впјека: въсть II. 93. - , асть Сав. стар. 4, 231. М. 14. 52. ІІб. 20. "роқасти М. 14. "з,қасти М. 52. и XV вијека: дасть М. 416. Нб. 122. шрєұасть М. 527. - мсть Сав. 5. - ицать

1 IIIто има XIV вијека: пио по єсь дохотка ПІб. 32. биhе у писању изостављено $T$ тласа $A$ ради, којл иде за том ријечју. 
M. 159. - Осим првога глагола остади нијесу сачували тога облика цијела, него им се окрњио изгубившп не само лични наставак него и крајње сугдасно од основе: тако долази један од XII вијека до данас: да М. 2. 16. 19. 27. 45. 52. 102. дах М. 208. 267. да Н. Рањ. 16. Збор. 43. Ст. пис. 4, 438. Град. дјев. 122. Злат. 12б. Гуч. 142. пода М. 52. 147. 462. прода М. 52. П. 110. прта II. 100. прида Н. Рањ. 90. уда Град дјев. 78. изда Буд. 138.' један од XIV вијека: кт П. 7. 9. 14. Пб. 43. вије Ст. пис. 2, 68. 262. 3, 293. 413. 4, 5. 163. ви Ст. пис. $1,120$. 2, 232. 5, 62. изви Стар. 3, 257. покю М. 102. повт ПI. 32. повне Збор. 32. пови Хект. 7. заповт М. 571. П. 31. запови Ст. пис. 2, 25. пспокие Збор. 166. пепови Буд. 69. пртповт М. 211. прнпокт М. 436. Пб. 71. прппове М. 355. сповије Ст. пис. $4,405$. вът ПI. 31. ввє М. 102. тако још XVII вијека: сповије Гунд. пс. 4. повије Андр. пут 254. запови Глав. 27. трећп од свршетка XV вијека: ји Ст. пис. 1, 10. Д. Рањ. 121. Зор. 2. ије Н. Рањ. 146б. Ст. пис. 2, 336. 4, 170. 5, 126. Д. Рањ. 93. Чубр. 12. Гунд. суз. I, LXII. ${ }^{2}$ вкћє Збор. 16. ујн Зор. 67. Брн. 28б. изије Ст. ппс. 5, 283. Гунд. суз. I, VI. - тако без дичнога наставка додазп од XIII вијека и нм М. 10. нмх M. 10. пе пиа М. 14. а иза не кад стоји мог.ло му се $u$ са $e$ од не саставити у п: тако од XIII вијека: нки М. 13. пемх 123. нима 281. Пбб. 58. Ст. пис. 1, 23. 2, 367. Хект. 9. 3ор. 1. Буд. 13. Брн. 3б. Мрн. 187. Јерк. 60. Глав. 12. - Прем да се у овпјех глагола овај облик држао оваки до краја XVII вијека, ипак у којих се основа свршује на $\not$, по што се треће лице мн., у ком се чувало д у основи, изједначи с истијем лицем глатола прве врсте првога раздјела, оно повуче за собом и остала лица, да бн се и њима ови глаголи изједначили с осталима, те из њега $\not$ пријеђе и у ово дище ${ }^{\mathbf{s}}$,

- IIIто се налази XVI вијека и дат Н. Рањ. 49. 140. ту је $T$ дошло ошако како ће се споменути шод Б. за друге глаголе.

2 У ивворима јужнога говора не стоји свагда $j$ на истом мјесту, а највише га и нема.

${ }^{3}$ To је потанко разложено у B. Jarnћa Das Leben der Wurzel dê, Wien 1871. стр. 67-69. Испореди й у мојшм Облицима срискога језика у Биограду 1863. стр. 123. 
али пстом од свршетка XV или од почетка XVI вијека ${ }^{1}$, и то у гдагода дати: даде Cт. пис. 1, 29. прпдаде 29. XVI вијека такође само у једнога писца: даде Буд 38. подаде 18. придаде 100. XVII вијека чепће: дад М. 560. Вран. жив. 11. 58. 68. 81. Банд. 91. Пос. 30. Радн. 2. 3. 16. Гдав. 20. одаде Вран. жив. 112. подаде Банд. 173. Мрн. 158. Глав. 44. придаде Мат. 41. у оба друга гдагола пстом од друге подовине XVI вијека: исповнде Буд. 19. 20. јшде Буд. 70. XVII впјека: повнде Вран. жив. 59. заповшде 94. јнде 53. 83. једе Радн. 17. 24. наједе 85. изједе 91. из овијех је гдагода прешло д и у глагол имати, који међу њих припада, али истом на крају XVII внјека: имаде Радн. 62. - А у једнога између њих, у кога је основа квд, налази се ово лице и према глаголима треће врсте (како је рсчено код првога лица јед.) па грају XV впјека: повиди Ст. пис. 1, 239.

Б. Основе с наставком: лични наставак ть отпада у сршском језику од првијех времена: истина, он се и налази у споменицима у којима је иначе чист народни језик и у тағшм споменицима допире до XVI вијека: тако XIV вијека: зиають М. 107. дакать 159. квдсть $239 . \mathrm{XV}$ вијека: достонть 481. "зиесеть 481. вҮинить II. 93. XVI вијека: шишсть М. 548. али се у таким споменицима налази тако ријетко а тако га често ни у њнма истијем ни у другима, у којима претеже језик црквени, нема, да се може без најмање сумже тврдити да је и на она мјеста дошао пз црквенијех књнга, а у народном језику да га није било од првијех времена, од којих имамо писанијех споменика. - На крају XV и XVI I самога XVII вијека појављује се неко $T$ иза садашњега тога облика у негшх писаца, појављује се чешће него у најстарија времена. дични наставак, прем да само у неких пи-

1 IIримјери које Jarиh Leben der Wurzel dê стр. 69. наводи из прве половине XIV вијека: дадс M. 102. подаде M. 108., како ја разумшјем мјеста гдје се находе, нијесу треће лице једнине него множпие; а примјери које спомиње на стр. 70. од године 1438 дадє М. 319-2. нијесу треће лице јед. садашњега времена него аориста. - Примјер воји имам од године 1400 пртдаде П. Зо. чини ми се да hе прије бити треће лице множине него једнине сад. вр. 
саца: на крају XV вијека: изреьи не уми т' Ст. пис. 1, 32. буде т' Јеросодим твој 43.' XVI вијека: имат Н. Рањ. 141б. сметет 142б. сусрјетет 23б. узнесет 35б. вржет 122. провржет 176. ужежет 112б. речет 39б. 79. останет 23б. будет 55. 210. нађет 140б. 208. 208б. пзгинет 140. пригнет 23б. уздвигнет 14. 15. 17б. споменет 48б. почпнет 179б. разумијет 169б. видит 1416. ненавидит 140. уздржит 23б. изгубит 208б. укријепит 23б. пољубит 210. помирит 6. смутит 47б. прпправит 146. напунит 135. запустит 118. одпустит 79. посветит 1436. насладит 118. услишит 49. посрамит 23б. отворит 49. $140 б$. ухватит 23б. схранит 80б. 140. очистит 20б. приблнжат 13. поддагат 112б. напитат 23б. уздвижет 34б. укажет 206б. закољет 112. узвишујет 52б. потрјебујет 35. почтујет 876 . сткорнть 3бор. 33. орєть 33. обарујет Брн. 4б. реqет Стар. 1, 225. устанет $225 .^{2}$ кунет се Буд. 55. ${ }^{3}$ шримет 6. знадет 78. 108. будет 7. 12.28. мрет 49. запрет 18. разумит 126 . пристојит 54. ненавидит 96. говорит 40. помирит 6 . прицичит 18. чтит 148 . подобајет 13. 33. црилагајет 36. помагајет 42. 64. упадајет 158 . наслањајет 14. постављајет 51. притискајет 14. згајат се 7. укдадат 123. ушадат 158. кажет 52. прокливет 120. достижет 52. простирет 122. наслидујет 81. сагрншујет 123. XVII вијека: сусритет Банд. 13. обучет 13. најмет 47. убщјет 42. будет 37. прибудет 228. прндет 4. пројдет 16. растарет 47. прнгнет 17. уздигнет 4. ускрснет 45 . узвисит 44. усквасит 24. раздучит 35. понизит 14. шримат 15. изарнет 76. усидујет 38. очитујет $8 .^{4}$ Али ово $T$ није лични наставак него је од ријеqце те п ти, поје постају од пронопина то, јер се налази и иза других ријечи а налази се и цијело те п $т \mathrm{~s}^{\mathrm{s}}$ за буди т се одлучује Н. Рањ. 25. правду т чињу 220б.

1 Наптамшано је на оба мјеста тањо растав.ьено.

2 Jom такпx прпмјера XVI вијека из другога извора виді у Г.аснпку IX. стр. 47. гдје се на.лази и дат мјесто $\not a$.

3 У тога писца много юојешта може бити п према црквенијем књигама, за то се не треба много обзпрати на његове примјере.

4 IIIто јоп један ипсац у другој половини XVII вијека има: спасен будет Г.ав. 97. то је јалгчно из црквенпјех књига, одакле је п цијело мјесто.

5 Вуди о том у у Гласнику IX. стр. 47-48. 
ево т сам ја 142. добро чпни те вам бог Н. Рањ. 48б. дрвzн ти гх ћє вчнинтн 3бор. 12б. ${ }^{1}$ паде ти их на ливу твоју тисућа Стар. 4, 111. он ти буде стабдо Банд. 45 . исто се тако додавало и то: додај то, Саре, брус Ст. пис. 4, 239. изљез' то 323. дај то се напшти 327. донес' то млијека још 328. нека то јих Хект. 14. тере то ми овако траду бесијаше 13б. Види и код трећега лица множине. - Најстарији су примјери без

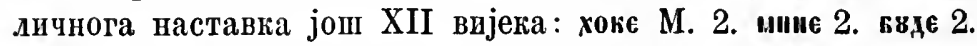
Бъжи 6. соүян 6. Познији hе се видјети ниже гдје hе се показати и друго што у овом облику бива:

I. 1. б.буде Ст. пис. 2, 336. Хект. 29. веде Ст. пис. 4, 114. греде М. 101. Ст. пис. 1, 307. 4, 32ј. пладе Ст. пис. 1, 4. вкраде. М. 208. праде Здат. 54. укреде Хект. 32. Крн. 10. исыпхе М. 31. паде Ст. пис. 1, 8. Н. Рањ. 153. Ст. пис. 3, 325. 4, 296. 5, 155. Д. Рањ. 38. Буд. 38. Орб. 224. Бун. 39. Мат. 39. Радн. 47. допаде Збор. 2. Ст. пис. 2, 141. Хект. 27. упаде Андр. пут 112. седе Ст. пис. 1,89 . Хект. $32 .{ }^{2}$ понете М. 17. уплете Вран. жнв. 23. ресте Брн. 28б. узресте Вран. жив. 81. шкрьтє М. 20. 27. Пб. 25. огрите М. $256 .^{3}$ џвате М. 249. Хект. 17б. чте Ст. пис. 1, 92. мјесто гредеи има и према глаголима без наставка у основи (внди напријед 1. и 2. дице јед.): гре Ст. пис. 2, 33. 315. 4, 248. 5, 5. 138. Д. Рањ. 2. 77. Злат. $11 б$. - I. 2. у.ьезе Збор. 93. Ст. пис. 4, 190. однесе Вран. жив. 65. спасе Буд. 93. - I. 3. дубе Ст. пис. 5, 324. пздубе 11. зебе 211. скубе Ст. пис. 4, 395. сопе 166. распе М. 154. раzаспє 370. 467. проспе СТ. пис. 4, 87. жнвє П. 112. Н. Рањ. 146б. Збор. 5. Ст. пис. 2, 273. 5, 41. 135. Град. дјев. 133. Брн. 72. Злат. 5. Гуч. 102. Вран. жив. 55. Див. 4б. Гунд. суз. III, XXXVI. Банд. 38. Јерк. 22. Андр. дев. 31. Радн. 28. - I. 4. брже Банд. 64. разврже Ст. пис. 2, 85. Буд. 71. Банд. 125.

' Још таких примјера XVI вијека види у Гдасвику IX..стр. 48. Примјера XV впјека с цијелијем ти шма у Никољском и Хвалову руконису, из оба су споменути у Старинама III. стр. 70.71 .

${ }^{2}$ Кад не би у шисаца који су писали западнијем говором долазвло и у другім приликама $e$ мјесто т, могло би се мислити да ово одговара староме словенском садеть.

${ }^{3}$ Писарска hе погрјешка бити шкрт M. 64. 
ражеже Банд. 125. сажеже Радн. 56. шожє М. 101. Ст. пис. 2, 116. 3, 106. 438. 4, 137. Град. дјев. 176. Буд. 11. Гуч. 42. Вран. жнв. 67. Дпв. 39б. Банд. 15. Канг. 67. Андр. дев. 135. поможе М. 106. 493. Ст. пис. 3, 466. 4, 7. 5, 39. З.лат. 28. Банд. 221. стрже Ст. пис. 2, 229. Хект. 8. Зор. 51. с промјеном г.даса ж на $p$ (види код 2. дица јед.): море М. 201. 258. 312. 344. II. 1. 11. 16. Ст. пис. 1, 4. Н. Рањ. 43б. Ст. пис. $2,55$. 319. 3, 64. 4, 173. 5, 6. 135. Д. Рањ. 6. Град. дјев. 5. Хект. 5. Зор. 1. Брн. 6. Вран. жив. 71. Банд. 56. Бун. 67. Каш. 67. Радн. 20. поморе Ст. пис. 1, 25. 50. Хект. 9б. Крн. 13б. узморе Хект. 22. обуче Н. Рањ. 24. Стар. 3, 306. врєчс М. 41. рече Буд. 23. посєүє М. 101. втечє М. 147. тече Злат. 46. мјесто можеи додази и окрњено као у 2. лицу јед. (које види): мож Ст. пис. 2, 102. вұмож М. 532. - I. 5. отквне М. 353. заквиє 410. начне М. 47. почне Ст. пис. 1, 109. 5, 185. Гуч. 40. Банд. 28. Глав. 109. зачне Ст. пис. 2, 64. 5, 118. Брн. 50. причне Чубр. 12. учне Ст. пис. 2 , 434. с промјеном гласа $\boldsymbol{н}$ на $м$ : почме Пб. 44. Банд. 195. Мрн. 66. Пос. 27. Радн. 33. синине М. 23. посажм Ст. пис. 1, 10. пме М. 48. 53. јаме Хегт. 21б. оүзие M. 15. 17. Н. Рањ. 107б. Злат. 54. вазме Ст. пис. 5, 4. Злат. 69б. взаме Стар. 3, 313. "зиме М. 102. II. 109. Збор. 23. Ст. пис. 5, 17. Д. Рањ. 85. обујме Н. Рањ. 161. Ст. ппс. 2, 468. 5, 183. Банд. 175. обујеме Брн. 46. однияе М. 225. однеме Брн. 5. отме Вран. жив. 22. приме М. 16. 27. 53. II. 7. Ст. пис. 1, 125. 3, 462. 5, 350. сниме Ст. пис. 1, 58. дме Збор. 122. - I. 6. рақкне М. 85. разакне М. 400. вкше М. 101. ушије Ст. пис. 1, 21. Злат. 34. завпне Збор. 125. КапІ. 53. вапије Ст. ппс. 2, 33. 5, 78. Брн. 29. Банд. 38. Радн. 96. завапије Ст. пис. 1,67. гније Вран. жив. 65. згније 27. изагњије Банд. 239. сагњије Канг. 21. покрьє М. 415. пије Ст. пис. 5, 283. и избацнвпи $и$ : попе (чптај попје) Стар. 3, 269. плије (natare) Ст. пис. 2, 61. 3, 61. Д. Рањ. 13б. исплпје Д. Рањ. 73б. утије Ст. пис. 1, 43. пије Ст. пис. 5, 276. стрвє II. 33. додије Ст. пис. 4, 329. Злат. 19б. здин М. 485. Ст. ппс. 1, 46. Хект. 29. Крн. 12б. одпје Вран. жив. 6. Гунд суз. I, XIV.' Мрн. 32. заодије Банд. 38. надије Ст. пис. 1, 131. Каші. 94. од исте

$'$ На том је месту имперфективно, па може бити да припада у пету врсту. 
основе сажете (види код 1. и 2. дица јед.): ди Хект. 29. Буд. 71. исти глагод с удвојеним корнјеном (види код 2. лица јед.): қалєге М. 85. 204. ПІ. 94. Пб. 18. Злат. 69. одеђе Н. Рањ. 46. исти глагол у садашњем вр. к основи каква му је у инжнитиву добија п $н$, те се изједначује с глаголима друге врсте: дадние М. 170. сыне М. 362. 467. 532. Ст. пис. 2, 66. 482. 5, 187. Град. дјев. 106. Злат. 54. Андр. пут 359. од исте основе сажете (впди код 1. дица јед.): си ІІІ. 31. 32. син М. 489. Ст. пис. 1, 42. 81. 5, 136. Буд. 75. Брн. 41б. Банд. 25. од основа у којима сс мијења $у$ у ов (види код 1. и 2. дица јед.): плове Ст. шис. 2, 48. 3, 76. 194. 378. 4, 62. Банд. 290. Мрн. 39. въпкове 3бор. 33. рове Ст. пис. 1, 153. слове Ст. пис. 2, 48. 4, 392. 5, 100.352. А. Рањ. 1б. Злат. 38. с промјеном гласа у оj: поје 3бор. 123. Ст. пис. 2, 17. 5, 153. запоје Н. Рањ. 98б. Ст. пис. 4, 23. од основе која се од давнина сажимала (видп код 1. дпца јед.) несажето : зиак М. 106. II. 2. сажето: зих М. 101. zьнха 147. зих 327. II. 17. 50. Н. Рањ. 40. Збор. 22б. Ст. пис. 2, 43. Буд. 116. Злат. 52. Вран. жив. 76. џозџх П. 73. Злат. 38. въих II. 2. 15. 92. нсти Г.дагод додази и са д (како је речено код 1. лнца јед.) од друге половине XVI вијека: знаде Буд. 8. 9. 15. 19. 24. 26. 55. Вран. жіпв. 12. 17. 21. 29. 54. 55. Банд. 172. Мат. 22. 45. Мрн. 19. 37. 141. Пос. 14. 25б. $27 б$. Радіг. 5. 9. познаде Буд. 79. Вран. жив. 17. 18. 80. Банд. 63. Мрн. 121. 158. Каш. 8. 12. 53. Пос. 19. Радн. 58. изазнаде Врап. жив. 100. у гяатода којнма се основа од свагда ширн добијајући $д$ (види код 1. лица јед.): ввде М. 2. М. 23.25. Сав. стар. 4, 231. докоүде М. 80. Н. Рањ. 59б. Ст. пис. $2,420$. 4, 51. Град. дјев. 179. Кашг. 39. забуде Ст. пис. 4, 51. 418. Хект. 26. прндобуде І'рад. дјев. 36. тај се глагод сложен са до XVII вијека изједначивао с осталијем глагодима овога раздјела: добије Андр. пут 266. прндобије Радн. 51. 88. надобије 86. пє М. 87. "зня М. 280. Н. Рањ. 16. Вран. жив. 40. обнде Ст. пис. 5, 39.214. Гуч. 68. отиде Н. Рањ. 786. одиде Ст. пис. 1, 80. унпде Ст. пис. 1, 26. прпде М. 24. Н. Рањ. 23б. Ст. пис. 2, 59. 3, 15. 4, 326. Злат. 2. донде М. 219. 254. 349. 446. 513. 515. II. 43. 66. Ст. пис. 1, 11. Вран. жив. 10. зајде Ст. пис. 3, 420. 4, 290. 3ор. 2б. мимојде Н. Рањ. 103. Врап. жив. 81. пиде М. 17. 46. 487. ПІ. 49. Ст. пис. 3, 172. 429. 
4, 49. Банд. 8. нуһнапде II. 127. обнапде II. 101. понде М. 13. 24. 411. П. 78. пројде Ст. пис. 3, 118. Крн. 3б. обајде Ст. пис. 3,154. изајде Банд. 10. Мрн. 20. надајде Мрн. 20. одајде Вран жив. 9. гласови $j д$ слијевају се у $ђ$ у овом лицу од XIV нијека (види 1. и 2. лица јед.): поге М. 108. 144. пхгє М. 153. 188. 203. ПI. 16. и послије: доге М. 258. 394. добле М. 377. доће М. 441. доге ПI. 32. 42. Н. Рањ. 19б. Д. Рањ. 147. Злат. 15. Гуч. 159. зађе Н. Рањ. 165б. Ст. пис. 2, 8. 4, 380. 5, 15. мплође Н. Рањ. 37. Збор. 74б. Ст. пис. 2, 401. нађе Ст. пис. 2, 91. 4, 269. 5, 15. Град. дјев. 82. Злат. 60б. Гунд. суз. предгов. цндр. дев. 164. изнађе Злат. 54. ође Ст. пис. $2,21$. поге II. 1!6. Ст. пис. 2, 4. 4, 418. Гуч. 44. Андр. дев. 11. прође Ст. иис. 3,317 . изађе Град. дјев. 152. узађе Град. дух. 70. отађе Чубр. 13.' п кад је сложено са хри: приђе Ст. иис. 5,53 . Град. дјев. 65 . из такпх сложенијех прелази $ђ$ и у сложена у којида остаје $u$ у основи без промјене: униђе Ст. пис. 5, 53. отиђе Пос. 13б. по том и у простога XVII вијека: пђе Мал. 69. Пос. 9б. 14б. Радн. 28. од основе ста, од које нема пити је кад било садапњега времена другачије него по друго, врсти: стие М. 24. прпстане Буд. 49. - I. 7. подре Ст. пис. 4, 159. вадре Ст. пис. 2, 195. удре Мрн. 64. Глав. 93. прождре Радн. 40. мре Збор. 66. Ст. пис. 4, 248. 5, 133. Злат. 44. умре 3лат. 79б. Вран. жив. 23. заире Буд. 23. тре Злат. 80. стре А. Рањ. 62б. сатре Злат. 73б. затаре Ст. пис. 1, 161. Стар. 3, 255. Банд. 263. с раштренпм коријепом: дере Злат. 17б. занере Ст. лис. 1, 108. - у глагола који су из треће црсте прелазпли овамо: вре Ст. пии. 1. 309. Н. Рањ. 144. зазре Ст. пис. 2, 356. 478. позре Ст. пис. 2, 3 . 59. 122. 150. 5, 297. гризре Град. дјев. 36.

II. прнбтие М. 22. побјегне Н. Рањ. 25б. брнне се Град. дјев. 44. прибрсн се (вино) Ст. пис. 1, 160. везне Ст. пис. 3 , 469. увезне 102. повене Ст. пис. 1, 104. вене Ст. пис. $2,95$. 5, 60. 191. Вран. зив. 19. Кап. 21. свене Андр. пут 295. врне Вран. жив. 37 погикин М. 37. гине Вран. жив. 28. чезне 3.лат. 33. двпге ऊ̆ор. 23. Ст. пис. 1, 8. 2, 364. подвигне Ст.

1 По ирајевима гјје $f$ гласп $j$, валази се $j$ и у овој прплици мјесто $f$ : доје (т. пис. 4, 326. у дну. Внди јопा пा код треhега лища мн. 
пис. 3, 428. Хект. 11. садвигне Вран. жив. 78. дигне Ст. пас. 5, 10. уздигне Ст. пис. 3, 273. Банд. 6. Андр. нач. 21. эене Ст. пис. 4, 264. 5, 172. зампне Ст. пис. 3, 129. прпоне 469 . падне Ст. пис. 2, 78. Стар. 3, 259.' пане Д. Рањ. 141б. Пос. 45. опане Ст. пис. 5, 32. сасне Радп. 51. сване Град дјев. 40. смагне Злат. 32б. соне Крн. 21. осоне Ст. пис. $3,165$. Крн. 21. ститне Злат. 54. тисне Ст. пис. 1, 260. стиснеД. Рањ. 69б. Брн. 28б. затисне Д. Рањ. 79б. Пос. 5. потисне Хект. 29. притисне Ст. пис. 5, 325. Хект. 22. Бри. 41. притиские Град. дјев. 76. почине Н. Рањ. $16 б$.

III. 1. желије Збор. 25. 75. Хект. 32. умије 35ор. 9. Ст. пис. 3, 107. 4, 470. 5, 184. Буд. 8. Злат. предгов. 2б. Банд. 62. Андр. нач. 6. развмне М. 370. 404. Гунд. пс. 4\%. Див. $5 б$. Радн. 20. и сажето (види код 2. лнца јед.) од XV вијека: раzвығ II. 155. развие М. 259. Пб. 95. уаи Ст. пис. 1, 9. Буд. 69. Стар. 1, 227. Чубр. 10б. разуми Ст. пис. 2,43. 3ор. 64. Буд. 52. 125. Брн. 58. 69б. Вран. жнв. 24. Ванд. 197. Каш. 30. Мик. 37. Глав. 12. доспије Ст. пис. 1, 124. гриспије Каш. 111. и сажето: приспи Ст. пис. 2, 335. који су мзеђу других глагола прелазили овамо: позрије Ст. пис. 5. 13. спије Пос. 20б. такођер ће бити шрешло овамо из друга раздјела ове врсте а по том сажето: џки II. 76. - IIJ. 2. ктап М. 6. бди Ст. пис. 1, 28. 2, 253. Брн. 58б. виси Ст. пис. 4, 117. Град. дјев. 125. врп Ст. пис. 2, 82. 102. 347. 361. Банд. 40. узаври Іунд. суз. II, XXVII. жрьжи М. 188. жели Ст. пбс. 5, 349. Злат. 62. Крн. 1б. Брн. 47. позри Ст. пис. ¿, 82. назри Андр. пут 165. сазри Ст. пис. 4, 273. саздри 273. мнп Ст. пис. 3, 136. $4,72.5,335$. Чубр. 12. исти глагол с додапи д, како је речено код 1. дпца јед., XVII вијека: мнаде Мрн. 137. прин М. 147. при 354 расти М. 38. стоп М. 44. тиныи Вран. жкив. 20. цавти Ст. пис. 2. 181. 4, 260. цафти Ст. пи. 2, 61. 103. 111. 213. 281. 5, 10. Д. Рањ. 32. процаттп Ст. пис 3 , 272. 351. цапти Ст. пис. 4, 268. 288. 5, 226. Андр. нач. 37. цти Ст. пис. $2,39$. 67. 88. 377. 434. 3, 193. 460. 5, 202. процт Ст. пис. 1, 232. 2, 338. 3, 131. цкни Ст. пис. 2, 100. 242. 33. 5, 17. Град. дјев. 90. Злат. 2. Мат. 51. Пос. 14. поцкни Злат. 8. уцкни Ст.

' С личнијем наставком: шхднть Стар. $4,83$. 
пис. 2, 142.' глагол жоји је прешао у други раздио пете врсте: хоке М. 2. 20. 41. 5ـ. оүскоке М. 80. 216. не хоће С'т. пис. 4, 420. А. Рањ. 141б. без првога слога (види код 1. лица јед.): кс М. 42. 109. 174. 245. ћє М. 461. Н. Рањ. 15. Збор. 22. Ст. пис. 3, 139. Буд. 90. Злат. 9б. Гуч. 121. Вран. жнв. 5. Орб. 221. Банд. 4.

IV. разорин М. 10. доходи 13. свди 20. нснакостн 22 . втнни 24. нотвори 27. "справн 29. прћскочи 30. находи 46. пкхти 51. "рнтежи" 80. "спроспи 80. постакни 81. косн 95. гокорн 101. вхити 102. пртствпн 109. квнн 162. порази 172. zапши М. 208. 435. отинин М. 363. сними Н. Рањ. 100. Ст. пис. 2, 20. прими Ст. пис. 2, 442. 5, 179. Злат. 97. ујми Ст. пис. 2 , 265. обујми Н. Рањ. 16. 195. Ст. пис. 2, 23. 362. 3, 278. Д. Рањ. ІХб. обујами Н. Рањ. 179. поднијеми Ст. пис. 4, 91. 312. зноби Ст. пис. 3, 97. Гунд. суз. III, LXII. озноби Злат. 76. понузи Ст. пис. 3, 109. 467. тјери Ст. пис. 5, 112. тири Ст. пис. 2, 319. Хект. 22. цкшли Гунд. суз. II, XVI. цори (тко говор тих цори) А. Рањ. 86. зори Ст. пис. 2, 79. вадри Ст. пис. 2, 109. 111. вапи Ст. пис. 2, 13. Андр. пут 106. упи Ст. пис. 2, 112. Д. Рањ. 1. плови Ст. пис. 4, 19. слови Ст. пис. 2 , 84. 335. свини П. 86 . свыми Мат. 57. сусрети Мат. 12. чти Ст. пис. 2, 278. 285. 5, 94. А. Рањ. 162б. Хект. 25б. 45б. Буд. 32. Брн. 5. Злат. предгов. 2. Гуч. 33. Вран. зияв. 54. Орб. 14. прохти М. 496. шти Ст. пис. 1, 206. 5, 210. Вран. рјеч. 54. Брн. 22. Банд. IV. Мат. 44. истн је глагол с основом какву има у овој врсти прелазио пі у прву врсту XVII вијека: процшє Мат. 95. глагол који интпнитивом прпнада у пету врсту: спи Н. Рањ. 77б. Збор. 40. C'т. піис. 5, 212. Злат. 976.

V. 1. несажето аю на крају основе има једном у почетку XV вијека: помираю П. 30. што пма XVI вијека: пуштаје Ст. пис. 2, 44. 333. скончаје Ст. пис. 2, 167. 400. 3, 178. 4, 53. 5, 111. Злат. 99. обоњаје Град. дјев. 114. то ће бити по 3. раздјелу ове врсте (внди стр. 266. 271.) ${ }^{2}$ - сажето од првијех

1 Овамо би ишло и ржй (мјесто рже) Злат. 2.

2 Несажето је qешће с личним наставком: пкагослакасть М.

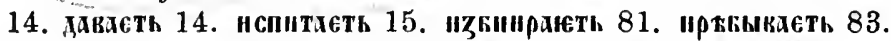
сажето се налази рјеђе с личним наставком: дакать М. 159. 167. оүзннать IIIаф. pam. 1873. 101. - Често има несажето у једнога писца XVI внјека, алг је у вега јамачно према 
времена: тағо XIII въјека: оүзиих М. 13. познка 13. иримага 13.

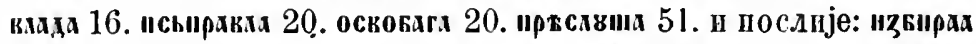
М. 80. разбира Ст. пис. 3, 71. 4, 269. Д. Рањ. IX. Град. дјев. 54. збира 3лат. 54б. брнја Злат. 47б. извира Ст. пвс. 3, 330. 476. 4, 11. Хект. 45. вика Ст. пис. 5, 319. Андр. дев. 103. ббхда М. 80. повслькх М. 153. плкрышх М. 139. гледа Злат. 616. гљеда Вран. жив. 35. пригљеда Буд. 5. дакх М. 159. 174. 223. Ст. ппс. 2, 75. 235. 4, 9. 313. 5, 5. 77. 290. д. Рањ. 3. Град. дјев. 74. Злат. 99б. Гуч. 160. Орб. 37. Фам. 5. задава Ст. пис. 2, 466. 3, 468. 4, 66. А. Рањ. 8. Злат. 52. издава Ст. пис. 4, 127. одава Ст. пис. 4, 379. придава Ст. ппс. 4, 9. 374 . продава М. 204. 474. дима Ст. пис. 4, 348. одира Стар. 3, 253. подпра Ст. пис. 3, 71. 4, 266. пождира Ст. пис. 3, 165. ужга Банд. 111. зажима Ст. пис. 4, 88. ждима (сажима) С'т. пис. 5 , 7. позика М. 13. 270. призива Град. дјев. 52. позихка М. 147. 559. Ст. пис. 2, 18. 4, 9. 5, 4. Д. Рањ. 70б. Орб. 92. зја Мик. 853. оязима IIIаф. pam. 1873. 101. Банд. 237. вазима Ст. пнс. 2, 112. 3, 368. д. Рањ. 17. Хект. 35б. изпа Ст. нис. 4, 228. заклина Ст. пис. 2, 172. проклина Банд. 168. проклиња Мат. 26. прндага Буд. 64. Мрн. 131. Каш. 74. одлага Ст. пис. 4, 349. шрилијета Злат. 41б. помага С'т. пис. 2, 404. 4, 349. 5, 5. 48. Злат. 44. І'уч. 28. Мрн. 131. Кап. 112. примага Ст. пис. 3 , 425. винрх II. 29. Н. Рањ. 24. Ст. пис. 3, 71. 477. 4, 266. А. Рањ. 5б. Вран. жнв. 39. Банд. 14. пуза Ст. пис. 3,469 . пондпра (стрми и бригом пондира) Мрн. 64. спхд М. 94. запина Ст. пис. 3, 469. пропина Ст. пис. 4, 273. упира (упрнјети) 269. опира (прати) Ст. пис. 3, 330. 4, 41. шкки М. 147. "спмна М. 139. помина Ст. пис. 1, 301. епомина Буд. 4. Див. 1б. Банд. 90. спомиња Ст. ппс. 1, 301. занлијета Град. дјев. 74. досеза Ст. иис. 4, 400. 5, 91. 300. Злат. 58б. посила Ст. пнс. 5, 17. Злат. 10. простира Ст. пнс. 2, 36. Хект. 45. Мрп. 79. сја Ст. ппс. 1, 9. 2, 50. 3, 399. обасја Ст. пис. 3,471 . просја Ст. пис. 2, 96. тез М. 520. затира Ст. ннс. 2, 400. утира 421. оптјеца Ст. пис. 2, 15. цвата

пргвенијем нњгама: подобаје Буд. 64. подобајет 33. прнлагаје 75. прнлагајет 36 . наслањајет се 14 . упадајет 158 . прптискајет 14. према глаголима у којима је могло бптп тако нма нсти и у глаголу којему основа нема наставка у садашњем вр.: пмаје Буд. 104. 
Ст. пис. 2, 416. 419. 459. цапта 488. почних М. 174. Ст. пис. 5, 224. Гуч. 96. Гунд. суз. II, XXIX. зачина Ст. пис. 4, 29. 5, 204. почиња Банд. 83. почима Радн. 44. - посађива Ст. шис. 4, 374. процјењива Ст. шис. 5, 26. обратива Бун. 20. продиљива Орб. 58. изискива Андр. пут 381. цромјенива Гунд. суз. I, XL. смрспва Андр. пут 66. смутнва 39. потлачива 35. ишчекива 252. глагол који је из црве врсте прелазио овамо како је речено код 1. дица јед.: обја Ст. пис. 2, 58. прија 51. 56. 211. 268. 3, 299. 472. 4, 26.69. 5, 38. - V. 2. сабире Ст. пис. 1, 61. приближе Н. Рањ. 13б. Ст. ппс. 5, 46. извире Ст. пис. 2, 393. окмаге М. 167. глође Радн. 51. движе Ірад. дух. 68. Хект. 10. Банд. 25. подвиже Хект. 10. Стар. 4, 113. уздвиже Ст. иис. 4, 168. 5, 350. Крн. 1б. здвиже Вран. жив. 44. диже Ст. пис. 5, 15. подире Ст. пис. 4, 337. дрxће Ст. пис. 1, 17. 5, 38. КапI. 94. задрхће Ст. пис. 2, 20. жере Ст. пис. 3,164 . раждиже Злат. 48. раздиже Град. дух. 66. знгє М. 206. 268. Вран. жив. 112. Гунд. суз. I, LX. зазире Cт. пис. 2, 87. позире 194. 245. призире 54. оүзеихе М. 13. 19. 46. въикх М. 387. въпихе II. 23. вазпмље Злат. 53. прнјимље Буд. 37. цримље Мат. 45. Глав. 40. шце М. 108. Злат. 56б. Банд. 8. ишће Ст. пис. 1, 123. Мрн. 23. јишће Вран. жнв. 79. обшшће Банд. 164. каже Град. дјев. 84. Злат. 43б. Вран. жив. 30. ироклиње Радн. 63. кушље се Ст. пис. 3, 327. липшс 3лат. 39. умпре Ст. пис. 1, 100. 2, 194. 420. 4, 359. 5, 133. д. Рањ. 33б. Хект. 47. Злат. 101б. Орб. 91. мирише Ст. пис. 4, 31. Чубр. 12. мрмње Ст. пис. 1, 22.' ниче Злат. 45. нуре Град. дјев. 36. орс М. 95. запире Ст. пис. 4, 266. напире Злат. 69б. пшше М. 16. Вран. жив. 9. плаче Град. дјев. 62. плеше Ст. шис. 3, 144. Д. Рањ. 6б. пљеже Ст. пис. 3, 313. ${ }^{2}$ прпшше Ст. пис. 2, 84. урјеже д. Рањ. 13б. одруже Вран. жив. 65. сппх М. 565. раснше Гдав. 27. шље 3лат. 10. пошке М. 108. щаље Хект. 2. Вран. жив. 101. попаље Бри. 22б. Вран. жив. 77. Банд. 5. стиже Злат. 96б. ирістире М. 239. стере Гунд. суз. II, XV. стрже Ст. пис. 1, 81. потеже Каш. 88. сатире Ст. пис. 4, 442. стире Ст. пाис. 5, 327. Злат. 100. втиче М. 61. истече М. 198. истјече Злат. 49б. оптјече Ст. пис.

1 Наптампано је мармње.

2 IIо том ће бити погрјешке штампарске: plješe Ст. пис. 3, 123. plješu 142. 
3, 46. почищс М. 411. Збор. 37б. почиве Град. дух. 19. Бапд. 83. Јерк. 11. Глав. 27. с промјеном у коријену: коље Ст. пис. 5, 120. - V. 3. с промјеном у коријену : дожене Д. Рањ. 816. ижене Дпв. 33б. ирожене Ст. пис. 3, 448. 4, 90. 5, 10. раждене Ст. пис. 3,21 . ждене Ст. Іпс. $2,20.3,156 . .^{\prime}$ с иромјеном гласа ж на $p$ : "зирение II. 32 . пзьрене 64.80 . рене Ст. пис. $1,52$. одрене 32. 227. 5, 185. Брн. 29. Банд. 108. порене Стар. 3, 245. прорене Зор. 59б. разрене Брн. 68. и избацивши $e$ између $p$ и $н$ : изарне Банд. 225. одарне 276. а тада се и г повраћало: одагне Андар. дев. 61. подипер М. 29. 33. позовє М. 13. зове Злат. 37. без промјене у коријену: рве Ст. иис. 4, 5. 293. 5, 153. обрве Злат. 54. тче Збор. 138б. Ст. пис. 3, 10. исти гдагод и по првом раздјелу ове врсте: отка Ст. пис. $1,46$. тка Мнк. 226. 692. ${ }^{2}$ - ние М. 79. 139. Стар. ние. 1, 18. 68. 2, 341. 465. 5, 111. Збор. 12. Град. дјев. 70. Вран. жив. 12. Орб. 118. Гунд. суз. II, ХXIV. Банд. 15. Радн. 2. задаје Ст. пис. 2, 112. издаје Гунд. суз. I, XXXII. подаје Мрн. 79. Гдав. 43. предаје Ст. пис. 2, 139. прпдаје Орб. 296. Банд. 14. продає М. 47. продлє М. 119. П. 11. удаје Град. дјев. 79. уздаје Буд. 69. даје Ст. пис. 5, 183. стхе М. 46. познаје Ст. пигс. 1, 37. 2, 139. Буд. 54. Мрн. 109. Капі. 52. 67. Радн. 22. кује Ст. пис. 3,118 . бљује Ст. пис. 5,263 . пљује Ст. пис. 4, 357. 5, 341. трује Гунд. суз. II, XXV. отрује Радн. 57. надпје се Ст. пис. 1, 114. Хект. 29б. Радој. 26. сте М. 531. смјеје се Ст. пис. 5,154 . смије се Брн. 66. с промјеном гласа и у п: пұлет Сав. стар. 4, 231. пропет Стар. 4, 70. прољеје Н. Рањ. 102.

VI. ктрує М. 25. окетвє М. 106. саблазнује Н. Рањ. 35. завежује Орб. 302. извршује Град. дух. 9. навншћује Вран. ж九в. 20. Банд. 230. обаљује Банд. 175. уврјеђује Град. дјев. 96. дарује Ст. пис. 2, 120. дјелује Н. Рањ. 158. здаменује Град. дјев. 11. паказвє М. 14. показвиє Збор. 1б. приказује Орб. 93. прикажује Н. Рањ. 25. мплује Вран. жив. 11. мјенује Ст. ппс.

' Гријешком еа жд мјесто ж: приждене Д. Рањ. 135б. одждеше 40. ождене Ст. пие. 5, 109.

2 Овамо hе бити прешло алп без промјепе гласа 2 пред ваставком да би било ближе пифннитиву жгати: сажге Буд. 162. Вран. жив. 62. Г.лав. 125. 
4, 12. вегује Ст. пис. 3, 369. псује Ст. пис. 1, 317. спује Ст. пис. 5,342 . наредује Стар. 1,219 . насљедује Злат. предгов. 36. отставмюе М. 81. потрјебује Н. Рањ. 88б. трнєкиє Збор. 8. Ст. пис. $3,430.5,96.160$. требује Д. Рањ. 9. Злат. 56. потребује Град. дјев. 22. уздрокује Јерк. 59. чтвє ІІб. 90. Н. Рањ. 19. Ст. пис. 3, 159. 4, 36. Хект. 11б. Зор. 18. Буд. 73. З.дат. 7. почтује Ст. пис. 5, 15. штује Ст. пис. 1, 172. Вран. жив. 6. Банд. 7. Крн. 24.

\section{ІРВО АНЦЕ МНОЖИНЕ.}

Постаје наставком masi, којему је најприје отпало крајње i, те остало mas, a тому у словенским језицима $\mathbf{s}$ стојећи на крају отпада, а а кратко будући гдаси $о$, које се налази и у старом словенском језику а у српском је остало једнако, по том је у старом словенском језику о ослабило у т, али мјесто z долази у старом словенском језику п ж из номинатива мн. мы, а кад кад и є начином до селе још не протумаченим довољно. По староме словенском језику налази се кад кад и у српским старим књнгама ь: можемь М. 66 . мохнм 78. 130. умтемь 121. скакния 121. І и или мјесто њега н: юсьмы Стеф. 4. жсмы Шаф. pam. 1873. 110. жсми М. 569. пмы Стар. 4, 73. пихин 234. привтгиям Стеф. 18. Алп је од првијех времена у српском језику $о$.

А. Основе без наставка: дични наставак долази ㄱ основи, која кад се свршује на $A$ слаже се с гласом $м$ од наставка као у 1. лицу јед. (видї стр. 257): єсмо Стеф. - 0 . П. 29. Н..Рањ. 50б. окрњено: сьмо М. 12 . смо М. 22. сложено са не (види Һод 1. дица јед.): нтсмо П. 5. несмо М. 246. инссмо М. 368. нијесмо Ст. пис. 5, 154. - дамо М. 22. 275. подмо М. 23. продамо II. 113. вдамо II. 78. - вьвсмо М. 36. вемо II. 17.

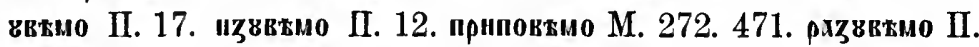
47. вимо Ст. пис. 1,65 . вијемо Ст. пис. 3,246 . - нмамо М. 7. 23. кад стоји иза не могло му се $и$ од основе са $e$ од не саставити у т: птихмо М. 47. 54. П. 13. 59. нимамо Хект. 16б. Мрн. 108. У оба поменута у којнх се основа свршује на $A$, налази се $A$ дометнуто како је речено код 1. лица јед. (стр. 258), али у овом лицу истом од почетка XVII вијека, 
па и тада врло ријетко: повндемо Вран. жив. 30. дадемо Мрн. 129. Радн. 95.

В. Основе с наставком: дични се наставак саставља с основом:

I. 1. поведемо Вран. жнв. 40. падемо Ст. пис. 5, 329. у једпога пзмеђу глагола овога раздјела налази се и према основама без наставка (види код 1. лица јед.): гремо Ст. пис. 5, 35. 161. 165. 3.ат. 26. Стар. 4, 112. Пос. 14б. - I. 2. уљеземо Град. дјев. 181. - І. 3. жикемо П. 127. Ст. пис. 1, 30. Н. Рањ. 20б. Ст. ншс. 4, 170. А. Рањ. 53б. Град. дјев. 176. Гуч. 229. Вран. жпв. 20. Мрн. 28. Пос. 37б. - I. 4. въможемо М. 23. поможемо Ст. пис. 5, 162. Мрн. 160. Радн. 95. у истога глагола с ирохјеном гласа $\leadsto$ на $p$ : норсмо М. 219. 274. 328. 405. II. 5. 9. 84. Cт. пuc. 1, 30. 111. 360p. 158. Ст. пис. 5, 312. 3ор. 57. Брн. 7. Вран. жев. 30. Мат. 50. стр( ()жено М. 44. свучемо Вран. жив. 27. речемо Злат. 54б. - I, 5. вумсмо М. 43. ІІб. 31. почнемо Ст. пис. $1,114.5,155$. Туч. 109. занмемо П. 18. "ринено М. 47. 215. II. 55. 145. Стар. 3, 297. пртмемо М. 106. 239. 261. - I. 6. чвнемо Збор. 122б. одијемо Банд. 215. смпјемо Ст. пис. 5, 244. Чубр. 4. сажето: смимо Ст. пис. $2,352$. Мрп. 93. с иромјеном гласа у у ов: пловемо Ст. пис. 4, 436. с промјеном гласа \$ у оj: појемо Ст. пис. 1, 124. Банд. 135. од основе у којој се иє ивједначује и сажима од давнина: zнмио Шаф. рат. 1873.94. ПІ. 2. Ст. пнс. 5, 235. исти гла'ол долази и са д (како је речено код 1. дица јед.) истом од почетка XVII вијека у овом диц: знадемо Вран. жив. 9. Мрн. 108. 120. узнадемо Мрн. 133. у гдагола којима се основа од свагда шири добнвајући д (види код 1. лица јед.): будемо Ст. пис. 3, 249. добудемо Гуч. 275. пзшдемо Банд. 43. внняено М. 176. пондено М. 23. г.ласови се $j_{д}$ састављају у 5: доғено М. 451. "zьнагємо П. 42. нађемо Злат. 70. пођемо Ст. пис. 4,446 . из таких сложених прелази $ђ$ и у прости XVII вијека: пђемо Мат. 97. Радв. 43. од основе која у инфинитиву гласи ста, и од свагда у садашњем времену добија те се изједначује с глаголима друге врсте: станемо М. 7. I. 7. стремо Злат. 70 .

II. прнмькнено ПI. 39. уздвигнемо Гуч. 105. 
III. 1. жемнемо II. 24. умнјемо Ђам. 5. разумијемо Пос. 40. сажето: развижио М. 535. умимо Вран. жив. 21. Мрн. 177. разумимо Брн. 42. Банд. 173. Каш. 47. 65. тако ће сажето бити У жемтно II. 17. 126. 177. - III. 2. дрьжнцо М. 23. жкмпмо II. 21. Ст. пис. 5, 213. 238. Хект. 21б. Вран. жив. 82. жнвммо М. 518. мнимо П. 21. 39. Ст. пис. 4, 78. глагод који је прешао у други раздио пете врсте: хокемо М. 23. 276. и окрњено од XII вијека: кемо М. 7. 216. ћемо М. 274. 327.

IV. вуниимо М. 22. пхатино М. 22. паностино М. 23. p.zдроүшино М. 23. мохино М. 192. П. 2. прниосимо М. 192. мнсхнмо М. 193. ирнмимо ПI. 116. Н. Рањ. 26. зоримо Мрн. 69. похтимо П. 143. чтимо 3бор. 46. Д. Рањ. УІб. Брн. 52. Гуч. 262. Орб. 261. штимо Ст. пис. 1, 197. Стар. 1, 227. пошљедњи је глагод с основом какву има у овој врсти шредазио п у прву врсту XVII вијека: штијемо Радн. 11. 23.

V. 1. несажето аю на крају основе пред дичнијем нанаставком мо налазп се врло ријетко, и тада јамачно према црквенијем квнгама: тако XIV вијека: внокемо М. 192. у почетку XVI вијека: "спитаємо Стар. 4, 79. а сажето од првијех времена према другим дицима: разбпрамо Вран. жив. 21. давамо М. 223. 509.522. Пб. 76. С'. пис. 5, 51. 149. Д. Рањ. 27б. Мрн. 185 придавамо Ст. нис. 5, 163. парткамо М. 494. прокхииано М. 77. зккиниано М. 192. помагми() М. 473. примагамо Банд. 193. умирамо Пос. 13. пропинамо Див. 20. споми-

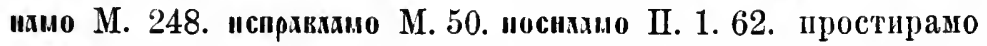
Ба̇дн. 42. гдагод поји је из прве врсте прелазио овамо како је речено код 1. лица јед.: пријамо (ассіреге) Ст. пис. $5,163$. 238. - V. 2. посежемо М. 23. шинемо М. 269. благосливљемо Cтар. 1, 231. примљемо Мрн. 90. узјашемо Банд. 176. - V. 3. рвемо Каш. 30.' нодаемо М. 23. данмо М. 106. даемо М. 177. 218. 225. 274. даємо М. 494. П. 39. 147. Пб. 83. Ст. пис. $1,89$. 124. Вран. жив. 68. Радн. 20. проданемо Збор. 5. подајемо Мат. 34. ихинемо се ПI. 23. 56.

VI. zакеzоүюео М. 77. ФБетвюмо Пб. 94. поткрьюено М. 217. чтујемо Н. Рањ. 1226. одпуштујемо Ст. пис. 5, 91. страгујемо (стражнмо) Мрн. 138. увриђујемо Пос. 29.

Ј Овамо би ищ.ло: врвемо Ст. пис. 5, 35. ако није погрјешка. 


\section{ДРУГО АИЦЕ МНОЖННЕ.}

Шостаје наставком tasi, юојему отнада $\mathbf{i}$ а за шим и s, нао и наставку првога дица жн., а од а у сдовенским језпцима бива.є: тако наставак гласп те.

А. Основе без наставка: које се свршују на $\not$, у вих ce тај глас пред гдасом $T$ од наставка мијења на $c$ као у трећем лицу јед.: юсте Стеф. 9. окрњено: стє М. 20. Н. Рањ. 228б. Хект. 31. кад је пред вим не, слаже се с вим како је речено год првога дпца јед.: нтсте М. 247. песте $M$. 535. инесте М. 546. Град. дјев. 28. - қасте Пб. 5. 28. 32.43. II. 71. 82. 99. вдасте Пб. 21. 42. прષ.дасте П. 98. тако у тијем примјерима прелази у XV вијек а једном се налази и XVII вијека: подасте Глав. 126. - јисте (вистє) Стар. 3, 284. 287. - вฐете ІІб. 31. внсте М. 185. II. 62. 135. кюесте ПI. 173. запоктсте II. 59. 148. тако још на свршетку XV или у почетку XVI впјека: весте Стар. 4, 232. висте Ст. пис. 1, 236. 259. 299. сповисте 259. - имате Ст. пис. 1,89. кад има пред собом не, могдо се вегово и слагати с $е$ од тога не како је веһ спомпњано: нъмате II. 23. исихте II. 26. nimate M. 280. - Којима се основа свршује на сугдасно, сви су оспм првога погубили сугдасно на крају основе пред личнијем наставком једначећи се с другим глаголима, и то од XV вијека: дате М. 484. Ст. пис. 5,195 . ијете Н. Рањ. 195б. ите Д. Рањ. 50. вите Ст. пис. 1, 305. сповијете Орб. 215.

Б. Основе с наставком: лични наставак приступа $\mathfrak{\kappa}$ основи :

I. 1. кююуст. М. 158. један између г.дагода овог раздједа пзједначпвао се XVI вијека с онима којима основа у садашњем вр. нема наставка, те се и у њега д дошавши пред дични наставак мијењало на $c$ : гресте Ст. пис. 1, 307. Стар. 3, 261. а тада је и отпадало крајње суг.дасно у основи као и у онијех гдагода: грете Д. Рањ. 99. - I. 3. жнњтте М. 46. гдје hе т бити само напнсано мјесто с. - I. 4. можете Н. Рањ. 51. Град. дјев. 63. Іууч. 12. и с промјеном гдаса ж на р: морєтє II. 3. 36. 65. 85. 131. Н. Рањ. 516. 167. Град. дјев. 63. Брн. 4. Вран. жнив. 4. Банд. 42. - I. 5. закьиете М. 174. zаквнете 3бор. 8б. разапнете Н. Рањ. 23. прнмете II. 153. Стар. 3, 297. 
- I. 6. смијете Cт. пnс. 3, 215. сажето: смите Cт. нис. 2, 91. с промјеном гласа у у ов: н.ловете Ст. пис. $3,12.4,155$. с.10вете Ст. пис. 4,478 . од основе у појој се м изједначује и сажпма: зиате М. 66. 174. 426. II. 87. 104. Н. Рањ. 30. псли глагод додази и са д доданим (како је речено код 1. дица јед.) али истом XVII вијега у овом лицу: знадете Вран. жив. 95. Банд. 7. Мрн. 76. 108. 158. у глагода којима се основа од свагда шири добивајући д (внди код 1. дица јед.): будете Н. Рањ. 74. идете, сложено с приједдозима за којима се $u$ мијења на $j$, те се $j$ д саставља у $\hbar$ : нађете Н. Рањ. 29. прођете Ст. пис. 2, 406. - I. 7. раз,рете М. 426. с раширеним коријеном: терете Банд. 13.

II. подвигнете Ст. пис. 5, 158. дунете Бун. 35.

III. 1. разумијете Орб. 281. сажето: умите Д. Рањ. $67 \sigma$. Банд. 148. доспијете Вран. жив. 26. - III. 2. жкивите Н. Рањ. 138. мните Ст. пис. $3,29.5,130$. млите Ст. пис. 3,36 . исти глагол с доданим д, како је речено код 1. дица јед., XVII вијека: мнидете Вран. жиз. 101. трпите Н. Рањ. 34б. цкните 3лат. 88. глагол који је прешао у други раздио пете врсте: хокете М. 20. и огрњено: ксте М. 178. кюте П. 38. ћете Н. Рањ. 23б.

VI. поткорните М. 81. "рнените М. 546. СТ. пис. 1, 281. Н. Рањ. 13б. птите Ст. пис. 1, 189. проч'пите Ст. пис. 3, 316. гдагол који инфинитивом ирипада у пету врсту: спите Ст. пис. 2,481 .

V. 1. помагате М. 158. обирате Вран. жив. 25. познавате Збор. 48. спомннате Н. Рањ. 19. Банд. 7. споменивате Орб. 2. - V. 2. раждижете Бун. 35. ишћете Банд. 103. V. 3. anere M. 19. 20. Мрн. 108. надијете се Мрн. 89. остаєет М. 20. синенете се Див. 316.

VI. верујете Вран. жив. 76. дарујете С'r. пис. 8, 231. обрјезујете Н. Рањ. 73. чтујете Ст. пис. 3, 231. почтујете 26.

\section{TPEЋЕ АПЦЕ MНОЖШНЕ.}

Постаје наставком anti, којему отшада а кад се основа садашњега времена сврпіује на самогласно; од $\mathbf{i}$ бива $\mathbf{y}$ I словенским језицима $\mathrm{h}$, a $\mathbf{n}$ се са самогласним за којим се нађе, саставља у један гдас, и то са а од.дичнога наставка или од наставка којпм постаје основа, саставља се у 
у српском језнку гласи $y$, а са ", воје осповама остаје на грају у глагола којпма оспове само у првом дицу јед. добивају наставак, саставља се у ж, које у српском језику гласи $e$.

Аичному паставку отпада грајње ти у српском језшку од првпјех времена: тако XII впјека имано: квдв М. 2. ходс М. 2. прихолс М. 6. врхкаю М. 6. ПІто се налази и са -ть, те дошире у XV вијек, јамачно је из црквенијех књига као и у трећем лицу јед. (види стр. 274. 276): сввть М. 413. ПІ. 99.

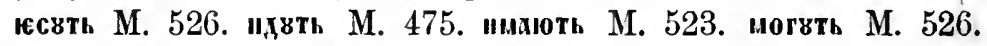
погють М. 527. позихкають II. 104. - На крају XV и XVI п XVII вијека налази се у неких пнсаца и $T$, али није од дичнога наставка него је додатак као п уз треће дице јед. (види стр. 274-5): на грају XV вијека: оставе т' Ст. пис. 1, 160. XVI вијека: пздадут Н. Рањ. 214. уљезут 115б. примогут 185. убпјут 214 . шокријут 28б. чујут 140б. изпдут 1616. дођут 28б. мимођут 170б. нађут 45. пођут 43. устанут $28 б$. кренут 13. приминут 13б. видет 208б. узвисет 79. изгонет 136. прихинет 214. учинет 137. прибпвајут 60. клањајут 576. скончајут 115. помањкајут 22б. благујут 108. господујут 55б. одпуштујут 143. могу т Ст. пис. 5, 181. остапут Брн. 2. одговорет Стар. 1, 225. скончајут 219. јесут Буд. 51. нисут 80. уздадут 40. упадут 42. могут 51. прокунут 123. примут 57. будут 30. впдет 39. уздржет 51. приводет 51. чинет 25. упадајут 33. исповндајут 34 . нарицајут 118 . зовут 7. насдшдујут $36 .{ }^{1}$ XVII вијека: увенут Вран. жив. 18. процватут Банд. 80. могут 45. пзыут 75. придут 13. одвратет 17. окусет 70. славет 7. ослободет 108. одпушћајут 74. плачут 29. мјесто тога окрњенога $т$ налази се п цијело ти као и уз треће лице јед.: на крају XV вијека: буду ти Ст. пис. $1,21{ }^{2}$ XVI вијека: украду ти њега Н. Рањ. 94б. одпуштају ти се тебје 1656.

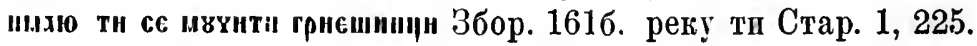

А. Основе беs наставка: између онијех које се свршују на сугласно само к једној долази у личнога наставка предње a састављено с потоњні $\mathbf{n}$ у

1 Jom таких примјера XVI вијека види у Гласвику IX. стр. 47.

2 Неколико примјера $\mathrm{XV}$ вијека из Никољскога и Хвалова рукописа с цијелпјем ти уз треће лице мн. споменуто је Старннама III. стр. 71 . 
али у ње отшада є још у старом словенском језику па тако п у српском: с цијелијем личнијем наставгом : соүть М. 12. без црајњега ть: соү М. 13. 232. 507. Н. Рањ. 33б. али је од XIV вијека прешло є из других лица и у ово, а облик без њега остаје енклитичьи: єсв М. 217. 283. 293. 429. 441. 492. єсв II. 3. Н. Рањ. 25. С'т. пис. 1, 150. 5, 70.' од истога времена долази са є и за ријечју иє, с којом се слаже како је речено код првога лица јед.: итсх М. 108. 109. 116. 168. 183. 203. 268. 435. 485. 535. II. 2. 9. 12. 148. пнесв М. 230. А. Рањ. VIII. Ст. пис. 4, 298. Буд. 79. Вран. жив. 50. Банд. 87. Ђам. 5. нису Буд. 87. што XIV и XV вијека шма и иєсв М. 206. 208. 354. 532. П. 81. не ће бити без є него ће бити по источном говору. У других гдагола у којих се основа свршује на сугдасно, мјесто а у наставку долази у словенским језицима и, с којнм се $\mathbf{n}$ од наставка саставља у ж, српски $e$ : прқдыс M. 7. 37. тако у тога l'sarosa до краја XV вијека: дақє $\mathrm{M.}$ 102. 104. 170. 331. П. 49. 77. 106. 109. 134. Пб. 58. 83. нсьдаде М. 46. пздаде М. 565. подаде М. 41. 108. продаде М. 43. 532. ПI. 107. 110. пртдаде М. 98. П. 111. и XVI вијека, алн ријетко: даде Н. Рањ. 56. Ст. пис. 4, 87. издаде Н. Рањ. 92. продаде 167б. тако у другога глагола с цијелијем личнијем наставком XIV вијека: ктдеть M. 201. без крајњега ть XVI вијека: заповиде Хект. 8. Али оба ова глагола п трећи қоме се као и њима основа свршује на д изједначише се у овом дипу с глаголима прве врсте првога раздјела, у које их притезаше партицип садашњега времепа, најближи овоме дицу: то се започело на крају XIV вијека, и најщрије у глагола дати: у то се вријеме у њега налази: вдадв ПI. 6. дад М. 232. чешће XV вијека: қа, ІІ. 115. 119. М. 286. 339. 423. 433. 507. 512. 530. Пб. 116. продауб ІІ. 131. М. 410. Пб. 107. допродадв П. 58. прқдадв П. 111. на крају XV и.ли XVI вијека: даду Ст. пис. 1, 25. XVI вијека: продыя М. 551. даду Н. Рањ. 178. 3бор. 28. Ст. пис. 2, 122. 3, 19. 451. 4, 404. 5, 131. 231. А. Рањ. 16. Град. дјев. 76. Хект. 18. Зор. 33. Буд. 48. Брн. 62. Чубр. 4б. зададу Ст. пис. $3,406.4$, 123. подаду Ст. пис. 3, 475. придаду Н. Рањ. 37. Ст. пис. 4, 56. Хект. 44 . Буд. 45.

- Са ть на крају долази и онда кад му је повраћено к: єсвть M. 276. 287. 
удаду Град дјев. 67. запродаду Чубр. 14б. XVII впјека даду Вран. жив. 14. Орб. 46. Мрі. 143. ПІос. 10. Радој. 21. прпдаду Банд. 44. - други тако долази од почетка XV вијека: повнья М. 248. тако XVI и XVII вијека: приповнду Зор. 41. повиједу Злат. 37. повиду Враш. жнв. 30. заповпду Вран. жив. 35. ириновиду Канг. 25. ... трећи од свршетка XV или од почетка XVI впјека: јиду Ст. пис. 1, 82. 255. Стар. 3, 279. Хект. 26. Брн. 7. иједу Ст. пис. 5, 127. Див. 226. Орб. 181. Банд. 38. Радн. 17. 89. - у глагода коме основа у осталијем лицима гласи ных одбацивало се још у старом словенском језику крајње $a$ те је к основи долазио наставак са својим а, па је тако и у нас било: жко п пивть потрьвокати М. 31. јошг XV вијека: да ния дати М. 464. и XVI впјека једном: не иму Злат. 12. али још од почетка XIII вијека тај је глагол у том об.дику прешао међу глаголе пете врсте шрвога раздјела међу које припада инфинитивом: шмю М. 13. 31. 106. Град. дјев. 111. Банд. 45. јимају Вран. жив. 3. нє инмю М. 13. стојеһп иза не могао се с том ријечју слагатн како је речено код првога лица јед.: шкмх ПІ. 39. мємаю М. 192. IIб. 70. нимају Ст. пис. 1, 106. Глав. 14.

Ђ. Основе без наставка: к основи приступа наставак како је речено:

I. 1. б.буду Ст. пис. 3, 140. доведу Вран. жив. 7. гредв М. 16. П. 20. Ст. пис. 4, 313. Д. Рањ. VIIIб. пладу Ст. пис. 4, 164. покрив М. 208. краду Д. Рањ. 53б. креду Зор. $73 б$. Буд. 103. сједј Н. Рањ. 53б. Ст. пис. 5, 101. Орб 45. седу Вран. жив. 54. сиду Банд. 44. плету Вран. жив. 19. расту Буд. 100. Брн. 43. ресту Ст. пnс. 1, 19. 3ор. 29б. подресту Ст. пис. 3, 218. пкрп1в ПI. 102. срету Ст. шис. 3, 215. цвату Вран. жив. 25. - I. 2. грнзу Град. дјев. 12. лјезу Н. Рањ. 116б. Ст. иис. 4, 269. шұкнету Збор. 76. несв М. 52. донесу Вран. жив. 14. - I. 3. нздубу Врап. жив. 112. скубу (т. пис. 2, 331. 4, 114. жнку М. 55. 102. П. 112. Ст. пис. 1, 118. 3, 135. 4, 437. Град. дјев. 32. Брн. 57б. Злат. 34. Вран. жив. 19. Див. 5. Орб. 49. Гунд. пс. 15. ожнву Банд. 121. Андр. пут 7. Радн. 3.' - I. 4. завргу Ст. ппс. 1, 160. развргу Д. Рањ. V. вргу

- Писарске ће погрјепке битп ži (мјесто živu) Ст. пис. 4, 437. 442. у днI. 
Вран. жив. 5. Банд. 126. пзкегъ Збор. 18б. ужегу Радп. 5\%. zахегу П. 18. легу (procumbere) Н. Рањ. 38б. Ст. пис. 3, 129. могв М. 55. попогв ІІб. 79. Н. Рањ. 150. Ст. пис. 5, 145. Орб. 290. Радн. 51. премогу Ст. пис. 1, 24. прнсегв М. 218. стригу Ст. пис. 4, 334. Див. 13. Банд. 291. стргу Ст. пис. 4, 332. Стар. 3, 297. Банд. 224. вуку Вран. жив. 43. рекв М. 215. 3бор. $33 б$. Ст. пис. 4, 215. 5, 181. Гуч. 117. Банд. 43. Радн. 14. одреку Радн. 2. теку Злат. 56б. - I. 5. почну Ст. пис. 4, 272. 5, 65. у истога се глагола може и промјенпти $н$ пза $и$ у . $и$ (вндп код 1. лица јед.): почму Мрн. 24. Радн. 10. зхкмыоу Шая. pam. 1873. 95. примх ПІ. 104. Вран. жнв. 23. Банд. 24. Јерк. 70. Радн. 93. вазму Ст. нис. 3, 453. Буд. 82. обајму Ст. пис. 1, 230. обујму Н. Рањ. 88. Банд. 76. однему Буд. 137. снему Вран. жив. 62. дму Ст. пис. 2, 386. од основе која добија наставак ја мјесто а: пожању Стар. 3, 264. Бапд. 172.--І. 6. бију Вран. жив. 26. дију Ст. пис. 1, 70. 86. Хект. 11. 40. 44б. Зор. 33б. надпју Ст. пис. 1, 3. одију 118. додију Апдр. пут 237. зико М. 535. Ст. пис. 1, 22. 12:. 2, 435. 3, 423. 4, 46. Јрад. дјев. 98. Хегт. 2. Буд. 86. Злат 3б. Динв. 34. Банд. 41. Канг. 51. Гдав. 80. позпхо М. 162. Ст. пис. 3, 470. Зор. 3б. Злат. 20. Банд. 41. КапI. 10. псти гдагод додазі и с доданим $\not$ (како је речено код 1. дпца јед.) од друге половине XVI вијека: знаду Буд. 78, 149. Вран. жив. 4, 17. 31. 72. Банд. 15. 40. 74. Мрн. 16. 58. 91. Андр. дев. 146. Пос. 21. Радн. 14. 17. 24. познаду Банд. 295. Мрн. 12. Каші. 25. Андр. пут 227. Радн. 24. смъо ПІ. 11. 17. сиен ПІ. 28. смшю II. 17. смјеју Д. Рањ. 27. смију Буд. 129. Андр. пут 210. исти глагод долазп једпом на крају XVII впјека и с доданим $A$ (о ком видп код 1. дица јед.): смиду Радн. 37. с промјеном гласа $y$ у ов: плову Ст. пис. $2, \widehat{343}, 3,342$. Д. Рањ. $1 б$. слову Ст. пис. 2, 15. с промјепом гласа т у ој: поју $A$. Рањ. VII. од основа које се од свагда шире добивајућп $A$ (видп код 1. дица јед.): кидв М. 414. Н. Рањ. 13. добуду Н. Рањ. 207. Ст. пис. 4, 46. 233. 5, 10. Хект. 46. придобуду Стар. 1, 221. иду Злат. 13б. изиду т Н. Ран. 161б. прнду Ст. пис. $2,50$. Злат. 39. допу М. 241. 259. зајду Ст. ппс. 3, 160. 4, 161. мимојду Н. Рањ. 194. шхи М. 108. 434. 449. II. 55. Ст. пис. 3, 161. 309. 402. 4, 50. Вран. жив. 23. ојду Ст. пис. 3, 19. пондв М.

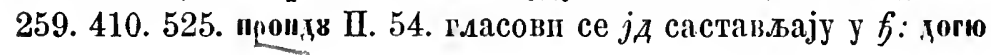


II. 8. 13. М. 258. 535. Н. Рањ. 23б. зађу Ст. пис. 3, 103. 4, 320. д. Рањ. 14б. мимођу т Н. Рањ. 170б. пагю М. 205. 208. 267. 353. Ст. пис. 3, 141. Гуч. 64. погю М. 102. 108. 464. П. 17. поћв М. 546. Н. Рањ. 15. прогю П. 7. Чубр. 6.' из таких је сложених прелазило ђ п у друге: пршђ Злат. 44б. 84. Андр. нач. 56. II у шрости, гдје остаје у основи $u$, на свршетку XVII впјека: иђу Радн. 45. - I. 7. удру Ст. пис. 5, 234. прождру Радн. 22. мру Шос. 13. с уметнутим а мећу два сугласна: затару Вран. жив. 101. тару Радн. ј6. у глагода који су из другога раздјела треће врсте прелазили овамо: вру Ст. пис. 1, 103. назру Ст. пाпс. 2, 92. 109. позру 47. прьо М. 16. прон M. 270. у неких се пзмеђу глагола овога раздјела могла и ширити основа добпјајући у коријену глас е: истеру Н. Рањ. 95. тако п олєев II. 121. прождеру Ст." пис. 4, 383. прем да бн у пошљедва два могло бити тако п по петој врсти.

II. ольеги М. 258. двигну Злат. 53. уздигну Гунд. пс. 22. помку Радн. 30. сасну Стар. 3, 236. смагну Ст. пис. 2, 495. тискпу Н. Рањ. 61б. прнтисну Зор. 28. истпсну Орб. 205. спадну Ст. пис. 2, 513. пану Д. Рањ. 108. ${ }^{2}$

III. 1. жекю Збор. 165б. Брн. 56б. импју Ст. пис. 1, 22. 86. Брн. 7. Здат. 86. внкю П. 58. 77. умију Ст. шис. 4, 483. А. Рањ. VIII. Хект. 21. Буд. 86. Град. дјев. 72. Гуч. 26. Вран. жив. 3. Банд. 248. разумију Н. Рањ. 36. Збор. 48. Буд. 89. Див. 9. Орб. 244. Банд. 26. Мат. 67. Ђам. 4б. како се у пошљедњега глагола основа и салимала у осталијем лицима, узимало се као да је из другога раздјела ове врсте, те се надази у овом лпцу XVI впјека п разуме Зор. предгов. разуме т Буд. 126. а XVII вијека пма и с уметнутим д као у гдагода ирве врсте шестога раздјела смјети (види мало напријед и код 1. лица јед.): умиду Мрн. 35. - III. 2. бде Ст. пис. 2, 57. Брн. 22б. везе Ст. пис. 2, 110. виде Н. Рањ. 14. вре Ст. пис. 15, 243. горе Злат 41. дрьже М. 106. Злат. 31. желе Збор. 73. 3дат. 40. ипе Ст. инс. 1, 79. 2, 272. 5, 145. пре М. 208. 209.

' По крајевима гдје $f$ гласп $j$, налази се и у овој прилици $j$ мјесто $f$ : пою М. 248. Вндап и код трећега лица јед.

2 у слику и јамачно њега раді пма но четвртој врсти: гибо (мјесто гину) Ст. иис. 1, 99. увене (м. увену) Ст. пис. 2, 468. тако и у 3. лицу јед.: повени Ст. пис. $2,468$. 
267. 270. 353. 434. прт M. 205. 206.' свире Ст. пис. 5, 158. стоє M. 17. сыс М. 21. тријеште Ст. ппс. 4, 17. ћуте Злат. $27 б$. цатте Ст. пис. 2, 28. 63. 82. Д. Ран. 54б. цте Ст. пис. 2, 71. 4, 434. Д. Рањ. 14. Гуч. 21. процте Ст. пис. 2, 418. уцкне Ст. пис. 2,312 . глагол који у осталијем дицима садашњега времена прелази у други раздио пете врсте остаје у овом дицу међу овијем глаголика допирући у XVII вијек: хотє М. 38. 41. 98. 327. 459. 472. I. 6. 16. 22. 71. Стар. 1, 219. 2, 298. Буд. 27. 71. Брн. 52. 56. Мрн. 117. Вран. жив. 60. Мат. 14. оүсхоте M. 208. 267. 434. у тога је г.лагола мог.ло о осдабити у ь: хьте М. 96. а и цијели први слог отпадао је: тако окрњено допире у XVI вијек: тє М. 106. 117. 215. 219. 242. :-47. 531. П. 5. 15. 16. 21. 22. 42. 140. Пб. 28. Ст. пис. 1, 60. Стар. 3, 262. Буд. 72. 82. 83. Брн. 47. али је из других лица продрло $f$ и у ово мјесто његова $T$, и то од краја $\mathrm{XV}$ вијека: ${ }^{2}$ хоће Ст. шис. 1, 101. 116. 167. Јеђупци завјетоватп хоће Н. Рањ. 17. сви се хоће снизити Збор. 53. хоће Ст. пис. 2, 397. 5, 68. Д. Рањ. V. 6. 92. Злат. 9б. Вран. жив. 24. Орб. 12. Банд. 18. Каш. грам. 101. тако и без првога слога: ће Ст. пис. $1,48$. 101. 115. похвалити he се мнози Н. Рањ. 206. људи qинити ће како но звијери Збор. б2. ће Ст. пис. 2, 432. 3, 437. $4,153.5,47$. ки су научени, вридни ће се звати Хект. 21. они су Јуде, муку ће Јудину поднести Брн. 53б. тебе ће они одправит' Злат. 9б. к теби се ће немнлосници обратити Гуч. 108. һе Чубр. 9б. Вран. жив. 56. Орб. 220. Гунд. пс. 19. Банд. 1. Јерк. 22.

IV. враме М. 219. говоре Буд. 7. zгоде М. 22. знобе Ст. пис. 2, 185. 239. лазе Н. Рањ. 115б. моле Н. Рањ. 39. посє М. 16. нузе Ст. пис. 3 , 470. тире Ст. пис. 4, 447. отјере 207. 5, 11. вапе Ст. пис. 2, 192. 336. чте Буд. 88. Гуч. 19. Орб. 244. ште Банд. $1400^{3}$ у глагола који пнтинитивом прппада у пету врсту : спе Н. Рањ. 106. Ст. пис. 4, 404.

V. 1. Првкнваю М. 27. одькнвю М. 232. збирају Збор. 2. 3.ат. 102. обирају Мрн. 44. гледају Ст. пис. 2, 135. пакаю М.

1 Види тај глагол и у првој врсті.

2 IIто има XIV вијека иє кє II. 5. за цијело мислим да је пाтампарска погрјешка.

з Једном има изван слика и згубу Ст. пис. $5,50$. 
97. д. Рањ. VII. Андр. 377. прпдавају Ст. пис. 5, 199. Банд. 139. проқакмо II. 11. даривају Хект. 35б. Вран. жив. 30. двизају Мрн. 48. познавају ІІос. 19б. вұнихю М. 52. шроклпнају Н. Рањ. 229. Див. 17. лијетају Ст. пис. 4, 268. помнраю ПI. 29. умпрају Стар. 3, 325. Банд. 271. Пос. 14. помагају Град. дух. 41. дјев. 71. Орб. 289. надају се Ст. пис. 4, 276. нузају Ст. пис. 3, 466. спомпнају Мрн. 9. проннихв Див. 13б. прнхю М. 69. потезају Ст. пис. 3, 321. чвкмо М. 208. јахају Ст. пнс. 2. 435. посвојивају Брн. 53б. ослобојивају Орб. 143. приказивају Орб. 90. - V. 2. збир! Ст. ппс. 2, 354. разбпру Ст. пис. 4, 359. пзвиру Ст. пис. 2, 354. 5, 125. двпжу Ст. пис. 1, 34. Град. дјев. 141. Крн. 19. подвпжу Ст. пис. 3, 131. Хект. 8. Орб. 7. уздвижу Град. дјев. 151. Гуч. 222. Орб. 207. уздижу Ст. пис. 3, 88. 362. Андр. дев. 16. дјељу Ст. пис. 3, 449. жеру Ст. пис. 1, 159. раждижу Ст. пис. 3, 362.' тигю М. 135. 208. зазиру Ст. пис. 2, 333. пићу Вран. жив. 15. оүземко М. 15. оүзикю М. 521. Мат. 34. вазпмљу Ст. пис. 2, 78. кажу Вран. жпв. 18. покхкоу М. 126. прожапњу Ст. пис. 5, 281. кушљу се А. Рањ. 28. прю М. 98. орв П. 26. оүзорог М. 98. пропињу Град. дјев. 180. заппру Ст. пис. 4, 263. пиш М. 23. пљежу Ст. пис. 3, 207. 4, 145. заплпјеһу Град. дјев. 74. усппу Злат. 90. стеру Вран. жив. 35. поппљу Орб. 289. прптежу Вран. жив. 20. чепу .Ст. пис. 4, 86. почињу Ст. пис. 1, 7. почимњу (мјесто почим.бу) Ради. 99. с промјеном у корпјену: загољу Ст. пис. 5, 180. - V. 3. с промјеном у корнјену: оперу Вран. жпв. 103. шждепу Ст. пис. 4, 217. ждену Ст. пис. 3, 13. у пстога гдагода с промјепом гласа ж на $p$ : пзрену Банд. 242. одрену Глав. 124. прорену Брн. 6. позовв М. 175. зову Вран. жив. 9. без промјене у корпјену: рву Ст. пис. $5,96 .^{2}$ тку $\mathrm{H}$. Рањ. 157б. даю М. 50. 98. 135. 173. 410. Ст. пис. 1, 31. $3,473$. 4. 46. 5, 9. А. Рањ. 78. Брн. 5зб. Вран. жив. 10. Банд. 27. Гунд. суз. III, LX. "zим М. 46. Ст. ппс. 4, 372. подају Глав. 112. прндају Ст. ппс. 2, 442. Здат 8. продаю М. 17. 52. 120. I. 146. Вран. жив. 48. Банд. 238. удају Орб. 303. надпју се Ст. пис. 1, 173. познају Н. Рањ. 50б. Хект. 30. Град. дјев.

1 Наптампано је радииц.

${ }^{2}$ IIorрjemla hе бити varu Ст. пис. 3,140 . мјесто rvu. 
12. Вран. жив. 26. Андр. пут 14. Банд. 15. кају се Вран жив. 8. pacкљују Ст. пис. 4, 388. pacпљују Ст. пис. 4, 388. сију Радн. 95. просију Н. Рањ. 102б. смјеју се Ст. пис. 5, 30. 342. Злат. 27. насмјејг $A$. Рањ. 104б. стлю се М. 182.'

VI. живују Радн. 86. квивю М. 193. оүписоүо М. 13. пмепвю II. 125. нослују Град. дјев. 52. трмгвю М. 168. чтују Ст. пис. $1,7.3,297.5,335$. А. Рањ. 48. Злат. 4. почтују Ст. пис. 3, 141. Хект. 43. штују Ст. инс. 1, 325. Вран. жив. 71. згрњују Радн. 40. ожив.ьуј Гунд. суз. предгов. кажују Ст. пис. $2,434$. прикажују Град. дјев. 28. Орб. 90. запречују Гуч. 272. запуштују Н. Рањ. 85б. одпуштују Андр. 48. оцкврнују Н. Рањ. 64. оцкврњују Злат. 4.

АВ О Ји Н А.

II р в о $\lambda$ II ц е. Постаје наставком vasi. коме отпада други сдог као у првом лпц мн., а мјесто а у словенским језицима додазп \$ јамачно пз номинатива двојине днчнога прономина за прво дице, који је пнате с овијем завршетком једнак (види напријед стр. 223), те наставаћ г.1асн вћ: єскк Стеф. 14. пасмидкк Стеф. 28. приноспкт М. 11. разиоүуаскк Сав. 10. али је тако само у најстарпја времена у српском језику, а послије се двојина замјењује множнном. Истина, налази се XVI вијека: умреве Стар. 3, 324. алп у књизи преписаној пз старије, па и у њој самој одмах до тога облшка стоји и множина: оба умреве и матере нане не вндимо. У другој половини XV впјека јоп се налазп овај облик од основе єс, огрњене каго се крњнла п у другим лпцима, али са а мјесто в, јамачно једначећи се с помпнативом двојине мушких ријечи с основом на а (види напрнјед стр. 221): ска М. 505.

Aруго $о$ ице. Постаје наставком tvasi, којему је такођер отнао други слог и гласа $\mathbf{v}$ нестало, а од а у словенским језицима бнва є, те наставак гласи тє као и у другом лицу мн., п тако се налази кад кад у старом словенском; а.ли је мјесто с обичние $а$, може бити за то што се друго лнце смијенало с трећпм, у ком у пеким прнликама сродни језици имају дуго а, коме у словенским језнцима одговара

- Једном у слику и дарију (даривају) Хект. 446. иснореди иартицип: даријући, целијућ. 
кратко л, тако наставак гласу и та; али шрем да то лице с таким наставком додази за сва три рода, инак за женски и средњи род долази н са п мјесто а у наставку, јамачно прежа номинативу двојине женских и средњих ријечи с основом на а (види нацријед стр. 222-3); у срнском језику долази тај облик само са ، на крају наставка,' адп неко.дко примјера піто их има сви су за мунши род: сптста Сав. 5. хоцета Сав. 5. поспорихтх Сан. 5. тако још XV внјека од основе

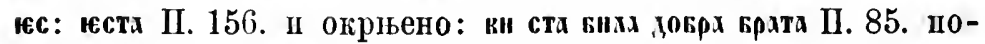
слпје се друго лице дв. не находи.

Т реће лице. Постаје наставком tasi, којему је такођер отпао други слог, а од а бива $\mathrm{s}$ словенским језицима с, као и у другом дицу, али је а у неким прнликама у сроднијем језицима бивадо и дуго, те јамачно за то долази у словенским језицима и $x$, II тако је обичније, и то за сва три рода, али за женски п средњи додази и ₹ мјесто х онако како је речено код дрјтога лица. Све три речене разлике у наставку налазе се у српском језику: али са є само једном и то XVI вијека, те лако може бити да є стоји мјесто в: да в४дете оун тконс домн гледлти Збор. 33б. - најобичније је бнло са п, и то за сва три рода: за мушки: до краја

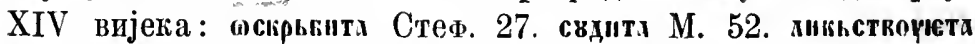

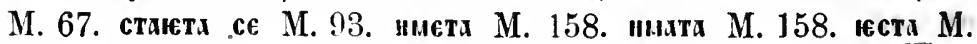
26. 176. окрњено : ста М. 23. Пб. 22. XV вијека: смвжита, жрьжнта, трьлита, шиата М. 462 . естьта М. 249. окрњено: ста М. 462. XVI вијека само у два извора п $\mathbf{y}$ једном од внх само од основе юс: оқа видст. Збор. 2. па се она дих прнта Збор. 158б. ста Хект. 12. 12б. 15б. 16. за женски: до краја XIV вијека: ста M. 107. р.қ,конта M. 176. XV вијека: потсзата М. 380. Пб. 92. на крају XV цди XVI вијека једном од основе єс: двије ста ми се карале Ст. пис. 2, 510. - за средњи: сымннта (оүшн) Стеф. 18. и XV внјека: пзията (дне годнци) М. 369 . - за женски и средњи род са к на крају.

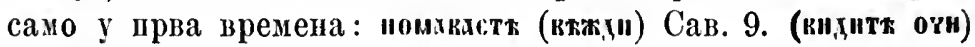
3. zpitr 9 .

' Једини је примјер у ком би могло бнти с мјесто а: родила се естс Стар. 3, 250. али је то XVI илй XVII вијега, те лако може бити друго лице мн. 


\section{ИМПЕРФЕКАТ.}

Основа је за овај облик у једнијех глагола онака кака је у садашњем времену, а у других онака кака је у инфинитиву. Основу онаку кака је $y$ ннфинитиву пмају рдаголи треће врсте оба раздіела, глаголи пете врсте првога и другога раздјела и глаголи шесте врсте. У осталијех је свијех у овом обдику основа онака кака је у садапњем времену, и то у глагола четврте врсте онака кака је у првом дицу једнине. Гдјекоји се глаголи појединце одвајају у том од свога друштва, те прелазе међу друге, а гдјекоји имају овај обдик двојак: и од основе кака им је $у$ инфинитиву и од онаке кака им је у садашњем вр.

у којих је глагола у овом облику основа као у садашвем времену, у њих се задње а у основи, гоје веһ у садашњем вр. у највише лица гласи $е$ у у овом облику продуљује, те бива \$, а пред в се гдасови $2, \kappa, x$ мијевају на 3 , $u, c$, ии се претварају у ж, и, и, а онда се за њима мијења на $a$; тако се п претвара у $a$ предњега гдаса ради н у основама које у садаињем вр. имају наставак ја.

До таке основе и до онаке кака је у инфинитиву долази од коријена од којега је у словенским језпцима основа єс глаголски облик ирошлога времена који без личнијех наставак гласи asa-; од тога шрво а остаје у словенским језицима, на кад̆ је пред пим у основи ж, могу се оба гласа и изједначити тако да или речено а буде \$ или ๘уде х, а по том се два једнака гдаса сажимају или један отпада; тако се речено а у позније вријеме сажима и са задњим а од основе; глас $\mathbf{s}$ прелазп у словенским језицима $y \boldsymbol{x}$, али кад за њим дође сугласно онда остаје с; а задње а у првом лицу јед. и у трећем лицу мн. саставља се с првијем гласом од личнога наставка у један гдас, а у другом и трећем дищу јед. гласи у словенским језицима є, иред којим се хностало од $\mathbf{s}$ мијења на $и$, а у првом дицу мн. гдаси о, које се у српском језику у іозније вријеме избацује према другом лицу мн., а тада и мјесто $x$ долази $c$ опет према другом дицу мн.; у другом дицу мн. отнада речепо задње а, те $\mathbf{s}$ које је пред њим 
остаје, али из првога лица мн. прелазп исто самогласпо гласећи $o$ и у друго дице, а тада и $x$ остаје мјесто s.'

Иза свега реченога долазе лични наставци као у садангем времену: али за прво дице јед. само m, гоје се са предњим а саставља у ї, које слаби у т, а то у српском језику отпада; за друго лице јед. само $s$, које у словенским језицима стојећи на крају отпада; за треће дице јед. само $t$, које такођер отнада; за прво дице мн. mas, којему у словенским језпция отпада $\mathbf{s}$ a a сдабп у $\mathbf{~}$ мјесто којега долазе и друии гласови опако гао у садашњем времепу, а пзмеђу жпх у српском је језику остадо $о ;^{2}$ за друго дице мн. tas, којему такођер отпада $s$, а од а бива у словенским језицима с; за треће лиде мн. само nt, од тега юрајње $\mathbf{t}$ отпада a n се с предњим а састав.ла у п, које у српском језнку гласи $y{ }^{\circ}$

Овај су облик доста често нмалп п свршенг глаголп.

А. Основе лао у садашњем времену:

a) ₹ које основи иа грају постаје реченијем начином остаје пред а, које за жим нде, гласећп према товору сриском: то бива у гдагода којима оенова саданшьега времена пма наставаг чнсто а:

1-во јед.: I. 1. иредијах Кап. грам. 132. - I. 5. кушијах Ст. пис. 2, 258. - II. целунпјах Ст. ппс. 2, 258.'

2-го и 3-һе јед.: I. 1: рлстишше Сав. 3. џзьтқаше М. 561. растијаше Банд. 16. гредпјаше Банд. 159. Кап. 20. Радн. 45. крадпјаше Банд. 180. Каш. 86. - I. 2. пасијапе Град. дјев. 155. 156. - - I. 4. обуцијапе Гуч. 999. рецијапе Орб. 95. тецијаше Каш. 18. Рад. 89. притецијаше Гуч. 216. - I. 6. у глагода у ком се $y$ мијена па ов: словијаше Ст. пाнс. $4,484$.

' Капи и Микаља у својш граматиіама пемају првога ни другога лица мн. другаqнје него с тијем вока.лом. - Испореди Cтарние IIl. 71.

${ }^{2}$ Само према црквенијем књигама палази се са $\mathrm{h}$ : жикехюмh Cтар. 4, 233.

3 Додано $T$ онако као у садапнем врсмену (видш напријед стр. 290) врло је ријетко: мотаху т Ст. пис. $1,14$.

4 Је ап у тијем прпјерима допста -иија- пли -жа-, не може се поуздапо знати правописа ради, којпм се садалње пздање Іітампа. 
у глагола ком се основа од свагда шири добивајући д: шдаше Стеф. 6. у глагола ком је основа у инфинитиву вт а у садашњем вр. добија $A$ на крају и пред шим ї мјесто т (види нашріјед стр. 259), у овом обднку долази без д и без речене промјене самогласнога, па се пред в које у садашњем вр. постаје основп на грају глас ы мпјева на 6 , које пза гласа б отнада: кыми: Стеф. 6. бпјаше Ст. пис. 4, 275. 289. Вран. жив. 70. Каш. 86. види и дабе под б. - V. 3. беријаше Ст. пис. 2, 421. зовнјаше Гуч. 144. Банд. 96.

1-во мн.: I. 6. у глагода ком је основа у инфинитиву кт (впди напрпјед код трећега дица јед.): а) с вога.лом пред личнијем наставком: бијахомо Каш. грам. 89. б) без вокала пред личнијем наставком и са $c$ мјесто $x$, XVII вијека: кн. асмо Пос. 9.

2-го мн.: I. 6. у гдагода ком је основа у инфинитиву кт (види наприед код тређега дица јед.) с вокалом пред личннјем наставком, XVII вијека: бијахоте Банд. 143. Каш. гран. 89.

3-ће мн.: I. 1. плетијаху Ст. пис. 4, 272. гредијаху Каш. 62. 104. Радн. 17. - I. 2. везијаху Гунд. суз. III, XXIX. III. 3. живијаху Ст. нис. 5, 74. жнннхв Пос. 7. - I. 4. стрзиjaxy Н. Рањ. 67. тецијаху Ст. пис. 4, 394. Каш. 44. - I. 5. кунијаху Див. 13б. Гунд. шс. 25. Банд. 145. - І. 6. у г.лагода ком је основа у пнфннитнву кт (види напријед код трећега дица јед.): бијаху Ст. пис. 4, 485. 5, 215. Каші. 38. види и даље под б. у г.дагола ком се основа нири од свагда добијајући д, сложенога са ири: прудијаху Ст. пис. 5, 121. V. 3. бернјаху Ст. пис. 4, 272.

Тако је и у глагода којима основа у садашњем вр. нема наставка него се свршује на $д$ : они се узщмају у овом облику међу глаголе прве врсте првога раздјела као и у старом с.ловенском језику : 2-го п 3-ће јед.: дадпјаше Орб. 113. Банд. 45. 49. 55 .

Тако је и у глагола који су изједначујући се с другима прпмили од њих у неким облицима д на крају основе (види код сад. вр.), па га ииају и у овом, те се изједначују с глаголима прве врсте првога раздјела, XVII вијека: 1-во јед.: знадијах Орб. 25. 2-го и 3-ће јед.: знадијапе Орб. 36. Каш. 54. Радн. 20. 24. 53. пмадпјапе Радн. 11. 12. 26. 29. 2-го 
мн.: с вокалом пред дичијем паставком: знадијахоте Каш. 21. 97. 3-ће мн.: зидинх Пос. 43б. имадијаху Радіг. 1. 3. 9. 26. видш јон код б. н е.

б) с крајњп пу основи изједначује се $a$ које шде за вим, те се оба сажимају у једно в : ${ }^{1}$ то бнва у истнјех гдагода: 1-во јед.: I. 1. плетпјех Ст. ппс. 4, 467. проведих Ст. ппс. 2, 173. гредшх Ст. пис. 2, 325. Зор. 2. Стар. 1, 230. падих Стар. 1, 229. предих Кап. грам. 112. - I. 2. паспјех Ст. пис. 3, 361. 4, 217. понесих Ст. пис. 2, 258. - - I. 3: жкивијех (živjeh) Ст. пис. 5, 344. - I. 4. рецијех Ст. пис. 2, 395. рецих Ст. пис. 2, 125. 258. 264. 276. 316. 326. тецих Ст. пис. 2, 316. дотецих Ст. ппс. 2, 125. потецих Ст. ппс. 2, 258. 264. стецијех Ст. пис. 5, 344. - I. 5. почних Стар. 1, 230. - I. 6. у г.дагода у појпуа се y мијења на ов: пловијех Ст. пис. $3,57$. 4, 337. пллових Ст. ппс. 2, 287. слових С'т. пис. 4, 425. у г.даrода ком се оспова од свагда шири добпвајући д: пдијех Ст. пис. 2, 54. 438. вднх Ст. ипс. 2, 466. 5, 59. придијех Ст. пис. 2, 204. најдих Стар. 1, 230. у глаго.ла који такођер добија од свагда у садашњем вр. д, али је у овом облику бев вега (види стр. 301) а има од основе само б пред сажетијем в, које је у њега (дај буди данас) кратко, може бити штто је тако оптећен: юнски М. 221. бјех Ст. пис. 2, 438. $4,81.5,39$. у истога је гдагода бндо и од цијеле основе каква му је у садапњем вр.: будих Ст. пис. 2,225 . у гдагола юом се основа од свагда пиии добнвајућп $\boldsymbol{*}$ : станих Ст. пис. 2, 276. Зор. 1б. постаних Ст. пис. 2, 258. пристаншх Стар. 1, 230. - II. вених Ст. пис. 2, 380. повених Ст. пис. 2, 239. ганих Ст. пис. 2, 276. згиних Ст. пис. 2, 129. паних Ст. пис. 2, 258. прионпх Ст. ппс. 2. 258. спомених Ст. пис. 2, 239. посрних 3ор. 67б. стпних Ст. пис. 2, 381. тоних Ст. пис. 2, 258. трннх Ст. нис. 2, 264. отрних Зор. 20. - V. 3. зових Ст. пнс. 2, 241. 287. Д. Рањ. 72. зовијех Злат. 70б.

2-го и 3-ће јед.: I. 1. растијеше Н. Рањ. 26. 30. 141. 202. Збор. 47б. 112. Ст. пис. 4, 117. 121. 133. Злат. 80б. растише Ст. пис. 1, 77. рестише Ст. пис. 1, 78. Зор. 34б. Вран.

' Да је у овом облику дуго и по том да у јужном (дај буди садашњем) говору гласі ије, види у Раду југосл. академнје 20. стр. 185-6. 
жив. 29. метпше Вран. жив. 85. цватище Ст. пис. 1, 115. Хект. 426. Крн. 4б. бодијеше Ст. пнс. 4, 1.9. збодише Крн. 5. грє Авшє П. 75. гредпјеше Н. Рањ. 82. 89. Збор. 1. Ст. пис. 2, 271. 403. Злат. 101. гредише Ст. пис. 1, 12. 29. Стар. 4, 111. Зор. 36б. 66б. Вран. жив. 98. Крн. 11. Банд. 49. 51. крадијеше Н. Рањ. 166. упадшше Стар. 4, 113. Буд. 41. - I. 2. нєстше Стеф. 16. понесише Вран. жшв. 90. пасшєше Збор. 102б. Ст. пис. 4, 104. пасише Ст. шис. 1, 78. напасише Стар. 1, 231. тресшеше Збор. 77. 101б. гризиєшє Збор. 102б. гризише Хект. 18. Зор. 2. слјезише Н. Рањ. 47б. слизише Батд. 39. улизише Вран. жнв. 36. - I. 3. скубијеше Ст. пис. 3, 202. скубише Зор. 29б. живијеше Ст. пис. 5, 321. - I. 4. врзише Вран. жив. 87. вуцише Ст. пис. 1, 14. Зор. 75. пецише Вран. жив. 93. рецијеше Ст. пис. 2, 257. рецише Крн. 2б. сицпше Вран. жнв. 89. тєџнєше 3бор. 47. 87б. Ст. пис. 4, 133. 5, 140. Эдат. 70. тецице Ст. шис. 1, 5. 29. 78. 4, 12. А. Рањ. 28б. 55. Хект. 8. 26. Зор. 36. Стар. 3, 242. Вран. жив. 7. 15. Крн. 18б. Мрн. 29. Радој. 31. - I. 5. кунијеше Н. Рањ. 131. кунише Ст. нис. 2, 392. вазмијеше Ст. пис. 4,310 . отмише 3ор. 75 . - I. 6. у глагола у којима се мијева $у$ на ов: пљовише Ст. пис. 2 , 295. Хект. 8. 33. 436. Зор. 70б. словијеше Ст. пис. $2,515.4,394$. 436. 484. словише Cт. пис. 2, 404. Злат. 86. Крн. 2б. у глагола ком се основа од свагда шири добивајући д: идијеше Н. Рањ. 29. 58б. 70. 102б. 113. 156б. Збор. 13. 76б. Злат. 17. 43. 45б. 68б. идише Ст. пис. 1, 23. Стар. 3, 243. 262. 279. придише Стар. 1, 230. пзајдшше Вран. жив. 36. дојдише Вран. жив. 104. у глагола коме основа у инфинитиву гдаси бт (види напријед код 1. лица јед.): кжшє М. 146. кнєшє М. 326. 391. ІІб. 111. 3бор. 104. бјеше Ст. пис. 4, 30. 5, 214. Злат. 53б. Каш. 81. бише Трад. дјев. 17. Вран. жив. 5. Мрн. 62. у истога је глагола било и од цијеле основе каква је у садапњем вр. допирући тако у XVII вијек у овом лицу: будијеше Н. Рањ. 47б. будише Банд. 39. Крн. 17б. добудише Стар. 1, 229. у глатода ком се основа од свагда шири добивајући $ж$ : нестанише Ст. пис. 1, 15. останише Ст. пис. 1, 23. Стар. 4, 113. - I. 7. жерише Ст. пис. 1, 197. Брн. 28. стерише Ст. пис. 1, 64. - II. бринише Стар. 3, 223. венише Ст. пис. 1, 23. 2, 315. венијеше Ст. пис. 4, 152. гинијеше Н. Рањ. 326. грезнијеше Злат. 18. двигнише Ст. пис. 
1, 67. уздвитнише Стар. 1, 235. помрзнине Стар. 3, 270. посрнијеше Ст. пис. 3 , 320. споменише Јерк. 31. ригнише Ст. ппс. 1, 49. такнијеше Н. Рањ. 41. тонијеше Ст. пис. 3, 303. протрнијеше Ст. ппс. 3 , 320. - V. 3. зовијеше Н. Рањ. 896. 130б. 177. Збор. 69б. 89б. Ст. шис 2, 3. 4, 307. зовнше Ст. пис. 1, 10. 32. 69. 288. 2, 295. Зор. 36б. Вран. жпв. 16. 24. Ванд. 13. 93. 139. Крн. 2б. Мрн. 34. 6․ доренијеше (гнати) Стар. 1, 231. рвпјеше Ст. пис. $2,439.4,175.176 .177$. рвипе Ст. пис. $1,23$. ревијеше Ст. пис. $4,166$.

1-во мн. а) с вокалом пред дичнијем наставком: I. 2. пасихомо Ст. пис. 1, 297. - I. 6. у г.лагола вом се основа од свагда пиири добивајући д: идијехомо Н. Рањ. 68. у гдагода коме основа у инфинитиву гдаси кт, али му у овом обдику остаје од ве само б (види напрпјед год 1. дица јед.): въхомо М. 349. ПІ. 42. 166. бјехомо Н. Рағь. 27б. 71б. Ст. пис. 5, 169. Град. дјев. 16 Злат. 45. Гуч. 307. Андр. дев. 2. бихомо Ст. пис. 1, 102. Н. Рањ. 25б. Зор. 39б. Вран. жив. 22. Банд. 15. Мрн. 51. Каш. грам 89. - б) без вокала пред дичнијем наставком а са $c$ мјесто $x$ пред њим XIV вијека: києсмо М. 229.

2-го мн. с вокалом пред личнием наставніо: I. 6. у глагола коме основа у инфинптиву гласи бы (внди напријед код 1. дица јед.) од XV вијека: квхюте.П. 127. кєхотє Пб. 113. бјехоте Н. Рањ. 151б. Ст. пис. 5, 134. 272. кихоте Пб. 40. Ст. пис. 1, 285. Банд. 50.

3-ће мн.: I. 1. плетијеху Ст. пис 3, 6. растијеху Ст. пис. 4, 108. 192. цватпху Ст. пис. 1, 76. Зор. 34б. 68б. ведиху Ст. пис. 1, 92. 244. докеднехв Збор. 13. грсдако ПІ. 63. 125. гредиjexу Н. Рањ. 35б. 125. Збор. 16. Злат. 86б. гредиху C'r. піс. 1, 12. 67. Н. Рањ. 179б. Хект. 12. Стар. 4, 112. Брн. 8. Банд.

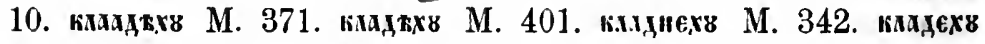
М. 414. 424. кахднхв М. 453. крадиху 3ор. 75. падиху Ст. пис. 1,24. - I. 2. несиху Ст. пис. 1, 94. понесиху Вран. жив. 90. паснехв Збор. 25. паспху Ст. пис. 1,256 . Зор. 43. грвзијеху Ст. пис. 4, 166. - I. 3. скубиху Јерк. 56. живехоү Сав. 8. живиху Ст. пис. 1, 24. 76. живијеху Ст. пис. $3,6 .-$ I. 4. пециху Ст. пис. 1, 257. сијецпјеху Н. Рањ. 89. спјециху Банд. 78. сициху Мрн. 112. тецијеху Н. Рањ. 129б. тєңщєх Збор. 81. 1146. Ст. пис. $2,432.4,394$. Злат. 48. тециху Ст. пис. 
1, 195. Хект. 8. Зор. 9б. Стар. 1, 234. Вран. жив. 59. Банд. 143. - I. 5. кунијеху Ст. пис. 4,162 . - 1. 6. у глагола ком се основа од свагда пири добивајући д: идијеху Н. Рањ. 21. 153. Збор. 31б. 99. З.лат. 17. 48. 80б. вдцху 仓т. пис. 1 , 9. Хект. 5. изндиху Стар. 3,278 . придиху Стар. 4,111 . појдиху Ст. пис. 1, 14. Вран. жив. 104. Банд. 226. изајдиху Вран. жив. 104. тако у тога глагода и кад се $j_{д}$ саставља у $f$ : пођнху Н. Рањ. 179б. у глагола коме основа у инфинитяву гласп бм (види папријед год 1. дица јед.): киехв М. 349. 393. бјеху Ст. пис. 5, 314. бихв М. 527. Н. Рањ. 21б. 8і. Хект. 4б. Вран. жнв. 25. Каш. 92. беху C'r. пис. 4, 119. у г.saro.sa ком се основа пири добивајући од свагда н: пристаниху Хект. 26. - I. 7. дериху Мрн. 39. стериху Банд. 78. 80. - II. сахниjexу Н. Рањ. 23. тониху Н. Рањ. 117б. Банд. 118. - V. 3. бериху Ст. пис. 1,13 . беријеху Ст. пис. 4, 272. перијеху $\mathrm{H}$. Рањ. 149б. Ст. нис. 4, 114. шериху Банд. 164. зокнеху Збор. 96. 121б. Ст. пис. 5, 64. зовиху Банд. 210. рвиху Ст. пис. 1, 244. ${ }^{\prime}$

Тако је и у глагода који у сад. вр. пмају основу без наставка, која се свршује на д (внди нашрнјед стр. 301): 1-во јед.: јидих Вран. јкив. 108. Каш. грам. 120. -- 2-го и 3-ће јед:: дадише Збор. 48. 156б. дадише д. Рањ. Уб. Вран. жив. 53. 113. једијеше (ћиєдсшс) Збор. 78. Ст. пис. 5, 70. једише Ст. пис. 1, 203. Стар. 1, 231. Вран. жіив. 85. 91. ‥ 3-ће мн.: једијеху Н. Рањ. 58б. 96б. јндиху С'т. пис. 1, 82. Вран. жнв. 82. 268.

Тако је и у глагола који су пзједначујући се с другима примили од њих $д$ на крају основе (вндп код сад. вр.), па га имају и у овом те се изједначују с глагодима прве врсте првога раздјела, али истом од XVI вијека: 1-во јед.: знадих Ђанд. - 0. (;8. 199. 2-го и 3-Һе јед.: знадшше Буд. 63. 114. Вран. жив. 12. 22. 53. 57. Банд. 21. 39. 62. 8६6. имадпше Банд. 57. 179. 3-ће мн.: знадиху Вран. жнв. 72. 77. 82. Банд. 20. 21. 55. Крн. 3. Мрн. 170. тако и у глагола м!ь ти, у кога се -находи д уметнуто иза основе садашњега времена већ приправљене за имиерч., и то XVII вијека: мњадиху Вран. жкив. 36. 89. 100. Банд. 33. 67. мњадихомо Банд. 202. 239.

' Види и у Гласнику IX. 49-50. 
в) п на крају основе изједначује се са $a$ које иде за вим п с њим се сажима, а тада гутурали шред њим остају непромјењени: то бива у неких између истијех глагола:

1-во јед.: I. 4. ногахи М. 368. могах Ст. пис. 4, 187. 426. 5, 119. Зор. 2. Вран. жнв. 57. - I. 7. мрах Ст. пис. 2, 281. 276. 302. 478. 5, 146. 228. Каш. грам. 132.

2-го и 3-ће јед.: I. 4. могашє II. 62. Ст. пис. 1, 158. Н. Рањ. 164б. 3бор. 101б. Ст. нис. 4, 114. 453. 5, 303. Злат. 21. Банд. 14. Kaш. 27. пекше Стеш. 3. тукаше Ст. пис. 1, 63. I. 6. пловаше Д. Рањ. 55б. - I. 7. мраше Ст. пис. 1, 190. 4, 146. Д. Рањ. 23. Див. 26б. Каш. 65. траше А. Рањ. 23. V. 3. бераше Ст. пис. 4, 347. пераше A. Рањ. 126. рваше Ст. Iпс. 4, 166. зокаше Шаф. pam. 1873. 112.

1-во мн. с вокалом пред личнијем наставком: I. 4. моraxwnо II. 171. Ст. пис. 1, 299. Зор. 6. Брн. 20.

2-го мн. с вокалом пред личнпјем наставком: I. 4. могахоте Ст. пис. 1. 286. 302.

3-ће мн.: I. 4. могаху Збор. 13. Банд. 175. Капा. 38. I. 7. мраху 3бор. 77б. Ст. нис. 4, 152. 5, 142. Мрн. 61. с'гераху H. Рањ. 89. -- V. 3. бераху Ст. пис. 4, 368.

г) ₹ на крају основе претвара се предњега гласа ради у $a$, па се сажима са $a$ које за вим иде: то бива:

aа) у гдагода у којих основа садашњега времена од које им постаје овај обдик, пма наставак ја:

1-во јед.: I. 6. вапијах Ст. пис. 2, 435. трујах 3ор. 2. 11. чујах Ст. пис. 5 , 205. смијах Ст. пис. 2,480 . Каш. гращ. 119. - IV. пажах Ст. пис. 4, 96. тражах Гунд. суз. I, LVII. пाњах Ст. пис. 4, 453. сњах Ст. пис. 2, 95. марах Стар. 3, 276. - V. 2. у глагола који има овај облик и од основе кака му је у садашњем вр.: шаљах Каш. грам. 132.

2-го и 3-ће јед.: I. 6. вапијаше Радн. 40. шијаше Каш. 38. у тога се̊ глагола могло $u$ п избацитн: птше (читај пјаше) Стар. 3, 324. чујаше Стар. 4, 114. Каші. 34. дијаше 3бор. 30. 69. Брн. 52. 66. смијаше Н. Рањ. 127. Вран. жив. 90. 109. Банд. 141. 155. појаше Ст. пис. 4, 13\%. - IV. говораше Банд. 24. јашњаше Збор. 75б. љубљаше Вран. жив. 77. мишљаше Вран. жив. 13. момхше М. 201. ношаше Ст. пис. 4, 157. Злат. 87б. Кашा. 61. прамхше ПI. 26. пруђаше Ст. пис. 1, 166. сла- 
јаше (сладити) Зор. 1б. служаше Банд. 55. тјешаше Ст. пис. 5,120 . - V. 2. у глагода који има овај обдик и од основе каква му је у садашњем вр.: кољаше Ст. пис. 4, 244. 454. 485. 1-во мн.: a) с вокалом пред дичнијем наставком: I. 6. чвпхомо II. 171. 172. Ст. пис. 4, 467. појахомо Ст. пис. 1, 289. - IV. бесјејахомо Орб. 219. вођахомо Ст. пис. 4, 414. мишљахомо Мрн. 71. сцјењахомо Град. дјев. 37. учахомо Каш. грам. 110. Мик. грам. 20. хваљахомо Ст. пис. 1, 289. хленљахомо Ст. пис. 1, 299. хојахомо Ст. пис. 1, 305. цињахомо Вран. жив. 2: - б) без вокала пред личнијем наставком и са $x$ пгепромијењеним XVII вијека: сцињахмо Банд. 95. и без $x$ кад га је нестајало и $у$ другим приликама XVII вијека: мишљамо Радн. 14. - в) без вокала иред личнијем наставком, али са $c$ мјесто $x$ у глагода који је из трећега раздјела прве врсте прелазио у шести одбацујући основи задње в XVII вијека: плијасмо Мрн. 126.

2-го мн. с вокалом пред личнијем наставком: IV. воҺахоте Н. Рањ. 153б. говорахоте Орб. 222. нахођахоте Андр. пут 155. учахоте Каш. грам. 110. Мик. грам. 20.

3-ће мн.: I. 5. жањаху („жанаху" С) Стар. 3, 242. - I. 6. зинтух М. 383. 453. впшахв М. 447. 453. ваппјаху Банд. 93. Каш. 54. у тога се глагола могло $u$ н избацити впькх М. 371. 414. впхх М. 424. 431. пијаху Ст. пис. 3, 475. Банд. 24. цролијаху С'гар. 4, 111. дијаху Ст. пис. 1, 71. Вран. жшв. 93. појаху Н. Рањ. 199. Ст. пис. 2, 293. Ірад. дјев. 173. - IV. обаһаху Н. Рањ. 69б. разведраху Зор. 61. весељаху Каш. 102. домњаху (ломљаху) Ст. пис. 4, 178. мољаху Каш. 83. наскочаху 3ор. 2. словљаху Мрн. 83. труђаху Ст. нис. 5, 119. yхојаху Н. Рањ. 164. цтакљаху (јим очи) Ст. пис. 1, 49. -V. 2. у глагола који је имао овај обдик и од основе каква му је у садашњем вр.: кољаху Ст. пис. $3,8.55 .311 .4,482 .{ }^{1}$

1 Није разлюка у постајању овога облика што неки између онијех писаца којп у говору свога краја мјесто $f$ пмају $j$, кад кад у овом об нику ппшу ш $а j$ мјесто $f$ плп мјесто свога $j$, јер они то тине и у другим прнликама (внди стр. 254) a не само у овом облику: чудјаху се (у рукопнсу ciudgiahu, гдје g гласи ј) Стар. 1, 233. находјах Вран. жив. 4. судјаше 36. надходјаше 74 . тру, јјахомо 25 . доводјаху 69. са- 
бб) у глагола прве врсте четвртога раздјела, у којих су се гдасови $2, x, x$ могли на ж, $и, u$ промијенити иред онијем ₹ које за вима пде, гао у садашњем вр. пред $e$, па се је онда \$ за њима мијенало на $a$, које се сажнмало са $a$ које за њим иде: 3 -Һе јед. гечаше Стар. 3,270 . 3-ће мн.: тучаху Ст. пис. $1,12$.

д) в основи на крају пза гдаса иза којега би му се ваљало промијенити на $a$ (види под г), налази се и непромијењено, па је с њим изједначено и сажето $а$ које за њим иде: I. 4. жежише Ст. пис. 1,92. жежиху Стар. 1, 112. -.. I. 6. појише Вран. жив. 16. појиху Вран. жнв. 67.72. - I. 7. мељише Зор. 75. самељише Зор. 75. - IV. паљиху Ст. пис. $1,15{ }^{2}$ - V. 2. у глагола који је имао ово вријеме и од основе каква му у садашњем: шаљише Вран. жив. 13. паљиху Банд. 89. Видш п под Б. г.

ђ) основана се крајњи гласови изједначују и сажимају као у садашњем времену, па се с гласом који им је тада на крају сажима или изједначује и сажнма $a$ које за њим иде у овом облику:

1-во јед.: 1. 6. знах Ст. пис. 2, 257. Злат. 40.

2-го п 3-Һе јед. I. 6. знаше Ст. шис. 1, 27. Н. Рањ. 93б. 3бор. 1. Ст. пис. 2, 513. 4, 164. 5, 315. Град. дјев. 88. Хект. 18. Зор. 27. Злат. 88б. Банд. 47. Каш. 49. познаше Каш. 60. 103. смтше П. 149. смијеше Ст. шис. 4,152 . смише Ст. пис. 5, 175. дише Зор. 9.

дјаху 25. исходјаху 37. проходјаху 25. чудјаху се 5. мимоходјаху Банд. 27. схо,Іјаше Банд. 39. мимоходјаху 27. чудјаху се 20. чудјаше се Kaш. 54. водјаху Радој. 20. треба ли тако читати и „с̌udjaše se" Ст. пис 1,75 . не може се знати правописа ради, којим је птампано. Исти су иисци то своје дја мијењали п на дија пипући или dija ili dia: чудијаху се Bран. жив. 87. 97. исходијаше 82. па је најнослије једав измеלу њих то ија преносио и у глаголе у којима је $\hbar$ онако као у предњима $ђ$ : крстпаше Кап 97. постиаше 86 . нистиаху 38. види и под е. ІІІто се находи и .убјах Ст. пाг. $4,77$. sубјапе 395. ту he бити само избачено $\lambda$ ॥ то у познијим пријешисима.

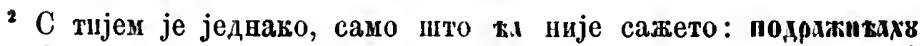
Стар. 4, 138. 
1-во эн. с вокалом пред дичнијем наставком: I. 6. зияx(i) 1 II. 172.

2-го мн. с вокалом пред личнјем наставком: I. 6. знахоте Ст. пис. 1, 199.

3-ђе мн.: I. 6. знаху Ст. пис. 3, 311. 5, 144. Бун. 48. познаху Ст. пис. 5, 121. диху Зор. 26 .

е) неке основе које пред крајњим п имају гласе за којима се не мпјења в мијењају те гласе мијешајући се с основама које у садашьем вр. имају наставак ја, па им се онда и к мијења на $a$ : тако је

aа) у неких глаго.ла прве врсте првога раздјела, и у г.дагола друге врсте од почетка XVI вијека: I. 1. јнјах (јеђах) Кап. грам. 120. јеђаше ("ћисћашс") 3бор. 44б. грејаше (мјесто гредијаше) Крн. 19б. - I. 5. нуњаше Ст. иис. 5, 346. 347. пропњаху Ст. ппс. 5, 139. - - I. 6. пђах Д. Рањ. 48. 71б. 92. нђаше Збор. 13. 45. 48. Ст. пис. 4, 417. 5, 138. Д. Рањ. 91. Злат. 17б. 87б. 100б. Гуч. 157. 173. 206. Радн. 17. 34. 38. Андр. пут 169. пођапе Ст. пис. 5, 143. иђахомо Гуч. 216. иђаху Н. Рањ. 205б. Збор. 81б. 102б. 107. Ст. пис. 4, ХІ. Град. дјев. 27. Злат. 53б. Банд. 201. Гунд. суз. I, LIII. Радн. 19. 56. у пстога глагола са $j$ мјесто $f$ : пјапе Јерк. 40. пјаху Орб. 171.' II. поникњах Злат. 39б. сахњах Каш. грау. 131. брињаше Cт. пис. 4, XI. Капा. 53. зењапе Злат. 101. крењапе Вран. жив. 49. гињаху Мрн. 49. ${ }^{2}$

бб) у г.лагода треће врсте другога раздјела и у онпјех ирвога раздјела који су прешлп у други који пмају имперфекат од основа каке су пм у ннфннитиву (впди под Б), али се од свршетка $\mathrm{XV}$ впјека у овом облику помијешаше с глаголима четврте, који тај облик пмају од основе кака им је у садашњем времену (у 1. дицу јед.):

1 Он пише iуahu, али може бити да му је y гласило $\hbar$.

2 Таки могу бити п ови примјери: целуњах Ст. пис. $2,258$. вењаше Ст. пис. 3,320 . гнњаше 4,139 . вењаху 3, 318. али може бити да бу мјесто -на-требало титати -мија-. - По ономе што је речено напријед под г) валази се и идјаше Вран. жив. 74. Банд. 52. Мрн. 45. 62. дојдјаше Мрн. 55. пдјахомо Мрн. 170. идјаху Банд. 118. а тако и у глагола који је од другпх примио на крају основе д: смидјаху Мрн. 36. види п вапрпјед под а. 
1-во јед.: вијах 3ор. 20. впђах Злат. 62. Гунд. I, LIV. Мик. грам. 23. горах Вран. жив. 116. жељах Зор. 1б. 6б. Злат. 46. Орб. 19. Мрн. 55. пожељах Ст. пис. 2. 265. живљах Ст. пис. 1, 306. 2. 326. 4, 394. Д. Рањ. 71б. Зор. 21. Злат. 19. жуЂах Ст. пис. 4, XI. мњах Зор. 75б. Злат. 97. Гунд. суз. II, XXI. Банд. 46. Крн. 20. мљах Ст. пис. 4, 82. сјеђах Злат. 45б. хћах Злат. ⒐ 40. 65.

2-го и 3-ће јед.: бђаше Збор. 105б. Град. дјев. 88. боъаше Каш. 92. виђапе Н. Рањ. 74б. 174. Д. Рањ. 23.71. Град. дјев. 181. Злат. 16б. Гуч. 146. Радн. 25. вијаше Стар. 4, 112. 116. Зор. 2. гораше Ст. шис. 1, 261. Зор. 66б. Злат. 100б. грньаше Збор. 115. Мпк. грам. 38. жељаше Ст. ппс. 4, ХІ. Град. дјев. 87. Брн. 66б. Гуч. 238. Банд. 49. Бун. 25. Каш. 54. Пос. 43. Радн. 34. живљаше Ст. пис. 1, 275. Д. Рањ. 56. Каш. 19. жуђаше Збор. 90б. Гуч. 252. Злат. 13. жујапе Јерк. 30. лећаше Ст. пис. 2, 279. Злат. 53. 69. Орб. 111. мњаше 3бор. 1. Хект. 3б. 33б. Стар. 4, 113. ненавиђаше Н. Рањ. 193. сјеђаше Н. Рањ. 82. 92. 123б. Збор. 1б. 107. Гуч. 233. спјаше Стар. 3, 314. Зор. 4б. смрђаше 3бор. 7б. 71б. 77б. тршљаше Ст. пис. 1, 200. Н. Рањ. 131. Гуч. 208. Вран. жив. 12. Див. $13 б$. Орб. 114. Банд. 145. Каш. 47. Радн. 8. ћућаше Гуч. 231. хоћаше А. Рањ. 106. хћаше Злат. 10. кћаше А. Рањ. 130. Злат. 27б. цапћаше Гунд. суз. I, XXIV. цћаше Д. Рањ. 52б. цкњаше A. Рањ. 20. Ст. пис. 5, 144.

1-во ми. с вокалом пред личнијем наставком: сјеђахомо Н. Рањ. 88б. жебахомо Зор. 6. мњахомо Н. Рањ. 13. 101. Збор. 72. 126. Cт. пин. 1, 285. 4, 307.'

2-го мн. с вокалом чред личнијем наставком: вијахоте Јерк. 45.

3-ће мн.: виһ,axy Н. Рањ. 70. Збор. 95б. Ст. пис. 4, XI. Ірад. дјев. 27. З.лат. 17. Гуч. 289. Радн. 24. вишаху Ст. пис. 5, 144. врвљаху Ст. ппс. 1, 12. жељаху 3ор. 32. Буд. 137. Банд. 10. Каш. 37. жпвљаху Орб. 49. Каш. 96. Радн. 63. жујаху Јерк. 75. јизјаху Ст. пис. 1, 12. лећаху Злат. 49. мњаху Злат. 80б. ненавијаху Стар. 1, 227. сјеђаху Н. Рањ. 85б. 196. Злат.

' На пошљедња оба мјеста не може се правописа ради звати је ліг мюа- или мнија-, а овдје се оба спомину ради вокала пред личпијем наставком. 
45. спјаху Стар. 4, 117. Зор. 10б. трпљаху Ст. пис. 1, 268. Радн. 34. хћаху Злат. 86.'

ж) основе у којих се м мијења на $a$ предњега rдаса ради налазе се кад кад и са т непромијењеним, а онда им ни чредњи гласови нијесу промпјењени у гдасове којих ради би се г промијенило, и тако се основе с наставком ја мијешају међу основе с наставком а: то се налазу кад кад у глагода четврте врсте, и са к које тада имају изједначује се и сажима $a$ које за вим иде: од свршетка XV вијека: молеше Стар. 4, 143. веселише Ст. пис. 1, 64. ухитише Ст. пис. 1, 49. жуберијеше Ст. пис. 2, 511. цви.лише Д. Рањ. 59б. слидијеше Злат. 17б. ресијеше Злат. 53. - 3-ће мн.: плодијеху Злат. 48. - Тако ће бити к реченијем начином дошло a по том са $a$ које за њим иде изједначено па и гласови $з$ и $c$ пред вим остали непромијењени, прем да врло ријетко, али још од почетка XVI вијека: улазапе Н. Рањ. 41. Банд. 33. излазаше Каш. 47. излазаху Н. Рањ. 142. грозах Ст. пис. 2, 438. носаше Ст. пис. 3, 320. 5, 127. Види и код Б. д.

з) У глагода друге врсте налази се овај облик и без н, али врдо ријетко: са сажетијем -қа- у т као шод б): посведих Ст. пис. 2, 248. 325.

и) Неки глаголи који имају овај облик од основе капва им је у садашњем времену, имају га и од основе каква им је у инфинитиву: види под Б. е.

b. Основе као у инфинитиву:

a) у основи остаје крајње гласећи према народном roвору :

-1-во лице јед.: III. 1. умијах Каш. грам. 119. разумијах КапI. грам. 119. - III. 2. мнијах Банд. 51. хотијах Н. Рањ. 23б. Ст. пис. 5, 197. Вран. жив. 106. Каш. грам. 101. Мик. 766. хтпјах Ст. пис. 5, 251. Злат. 46. ктијах Ст. пис. $3,336$. тијах Ст. пис. $4,482$.

2-го и 3-ће јед.: III. 1. вмнаше Збор. 43. разумијаше Каш. 86. 103. Радн. 6. 93. чтијаше Вран. жив. 47. 53. по-

' Шо овом пाто је реqено вапријед под е) валази се у неких писапа и ненавидјаху (у рукопису nenavidgiahu) Стар. 1, 227. сндјах 229. видјаху Банд. 100. сидјахомо 77. видјахомо Мрн. 170. 
чтијаше Гуч. 133. штијаше Стар. 1, 227. - III. 2. зржашс Стеф. 16. видијаше Гуч. 289. желпјаше Јерк. 75. завпдијаше Гунд. суз. I, XI. мниаше Стар. 3, 302. Ст. пис. 4, 289. ћутпјаше Гуч. 303. хптијапе Банд. 221. хотијаше Н. Рањ. 59. 193. хотнхше Збор. 2б. 5б. 13. Ст. пис. 4, 275. Град. дјев. 156. Вран. жив. 89. 91. 112. Див. 32. Орб. 112. 278. Банд. 33. 211. Јерк. 57. 81. Капі. 26. 87. Радн. 35. 68. хтшхше Збор. 15б. 17. 446. Ст. пис. 4, 114. 372. 5, 140. Каш. 81. 99. ктијаше Ст. пис. 3 , 462. 5, 332. Радн. 20. 25.

1-во мн.: а) с вокалом пред лпчннјем наставком: III. 1. умијахомо Ст. пис. 4, 414. - б) без вокала пред личнијем наставком и са $x$ : хтпјахмо Ст. пис. 5, 217.

3-ће мн.: III. 1. умпјаху Каш. 6. разумпјаху Банд. 144. Канг. 6. - III. 2. бдијаху Радн. 49. даждијаху Гунд. суз. II, XXVII. желпјаху Радој. 20. летијаху (letjahu) Cт. пис. 4, 283. мнијаху Банд. 25. хотијаху Вран. жив. 58. Орб. 43. 115. Каш. 62. Радн. 44. 51. хтијаху Н. Рањ. 207. Ст. пис. 4, 481. 5, 215. д. Рањ. VIIб. Гуч. 217. Каш. 38.

б) с крајњпм ₹ у основи изједначује се $a$ које за вим иде, те се оба сажимају у једно в, које гласи тројако у садапњем говору:

1-во јед.: III. 1. пмпх Ст. пис. 2, 15. -- III. 2. везих Ст. нис. 2, 258. цаттпјех Ст. пис. 4, 90. цтијех Ст. пис. 3, 62. ктијех Ст. ппс. $3,362$.

2-го и 3-ће јед.: III. 1. зрише (maturescere), А. Рањ. 29. импше Ст. пис. 1, 8. 32. 4, 112. А. Рањ. 142б. Зор. $10 б . ~ 34$. Буд. 106. Злат. 86. Мрн. 33. умијеше Ст. пис. 3, 7. умише Хект. 33б. - III. 2. бјеснише Ст. ппс. 2, 249. блнједише Ст. пис. 4. 152. ведпше Ст. пис. 1, 19. видише 23. врвијеше Злат. 13. вријеше Ст. пис. $3,182.4$, 151. врише Злат. 48. 87. дахтијеше Ст. пис. 3, 302. жеднијеше 321. желипе Ст. пис. 1, 32. 300. 2, 375. Хект. 16б. 25б. желпјене Ст. пис. 2, 202. 227. 4, 176. жудпјеше Н. Рањ. 5ะб. зелепијеше Ст. пис. 2. 511. јездише Стар. 3, 261. летијеше Ст. пис. 3, 255. мнијеше Ст. пис. 3, 311. 4, 166. мнише Стар. 3, 323. Cт. пис. 2, 375. Д. Рањ 296. сједпјеше Н. Рањ. 70. 74. 90. 103б. 192б. 213б. сједппе Н. Рањ. 98. смрдпјеше Ст. пис. 5, 120. стидшие се Стар. 4, 76. трептијеше Ст. ппс. 3, 54. 258. 317. трпијеше Н. Рањ. 169. хоти- 
јеше Н. Рањ. 20. 25. 350́. 184. Ст. пис. 3, 345. 4, 157. 162. 5, 121. 127. Див. 32. хотнше М. 254. Збор. 1б. 37. Стар. 3, 264. 4, 116. Ст. иис. 5, 218. Банд. 169. Крн. 11. Јерк. 83. хтијеште Н. Рањ. 4б. 826. 154. 3бор. 38б. Ст. иис. 2, 55. 132. 226. 3, 311. 326. 4, 133. 290. 472. 5, 123. 215. А. Рањ. IX. Злат. 71. хтише C'т. пис. 2, 33. 378. 5, 175. Хект. 13. 33б. Зор. 4. Буд. 79. Банд 71. ктијеше С'т. ппс. 3. 8. 149. 4, 231. 454. 5, 298. цавтнјеше Ст. пис. 4, 451. щафтијеше Ст. пис. 2, 292. цаптијепе Cт. пис. 4, 30. 108. 397. цафтише Ст. пис. 2, 246. 396. цтијеше Ст. пис. 2. 264. 515. 3, 52. 4, 29. 117. 119. 139. 184. 469. Здат. 39б. цтиіге Ст. пис. 2, 253. Д. Рањ. 97б. 139. цкнише Злат. 87.

1-во мн. с вокалом пред личнијем наставком: III. 1. нимихомо Ст. пис. 1, 102. -- III. 2. мнијехомо Н. Рањ. 210. мнихомо Ст. пис. 1, 287. хютћхмо П. 176. хтихомо Ст. пис. 5, 217.

3-hе мн.: III. 1. имиху Ст. пис. 3, 246. Стар. 1, 223. Хект. 46. 7. Мрн. 44. умиху Хект. 23. разумијеху Н. Рањ. 37. разумиху Стар. 3, 240. Банд. 79. - III. 2. видијеху Ст. пис. 5, 314. видиху Д. Рањ. 55. вриху Д. Рањ. 23. дахтијеху Злат. 17. зрвхоң Стар. 4, 76. мнијеху Н. Рањ. 29б. Ст. пис. 4, 178. мниху Ст. пис. 1, 84. сједијеху Н. Рањ. 193б. спдиху Ст. пис. 1, 94. прпседиху 79. трептијеху Ст. пнс. 3, 305. трептиху Д. Рањ. 55. хотпјеху Н. Рањ. 39. 70б. хотиху Ст. пाг. 1, 6. 68. Буд. 137. Банд. 146. хтијеху Н. Рањ. 166. Ст. пис. 3, 336. 338. 4, 307. хтиху Ст. ппс. 1, 5. Хект. 23. 3ор. 22. тиjexy Ст. пис. 3,321 . цафтијеху Ст. пис. 3 , 58. пафтиху Ст. пис. 2, 421. цтијеху Ст. пाис. $3,76.255 . '$

в) ₹ на крају основе претворено предњега гдаса ради у $a$ сажпм се са $a$ које за нци иде:

2-го и 3-ће јед.: држа̃ше Злат. 17б. лежаше Злат. 21. мучаше Н. Рањ. 91б. мјесто стоја- сажето ста- (као и у инфпнитпву): сташе Ст. пис. 4, 95. Вран. жив. 17. Бун. 49. Каш. 91.

1-во мг.: с вокалом иред .пчнијем наставком: држахомо Вран. жив. 25. стахомо (сажето ста- од стоја-) Гуч. 233.

3-ће мн.: стојаху Ст. пис. 5, 64. и сажето : стаху Н. Рањ. 92. Ст. пнс. 4, 408. Стар. 4, 112. Банд. 86.

' Види и у Гласнику IX. 50. 
г) \$ основи на крају иза гласа пза кога би му се ваљало промијенпти на $a$ (као под в) налази се и непромпјењено па је с њим изједначено и сажето $a$ које за њим иде (испореди напријед под А. д): 1-во јед.: лежпх Стар. 1, 229. 3-ће јед.: лежише Ст. пис. $1,49$.

д) крајње у основи изједначује се са $a$ које за њим иде и с њим се сажима (испореди под А. в. ӝ.) III. 2. 2-го и 3-ће јед.: враше Ст. пис. 3, 384. 4, 96. 109. 141. А. Рањ. 526. Вран. жив. 90. прозраше Ст. шис. 5, 314. - 3-ће мн.: враху 3лат. 81. у других глагола тога раздјела врло ријетко: висанге Ст. пис. $3,343.350 .5,141$. 144. 146 . јездаше Ст. пис. 4, 109. три пута.

Ђ) крајње $a$ у основи сажима се са $a$ које иде за впм:

1-во јед.: V. 1. сисах Ст. пис. 4, 430. тезах Ст. пис. 2, 206.' - V. 2. двпзах 3лат. 80. уздпсах Злат. 45б. писах Мик. грам. 27. - VI. његовах Злат. 27.

2-1'0 и 3-ће јед.: V. 1. дарпваше Каш. 87. димаше Ст. пис. 4, 82. ждимаше Збор. 109б. жејаше Ст. пис. 1, 188. имаше Н. Рањ. 164б. Ст. пис. 2, 94. Злат. 99б. Јерк. 18. јимаше Врав. жив. 16. нимаше Ст. пис. 1 , 8. леживаше Вран. жив. 69 . измиташе Вран. жив. 46. одырлихе II. 29. спраљаше Зор. 75. сјаше Стар. 3, 307. Ст. пис. 3, 315. 5, 178. посгитапе Вран. жив. 37. спавапе Банд. 22. стављаше Збор. 37б. цваташе Ст. пис. 2, 386. целиваше Н. Рањ. 85. Збор. 40б. Банд. 74. читаше Вран. жив. 110. чташе Н. Рањ. 160б. птташе Банд. 141. mhame ${ }^{2}$ (legere) Стар. 1,226. забрањивапе Радн. 16. погрђиваше Радн. 28. сагрипиваше Радн. 21. скратјиваше Вран. жив. 77. опасиваше Банд. 211. пушћиваше Ст. пис. 1, 55. проскнеткнкаше Збор. 113. 118б. утјешиваше Андр. пут 173. захваљивашге Д. Рањ. 27. (види код инфпнитива пто је речено за ове пошљедње глаголе). - V. 2. двизаште Зор. 68б. Злат. 22б. Каші. 102. подвизаше Ст. пис. 3, 317. дрхташе Стар. 4, 112. Каш. 9. дркташе 3лат. 88б. јискаше Вран. жив. 40. лизаше Вран. жив. 111. писаше Мик. грам. 27. рјезаше Д. Рањ. 134б. пкргиташе Вран. жив. 90. - V. 3. даваше Злат. 99б. Вран. жив. 21. смјејаше

' Има партицил: чезаје Ст. пис. 2, 467. за то тај примјер ту стављам.

$2 \hbar$ стоји мјесто т не за то штто је имп., него вао у $и ћ е$ мјесто ито. 
се Злат. 53. - VI. ириближевапе се Банд. 27. пробуђеваше Град. дјев. 155. обаљеваше 3бор. 87. прикеzокаше М. 5. обишеваше Банд. 229. обесе жеваше Каш. 104. узвшеваше Вран. жив. 12. угашеваше Град. дјев. 155. разгласоваше Вран. жив. 39. погрђеваше Радн. 10. загрљеваше Зор. 68б. диєккаше Збор. 105б. одиљеваше Каш. 85. одиљоваше Град. дјев. 30. зламеноваше Каш. 70. казоваше П. 54. Каш. 13. показоваше Н. Рањ. 57. приказоваше Каш. 104. сказоваше Зор. 2. крипљеваше Банд. 16. помазеваше Н. Рањ. 85. размпшљеваше Банд. 4 iі. умножеваше Банд. 155. смућеваше Банд. 39. напредовапе Град. дјев. 85. паметоваше Каш. 98. исшитовапе Банд. 19. Каш. 20. пушћеваше Мрн. 57. допушћеваше Вран. жив. 66. припоручеваше Вран. жив. 16. Каш. 93. наређеваше 3бор. $46 б$. Каш. 4. посвећеваше Каш. 85. просвјетљеваше Град. дјев. 170. просвитљеваше Каш. 31. наслађеваше Збор. 78. Каш. 104. обслужеваше Каш. 38. становптјеваше Банд. 224. потврдјеваше Банд. 98. притисковаше Збор. 98. утишеваше Врап. жив. 74. захваљеваше Збор. 45б. схрањеваше Н. Рањ. 21б. сахрањеваше Банд. 11. целоваше Н. Рањ. 85. причешћеваше Град. дјев. 156. поштоваше Каш. 12.

1-во мн.: а) с вокадом пред дичнијем наставком свега времена: V. 1. прибивахомо Банд. 61. нмахомо М. 400. Стар. 1, 220. Гуч. 191. Kaап. 24. Мик. грам. 16. одкун.ьахомо Ст. пис. 1, 306. ругахомо Вран. жив. 25. посихахомо П. 130. уздахомо Банд. 139. уфахомо Збор. 112б. Мрн. 71. шнотахомо Вран. жив. 25. - V. 2. искахомо Каш. 21. 97. писахомо Мик. грам. 27. - VI. благовахомо Н. Ран. 88б. Банд. 77. - б) без вокала иред дичнијем наставком и са $x$ XVII вијека: V. 2. искахмо Банд. 20.

2-го мн.: с вокалом пред личнијем наставком од XV вијека: V. 1. пмахоте Ст. пис. 1, 301. Мнк. грам. 16. имаоте Пос. 11. чекахоте Јерк. 45. - V. 2. пскахоте Банд. 20. Каш. 21. пнсахоте Пб. 110. 113. Мик. грам. 27. - VI. погрђевахоте Збор. 55.

3-ће мн.: V. 1. имаху Ст. пис. 5. 34. Буд. 143. Јерк. 62. Каш. 82. самилаху 3ор. 75. узмитаху Ст. пис. 1. 12. нам.лзаху 3ор. 73. мрмњаху Банд. 25. мрмљаху Банд. 90. повидаху Вран. жие. 72. распинаху Ст. пис. 3, 321. сјаху Ст. пис. 3 , 75. стамахв М. 447. Н. Рањ. 140. остављаху Збор. 95. целиваху 
3лат. 48б. зачннаху Каш. 109. сагриниваху Радн. 22. подпдливаху (псујуһн подндливаху помањкање Давидово) Радн. 48. подраживаху Збор. 95. прикаживаху Ст. иис. 1, 159. Стар. 4, 116. прнказиваху Ст. пис. 1, 159. Банд. 263. Радн. 85. смуҺнваху Радн. 21. посвећнваху 3ор. 72б. наслајиваху Брн. 27. zахкхмикаху 3о́ор. 74б. 93б. - V. 2. двизаху Ст. пис. 1, 14.15: 44. Хекіт. 23б. подвизаху Ст. инс. 3, 336. здвпзаху Вран. жив. 37. подвигаху Мрн. 4. уздихаху Стар. 4, 118. дрхтаху Cт. пис. 1, 81. пондираху Мрн. 54. рјезаху Збор. 105.' - V. З. даваху Cтар. 4, 233. смјејаху се Ст. пис. 3, 322. 3лат. 43. - VI. бесидоваху Банд. 139. наваљеваху Банд. 98. навипћеваху Јерк. 25. пзврневаху Г'чч. 300. погрдјеваху Каш. 38. пзпсковаху Банд. 139. прнказоваху Град. дјев. 156. Банд. 40. подложеваху Мрн. 105. у.ижеваху (intrare) Вран. жив. 106. помазоваху Днв. 15. замипьљеваху Њанд. 153. снићеваху Зор. 1. упитоваху Бавд. 149. псоваху Кан. 66. поруговаху КаІІ. 52. притисковаху Банд. 237. пттовах! Јерк. 25.

е) Неки глаголи којима овај облик постаје од основе каква им је $y$ инфинитиву имају га и од основе каква им је у садапњем времену; види напријед под А. е - Измеђ глагода којима овај облик постаје од основе каква је у садапњем времену, неки та имају п од основе каква им је у инфинитиву: звах Н. Рањ. 24б. Злат. 27. браше Радн. 97. звапе Н. Рањ. 158. Орб. 54. брахомо Ст. пис. 5, 217. зваху Ст. пис. 5, 73. Мрн. 57. браху Ст. пис. 5, 315. а неки и немају другачнје него од основе каква им је у инфшнитиву: коваше З.ат. предгов. 1б. заткаше Крн. 5. ткаху Ст. пис. 3, 10.

\section{АВОЈИНА.}

Двојина се раздиюује од множнне само личнијем наставцима, а они су као у садапњем времену. Ни у другом ви трећем дицу није било вокала иред личнијем наставком, али како је у множини из ирвога лпца прелазио и у друго, таво је у двојини прелазио и у друго и треће једнако с другим: 3-ће без вокала пред дичнијем наставком : ривста Стеф. 21.

' IIIто се находи: ужнжаху Н. Рањ. 496. ржаху Злат. 17. према томе се находи и инфинитив: ражижати Н. Рањ. 1226. ржати Вран. рјеч. 44. 
с вокалом пред личнијем наставком: дркжахота ІІб. 22. тако у почетку XVI вијека још само у глагола бити (esse): дна дужника дужна бјехота Н. Рањ. 188б. тан бнехота сівге 3бор. 25. Хекторовић, гоји од истога гдагода у садашњем вр. још има кад кад двојину, у овом облику има мјесто ње само множину биху два сиромаха Хект. 126.

\section{А ОРИСТ.}

Основа му је онака каква је инфинитиву, а дични наставци онаки какви су у имперфекту, али је у главном двојак:

I. Један постаје од саме основе и личнијех наставака: основа му добија наставак i као у садашњем времену, кбји се у првом лицу јед. и у трећем мн. с личнијем наставком саставља у један глас, а ! другом и трећем лицу јед. и у другом лицу мн. гласи $e$ као у садашњем времену, а у првом лищу мн. гласи о. Аични се наставак у првом лицу јед.

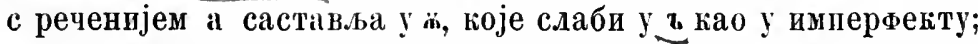
у другом и трећем лицу јед. окрњени лични наставци $c$ и $T$ стојеһи на крају отпадају као у имшерфекту; у првом лицу мн. дичн наставак гласи шн као у садашњем вр. и у имперфекту; у другом лищу мн. остаје лични наставағ те щио; у трећем лищу мн. $и$ се од личнога наставка с предњим а "саставља у ж. - Тај се аорист зове прости, и налази се само у онијех глагола којима је основа у инфннитиву сам коријен са сугласнијем на крају: међу жих иринада и г.лагол ити, коме се основа у пнфинитиву истина свршује на самогласно али у садашњем времену добија на крају д, те га добија и у аористу, п глаголи друге врсте, који у овом аористу одбацују у основи иж и тада им се свршује на сугласно.

II. Други добива између основе и дичнијех наставака исти глаголски облик који добива и имперфекат, али без црвога самогдаснога, те без дичнога наставка гласи Sil-. Од тога сугдасно $\mathbf{s}$ као у имнерфекту остаје кад се $\widetilde{\overline{\text { наһ̆ }}}$ гред сугласним, а кад је за ьим самогласно онда предази у словенским језицима у $\boldsymbol{x}$, али је у старо вријеме могло и пред самогдаснијем остати с; задње а отпада у 2 . и 3 . јед. и у 2. мн., а у 1. јед. остаје те се с личнијем наставком са-

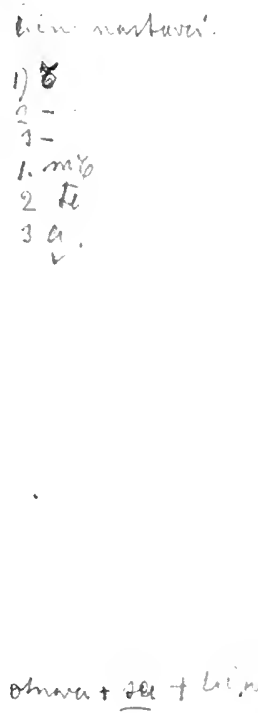

3

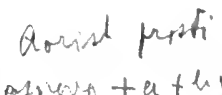

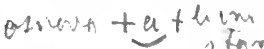


став.ъа у један гдас; у 1. мн. остаје гласећи о, али се у позније вријеме у српском језику избацйло према другом дицу мн., а тада је и с дошло мјесто $x$ према другом дицу мн.; у 3. мн. остаје а али слаби у $\mathbf{i}$, те се саставља с личнијем наставком у један глас. - Аични наставак у 1. јед. само m као у инерфекту саставља се са а које је шред вим $у$ ж, које слаби у к, а то у српском језику отпада; дични наставци у 2. јед. - и у 3. јед. $t$ не имајући за собом самогласнога отпадају као у имперфекту, а тада и s од гдагодскога облика који додази до основе нашавши се на крају без самогдаснога отпада: у 1. мн. дични наставак гдаси као у садашњем времену различно, а у српском језику одржало му се на крају о; У 2 мн. остаје лични наставак као у имперфекту и у садашњем вр.; у 3. мн. и, које као у имперфекту долази сано од дпчнога наставка, саставља се с предњим i посталия од а у $⿻$, пред којим се $x$ мијења у $u$ а које у српском језику гласи $e$. - Аорист поји овако постаје зове се сложенп. Али је он двојак према томе како се основа саставља с глагодским облнком sа - којн до ње додази:

1. основа онака каква је прима до себе $x$ ностало од s и само с кад се не мијења на $x$ : које се основе свршују на сугласно, у њих се крајње сугдасно изједначује сӓ сугласнијем $x$ нди с које за њим иде, те се један од оба једнака гласа избацује, а самогдасно се у основи продуљује, које се може продуљити, и то єу в, о у қ, ь и, в у оү. - Таки се

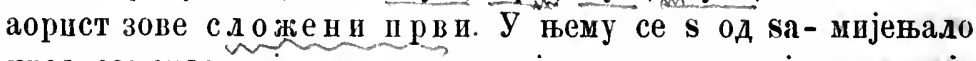
прел самогдаснијем онако како је речено, али је у старије вријеме остајало и непромијењено: по томе се први сложени аорист, у ком је с остајало и пред самогласнима непромијењено, може звати старији, а у ком се мијењало, млађи. Али ни старији ни млађ; није имао од основа на сугласно другога ни грећега лица јед., јер за та два лица по ономе IIто је речено не остаје ни сам коријен цио: ппак у глагола с основом на $u$ и в налазе се од старине и та два лица, а у сриском су се језику и у других глагола у којих се сачувво таки аорист, у позније вријеме начинила према осталијем лицима и та два без личнијех наставака и без $c$ иза основе, али се нијесу одржала. 
2. основа добива наставак а као у садапњем времену, и оно остаје гласећи у свијем лицима осим 2. и 3 . јед. $o$, а у та два $e$, па до њега долази с од sa- мијењајући се пред сугдаснима на $x$, п отпадајући кад се нађе на крају. - Тај се аорист зовесложени друг и и може бити само у онијех глагода у којих може бити прости (види нашријед под I).

Како је речено, у 2. и 3. јед. дични наставци не имају ћи за собом самогласнога отпадају. Истина, у старом словенском језику а по том и у старим српским књитама има: жысть М. 5. шұьвысть М. 90. дасть М. 4. 187. 571. н.четь М. 5. ириєть М. 9. али је ту лични наставак иренесен из садашвега времена да би дице у једном времену имало што има у другом; а како је у аористу 2. и 3. јед. једнако, узимало се треће лище тако вачињено и за друго. А што то није даље узело мах, томе һе бити узрок што је у некнх Словена нестало аориста, а у других (као у Срба) одбацио се лични наставак и у садашњем времену у 3 . јед. - Исто $T$ које се налази додано у садашњем вр. иза трећега лица јед. и мн. (види стр. 275. 290), налізии се додано и иза 3-ћега јед. аориста, прем да много рјеђе: да т Н. Рањ. 140. сједе т Н. Рањ. 1886 .

Речено је напријед да лични наставак у 1-вом мн. различно гласи као и у садапњем вр. (види код сад. вр.) али да је у српском језику остало мо и да је пред њим у Српском језику избачен вокал према 2-гом дицу мн., те се и с мјесто $x$ повратило: тако је у нас од првијех времена: кхиосковнсмо М. 13. писно (имсмо) Сав. стар. 4, 231. палкисьмо се Стеф. 19. - Долази -мо и с вокалом пред собом и по том са $x$ мјесто с, али рпјетко и истом од друге половине XIV вијека и престаје XV вијека: поскахомо Пб. 32. кристихомо М. 257. 430. - чешће долази -м10 б́ез вокала шред собом а са $x$ мјесто с, п то од XIV вијека иа допире у XVI: zмпискмио М. 131. спракихно ІІІаф. pam. 1873. 111. бихмо Ст. пис. 5,98. ${ }^{2}-$ Често долази и -мь имајући вокал иред собом и пред њим $x$, али у сиоменицима $y$ којима се тако узимало јамачно пз

1 Beiträge zur vergl. sprachforschung VI. 184.

2 Јамачно су писарске погрјепке XVI вијека ндходнхсмо, одтоворнхсмо IIIaф. pam. 1873. 111. 


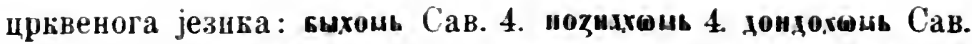
стар. 4. 230. квдқтонь Стеф. 29. пожртхонь 22. прнхожнхон. М.

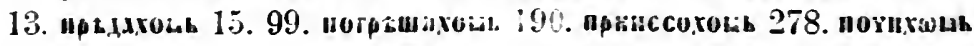
332. - На.1азп се и ин ! спо:еншку инсану црквенпјем језикоу, али опет без вока.1а и ио том са с мјесто х: штидосин Стеф. 29. погртшнсин 19. сьторнсьиы 29. - Будући да је само завршетак -мо остао ! српском језнку, за то hе се даље наводити иримјери за то .ице само с њим, а о оба пошљедња завршетка биһе дово.ьно ово што је речено.

Прости аорист (внди иод I) на.1ази се у наших црквенијем нњигама ! свијем .ицима: 1-во јед.: "зндь, 1-во мн. wrskpьrouh, 2-го зн.: нзндетс Стар. 3, 72. ! другим књггама нашим гоје су шисане црквенијем језиком налази се 3-ће мн.:

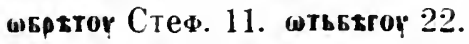

ІІрви с.1ожени старији (види шод II. а) ва.дази се само у црквенпјем ьњигама: 1. јед.: тсь, прнксь, 1 . мн.: кынтсошь, вьит-

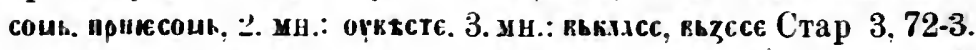

Оба оста.да аориста, први сложени м.лаһи и други сложени. сач!вала су се ! сриском језвку, али од основа на сугдасно сач!нао се први сложени м.дай само у неколико r.1ar0.1d.

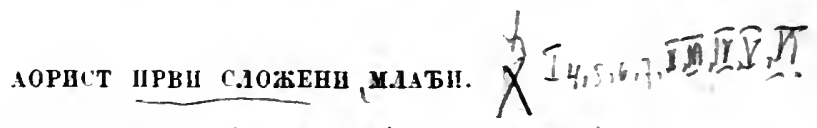

А. Основе на спг.1асно (осим онијех на $\boldsymbol{н}$ и. ):

1-но јед.: I. 1. изих Вран. аив. 107. - I. 2. ломихи ПІб. 51. 58. 60. погинек 3бор. 96. Ст. пнс. 5. 111. поннх Ст. пис. ‥ 240. 258. 332. подних ,. Рањ. 80б. - - І. 4. рнехь 3бор. 32. Ст. пис. 3. 316. 4, 101. 103. 5, 112. 178. Гуч. 58. Гунд. суз. I, LI. p프 Ст. нис. 1. 31. 2. 33. 4, 330. А. Рањ. 8. Хект. 5б. 34. Зор. ¿об. З.дат. 3. дорих Ст. нис. 2, 232.

2-го и 3-ђе јед. І. 1. ји Ст. иис. 1, 257. Вран. жив. 91. !ји 3ор. 63. изије Ст. пис. 3,475 . - I. 2. понг П. 112. доnх П. 114. 178. Пб. 55. 58. дони Ст. пис. 1, 45. 188. 2, 237. 4, 405. Хект. 11б. З.лат. 1£б. зани Ст. пис. 2, 267. Мрн. 54. одни Ст. пис. 1. 51. 5, 31ю. Зор. 37б. Крн. 2об. пони ( т. пис. 1, 4і. $2,94$. 125. 320. подни Ст. иис. $1,196.5,36.43$. А. Рањ. 10б. донвје Ст. пис. 4, 127. 5, 119. 230. З.ат. 28. Орб́. 29. заније Ст. пис. 2, 57. 4, 86. 103. 121. изније Н. Рањ. 8̌́б. поније Ст. пис. 
4, 100. Злат. 99б. Гуч. 205. подније Збор. 117. Ст. пис. 3, 428. 4, 230. 5, 118. Град. дух. 44. дјев. 77. Гуч. 191. Андр. нач. 17. дев. 143. пут 214. приније Ст. пис. 4, 85. Злат. 46. - I. 3. расв М. 217. посу Вран. жив. 92. "спхе Стар. 4, 84.

1-во мн.: без вокала пред личнијем наставком: I. 1. јисмо Хект. 5б. - I. 2. понијесмо Н. Рањ. 34. поднијесмо Ст. пис. 5,236 . изнијесмо Ст. пис. $4,135$. - I. 4. рисмо Хект. 17. ријесмо Гуч. 9.

2-го мн.: I. 4. ристе Ст. пис. 1, 286. 288.

3-ће мн.: I. 1. јцше Ст. пис. 1, 75. Хект. 7б. Мрн. 39. најише Ст. пис. 1, 257. објише Ст. пис. 1, 48. јеше Ст. пис. 5, 123. изише 237. - I. 2. пртиєше М. 102. доптше П. 51. 105. 106. прнитие П. 111. прнинแе М. 292. понтше М. 350. II. 66. 67. занине Ст. пис. 1,41 . однише Ст. пис. $1,26.56$. узнипе Ст. пис. 1, 8. донијепе Н. Рањ. 31. Збор. 31. ванијепе Ст. пис. 4, 154. 292. однијеше Ст. пис. 4, 482. поднијеше Ст. пис. 5, 123. Град. дјев. 85. Г'уч. 191. поднише Каш. 93. - I. 3. посупе Вран. жив. 38. -- I. 4. рише Ст. пис. 1, 10. Д. Рањ. 38б. Хект. 33б. 3ор. 60. puјеше Н. Рањ. 14б. Збор. 35. Ст. пис. 4, 112. 5, 216. Злат. 43.

Сви наведени глаголи, осим она два прве врсте трећега раздјела, пмају и други сложени аорпст (види даље), а у она се два налази само овај.

Глагод у кога је основа у инфинитиву къдћ једнак будући с глаголом јести у садапњем времену, у ком су оба шмала основу без наставка, изједначивао се с њим п у аористу на крају XV п XVI вијека: 1-во јед.: впх Ст. пис. 2, 33. 141. 209. вијех Ст. пис. 4,172 . - 3-ће јед̄.: пови Ст. пис. 1, 185, али је пмао и прави свој аорист (види под Б).

Б. Основе на самогласно; међу њих ваља овдје увети и оне које се свршују на сугдасна $\mu$ и $\mu$, али се ти гласовп с предњим самогласнијем састављају у самогласна и ж кад за впма нема самогласнога, као што га нема у овом облику :

1-во јед.: I. 5. зачскь М. 4. заучех Ст. пис. 2, 438. почех Вран. жив. 106. почах Ст. пис. 1, 276. вазех Ст. пис. 2, 138. 4, 83. 121. Здат. 21. Врап. жив. 93. узех Ст. пис. 5, 217. пријах Ст. нис. 2, 168. 194. 212. 256. 326. Хект. 36. Зор. 5б. Вран. 
жкив. 33. Банд. 25. ${ }^{1}$ - I. 6. пих М. 6. 124. 174. 234. 488. 546. 564. Збор. 126б. Ст. нис. 2, 117. 120. 202. 426. 4, 418. 5, 37. 111. Злат. 70. Вран. жив. 106. ирндххи М. 62. 130. Збор. 33б. про„ахь 3бор. 25б. прједах Ст. пис. 5, 178. подах Чубр. 5. Бапд. 223. узазнах Ст. пис. 5, 271. завапих Ст. пис. 2, 394. чух Ірад. дјев. 173. пех Зор. 76. од основе кт: кихь М. 4I1. Злат. 5. - I. 7. од основе ращирене као у ннтинитиву: умрих Ст. пис. 2, 433. А. Рањ. 88б. Злат. 2б. Вран. жив. 80. прострих Хект. 42. прострпјех Гунд. пс. 35. разастријех Андр. пут 75. од основе нераширеге која се ни у инфинитиву не шнри: сатрх Ст. пис. 2, 485. - II. одбјегнух Н. Рањ. 35. повенух Ст. пис. 2, 221. 246. извехнух 461. погинух Ст. пис. 2, 388. Злат. 16. Вран. жив. 14. пригнух Ст. пис. 3, 23. 4, 105. одахнух Ст. пис. 2, 398. двигнух Ст. пис. 5, 290. клекнух Вран. жив. 107. усирегнух Ст. ппс. 2, 387. сахнух Ст. пис. 2, 398. остинух Ст. нис. 2, 388. устегнух Ст. пис. 2, 387. - III. 1. рхұвмехи II. 56. умих Зор. 10б. - III. 2. прнбдјех Ст. пис. 4, 290. покекиєхь М. 312. пиянхи М. 444. видих II. Рањ. 30. огрубјех Ст. шис. 5, 39. жикисхи Збор. 93б. Злат. 45. Андр. дев. 48. желих Н. Рањ. 102. жељех Ст. пис. 4, 81. І'уч. 279. жудјех Ст. пис. 5, 86. зрнх Злат. 16б. назрјех Здат. 64. обазрјех се Н. Рањ. $100 б$. узрих Ст. пис. 2, 117. позрјех Ст. пис. 4,192 . јехтјех Ст. иис. 4, 136. инъхь П. 13ј. Ст. пис. 4, 86. 110. слпједјех Бун. 17. сњех Ст. пис. 4, 405. усњех Ст. пис. 2, 403.8 oһy'гјех Г'уч. 286. хтих Ст. пис. 2, 435. птјех А. Рањ. 32. І'унд. піс. 25. тих Cтар. 3 , 274. цкних Злат. 8. тако и у глагола те врсте који је садапюе вр. имао без наставка у основи: пронокндехи Збор. 30б. сповпдих Ст. пис. 2, 62. 85. Злат. 61. повидих Мрн. 143. исповидјех Андр. дев. 42. - IV. кагосокихь М. 457. обујмих Ст. нис. 2, 465. поники Збор. 32. ирнмихи М. 329. 443. 502. Ст.

1 Има и у других : јах Ст. пис. 4, 293. 290. пријах Ст. пис. 4, 43. 142. 5, 53. 351. али они узимају тај глагол међу оне пете врсте (види код пнфинитива и садашњег вр.)

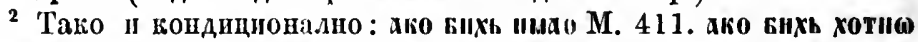
М. 500. али и само би XV вијека аво није погрјешка у прс-

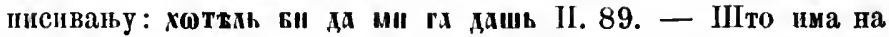
једном мјесту внмь, за цијсло мислим да треба читати Би шмь: мохите киеzх кинега, како кй (н)мь рукв дакь М. 54.

3 Тако у ову врсту прснесено налази се п учињех Андр. пут 356. 
пис. 2, 215. 5, 193. снимгх 3бор. 104б. сусрптгх Мрн. 33. отјеpux Ст. пис. 4, 282. чтих Злат. 43. прочтих Ст. пис. 4, 122. - V. 1. уфах Ст. пис. 3, 453. згромињах Ст. пис. 3, 23. V. 2. додијах Ст. нис. 2, 341. подвизах Ст. пис. 3, 273. V. 3. разабрах Ст. пис. 4, 43. смјејах се 3лат. 53. - VI. нјеговах Злат. 27. окетокхх М. 414. почтовахь Збор. 27.

2-го и 3-ће јед.: I. 5. zакає М. 414. закље Зор. 36б. припе 3лат. 69. заче Ст. пис. 1, 238. Вран. жив. 111. Глав. 14. наче Ст. пис. 4, 440. поче Ст. пис. 1, 16. 177. 179. 187. 284. 296. Стар. 4, 113. Хект. 4. Зор. 66б. Злат. 45б. Вран. жив. 7. Крн. 12. Mpн. 47. приче Хект. 18б. поча Ст. пис. 1, 284. 324. Стар. 1, 226. 4, 112. 113. Брн. 23б. Мрй. 30. Јерк. 45. прича Ст. ппाс. 1, 9. 15. Н. Рањ. 164б. ја Ст. пнс. 1, 9. 47. 82. Хект. 16б. наја Банд. 46. поја Ст. пис. 1, 5. Зор. 2б. Банд. 27. прија Ст. пис. 1, 5. 19. 2, 221. Зор. 30б. Вран. жив. 22. Банд. 93. обуја Ст. пнс. 1, 5. Н. Рањ. 174. Зор. 29. Стар. 3, 298. Вран. жив. 14. зауја Мрп. 44. изе Ст. пис. 1, 52. Н. Рањ. 97б. Збор. 17б. Ст. пис. 2, 497. 4, 223. 441. 5, 118. А. Рањ. VIIIб. 25б. Злат. 88. І'унд. суз. I, XXVIII. оте Ст. пис. 1, 113. прие М. 530. вzе M. 226. 400. Злат. 92б. вазе Cт. пnс. 2, 71. 4, 295. 304. Стар. 4, 113. Злат. 91. Вран. жив. 39. взе Ст. ппгс. 1, 47. обује Вран. жив. 44. изне Стар. 3, 319. сне Стар. 1, 53. наду се Ст. пис. 4, 262. - I. 6. прхда (пз познијега пријеписа) М. 18. прждаa Стеф. 18. продх Сар. 6. ирида М. 62. 63. пртдах (из позинјега пријеписа) М. 72. да М. 94. а М. 220. 226. II. 115. прода М. 260. 287. 307. 311. 383. 414. 4ः,6. да Н. Рањ. 13б. 20б. 37. 57. Збор. 26б. Ст. нис. 2, 75. 339. 3, 149. 267. 4, 103. 5, 149. 217. Град. дјев. 10. Злат. 17б. 47. Гуч. 13. Вран. жии. 7. Див. 11. Гунд. суз. III, XCI. Банд. 105. Бун. 32. Андр. пут 358. зада Злат. 13. изда Ст. иис. 2, 60. 76. пода Град. дјев. 81. Злат. 67. Вран. жив. 23. Гунд суз. III, LXXIV. Банд. 46. Андр. дев. 32. прида Н. Рањ. 94. Збор. 26. Ст. пис. 4, 454. Злат. предгов. Зб. Див. 27. Каш. 40. прода Каш. 67. разда Стар. 3, 276. узда Ііанд. 28. позна Вран. жив. 102. Банд. 12. ста Н. Рањ. 27б. Збор. 93. Ст. пнс. 2, 318. 4, 139. Хект. 6. Злат. 21. Гуч. 39. Вран. жив. 18. Орб. 32. Банд. 19. Андр. дев. 133. шста М. 507. приста Н. Рањ. 41. уста Вран. жив. 110. изби (пламен) Н. Рањ. 496. обвп Н. Рањ. 57. завапи Ст. пис. 1, 56. свапи Ст. пис. 2, 207 
Іпи Н. Рањ. 45. Збор. 113б. Вран. жив. 91. чу Здат. 11. оүты Стет. 23. задје Злат. 64. оди Брп. 42. Вран. жив. 99. пе Ст. пис. 1, 149. запје (мјесто садашњега вр. Мат. 26, 74) Н. Рањ. 92.' смје Ст. пис. 4, 209. од основе кт: км Стеф. 23. ки М. 4. II. 55. Н. Рањ. 16. доби Здат. 1. звни се Збор. 26б. - I. 7. од рапирене основе: одрпје Бун. 47. подрије Гунд. суз. III, XIV. раздрп Ст. пис. 4, 441. Банд. 46. раздрпје Ст. пнс. 5, 142. Злат. 87б. разадри Вран. жив. 76. иожри Стар. 1, 232. нождри Банд. 49. прождрпје Гунд. суз. I, XLVII. умрије Ст. пис. 4, 232. 5, 110. Град. дух. 84. Здат. 97. Див. 25. умри Стар. 1, 228. Враш. жив. 52. зачрије Ст. пис. 3, 208. заири Вран. жнв. 64 . наприје Злат. 89. одапри Вран. жив. 102. впрне Збор. 112. прострије Н. Рањ. 44б. Збор. 98. Град. дјев. 90. Здат. 81. Орб. 32. Бун. 41. Андр. нач. 43. прострп Вран. жив. 68. Банд. 65. Кан. 108. разастри Вран. жнв. 37. обастрг Стар. 1, 235. Банд. 47. такође од рашџрене основе на једном мјесту : сатри Ст. пис. 4, 452. од исте основе нераширене: отр Н. Рањ. 77. 189. 3бор. 110. Банд. 66. потр Ст. нис. 1, 16. 62. шритр Зор. 72. сатр Ст. пис. 4, 451. Андр. пут 150. затр Радн. 66. нзмеђу основа ьоје се пшре једном и од нераширене XVII вијека: обастр Радн. 73. - II. одбјегну Ст. пис. 2, 417. побјегшу Град. дјев. 96. побигну Злат. 14. Вран. жив. 22. обисну Gт. пис. 1, 202. 3, 152. Здат. 73. повехну Ст. иис. 2 , 475 . повену Ст. шис. $4,314.320$. приврну Ст. иис. $2,109 .{ }^{2}$ сврну 368. погину Злат. 91б. Вран. жив. 38. пригну 3бор. 48. Злат. 46б. сагну се 3бор. 71б. загрну Стар. 3, 277. пздахну Н. Рањ. 100. Град. дух. 57. Злат. 34. Вран. жив. 28. Орб. 171. Јерк. 69. Каш. 70. Андр. пут 388. уздахну Н. Рањ. 68. Збор. 31. двнгну Збор. 45. Орб. 11. Каш. 18. подвигну Ст. пис. 1, 50. Вран. жив. 37. Крн. 11б. уздвигну Н. Рањ. 159б. Гуч. 238. Банд. 155. уздигпу Банд. 118. кину Ст. пис. 4, 441. клекну Збор. 9. поклекну Н. Рањ. 167б. ускрсну Н. Рањ. 126б. Збор. 124. Ст. нис. 3, 380. Вран. жив. 23. Банд. 138. Бун. 39. Каш. 101. Андр. пут 43. мину Вран. жив. 19. замукну Злат. 100б. приону Ст. пис. 2, 283. Хект. 12б. опрегну Ст. пис. 2, 33. успрегну Злат. 88б. усахну

- На једном мјесту, јамачно гријепком: узпа хвалу Јерк. 30.

2 Јамачно би тако требало читати и „privarnu“ Ст. пис. 2, 320. 
Банд. 26. свану Д. Рањ. 66. освану Здат. 1б. достигну Злат. 14. такну Банд. 21. дотакну Вран. жив. 47. дотегну Злат. $80 б$. истегну Банд. 141. потеги М. 502. Каш. 88. растегну Ст. пис. 2, 33. стегну Злат. 80. затнски 3бор. 7б. притискеу Град. дјев. 176. стнскив Збор. 120. тисну Ст. пис. 1, 202. затнснв Збор. 7б. притисну Ст. пис. 1, 90. Стар. 3, 309. Банд. 49. стнснв Збор. 80. Д. Рањ. 64б. Каш. 75. протрну Злат. 72б. стрну Ст. пис. 5, 216. утрну Вран. жив. 68. целуну Н. Рањ. 91. Ст. пис. 2, 248. КаІІ. 49. - III. 1. пми Ст. пис. 1, 32. - III. 2. вндє Пб. 110. изаврје Гуч. 248. падазре Ст. пис. 2, 353. обазре Ст. пис. 2, 353. zагрине Збор. 116б. жекие Збор. 110. же.је Д. Рањ. 63б. жикн М. 519. живје Н. Рањ. 26. Збор. 48б. Злат. 97. Див. 19. Андр. нач. 17. оживје Н. Рањ. 58б. омуча Н. Рањ. 166б. Див. 30. стаја Радн. 17. сажето: ста Зор. 37. затаја Вран. жив. 113. иритрпје Збор. 48б. хоти Н. Рањ. 101. Ст. пис. 2, 433. Вран. жив. 64. хотје Ст. пис. 4, 453. хтнє М. 239. хтв 367. хтнє Збор. 99. хтје Ст. пис. 4, 453. 5, 34. Д. Рањ. VІб. Злат. 72. хти Н. Рањ. 167б. Хект. 11б. ктје Ст. пис. 3, 44. 297. 4, $221.5,304$. А. Рањ. 4. Гуч. 134. Див. 30. Андр. дев. 9. кти Д. Рањ. 25. Банд. 58. Радн. 21. ти Стар. 3, 283. нкнне Збор. 107б. процавтје Ст. пис. 5,338 . "роџтне 3бор. 121.' тако и у г.лагода те врсте који је садашње вр. имао без наставка у основи: повида II. 94. покндне Збор. 27б. повиди Хект. 48б. Злат. 10. заповидје Н. Рањ. 31б. Збор. 1. Град. дјев. 73. Гуч. 142. Андр. пут 254. оповидје Град. дјев. 161. спокнд П. 25. З.ат. $80 б$. изувиди Вран. жив. 87. Мрн. 47. - IV. приб.ази Ст. пис. 2, 265. ускријеси Банд. 89. занори Злат. 87. понузи Ст. иис. 4, 76. вадри Хект. 33б. удри Злат. 88б. Вран. жив. 68. Банд. 98. најеми Н. Рањ. 34. обујми Н. Рањ. 21. Ст. иис. 2, 119. 484. 3, 140. А. Рањ. 130. Град. дјев. 139. Злат. 90. Гуч. 303. ириии М. 310. Ст. пис. 1, 60. Збор. 37б. Д. Рањ. 66б. Град. дјев. 87. Злат. 3б. слими Ст. пис. 4, 253. дотјери Ст. пис. 4, 282. растјери Ст. пис. 3, 455. сусрити Вран. жив. 71. 100. прочти Вран. жив. 18. шти Банд. 175. - V. 1. прибива Врав. жив. 100. сажга Вран. жив. 77. има Гуч. 4. умча Стар. 3, 233. 278. запива Банд. 86. плива Ст. пис. 5, 311. хара Злат. 21б. -

1 У слику и видије Злат. 87б. скопније Ст. ппс. 2, 129. 
V. 2. веза Вран. жив. 41. вика Злат. 34. каза Вран. жив. 24. mıса M. 16. Н. Рањ. 183. пририеза Збор. 43б. уреза А. Рањ. 102. - V. 3. "зекрх М. 310. обра Буд. 76. рхұхгих М. 226. изагна Андр. дев. 399. дозва Здат. 13б. скова Ст. пис. 3, 9. додија Ст. пис. 5, 223. пхсмиек се Збор. 38. пхсмї се Стар. 4, 75. Д. Рањ. 7б. подсмјеја се Ст. пис. 5, 317. - VI. шьнтока П. 22. знаменова Вран. рјеч. 105. пютрневова М. 312. целова Ванд. 48. чтова Ст. пик. 1, 7. похтовх М. 310. 3бор. 276. Хект. 24. штова Ст. пис. 1, 307. поштова Ст. пис. $1,330$.

1-в0 мн.:

a) с вокалом пред личнијем наставком: IV. крьстияомо М. 257. 260. 275. 430. - V. 2. поскахомо Пб. 32.1

б) без вокала пред личнијем наставком али са $\boldsymbol{x}$ до основе: I. 6. од основе кт: бихмо Ст. пис. 5,98. - III. 1. рхzвмихмо М. 554. - IV. крьстихмо М. 239. справихмо ШаФ. рат. 1873. 111. - V. 1. "рогатдахмо М. 554. ниахмо M. 554. - V. 2. zаписахио М. 131. - V. 3. разакрахмо М. 555. - VI. юврадокахмо М. 554.

в) без вокала пред личнпјем наставком и са $c$ до основе: I. 5. почесмо М. 130. Ст. ппс. 5, 217. почасмо Мрн. 65. прнесмо II. 90 . вұєсмо М. 289. Ст. пис. 5, 231. zаисмо II. 176. пршасмо M. 239. 257. 260. 284. 296. 418. priasmo М. 279. Злат. 2. Банд. 8. - I. 6. дасмо М. 106. 217. 226. 234. 242. 472. 491. 494. 503. 510. II. 18. 50. 65. 112. 115. Пб. 59. Ст. пис. 5, 218. прндасмо М. 440. П. 50. одјесмо Н. Рањ. 43. пјесмо Ст. пис. 4, 335. смјесмо Ст. пис. 5, 231. од основе кт : кнсмо Сав. стар. 4, 231. М. 216. висьмо М. 44. ${ }^{2}$ - I. 7. од раппрене основе: прострссмо М. 346. од основе нераширене која се ни у интинитиву не шири: стрсмо Ст. ппс. 4, 440. сатрсмо Ст. пис. 4, 440. - II. пьнвсмо II. 87. двагнусмо Ст. пис. 5, 164. - III. 1. вмиєсмо М. 443. радвмюсмо II. 2. - III. 2. покекесио М. 380. повемесмо Пб. 92. индтсмо ПІат. рат. 1873. 100. видпсмо Н. Рањ.

' Јамачно је погрјепка: внхосмо М. 248.

Тако и кондиционално: не кнсно моги М. 216. да внсмо потврьдим М. 221. хио Бисмо хотем М. 259. хотјелг бисмо Н. Рањ. 45 ие кнсмо нхһ продхвми Збор. 5. ималі бисмо се скрушитн Гуч. 106. ако бисмо хтнли Каші. 117. да бисмо ималі Mur. грам. 17. 
43. живисмо Д.Рањ. 123. мњесмо Ст. ппс. 5, 196. хотнесмо М. 311. хтъсмо Пб. 35. у гдагода те врсте којп је садапње врпјеме имао без наставка у основи: нъввєдесмо М. 230. ввндесмо II. 27. покидтсмо П. 19. zановидесио М. 230. zаповедесио М. 230. zапокидисио М. 489. - IV. кхагосхокнсио М. 13. оүкраснсио М. 137. прнхожнсмо ІІІаф. рат. 1873. 100. оүдарнсно 100. осководисмо Пб. 40. пртинсмо М. 285. прнинсмо М. 296. 300. 357. 399. 425. 491. П. 4. 7. 15. 90. Здат. 87. схткорисмо М. 491. вцининсмо II. 152. - V. 1. өвєћасмо M. 218. хптасмо Ст. пис. 5, 231. V. 2. посласмо Стар. 4, 233 . - V. 3. разекрасмо М. 309. II.

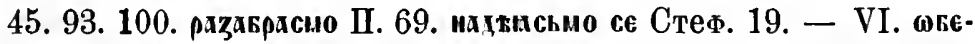
товасио М. 298. овттовасио ПГ. 9. атрьвасно М. 238. поревиокасно IIIат. pam. 1873. 99. ноћевасмо Хект. 12. веровасмо Хект. 9.

2-го мн.: I. 5. єстє М. 42. прнјасте Банд. 35. - I. 6. дасте М. 42. Н. Рањ. 42б. Ст. пाг. 3, 350. 5, 213. Банд. 35. продасте М. 42. zадастє П. 79. подасте Н. Рањ. 70б. прудасте Банд. 99. чусте Н. Рањ. 39б. дјесте Ст. пис. 5, 235. одјесте Н. Рањ. 43. Збор. 125б. одисте Ст. пис. 1, 305. Банд. 35 . од основе кт: кисте М. 368. Гуч. 12.' - I. 7. од основе рапирене као у инфипитиву : прострпјесте Н. Рањ. 103. од основе нерашпрене која се ни у инфинитиву не пири: сатрсте Cт. пис. 4, 441. III. 2. хотјесте Д. Рањ. 73б. хтјесте Ст. пис. 5, 136. Д. Рањ. 45. ктјесте Н. Рањ. 56. ведисте Мрн. 99. чтјесте Н. Рањ. 56. - IV. вговорнсте M. 7. - V. 1. пмасте Ст. ппс. 5 , 148. впхсте 3бор. 176. споминасте Хект. 31б. - V. 2. кеzхсте М. 7. - VI. почтовасте Н. Рањ. 80б.

3-ће мн.: I. 5. почепе Ст. пис. 1, 84. 185. Злат. 86б. Вран. жив. 11. Мрн. 40. поуаше Ст. ппс. 1, 22. 219. Хект. 3б. Стар. 4, 111. Зор. 35. Јерк. 50. прпчаше Ст. пис. 1, 21. 27. Хект. 26. еше М. 42. приєше М. 19. отнеше Стар. 4, 233. вазеше Ст. пис. 2, 142. Вран. жив. 14. Мрн. 40. изеше Ст. пис. 5,145 . јаше Ст. пис. $1,22.57 .4,166$. Хект. 17. Крн. 12б. Мрн. 29. пријапе Банд. 12. Мрн. 41. ујаше Хект. 3б. обујаше Стар. 4, 114. - I. 6. продаше М. 126. даше М. 178. 289. 337. 389. 403.

' И кондиционално: да Бисте дослахн М. 368 . юбда Бисте вҮнвнхи П. 51. ерь внсте хютьхн ПГ. 132. нека бисте оздравили Гуч. 12. да бисте имали Мик. грам. 17. али и само кн XIV вијека: уеса ин кн ие ви дакн М. 247. 
443. 502. 507. II. 77. 101. 117. Ст. пис. 1, 185. 3, 212.340. 4, 206. 5, 128. 140. 216. А. Рањ. V. Хект. 5. Злат. 87. Гуч. 146. Вран. жив. 64. Бун. 46. Андр. пут 259. задане Ст. пис. 4, 127. поданге Ст. пис. 3, 101. Вран. жнів. 99. пртдаше М. 261. 479. прндаше Ст. шис, 3. 338. 4, 232. Гуч. 301. удаше Град. дјев. 129. познаше Злат. 48б. изосташе Н. Рањ. 70б. прибипе Н. Рањ. 111. упшше Каш. 83. исплише Ст. пис. 1, 114. сагњеше Ст. пис. 5, 61. додјеше Н. Рањ. 161. задјеше Ст. пис. 2; 508. задише Хект. Зб. наднше Канг. 14. запјеше Ст. пис. 2, 435. кмшє М. 11. бнше Буд. 101.' - I. 7. од раширене основе: одријеште Збор. 30б. Ст. пис. 5, 137. здријеше Андр. дев. 143. издрише Зор. 60б. продрише Мрн. 52. умријеше Злат. 97б. умрпше Д. Рањ. 23б. помрише Радн. 51.2 запријеше Ст. пис. 3, 449. допријеше Град. дјев. 172. наприше Банд. 13. ирострнше М. 288. прострише 300. простријеше Андр. дев. 173. прострише Каш. 15. обастрише Банд. 89. растрише Ст. шпс. 1, 169. разастријеше Андр. дев. 144. од основе нераширене која се није ширила ни у инфинитиву: потрьше II. 143. затрше Стар. 3, 263. - II. свенуше Ст. пис. 3, 329. обрнуше Хект. 18б. погинуше Банд. 120. прнгнуше Ст. пис. 3, 310. 4, 180. огрезнуше Ст. пис. 3, 329. подвитнуше Н. Рањ. 68. двигнуше Ст. пис. 3, 310. 4, 116. Каші. 15. дигнуше Каш. 100. одкинуше Вран. жив. 14. клекнуше Вран. жив. 28. ускрснуше Ст. пис. 2, 232. помркнуше Ст. пис. 4, 232. умукнуше Вран. жив. 55. прионуше Ст. пис. 5, 69. паднуше Гуч. 301. вьсиомпивше М. 130. попузнуше Н. Рањ. 1126. свануше Мрн. 12. натакнуше Каш. 70. затпскнуше Н. Рањ. 23. тиснуше Мрн. 129. затиснуше Банд. 13. стиснуше Ст. пис. 4, 352. - III. 1. имише Мрн. 4. - III. 2. вапјеше Ст. пис. 5, 74. висјеше Гунд. суз. II, XXXIV. волјеше Град. дјев. 152. огмадинєшн Збор. 27. ожпвише Банд. 121. жпвише Каш. 96. назрјеше Ст. пис. 4, 115. словише Мрн. 18. стамнјеше Злат. 100. хотнєшє $M$. 276. хотише Вран. жив. 28. хткшє II. 38. хтпше Ст. пис. 1, 72.

1 Кондищионално не долази него само бн: ако бн иє тккн ко-

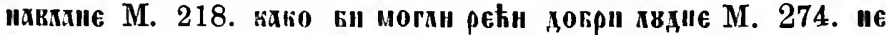

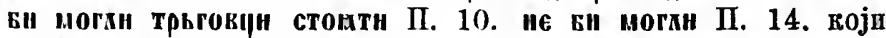
ве би могли доћи Гуч. 35. да би пмали Мик. грам. 17.

2 На једном мјесту: umraše Злат. 27. 
ктјеше Ст. пис. 3, 379. 4, 439. цаптише Ст. иис. 3, 255. шроцаптјеше Ст. пис. 2,511 . и у гдагода те врсте који је садапње

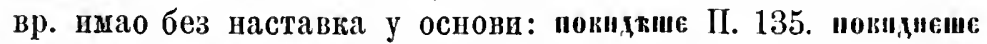
3бор. 31. сповпише М. 375. сповидјеше Ст. пис. 5, 164. - IV. кхагосовише ІІб. 106. говорише М. 86. удрише Злат. 17б. тхиинис; М. 493. 522. обујмите Град. дјев. 23. иртипше М. 21. иримнше М. 229. 318. 350. 368. 487. 497. Д. Рањ. У. Џанд. 105. снимише Ст. пис. 1, 10. сритише Мрн. 56. втакынше Нб. 106. потмине Ст. нис. 2, 256. пояьтише М. 19 . Орб. 5. прочтипе Стар. 3, 323. птише Ст. пис. 1, 272. 5, 64. Банд. 105. 175. -V. 1. обећане Ст. ппс. 1, 118. Н. Рањ. 96б. помчаше 3бор. 157б. опрахаше M. 221. прочтапе Ст. пис. 1, 57. - V. 2. ирьнсписаше М. 396. двизаше Град. дјев. 157. - V. 3. изагнаше Стар. 3, 293. Банд. 52. како је из садашњега времена ж претворено у $p$ прелазнло у инфинитив, ирелазило је и овамо: порнаше Стар. 1, 232. - VI. споване С'т. пис. 1, 286.

Глагод Бытн пмао је аорист и од основе онаке гака му је у импертекту: 3-ће јед. кт М. 5. а то као да је аорпе' имперфективноме кттн.

Надазп се кад кад од краја XV вијека аорнст у 3-ћем мн. помијешан с имерфектом тако да му је завршетағ ие замијењен завршетком - $x y$ : забиху Ст. пис. 1,94. ииху 94. одтоворнхон Шаф. pam. 1873. 111. почеху Ст. пнс. 4, 331.'

\section{АОРПСТ ДРУГИ С.АОЖЕНН.}

Само је у глагола којнма се основа свршује па сугдасно и у онијех друге врсте поји могу одбацитн ну, те добшвају основу на сугдасно.

-1-во јед.: I. 1. прноврттохь М. 4. срјетох Ст. пис. 4, 111. Злат. 69. похтохь М. 129. пзједо Радн. 39. - I. 2. принєсохь ІІб. 78. нонесох Вран. жив. 107. поднесох Див. 26. шзкъзохи M. 19. улјезох Д. Рањ. VIIIб. - I. 4. рекохь М. 100. II. 136. Ст. пие. 2, 243. Вран. жив. 107. увукох Ст. шис. 5, 290. стргох Ст. пис. 4, 142. - II. погибох Ст. пис. 3, 38. уздахох Ст. пис. 1, 238. кқzукнгохь М. 4. двигох Н. Рањ. 71. дигох Ст. инс. 5, 79. Банд. 39. подитох Ст. пис. 4, 94. уздигох Гунд. пс. 36. укидох Брн. 72б. поканкох Ст. ппс. 4, 94. пртмкохь М.

1 Внди и у Миклотића vergl. gram. III. 96. 
103. вижоки М. 103. пзмакох Ст. ппс. 4, 21: успрегох Злат. 72б. успредох Ст. пис. 2, 470. сахох Ст. пाгс. 5, 71. остидох Ст. пис. 4, 114. устндох Ст. пис. 2, 482.'

2-го и 3-ће јед.: I. 1. срјете Н. Рањ. 96б. сусрјете Н. Рањ. 78. Збор. 76б. Ст. пис. 4, 185. Злат. 81. уздрасте Д. Рањ. 87. наресте Вран. жив. 46. нарасте Банд. 23. зб.бде Ст. ппс. 4, 335. прободе Злат. 71. вазьяєде М. 220. уједе Здат. 45б. једе Орб. 276. пзједе Радн. 61. покреде Мрн. 19. паде Ст. пис. 4, 446. Злат. 20. седе Ст. пис. 1, 8. сиде 214. I. 2. поднесе Н. Рањ. 101. Д. Рањ. 12б. Дпв. 25. Андр. пут 216. занесе Ст. пис. 4, 90. понесе Ст. пис. 4, 100. унесе Зор. 38б. стресе Вран. жпв. 80. вмєзє ПІ. 36. улјезе Н. Рањ. 47. Гуч. 153. скнеzє Збор. 94. напузе ${ }^{2}$ Ст. пис. 4, 169. - I. 3. издубе Ст. пис. 4, 122. скубе Банд. 109. оскубе Д. Рањ. 99. поцрпе Ст. пис. 4, 151. зацрпе Д. Рањ. ІХб. пожнке Сав. 8. - I. 4. врже Ст. пис. 4, 99. Вран. жив. 101. раждеже Андр. нач. 48. раздеже Град. дух. 49. може Злат. 62. у тога се глагола и у том облику мпјењало ж на $p$ : море Збор. 35. Хект. 4б. Банд. 91. обуче Н. Рањ. 81. Вран. жив. 74. у тога се глагола у старије вријеме ширнла основа и у том облпку као у инфинитиву: пқккқте Стеф. 25. рече Н. Рањ. 137. Злат. 61. Вран. жив. 110. одсиче Вран. жив. 64. утече Злат. 61б. - II. погибе Ст. пис. 3, 256. 4, 261. Банд. 239. эгибе Ст. пис. 2. 330. огрче Ст. пис. 2, 187. издаше Ст. пис. $1,51$. 102. 124. 3, 322. 330. 341. 350. 461. 4, 39. 206. 232. 5, 142. 144. уздапе Ст. пис. 4, 97. 117. 121. подкнже П. 141. Ст. пвс. $3,340$. 4, 84. 5, 322. Злат. 80б. двпже Збор. 31б. Ст. пис. 1, 11. 4, 296. 5. 133. Д. Рањ. 12. Зор. 35. Мрн. 44. Радој 28. уздвиже Ст. пाтс. 2, 264. 415. 3, 352. днже M. 177. Д. Рањ. 46. Банд. V. Бун. 45. раскиде Злат. 80б. скиде д. Рањ. 55б. укпде Ст. пис. 5, 244. Злат. 88. клече Збор. 70. поклече Ст. ппс. 2, 440. измаче Ст. пис. 4, 318. помче Радн. 59. прпмче Радн. 47. помрче Ст. пис. 2, 187. смрче се Злат. 91б. умуче Ст. пис. $2,254$. пуче Злат. 73. усаше Н. Рањ. 35б. Ст. пис. 2, 368. присаше

' IIIто једном пма: борох се Д. Рањ. 135б. као да би било од глагола пете врсте, дако може бити штампарска погрјеIIrкa мјесто борах ce.

: Може бити и од глагола друге врсте; пспореди и 3. лиде мн. 
Ст. пис. 5, 79. присеже Вран. жпв. 17. поските Стар. 4, 113. достиже С'т. пис. 5, 234. устеже Злат. 81. Раді. 52. затиште Ст. пис. 4, 158. притиште Злат. 81. стиште Ст. шис. 2, 296. притниће Стар. 3 , 328.'

1-во мн. а) без вокала пред лпчнијем наставгом, али са $x$ до основе: I. 4. рєкохьмо II. 176. - б) без вокала пред дичнијем наставком п са $c$ мјесто $x$ до основе: I. 1 . кдадосмо Мрн. 178. седосмо Ст. пис. 1,94 . сидосмо Хект. 16. I. 3. сопосмо Ст. пис. 1, 85. - II. подвигосмо Хект. 23. (1)мarsocmo II. 6.

2-го мн.: I. 1. покрадосте 3бор. 27б. - II. двигосте Ст. пис. 1, 33.

3-ће мн.: I. 1. овритоше М. 305. свсрнетоше 3бор. 9. шропњтоше М. 136. бљудоше С'т. пис. 1, 40. пакєдошє М. 89. јидоше Ст. пис. 1, 267. једопе Н. Рањ. 70б. Ст. пис. 5, 152. поједоше Збор. 26б. падопе Врап. жпв. 11. седопе Ст. пис. 1, 19. 70. 84. 274. Хект. 15б. Мрн. 34. обседопе Ст. пис. 1, 71. - I. 2. донесоше М. 207. однєсоше 3бор. 75. Вран. жив. 38. понесопе Кашг. 198. улјезоше Гуч. 296. Орб. 116. испузоше² Бапд. 198. - I. 4. обукоше Н. Рањ. 81. Радп. 73. рекоше Н. Рањ. 15. Збор. 35. сжегоне Ст. пис. $1,244 .^{3}$ - II. згибопе Д. Рањ. 124. погпбоше Банд. 168. уздахоше Ст. пнс. 1,62. двпгопе Н. Рањ. 32б. Збор. 91. Ст. пис. 4, 239. 5, 129. подвпгоше Мрн. 4. Капг. 64. подитоше Банд. 93. сгпдоше Ст. пис. 5, 144. клекопе 3бор. 97б. кликопе Ст. пис. 4, 435. Хект. 15б. макоше Хект. 22б. сахоше (т. ј. cacaxome) Cт. пис. 5, 96. усахоше 3ор. 73б. Гунд. пс. 24. прнсегоше II. 111. тискоше Хект. $15 б$. Андр. дев. 144.

- Тако је и у глагола прве врсте пестога раздјела којему се основа од свагда ширп добпвајућн у садашњем вр. на крају $Д$, па тако п у овом облику: 1-во јед.: ндохь М. 187. шрщдохь М. 5. обидох Ст. шис. 1, 105. 2, 27. узидох Бун. 51.“

' Iогрјешка ће бити: омрже Ст. пис. 1, 256. мјесто омрзе.

2 Може бпти и од глагола друге врсте; испоредш и треће лице јед.

3 IIIтампарска he погрјепка бпти: издубеше Андр. дев. 157.

4 Једном нађох и $и x$ : веће пута путујуһи $u x$ по дажду $A$. Рањ. 486. 
- 2-го и 3-ће јед.: иде Вран. жив. 42. изиде Н. Рањ. 34. Збор. 27. Ст. пнс. 2, 55. 4, 372. Банд. 61. надиде Д. Рањ. 16. обнде Ст. шис. 2, 55. 4, 91. 5, 216. отнде Ст. пис. 2, 324. Вран. жиз. 45. прнде Ст. пшс. 1, 6. Н. Рањ. 27. Збор. 27б. Ст. нис. 4, 91. смпуе М. 220. 235. сиде Ст. пис. 5, 148. Н. Рањ. 21. Злат. 87б. Гуч. 148. Андр. пут 99. униде Ст. пис. 1, ¿0. вънде М. 438. - 1-во мн.: шрндосио М. 137. - 2-го мн.: нзидосте Н. Рањ. 14. придосте Ст. иис. 5, 218. - 3-ће мн. нзидошє ПI. 38. Гуч. 254. Андр. дев. 161. одндоше Ст. нис. 1, 64. прндоне ІІ. Рањ. 41. - У сложеном с приједлозима који се свршују на вокал слажу се вокали који тада дођу један до другога како је речено напријед (стр. 249): 1-во јед.: дондохь М. 391. зајдох Ст. нис. 3, 352. 4, 121. пхндох М. 281. Ст. шис. 2, 108. 4, 47. Хект. 2. појдох Ст. пис. 4, 142. 185. пројдох Ст. пис. 4, 116. Зор. предгов. дојдох Мрп. 27. - 2-го и 3-ће јед.: донде М. 444. II. 28. 71. 108. Ст. пис. 1, 44. 4, 203. Каш. 28. зајде Ст. пис. 4, 193. пхпде М. 504. П. 114. 130. Н. Рањ. 164б. Зор. 29. Банд. 7. КашI. 4. "зихия М. 249. понде П. 64. Ст. пис. 1, 5. пројде Ст. пис. 1, 5. 4, 22. мимојде Мрн. 32. 1-во мн.: дојдосмо Ст. ппс. $1,94.4$, 137. зајдосмо Ст. ппс. 3, 287. 4, 106. нандосио М. 254. II. 50. Ст. пис. 3, 297. 4, 134. "зьнидосио II. 88. огиацосмо М. 305. II. 107. ојдосмо Ст. пис. 3, 246. појдосмо Хект. 11б. - 3-Ђе мн.: допдоше М. 231. ПI. 75. 96. Ст. пис. 1, 26. 3, 307. 4, 124. Каш. 10. зајдоше Ст. пис. 1, 40. минојдоше Зор. 60. пхпоше М. 260. 501. П. 55. 87. Н. Рањ. 121б. Ст. пис. 4, 124. Стар. 4, 114. ондоне Стар. 3, 274. пондоше М. 217. Ст. шис. 1, 49. 4, 157. Хект. 23б. Банд. 10. Капі. 10. - тако и кад се прпједлог свршује на сугдасно али сс умеће $a: 1$-во јед.: обајдох Ст. пис. $1,150.4,83.2$-го и 3-ће јед.: изајде Ст. пис. 4, 81. Зор. 2б. сајде Н. Рањ. $163 б$. Банд. 20. 1-во мн.: отајдосмо Хект. 23б. 3-ће мн.: пзајдоше Град. дјев. 11. Вран. жшв. 37. одајдоше Вран. жив. 63. разајдоше се Вран. жив. 69. - али ако и донире тако у XVII вијек, инак се још од XIV вијека састав.ба $j_{A}$ у $ђ$ (види стр. 249. 279): 1-во јед.: догохь М. 183. Н. Рањ. 73. Ст. пис. 4, 453. 3лат. 21б. Див. 12. зађох Ст. пис. 2, 199. пххћохь М. 367. Н. Раґь. 32. Ст. пнс. 2, 120. 4, 309. 4, 453. А. Рањ. 84б. Град. дух. 4. Злат. 5б. Гуч. 287. изађох Ст. пис. 4, 347. погохь М. 
241. Ст. пис. 2, 277. 464. 2-го и 3-ће јед. доге М. 174. 202. доге II. 21. 25. 42. 150. Пб. 113. Н. Рањ. 19. Збор. 2б. Ст. пис. 2, 35. 416. 4, 201. Злат. 6. Гуч. 243. Див. 19. Бун. 13. Андр. нач. 57. зађе Ст. пис. 2, 232. позађе Д. Рањ. 21б. мпмође Іуч. 189. шаrıе Пб. 18. 20. Н. Рањ. 97. Зор. 2б. Ст. пис. 4, 310. д. Рањ. VІІб. Злат. 20. Гуч. 18. нзихге М. 117. надађе Гуч. 168. ође Злат. 95б. поге Пб. 120. Н. Рањ. 16б. Ст. пис. $2,17$. Злат. 27. Гуч. 148. Див. 31. прође Збор. 100. Злат. 16б. сађе Здат. 15. узађе Гуч. 138. 1-во мн.: юкихосио М. 230. шћосмо М. 503. пхосмо М. 513. Пбб. 110. Н. Рањ. 104. пођосмо Ст. пис. 4, 295. дођосмо Ст. пис. 5, 317. 2-го мн.: дођосте Н. Рањ. 43б. "зьнагосте II. 35. пођосте Ст. пис. 2, 513. 3-ће мн.: догฒше M. 204. 207. 472. 535. П. 20. доћоше М. 545. дођоше Н. Рањ. 21б. Збор. 31. Ст. пис. 4, 447. 5, 129. Злат. 2б. Гуч. 299. мимођоше Н. Рањ. 41. шаћоше М. 493. Град. дјев. 13. Злат. 81. Гуч. 168. Бун. 48. обађоше Радн. 47. прогоне МІ. $28 . '$ - цз овагих сложенијех прешло је 5 и у сложене са ири и прије од XVI вијека: приђох Ст. пис. 2, 435. Злат. 28. приђе Н. Ран. 25. Збор. 35б. 4, 224. 253. 327. Град. дјев. 18. 21. Злат. 79. Іуч. 38. пријеђе Ст. пис. 2, 391. приђосмо Злат. 1б. приђоше Збор. 27. Град. дјев. 95. Злат. 80б. по том је препло $f$ и у сложене у којима се не мијења $u$ на $j$ шего остаје, и то оцет од XVI вијека, ако није из познпјега пријеписа: спђоше Ст. пис. 4, 306. поуздано XVII вијека: отпђе Див. 17б. отиђоше Радн. 22. 24.55. а тога је вијека прелазило п у прости: иђох Радн. 5.

Глагол дати осим првога сложенога млаһега аориста (види напријед стр. 322) има и овај други, и то још у старом словенском језику, прем да у познијим изворпма : имајући у садашем вр. основу на сугласно, које му се у 3-ћем мн. једнако чувало, дако му је било помијешати се меלу глагоде који имају основу на сугдасно, и добити оваки аорист, а у том му је јамачно много помогао глагод јести, који је у

' Према говору у вом $ђ$ гласи $j$ валази се и у овој прилици j: дојосмо Мрн. 27. ојоше Ст. пис. 4, 312. у дву.

2 Налази се - јамачно само наплсано - и $£$ и иред вим $j$ : донћє M. 229. "зынангосте II. 35.

${ }^{3}$ Muksombh, vergl. gram. III. 164. 
садапњем вр. био једнак с њим али је имајући у интнитиву основу на сугласно имао и оба ова аориста, те је налазећи се у друптву с глаголом дати и у саданшем вр. и у првом сложеном аористу привлачпо га и у други сложени: у нас долази у том облику много прије него му се у садапњем вр. разинло $д$ из трећега дица мн. по осталијем, - долази XIII вијека: прқдауюки М. 19. али то мјесто није поуздано, јер је познпји прпјепнс; поуздано долази од средине XIV вијека и то у 3-ћем лицу јед.: дақє Шаф. pam. 1873. 100. М. 164. а у 1-вом јед. истога вијека: дадоки М. 169. у множпни додази истом XV и XVI впјека: истина било би XIV вијека ддљопе М. 182. алп нема јамства да је тако у оригиналу; по свему томе имамо: 1-во јед.: пртдықохь М. 19. дақохь М. 169. 416. 526. 531. 552. продхоохь Пб. 79. дадох Банд. 30. 68. придадох Банд. 149. - 2-го и 3-ће јед.: дыс ІШаж. pam. 1873. 100. M. 164. 168. 171. 293. 308. 388. 391. 39 3. 524. II. 71. 73. 89. ІІб. 55. 59. 111. 122. 130. Ст. пис. I, 16. 5, 56. Стар. 3, 326. Дпв. 21б. Банд. 47. І’адп. 11. Радој. 7. шрждде М. 479. подаде Банд. 12. пипдаде Банд. 86. -- 1-во мп.: а) без вокала иред дичнијем наставком али са $x$ иред вим: дылхмо М. 554. б) без вокала пред личпијем наставком али са $c$ : дадосмо Чубр. 4б. -- 2-го мн.: продадосте Збор. $25 б$.

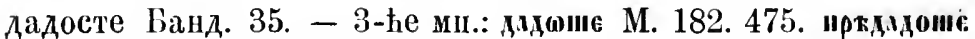
М. 514. 552. дадоне Банд. 84. Радн. 86. подадоше Банд. 213. придадоне Банд. 86.93.

И у глагода имати п знати, ғоји пмају оспову на самогласпо али су у повпје пријеме изједначујућп се с глаголом дати узимали у садашњем вр. д на крају основе, иреносида се така основа и у аорпст, те се осим првога сложенога млађега аориста (види стр. 322.325) налазе и у овом другом, али истом од XVII внјека: пмаде Радіг. 17. 25. 32. 55. знадосмо Мрн. 82. познаде Радн. 12. знадоше 56. нознадоше 55.

\section{ДВојИнА.}

Разликује се од множие само динијем наставцима, а они су као у садапњем вр.: 1-во днце налази сс само у пајстарнје врнјеме: ирткихок Сав. 12. Стеф. 29.' наскадиховє ск

$'$ Биће ногрјенка писарска кьсемик Сав. 8. мјесто вьсекихокт. 
Сав. стар. 4, 231. - 2-го и 3-ће дице држало се дуже: тако за сва трп рода до граја XIV вијека: хотвста Стет. 21. ирткыкаста СтеФ. 13. погоүвнста М. 67. вьzнесоста СтеФ. 21. XV вијека: киста М. 462. 544. вголиста М. 462. скрьниста М. 462. доскаста М. 375. XVI вијека само у два извора: улјезоста Н. Рањ. 154. дкнгнвст Збор. 36. пмакаста 31. за средњ род и са $e$ на крају мјесто $a$ : кшднссте (очи), сквшисте (уни) Збор. 149. XVII вијека нађох само једном: пгодаста Вран. жив. 27.

\section{ИМПЕРА Т ИВ.}

Основе су онаке какве су у саданшем вр.; $\boldsymbol{k}$ њима ириступа наставак ji, који се и сажима у $\mathbf{i}$, а иза њега долазе дичи наставци онаки какви су у имперекту и у аорпсту, те у 2. н_3. јед. стојећи на крају без самогдаснога за собом отпадају. ІІрвога днца једнине нема, нема ни трећега множине, него се оно кад кад замјењивало другим мн.' Онако како је речено напријед код садапюега времена долази и у имнеративу у првом люцу мн. лични наставак и са ь па крају: разоүмтнми М. 100. дадния Стар. 4, 234. (внди јоні под II. А).

I. Основе које у садапњем вр. немају наставка:

a) у једнини основе добивају за овај облик настапак ja, од кога се глас $j$ са задњим гдасом од основе слаже по својим законима, т. ј. од дj, које се тада састаје, бива у старом словенском језику жа а у сриском $f$ и но некпм крајенима $j$, које се иза гласа $u$ често и не пише, а а од тога наставка слабећи у словенским језицима постаје т, које се предњега гласа ради мијења на ь а по том у сриском језику-отнада: тако 2-го и 3-ће јед. имамо до краја XVII вијека од двпје основе: од основе јед: јеђ Н. Рањ. 45. Збор. 40. Ст. пис. 5, 22. 254. јиј Ст. пис. 1, 137. Хект. 346. Брн. 54б. изиј Стар. 1, 232. в XVII вијека: јиј Вран. жпв. 91. од основе ктд: zапоктг ІІ. 34. 57. 102. 109. 148. 163. зановиђ

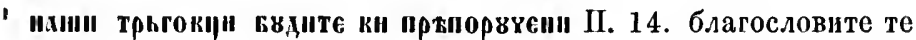
сви ангели Банд. 7. - Mеbу примјерима који hе се наводіти за друго и треће лице јед. заједно има их довољно за треће, เао: свети се име твоје Вран. рјеч. 127. бог обаруј Вран. жив. 102.

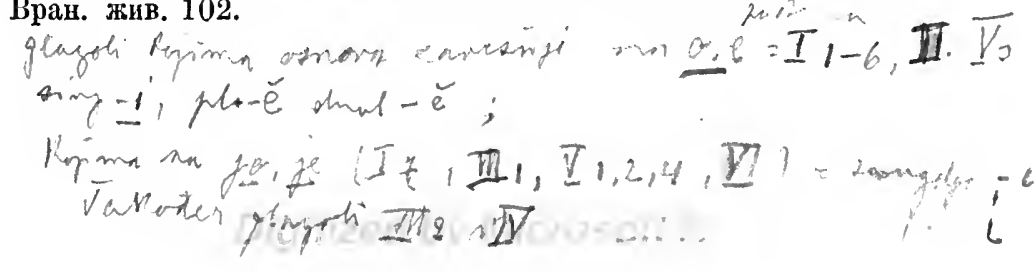


Ст. пис. 2, 151. 184. 215. 226. заповиј Стар. 1, 219. повнсћ Збор. 29б. 30. 30б. 40б. 70. повпј Ст. пис. 1 , 306. Хект. 49. пови 3ор. 14б. Стар. 3, 306. испови 3ор. 64б. Брн. 40б. приповјеђ Ст. пис. 5, 60. сповне Збор. 68. сповјеђ Ст. ппс. 4, 401. Здат. 9б. 57б. 80. сповиј С'r. пис. 1, З03. сви Брн. 65. изувиј Ст. пис. 1, 24. и XVII вијека: повиј Вран. жнв. 85. заповиј 55. оповјең, Гуід. пгс. 7. заповјеђ Андр. дев. 120. исповјеђ Андр. пут 54. - тако је у старом словенском језиіу и од основе пад: дақды Сав. 7. - Међу ове глагоде прешао је још у старом словепском језику у овом облику глагол треће врсте видтти, те и у српском језику пма у императиву у једнини као и поменути глаголи: кигь II. 10. 84. 178. виђ Н. Рањ. 28б. 31б. 37. Збор. 34. Ст. ппс. 2, 44. 276. 3, 41. 393. 4, 60. 5, 12. 34. 109. 111. 257. Злат. 2. Чубр. 6б. впј Ст. шис. 1, 49. Хект. 40б. Зор. 63б. Стар. 3, 275. ви Стар. 4, 114. ненавиђ Н. Рањ. 39б. извиђ Ст. пис. 2, 46. развиђ Ст. ппс. 5, 143. п XVII впјека: вић І'унд. суз. I, VII. Ђам. 6. Андр. пут 317. свиђ Гунд. суз. II, XLII. виј Вран. жив. 37. Орб. ⒎ 74. Јерк. 71. развиј Јерк. 39. - Али овп облици ако су се и држали до краја XVII вијега сви оспм опијех од основе дал, ппак су се још прије почели помијерати: најприје се помјерише тијем што једначећи се с пстијем облицима других глагода примише на крају ппхово $и$ : тако је у глагола видјети од почетка XVI вијека: виђи Збор. 149. вији Брн. 65. XVII вијека: впђи Див. 17. 26б. Андр. нач. 55. дев. $7 \varepsilon$. од основе квд тако се налази истом XVII вијека: сповиђп Андр. пут 57. 276. и са дj мјесто $f$ у писца који је п у другим прпликама тако писао (впди код имперч.): одповидји Банд. 46. а најпослије једначеһи се јоп више с другим глагодима пред примљеним $u$ повратише $\not$ мјесто $f$, алп истом XVII вијека: од основе књ: повиди Вран. жив. 17.' од основе јед: једи Радн. 17. у гдагода видјети: види Банд. 144. Мик. грам. 23. - Глагод је дати у српском језнку од првијех времена прешао у овијем обдпцшма међу глаголе међу поје припада инфинитивом (впди даље II. Б. б.): XII вијека: дан М. 7. XIII вијека: даи М. 21. 43. подаи М. 53. раздан Сав. 7. и даље: дан М. 215. 338. II.

' И без крајњега $u$, али истога времена: сповјед Ст. пnс. 4, 401. у дну. 
5. 25. 97. Пб. 21. 25. дај Ст. пис. 1, 119. Збор. 12. Ст. пис. 4, 209. 5, 5. Град. дух. 86. Хект. 26. Брн. 9. Злат. 76. Вран. жив. 68. Гунд. суз. I, XXV. Банд. 21. подај Злат. 11. Банд. IV. Јерк. 20. продај Збор. 29. Брн. 58б.

б) у множнни долази к основи наставак ја сажет у $\mathbf{i}$, које у словенским језицима остаје: проповт.јите М. 164. тако је бпло и у глагола дати до краја XIV вијека: 2-r'о мн.: прқдадтте Пбо. 37. у гдагода өидјети и послије једнако: видите Н. Рањ. 66б. Мик. грам. 23. - Али штто је бивало у једнияи преноспло се п у множнну, и то од XIV вијека, те

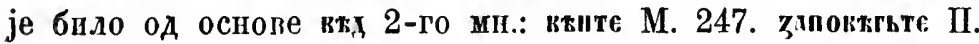
1. 11. 12. 14. 16. заповијте Ст. ппс. 1,4 . и у глагода видјети: виђмо Н. Рањ. 21б. 94. Збор. 28. Град. дјев. 159. Мик. грам. 23. виђте Н. Рањ. 60б. 126. Збор. 113. 122. Ст. пис. 2, 132. 342. 3, 93. 195. 4, 114. 333. 5, 134. 159. Банд. 19j. вите Хект. 31. извиђте Н. Рањ. 31. али ако и долази тако до краја XVII вијека, ипак се од XV вијека узимало пред лични наставак још и $u$, које припада пмперативу у множпни, као пाто се у једнини из других глагода дометало $u$ : у глагода видјети јопг од XV вијека друго .пце: вигите П. 59. Збор. 176. Див. 26. а прво истом XVII впјека: виђимо Дпв. 9. 9б. - Гдагол се дати као у једнини од првијех времена изједпатио с глаголима меלу које припада инфпнитивом: 1-во мп.: қпмо Збор. 124. Ст. пис. 5, 199. 2-го мн.: поданте М. 50. пртұите М. 50. даите М. 185. 529. Пl. 1. 62. 71. 105. Пб. 25. 32. Збор. 25. дајте Ст. пис. 2, 42. А. Рањ. 132. Злат. 35б. Банд. 49. "здите Пб. 33. "ридаите М. 426. а $j$ се у једнини на крају и у множини пред-личнијем наставцима могдо п одбацити (види даље и код других глагода): да Ст. пис. 4, 10. 327. 362. 440. пода Див. 21. прпда Ст. пис. 4,192 . дате Ст. пис. $5,265$.

II. Основе које у садашњем вр. имају наставак: међу глаголима с таким основама бивају разлике у пмперативу с тога што је у садашњем вр. у једнпјех наставак чисто а a других ја, пाто се од наставка ја глас $j$ саставља с предњим сугдасним а иза самогласнога остаје $j$, и што наставак jа имају неки глаголи сано у првом лпщу јед.:

А. Основе с наставком a: к такој основи приступа за императив наставак ja сажет $\mathbf{y} \mathbf{i}$, а то се $\mathbf{i}$ са задњим а од 
основе саставља у словенским језицима у , пред којим се гласови $2, \kappa, x$ мијењају на $3, u, c$, али у једнини слаби те бива $u$, а само је у множини остајало:

2-го и 3-ће јед.: I. 1. бљуди Ст. пис. 4, 48. поведи Н. Рањ. 62. грєди М. 177. Н. Рањ. 45. клади Хект. 42. пади Ст. пис. 4, 409. допади Ст. пис. 2, 312. напади Ст. пис. 5, 231. понади Ст. пис. 1, 149. Мрн. 73. седи Ст. пис. 1, 89. сједи Ст. пис. 5, 186. саседи Стар. 3, 273. - I. 2. улјези Н. Рањ. 27. Гуч. 181. Андр. дев. 83. паси Н. Рањ. 184. - I. 3. дуби Ст. пис. 4, 383. оскуби Ст. пис. 4, 261. - I. 4. врзи Ст. пис. 4, 241. 309. 374. 5, 87. Вран. жив. 105. Банд. 261. одьврьзн ПІ. 133. Ст. пис. 5 , 237. Гуч. 108. Вран. жив. 114. поврзи Ст. пис. 1, 115, 5, 152. сврьз" П. 133. дези Ст. пис. 5, 140. помози Ст. шис. 4, 143. мози Каш. грам. 156. стрзи Ст. пис. 3, 270. рєџи II. 23. 138. Н. Рањ. 62. Ст. пис. 5, 192. Злат. 88б. у тога је гдагода могло $e$ ослабивши у ь испасти: рыји II. 18. 30. 143. тако се може $e$ избацитп и у глагола жећи, а тада се $з$ које постаје од 2 пзједначује с предњим ж, па се ж замјењује гласовима жд: вждн II. 149.' - I. 5. вазми Н. Рањ. 161. Ст. пис. 1, 99. 2, 3. 4, 92. занин М. 501. изми Н. Рањ. 196б. Збор. 99б. Ст. пис. 2, 430. 5, 243. Хект. 4. однеми Н. Рањ. 161б. Ст. пис. 1, 50. Брн. 3б. однами Ст. пис. 1, 53. узми Н. Рањ. 1656. пропни Н. Рањ. 93. почни Хект. 19. Каш. 64. у пошљедњега гдагода и м мјесто $九$ : почми Ст. пис. 1, 271. Мрн. 26. - I. 6. од основе која се шири добивајући од свагда на крају $\dot{A}$ : прпди Ст. ппс. 4, 217. 5, 41. Вран. рјеч. 127. сиди Здат. 94б. Каш. 66. исти глагод сложен с приједлозима који се свршују на вокал: допл" Збор. 118б. појди Вран. жив. 20. и кад се приједлог свршује на сугласно ади се домеће $a$ : изајди Н. Рањ. 161б. Ст. пис. 4, 153. Вран. жив. 44. обајди Ст. пис.

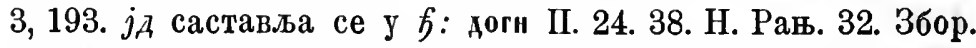
98. Див. 21б. зађи Ст. пис. 3, 139. нађи Ст. пис. 3, 113. 4, 239. пођв Н. Рањ. 31б. Збор. 25б. Ст. пис. 2, 55. 224. 445. 4, 343.

1 ІІІто се находи: сажги Вран. жив. 27. ужги Мрн. 22. Јерк. 25. 34. 66. Ouhe удснавано према инфинитиву жсати, као у садапњем вр.; види стр. 284. 
А. Рањ. 73. Град. пјев. 86. Злат. 71б. прођв Збор. 101б.' тако и. у сложеном са при: приђи Н. Рањ. 171б. Збор. 34. Град. дух. 85. Гуч. 277. Гунд. пс. 23. Мат. 99. из таких сложених предази $\hbar$ и у друге, у којима остаје $u$ не мпјењајући се у $j$, и у прости, али истом XVII вијека: отиђп Радн. 3. пђи Радн. 36. 68. у глагола који тапођер добнја д од свагда на крају основе и мијења самогдасно: буди Зор. 6. Вран. рјеч. 127. добуди Крн. 23б. забуди Вран. жив. 94. сложен са до изједначује се с осталијем глаголпма овога раздјела војвма се основа у пнфинитиву свршује на самогдасно од XVI вијека (види даље Б. б.): придоби Град. дјев. 28. у гдагола који од свагда добија у садашњем вр. $\boldsymbol{t}$ на крају основе: устанп Н. Рањ. 100. глагол знати како је у садашњем вр. прпмао од других гдагода $A$ на крају основе, налази се тако са $A$ и у императиву, али истом XVII впјека: познади Вран. жив. 31. Радн. 80. - I. 7. умри Ст. пис. 5, 179. нажери Стар. 1, 232. стари Брн. 44. потари Банд. 75. - II. побјегни Н. Рањ. 246. убигни Вран. жив. 44. обрни Ст. пис. 5, 42. двигни Н. Рањ. 286. Збор. 9б. Ст. пис. 3, 79. 5, 196. 3ор. 64б. Мрн. 94. вұдкигин M. 513. Ст. пис. 1, 7. Н. Рањ. 176. Банд. 6. Јерк. 34. подвигни Ст. пис. 4, 438. Злат. 88б. Гуч. 135. дигпи Ст. пис. 4, 422. А. Рањ. 45. Пос. 丂. Радн. 3. узднгни Банд. 18. домьки Пб. 110. измакни Ст. пис. 4, 299. падни Ст. пис. 2, 126. Зор. 14. присегни Сэ. пис. $5,187$. такни Ст. пис. 4 , 374. стегни Ст. пис. 4, 301. стисни Ст. пис. 1, 109. Хект. 26б. Гунд. пгс. 9. притисни Брн. 46. затисни Андр. пут 133. - V. 3. прожени Ст. пис. 4, 231. иждени Ст. пис. 4, 213. 5, 264. 273. оджени А. Рањ. 27б. Андр. нач. 56. одждени Ст. пис. 5, 151. Д. Рањ. 1426. 1476. с промјеном гласа ж у $p$ : изрени Н. Рањ. 70. Ст. пис. 4, 213. зарени Ст. пис. 5, 189. одрени Зор. 41. Брн. $14 б$. Гунд. пс. 19. Јерк. 16. шрорени Брн. $46 \sigma^{2}$ зови Н. Рањ. $65 б$. одрви Ст. пис. $3,448$.

' По говору у ком $f$ гласи $j$ налази се $j$ и у овој прнлици: поји Ст. пис. $1,11.3,399$.

2 у тога се глагола могло $e$ и избацити а тада се и 2 повраҺало мјесто ж: одагни Андр. пут 30. 205. 420. пзагни Авдр. дев. 64. пут 352. 373. тако би могло бпти и одагни Ст. пнс. 4, 480. премда би на том мјестү могао бити и глаго.л друге врсте. 
1-во и 2-го мн. са п пред личнпјем наставцима долази само у прва времена нити прелази преко $\mathrm{XV}$ вијека, и у такога је првога лица мн. лични наставак само иь: 1-во мн.:

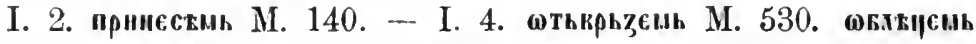
Стар. 4, 234. - II. вьзинкиы М. 86. - 2-го множ.: I. 1.

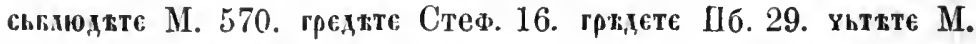
84. - I. 2. прниесьте М. 88. - I. 4. понозете Стар. 4, 233. - I. 5. пхинте Стеф. 18. шићте Стеф. 10. мићте М. 54. выzьшьте М. 4. - I. 6. у глагода коме се основа у садашем вр. од свагда шири добивајући на крају д: џдте М. 160. 164.

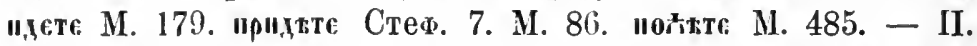

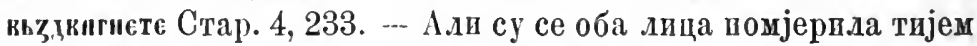
што су се изједначивала с нстијем лицима једнине, те је из једнине препло $и$ у множпну пред литне наставке истисвувши t: то се налази и у старом словенском језнку, ирем да врло pнјетко (Миклошић, vergl. gram. III. 99), а у нас се јавља XIV вијека: ихгте. IІб. 15. рџнте 27. квдите ПІ. 14. реините II. 20. а по том имамо:

1-во мн.: I. 4. одврвпмо Н. Рањ. 13. Банд. 1. врзимо Збор. 77б. Банд. 46. мозим Каш. грам. 15\%. рецимо Збор. 886. пзврсимо Мрн. 128. - - I. 5. зачнимо Ст. пис. 5, 226. I. 6. у глагода ком се основа од свагда шири добнвајућп на крају д: сидимо Ст. пис. 4, 306. сложено с приједлозима који се свршују па самогласно: ирођимо Н. Рањ. 21. нађимо Ст. пис. 2, 444. ођимо Злат. 98. пођимо Ст. Іпис. 2, 444. 4, 438. 5, 128. - II. двигнимо Мрн. 65.

2-го міг.: I. 1. бљудите Ст. пис. 4, 238. падште Ст. пис. 3, 306. 321. Банд. 125. Јерк. 76. сусретите Андр. дев. 62. I. 2. улјезите Злат. 3об. - I. 3. успите Ст. пис. 4, 332. - I. 4. одврзите Вран. жив. 27. мозите Кап. грам. 156. обуците Н. Рањ. 58б. теците Ст. пис. 5, 336. -- I. 5. вазмите Н.. Рањ. 161б. Ст. пис. 4, 240. взамите Стар. 3, 325. почните Ст. пис. 5, 232. - I. 6. у глагола ком се основа пири од свагда добијајући д: прндите Н. Рањ. $15 б$. Ст. пис. $3,342.4$, 335. сложено с приједлозпма иза којих се $u$ мпјења на $j$ па се $j$ са д саставља у $\mathfrak{f}$ : шхгтс Пб. 15. пођите Н. Рањ. 14. 29. Ст. пис. 2, 56. Злат. 31. ођнте Ст. нис. 4, 208. Злат. 6. тако и сложено са ири: ириђите Н. Рањ. 118. Ст. пис. 4, 223. у гдагода 
пом се основа такођер шири од свагда добивајући д: квдите II. 14. Буд. 45. Јерк. 22. - I. 7. одрите Збор. 30б. прострите Ст. пис. 5, 247. - II. уздвигните Н. Рањ. 13б. Банд. 1. двнгните Ст. пис. $3,152.4,388$. Злат. 35. дигните Банд. 82. паните Ст. пис. 2 , 402. падните Банд. 99. - V. 3. ждените Ст. пис. 4, 331. срените 331. разрените Глав. 127.

Глагол моћи у порицању пмао је још XVI п XVII вијека као и остали четвртога раздјела прве врсте: не мози Буд. 131. Мрн. 104. не мозите Буд. 132. али од XIV вијека избацује му се цијели слог зи, те се мјесто пега домеће $j$ у једнини и у множини: иє мон ПІ. 26. Н. Рањ. 40. Збор. 12. Ст. пис. 2, 58. 5, 221. Д. Рањ. IV. Град. дух. 14. Зор. 65. Злат. 6. Гуч. 286. Вран. жив. 26. Орб. 29. Банд. 6. ме монте М. 185. 538. ПІ. 9. Пб. 2. Н. Рањ. 19. Ст. пис. 2, 32. 3, 265. 5, 160. Злат. 3. Гуч. 11. Банд. 6. а $j$ се опет одбацује : не мо Ст. пис. $4,421$. Д. Рањ. 27. Див. 21. не моте Див. 2б. (впди и да.ље под Б. б.) а једном у слику налази се додано на крају $е$ : не моје Ст. пис. $5,4$.

У неких глагода четвртога раздјела прве врсте мјесто гласа 3 , којп у вих постаје у том об.лику од г, налази се кад кад и ж узето из садашњега вр. од свршетка XV вијека у једнини п у мпожини : бржи Ст. пис. 1, 222. жежи Ст. пис. 1, 332. Андр. дев. 70. ражежи Ст. пис. 1 192. раждежи Ст. пис. 2, 341. ужежи Ст. пис. 2, 343. 344. 445. 5, 190. Град. дух. 64. А. Рањ. 16б. Банд. III. Андр. дев. 13. стржи Ст. пис. 1, 129. ижежите Н. Рањ. 108. Банд. 102. ждежите Ст. пис. 4, 383.'

доста се често од XV впјека одбацује $и$ у једпнни на крају. и у множини пред личнијем наставцима, и то не само у пјесмама него п у прози : блуд' Ст. пис. 5,5 . вед' Ст. пис. 1, 139. припад' Ст. пис. 4, 194. врз' Ст. пис. 5 , 183. рец' Ст. пис. 2, 225. 4, 137. Д. Рањ. 67б. Злат. 13. жпв' Ст. пис. 4, 247. 271. пођ' Ст. пис. 2, 37. 3, 133. 4, 186. 202. Злат. 13б. са $j$ мјесто Б: пој' Ст. пис. 1, 46. 148. 180. Хект. 22б. Зор. 14. Стар. 3, 294. Вран. жив. 89. буд' Злат. 9. Јерк. 22. придобуд' Ст. пис. 4 , 480. не брин' се Злат. 34б. - пођ'мо Н. Рањ. 56. Ст.

' Гријешком је наштампано попєьнте M. 417. мјесто ннфивитпва попекH сє ППб. 123. 
пис. 5, 208. са $j$ мјесто 5 : пој'мо Стар. 4, 112. 117. - вед'те Ст. нис. 1, 26. просед'ге се Ст. пис. 1, 235. донес'те Н. Рањ. 31. номоз'те Злат. 10. свуц'те Ст. пис. 5, 269. рец'те Збор. 63б. Ст. нис. 2, 10. 56. 3, 29. 288. 5, 129. 134. Д. Рањ. 67. Злат. 6б. тец'те Ст. пис. 4, 361. 427. погьте II. 112. Ст. пис. 4, 295. 471. нађ'те Ст. пис. 3 , 306. са $j$ мјесто $ђ$ : пој'те Ст. пис. 4, 355. 5, 210. Стар. 3, 271. буд'те Ст. нис. 1, 240. стан'те Ст. пис. 5, 210. Злат. 34. ус'тан'те Ст. пис. 4, 332. спомен'те Ст. пис. 3, 121. прожен'те Ст. пис. 3,121 . - Кад се тако одбаци $u$ ша на грају остане $\theta$ пред ријечју која се почиње гдасовима $\dot{M}$ или $T$, 'raда се и 6 често одбацује: жи ми Ст. пис. $2,8{ }^{1}$ 169. 229. 270. 319. 506. 4, 260. 273. 329. 5, 215. 241. жи ти Ст. пис. 4, 328. 5, 248. 254. Чубр. 13б. ${ }^{2}$ тако је одбачено $u$ а за вим и $\pi$ : огр Ст. нис. 5, 284. (види напрнјед стр. 11 смр).

Б. Основе с наставком ја у свијем дицима садашњега времена :

a) основе у којима $j$ од вихова наставка долази иза сугласнога, те се с вим саставља по својим законима: у гдагода с таком основом бива у императиву исто што у онијех под А., само је у жих у у множини предњега гласа ради прелазило у $a$ : тако је у старом словенском: съвжжақ, съвжкатє; али у срнском језику тога нема, него је в пз онијех предњих глагола (II. А) докле се у њима држало прелазило кад кад I у ове, па се није мијењало у $а$ : пошкттс М. 175. свежете Стар. 4, 137. али се то није одржало, прем да се и У старом словенском језику кад кад налази, него је као у онијех предњих из једнине прешло $u$ и у множнну, а и то је бивало и у старом словенском језику (Миклошић vergl. gram. III. 98):

2-го и 3-ће јед.: I. 5. у глагола којему основа у садашњем вр. добпва наставак ја: жањн Радн. 42. - I. 6. у глагода који је у садашњем вр. удвојавао основу и она му тада добпвала наставаг ја: одеђи Н. Рањ. 39б. -- V. 2. завежи Ст. шис. Ј, 189. движи Ст. пис. 2, 496. уздвижи Н. Рањ. 39. урјежи Ст. пис. 5, 266. зиђ Збор. 35. пошиљи Стар. 3, 292.

1 Наптампано је жими.

2 Тако је и адјективу одбаqено в у примјерима: жи ми ја Ст. шис. 184. 294. жи ти ја Ст. пис. 261. 271. 
пошљи Гунд. суз. I, III. Радн. 89. пошаљи Ст. пис. 5, 100. Банд. 45. Мат. 14. Радн. 57. Глав. 126. закољи Ст. пис. 5, 179.

1-во мн.: I. 6. у глагода којему се основа у садашњем вр. удвојавала те добпјала наставак ја: одеђимо Н. Рањ. 13. - V. 2. ишћимо C'r. ппс. 1, 104.

2-го мн. V. 2. ишћпте Брн. 24. пошаљите Банд. 58. кољите Ст. пис. $4,489$.

И у тијех се глагола $u$ у једнини на крају а у множини пред личнијем наставцима може и одбацити: движ' Ст. пис. 4, 107. каж' Ст. пис. 5, 220. ппш' 136. движ'те Ст. ппс. 3, 290. 4, 70. плач'те Ст. шис. 3, 337. Гунд. суз. III, XXXVII. попдеш'те Ст. пис. 3, 427. обрип'те Ст. пис. пис. 5, 270.

б) основе у којима $j$ од вихова наставка долази иза самогласнога, те остаје: у глагода с таком основом у једнпни $u$ које постаје као и у предњих на крају отпада иза $j$, а у множини се т мијењало као и у предњих на $a$, али је и у тијех глагола у српском језику оно што бива у једнини прешдо и у множину, те нп у множини нема т нити какога гласа мјесто вега, као пто у једнини нема $u$, а тако је бивадо и у старом словенском језику :

2-го и 3-ће јед.: I. 6. продиј Хект. 10. упиј Н. Рањ. 70б. умпј 38. зиаи П. 6. Ст. пис. 2, 486. 4, 402. познај Вран. жив. 43. одшј Ст. пис. 1, 99. заодиј Банд. 32. с промјеном гласа ₹ у ој: пој Ст. пис. 5, 80. Гунд. пс. 40. запој Ст. пис. 4,99. - III. 1. жекнеи 3бор. 2. разумјеј Збор. 48. Град. дјев. 143. Орб. 56. - V. 1. давај Ст. пис. 1, 130. мжман М. 53. ме иман II. 36. угопај Здат. 97б. озирај Ст. пис. 3, 267. прнхаган М. 9. помаган М. 2. Ст. пис. 5, 307. питај Ст. пис. 4, 308. педјепсај Ст. пис. 3, 431. опрахан II. 78. пријај (ассіреre) Ст. пис. 2, 3. впкан ПI. 19. уфај Брн. 3б. простирај Н. Рањ. 117. споменпвај Авдр. дев. 199.' - V. 3. разгрнєн Збор. 98. кај Ст. пис. $2,244.5,134$. покај Ст. пис. 3,224 . у гдагола који је прелазио из тога раздјела у први исте врсте: одагнај Брн. 44. - VI. вјеруј Д. Рањ. 17. даруј Ст. пис. 2, 154. газуј Злат. 2. чтвн 36ор. 164. поптуј Н. Рањ. 63б. птуј Стар. 1, 219. Мат. 42. Вран. жив. 10. поштуј Глав. 67.

1 Мјесто гледај има и глеј Глав. 123. 
J-во мн.: I. 6. познајмо Каш. 113. иојмо Ст. пис. 5, 199. - V. 1. поминајмо Ст. пшс. 1, 208. споминајмо Вран. жив. 33. - V. 3. страјмо Ст. пис. 5, 199. - VI. пाтујмо Вран. жив. 33.

2-го нн.: I. 6. знајте Ст. пис. 4, 58. бијте Вран. жив. 61. нсп.ли(j)те Ст. пис. 3, 41. - III. 1. раздиненте П. 175. Н. Рањ. 63б. Град. дјев. 42. разумијте Вран. жив. 76. - V. 1. давајте Ст. пис. 1,44 . шихите М. 483. Ст. пис. 5,158 . помагајте Збор. 5б. постамате П. 20. - V. 3. у глагода ком се у основи самогласно " (иромнхтн) ширндо у ћ: прольнте Стеф. 10. - VI. напредујте Ст. шис. 5, 158. почтујте Ст. пис. $3,315$.

Глагод хтјети, који у садашњем вр. осим трећега дида мн. предази меלу г.лаголе другога раздјела пете врсте, остаје у имеративу међу глагодима првога раздједа треће врсте, те иде овамо : 2-го п 3-ће јед.: хотјеј Ст. пис. $2,479.485$. 4, 143. 420. 5, 40.52. 55. 196. 217. 237. 314. Злат. 10б. хотиј Ст. нис. 1, 86. 2, 411. 5, 40. Вран. жив. 68. Мат. 15. Мрн. 37. Јерк. 25. Каш. грам. 104. хтјеј Ст. шис. $2,10.4$, 298. 5, 5. 8. 12. 142. Злат. 22. Бун, 50. хтиј Ст. пис. 1, 7. Хегт. 9б. 206. 43. Стар. 4, 111. 115. - 1-во мн.: хотјејмо Ст. пис. 5, 222. хтијмо Хект. 32б. - 2-го мн.: хотјејте Ст. пис. 2, 403. 5, 223. хотијте Банд. 61. хтјејте Н. Рањ. 38. 496. 84. 36ор. 52. Ст. пис. $2,403$.

У једпни на крају и у множини пред дичнијем наставком доста се често $j$ и избацује: ироли Н. Рањ. 49. разумје Ст. пис. 2, 497. пожеме Збор. 165б. хотје Ст. пис. $2,497$. Андр. дев. 153. хтје Здат. 7б. хотн Н. Рањ. 172б. Ст. пис. 5, 14. Д. Рањ. 74. хти Ст. пис. 5, 41. кти Д. Рањ. 7. прјеповпједа Н. Рањ. 64. кастига 27. г.еда Ст. пис. 4, 249. 5, 232. д. Ран. 48. чува Ст. инс. 4, 238. вика Ст. нис. 5, 250. уча Ст. нис. 5, 77. ражива Ст. ншс. 5, 89. извида Д. Рањ. 17. гриска 20б. пита Град. дјх. 44. 45. З.лат. 31. слуша Гунд. суз. I, VIII. погледа Андр. дев. 168. ужива 25. - хтјемо Каш. 46. гдедамо Ст. пис. 5, 235. пранамо 212. чекамо 235. - развннете Збор. 173б. хтјете ,. Рањ. IX. Злат. 1б. хтите Н. Рањ. 17. 160б. имате Збор. 111. чввате М. 553. чувате Ст. пис. 5 , 99. тако и кад је $y$ пред $j$ налази се и без $j$ : втру М. 553. чу Н. Рањ. 48. 
У једнини надази се XVII вијека додано на крију $e$ : заодије Радн. 95. 99. сије 95.'

Само у једном гдагоду налази се у једнога писца XVII вијека у оба дица мн. $u$ шред дичнијем наставцима, као што се у истом глагоду данас и говори: уздајимо (даватп) Банд. 112. уздајите 41.

В. Основе које у садашвем вр. имају наставак ја само у првом лицу јед.: у таких глагола основа онака каква је у другим дицима оспм првога јед. долази у императив а иза везина крајњега $u$ отпада и у једнини и у множини наставак којим постаје императив, па и само вевино ирајње $u$ отпада кад стоји иза $j$ :

a) од основа које пред крајњим $u$ немају $j$, те им $u$ остаје: 2-го и 3-ће јед.: III. 2. жели Н. Рањ. 32. позри Ст. пис. 5. 78. Јерк. 39. цкни Збор. 106. Ст. пис. 2, 94. 5, 36. Злат. 856 Авдр. нач. 57. ${ }^{2}$ - IV. коүип М. 126 . говорп Н. Рањ. 63. слободи Ст. пис. 2, 132. одними Злат. 15. чти Ст. пис. 3, 112. Злат. 98б. Гуч. 43. Вран. жив. 18. прочти Ђам. 6.

1-во мн.: III. 2. цкнимо Ст. пис. 4, 438. - IV. чинимо H. Рањ. 158.

2-го мн. III. 2. бдите Каш. 43. позрите Ст. пис. 5, 160. свирите Ст. пис. 4, 335. ц(к)ните Збор. 143б. Ст. пис. 5, 217. - IV. пхоүитсе М. 4. модите Н. Рањ. 91. чтите Ст. пис. 3, 327. Орб. 176.

У множини је кад кад из других гдагода прелазило в и у ове, у којих оно не може ни постати: кндкте Стеф. 7. поколете М. 417. zмдрьжете Пб. 20. шстхкете Стар. 4, 136. соүдете Стар. 4, 134. (види напријед стр. 340. 342).

И у овијех глагода $и$ у једнини на крају и у множини цред личнјем наставком може се и избацити од XIV вијека

1 Мог.1о би се мислити да је и ту одбачено ва врају $j$, те да тако стоји мјесто заодjej, сjej, али у то вријеме и у тога писда тепко би ту могло бити је мјесто $u$, а и напријед је споменуто (стр. 341 ) да се налази $e$ додаво и пршје и у другога писца.

2 ШІто има волиј Х(кт. 30. мниј Ст. пис. 2, 271. 282. дњниј Ст. nuc. 1,243 . тешко hе бити по првом раздјелу треће врсте, него he $u$ стајаті мјесто самога $u$. 
(види друго мн.): учпн' Н. Рањ. 58б. 61. Злат. 11. Вран. жвв. 99. чннь Збор. 60. 121. Ст. пис. 3, 391. 4, 231. Град. дјев. 37. Брн. 18. говор' Ст. пис. 5, 215. одговор' Брн. 23б. отвор' Ст. пис. 3 , 443. прнм' Ст. пис. 4, 48. сцјеп' Град. дјев. 78. одријеш'мо Ст. пис. 4, 132. ход'мо Ст. пис. 5, 132. Хект. 4. ()тправте Пб. 30. псиравте Пб. 30. Ст. пис. 3, 316. остав'те Ст. пис. 1, 35. учин'те Н. Рањ. 63. чин'те 36ор. 80. Ст. пис. 4, 4. 255. 5, 213. Град. дјев. 4. Брн. 56. Злат. 3. брап'те Ст. пис. 5, 160. поклон'те Ст. пис. 3, 306. мол'те Ст. пис. $1,35$. 3, 327. скоч'те Ст. пис. 4, 478. прим'те Злат. 3. скуп'те Брн. 56. ход'те Ст. пис. 4, 222. 5, 211. Злат. 4. - у једнини гад остане на крају ст, жоже се и т одбацити: допус Ст. иис. $2,426.4,48.5,40.50$. (испореди стр. 6).

б) од основа које пред крајњим $u$ имају $j$, те нм $и$ отпада:

2-го и 3 ће јед.: III. 2. стој Ст. пис. 5, 208. настој Вран. жив. 57. - IV. опој Ст. пнс. 2, 341. тај Ст. пис. 3, 183. 4, 11. 5, 190. затај Вран. жив. 30 .

2-го мн.: III. 1. бојте се Ст. пис. 5, 211. постојте 213. - IV. гојте Ст. пис. 4, 78. напојте Ст. пис. 5, 160. тајте Ст. Inuc. $3,216.4,262.386$.

дВоЈинА.

Разликује се од множине само личнијем наставцима, а они су као у садашњем времену; у нашим књигама долази само друго дице, и то само у старија времена: чьттта Сав:

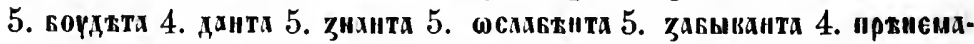
raнта 5. векнумта 4. млпншита 4. - налази се и на свршетку XVI вијека, п то са $и$ гдје је прије бшло т, али за треће дице множине: (иашн трьгокырн) ввднта првпорвуенн П. 16.20.22.

\section{ПАРТИПИП САДАПІЊЕГА ВРЕМЕНА}

АКтивни.

Основе су онаке какве су у садапњем времену, а које у садапшем вр. само у првом лицу јед. пмају наставак ја, оне додазе у овај партицип онаке какве су у осталијем лицима осим првога јед.
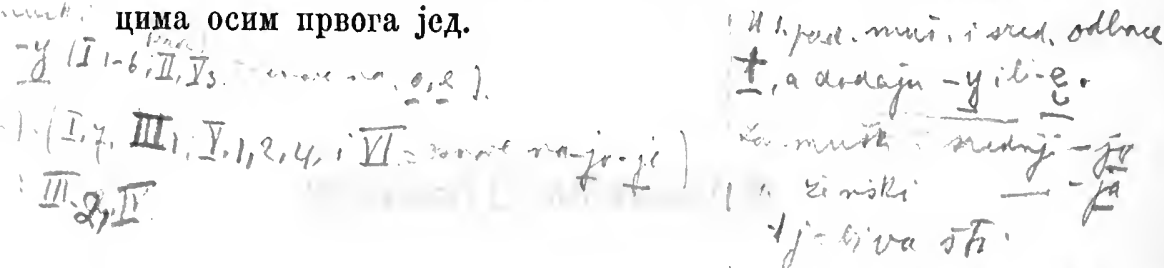
Наставак је ant, алш с такии наставком остаје партициі само у неким падежима, а у другима прелазећи међу ријечи с основом на ја добпја јон наставак ја, те му наставак тако од два сложен гласи intja. И простоме и сложеном наставку остаје а у почетку сащо иза основа које се свршују на сугдасно, а то су основе које у садашњем вр. немају наставка, а иза основа које се свршују на самогласно отпада му речено а. Од основа садашњега времена састављенијех с тијем наставком простијем или сложенијем постају овоме партиципу основе за падеже.

I. ІІрости наставак. Основу посталу тијем наставком

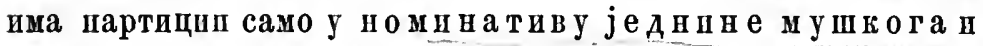
средьега рода. Оба падежа постају онако као у имена, и то као у имена којима се основа свршује ва сугласно, јер се и партиципу с простпјем наставком основа свршује на сугласно: у мушком роду наставак $\mathbf{s}$ стојећи на крају отпада, а у средњем роду и нема наставка за тај падеж као штто га нема ни у имена средњега рода с основом на сугдасно (стр. 11-12): што остаје - а то је основа - једнако је за оба рода и за то је номинатив јед. и мушкога и средњега рода једнак у овога партиципа. Али у самој оспови, која остаје за номинатив, бивају разлике према гласовима до гојих долазн њезин наставак: пзмеђу глагола којима основе у садашњем времену немају наставка и онијех којима основе у садашњем времену имају наставак а не може бити разлике, јер ако прве и добшвају цијели наставак ant a друге само nt, опет ове друге веһ пмају а пред nt: али се од вих разликуј глаголи којима основе у садашњем вр. имају наставак ја, па се п између њих самијех одвајају они којима основе имају наставак ја само у првом дищу јед. садапњега вр.

a) Основе у садашњем вр. без наставка и с наставком a: кад к првима пристуши наставак ant a $к$ другима само nt, тада (као на стр. 11. 16.64. 103) а пмајућп за собом n и за њим $t$ прелази са $n$ у дуго $u$, које у словенским језицима гдаси т, а сугдасно $\mathbf{t}$ оставши на крају отпада: тако у нашој књижевности долазп само у споменицима у којима претеже црквени језик а у вима се жјесто ы пише и и (а 
долази тај падеж н сложен као у адјектива имајући у мушком роду још и на грају, внди даље): қады Стеф. 23. сни 11. ұкьты 18. моги 20. пккы 10. М. 91. нұм Стеф. 16. али од првнјех времева додази са $e$ мјесте ш преносећи основе на чпсто а међу основе на ја: ноге М. 2. 6.' 255. пвде М. 22. 237.300. 336. М. 19. кове Зак. 49. тако допире у XVII вијек: пде Ст. пис. 5, 183. греде Збор. 47б. Ст. пис. 2, 58. 5, 138. Зор. 7б. Вран. жив. 38.

б) Основе у садашњем вр. с наставком ја у свијем лицима: прајње а у основи гласећи у словенским јевидима 0 мијења се на $\epsilon$ иредњега гласа ради, па се $e$ са n од наставка nt састав.ба $\mathrm{y}$, које у српском језпку гласп $e$, a t оставши на крају отпада: таки се партицип много јаче држао: I. 6. выние М. 9. - V. 1. гхстас М. 444. пике 301. прниае 381. 412. 469. разиншаке 444. смннала 444. 507. припадаю 9. 134.

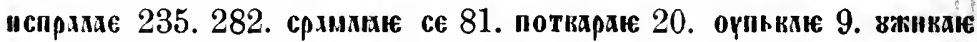
285. 300. - V. 2. пнше II. 74. пауче Стеф. 18. скауе 16. шие 16. - V. 3. дақ М. 9. 300. дає 221. 235. 288. пае 134. с промјеном гдаса н на \$, као што је бивало и у садашњем вр.: лтє Стеф.

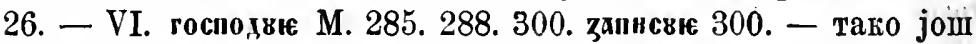
на крају XV п XVI вијека: I. 6. с промјеном гласа п па ој као у садашњем вр.: поје Ст. пис. 2,129 . - III. 1. желије ${ }^{2}$ Ст. пис. 2, 111. - V. 1. бираје Ст. пис. 3, 452. бигае Стар. 3, 301. враћаје Буд. 60. обраћаје Злат. 17б. гледаје Ст. пис. $2,13$. 3, 471. 4, 319. 5, 297. А. Рањ. 4. Злат. 7. згрншаје Ст. пис. 1, 296. имаје Ст. пис. 2, 442. складаје Ст. пис. 2, 94. 3, 217. 4, 28. клањаје Д. Рањ. 148. скончаје Злат. 7. покриваје 3бор. 6. Злат. 93. пушаје Ст. пис. 3, 463. лјеваје Д. Раґ. 19. прољеваје Ст. пис. 3,322 . размишљаје Ст. пис. 3 , 323. смишљаје Ст. пис. 2, 188. 3, 304. 5, 118. 297. Злат. 18. понав.баје Ст. пис. 3, 24. пппаје Ст. пис. 4,476 . спјеваје Ст. пис. 2,62 . приппваје Хект. 29. плпваје Ст. пис. 5, 103. прапаје Ст. пис. 3, 297. пуптаје Злат. 17б. ругаје се Збор. 154. слишаје Ст. пис. $3,3$. 4, 269. услишаје Ст. пис. 3 , 413. уфаје Ст. пис. $2,234.3,471$. 5, 325. чекаје Ст. шис. 2, 129. шетаје Д. Рањ. 102б. - V. 2.

1 На та ће оба мјеста бити средњи род, који је, како је речено, једнак с мушьим у том падежу.

${ }^{2}$ Наштампано је žеlје, али мислим да је партиции и да треба чнтати: желије. 
доче Ст. пис. 5, 306.' - Каюо се внди, између свијех гдагода којима основа у садашњем вр. има наставак ја, највпше се још XVI вијека држао овај обдик у онијех првога раздјела пете врсте; јамачно су за то у исто вријеме прелазили међу њих у овом облику и гдјекоји глаголи другога раздјела пете врсте, прем да су неки и у другпм облицима онамо прелазили: грагаје Д. Рањ. 119б. двизаје Злат. 17. искаје Ст. шис. 4, 476. плакаје Ст. пис. 2, 129. 461. 5, 38. 56. Д. Рањ. $103 б$.

в) Основе поје у садашњем вр. само у 1-вом јед. имају наставак ја, а у осталијем се лиция сврпују на $u$ : крајње $u$ од основе састав.ьа се са $\boldsymbol{\mu}$ од $\mathrm{nt}$ у $₫$, гоје у сргском језику гласи $e$, а $\mathbf{t}$ оставни на крају отпада: у таких глагода овај облик допире у XVII вијек: тако до краја XV вцјека: III. 2. Боє сє М. 81. 90. II. 103. веке М. 9. виде 241. сиєдє 412. и у глагода те врсте који у садашвем вр. само 3-ће мн. има по овој врсти: хоте М. 4. 9. 241. исти је гдагод предазно п у први раздио ове врсте те му овај облик принада и напријед год б): хотье II. 242. 260. - IV. весеке се М. 90.

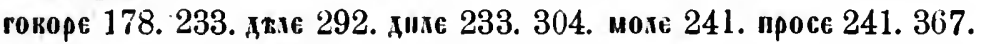

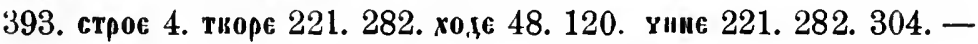
на крају XV ІІ свега XVI вијека: III. 2. виде Хект. 7б. држе 3бор. 38б. муче Ст. пис. 2, 45. 378. Зор. 12б. Злат. 35. сједе 3бор. 35. сиде Зор. 35б. стоје Н. Рањ. 109. Ст. пис. 3, 3. 338. 4, 19. 73. 98. 162. 4, 103. 190. 290. 344. 5, 341. хоте Збор. $2 б$. Буд. 9. - IV. говоре Н. Рањ. 91. 92б. 98б. 150. 169. Збор. 39. Ст. пис. ¿, 249. 276. 5, 121. моле (т. пис. 5, 9. просе М. 557. срде се Ст. пис. 1, 9. творе Д. Рањ. 63б. 77б. туже Ст. пис. $2,126.5,182$. ходе Ст. пис. 4, 9. 54. 95. 104. 112. 143. чуде се Ст.- иис. 1, 9. - XVII вијека: III. 2. муче Див. 30. Мик. 679. стоје Гунд. суз. I, LXIV.

Сложени ном. јед. мушгога рода постаје као у адјектива кад к номиналном ириступи номинатив јед. истога рода ", али додази само у споменнцима у којима претеже црквени језик: тако у партпцина поменутога под а): къдын М. 9.90. вмады" М. 562. у онијех иод б): нспнтаки М. 90. овмадаєи М.

1 Једвом у слику има наде Ст. пис. 1, 16. по свој прилиди мјесто надије. 


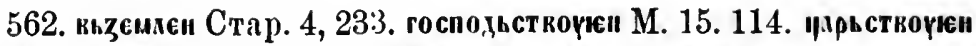
М. 562. у онијех под в): пенхинде М. 89. пюкеи Сав. 2. творен Сав. 1. М. 203. искоқси М. 277. Али од XIV вијека долази овај сложенп облик и норемећеп : из падежа у којима оспова има сдожени наставак (видн под II) прешла је така основа и у овај сложени, те је са свијем онакп кагав је у адјектива с основом на ја; али и таки додази до свршетка $\mathrm{XV}$ вијека само у споменицима у којима претеже црквенй језик, в за то ижа у основи шт мјесто $ћ$ : господьствоүючии М. 81. вмахвцини М. 135. кмххвчи М. 205. 266. Пб. 66. скемогвци II. 14. (даље види под II. 3. б. в.). - У средњем се роду сложенп номинатив јед. још у старом словенском језику замјењивао акусативом, а он је постајао од основе у којој је сложени наставак (впдп II).

Али номинални овај облик ако се и сачувао тако да у гдјекојега глагола допире и у XVII внјег, опет се много прије заборавило што је, те још од свршетка XIV вијека додази и за друге падеже, п то за номинатив мн. кога му драго рода, за поминатив јед. женскога рода и за акусатив јед. мушкога рода: а) за номинатив мн. кога му драго рода, на свршетку XIV вијека не само кад један говори о себи у множини: ми хоте хари кити М. 241. него и кад је ријеч о правој множини: хтне (Аубровчани) М. 239. в нмие кмххинне не нюмо (Аубровчани) ди стон, нв пауе смо поскаки zаповюдаю II. 20. догоше ихии модиєе твже П. 20. тако XV впјека: I. 6. квде (кь нхвин ,рьжи.ии дубровчанп) М. 260. 307. 430. П. 72. 96. 144.

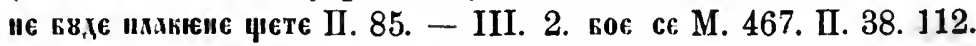
свииє ПI. 103. хөтє М. 258. 289. 308. П. 151. у пошљедњега : као у глагола првога раздјела исте врсте: хотьє М. 497. IV. moxe M. 294. П. 127. 129. просе М. 294. твже ПI. 73. - V.

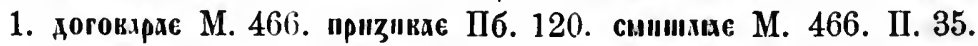

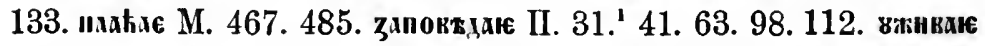
М. 285. вфак П. 96. чекале II. 92. - VI. госпоуве М. 285. пртпорвчвє II. 76. zахванюю П. 123. - на свршетку XV и свега XVI вијека: I. 1. греде Ст. пнс. 1, 13. Злат. 58. - I. 6. знаје Ст.

' ІІІто има на истој стравп II zınокт,ц, биће погрјешка мјесто zanовтддақ. 
пис. $3,430.4,373.5,35 .-$ III. 2. виде Ст. пис. 5 , 139. стоје Ст. пис. 3, 2.32. хоте Буд. 135. 140. - IV. воде Ст. пнс. 3, 247. говоре Н. Рањ. 103б. 156б. Ст. пис. 2, 82. 5, 14. Збор. 29б. ходе Ст. пис. 3, 239. 4, 138. 5, 127. 201. 208. обходе Ст. пис. $1,28$. чине Ст. пис. $1,18$. - V. свртаје Ст. пис. 1, 14. 28. гледаје Ст. пис. 4, 180. 317. подпраје Ст. пис. 3,240 . играје Ст. пис. 1, 12. складаје Ст. пис. $3,178.4,20$. смишљаје Ст. пис. $2,379$. 5, 113. 145. припјеваје Ст. пис. 3, 246. спјеваје А. Рањ. VІб. предаје Ст. пис. 4, 307. скрипаје (кола) Злат. 17. слишаје Ст. пис. 3,30 ј. поступаје Хект. 11б. удараје Ст. пис. 5 , 157. чекаје Ст. пис. $1,19.4,307.466$. шетаје Ст. пис. $4,60 .-$ V. 3. даје Ст. пис. $1,57$. - б) за номинатив јед. женскога рода: XV вијека: винса (тоснођа Вукава) просе П. 91. ш госnогм Ехпа бвде у Двкрокьник М. 359. юст вунина госпога Екм хоте М. 415. моле се винсах (госпођа Јела) М. 417. пствин Стхпхнда nнтає а гокоре ПІб. 117. - на сврпетку XV и свега XVI вијека: I. 1. јиде Ст. пис. 1, 64. греде 3ор. 35б. - I. 6. поје Д. Рањ. 91. - III. 2. муче Злат. 29. сједе Ст. пис. 3, 194. стоје Ст. пис. $3,80.250 .4,183.355$. -- IV. воде 'злат. 486. говоре Ст. пис. 4,289 . ходе Ст. пис. $3,336.5,263$. Гуч. 1 : 8. - V. 1. набадаје Ст. пис. 4, 93. разбираје Ст. пис. 2, 506. 3, 322. повијаје Ст. пис. 4, 467. гледаје Ст. пис. 3, 435. 3лат. 29б. 42б. играје Ст. пис. 5, 201. складаје Ст. пис. 3, 388. кушаје 178. лупаје 127. размишљаје Н. Рањ. 21б. 30. Ст. пис. 3, 345. смишљаје Ст. пис. 3, 6. спјеваје Ст. пис. 2, 118. Д. Рањ. 135б. пуштаје Ст. шис. 2, 393. стриљаје 347. 373. ганцаје Ст. пис. 2, 85. чезаје 467 . чекаје Ст. пис. 4, 290. шетаје A. Рањ. 23. тако и у глагола који су из другога раздјела ове-врсте прелазпли у овај (вндп напријед стр. 349): викаје Ст. нис. $2,434.5$, 133. крекаје Ст. пис. 5,11 . махаје Ст. пис. 2, 434. - XVII вијека: хоте поднесла јест смрт Вран. жив. 38. Фебронија исплази свој језик хоте да се одриже Вран. жив. 62. - в) за акусатив јед. мушкога рода, вди управо за генитив, кад се вим замјењује акусатив: XVI ви јека: деже (јоште дан не бјеше, кад та сам састао дошадши туј леже) Ст. пис. 5, 212.

II. Сдожени наставак. C њим се основе садашњега времена састављају двојақо према свом завршетку : 
a) све основе осим онијех које у садашвем вр. само у првом дицу јед. имају наставак ја састављају се једнако с наставком, јер ако паставаг пза основа на сугласно и гдаси antja а иза опијех на самогдасно само ntja, опет је то самогдасно свагда а, те се у свијех састају једнаки гдасови којв треба да се сложе, а гласовп nt у наставку не стоје на крају да бп се $n$ с предњнм а другачпје слагадо иза $j$ a другачије иза других сугласнијех, него $\mathbf{t}$ имајуһи за собом ја припада другом слогу: по томе се $\mathbf{n}$ од наставка

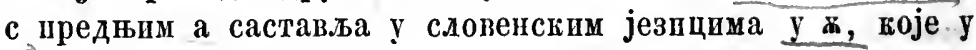
сршском језику гласи $y$;

б) основе које у садашњем вр. само у нрвом днцу јед. имају наставаг ја а у осталијем се свригују на $u$ (у глагода другога раздјела треће врсте п четврте врсте), долазећи с тијем завршетком п у шартицип, састав.ају своје грајње: са n oд ntja у , које у српском језику гласи $e$.

у основама тако састављеним за партицип гдасови се tj од наставка слажу по својим законима, т. ј. од њих бива у староме словенском језику шт а у српском $\hbar$. Од основа тако саставленијех имао је партицип све падеже у сва три рода осим веһ поменутога (под I) номинатпва јед. мушкога и средњега рода; а будући да се те основе сврнују на ја, за то су од них сви иадезіп (осим поменута два) постајали онако као у имена с основом на ја, осим номинатива мн: мушкога рода, који је постајао другачнје, и номинатвва јед. женскога рода, који се разликовао од обичнога.

1. Но минатив м ІІ. му уг ко ог а рода одбацивао је својој основи крајње а, те постајао као у имена мушких којима се основа свршује на сугласно (види напријед стр. 66) и тако се сврнивао на $e:$ у основи му мјесто $\hbar$ додазп штт у споменцима у којвма претеже црквени језпк: a) основе са a пред ntja: V. 1. жхьдмоцс: M. 35. спасаюцє М. 43. - V. 2. у глагола у којега је основа садашњега вр. имала наставак а мјесто ја за овај облик: "скоүцє Стеф. 22. - б) основе са н пред ntja: III. 2. свьтеціє M. 133. -- IV. проходсце M. 81. - Али од првијех времена додази по живом говору у основи : трыгвюћс M.2. тако до краја XVI вијека: 
a) основе са а пред ntјa: у глагола којима основе у садашшем вр. немају наставка: вндъс М. 449. - у осталијех: I. 1. тредвће Збор. 256. - I. 5. каннвће М. 176. - I. 6. внюће 3бор. 25б. криюће Збор. 27б. зиаюће М. 217. 462. Буд. 88.90. 140. у гдагола овога раздјела у којнх основа у садапњем вр. добија д: квдвкс М. 239. 493. 499. попоркс М. 34. шрдоүке М. 34. - III. 1. миююће М. 448. у гдагода који је из другога раздјела ове врсте прелазио и у овај овијем обликом (види и под б): хотнюће М. 448. - V. 1. прквнгаюће М. 211.

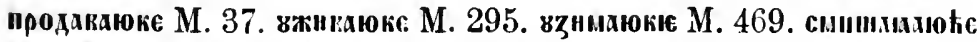
M. 473. попвирюће М. 249. впкаюьє П. 67. - V. 2. уз(д)ишуће Н. Рањ. 13. "ұुпмюће М. 368. вұзимюће М. 381. 412. - V. 3. даюће M. 336. 412. П. 115. продаюк M. 14. - VI. бдаryjyћe Н. Рањ. 180. господвюке М. 295. вдкмююће М. 336. ๘впвюке М. 37. квивюће Збор. 29. прнпорвчвюће М. 448. скияовюће М. 249. трһгвюке M. 2.

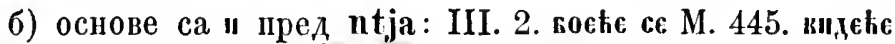
М. 445. Ст. пис. 1, 54. жхьдеће М. 210. unesse П. 143. сп, пеке М. 469. стоске М. 34. 211. хотеће М. 218. 445. 507. Буд. 128. хтеће М. 446. (види п под а). пієдеће М. 226. - IV. крапєке II. 115. говораке М. 117. говореке М. 158. гокореће М. 231. 248. 249. Н. Рањ. 93. Збор. 39б. Стар. 3, 231. дтеће М. 381. диекеке М. 412. крхесће М. 486. молекіе II. 39. 94. прюетеке П. 58. сликеке М. 319. 343. стакеће М. 498. стрниеће М. 249. ходеке M. 46. ходеће Ст. пис. 1,54 .

Сложени је облик постајао кад к оваком номиналном облику приступи номинатив мн. од прономина ", као у адјектива, али се налази само у споменицима у којима претеже црквени језик те је и у основи само ит мјесто $ћ$ :

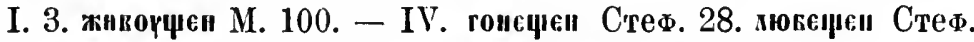
28. мнскецеи Стет. 28. - V. 1. трорждаюұен М. 530. - V. 2. начющен Сав. 8.

Како су друге ријечи мушће с основом на сугласно шрешгде у овом падежу међу мушке ријечп с основом на ја (види cтp. 66), тако је онамо прешао и партицип те је и он своје крајње $e$ у овом падежу замијенио гласом $и:$ то се појављује још XIII впјека и најприје долази у сложеном облику, у ком се $u$ које је дошло на гјесто $e$ сажело сл прономином 
I у један глас, а пред њим је према црквеном језику шт мјесто $f$ : господьствоүюци М. 15 . тано п послије у споменицима у којима претеже црквени језик: мдоүни М. 244. и с несажетпјем ни: соүцйи М. 332. у таким споменицима додази тако п у номиналном облику XIV вијека: соүни" M. 60. IIо живом rовору са $\hbar$ у основи долазн номпнални облик у правом свом послу тако промијевен од XIV вијека: "схо-

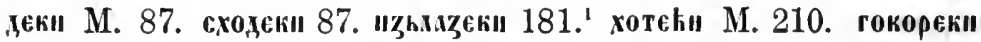

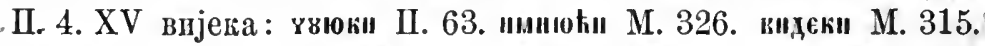

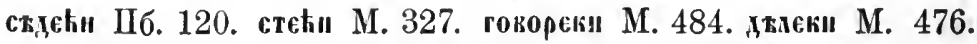
нохеки П. 46. 59. 61. 142. допосеки М. 528. холећ॥ М. 327. врхҺаюћ॥ М. 327. щцвки II. 138. минвюки П. 60. у свијем је овијем примјерима права множина, а има их тога времена и више у којима један говори о себи у множини изријеком тако да пе може бити сумње да стоји множина: вздъћи М. 300. 493. жельюћи М. 325. hotiiuchi М. 279. пржноссћи М. 494. wгрхћхюћи М. 327. пропинвюћи М. 494. п послнје додази таки облнк свега времена: I. 1. ведући Стар. 3, 321. - I. 3. дубући Ст. ппс. 5, 313. скубући Ст. пис. 1, 102. живуһи Стар. 3, 254. I. 4. жегући Ст. ппс. 1, 8 . жогући Вран. жив. 50. стргући Банд. 11. текући Ст. пис. 1, 247. - I. 6. бијући Н. Рањ. 23. вапијући Ст. пис. 1, 31. словући Ст. пис. 4, 4. појући Збор. 102б. Ст. пис. 4, 4. 5, 198. знајући Стар. 3, 280. Каш. 67. идући Збор. 7б. будући Збор. 48б. Ст. пис. 5, 224. Див. 17б. Банд. 11. - I. 7. мрући Ст. пис. 2, 416. трући Ст. пис. 5, 101. - III. 1. жедијући Ст. пис. 1, 186. умјејући Н. Рањ. 119. разумјејући Н. Рањ. 59.-III. 2. бдећи Вран. жив. 38. вндећи д. Рањ. VI. Злат. 84б. држећи Здат. 17. живећи Ст. пис. 1, 151. 309. седећи 28. стојећи Збор. 5б. Ст. иис. 2, 52. 4, 178. Град. дјев. 142. хотећи Ст. нис. 1, 72. Стар. 3, 231. Брн. 58. Вран. жнв. 59. хтеһи Ст. пис. 1, 19. 70. Каш. 62. од истога гдагола и по шрвом раздјелу

- О ова три примјера могло би се сумњати је ли у њима доиста овај падеж, јер долазе међу ријечима којима се казују међе па нема ријечи којој су прпдјевени, али мислим да је у њима овај падеж за то пто у такој прнлици долази и сия-

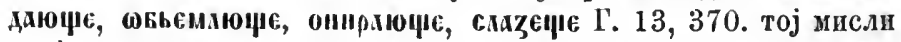
не hе сметати што у такој прилици долази и једнина: похьи, шкишьди Г. $13,371$. 
ове врсте: хтијући Ст. пис. 4, 107. од гдагола овога раздјела ком је основа у садашњем вр. І д добијала, па је и у овај облик прелазило д XVII вијека: мнидући Вран. жив. 62. IV. изводећи Ст. пис. 3 , 66. возећи Хект. 12. говорећи Ст. йс. 1, 44. Н. Рањ. 34. Збор. З1б. Стар. 3, 254. 4, 112. пзгонећи Н. Рањ. 23. ловећи Ст. пис. 1, 3. Хект. 34. мислећи Ст. пис. 2, 388. мрмљећи Ст. пис. 5, 64. носеһн Ст. пис. 3 , 309. подносећи Див. 31. просећи Ст. пис. 1, 9. слишећи Ст. пис. 1, 21. хвалећи Н. Рањ. 216. Збор. 89б. Банд. 11. ходећи Ст. пис. 1, 8. 4, 115. Јерк. 25. приходећи Ст. пшс. 3, 334. хрлећи Злат. 17. чинећи Ст. пис. 3, 208. Хект. 22б. Буд. 88. Брн. 3. Див. 23б. чтећи Ст. пис. 5, 350. Орб. 43. штећи Стар. $1,227$. чудећи се Капг 20 . у глагола који инфинитивом припада у пету врсту: спећп Орб. 113. - V. 1. одвраћајући Брн. 9. гледајући Збор. 27. карајућп Ст. пис. 1, 186. спомвнајући Брн. 13. сповидајући Ст. пис. 1, 68. чекајући Н. Рањ. 20б. Стар. 1, 224. - V. 2. нагињући Ст. пис. 1, 12. јишћући Вран. жив. 20. пдачући Ст. пис. 1, 21. 3, 224. - V. 3. зовући Стар. 4, 116. дајући Ст. пис. 1, 58. Банд. 99. подајући Каш. 84. познајући Каш. 71. смјејући се Ст. пис. 5, 254. овамо је из првога раздјела ове врсте прелазило: даријући Ст. пис. 1, 3.' VI. вјерујући Збор. 27б. оглушујући се Гуч. 11. пљенујући Ст. пис. 3, 20. потврдјујући Вран. жив. 23. тугујући Ст. ninc. 3,35 .

Али оба ова номинатива, и- онај прави на $e$ и овај промијењени на $u$, ако се онај први п држао јопा XVI вијека а овај други остао до данас, опет се ни један ни други од давна није осјећао ни да је номиватив, ни да је у множини, ни да је мушкога рода: за то се баш и могао држати тако дуго један уз други не сметајућп један другом, те вајпослије од двпје ствари пстога значења једна взађе из обичаја; што се ни један ни други није осјећао што је, с тога додазе оба и за друге падеже од XIV вијека:

a) прави ном. мн. на $e$ додази: аа) за ном. јед. мушкога рода: XIV вијека: спомепвюке (и господниь Бхиша) М. 193. трє „вће

1 Испореди даље под б. пцелијући" и споменуто напријед стр. 297 „дарију“. 


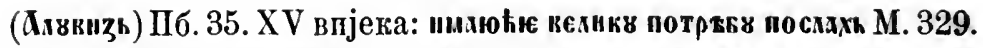

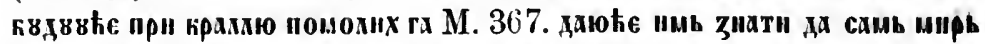

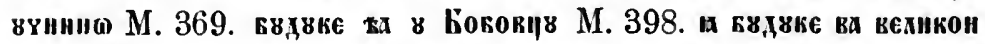

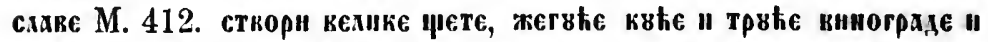
пхиแ

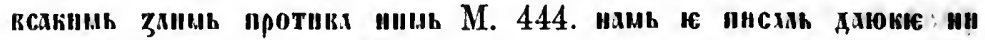

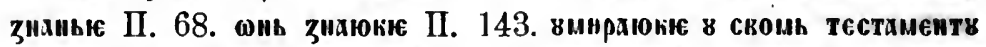

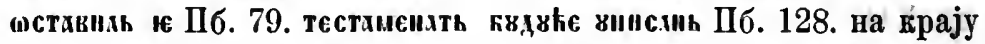
XV и свега XVI вијека: чинеће Ст. пис. 1, 153. видеће Ст. пис. 2, 225. желеће 118. 141. хтеће 438. мислеће 438. будуће Н. Рањ. 20.22. 41б. 79б. говореће 15. 92. 103. имајуће 386. приповиједајуће 19б. пдуће (краљ) 3бор. 93. будуће (највећп, поче просити) 36. кимајуће 38. плачуһе 31б. минујуће (Абрам) 38. текуће А. Рањ. 44б. крпјуће 11б. 21б. знајуће Буд. 20. (ако купил јест ствари укредене или по сили вазете, знаjyћe) 90.136. - бб) за номинатив јед. женскога рода: XIV внјека у једном примјеру још са шт мјесто $\hbar$ : м(хоү)чє $M$.

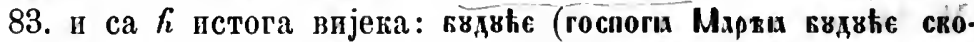
кодна) М. 211. XV вијека: госпога Тодора, ви,цие (т. ј. вะдорће) " раяььмикаюке M. 418. на крају XV и XVI вијека: лежеће Ст. пис. 1, 65. велеће Ст. пис. 2, 245. желеће 205. говореће Н. Рањ. 93. имајуће 20. плачуће 25. беруће 52. обслужујуће 26. - вв) за номпнатив јед. средњега рода (кад се налази за номинатив оба прва рода, нема сумње да је исти облик a не други какав и за средњи род): на крају XIV впјека:

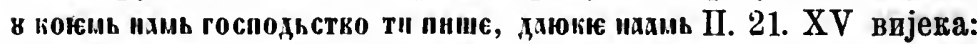
крахекстко ми хотећє пхатити М. 248. јер сунде ничеће нагнуд' бише кола, свитли образ хтеһе замакнути дода Ст. иис. $1,27$. - гг) кад нема номинатива, којему би био пршдјевен: рахзг

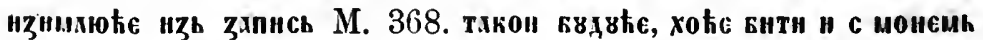
н с кашнемь почтеннемь М. 501. - АД) за акусатив јед. мупкога рода, или управо за генитив, кад стоји мјесто акусатива, XVI вијека: овогај нађосмо обраћајуће људи Н. Рав. 104. нађе њега тако чинеће Н. Рањ. 219б. застх мвжа пххувће

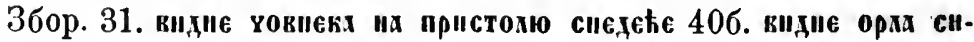
дсће 38. тогај чдовика видјет ћеш смрт хтеће Ст. пис. 2, 124. поновит' чини ме не ктеһе Ст. пис. $5,352 .-$ Ђђ) за датив 
апсодутни стоји прудјевен дативу: обдадајуће шонцноскому Пвдату (Лук. 3, 1) Н. Рањ. 19.

пнан б) промпјевени ном. мн. на $u$ долазп : аа) за ном. јед. мушкога рода (кад правп ном. мн. мушкога рода долазп и за ном. јед., вема сумве да додази и промнјењени нити има раздога тражити другп облик који бп једнако с вум гласио); a тај номинатив мн. додазп за ном. јед. мушкога рода још од XIV вцјека, најшршје долази са шт мјесто $\hbar$, али у споменику познату само пз рђава прпјешвса и с тога у овој ствари по све непоуздану: поканаюцн се М. 129 . поуздано је тога вијека: хотеки М. 202. мнскећн М. 210. али у то вријеме као да се је овај облик још колебао кад је замјењивао номинатив јед., јер се надази (н)щєки М. 178. вддећи М. 211. мјесто пштоүћ, воүдоүћн, а ту ће бити номиналном номинативу јед. пштс, воүдє, појн је овај замјењивао, додано његово ћи. XV вијека: I. 4. вртгвки П. 168. могвки II. 99. - I. 6. од гдагода коме основа у садашњем вр. добива д: кдынин М. 336. Бвдвћ॥ М. 495. 511. 519. П. 52. 169. Пб. 120. - III. 2. Боєки се М. 409. Пб. 100. เидекН М. 518. - IV. мокећн М. 326. II. 148. - V. 1. окећиваюћн М. 326. - V. 2. кахвки ПI. 164. - V. 3. хаюки II. 168. - VI. скттвюкН II. 154. потреввюћн М. 339. и послије: у глатола којима основа садашњега вр. нема наставна: једући Ст. пис. 5, 89. Каш. 26. Радн. 17. Андр. пут 169. у других : I. 1. чтући Ст. шис. 1, 3. гредући Зор. 2б. Радн. 45. гудући 3ор. 15. 47б. гредући Мрн. 53. - I. 2. љезући Ст. пис. 2, 334. - I. 3. живући Брн. 24. Вран. жив. 106. Див. 31. Банд. 49. Пос. 6.' - I. 4. могућп Зор. 30. Злат. предгов. 2. Стар. 4, 114. стригући 3ор. 46б. рекући Н. Рањ. 87б. Ст. пис. 5, 278. тукући Ст. пис. 4 , 18. 160. - I. 5. кунући Ст. пис. 5, 38. Буд. 90. дмући Здат. 88б. - I. 6. вапијћи Ст. шис. 3, 25. кријућп Ст. пис. 4, 472. чујући Збор. 104б. Каш. 35. рујући Вран. жив. 65. с промјеном гласа $y$ у ов: пловући Ст. цис. 3, 4. 129. 284. ровући Ст. пис. 1, 31. смјејућп Ст. пис. 5, 254. с промјеном гласа у ој: појући Ст. пис. $3,4.205$. 4, 25. Д. Рањ. VII. од глагода коме основа у садашњем вр. добија $\varkappa$ : денући Андр. пут 254. од глагода којшма се основе

' IIIтампарска һе погрјепка бвти: жиуһи Радн. 10, 
у садапњем вр. шире добивајућп од свагда д: будућп Ст. пус. 1, 128. Н. Рањ. 23. Здат. 14. идући Збор. 92. Гунд. суз. III, LXXXVIII. како је у пошљедњега у садапњем вр. долазило II 5 мјесто $A$, тако и у овом облику XVII вијека: пђући Радн. 6. 7. 12. Пос. 16. знајући Ст. пис. 5, 126. како је у пошљедњега глагола у садашњем вр. основа добивала д, прелазио је тај глас п у овај облик XVII вијека: знадући Вран. жнв. 22. 35. 69. 74. Мат. 18. 52. 53. Мрн. 34. Каш. 88. 92. Гдав. 62. 63. 72. 77. 81. вцдн І у трећој врсти. - I. 7. мрући Злат. 88б. од глагола који је из другога раздјела треће врсте у садашњем вр. прелазио в оваго: врући Брн. 68. - II. сахнућн Злат. 88б. поникнући Бун. 49. - III. 1. желијући Хект. 35б. 39. пrјејућп Н. Рањ. 164б. пмијући Н. Рањ. 164. Буд. 86. Мрн. 39. Гдав. 48. умпјући Андр. пут 207. разумијуһ Вран. жив. 75. Радн. 89. разумјејући Мат. 53. у овај су раздио прелазили овијем обликом гдјекоји глаголи из других раздјела и врста прем да га имају и према глаголпма међу које припадају : тако из другога раздје.да ове врсте (види стр. 353) хотијући Збор. 92б. Град. дјев. 78. 105. 172. дух. 4. Зор. 28. Стар. 3, 303. 308. Вран. жив. 92. Див. 20б. Банд. 9. Мат. 27. Каш. грая. 108. Радн. 25. 34. хтпјућш 3бор. 68б. Андр. дев. 41. ктијући Гуч. 66. 123. Радн. 42. ћутијући Град. дјев. 103. из нстога раздјела (внди п на стр. 360): млпјући Пос. 30. гдагоди којина је основа у садашњем вр. примала од других на крају, , XVII вијека: знадијући Радн. 15. ищадијући Радн. 75. 91. - III. 2. бдећи Н. Рањ. 21. Хект. 2б. бјеснећи Ст. пшс. 3, 358. бшжећи Стар. 3, 301. велећи Гуч. 12. впдећи Ст. пис. 2, 385. 5, 119. Д. Рањ. ІХб. Вран. жив. 35. горећи Ст. пнс. 3, 262. Радн. 66. желећи Ст. пис. 2, 116. 3, 139. 4, 28. Хект. 42б. Крн. 12. Јерк. 15. жеднећи Ст. пис. 3, 139. живећи Ст. пис. 2, 100. Хект. 27б. Брн. 24. Јерк. 88. Андр. дев. 59. клечећи Ст. пнс. 3,140 . лежећи Стар. 3, 273. летећи Збор. $96 б$. мнеһи Ст. нис. $2,140$. Вран. жив. 33. од истога глагода има и с доданим $д$ на крају основе као у садашњем вр. а по том према глаголима прве врсте ирвога раздјела, XVII вијека: мнндући Вран. жив. 73. 80. прећи Н. Рањ. 23. пузећп Хект. 4. 33б. растећп Град. дух. 68. рестећп Ст. пис. 1, 38. свпрећи Ст. нис. 4,122 . седећи Ст. пис. 1,46 . сједећи Ст. пис. $3,217$. 
Д. Рањ. 12. стојећи Ст. пис. 2, 129. 276. 3, 352. 4, 157. 377. Град. дјев. 155. сажето: стећп Ст. пис. 2, 385. Зор. 2б. Злат. 86б. Стар. 1, 218. Вран. жив. 35. 39. 86. Јерк. 40. 88. хотећп СТт. пис. 1, 3. Н. Рањ. 26б. Збор. 5. Ст. пис. 5, 127. Брн. 8. Пос. 18б. хтеһи Д. Рањ. ІХ. Хект. 42б. Зор. 28. Здат. 4б. Јерк. 8. Каш. 44. ктећп Злат. 16. цафтећи Ст. пис. 3, 272. цватећп 3ор. 68. цвидећи Ст. пис. 2, 188. 3, 3. 5, 302. процвилећи Бун. 50. дквећи Орб. 129. Гунд. суз. III, ХC. Андр. пут 283 - IV. вапећи Ст. пис. 5, 40. Злат. 7б. 17. приводећи Банд. III. говорећи Ст. пис. 1, 9. Н. Рањ. 56. Збор. 6б. Брн. 4б. Стар. 3, 303. Гуч. 2. гојећи Ст. пис. 4, 394. грозећи Ст. пис. 3, 91. јидрећи Ст. пис. 1, 158. крстећп Н. Рањ. 15. ловећи Ст. ппс. 3, 4. мислећи Н. Рањ. 20. Ст. пшс. 4, 442. модећи Ст. пис. 3, 465. Вран. жив. 18. носећи Ст. ипс. 3, 91. правећи Злат. 14. славећп Збор. 34. Ст. пис. 2, 121. служеһн Ст. иис. 2, 438. сумњећи Н. Рањ. 33б. ходећп Ст. пис. 3 , 4. мимоходећи $\mathrm{H}$. Рањ. 37. чинећи Банд. 6. чтећи Град. дјев. 85. Хект. 36б. Буд. 80. птећи Банд. 141. Јерк. 14. чудећи се Стар. 1, 220. од глагола који инфпнптивом припада у пету врсту : спећи Ст. пис. 4, 3. -- V. I. благосливљајући Н. Рањ. 57б. благосливајући Вран. жив. 109. благосивљај ући Гуч. 131. Банд. 48. разбирајући Гуч. 118. обећајући Д. Рањ. ІVб. викајући Збор. 50б. 76б. 95б. одговарајући Банд. 2. гукајући Зор. 68б. давајући Андр. дев. 53. одавајући Вран. жпв. 47. уздавајући Јерк. 41. дарпвајући Банд. 194. Каш. 25. дихајући Банд. 191. познавајући Банд. 243. Јерк. 45. имајући Н. Рањ. 164. Зор. 1. Вран. жив. 44. Банд. 227. Капा. 43. јахајући Стар. 3, 258. прокдинајући Збор. 74б. заклпнајући Кап. 52. закливајући Вран. жив. 12. искушавајући Банд. 170. лелекајући Ст. пис. 5, 186. умирајући Мрн. 13. размишљајућп Д. Рањ. VIII. помагајући Орб. 103. Кашг. 29. споминајући Зор. 54б. наслађивајући Пос. 19. остаљајући Д,ив. 13б. уфајући Ст. пис. 1, 329. целивајући Зор. 29б. Злат. 36g. Андр. дев. 44. читајући Вран. жив. 47. почигајући Зор. предгов. - V. 2. дрхћући Вран. жив. 47. Банд. 22. Мрн. 34. Јерк. 47. пштући Ст. ппс. 2, 435. 3, 139. 4, 160. Радн. 62. јишћући Врап. жив. 71. Јерк. 8. јашући Збор. 1б. Каш. 40. заклињући Н. Рањ. 216б.' кољући Ст. пис. 1, 48. подла-

' У рукопису стојн „заклинући " може бити само шисар. грпјешком. 
жући Радн. 56. одмећући Гуч. 14. умирући Шос. 3б. пишући Ст. ппс. 1, 19. Апв. 20. плачући Ст. ппс. 1, 110. Зор. 29. Брн. 12б. Стар. 4, 114. Злат. 90б. примьући Банд. 194. простирући Хект. 23. шаљући Радн. 56. храмљућп Радн. 19. зачињућй Хект. 15б. Банд. 180. - V. 3. дајући Ст. пис. 1, 48. 3бор. 94. Брн. 64. Вран. жив. 45. Банд. 230. Каші. 22. Радн. 2. продајући Буд. 91. Гдав. 71. наднјући се Ст. пис. 1, 67. познајуһп Здат. 75б. Пос. 18б. Јерк. 46. Капा. 92. Андр. нач. 19. Радн. 12. сазнајућп 3ор. 2б. кајућп Ст. пис. 3, 465. Радн. 62. рвући Ст. пис. 2, 42. овамо је прелази.ло пз првога раздјела ове врсте: целијући Јерк. 71.' - VI. обитујући Ст. пис. 1, 5. завршујућп Злат. 85. прикажујући Андр. дев. 47. купујући Буд. 91. милујући Стар. 1, 223. paдуjућп се Стар. 3, 226. штујући Вран. жив. 15. у овој се врсти налази и одведујући Врап. жив. 90. упутујући Град. дух. 86. - бб) за номпнатив јед. женскога рода: прем да и прави номинатив јед. женскога рода псто тако гдаси (види даље под 2.), инак кад прави номннатив мн. мушкога рода долазп и за номннатив јед. женскога рода (внди напрпјед стр. 356) п кад промнјењени ном. мн. долазп и за ном. јед. мушкога п (како ће се одмах впдјетп) средњега рода, не може бити сумње да псти промијењени ном. мн. долазн и за ном. јед. женскога рода : скубући 3лат. 100. жввући 18б. кунући Ст. пис. 4, 448. вапијућ Стар. 4, 113. пијући Ст. пис. 1, 64. пловућп Ст. пис. 4, 62. појући Ст. пис. 3 , 4. с.ловућн Ст. пис. 2 , 87. будући Вран. жив. 105. мрући Злат. 88б. вндећи Ст. ппс. 5, 119. Вран. жив. 42. горећи Ст. пис. 2, 352. живећи Андр. пут 145. летећи Ст. пис. 2, 19. мнећп Злат. 87б. мнијуи Ст. пис. 2 , 19. сједећи Ст. пис. 5, 27б. стојеһи Зор. 6б. Каш. 94. стећи Ст. пис. 2, 444. Буд. 146. Јер. 24. хотеһи Вран. жив. 113. хтеһп Ст. пис. 1, 10. 2, 150. 334. 444. Бун. 14. цафтеһи Ст. пис. 4, 30. говореһи Банд. 38. гојећи Ст. пис. 3, 88. мпслећи Р. Рањ. 67. ронећи Ст. пис. 3 , 88. норећп 129. находећи Каш. 89. штећи Кашг. 86. пмајући Банд. 9. целивајући Н. Рањ. 85б. движући Ст. пис. 5, 196. дрћући 3ор. 28. плач. һи 3бор. 26. наднјући се Зор. 28б. познајућп Каш. 92. остајући Каш. 81. смјејући се Ст. пис. 5, 257.

' Испореди вапријед на стр. 355 споменуто „даријуһв." 
ишчегујући Андр. дев. 92. - вв) за ном. јед. средњега рода од XVI вијека: цвијеће цтећп Ст. пис. 4,133 . будући усахиуло тило Каш. 70. будућп писмо једно Бам. 4б. - гг) за пом. мн. женскога рода: текући Злат. 966. Андр. нач. 32. пловући Ст. пис. 2, 78. појућп Ст. шис. 2, 78. 5, 208. хотнјућп 3бор. 105б. видећи Ст. пис. 3, 330. цвилећи 88. веселећи Стар. 4, 115. хвалећп Вран. жив. 41. дршћући Ст. пис. 4, 222. берући Ст. пис. 5,208 . уздајући Стар. 4,115 - - дА) за ном. мн. средњега рода: видећи Ст. пис. 3,330 . цвилећи 330 . пмајући Злат. предгов. 26. 84б. - ђђ) кад нема номинатива којему би био придјевен: доходећи мамь их пхметн М. 326. с проштењем рекући Ст. пнс. 5,101 . испореди и напријед на стр. 356. - еe) за акус. јед. мушкога рода и то не само гад је ријеч којој се придијева доиста у агус.: жпви плам угледах горећв Ст. пис. 3, 353. од суза живући к.адепац продитв Ст. пис. 3,389 . него и кад се акусатив замјењује генитивом: гдје чујаху Исуса будући Н. Рањ. 41. сина чловјечанскога стојећи 23. спна човјечавскога гредући 13б. вука гредући 25б. видивши сатира у дипли свирећи Ст. шис. 4, 117. зачује Радата лелекајући Ст. пис. 5, 186. ако га гледа краљујући Брн. 24. кога види празнујућп Брн. 55. вцди граља до паса у огањ стећи Стар. 4, 116. тада ће видити сина божјега прнходећи у облаку Банд. $1 .^{1}$ - жж) за акус. јед. женскога рода: ходеһи Н. Рањ. 67. нека ју не би састао цвилећи Ст. пис. 5, 121. види звизду гредући Стар. 4, 111. чула сам ју вапијућ Вран. жив. 56. - з3) за акус. јед. средњега рода: видећ добро своје тако на криж мрући Ст. пис. 1, 188. - ии) за акус. мн. мушкога рода: видје друге стојећи Н. Рањ. 34. видећи ученике своје трудећи се 40б. нађе пх спећи 97б. нађе их цвнлеђг Ст. пис. 2,416 . спећи их находи Ст. пис. 5,129 . анђеле у(з)дазећи Брн. 56б. најде их бдећи Банд. 17. - јј) за датив јед. мушкога рода: ки би дал жејући капљу воде теби Ст. nuc. $1,188$.

Исти овај облик у пстој служби долазп и без крајњега вокала: пије прилике мислити да би таки обликбез вокала

1 Tако и са шт мјесто $\AA$ према црквенијем књнгама: скмша вепр. сапхюції Стар. 4, 74 . 
бно номннатив јед. зуикога рода начињен од основе у којој је сложени наставак, јер се служба за коју би бно начињен веһ ипје осјеһала да је служба юоја иште падеж, п ако би за ту службу био начнњен, - ако би бпо начињен да буде номнналнг номинатив јед. мушкога рода, не би могао одмах чим је начињен замјењивати и друге падеже и друге родове; с тога облик без вокала на крају не ће битн пишта друго него исти номинатив мн. окрњен онако од шрнлике како се крњио пнтинитив, те окрњен долази онако као цио и за друге облике: таки се облик јавља у почетку XV вијека на мјесту гдје један говори о себн у множини: творећь М. 248. то је једнни прпмјер до свршетка XV вијека, а на свршетку тога впјека и послије долази чешће, али опет много рјеђе него цио: а) за номинатив јед. мушкога рода (тај падеж види још и даъе под 3. б.): І. 1. бљудућ Хект. 48. гредућ Ст. пис. 1, 16. гудућ 3ор. 14. - I. 3. скубућ Крн. 22б. живућ 3лат. 63б. Гунд. суз. I, LXVI. - I. 4. бргџћ Ст. пис. 1, 278. могућ Ст. пис. $3,185.5,82$. А. Рањ. $32 .{ }^{\prime}$ - I. 6. пролијућ Ст. пис. 1, 75. полијућ Д. Рањ. 71б. плијућ Д. Рањ. 58б. чујућ 3ор. 66б. знајућ Ст. пис. 4, 392. од гдагола којшма оспове у садашњем вр. од свагда добнвају д: пдућ.д. Рањ. 29. будућ Ст. пис. 1, 189. 5, 81. Д. Рањ. 68. Зор. предгов. Злат. 2. Мат. 12. Радн. 21. - III. 1. желијућ Крн. 11б. - III. 2. впдећ д. Рањ. 22. Хект. 2б. Бун. 31. горећ Д. Рањ. 105. гудећ 3ор. 57. држећ Зор. 2. Буд. 109. желећ Хект. 47б. кпиећ Мрн. 49. лежећ Ст. пис. 1, 9. пузећ Хект. 43б. растећ Д. Рањ. 51б. силећ Банд. 98. достојећ Злат. 40. сажето : стећ Д. Рањ. 21б. Хект. 7. 41. Злат. 7б. 17б. 30б. тағођер сажето: постећ Ст. пис. 1, 18. хотећ Ст. нис. 1, 18. Д. Рањ. VII. Стар. 3, 240. хтећ Ст. Iис. 1, 31. Хект. 3. 15б. Зор. 15б. Злат. 14б. Мрн. 46. ктећ Д. Ран. 27. Чубр. 10б. од истога глагола и по првом раздјелу ове врсте: хотијућ Ст. пшс. 1, 321. цтећ Д. Рањ. 41. птедећ Хект. 46б. - IV. бранећ Радн. 39. вапећ Ст. пис. 3, 388. говорећ Банд. 21. Радн. 45. ळубећ Хект. 33. мпслећ Буд. 109. молећ Злат. 40. доносећ Радн. 24. служећ Злат. 82. судећ Радн. 23. утопећ Бун. 52. тужећ Зор. 2б. находећ Буд. 114.

i ' И са Ж мјесто г: жежуы Зор. 12б. 226. 
чтеһ Хект. 2. - V. 1. разбирајућ Гунд. пс. 35. викајућ Злат. 81б. владајућ Радн. 48. даривајућ Глав. 12. делајућ Глав. 12. имајућ 3лат. 37. Радн. 35. размишљајућ 3ор. 28б. смнш лајућ Ст. ппс. 5, 351. Мрн. 49. надајућ се Злат. 18б. питајућ Хект. 32б. предајућ Злат. 18б. пуштајућ Злат. 17. устезајућ Злат. 17б. ишчекивајућ Андр. пут 394. - V. 2. мажућ Хект. 22. плачућ Зор. 2б. Мрн. 31. - V. 3. дајућ Буд. 153. - VI. обслужџј! Хект. 28б.- б) за ном. јед. женскога рода: јвдућ Ст. ппс. 1, 268. крадућ Д. Рањ. 7б. могућ Злат. 45б. текућ Ст. пис. 4, 434. Хект. 8б. 24б. ппјућ Ст. пис. 1, 268. п.ловућ Крп. 22б. пдућ д. Рањ. 125б. будућ Бун. 20. впдећ Злат. §9. желећ Јерк. 47. стећ Ст. пис. 1, 51. молећ Злат. 32. носећ Злат. 99б. срдећ Ст. пис. 1, 111. творећ А. Рањ. 30. чвнећ Ст. пис. $1,127$. приближајућ Каш. 75. викајућ Злат. 7б. згледајућ Злат. 53. дпвјајућ А. Рањ. 91б. примајућ Злат. 27. движућ Ст. ппс. 1, 27. nшћућ Ст. пис. 1, 268. кунљућ Д. Рањ. 22." берућ Злат. 45б. трајућ Злат. 5. ткајућ Крн. 3б. вјерујућ Злат. 46. - в) за ном. јед. средвега рода: зријућ Ст. пшс. 1, 223. впдећ д. Рањ. 22. пландујућ Д. Рањ. 22. - г) за ноу. мн. свакога рода: гредућ Ст. пис. 1, 29. бвјућ Ст. пис. 1, 20. 4, 422. впјућ Ст. иис. 1, 117. пцјућ Н. Рањ. 180. појућ Хект. 25б. чујућ 3.1ат. 17б. с уметнутим у основи д XVII вијека: знадућ Банд. 21. жерућ Ст. пис. 1, 294. стерућ Ст. пис. 1, 38. 294. ввдећ Злат. $80 б$. држећ Ст. пис. 1, 13. Хект. 12. живећ Ст. пис. 2, 444. лежећ Cт. пис. 1, 112. с уметнутим у оснопи д XVII вијека: мдидућ Радој. 19. бесједећ Здат 87. брашећ Злат. 86б. возећ Хект. 3. г'оворећ Ст. пис. 5, 125. Радн. 65. грдећ Радн. 17. жалећ Ст. пис. 1, 66. словећ С'. пис. 1, 162. сусритећ Збор. 61б. ходећ д. Рањ. Уб. привртајућ Ст. пис. 1, 195. гледајућ Ст. пшс. 4, 365. нукајућ 3бор. 100 . зачнвајућ Крн. 12б. размашућ Ст. пис. 1, 14. дајућ Јерк. 25. постајућ Хект. 11б. подвикујућ Хект. 226 путујућ Ст. пис. 4, 264. А. Рӓ. VII.

2. Номинални номинатнв јед. женскога рода раздиковао се од обшчнога само тпјем што је на крају мјесто а имао н, као и нека имена женскога рода с основом на ја (види стр. 9), а тако долази само у споменицима у којима

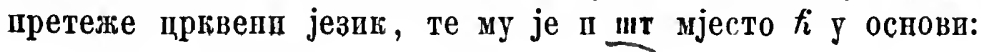


Фстакахюци М. 14. соүштин М. 65. У живом се говору тај облик замјењпвао како је речено напријед под I. II. 1: Види п ниже под 3. - Сложени је облик постајао као у адјектива: к реченом номиналном облику приступао је ном. јед. женскога рода од прономнна м: слитна, али не долазп изван споменика у којпма претеже црквенп језик.

3. Сви остали надежп оспм веһ поменутијех (номинатива јед. мушіога, средњега п женскога рода и номннатива мн. мушкога рода), капо је речено, постајали су од основа у којима је сложени наставак са свијем онако као у ихена с основом на ја:

a) Долазе са шт у основи мјесто $\hbar$ у споменццима у којима претеже щрквепп језик, а тако са шт долазе кад кад и у другима до свршетка XV вијека, али јамачно и у вима према црквенијем књигама пли према књигама старијим у којима се више држао дрквени језик (исшореди даље под в.): Г'енитив једнине мушкога и средњега рода номинални:

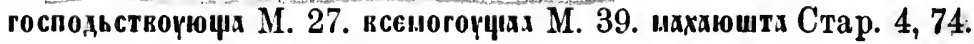
сьціх (гријешкох мјесто соүшта) П. 99. сложени: паходецаго М. 4. жнкоткореціаго М. 10. 299. вмддццаго ПГ. 90. П. 145. изједначен с прономпналним (видп стр. 160): соүчега М. 116.

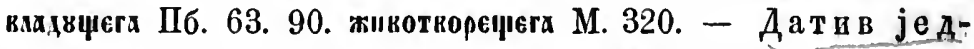
нине мупкога и средњега рода номинални: лрьжешв М. 161. веселеців М. 161. сложени (види стр. 164): втдоүцормоү М. 90. 91. посптюфориоү IIIаф. pam. 1873. 100. лежечоүмоү Стеф. 22. паголющормоү ШШач. рат. 1873. 100. зовоүщориоү Стеф. 18. са о мјесто оү (вПди стр. 164) ммдвцомв Пб. 82. живоүштомоү Стар. 4, 74. пртірьжецомоү М. 48. испхьихючомоү ШІаш. рат. 1873. 100. гхголющомоү 100. изједначен с прономиналним (види стр. 164): свтдоүшемоү Стет. 17. кмадвценв Пб. 42. - А п у с ат и в је д. мушкога рода номпнални: гмагокюци М. 3. мекець Сав. 11. соүчи Стет. 24. сложени: воүдоүцини М. 27. придоүщин М. 114. свци П. 68. женскога рода: имвщв М. 233. - Аок а ти в ј ед. мушкога и средњега рода номинални: кхюцн ск М. 5. сложени (види стр. 182-3): коүдоүщшы М. 216. 278. жнвоткорецнмь М. 273. изједначен с прономиналнии (види стр. 183): пудоүшень М. 10. 223. 263. 333. 569. прндвцемь М. 109. прнходешемь М. 188. животворецемь М. 290. 295. 324. 331. 401. 
413. са о мјесто $e$ (јамачно гријешком према дативу): коүдоүштом Стар. $4,139$. - Генит ив мн ож. за сва три рода

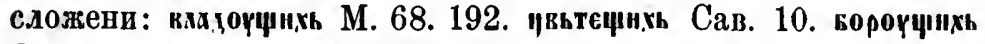
Стеф. 7. вфмючихь М. 427. - Да т и в множ. номиналии мушкога рода: покманњюцєик се Стеф. 29. сложени (внди стр. 198): грєдоүштїнмь Стар. 4, 233. зирефими М. 88. скоүмечимь М. 11. господьствоүючннь М. 15. жалоүючнми М. 88 . - Н о м и нати в икусатив двојине мушкога рода номиналнг: мосеціа Сав. 13. проссци М. 166. прнпханоча 166.

б) По живом говору са $\hbar$ у основи долазе врло ријетко: XIII впјека само у једном сиоменику, а у њему само три шадежа сва три од исте основе: дат. јед. мушк. номинални: воүдоүкоү М. 20. дат. јед. жен. номинални: воүдоүкн М. 20. акус. јед. мушк. сложени: кордорин М. 20. XIV вијека немам ни једнога примјера. XV впјека долази један пут ном. мн. женск. номинални: "мыћюћє М. 327. један пут дат. мн. сложени: доходћим М. 327. три пута инстр. мн. сложени, алп од исте основе, која се је још и помјерила прешавши пзмеђу основа садашњега времена на " међу оне на а: кисвҺнєми М. 404.509. висвћнмн 510. три пута локатив мн. али само од једне основе: квдвкехь М. 299. 348. Бвдвкнехь М. 414. један пут ном. дв. мушк.: сквжећа М. 462. - IIIто свега тога времена тако - за чудо - мало примјера има, ако би се и мислило да су сви узети из живога говора, опет ће бити свједочанство да је веһ у то вријеме у партиципу једва више живота било него данас. - На свршетку XV вијека и послије до свршетка XVII чешћи су примјери и за нене измеңу поменутијех падежа и за друге: у пнсаца је било мисли за које треба партицип, јер су им долазиле из странијех књига, али у језику није било облика за њих, те су их писци пз нова градшли у основи шрема сачуваном номинативу мн. а у осталом према другим ријечима; а тако су из нова градили од основа у којима је сложени наставак - дакле од основа на ја - п оне напријед споменуте падеже који су се још чували у језику али се нијесу осјећали да су падежи, као номинатив јед. сва три рода. На тај иачин од свршетка XV вијека додази: нов номинатив јед. мушкога рода п једнак с вим акусатия: смрдећ кип Ст. пис. $1,107$. 
краљ грабећ Ст. пис. 4, 39:. с.хоени, који замјењује и вокатив: дух живући Ст. цис. $3,130.4,82$. од суза живући кладенац продитп Ст. Iпс. 3,389 . боже жпвући 442. свемогући Вран. жив. 41. тамјан горећи Банд. 228. - Номинат., акусатив и вокат. јед. средњега рода: свако живуће Ст. ппс. 3, 357. жпвуће све Ст. шис. 4, 212. пловуће Град. дјев. 54. смрдеће тиједо Гуч. 11. - Но минат. јед. женск ога рода: смрдећа ствар Збор. 23б. спећа Вран. жив. 35. дежећа 62. сложени, којим се замјењује вокатив: около стојећа браћо Банд. 112. - Генитив. јед. мупкога п средвег а рода номина.нн: имијућа Буд. 152. умијућа Стар. $3,240$. чинећа Буд. 85. говорећа Банд. 13. сложени, који долази и мјесто номиналнога: дпзућега Банд. 116. уппјућега Н. Рањ. 19б. 23. вапијућега (в говорећа) Банд. 13. идућега Н. Рањ. 22б. говорећега 23. невољећега 17. умирајућега (винсривћєг) Див. 27. - Генитив јед. женскога рода, који је номинални и сложени једнаг: живуће Андр. дев. 163. сијевајуће Банд. 226. - Датпв јед. муши ога п средыега рода сложени: живућему Вран. жив. 14. сједећему (узли на главу његову сједећему, super caput ipsius recumbentis) Н. Рањ. 89. ходећему Банд. 294. - Датпв јед. женск о га роданоминали: текуђн (к једној вруљи раскошни, нотоком текућп) Зор $10 б$. летеһп Ст. пис. 3,429 . сложеви: живућој Ст. пис. 3 , 287. стеһој Буд. 37. - Акусат. јед.жен ск ог а рода: носећу (траву носећу сјеме) Н. Рањ. 113б. чинећу 113б. говореһу Вран. жив. 39. - Иструментал јед. женскога рода: цтеһом 360 . 49. - окатив јед. мушкога и среджега рода: robopeћем Банд. 14. замијењен дативом: у трпећему Андр. дев. 154. - - Номинатив мн. мушиог а рода сложения: траци врући од сунца Ст. пнс. 2,405 . - Номинатив мн. женко г а рода: пловуће Ст. шис. 3,313 . - Ге нитив мн.: живућпјех Андр. дев. 92. упијућијех Н. Рањ. 53. саснућих Банд. 36. уфајућих Ст. пnс. 1, 27. продавајућих Банд. 168. почивућих Банд. 210. - Датив мн.: сједећијем Н. Рањ. $70 б$. 193. стојећијем 98б. блудећим Брн. 24. просећим Зор. 296. чекајућијем Див. 7б. кажућим Д. Рањ. 67б. продајућим Банд. 253. празнујућим Һрн. 24. насдидујућим Банд. 31. замијењен инструменталом: љубећими Див. 8. - Акусатив мн. му- 
ш ко га жен ско г а рода: саснуће Банд. 29. нађе их спеће $\mathrm{H}$. Рањ. 97б. имајуће Н. Рањ. 24. иродавајуће Банд. 61. видје друге стојећи на двору шразнујуһе Н. Рањ. $34 .^{\prime}-$ Ин струментал мн.: сврбећими Н. Рањ. 26б. Банд. 17. нлачућпјеми Див. 31. наслидујућими Банд. 150. изједначен с дативом: стећим Н. Рањ. 173б. - Локатив мн.: минућијех Град. дјев. 41. - Види још даље под в.

в) Гинући овај партицип није само падеже губио, како се напријед видјело, него су му се и основе помијерале, и то од друге половине XV вијека, ${ }^{2}$ прем да су се сачувале и нешомјерене, а помијерале су се на различне начине:

aа) основе које пред ntја имају а пзједначивале су се с онима које пред ntja имају н: I. 5. дмећи Ст. пис. 1, 55. 4,17 . кунећп Ст. пис. 2,518 . - I. ن. од основе којој се * шири у ој: појећи Ст. пис. 5, 226. 349. Брн. 52. појећ Ст. шис. 1, 195. 252. од основе која је од других гдагода примала д: знадећи Буд. 55. Мрн. 155. - I. 7. мрећи Ст. пис. 2, 394. 5, 186. Стар. 1, 234. Орб. 61. Јерк. 51. 96. - II. гинеће весеље Вран. жив. 49. - III. 1. разумећим (дат. мн.) Зор. 67. - V. 2. вичећи Cт. пис. 4, 137. иштећи Бун. 50. кољећи Мрн. 54. раздазкећи Зор. 1б. миришећи Ст. шис. 2, 361. V. 3. зовеһи Орб. 269. Андр. дев. 58. пут 437. рвећи се Буд. 100.

бб) основе које шред ntja имају " изједначнвале су се с онима које пред ntja имају a: III. 2. хотьћи Пб. 120. Ст. пис. 1, 62. хотућ Ст. шис. 1, 21. видући Ст. шис. 1, 31. горући Н. Рањ. 44б. Збор. 53б. Ст. пис. 2, 94. 3, 353. Вран. рјеч. 84. Злат. 18. Ј'унд. суз. II, LI. горућ Ст. нис. 2, 445. 344. Мик. 115. горуће (на модатви горуће сташе. ном. јед.) Град. дјев. 157. 'орућеra Н. Рањ. 122. Брн. 41. Банд. 125. ropyћy (акус. јед. жен.) Ст. иис. 4, 114. горућијем (инстр. јед. иуш.) Ст. шшс. 2, 445. 3, 277. горућом (ипстр. јед. жен.) Гуч. 14. Кашг. 86. Радн. 56. горућу (докат. јед.) Зор. 18. горућему (за докат. јед.) Збор. 89. горућој (локат. јед. жен.) Андр. дев. 176. горући (плами) Ст. пис. 2, 446. (свитњаци) Брн. 19б. горуће (акус.

1 У примјерима Н. Рањине може бити и да није акусатив него мјесто њега номннатив на $e$; види нашријед стр. 356.

${ }^{2}$ Има и XIV вијека поскидчџон М. 229. али лако може бити да је само писарском гријешком иза првога в изостављево 
мн. жен.) Град. дух. 37. (муш.) Кан. 66. горућп (пнстр. мн.) Ст. пис. 1, 186. горућими (внстр. мн.) С'гар. 4, J14. горућијем (за пнстр. мн.) Град. дјев. 177. Андр. пут 42. уздржући Кашг. 105. уздржућ Ст. пис. 1, 1:.0. јиздући (ном. мн.) Ст. пис. 1, 12. пипући Вран. жив. 89. Мрн. 53. детуђа (ном. мн. сред.) Брн. 53. сидући Ст. пис. 1,11 . стојући 31. стојуће А. Рањ. 8б. хитућ Ст. пис. 1, 16. 223. - IV. јндрући Ст. пис. 1, 31. сдазући 57. мрмњући 29. мрм.бући Брн. 52б. слинући Ст. пис. 1, 21. тишући 21. тртњући 31. носуће (акус. мн.) Н. Рањ. 1146. животворућега Банд. 133. плазућије (ген. мн.) Радн. 64.

вв) основе које пред ntja имају " изједначивале су се с оншма које у садашњем вр. пмају наставак ја: III. 1. жељуь 3ор. 49. - III. 2. мњуһи' Ст. шис. 1, 36. - IV. юкхюкмюће М. 444. мишљьћим Брн. 57.

гг) основе које пред ntja имају н шзједначујућп се с онима жоје у садашњем вр. пмају наставак ја узимале су од њих само ј које се с шредњпм гласом слагало по својим законпма: III. 2. живљећп Н. Рањ. 151. Орб. 120. 300. тр пљећу (акус. јед. жен.) Мик. грам. 34. жељећ Радн. 44. IV. протнкхећс IIб. $119 .^{2}$ слављећи Н. Рањ. 217. стављеће Н. Рањ. 174. бубљећи Ірад. дјев. 50. 53. дух. 78. 86. Брн. 16. 65б. жубљећим Н. Рањ. 204. љубљећега Орб. 70. и без $\lambda$, које се п у другим таким приликама могло избацити: љубјећп Н. Рањ. З0б.

АА) основе су пред ntја и гдасом а, који пред њим имају, губиле друге наставке: тако у глагола $\mathrm{V}$ врсте другога раздјела: затварућ Ст. ипс. 1, 49. размпшљући Зор. 75. бјегуће (вријеме) Ст. инс. 2, 493. бјегућијем (инстр. јед.) Ст. пис. 4, 443. бјегућим 443. бјегућу Злат. 39. бигућих Мрн. 54. у глагола VI врсте: вјекуће Ст. пис. 3, 123.

Ђђ) основе гакве су у глагола шесте врсте у пнтинтниу предазиле су цијеле меלу основе глагола првога раздјела пете врсте: сидовајућ Зор. 16. куповајућп Банд. 168. приноћевајући 222.

' Ако не би треба.10 читати: мнијуһг.

2 Овамо би могло иhn и днхєке M. 469. алп може бити да је є стоји само писарсіом грнјешном мјесто є, као што стоји у истом споменику и босанскє, кнднвию. 
( жљ ее) у основи се мјесто $\hbar$ узимало из црквенпјех књпга шт; то мислим да се догодило овако: кад се на свршетку $\mathrm{XV}$ и у почетку XVI вијека почеше повраћати падежи, онда се и сам номпнални номинатив сачувани како је напријед ноказано тапо слабо осјећаше шта је да не могаше бити довољан углед за остале падеже него се мишљаше да је ит у облицима који бијаху познати нз црквеннјех књига или из књига ппсанијех випе црквенијем језиком непто друго него његово $\hbar$, те се и они узимаху за углед; а томе ће бити потврда што се номинални номинатив јед. мушкога рода не находи са иит, него само другп падежи и сложени номинатив јед., којих у живом говору већ није бнло; основа је или остајала помјерена само тпјем начином или се п више помијерала: основа помјерена само пошљедњим начином: дјезушта (ном. мн. сред.) Н. Рањ. 114. живушти Н. Рањ. 141б. жнквце (ном. јед. сред.) Збор. 65. текуште (ген. јед. жен.) Ст. пис. 3, 330. 4, 82. вимраюцв (акус. јед. жен.) Збор. 33. - основа још вине помјерена, и то а) још онако како је споменуто напријед под бб.: горушта (ном. јед. жен.) Ст. пис. 2, 343. 3, 465. Гуч. 183. (вок. јед.) Ст. пис. 2, 324. горуште (ном. јед. сред.) Ст. пнс. 3, 357. 4, 258. (ген. јед. жен.) Ст. пис. 2, 111. Гуч. 155. горушти (акус. јед. мушк.) Ст. пис. 3, 357. горвцега Збор. 126б. Јерк. 96. горушту (акус. јед. жен.) Каш. 72. горуштом (инстр. јед. жен.) Ст. пис. 4, 243. горушћем (док. јед. мушк.) Ст. пис. 1, 281. горуштијех (ген. мн.) Ст. ппс. 5, 36. горуште (акус. мн. мушк.) Каш. 42. детушта (ном. мн. сред.) Н. Ран, 114. (ном. јед. жен.) Ст. пис. 2, 19. 3, 142. летуште (ахус. јед. сред.).Ст. пис. 3, 356. Град. дјев. 54. (ном. акус. мн. жен.) Ст. шис. 3, 354. 4, 318. Див. 20. свјет.ушта (ном. јед. жен.) Ст. шис. 3, 353. 4, 308. свјет.луште (ном. вок. јед. сред.) Ст. пис. 4, 204. 318. (ном. мн. жен.) Ст. пис. $3,314.5,314$. свјет.душтему Ст. пис. $3,317 .-\sigma)$ још онако како је споменуто напријед под дд.: у глагода друге врсте: гркуште (ген. јед. жен.) Ст. пис. 3,122 . у глагода пете врсте: бјегуште (акус. мн. жен.) Ст. пис. 5, 93. у глагола шесте врсте : вјекушти (ном. акус. јед. мушк.) Ст. пис. 3, 58. 4, 245. вјекуште (акус. јед. сред.) (т. пис. 3, 143. (ген. јед. жен.) Ст. пис. 4, 4. 204. вјекуштему Ст. пис. 3, 317. - Иза шт у ном. акус. јед. средвега рода 
долази и о мјесто $e$ изван слика, а то опет показује како се слабо осјећало да је ит исто што и $\AA$ : вјекупто Ст. пис. 3, 143. 144. 145.'

\section{ПАРТИЦИП САДАШЊЕГА ВРЕМЕНА ІІАСИВНИ.}

Постаје од основа садашњега времена наставком ma, од којега остаје $\mathbf{m}$ у словенским језицима, a крајње се а слаже с падежнијем наставцима као у имена којима се основа свршује на чисто а. Основе које у садашњем вр. немају наставка, добивају у овом облику наставак а, који у словенским језицима гласи о. Изван споменика у којима претеже црквени језнк врло је риједак, и гдје се находи само је остатак из старпјих књига у којнма се вшще држао црквени језик: XIV и XV вијека од основе која у садашњен вр. нема наставка: ведомо ПІ. 25. видомо ПІ. 66. 156. IIIто има XVI вијека: негасимаго Збор. 16ะ. мислима Буд. 43. непасптиме 43. узето је из црквенијех књига.

\section{ПАРТИЩИП ПРОШЛОГА ВРЕМЕНА}

\section{АКТИВНИ ПРВИ.}

Основа му је онака каква је инфннитиву; у глагода друге врсте могло се основи крајње иж и одбацити, апо би се тада сврнивала на сугласно.

Наставак је двојак: (ans п vank; шрви додази до основа које се свршују на сугдасно, а другш до основа које се свршіују на самогдасно; али између основа на самогдасно оне у глагода четврте врсте иримају и један и други наставак, н кад примају први, онда им се крајње $u$ мијења на $j_{2}$ које се с предњим сугдасним слаже по својим законима; у српском се језику од скора наставак aus иза сугласнијех замијенио наставком vans. И једнијем и другим наставком постаје основа овому партиципу само за номинатив једнине мушкога и средњега рода, а за све друге падеже добија још наставак ја (као у партиципа садашњега вр.), те оба

1 IIто и давас има жемуиити (Вук. рјеч.) ви то није другачије дошло у народни језик (онолико колико је дошло). 
наставка тако сложена гласе ansja и vansja. У сложеном се наставку глас j с предын $\mathbf{s}$ у словенскн језпцима саставља I ш; а у сложеном и у несложеном отпада $n,{ }^{1}$ a a пред њим слаби у т, које кад се основе у глагола четврте врсте састављају с наставқом без $\mathbf{v}$ прелазп предвега гласа радп у ь, а у српском језпку отшада и т и ь.

I. Iрости наставцп. Од основа које имају прости наставак, како је речено, постаје само номннатпв јед. мушкога и средњега рода и то као у имена у којнх је основа на сугласно, јер се и ове основе свршују на сугласно s: у мупком роду отпада наставак падежни, а у средњем га роду и нема, као што га нема ни у имена средшега рода с основом на сугласно; тада и крајње $\mathbf{s}$ од основе не имајући за собом самогласнога отшада; што остаје показано је напријед, п по томе у оба рода номинатив јед. једнако гласп, као што једнако гласп и у партиципа садашњега времена.

A. наставак ans:

а) иза сугласнога: I. 1. прочьть Стар. 4, 75. довед Стар. 3, 275. изјид Ст. пис. 1, 77. пхд Стеф. 14. Стар. 3, 228. Ст. пис. 1,49 . усед Стар. 3,321 . од основе којом се замјевује у овомं облику глагол ићи: пад Ст. пис. 1, 19. дошадь М. 394. П. 83. ${ }^{2}$ 112. Ст. пис. 1, 21. Н. Рањ. 31б. Ст. пис. 5, 201. Хект 6б. Зор. 28б. Злат. 29б. Чубр. 8б. Крн. 23б. пшад (egressus) Н. Рањ. 167б. изашад Ст. пис. 4, 174. Злат. 87б. Вран. жив. 37. нашад Н. Рањ. 40б. Ст. пис. 2, 438. 3, 164. 4, 135. А. Рањ. 21б. нұьихшадь П. 134. овнхшхдь М. 260. Пб. 19. ошад 3дат. 96. шььшьд Г. 13, 371. обашад Ст. пис. 4, 9. одапад Н. Рањ. 61. пошад Н. Рањ. 97б. Збор. 30б. Хект. 4б. Буд. 68. приншад Ст. пис. $3,379.4$, 96. 151. Злат. 18б. шрошад Ст. пис. 4, 116. 5, 214. Зор. предгов. сапад Д. Рањ. 81. Вран. жпв. 23. у сложеном с. приједлогом на сугласно долази и од XVI вијека: пзишад Н. Рањ. 59. узншад 203б. обншад Ст. пис. 2, 411. - I. 2. понесь М. 162. нъьнесь П. 139. удиз Стар. 3, 250. - I. 4. одынрьгь М. 457. раждегь М. 134. помог Ст. пис. 1, 52. рек Стар. 3, 233. потек Н. Рањ. 996. утек Стар. 3, 301. с ра-

1 Кад не би отпадало $\mathbf{n}$, било бп од вега и предвега а исто Iпто је $\mathrm{\gamma}$ партиципу садашњега времена.

2 На том је мјесту средњега рода: дошадь оно дртко. 
ширенпм коријеном као што се и у инфинитиву шируо: шзкмкь Стеф. 15. - I. 5. кмын М. 1. напан Ст. шис. 1, 62. 3ор. 41б.' почьнь Г. 13, 37э. почан Ст. пис. $1,47.2,385.5,146$. 3бор. 173. Хект. 27б. 39б. ${ }^{2}$ въьмь М. 53. вземь М. 146. взамь М. 462. Н. Рањ. 47б. 102. 111. Збор. 25б. С'г. пис. 5, 122. А. Рањ. 55б. вазам Ст. пис. 1, 20. 3, 119. Хект. 10. 32. 3ор. 176. нзамь М. 508. Пб. 125 . Ст. пис. 5, 37. изнам Хект. 25. окьєм Сав. 12. обујам Зор. 75б. однам Ст. пис. 1, 84. 94. повмь Збор.

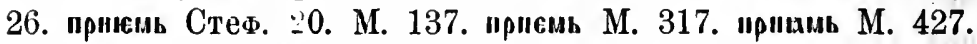
Ст. пис. 1, 196. А. Рањ. 28б. Радој. 24. снам Стар. 3, 302. дам Ст. пис. 1, 94. надам 113. -- I. 7. глас $p$ узимао се за сугласно: стар (conterere) Ст. пис. 2, 482. ирострь (expandere) Стеф. 18. простьрь Стеф. 27. простар Ст. пис. 1, 35. - II. у глагола те врсте да би био шартицип с овијем наставком, одбацивало се основи крајње ну, ако би се тада сврнивала на сугдасно: двиг Стар. 3, 282. досег Крн. 23. истег 6. потег 6. иротег 23. истрг Стар. 3, 237. замах Ст. пшс. 1, 254.

Ірема оваком партиципу од основа гоје се свршују на сугдасно налази се на свршетку XV вијека у једнога књпжевника начињен и од основа које се у интннитиву свршују на самогласно: од гдагода треће врсте другога раздјела: потрп Ст. пис. 1, 16. од гдагола четврте врсте: свад се Ст. пис. 1, 49. попуст 17. од глагода пете врсте: продвпт Ст. пис. 1, 233. у истога књижевника има тако и од гдагода стати, ити, са сугласнима, која добпјају основе у садашњем вр.: устан Ст. пис. 1, 231. унид 50.

б) иза самогласнога у глагода четврте врсте промијењенога на $j$ : налази се само у споменпцима писаним више црквеним језиком: юьраць Стеф. 24. кьскмонь 18. прккои Стар. 4, 233. корпаь М. 10. прнаожь Стеф. 23. поүщь 13. шстака 30. пртстоүнак 9. створь 9. сыхрань Сав. 2.

b. наставак vans:

a) иза самогдаснога: I. 5. основа се глагодска истина свршује на сугдасно, те је био од ње партици како је поменуто под А., али јој се грајње сугласно може саставити с предњим гласом у самогласно као у аористу, те додази и

1 С промјеном крајњега $\varkappa$ на $M$ : напам 3ор. 206.

${ }^{2} \mathrm{C}$ промјеном крајњега $\boldsymbol{t}$ на м: почамь II. 101. Ст. пис. $1,16$. 
с овијем наставком (од XIV вијека, видп II. 1. Б.): пожав Ст. пис. $1,84 .^{\prime}$ - I. 6. даяь М. 41. Ст. пис. 1, 48. Хект. 41. узд дв Ст. пाис. 4, 454. знав Ст. ппс. 4, 445. став Ст. пис. 4, 440. постав Хект. 15б. пристав Ст. пис. 5, 339. устав Н. Рањ. 169. узбнв Ст. пис. $2,466$. попив Ст. пис. 1, 196. чввһ М. 405. истрыкь Стар. 4, 143. - I. 7. глас се $p$ истина узима0 за сугдасно, како је показано под А., алй се узимао и за самогласно од свршетка XV впјека (види п даље стр. 375. и под II): затрв Стар. 3, 252. протрв Крн. 15. и у глагола којима се у инфинитиву $p$ шпин: подрв Сар. 3, 264. Карн. 176. раздрв 19б. прострв Ст. пис. 1,170 . али се узимало п раширено $p$ у рг као у интинитиву: прострив Зор. (види још под II). - II. вршснув Стар. 3, 278. вздахияки Збор. 31б. двигнув Ст. пис. 5, 128. Злат. 88. подвигнув Ст. пис. 4, 118. Зор. 30. дигнув Ст. пис. 5, 129. поклекнув Зор. 67. лискатнув Ст. пис. $2,440$. стиснув Ст. пис. 1, 188. целунув Ст. пис. 5, 216. - III. 2. кнджкь II. 12. кидекь М. 159. 202. видјев Н. Рањ. 103б. Збор. 26. кианвь М. 305. Н. Рањ. 81б. Ст. пис. 2, 124. 4, 395. Банд. 15. гудив Зор. 47б. погудпв 12б. попогудив 16. позрив Ст. пис. 2 ,.13. позрјев 458. цкнив 260. - IV. обратив Н. Рањ. 24. Стар. 4, 115. згријешив Злат. 102. загрлпв Зор. 29б. снєднинк М. 457. одьининкь М. 457. прнмикь М. 405. Збор. $40 б$. скупив Н. Рањ. 36б. одьхожнкь Пб. 90. замислив Зор. 2б. смискнвь М. 238. Зор. 1. допвстивь М. 445. родпв Ст. пис. 3, 435. сритив Зор. 40. оставив Н. Рањ. 195б. странив Ст. пнс. 4, 392. приступив Н. Рањ. 57. осудив Ст. пис. 4, 486. присудив Ст. пис. 5,220 . удрнв Стар. 3,245 . прюиненнвь М. 546 . оцкврнив Ст. ппис. 4, 484. вчнннк Збор. 38. очнстнкь М. 457. прочтив Стар. 3, 237. 250. 3ор. 72. - V. 1. скекакь М. 242. гледав Ст. пис. 5, 88. А. Рањ. ІХб. крсмав Ст. пис. 4, 471. послушав 3бор. 35. прочтавь М. 166. Ст. пис. 1, 132. Стар. 3, 245. 319. - V. 2. указав Ст. пис. 4 396. сказав Хект. 28б. - V. 3. разекравь II. 143. - VI. скттокакь М. 242. ${ }^{2}$

1 Таво би могло бити и пријав Ст. пис. 2, 163. Злат. 16. алп се у тијех писаца узимао тај глагол у пету врсту, како је споменуто код садашњега вр.

2 Писарске Һе погрјешке бити: помнхорвавь М. 110. џемовь (м. "ековавь) М. 14. 
б) иза сугдаснога долази овај наставак као данас пстом од XVI впјека, а међу два сугдасна па крају умеће се $a$ : могав Гуч. 47. види и под II. б. бб.

Једном такођер XVI вијека додази с овијем наставком

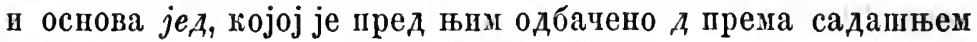
вр.: пзив Ст. пис. 5,90 . Внді и под II. 1. Б.

С. $о$ жен и облнк за щушкп род постаје као у адјектива, али долазп само у споменицима у којима се држао црквени језик: тако у партпципа који иде напрпјед под А. а.: прикедїи М. 277. рекын М. 9. под Б. а.: І. 5. сыневи Стар. 4, 138. IV. порстивни М. 15 . створнвын М. 25. V. 3. нұхбрхвн М. 316. У онијех који постају како је речено под А. б., додази у сложеном обдику на крају ин, које се могло п промијенити разједначивањем на єш: ськрышє М. 77. Али од XIV вијека долазп у овом облику основа пз других падежа, у којој су наставцп сложени (види пі под партицнпа сад. вр.): впвшн М. 231. 390. 393. 396. II. 177. почнкшн II. 7. 12. 63. М. 496. 497. - У средњем се роду сложени овај облик замјењивао акусатпвом као у активнога партиципа садашњега вр. (види напријед стр. 350).

Али овај партицпп, кад постаје како је речено под А., aro cе од гдјекојега глагола и налази у номиналном номинативу јед. још XVII вијека, а кад постаје како је речено под Б., ако се и одржао у томе падежу до данас, опет се и у вега, као и у активнога партициша садашњега времена, тај падеж још на свршетку XIV вијека престао осјећати што је, те додазі и за номинатив мн. свакога рода и за номинатив јед. женскога рода, и кад, нема номинатнва коме би био придјевен:

a) за ном. мн. пога му драго рода на крају XIV вијека: с наставком ans: қошдь ПI. 14. - с наставком vans: чвкь П. 17. вндекь М. 239. ввндъвь (ктдтті) П. 21. синскнвь М. 238. пкатнвь П. 5. вхнатикь П. 13. - XV вијека: с наставком ans: I. 1. дошадь П. 45. 75. 76. 110. 123. 151. М. 484. ФБьнашадь II. 41. 152. 160. пошхқ II. 58. прншхқ II. 97. ПІб. 69. - І. 5. взмь ПI. 121. - с наставком vans: I. 6. чввь ПI. 52. 74. 117. - II. ирнсегиввь П. 105. - III. 1. рабвитвь II. 160. - III. 2. вБоқвь се П. 38. видевь ПІ. 66.91. 118. вкндевь (втдтті) П. 43. - 
IV. синскивь М. 258. 308. 315. 319. П. 103. размнскняь М. 308. смотрхвь М. 258. 319. пкатикь М. 410. прнинкь П. 64. 77. 110.

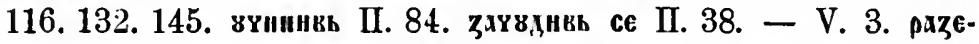
вракь П. 74. 81. прнзвхьь П. 170. - тако и послије: с наставком ans: I. 1. пад Ст. пис. 1, 10. дошад Ст. пис. 5, 130. 237. Хект. Збб. 5. 7б. изашад Ст. пис. 3, 132. 4, 333. Мрн. 66. нашад Н. Рањ. 29б. Ст. пис. 2, 435. Хект. 19. Вран. жнв. 78. пошад Н. Рањ. 166. З.ат. 87. (оне) Вран. жив. 95. пришад Ст. пис. 4, 49. 166. 5, 331. Буд. 152. прошад Ст. пис. 5, 315. сашад Ст. пис. 1, 26. - I. 5. вазам Ст. пис. 1, 197. појам Стар. 1, 223. напан Ст. пис. 1, 279. почан Ст. пис. $1,85$. почам 258. - с наставком vans: I. 6. дав Ст. пис. 1, 51. став 17. постав Хект. 11б. пристав Ст. пис. 5, 112. Д. Рањ. 13. устав Хект. 8. 11. подбив Ст. пис. 5, 164. разбив Мрн. 42. бив (км) Злат. 18. свив Крн. 19. - 1. 7. стрв Стар. 3, 241. (види нашријед под Б. а.) - II. двигнув Ст. пис. 5, 217. - II. 2. видив Ст. пис. 1, 6. 243. Д. Рањ. 82. - IV. загазив Крн. 19. дилив Ст. пис. 1, 70. удијелив Ст. пис. 5, 161. удрив Мрн. 61. справив Хект. 24. примив Ст. пис. 5, 169. пустив Хект. 26. спустив 3б. уресив Ст. пис. 2, 352. поставив Злат. 18. приступив Ст. пис. 5, 217. учпнив Злат. 3. - V. 1. вечерав Хект. 23. 31. учав Ст. пис. 4, 3. - V. 2. свезав Ст. пис. 2, 403. пухав Ст. ппс. 4, 434. б) за ном. јед. женскога рода: у првој половини $\mathrm{XV}$ вијека: впнсквь М. 387. поскхвь М. 387. ш послије: с наставком ans: I. 1. пад Ст. пис. 1, 29. дошад Ст. пис. 1, 45. 5, 205. 235. 270. Хект. 20б. Злат. 88б. Вран. жив. 54. изашад Ст. пис. 4, 185. Злат. 8. нашад Ст пис. 2, 95. 5, 69. 173. 204. Вран. жив. 87. пошад Ст. пвс. 5, 191. Вран. жвв. 90. 94. пришад Ст. пис. 4, 95. 111. 127. Зор. 33б. сашад Ст. пис. 1, 37. - I. 4. рек Стар. 3, 308. помог Ст. пис. 1, 37. - I. 5. напан Ст. шис. 1, 39. 51. зачан 167. почан Ст. пис. 5, 172. вазам Ст. пис. 1, 37. 3, 201. З.дат. 90б. узам Ст. пис. 5, 257. А. Рањ. 404. појам Зор. 8. $66 б$. пријам Ст. пис. $1,52$. - II. замак Ст. пис. 1, 38. поклек 43. с наставком vans: I. 6 . став Ст. пис. $2,467$. Д. Рањ. 19б. постав Крн. 19. пристав Ст. пис. 4, 461. бнв (ка) Д. Рањ. 71б. Злат. 35. нокрив Ст. пис. $2,403 .-$ I. 7. прострв Ст. пис. $1,37$. - II. пригнув Ст. пис. 1,168 . прикинув $А$. Рањ. 82б. протегнув Зор. 32б. -- III. 2. убојав се Стар. 3, 308. вндив Ст. 
пнс. 2 , 276. обазрив се 3ор. 31б. хтив Крн. 9. - VI. избечив Ст. пис. 4, 402. обратив 3ор. 31б. Банд. 142. одговорив Н. Рањ. 183. загрлив Ст. пис. 5, 124. Здат. 88б. пожалив 3лат. $67 б$. сломнв Ст. пис. 5, 118. ранив Злат. 70б. изранив Ст. пис. 2, 26. уреспв Ст. пाг. 2, 389. ставив Ст. пис. $4,441$. 3op. 7. поставив 3ор. 36. страшив Ст. ппс. 4, 397. ступив Ст. пис. 1, 42. - V. обећав Ст. пис. 1, 219. гледав Ст. пис. 4, 433. уг.дедав Ст. пис. 2, 467. разгнивав се 3ор. 28. старав Ст. пис. 5, 6. заспав Ст. пис. 4, 402. - VI. путовав Хект. $20 б$.

в) кад нема номинатива ком се шршдијева: wкшыль $\Gamma$. 13, 370. почьнь Г. 13, 370. почамь ПI. 101. "зммь М. 508. Пб. 125.

II. Сдожени наставцш. Од основа у којима се сложени наставци састављају с основом глаголском имао је овај партидиі као ш активни партицип садашњега времена све падеже у сва трп рода осим већ поменутога (под I) номинатива јед. мушкога и средњега рода, и они су му сви постајали као у имена с основом на ја осим номинатива мн. мушкога рода и номннатива јед. женскога рода, којн су се одвајади онако као у активнога партициша садапњега времена.

1. У номинативу мн. иу пा ког а рода предазио је овај шартициі онако као активни партициш садашњега времена (види стр. 352) међу имена с основом на суг.дасно, те се свршивао у словенским језицима на $e$ :

A. наставак ansja :

a) пза сугдаснијех: I. 1. падіше Н. Рањ. 160б. Зор. 26. сритше Стар. 3, 244. дошадше Стар. 3, 305. одашадче (отьшьдьшс) Н. Рањ. 14. пошадуе Н. Рањ. 34. 94. прншаус (при-

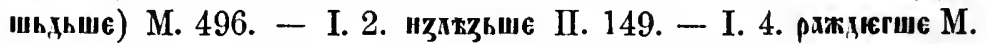
190. свукше Н. Рањ. 93. рекше Н. Рањ. 90б. 97. - I. 5. смьшє М. 46. оүзьмыше М. 50. узамше Н. Рањ. 34.' пржицше М. 284. 296. 319. прнтише М. 381. прнхише М. 412. види и даље под Б.

б) иза самогдаснога у глагода четврте врсте: шставыше M. 89. смотрыне M. 238. 239.

b. наставак vansja:

a) иза самогласнијех: І. 5. у глагола тога раздјела апо се основа и свршује на сугласно, те је био-партицип и

1 Са $\boldsymbol{H}$ мјесто ж: узанше Н. Рањ. 110. 
с првијем наставком (види под А.), опет им се основа може свршивати на самогласно (види под I. Б.) па и од таке пма партпцип од XIV вијека: пршевше М. 186. узевше Стар. 3, 287. - I. 6. дакише М. 7. 21. 46. подхвыне М. 41. поzпхише М. 217. 307. ставше Н. Рањ. 23. уставше 61б. одьвкьше Пб. 35. пртпхорвьие Стеф. 10. чвкше М. 230. 375. 491. ПI. 8. 11. 17. Н. Рањ. 23. Стар. 3, 264. zабыкше М. 89. - I. 7. глас се $p$ узима за самогласно (види под I. Б.): умрвше Стар. 3, 279. - II. приминувше Ст. пис. 1, 261. затискнувше Н. Рањ. 23. притиснувие Банд. 230. - III. 1. раұвиниьие М. 236. 317. 412.

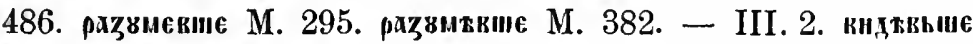
М. 270. видиние М. 272. 289. 323. 448. видевше М. 295. 343. вндекше М. 393. впдјевше Н. Рањ. 40б. Збор. 6. 29. впдшвше Стар. 3, 259. скидкие М. 302. - IV. кесьикие М. 367. згокорккше М. 248. примпвше Н. Рањ. 92. промнскивше М. 217. сиотрвкше М. 315. испхтнвше М. 232. приступивше Н. Рањ. 46. эткоривне М. 497. чтнвше М. 503. прочтивпе Стар. 3, 254. - V. 1. радгяедикше М. 232. угдедавше Ст. пис. 5, 228. шиккше M. 221. 236. 272. 293. 305. 486. оружавше Стар. 3, 260. скишхкһше М. 221. 226. 236. 317. 382. 412. 486. сквшхвше М. 529. V. 2. ортесхкын ПІаф. pam. 1873. 95. - V. З. загнавше Зор. 18б. - VI. кнероклкне Збор. 29.

Сложени је номинатив мн. мушкога рода постајао као у адјектива, пад к оваком номиналном облику приступи номинатив од прономина н, али се од XIII вијека пзједначво с истијем обликом какав је у адјектива с основом на ја, те је мјесто свога єи на крају добпо ин, које се сажима у, н: вгождыни М. 25.

Овај номинални номинатпв мн. на $e$ долазп од свршетка XIV вијека п за друге облике: а) за вом. јед. мушкога рода: на свршетку XIV вијека: снотривше П. 12. XV вијека чешће: пошху (пошыдиє) М. 473. пошддуе (пошьдише) М. 529. шрнтине М. 469. поzнавше М. 281. чвкьше П. 134. внАнкше М. 281. Приповидввше М. 468. Фдьможнвьше Пб. 91. Прнпожнкише 91. допвстикше М. 445. XVI впјека: падше Н. Рањ. 122. дошадше (да п ја донадше поклоним се) Н. Рањ. 29. узамше Н. Рањ. 161б. почамше Буд 24. ставпе Н. Рањ. 37. 61. Збор. 6. уставше Н. Рағ. 24б. 28. (уставше Јона) 81. 
(уставше наслједовао јест њега) 195б. бпвше (ки-) Н. Рањ. 99. чувше 32. 38б. говоривше 88. одговоривше 45. 45б. примивше 93. отворивше (врата, шзпде) 68. пославше 29. дозвавше 29. - б) за вом. јед. женскога рода: XV и XVI вијека: пртстанше М. 418. сплетче (сппктише) Ст. пис. ], 56. допадше (звијезда) Н. Рањ. 29. - в) за ном. јед. средњега рода: кикише (топ кинше, господокии висте) II. 43. падше Н. Рањ. 87б. пзникнвше $35 .-$ г) за ном. мн. женскога рода: одрвше Стар. 3,242 . - д) кад нема номинатива ком се придијева (од друге половине XIV вијека): рекше M. 157. почапше $M$.

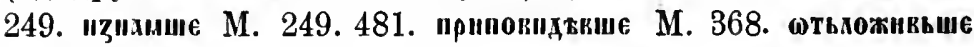
М. 176. астакнвыне М. 211.

Као што се активни партицип садашњега времена изједначно у номинативу мн. мушкога рода с ријечима у којвх је основа на ја (види стр. 353), тако се изједначно с њима и овај; а то се изједначивање п у њега почело још XIII вијека и најприје се јавља у сложеном облику: вгождыши М. 25. у номиналном облпку XIV вијека: кад је ријеч о правој множнни: пхтивши М. 204. без номинатива ком се придпјева: бљьнььши Пб. 35 (два пута). XV впјека кад је ријеч о правој множини: докедишн П. 135. вкрхдыни П. 134. пртшадун М. 484. донєсьшн П. 133. взанын!" М. 529. дав!I" М. 521. продаюши М. 529. вънакши П. 44. чвкьшн ПГ. 47. кндввыши П. 149. 165. кндекишн Пб. 79. сквпнши П. 141. кад један иди једна говори о себи у множинш: razumifsi М. 279. razgledausi 279. кндевшн 536. гад нема номинатива ком се придијева: почмин М. 248. "zихмши М. 249. 386. У исто врпјеме додази овај обдик п за друге као што додази и прави номинатив множ. на $e$ : a) за ном. јед. мушк. рода XV вијека: опнвьшн сє П. 160. 164. юдможнкш М. 518. б) за ном јед. средњега рода XIV вијека:

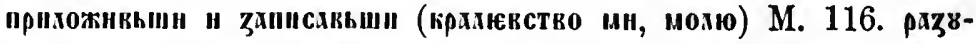
итвьни (крхмевьстио ми, не хоть) М. 201. в) за ном. мн. женскога рода: налазе се примјерп од свршетка XV вијека: свргши Ст. ппс. 1, 60. стргшш 60. пошадчи Н. Рањ. 123б. дошадчи Ст. ппс. 5, 205. дошадшп Д. Рањ. ІХб. почанши Ст. пис. 2,435 . за друге шадеже, осим номпнатива, вр.о ријетко: г) за акусатив мн. мушкога рода XV вијека: вгодикши М. 295. 456. (ако није помјерени акусатив множ.; види под 3). 
д) ва акусатив јед. женскога рода XVI вијека: ву најдопе размрзнувши се Стар. 3, 270. Као што је прави номинатив мн. на $e$ долазио и за номинатив јед. женскога рода (види напријед), п као што је у актшвнога партицина садашњега вр. промијењени ном. мн. допао и за ном. јед. женскога рода (види стр. 360 ), тако је без сумње и у овога партиципа овај помјерени ном. мн. мушкога рода дошао и за ном. јед. женскога рода шрем да оба облика једнако гдасе (внди даље под 2) те је у том послу остао до данас. - Да би се потпуно показало састављање сложенијех наставака с основама и колико се које држало, чему довле није било прплике, јер није било довољно примјера, стављам овдје примјере од свршетка XV впјека до свршетка XVII, у којима помјерени номинатив мн. долази за номинатив свакога рода и множине и једннне, a да додази за све те облике, то мпслим да код онога што је већ речено није тријебе иоједипце потврђпвати:

A. наставак ansja иза сугласнијех држи се до краја XVII вијека: I. 1. ободчи (окодьшн) 3бор. 47б. прободши Зор. 33б. доведши Ст. пис. 5, 144. Злат. предгов. 2. доветши Брн. 23. заведши Ст. иис. 4, 158. поведши Вран. жив. 33. приведши Град. дух. 26. кла(д)ши Ст. пис. 4, 279. падши Ст. пис. $1,70$. Н. Рањ. 42.' Ст. пис. 4, 124. 424. 3ор. 8б. Гуч. 118. Вран. жив. 5. Банд. 19. Мрн. 166. Јерк. 44. Каш. 15. попадши Хект. $30 б$. 3ор. 29. сједчи Н. Рањ. 229. сједши Град. дух. 32. седши Хект. 23. Зор. 55б. Мрн. 102. сндши Банд. 136. засједшпи Ст. пис. 5 , 320. основа шьд долази само сложена: дошадчи Ст. пис. 1, 84. Н. Рањ. 28. Град. дјев. 37. Гуч. 143. Орб. 99. дошатчи Аив. 296. дошачи Град. дјев. 88. дошадши Ст. нис. 5, 147. 310. Д. Рањ. V. Хект. 30. Брн. 68б. Гуч. 243. Вран. жив. 5. Каш. 27. Радн. 32. Глав. 17. дошатши Брш. 61. Андр. дев. 2. изашадши Зор. 6б. Банд. 24. Радн. 50. изашатчи див. 25. нашадчи Н. Рањ. 60. 3бор. 44б. Гуч. 170. нашадши Ст. пис. 3, 224. Д. Рањ. У. Гуч. 42. Банд. 139. Кашт. 15. Радн. 26. обашачи Зор. 2. обашадши Банд. 152. одашадши Ст. пис. 1, 35. Вран. жив. 112. Банд. 86. пошадши Ст. шис. 1, 16. Банд. 47. пошадчи Ст. пис. 1, 85. Н. Рањ. 123б. Збор. 9. Стар. 4, 111.

' Исти пише и пачши (расхіj) 122. 
Гуч. 129. пришадчи Ст. пис. 1, 183. пришадши 3, 134. 4, 233. 5, 25. Банд. 16. пронадчи Збор. 15б. прошачи Град. дух. 60. пронгадши Злат. 44б. Банд. 84. Радн. 31. узашадши Хект. 24. са " пред шид у сложеном XVII внјека: отишадши Банд. 91. Каш. 75. узишадши Банд. 29. - I. 2. слјеши (сьмвънши) Н. Рањ. 141б. улјешп Н. Рањ. 29. удиши Буд. 87. улшспи Ст. ппс. 1. 55. Вран. жпв. 37. удизши Хект. 3. Буд. 144. Банд. 4. уз.иснш Стар. 3, 266. понесши Ст. ппс. 1, 4. прпшеши Н. Рањ. 57. принеспи Банд. 47. узнеши Н. Рањ. 41б. „поднехчи (подьпссьш!) Див. 23б. - I. З. од основе која у инфинитиву губи задње $\pi$, а вокал в шири у оү, а у овом се облпку и цијела држала још XVI вијека: просаппи Ст. пис. 3, 90. - I. 4. основе на 2: одбјегши Град. дух. 79. вргши Ст. пис. 1, 47. Банд. 86. врхши Ст. пис. 2, 353. Град. дух. 32. вркши А. Рањ. 91б. Гуч. 105. Вран. жив. 91. одвргши Ст. ппс. 1, 60. Банд. 17. Јерк. 8. одврхпи Ст. иис. 2, 467. разврхши Ст. пис. 2, 467. уврхши Ст. пис. 2, 496. Град. дух. 4. пожекши Збор. 82б. дегши Хект. 16б. декпи Збор. 37б. налегши Стар. 3, 329. из.ъегши Ст. пис. 5, 244. удјегпи Град. дјев. 86. могши Ст. пис. 2, 201. помогши Ст. пис. 1, 52. Орб. 149. пристргши Зор. 27б. основе на $\kappa$ : извушши Зор. 66. Банд. 165. обукши Банд. 99. свукши Банд. 87. рекши Ст. пис. 1, 22. 51. Н. Рањ. 130б. Збор. 7б. Ст. пис. 2, 222. 388. 3, 149. 4, 99. 5, 99. 131. Хект. 18б. Зор. 26. Буд. 39. Злат. 62. Гуч. 49. Вран. жив. 18. Див. 16. Орб. 49. Банд. 84. Мрн. 125. Јерк. 11. Каш. 65. изрекши Град. дух. 43. Чубр. 12б. пзсикши Вран. жпв. 13. одсикши Банд. 122. усјекши Н. Рањ. 193б. дотекши Ст. пис. 5, 223. Вран. жив. 65. истекши Ст. пис. 1, 56. Зор. 66. обтекши Стар. 4, 112. потекпи Н. Рањ. 41. Ст. пис. 4, 111. Банд. 49. притекши Ст. пис. 1, 148. Н. Рањ. 58б. С'т. пис. 4, 135. стекши Ст. ппс. 1, 106. 2, 53. 438. 4, 85. 5, 169. утегши Ст. пис. 1, 106. 2, 40. 5, 80. Гуч. 164. стукши Ст. пис. 1, 36. - I. 5. основе на м: јампи Ст. пис. 1,85 . 3ор. 7б. вазамши Ст. пис. 2, 130. 4, 112. Зор. 27б. Стар. 1, 224. 3, 307. Вран. жив. 7. Јерк. 44. узамши Н. Рањ. 89. Збор. 47. Ст. пис. 3, 191. 5, 121. д. Рањ. ІVб. Град. дух. 18. Гуч. 198. Банд. 24. Каш. 42. Пос. 15б. Радн. 50. зајампи Зор. 35. појамши Ст. пис. 1, 22. 3, 134. Банд. 92. појанши 3ор. 11б. пријамши Ст. пис. 3 , 455. Буд. 11. Брн. 72. Банд. 19. однамши Буд. 47. под- 
намши Чубр. 12. ујамши Банд. 117. пријемши Глав. 105. знемши Крн. 21б. ожамши Зор. 27б. основе на $н$ : разашанш Вран. жив. 17. 37. почанши Н. Рањ. 34. Ст. пис. 2, 435. Гуч. 85. Банд. 25. Каш. 22. почамши Н. Рањ. 81. Збор. 113. Град. дух. 45. Пос. 10б. Андр. дев. 12. Радн. 58. - I. 7. $p$ се узима за сугласно: нотарши Ст. пис. $1,18 . '$ одпарши 45 . настарши 45. умарши Банд. 145. - II. двигши Ст. пис. 1, 22. 3, 56. 3ор. 66б. замахши Ст. шис. 4, 140. смакши Ст. пис. 1, 26. тркши (трьгыши) Ст. пис. 4, 376. стргши Ст. пис. 1, 60.

Б. наставак vansja.

a) иза самогласнога: I. 3. од основе гоја се, истина, свршује на сугдасно $a$ те је и од таке био овај облик, како је поменуто (стр. 380), али која у инфинитиву губи задње сугдасно а самогласно т шири у оү, од ве тако промијењене има овај облик с овијез наставком: просувши Ст. пис. 2, 394. А. Рањ. 71. посувши Пос. 25б. - I. 5. основе и тога раздјела ако се и свршују на сугдасно, пга је и од таких био овај облик (виді напријед стр. 380), ппак како им у инфинитшв од тога сугласнога и предњега самогласнога постаје самогласно, од жих и тако промијењених има овај облик: пријавши Ст. пис. $2,146 .^{2}$ разапевши Вран. жив. 110. зачавши 3ор. 26б. 36б. зачевши див. 39. Каш. 81. - I. 6. давши Ст. пис. 2, 444. 3, 279. 4, 39. 5, 109. 334. Д. Рањ. У. Град. дјев. 4. Хект. 8. придавши Злат. предгов. 3. Чубр. 8б. Орб. 13. Јерк. 26. Каш. 63. Радн. 48. знавши Ст. иис. $4,86.5,166$. изазнавши Мрн. 13. познавши Орб. 88. узазнавши Каш. 88. ставши Ст. иис. 1, 182. Хект. 13. приставши Орб. 30. уставши Стар. 4, 118. Хект. 6. бивши (esse) Ст. ппс. 4, 447. добнвши Ст. пис. 1, 6. забнвши (oblivisci) Ст. пис. 3,165 . разбивши (frangere) Ст. пис. 1, 8. завапивши Банд. 13. разгнпвши Д. Рањ. 57б. сакривши Д. Рањ. 95. покривши Злат. 87. умнвши Ст. пис. 5, 128. пивши Ст. пис. 1,52 . опнвши се 70 . изувши Пос. $37 б$. чувши Ст. пис. $1,4.48 .2,394.4,113.5,118$. Збор. 10. Град. дјев. 86. Хект. 9. Стар. 3, 238. Злат. 61. Вран. жив. 18. Каш.

' Наптамнапо је јамачно гријешком: потрши.

2 Овај примјер није поуздав, јер може бити да је писац већ узимао овај глагол међу глаголе пете врсте, види напријед cтp. 248. 266. 271. 283. 
17. одивши Брн. 11. смивши Злат. $876 .-$ I. 7. $p$ се пирндо у ръ као у инфпнитиву: тако се налази до краја XVII вијека, али ријетко: умривши Н. Рањ. 134. Д. Рањ. 134. помривни Радн. 51. вприєкши Збор. 80. прострије(в)ши Н. Рањ. 117б. прост(р)ијевпи 188. простривши А. Рањ. 103. чешће се $p$ узима за вокал, као данас, те се не шири, не само у основама које се ни у шнфинитиву не шире: потрвши Ст. пис. 1, 244. сатрвши Мрн. 41. него ни у онијема које се у ннфинитиву шире: нодрвии Ст. пис. $1,15 . \mathrm{Mpн.} \mathrm{31.} \mathrm{продрвши} \mathrm{Мрн.}$ 100. раздрвпи Бапд. 92. Радн. 10. умрвши Ст. пис. 1, 58. 150. 151. Н. Рањ. 28. Збор. 147. Град. дух. 26. Бріг. 51. Банд. 18. Крн. 21б. Радн. 84. занрвши 3ор. 6. 29. 29б. одпрвши Ст. пис. 1, 54. прострвшв Град. дух. 32. Стар. 4, 111. Банд. 21. 37. 214. Радн. 58. - II. одвргнувии Вран. жив. 75. пригнувни Буд. 87. Каші. 70. Ђам. 3. дкигивкши Збор. 82б. Зор. 18б. Стар. 1, 222. подвигнувши І'рад. дух. 69. Вран. жпв. 63. Мрн. 13. уздвигнурвии Гуч. 133. Јерк. 30. Кані. 8. здвигнувши Вран. жъв. 14. 40. уздигнувши Гуч. 261. Гунд. пс. 25. Банд. 45. дигнувши Радн. 48.' кдекнувши Ст. инс. 5, 151. 3бор. 73. Гуч. 23. Вран. жив. 17. окренувши Радн. 26. ускрснувши Јерк. 76. Каш. 39. макнувши Радн. 58. метнувши Радн. 34. размрзнувши се Стар. 3,270 . пзникнувши Банд. 26. поникнувши Ст. ппс. 1 , 92. шаднувши Ст. пис. 5, 61. А. Рањ. 73б. Гуч. 158. Вран. жив. 109. прншаднувши 89. упаднувши Радн. 47. посрнувши Ст. шис. 1, 117. стигнувни Ст. пис. 2 , 366. достигнувпи Банд. 151. такнувши Стар. 4, 114. Вран. жив. 110. дотакнувши Радн. 92. стискнувши А. Рањ. 92б. затисну(в)щи Радн. 17. прптиснувши Стар. 3, 322. стиснувшп Д. Рањ. ІХб. - III. 1. имивши Буд. 87. рхзвинскши Збор. 45. -- III. 2. видјевши Н. Рањ. 94. видивши Ст. пис. 2, 73. 378. 3, 326. 4, 116. 5, 133. Злат. 29б. Каш. 35. живнвши Брн. 26. Каш. 87. пожудившп Град. дјев. 61. позривши Н. Рањ. 98б. Ст. пис. 5, 112. озрнвши Ст. пис. 4, 95. узривши Каш. 23. услрдивши се Гуч. 11. хтивши Каш. 63. ктивши Ст. пис. 3, 386. заповидјевши Орб. 33. исповидјевпи Мат. 17. Андр. дев. 31. - IV. бдагосовивши Гуч. 24. заборавнвшп Каш. 48. веселивши Ст. пис. 1, 5. вративши

' Исти има често без в иза у јамачно гријетком: дигнуши 21.38 . 
Каш. 7. обративщи Хект. 7б. сврщивши Хект. 15б. одговоривши Јерк. 45. сагријешивши Збор. 16б. удривши Мрн. 63. Банд. 274. примивши Каш. 75. снимивши Јерк. 70. слнмивши Каш. 42. 75. пок.онивши Хект. 16б. скрушивши Орб. 170. покупивши Стар. 1, 221. окусивщи Хект. 6б. промисливши Див. 24. наредивши Хект. 16. заробивши Д. Рањ. V. услишивши Вран. жив. 15. услободивши Там. 3. ставивши Каш. 20. оставивши Ст. пис. 5, 163. приступивши Н. Рањ. 33. отворивши Брн. 58. створивши Ст. пис. 1, 35. ухитивши Н. Рањ. 56. чтивши А. Рањ. 140б. прочтивши 54. зачудивши се Хект. 5. - V. 1. вечеравши Хект. 12. обећавши Злат. 67. разгњивавши се Вран. жив. 45. у багавши Хект. 10. имавши Ст. шис. 3, 161. помањкавши Каш. 98. слишавши Ст. шпс. 1, 10. Банд. 4. уздавши се Орб. 36. џскикиши М. 552. чекавши Зор. 19. - V. 2. приказавши Ст. пис. 1, 63. пискииї М. 549. пославши Банд. 2. - V. 3. раж(в)авши Ст. пис. 5, 90. одагнавши Банд. 295. изарнавши Банд. 111. одарнавши 79. 294. (види нашријед стр. 253. 284) покајавши Радн. 58. - VI. војевавши Мрн. 13. б) иза сугласнога додази овај наставақ као данас истом од XVI вијека а измеלу задњега сугдаснога од оспове и првога од наставка умеће се $a$ као и у другим приликама кад се стёче више сугдаснијех: једини је примјер XVI вијека: донссхкши М. 549. (види напријед І. Б. б). XVII вијека има их већ више: I. 1. доведавши Радн. 25. једавши 61. ш основа шад (шьд) додази у исто вријеме с тијем наставком, али се њојзи одбацује крајње $A$ па се онда не умеће $a$ између ње и наставка: дошавши Јерк. 18. Пос. 37б. изашавши Јерк. 24. нашавши Јерк. 37. Пос. 24б. прншавши Јерк. 45. са $u$ пред $и а_{A}$ у сложеном: отишавши Јерк. 44. основа јед још на свршетку XV вијека долази с овијем наставком, али јој се тада одбацивало крајње $д$ према садашњем вр. какво има без наставка: објивши Ст. пис. 1, 70. - I. 2. удјезавши Орб. 114. улнзавши Банд. 138. 200. Радн. 93. - I. 4. вргавши Радн. 49. извргавши 96 . сажегавши 94. помогавши 96 . остригавши Банд. 292. обукавши Пос. 25б. Радн. 92. ировукавши Радн. 9. рекавши Радн. 39. 61. одсјекавши Радн. 47.61. утекавши 54. - II. растргавши Радн. 2. 
Исти об.дик у свакој поменутој служби додазп од XVI вијека и окрњен, без крајњега $u$, па му је онда додано $а$ : само окрњеи до.1ази XVI вијека само један пут: душивш кога Зор. 3. с доданим $a$ XVII вијека у два писца: рекша (како рекша, добро се могу штити) Мик. иредгов. како рекша 182. заборавивша се Радлі. 17. 83. оз.10срдивша се (иригни убогому твоје ухо не оздосрдивша се) 97. покваспвша (ријеке остављају многе земье пе поквасивша и[х]) 99. покловнвша се (сагрнши пук покдонивша се јунцу) 47. намиривша 69. смутивша 48. осптивша 28. нас.10нивша 27. уставивша 55. 87. очистпвша $52 .{ }^{\prime}$

2. Номиналнг ном инат тв јед. женскога рода разликовао се од обичнога онако као у активнога партицина садашњега вр.: пришь,ыни М. 264. - Од тога је облика као и у адјектива с номпнативом од ирономина м, постајао сложени об.ли: рождьшных М. 569. мјесто такога сложенога облика налази се XV вијека као у адјектива с основом на ја, те је од номнна.лнога тако начшњенога крајње $a$ сажето с прономнном: шстхишх М. 501. Шослије сложени п не до.ази; а номннални како је једнак бно с новијем номшнативом мн. мушкога рода, замијенпо се впм као и у оба друга рода; видп нашрпјед под 1.

3. Остали су шадежи би.и као у адјектива, али додазе само у споменпцима који су писани впше црквенијем језиком уди на таким мјестима у споменицнма гдје се хтјело да буде преха црквеном језпку:' l'енит. јед. мушкога п средњега рода номпналнп: кмкьшх (мјесто чега стоји вмкаш) М. 112. с.10жсни: zльтгшано Сав. 7. кившхго М. 400. почнкшхго П. 16. 32. изједначен с прономиналнијем (види стр. 160): кнкшегх М. 457. почикшеr. М. 52. 55. 191. 352. 499. погрјешка ће бпти похивmor. II. 10. женскога рода: остикше ПІб. 55. 58. - Да ти в јед. мушкога и средњега рода номиналип: шропкьтшя М. 133.

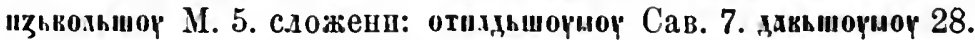

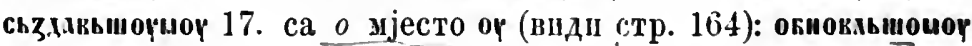

' „сврнув пуст" Ст. пис. 1, 17. моде бити да би треба.ю читатп: сврнувп уст, и то би бно најстарији прпмјер.

2 IIIто још XVI впјека има Будинић ноч. јед. средњега рода: погибше 99. у њега има и другога којечега но црквеном језнку. 
M. 143. почившону П. 29. изједначен с прономиналнпм (види

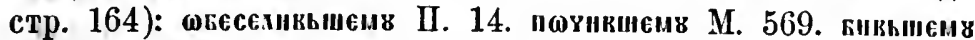
II. 155. женскога рода сложенп изједначен с прономиналним: вывьшен М. 100. нстекшоп Стар. 3, 249. - А кус. јед. мушкога рода од номиналнога кывьш сложени: вывьши М. 5. средњега рода номинални: ихус (мхьше) М. 486. женскога рода номинални: споқовхкшу М. 233. кикшу М. 457. сложени: погикьшвю М. 4. шставхмыню М. $233 .^{1}-\lambda_{0}$ к а т. је д. мушкога и средњега рода сложени (види стр. 182-3): почнкиниь М. 354. пзједначен с шрономиналним: прнхвиньшснь П. 104. женскога рода сложени изједнатен с ирономиналним: почикmон М. 268. - Ге н и т. м н. за сва трп рода сложени: вгождашихь (оугождыниь) М. 73. изједначен с прономиналним: кивннсхь М. 207. - Да а т. мн. номинални мушкога рода: нспминнень Стеф. 18. сложени: оүмножинии СтеФ. 19. простинынны Сав. 11. А кус. мн. мушкога и женскога рода сдожени: ногньыше М. 6. налази се у номиналном облику п " на крају мјесто $є$ начином споменутим напријед стр. 16: вгодивин М. 295. 456. (ако није помјерени ном. мн. узет за акус. види напријед под 1), а по томе п у сложеном: погињынє М. 220.282. - Ин стр. мн. мушкога рода номиналнп: вгоднкшн М. 260. сложенп: распхинин М. 73. изједначен с прономиналним: вголнкшнсын М. 457. окрвен и изједначен с дативом: рекшим М. 167. вгоднвшнми М. 431. 453. -- Номин. дв вој ине мушкога рода: бжс"Hкина се M. $544 .{ }^{2}$

\section{ПАРТИЩИП ПРОПЛОГА ВРЕМЕНА}

\section{АКТИВНИ ДРУГИ.}

Основа му је онака паква је пнфшнитиву. Наставак је la, у ком остаје у словенскп језпцима $\boldsymbol{x}_{\text {, }}$ a a се саставља с падежнијем наставдпма као у пмена којика се основа свршује на чисто а. Пред $\lambda$ од наставка отшада основи крајње

1 Погрјешке су: сподовашш М. 239. сподовахшвю 275. сиодокьшаю 260 . сподовашхю 430 .

2 Датив дв. гријешком: сьстакьнспия Стеф. 27. - Од остати има гријешком ном. мн. мушк. остакши Пбб. 53. средње: бстакшх Пб. 53. женско: өстамиє М. 361. 
д II $T$, а између других сугласнијех и $\pi$ од наставка кад за вим нема самогласпога умеһе се у српском језику $a$, a $\lambda$ ce и тада и кад год стоји на крају мијења на о, као и у другим прндикама, прем да се дуго држало в непромијевено особвто по неким странама; основе које се свршују на $\boldsymbol{x}$ пли $\varkappa$ (у гдагода прве врсте петога раздјела) састављају те гласове с предњим самогласним пред наставком у самогласно као у инфинитпву.

I. 1. кмюхн М. 308. бљул Ст. пис. 2, 21. увели Н. Рањ: 88б. навед Вран. жив. 85. пзвео Банд. 62. нұно П. 175. Збор. 33б. појшл Ст. пис. 1, 254. јелп Н. Рањ. 157. крали Ст. пис. 1, 157. украо Збор. 27б. крао Ст. пис. 4, 225. крад Зор. 656. укрел Буд. 67. укрео Стар. 4, 113. одпао Ст. пис. 1, 157. пал Злат. 2б. упал Јерк. 38. упао Ст. пис. 4, 474. Јерк. 38. сео Ст. пис. 1, 155. спо Ст. пис. 1, 41. Н. Рањ. 85. Збор. 87б. Ст. пис. 3, 362. 4, 22. Гуч. 299. Банд. 141. сед Хект. 20б. обсел Вран. жив. 100. окрках Пб. 50.' срио Збор. 37. срил Хект. 24. продвала Хект. 3б. од основе шьд којом се у овом облпку замјењује глагод ити: шми ПI. 23. 104. дошкн Сав. стар. 4, 231. дошакь II. 9. М. 347. Вран. жив. 18. Јерк. 45. дошко М. 326. 349. Ст. пис. 4, 439. Злат. 29. Банд. 58. нұшхн М. 535. нұашао М. 462. мимошло Банд. 91. мимошла Каш. 44. пхшамь П. 109. Н. Рањ. 33б. Ст. пाис. 3, 441. 4, 4. Вран. жив. 39. пашью М. 302. пхшхо 394. Ст. ппс. 1, 3. Град. дух. 57. окимшао М. 459. обашал Ст. пис. 3, 267. 4. 97. одашах М. 218. шдашаш М. 461. Н. Рањ. 116б. одашли Банд. 46. оташао Хект. 14б. пошхь М. 218. пошхо М. 458. Банд. 45. прншхо М. 326. 496. Банд. 49. пришад Ст. пис. 2, 123. 3, 26. 4, 261. Банд. 15. сашал Банд. 21. у сложеном с прнједлогом који се свршује на сугдасно додази $и$ додано пред шьд јамачно од глагода ити од XIV вијека: "zишмо ПI. 24. XV вијека: рхъними П. 54. Фтинми 118. XVI п XVII впјека: изишао 3бор. 112б. Каш. 9. Пос. 216. изишла Збор. 2. Ст. шис. 4, 397. Андр. дев. 438. изишли Буд. 130. пзншло Орб. 117. Јерк. 27. Kaш. 61. надипшла Cт. пис. 2, 471. падишли Ст. пнс. 5, 66. надишал д. Рањ. 18б. надишле Гунд. пс. 12. обишлп Ст. пис. 4, 334. отншао Збор. 93б. Гуч.

' Іусарском гријешком са ь мјесто в: юьрьхн М. 417. Пб. 122. 
42. Банд. 55. Радн. 40. отишал Вран. жпв. 47. отинди Дпв. Х. Орб. 112. Радн. 26. отишла Јерк. 37. отишле Каш. 78. сишла Ст. пнс. 2, 351. сишао Банд. 156. Каш. 35. сишло Андр. нач. 38. узишао Банд. 36. узишло Каш. 111. с таким и долази и прости од XV вијека: ншхн П. 75. алп тај једини примјер тога времена није поуздан, јер може бити да стоји мјесто "зышк; поуздано долази од XVI вијека: ишли д. Рањ. 98. ншло Див. IX. ишао Радн. 12. ишла 66. в у сложенога с приједлозима који се свршују на самогдасно додази тако додано и од XVI впјека: "ропшка Стар. 4, 72. мимоншлим Буд. 123. основама воје пред крајњим т имају још једно сугласно отпада такођер $т$ пред $\lambda$, осим кад нх раставља $a$, које би се уметнуло пзмеђу $c$ и $\lambda$ кад би $T$ п отпало: узреслш Ст. пис. 1, 252. узресло Мрн. 13. изресли Стар. 3, 229. ресло Чубр. 15. кад се умеће $a$, остаје п $T:$ растал Ст. пис. 4,145 . узрастал Јерк. 40. али п тада долази и без $т$ : проресал Н. Рањ. 164. из облика у ком се умеће $a$ па се и $T$ повраћа преносили су неки писци $T$ и у облике у којима се не умеһе $a$ : изрестла Вран. жив. 97. тако : цафтдо Чубр. 15. из глаголских облпка у којима се држи $д$ основама на крају налази се у једнога шисца XVII вијека пренесено $九$ и у овај облик: поведал Вран. жив. 14. падла 89. ушад.ла 90.' - I. 2. нзпвzан М. 447. улјезао Н. Рањ. 76б. Град. дјев. 119. Орб. 39. улизао Ст. пис. 4, 115. улјезла Н. Рањ. 76. опузле Ст. пис. 3, 215. напузде Ст. пис. 4, 166. нұпескь М. 477. понесамь М. 184. допесххь П. 42. Пб. 117. пзнесал Ст. пис. 3, 357. понесал Вран. жив. 104. нзиєсаш М. 457. 466. донєсао ІІб. 98. Злат. 68. поднесао Н. Рањ. 131. принеса о Банд. 56. Каші. 74. прниески М. 383. донески 512. нанесла Ст. пис. 4, 313. 346. поднесла Вран. жив. 38. донеслш Банд. 215. та основа и онаћо иромијењена како се мијева у првом сложеном аористу млађем п по вему у интинитиву прелазш пз инфинитпва у овај облик од XV вијека: виххь П. 33. донно Пб. 51. поньхо П. 123. Фднтах П. 173. тако п послије : понил Ст. пис. 2, 332. поднпл Ст. пис. 5, 34. Буд. 94. Злат. 82. Јерк. 69. донијел Злат. 71б. поднпо Збор. 99.

' IIтто на једном мјесту у почетку XV вијека стоји шкрвти" II. 32. не могу мислити да је што друго него писарска погрјешка, ако није штампарска. 
Ст. пис. 3, 324. Град. дух. 58. Гуч. 182. Див. 24. Банд. 238. Андр. дев. 8. донио Каш. 94. занијела Ст. пис. 2, 16. 34. 4, 101. занила Ст. пис. 2, 334. занела Крн. 11б. дониједа Ст. пис. 4, 450. 473. Гуч. 131. донили Злат. 34б. однила Вран. жив. 108. Бун. 49. понила 3ор. 6. 63. поднпјеле Град. дјев. 100. поднијела Гуч. 311. ноднпјели Орб. 250. Андр. пут 334. - I. 3. издубао Банд. 88. озебал Ст. пис. 3, 302. пскубла Бун. 13. зацрпао Банд. 56. поцрпли Н. Рањ. 31. од основа промијењених као што се мијењају у инфинитиву: жюхн М. 46. П. 150. жнкь II. 162. просула Ст. пис. 4, 101. - I. 4. блкрьго М. 260. 431. одькрги М. 218. стргли Мрн. 157. свжькх ПІ. 104. обукао Н. Рањ. 170б. обукал Вран. жив. 33. рекхи М. 21. порекхи 219. рекак П. 22. Ст. пис. 2, 54. 3, 297. Брн. 72. Вран. жив. 8. Банд. 12. одректо М. 230. порекао М. 307. рекаш М. 327. Н. Рањ. 65. 3бор. 1. Ст. пис. 4, 308. Гуч. 10. Банд. 51. и од основе промијењене како се мијењада. у првом сложеном аористу мдађем а по вему и у инфинитиву, алп само у једнога писца: рул Ст. пис. 1, 19. 33. - I. 5. пожели Н. Рањ. 143б. пожео Злат. 47. жњело Ст. пис. 2, 433. зхкхео М. 377. Н. Рањ. 1176. Банд. 62. закљел Вран. жпв. 108. почел Хект. 36. Вран. жив. 37. Мрн. 165. почео Град. дјев. 3. почела Вран. жив. 30. зачела Јерк. 16. прпчао Хект. 15. почао Брн. 24б. зачала От. пис. 1, 168. Зор. 2. почала Јерк. 15. нзек П. 84. вzекь ПІ. 33. Злат. 10. вазел Д. Рањ. 6. Вран. жив. 36. вұео М. 373. 378. 380. Ст. ппс. 1, 156. Град. дјев. 38. Злат. 84. Банд. 48. вазео Ст. піс. 3, 471. Злат. 57. изео Н. Рањ. 117. Збор. 45б. обујед Вран. жив. 33. пријел 24. еки М. 21. въеки ПІ. 102. Н. Рав. 92б. вазела Ст. пис. 2, 26. 4, 272. Злат. 7. Вран. жив. 57. јал Ст. пис. 1, 51. прпјал Буд. 39. Вран. жив. 18. пријао Стар. 4, 118. приками М. 323. II. 53. Буд. 135. Брн. 5. Вран. жнив. 19. Мрн. 43. прнамо П. 160. обујало Н. Рањ. 150. прнххь Збор. 5. Ст. пис. 2, 6. Банд. 2. прпјао Банд. 45. обујале Банд. 12.' - I. 6. дахь М. 312. Н. Рањ. 226б. Ст. пис. 3, 195. Буд. 78. Вран. жив.

' Тај глагол, кад му основа гласи $j a$, мвоги узимају меңу глаголе пете врсте првога раздјела (види код садашњега вр.); за то оназо иду ови примјери а може битп и тајекоји између горњих: пријал А. Рањ. 53б. пријали Ст. пвс. 3, 216. пријала Ст. пиг. 4,74 . Злат. 86. 
8. Банд. 40. дао ІІб. 14. М. 364. Ст. пис. 1, 45. Н. Рањ. $226 б$. 3бор. 9. Ст. пис. 5, 36. Злат. 13. Банд. 56. ким М. 101. Н. Рањ. 18б. Ст. пис. 3, 204. 4, 225. А. Рањ. 10. Буд. 59. Злат. 1. Вран. жив. 45. Банд. 2. кио М. 101. 237. 258. Пб. 54. Ст. пис. $1,159$. 4, 221. 5, 11. Хект. 34. Зор. 32. Злат. предгов. 2б. Гуч. 23. Банд. 139. Мрн. 179. Јерк. 76. исплила Ст. пис. 2, 347. 4, 182. стрва М. 158. зичио М. 411. дио Ст. пис. 3, 378. одио Хект. 25б. дпла Ст. пис. 2, 46. Хект. 6б. одјела Ст. ппс. 4, 260. запјели Ст. пис. 4, 312. спјела Град. дјев. 140 . спшл Ст. пис. 2, 80. пел Зор. 69б. пио Ст. пис. 3, 208. 410. спио Ст. пис. $3,400.4,63$. - I. 7. $p$ се узима за самог.дасно, нити се шири, п то не само у основама у којима се у инфинитиву не шири: стр. Ст. пис. 4, 283. Злат. 16. отрьо Каш. 62.' него остаје нерапнрено и у онијем основама у којима се у инфннитиву шири: подврьо Див. 20. раздрьо Збор. 59. Ст. пис. 5, 31. Банд. 51.163. пождрьо Н. Рањ. 148б. Банд. 216. умрл Злат. 16. Вран. жив. 47. Банд. 70. умрьо Н. Рањ. 111. Збор. 51б. Ст. пис. $2,407$. 4, 473. Град. дјев. 140. З.дат. 16. Див. 24. Банд. 49. Бун. 43. Пос. 12б. допрьо Злат. предгов. прострьо Ст. пис. 1, 51. Н. Рањ. 76б. Банд. 118. обастрьо Банд. 220. - II. побнгнуле Вран. жив. 58. изгинудо Н. Рањ. 42б. погинуо Банд. 49. гынка П. 87. пригнуо Ст. пис. 3,475 . нагнуо Банд. 139 . гануо 49. издахнуо 36ор. 84. Каш. 71. двигнуо Град. дјев. 62. Мрн. 130. двигнуди Каш. 37. уздигнуо Банд. 125. раскиднуо Мрн. 130. ускрснуди Н. Рањ. 123. ускрснул Вран. жив. 10. ускрснуо Банд. 139. умкнуда Див. Х. уэмакнуда Аив. Х. паднул Ст. пис. 5, 39. паднуо Ст. пис. 2,512 . паднуди Хект. 14. споменуо Ст. иис. 2, 483. пукнуло 496. саснуо Вран. жив. 51. посегиво М. 462. посмагнули Радн. 85. достигнуо Ст. шис. 4, 477. такнуо 136. отврднуд Ст. пис. 5, 35. тегвљ М. 367. притиснуд Ст. шис. 1, 80.

- Аа $p$ и пред о остаје самог.ıасно (чега ради за вим стављам ь) потврђује се тијем птто неки писци пипу: рақдаро Збор. 59б. вмхро Збор. 516. 64б. 67. 71. 96. Анв. 24. полкхро Апв. 20. razdaro Банд. 163. prostaro 118. razdarho 51. poždarho 216. umarho 49. 52. 67. вмхрхо Пос. 126. итraо Банд. 271.

2 IIIто на једном мјесту пма вмрєо М. 527. ту $e$ нема ништа са $e$ које је у пнфинитиву, пего вриједи онолико колпко у нашсо у истом споменшку. 
отиснуда Андр. дев. 103. притискиула Вран. жив. 12. у гдагола ове врсте може основа у овом облику бити п без свога наставка -ну-: побигле Вран. жив. 58. повело Ст. пис. 2, 200. свехла Ст. пис. 4, 291. обпсле (гране сухе) Ст. пис. 3, 253. погивм II. 47. 115. "зһгикае Пб. 80. погибде Н. Рањ. 46б. погибло Ст. пис. 4, 21. Банд. 34. пзгибло Брн. 20. згпбал Ст. иис. 1, 214. погибал 219. пзгибал Јерк. 101. погибао Збор. 26. 30б. Јерк. 38. уздахал Ст. иис. 2, 412. задахла Ст. пис. 3, 437. дкигаль ПI. 88. Ст. пис. 1, 43. Злат. 18. двигао Ст. ппс. 4, 422. Јерк. 38. уздигао Банд. 125. дкигма М. 338. подкнки П. 133. двпгди Злат. 84б. клекао Збор. 114б. размакла Злат. 7б. одникао Ст. ипс. 4,105 . присахал Ст. пис. 1, 292. усахал Ст. піс. 2, 412. 427. 460. присахло Гуч. 104. стискао Збор. 676. потискли Ст. пис. 3,60 . стискла Крн. 3. стисли Д. Рањ. 108. 142. стисле Злат. 87б. - III. 1. имнд Ст. пис. 2, 322. имиди Хект. 29б. имио Брн. 5б. Мрн. 101. разумио 3бор. 62б. разумјели Н. Рањ. 126. - III. 2. бдјелп Ст. пис. 4, 306. видио Збор. 94б. Хект. 20. впдје.л Н. Рањ. 21. изаврил Ст. пис. 4, 57. изврјела 57. пазрио Апдр. пут 299. пазрјела Ст. пис. $2,487$. жнкъи П. 32. пожнвнл Ст. пис. 2, 9. живио Ст. нис. 1, 128. 4, 303. живјела Ст. пис. 4, 242. Гуч. 288. хоти( М. 445. Н. Рањ. 43б. Хект. 9. хотјели Н. Рањ. 87б. хьтеп М. 36. хтпо Н. Рањ. 230. Хект. 19. процтјеле Н. Рањ. 186б. процтио Ст. пис. 4, 30. процтјела 30. цафтил 145. процаптио 30. процаптид 57. од глагола ове врсте који има садашње вр. без наставка у основи: zаповидақ П. 52. zапокедео П. 175. заповидно Н. Рањ. 48. сповидио Н. Рањ. 75. Збор. 35. псповидио Н. Рањ. 14б. Гуч. 43. покидьми II. 45. сповидјели Н. Рањ. 75. псповидјела Андр. пут 54. како је тај глагол у садапњњем вр. бпо једнак с гдагодом јести, налазп се у једнога писца пзједначеп с жим и у овом облику : вил Ст. пис. 2,111 . - IV. вчннньь М. 219. говорид Н. Рањ. 178. бугаршд Хект. 36б. водшл Буд. 85. скупил Вран. жнв. 7. заборавнд Банд. 39. прогонил Гунд. пс. 35. квпно М. 102. вчнино 261. 283. чннио Ст. пис. $1,14 \varepsilon$. говорио Н. Рањ. 22. Хект. 9. - V. 1. шимь М. 311. питал Вран. жив. 21. скушाхо М. 307. имха 327. сисао Н. Рањ. 60. - V. 2. винсмх М. 298. посдал Н. Рањ. 226. zапнсао М. 306. посмо М. 367. Н. Рањ. 
43б. - V. 3. посијал Н. Рањ. 33. дозвал Вран. жив. 9. всшхо М. 466. зкхш М. 544. покајао се Ст. пис. 1, 303. обрао Брн. 3б. изарнали (изагнали) Банд. 65. појал (canere) Д. Рањ. 11. - VI. показокахь М. 420. војевал Вран. жив. 12. дарокао М. 258. целовао Н. Рањ. 58б.

Пред крајњим $о$ посталим од $\lambda$ кад стоји $a$, налази се кад кад изједначено с њим и сажето у дуго о од XV вијека, и то не само у пјесмама: најстаријп је примјер: жпего $\mathrm{M}$. 464. тако п послије: I. 1. дошо Н. Рањ. 208. Ст. нис. 4, 429. Андр. пут 328. - I. 4. пореко Ст. пис. 4, 249. реко Бун. 7. Андр. дев. 8.' помого Мик. 680. Андр. дев. VI. - I. 6. до Бун. 31. Андр. пут 80. зно Ст. пис. 4, 246. Бун. 31. -- II. диго Ст. пис. 5, 80. Андр. пут 82. - III. 2. настојо Cт. пис. 4, 417. 5, 11. Андр. дев. 53. - V. 1. погледо Гун. пс. 27. сазидо 27. имо Ст. шис. 5, 3. надо се Ст. пис. 5, 8. сачуво Андр. дев. 14. ушо Ст. пнс. 5, 77. - V. 3. обро Гунд. суз. III, XXXVI. Андр. пут 405. зво Андр. пут 78. - VI. вјерово Андр. дев. 82. номилово Гунд. суз. предгов.

По неким се странама $x$ стојећи на крају може и одбацити као и у другим приликама (види стр. 68), и то од XV вијека: них Пб. 119. пита Пб. 120. и послије: І. 1. набо Стар. 1, 231. прнша 228. - I. 4. мога Брн. 2. -- I. 5. прија Cтар. 1, 227. - I. 6. би Стар. 1, 230. позна Радој. 40. - I. 7. умр Брн. 69б. - III. 1. достоја Стар. 1, 223. лежа 234. IV. сагриши Стар. 1, 230. скуши Брн. 71б. .уби Стар. 1, 228. исправи Мрн. 40. пусти Стар. 4, 117. остави Ст. пис. 3, 201. сатвори Ст. пис. 4, 206. чуді Ст. шис. 1, 122. зачуди Стар. 1, 231. - V. 1. ваља Cт. пис. 1, 123. обећа 121. 4, 225. кара Cтар. 1, 228. слиша Мрн. 31. - V. 2. писа Стар. 1, 235. VI. благова Стар. 1, 228. поштова 228.

Тако окрњеном ошет се од XVI впјека додаје $a$ (као у генитиву мн.), ако се веһ не свршује на тај rлac, та се и зијевање које би настало кад кад укпда гдасом $j:$ I. 5 . узеја (vzegia) Радој. 38. - І. 6. биа Зор. 3. Мрн. 95. ужиа Зор. 3. сакрија Крн. 20. дпја Радој. 14. - I. 7. умрьа Вран. жив. 53. 65. Банд. 68. 70. - III. 2. хотиа Мрн. 91. хтиа 72.

' Што има: рек би Ст. пчс. 5, 72. ту као да се таково о одбпја. 
дојаздна 57. - IV. довршиа Мрн. 143. сагришиа Стар. 1, 228. скусиа Зор. 70б. сдожна 5б. 13б. 20б. подложнја Радој. 10. помодпја 9. чиниа Мрн. 172. учинија Радој. 9. 10.

\section{ПАРТИЦИП ШРОШЛОГА ВРЕМЕНА}

\section{ПАСИВНИ.}

Основа му је онака каква је интпнтиву. А три су наставка: ana, na и ta. Првому наставку прво а гласи у словенскп језццим $e$, а задње се а $у$ сва три наставка слаже с падежнијем наставцима као у адјектива у којих је основа на чисто а. Први паставак долази глаголима прве врсте осим онијех којима се основа свршује на $a$, и га аголима друге и четврте врсте; други наставак долази глаголима прне врсте којима се основа свршује на $a$, глаголима треће врсте и пете и шесте; трећи наставак долази некпм гдаголима прве врсте, свјема друге врсте и врло ријетко још којему.

A. Наставак ana: I. 1. заведен Ст. пис. 1, 24. вкрхдєиь М. 102. заседени Ст. пис. 1, 22. подседена Крн. 146. обсједени Андр. дев. 173. сметене Здат. 24б. чтене Ст. пис. 3, 250. чтено Д. Рањ. 56б. почтен М. 217. 515. похтсне II. 145. почтено Н. Рањ. 13. Збор. 100. почтене Ст. пис. 1, 3. почтен Ст. пис. 2, 107. 3, 200. 4, 185. 5, 12. почтена Д. Рањ. 36. Град. дјев. 79. поч'rено Хект. 27. 3ор. 34б. С'гар. 3, 308. непочтено Буд. 57. почтен Здат. 90. Крн. 9б. почтене Бун. 24. почтена Каш. 26. почтено Андр. дев. 14. поштен Ст. пис. 1, 149. 4, 266. поптени Ст. пис. 5, 29. поптена Зор. 43б. поштен Вран. рјеч. 44. жив. 40. непоштено Дпв. 7б. поштену Каш. 92. поштена Радн. 27. од основе иья $с$ промјеном гдаса $A$ на $T$ иза $и$ (тако бих рекао да је): наштен Н. Рањ. 199. 2276. (впди и под В.) - І. 2. докезєих ІІ. 12. покрьзсно Пб. 74. припєсєинхь М. 380. донесено Збор. 8б. разнесене Хект. 17. однесена 3бор. 60б. принесена Гуч. 80. донесен Орб. 235. понесен Банд. 45. шринесено Каш. 14. поднесене Андр. дев. 159. однесена Радн. 70. (впді и под В.) спасени Ст. иис. 1, 240. спасен Ст. пис. 5, 56. Хект. 30. Банд. 295. спасено Каш. 48. спасен Андр. дев. 28. Радн. 62. - I. 3. дубен Вран. 
рјеч. 38. издубена Кап. 65. удубену Шос. 39б. оскубена Ст. шис. 3, 32 1. Јерк. 58. оскубене Каш. 46. тепен Банд. 27. распен (т. ј. расут) Крп. 21б. распене (цић мене распене, т. ј. расуте) Крн. 22б. (види и под В.) - I. 4. гласови $2, x, x$ на крају основе мпјењају се пред $е$ од наставка на ж, $и, u$ : бржен Ст. пис. 1, 5. врькень II. 115. Ст. пис. 1, 240. одвржени Н. Рањ. 119. вржен 3бор. 886. Гуч. 191. Вран. жив. 72. завржен Орб. 285. вржен Банд. 125. вржене Јерк. 33. развржене Андр. пут 64. завржен Радн 4. рхждежешьи М. 109. раздежене Н. Рањ. 123. раждежене Збор. 162. здежено (сажежено) 3бор. 8б. раждежена Андр. пут 404. поможени Збор. 114. Гуч. 7. поможен Брн. 2. Орб. 126. Каш. 116. Радн. 10. с иромјеном гдаса $\nsim$ на $p$ : приморен Гуч. 248 . стрежени М. 37. стржен Банд. 211. обучен Н. Рањ. 98. Радн. 80. речемога М. 235.' - I. 5. zинмеше М. 493. zапиешқхь Ш. 176. најмено Ст. пис. 3, 213. надмена 3бор. 110. надмен Ст. пис. $1,49$. 4, 85. 445. Гуч. 202. (види и под В.). - І 6. $u$ на крају основе пред $е$ од наставка цијепа се у ьј, од чега у српском језику отпада ь: вькнн II. 43. ввтнога II. 91. развтих II. 115. поразвтих М. 498. бјен Ст. пис. 1, 143. бјена 83. убјена 89. бјен Ст. пис. 2, 383. прибјен Ст. пис. 3, 317. побјен 318. убен (читај убјен) Стар. 3, 273. убено (читај убјено) 292. разабен (разабјен) 309. разбјена („ґаbуена“) Јерк. 46. и на_қрају основе поста.до од и стојећи иза гдаса у вом је $j$ цијепа се шред $e$ од наставка у ьк, од чега ь у срнском језику отпада: z.швень Пб. 74. швено Ст. иис. 4, 109. швене Каш. 63. швену 66. 86. т на крају основе постадо од и цпјепа се пред $e$ од наставка у ти: скрькеньною М. 91. скрькень М. 108. скрькено I. 56. 140. покрвена Стар. 4, 84. истш се гдас и шири у об: скровену Н. Рањ. 40. Ст. пис. 2, 11. скровепа Ст. пис. 2, 418. $3,100.4,116.5,18$. скровен А. Рањ. 1. скровена Град. дјев. 146. скровено Хект. 27. Буд. 108. Здат. 15б. скровене Гуч. 1. скровено Орб. 2. скровен Г'унд. пс. 42. скровена Каш. 112. скровене Андр. пут 124. ю замијењено иза гласа у ком је j гласом оү щијепа се у кв, од чега отпада ь у српском је-

' IIIто има руєиI M. 235. пепорьуєแฐиһ II. 175. јамачно је тако гријешком писарском. 
зику: чкено II. 9. 122. у се шири у ов: отрокень Стар. 3, 326. исти вокали остају и непромијењени (управо враһају се у позпје вријеме из гдаголских облика у којима се не мијевају) а тако и други, те се зијевање које би настало између ๓их и наставка укида а) гласом $j$, који се више пута п не пише: разивиєи Пб. 102. разбщена М. 510. убијени Ст. пис. 4, 464. разбиен Стар. 3, 301. разбиен Вран. рјеч. 91. пробијена Вран. жив. 50. биен Гуч. 189. прпбијене Каш. 46. б) гласом 6: забивен (ки-) Ст. пис. 3, 359. 453. пробивена Вран. жив. 50. придобивене (кы-) Град. дјев. 36. прндобивен Радн. 59. бривеном Мрн. 33. скривена Ст. иис. 1, 116. Н. Рањ. 37. покривен Збор. 76б. Хект. 25б. одкривено Град. дух. 85. скривено 3бор. 53. сакривен Вран. жив. 17. откривен Орб. 11. сакривена Банд. 168. покривене Гунд. пс. 6. одкривена Јерк. 87. скрпвен Каш. 92. сакрпвена Андр. пут 398. покривено Радн. 73. сливенп Вран. жив. 35. обливену Бун. 43. сьшикень Пб. 61. ушивен Зор. 65. шивена Банд. 105. чувен Н. Рањ. 25. Орб. 237. Каш. 47. одјевена Збор. 7б. Ст. пис. 3, 416. 5, 39. однвен Хект. 25б. одивена Вран. жив. 16. одввен Банд. 172. Јерк. 50. одивени Радн. 73. у гдагода вмти надази се једном XVII впјека и од основе раширене као у садашњем вр.: добудени Вран. жив. 9. а један пут и ияједначен с глаголима четврте врсте: забљен Вран. жив. рјеч. 68. I. 7. гдас се $p$ или узима за сугдасно ка о садашњем вр.: прождрени Орб. 154. потрено Н. Рањ. 35б. стрене 28б. сатрен Ст. пис. 2, 514. потрени Ст. пис. 3, 137. отрено Град. дух. 19. сатрено Злат. 18. сатрен Гунд. суз. III, LIX. стрену I, LXXI. трене Бун. 43. по'арене Јерк. 57. или се узима за самогдасно те се зијева ради умеће в: сатрвен Н. Рањ. 101. стрвен Зор. 62. трвени Банд. 244. (внди в под В.) - II. основа мјесто наставка ио (na-n) који има у инфинитиву, пма наставак поү (nu), ком се крајње оү пред с шири у ов, а.ди само у прва времена: бтрнновень М. 15. потькнокеньоү М. 75. 124. основа додази и без наставка који има у инфинитиву, те се изједначује с основама у глагола прве врсте које се свршгују на сугдасно: тако се налази у гдјекојнх гдагода свега времена : раскидеи М. 477. Злат. 72б. постнжени Сав. стар. 4, 230. спрежен 3ор. 25. протежен Брн. 66б. уздижена 
Андр. пут 99. потиштенијех Гуч. 202. потиштен Орб. 190. Гунд. суз. III, LXXXI. потшштена Бун. 31. КашI. 33. потиштеној Андр. пут 26. (види и под В.) - IV. крајње се $u$ од основе пред $e$ од наставка хијева на $j$, те се с предвим гласовима слаже по својим законима: кммоскокень М. 111. Ст. пис. 1, 180. Н. Рањ. 18б. благосдовљени 3бор. 176. Стар. 4, 117. Каш. 40. благословљево Брн. 43б. благословљен Вран. жив. 81. благосовљен Збор. 34. Банд. 5. обншен Врап. жив. 10. кхзвраћенє М. 486. повраћен Буд. 4. иекрьгень М. 23. задњена Хект. 31. удрен Ст. пис. 1, 254. удрена Хект. 21. Радіг. 59. ожалоштени Банд. 33. 84. прниянь П. 32. Ст. пис. 2, 435. обујмљен Збор. 130. Гуч. 155. слимљена Андр. пут 100. покријешљено Іуч. 104. ускришена Јерк. 78. крштени Див. $15 \sigma$. крштена Орб. 264. омаштен Ст. пис. 3 , 137. помнрен Буд. 4. опаљен Вран. жив. 72. оплажене Ст. пис. 3,10 . шрпправљен Збор. 48. папрхвменх М. 302. испрлкенн М. 510. опрамени II. 89. прошћено М. 385. напуњени Н. Рањ 168. пуштена Здат. 88. одпуштене Гунд. пс. 5. запушћен Вран. рјеч. 28. допушћено Јерк. 15. израмљен (нзравњен) Андр. пут 1. поcareno М. 46. слобођен Град. дјев. 38. ослобојена Зор. $64 б$. постакмень Пб. 66. оставмена П. 77. слстаменх М. 220. 235. постамєшь П. 71. Пб. 104. стмєно ПІ. 126. остаљена Збор. 1016. стаљену Хект. 7б. стаљен Див. 22. ๘свгєн М. 206. оскврњена Глав. 21. оцкврњено Ст. пис. 1, 4. Град. дјев. 154. оцкврњенога Гуч. 11. оцкврњеному Див. 34. оцкврњена Вран. жив. 49. Орб. 106. Каш 121. сатворен Гуч. 10. потврћиємо М. 288. потмєо М. 562. ухићена Зор. 105б. причешћен Гуч. 11. очиштен Н. Рањ. 61. Банд. 51. очишћен Вран. жив. 18.

У гдагода четврте врсте $\lambda$ иоје им се у основи између крајњега $j$ и предњега $\sigma, 6, \bar{a}$ умеће, гдје гдје се опет и избацује од XVI вијека: пољубјени Ст. пис. 3, 257. љубјен Ст. пис. 5, 3. љубјена Гунд. пс. 41. раставјен Ст. пис. 4, 320. купјен 239. склопјен 202. - У писаца који су писали говором у ком $ђ$ гласи $j$ или који су се тога говора у гдјечему придржавали налази се $\not j$ мјесто $ђ$ или мјесто $j$ тога говора, које се у вих такође наході (видп п на стр. 307-8): наредјен Буд. 12. осудјен 11. уврндјеному 143. потврдјена Брн. 22. родјен Вран. жив. 16. 21. одсудјени 19. родјени Банд. 
12. наредјену Каш. 93. а неки су према овој замјени замјењива.ли и $\hbar$ гдасовима $т j$ : ротјен Вран. рјеч. 52. крстјена Вран. жив. 78. - Од почетка XVI налази се овај обдик и без $j$ на врају основе посталога од $и$ а по том и без промјене иредњих сугласнијех, али врло ријетко: најстаријш је прпмјер: очистени Н. Рањ. 73б. гдје вр.о дако може бити и писарска погрјешка;' по тох се находи: уресен Ст. пис. 2, 351.367. Брн. 11. пресена Каш. 81. водена Стар. 1, 223. очнстен Град. дух. 24. частено А. Рањ. 72б. 151б. допустена Гуч. 3. опћетен Буд. 104. юрстен Каш. 97. омастене 111. навпстену 105. очпстено Банд. 12\%. раздрпена Каш. 99.

У гајекога писца XVI п XVII вијека налазп се гдјебоји глагол прве врсте пренесен у овом облику међу глаrоде IV врсте: иробођена I'рад. дјев. 114. пробођени 182. украђен Мкк. 722. искуб.ьен Мик. 143.

Б. Наставак na: I. 6. у г.дагода војпма се основа свршује на $a$ : дан Ст. пис. 2, 215. дано Брн. 29б. Здат. 266. издан Буд. 123. дан Мик. 55. знано Град. дјев. 127. незнанш Буд. 91. знан, познан Мик 875. (впди ниже код иете врсте) - III. вндеин П. 46. видјен Н. Рањ. 52б. 121б. 1256. внднємо 36ор. 71. видјене Град. дјев. 158. вндин Хект. 35. видјенога Гуч. 85. невшдјен З.хат. 37. Гунд. Пп. 41. невидпни Бавд. 111. впдјен Банд. 120. впдјенијех Андр. дев. 143. венавидјен 3бор. 20б. Гуч 141. ненавиден Брн. 46б. изгорјене Гүнд пс. 24. разгорјена Андр. нач. 25. желином Ст. пис. 1, 195. жємєно Збор. 98б. желинога Зор. 7б. 53. желину 10. 66б. желино Брн. 12б. Јерк. 32. зазрено Град. дјев. 78. мнину Ст. нис. 1, 87. стрпина Ст. пис. 1, 174. устрпин 154. устрпјен Н. Ращ. 37б. стрпјено Ст. иис. 3 , 385. 4, 73. од

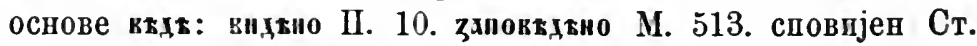
пис. 1, 149. сповпдјен Н. Рањ. 20. заповидјено Н. Рањ. 416. Збор. 122б. Град. дјев. 28. споввдјево Збор. 72б. исповидјен Гуч. 11. али гдагоди ове врсте од свршетка XV вијека предазе у овом облику као и у имерфекту међу гдагоде четврте

1 ШІто има XV вијека потврьено М. 300 . ту је јамачно само наппсано де мјесто $f($, као ш у томнколе на пстој страни, као тпто и у втврьдненнен стојп де мјесто ђе у истом споменпку. 
врсте, те пмају као они (внди под А); најстарији су прпмјери : жељеном Ст. пис. 1, 195. стрп.љено 228. а послије: впјене Јерк. 54. виђена Радн. 46. жељени Зор. 20б. жељен Град. дух. 20. Вран. жив. 71. жељену Банд. 266. жељено Радв. 42. жуђени Ст. пис. 4. XI. А. Рањ. 73. Злат. 28б. Гуч. 275. Гунд. пс. 44. пожујени Јерк. 85. жуђено Андр. дев. 84. стрпљенијем Ст. пис. 4, 54. стрпљен Ст. пис. 5, 50. стрпљено Гуч. 209. устріљена Јерг. 96. трпљене Андр. дев. 159. хоћен Радн. 2. заповиђене Радн. 34.' -- V. 1. zlamenan M. 280. впван П. 14. прјеповиједано Н. Рањ. 89б. - V. 2. везан Буд. 85. обезан Хект. 5. писано Н. Рањ. 84. - V. 3. пзикрхик М. 104. прогнан Вран. жнв. 37. ${ }^{2}$ зван Злат. 14. у глагола који пначе иде овамо налази се и од основе какву би имао у првој врстп: ненадину Ст. пнс. 1, 52. пенаднно Јерк. 47. VI. qтован Ст. пис. 1, 5. почтованощу 3. почтована Збор. $90 б$. Брн. 2. почтован Зор. 75б. Стар. 3, 257. Гуч. 34. почтовани 3лат. 36g. птована Стар. 1, 221. поштован Зор. 8. поштовани Вран. жвв. 44. поптоване Бавд. III. поштована Радв. 4.

B. Наставак ta: I. 1. од основе шьд налази се до краја XVII вијека, а није свагда пасивнога значева: дошасти Ст. пис. 5, 78. дошаста Радн. 71. мимошастих Буд. 3. нашаст Н. Рањ. 20б. нашаста Збор. 89б. нашаст Гуч. 167. нашасте Буд. 107. нашаст Вран. жив. 16. Банд. 83. Јерк. 10. Пос. 24. Радн. 78. нзнашасте Град. дјев. 121. пзнашаста Орб. 67. изнашастих Банд. 42. обашаст Радн. 26. пропастијех Андр. пут 52. Радн. 48. - I. 2. од основе иєс промпјењене као у инфинитиву од свршетка $\mathrm{XV}$ вијека: узниту Ст. пис. 1,64 . узнит Зор. 35. однито Буд. 138. - І. З. од основе скп промијењене као у инфинитиву: расуто Радн. 65. - I. 5. прокдет Буд. 85. пропет Вран. жив. 10. изажет Мпк. 151. вазето Буд. 71. вазет Вран. жив. 23. узет Мик. 753. изета Збор. 100. А. Ран. 77. изете Ст. пис. 5, 3. обујат Н. Рањ. 1576. Вран. жив. 17. Банд. 15. обујет Вран. жив. 41. отет Мик.

- Гајекојш писци који су писали говором у ком $ђ$ гласи $j$ шмају І у тијех глагола кая кад $\not j$ мјесто $f$ илш мјесто свога $j$ : впдјен Вран. жив. 45. Каш. 15.

2 Налази се као в у ивфпнитиву (виді стр. 253) према садапьем вр. шромијёвено г у ж, па у $p$ : изарнан Банд. 31. 64. 


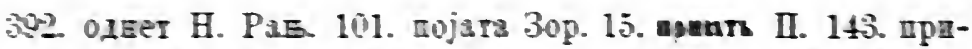

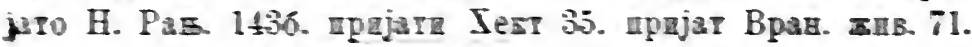

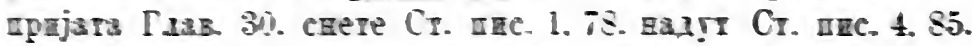

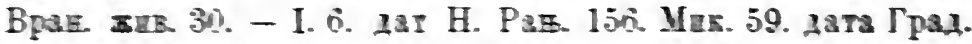

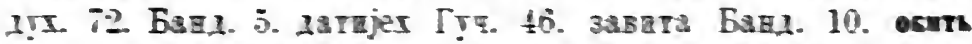

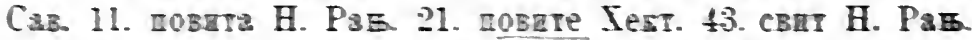

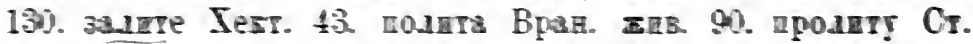

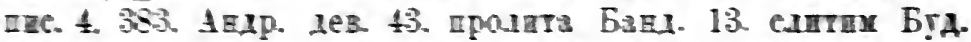

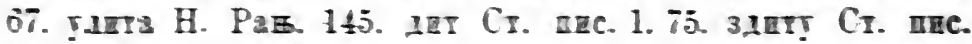

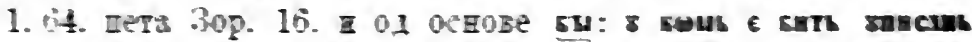

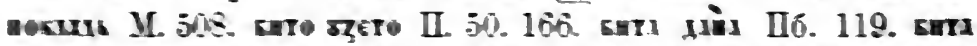

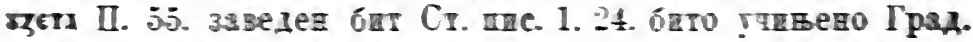
III 74. cBRT je ctropee бET Xest. 19. Rlact бата је дана

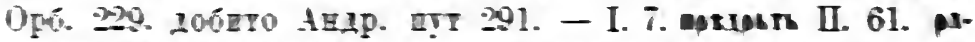

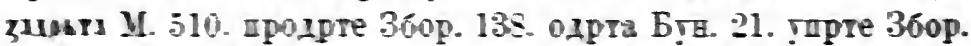

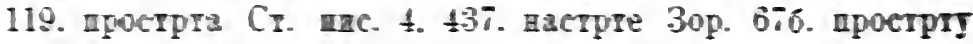

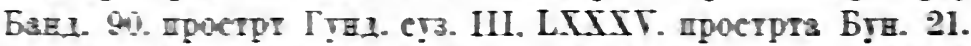
проетрт Аeдp. дев 44. сатрт CI. пас. 4. 432- - II. твезнут

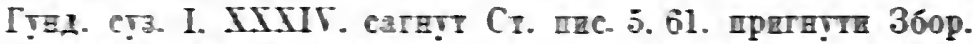

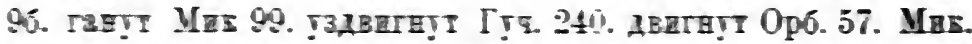

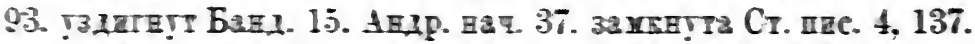

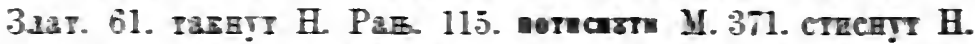

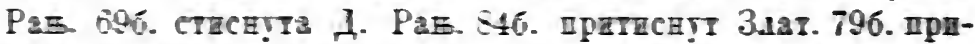

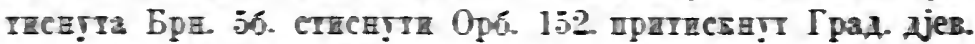

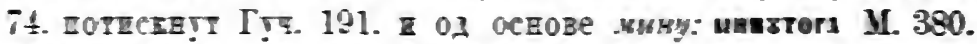

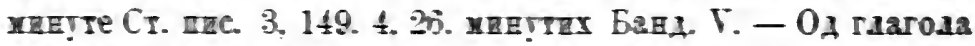

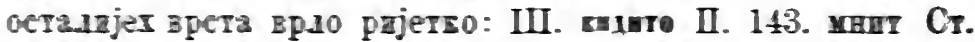

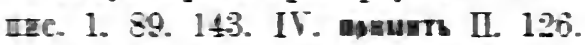

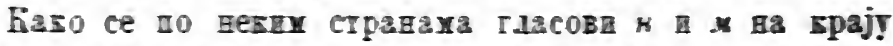

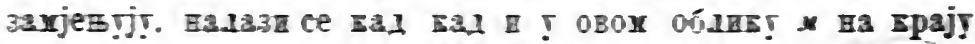
rjeсто к: познаи д. Ран. IX. послах Вран. вив. 72 посве-

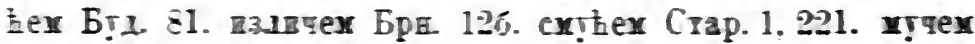
Банд. 133. поставьен Банд. 259. 


\section{ДОПУНЕ И ПОПРАВЦИ.}

Страва 9, врста 19. додај: тепьчи М. 85.

Стр. 20, вр. 11. додај: и одбаппвши б а задрғавши $6:$ вуве Cт. пвс. 2,103 у дну.

Стр. 26, вр. э. хјесто „Ст." треба Стеф.; ијесто „д. " треба дом.

Стр. 26, вр. 7. иза -средњега длдај: рода.

Стр. 26, вр. 10. хјесто „Ст." треба Стеф.

Стр. 31, вр. 18. додај: коно ПI. 56. М. 417.

Стр. 42, вр. 8. додај: и У адјектвва: инмостио кохниь М. 469.

Стр. 43, вр. 19. ујесто, $20^{-2}$ треба $0 .$.

Стр. 45 у дну додај: хјесто инстр. јед. на.иази се датив, преу да вр.10 ријетво: уеу пуку неверному Вран. жив. 40. вспореді дат. чн. на стр. 9т.

Стр. 54, вр. 26. вод дьпе додај: г,је ђс основа бвти ва сугласно а наставак i ослабио у $e$.

Стр. 56, вр. 10. -рахи" приада чеђу ријеqв с основом ва а, те треба премјести на стр. 47.

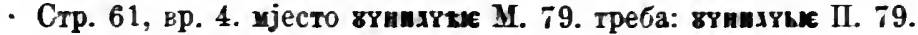

Стр. 61, вр. 9. додај: двадесет и четири старде падоте Н. Рав. 199. двадесет п четпри старде покіањау се Н. Рањ. 1996. истореди на стр. 65 . мюдс.

Стр. 63, вр. 30. додај: таго и измеһу ријечи средвета рода с основоу ва суг.нсво прешавши овамо: Бопи.1и Ст. пис. $3,229$.

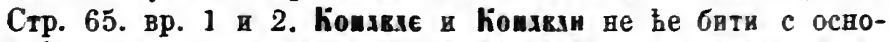

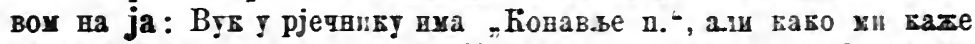
једав пријатеь, сада се зову Конав.и п Ковав.ле, гев. Конава.л, дат. Ковав.ıиа; по тох у вегпу падекпма треба то име премјестити меһу рвјеqи с основом ва чисто а, а.в међу венске, а у векпм меһ! рпјечи с освовоя на i. јер да је било девскота рода,

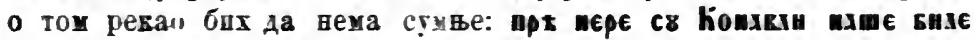
II. 173. види т моч рјечнику.

Cтр. 88, вр. 24. мјесто $X \Gamma$ треба $X V I$.

Стр. 90, вр. 22. 10дај: охохо (т. ј. охо, охо.1) Пос. 4.

Стр. 92, вр. 4. додај: впвтне М. 33.

Стр. 95. вр. 35. вза мадедонау“- додај : (читај : мапедовах).

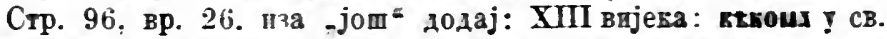
Саве тнпигу хинандарскоу Г. 24, 224. в од сншка на дртгој страви nоm.ьедвега .иста.

Стр. 97, вр. 4. додај: двима дитйи Ст. пнс. 4, 294 у дну. 
Стр. 105, вр. 17. додај : Дєханє М. 92.

Стр. 106, вр. 4. додај: що щна три рогоки М. 127.

Стр. 108, вр. 24. код Кіншван додај: М. 188. 292.

Стр. 113, вр. 12. „родш" поправн: радн.

Стр. 123, вр. 3.. мјесто „От." треба: Ст.

Стр. 154, вр. 32. код „нинће" додај: у говору у ком се гласови ит замјењују г.иасовпма $и ћ$ (тань, пшһе), зампјеннли су се II у тој рнјечн, па се иза $ћ$ промиј пн.10 о на $e$.

Стр. 158, вр. 15. пза 84. додај: а

Стр. 167, вр. 29. мјесто 4. треба 5.

Стр. 175, вр. 21. добровхуырты поправн: двкровхуыркић.

Cтр. 183, вр. 15. дүхокнонь поправн доүхоннонь.

Стр. 239, вр. 27. додај: три сире Ст. пис. 5, 187.

Стр. 240, вр. 3. додај: четр Ст. пис. 5, 312.

Стр. 240, вр. 27. додај: с овнјем тријема Ђам. 136.

Стр. 244, вр. 4. додај: триес Ст. пис. 5, 126.

Стр. 244, вр. 15. додај: и окрњено као у акус. јед.: дваес C'r. nilc. 5, 185.

Стр. $26 \overline{6}$, вр. 13. додіј :-пријам-Ст.-пнс $4,72.89$. 



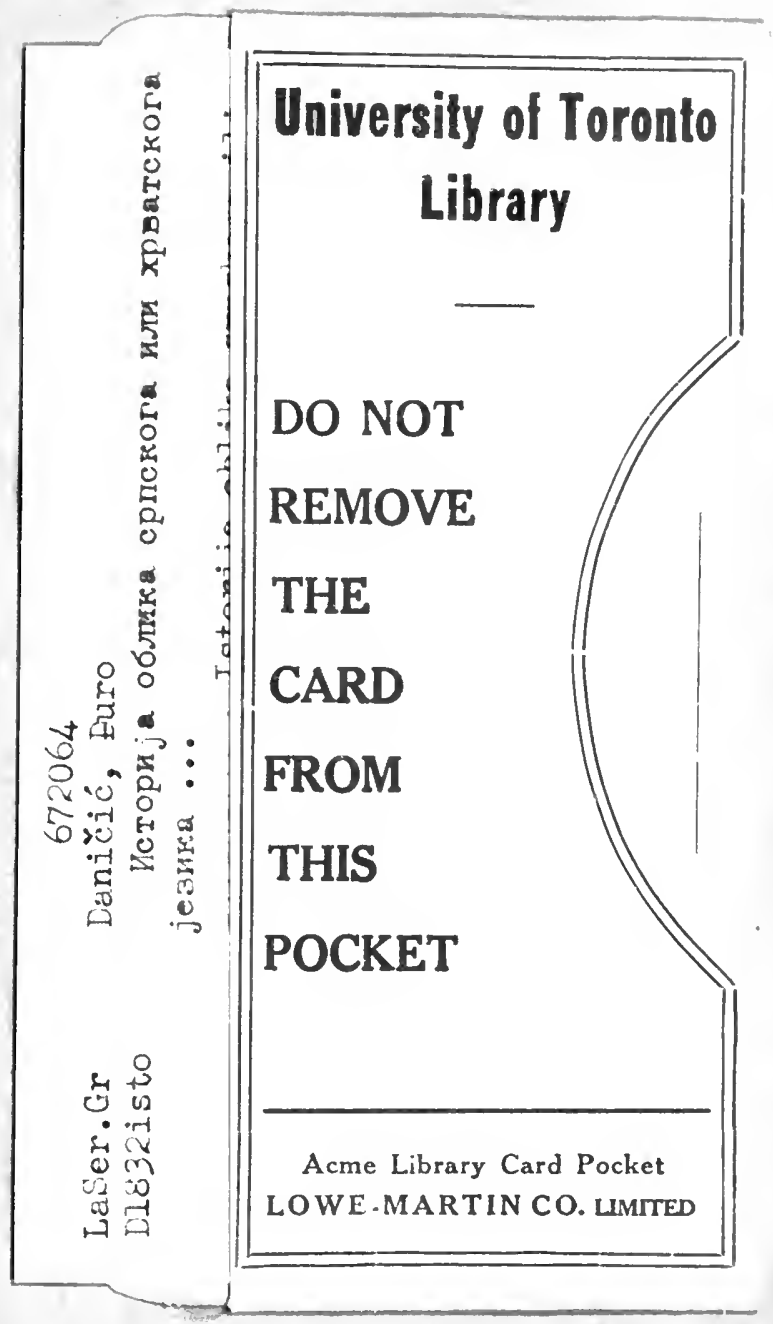


